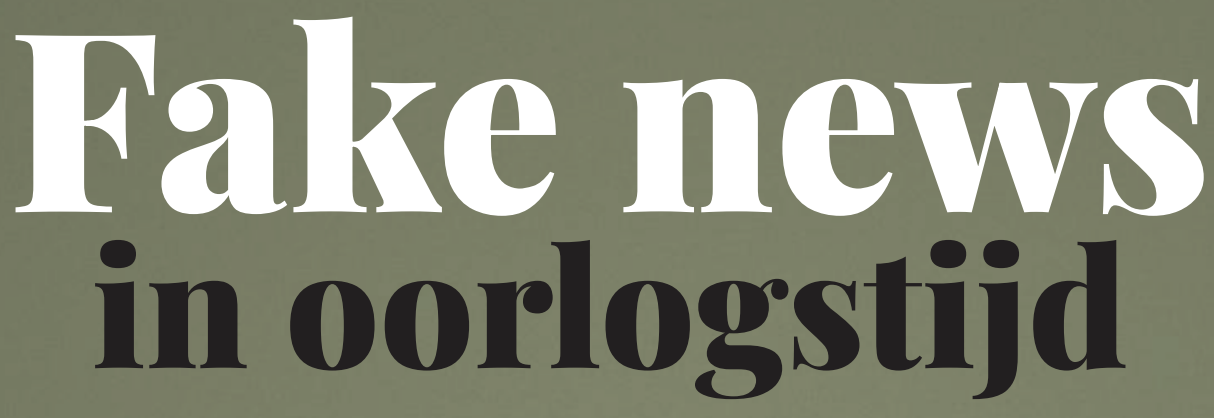

Duitse mediamanipulatie en de Flamenpolitik (1914-1915)

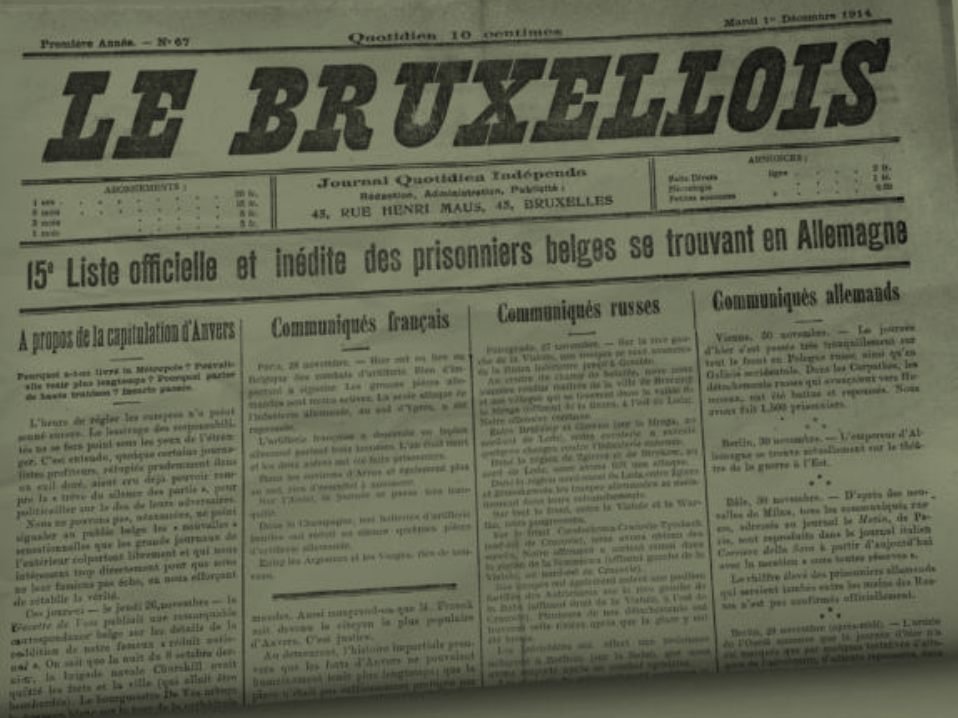

Bruno Yammine 
Fake news in oorlogstijd

Duitse mediamanipulatie en de Flamenpolitik (1914-1915) 



\section{Fake news in oorlogstijd}

Duitse mediamanipulatie en de Flamenpolitik

(1914-1915)

Bruno Yammine 
Uitgegeven met de steun van KU Leuven Fonds voor Fair Open Access

en

de Universitaire Stichting van België

西

2021 Universitaire Pers Leuven / Leuven University Press / Presses Universitaires de Louvain.

Minderbroedersstraat 4, B-3000 Leuven (Belgium).

(C) 2021, Bruno Yammine

Dit boek is uitgegeven met de Creative Commons Attribution-NonCommercial-

NoDerivatives 4.0 International Public License.

\section{(1) (1) (9)}

Meer details over Creative Commons licenties op http://creativecommons.org/licenses/

De referentie naar het boek moet de volgende informatie bevatten:

Bruno Yammine, Fake news in oorlogstijd: Duitse mediamanipulatie en de Flamenpolitik

(1914-1915). Leuven, Universitaire Pers Leuven, 2021. (CC BY-NC-ND 4.0 International Public License)

ISBN 9789462702707 (Paperback)

ISBN 9789461663788 (e-PDF)

ISBN 9789461663795 (e-PUB)

https://doi.org/10.11116/9789461663788

D/2021/1869/11

NUR: 688

Boekverzorging: Crius Group

Ontwerp omslag: Frederik Danko

Illustratie omslag: Le Bruxellois, 1 december 1914, p. 1; KBR J.B. 28

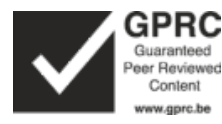




\section{INHOUDSTAFEL}

Algemene inleiding 11

I. Een polemische geschiedschrijving 12

II. Verwetenschappelijking 16

$\begin{array}{ll}\text { III. Recente evoluties } & 17\end{array}$

IV. De ondermijnde Godsvrede $\quad 18$

V. Flamenpolitik en activisme 21

Hoofdstuk 1: Het vooroorlogse spanningsveld 25

1. Het völkische denken $\quad 26$

2. Een "Duits" Antwerpen? 36

3. Het nieuwe Carthago 38

4. Het völkische element in de Waalse beweging 40

5. De ophef rond Pol de Mont 44

6. Een Nederlands-Belgische Entente? 47

7. Besluit $\quad 50$

Hoofdstuk 2: De Godsvrede tot de val van Antwerpen 53

1. Francofilie en pan-Germanisme? 54

2. Een vermeend anti-Vlaams artikel

3. De Gentse Godsvrede $\quad 60$

4. Besluit 62 
Hoofdstuk 3: Perspolemieken in de nasleep van de val van een "onneembare" vesting

1. Omtrent de val van Antwerpen 66

2. De vluchtelingenkwestie als splijtzwam 68

3. Het Journal des Réfugiés verbreekt de Godsvrede 70

4. Het beleid van Franck en het verdrag van Kontich 79

5. Een katholiek volksvertegenwoordiger in het oog van de storm $\quad 82$

6. De pers in het bezette land: een schietschijf 88

7. Vier actoren uit de "anti-Vlaamse campagne" en een dreigement 92

8. Besluit

Hoofdstuk 4: De Duitse diensten treden in actie 105

1. De Flamenpolitik 106

2. De oorsprong van de Duitse voorstelling van zaken 117

3. De propagandamolen komt op toerental 133

4. Antwerpen moet kapot! 139

5. Andere vlugschriften 154

6. De ontwikkeling van het activisme in het bezette land 159

7. Omtrent de Duitse pers in bezet België 178

8. Besluit 184

Hoofdstuk 5: De waarheid over La Vérité 193

1. Ontleding van een mysterieus vlugschrift 196

2. Apocalyps van een nieuw Carthago 201

3. In het spoor van de Duitse cultuurpolitiek 208

4. Caveant Consules 212

5. De mensen achter de schermen 214

6. Een opmerkelijk stuk van Harry 217

7. Besluit 223

Hoofdstuk 6: De top van de ijsberg 227

1. La Politique Belge après la Crise - Un Parti National 229

2. Het Appel aux Wallons 238

3. De koers van De Vlaamsche Stem 247

4. Een Duits programma voor Nederland 254

5. De zomer van 1915: een doorbraak 264

6. De zaak-Buisset: een Duitse tegenzet 272

7. De Groot-Nederlandse beweging 277

8. Besluit 286 
Hoofdstuk 7: Radicalisering 293

1. Demoralisatie en frontbeweging 294

2. De propaganda intensiveert 298

3. Een verslag van het Vlaams-Belgisch Verbond 304

4. De "sublieme deserteurs" 309

5. De propaganda van de Raad van Vlaanderen 310

6. Besluit 313

$\begin{array}{ll}\text { Slotbeschouwingen } & 315\end{array}$

$\begin{array}{ll}\text { Noten } & 329\end{array}$

$\begin{array}{ll}\text { Bibliografie } & 371\end{array}$

1. Dagbladen $\quad 371$

2. Opiniërende tijdschriften 373

3. Aangehaalde bronnen en werken $\quad 374$

4. Naslagwerken 385

5. Repertoria voor verder archiefonderzoek 385

$\begin{array}{ll}\text { Personenregister } & 387\end{array}$ 



\section{VOORAF}

Ons collectieve geheugen bestaat uit gedeelde herinneringen die mee een gemeenschap vormgeven. Daarin spelen mythen, idealiseringen en onwaarheden een minstens even belangrijke rol als feiten zelf. Tal van historische gebeurtenissen of interpretaties ervan waren al vanaf hun oorsprong propagandavoorstellingen. Een doelbewust vertekend beeld op de realiteit vertroebelde niet alleen de visie van tijdgenoten. Het werd later doorgegeven, niet het minst om een ideologie te legitimeren. De deconstructie van mythen is de grootste uitdaging voor een historicus. Het is met dit in het achterhoofd dat ik dit werk geschreven heb.

Mijn bijzondere dank gaat in de eerste plaats uit naar professor Lode Wils, die zich de moeite getroostte om eerdere versies van dit manuscript te corrigeren. Zijn talrijke suggesties, op- en aanmerkingen waren een voortdurende bron van inspiratie. Ook wil ik graag professor Louis Vos danken voor zijn zeer gewaardeerde inbreng. Een bijzonder woord van erkentelijkheid gaat ten slotte uit naar professor Nel de Mûelenaere, dr. Ulrich Tiedau, dr. Mirjam Truwant en last but not least naar mijn vader.

Bruno Yammine

Leuven, januari 2021 



\section{ALGEMENE INLEIDING}

De bedoeling van dit werk is om de mechanismen die in de context van een grootschalig conflict aan de grondslag lagen van propaganda en als dusdanig de publieke opinie beïnvloedden, aan een grondige analyse te onderwerpen. De deconstructie van die propaganda, legt de mechanismen ervan bloot en contextualiseert figuren die eraan meewerkten. Hiermee wordt niet alleen nieuw licht geworpen op het verleden, maar ook op een onderwerp dat van alle tijden is: fake news. ${ }^{1}$

Bij propaganda in oorlogstijd denkt men onwillekeurig aan het nationaalsocialistische tijdvak, inzonderheid aan de situatie gedurende de Tweede Wereldoorlog (1939-1945). Berlijn was echter toen niet aan zijn proefstuk toe. Want al tijdens de Eerste Wereldoorlog (1914-1918) maakte Duitsland ook in de bezette gebieden gebruik van de media om zijn ideologische visie te verspreiden. De historiografie heeft dit onderwerp onderbelicht voor wat België betreft. Enigszins vreemd, want bleek het resultaat ervan net daar niet erg duurzaam? In 1918 waren "België" en "Vlaanderen" immers voor een toen weliswaar nog klein deel van de Vlaamsgezinden onverzoenbare vijanden geworden. Tijdens het conflict had die fractie, de zogenaamde activisten, met de Duitse bezetter gecollaboreerd. Die voerde een Flamenpolitik, een völkisch beleid, waarvan het doel was om België politiek te ontwrichten. Berlijn wilde op termijn immers een verbrokkeld België, samen met Nederland, in het Duitse Rijk incorporeren. De Flamenpolitik speelde daarbij in op bestaande verlangens en frustraties van Vlaamsgezinden. Daarom werd bijvoorbeeld in 1916 de vernederlandsing van de Franstalige universiteit van Gent, een vooroorlogse eis van de Vlaamse beweging, doorgevoerd. De 
bezetter trad gaandeweg nog verder buiten het Belgisch wettelijk kader en kondigde in 1917 de "bestuurlijke scheiding" tussen Vlaanderen en Wallonië af. Begin 1918 werd door de Raad van Vlaanderen, het activistische parlement, zelfs bekendgemaakt dat het orgaan de "zelfstandigheid" van Vlaanderen uitgeroepen had.

De enorme propaganda-inspanning die Berlijn zich getroostte, was er niet alleen op gericht om de Vlaamse beweging voor de Duitse zaak te winnen, maar behelsde meerdere thema's. Het discrediteren van het Verenigd Koninkrijk en Frankrijk, de garanten van de Belgische neutraliteit; aanvallen op de Belgische regering-in-ballingschap; het ophemelen van militaire successen van Duitsland; het stimuleren van partijtwisten tussen de Belgen onderling; het positief beoordelen van pacifisme; het demoraliseren van de Belgen enzovoort. Hierbij deed de bezetter nauwelijks een beroep op film en radio, media die trouwens nog in hun kinderschoenen stonden. Er waren andere middelen om de publieke opinie te beïnvloeden, waaronder vlugschriften en de schrijvende pers. Die worden in dit werk binnen het kader van de Flamenpolitik bestudeerd. Daarbij komt het accent op het eerste oorlogsjaar te liggen. We hebben na medio 1915 geen systematisch en gedetailleerd bronnenonderzoek meer gevoerd naar de Duitse mediamanipulatie in België. Op dat moment, toen een niet onbeduidende fractie Vlaamsgezinden collaboreerde, was het activisme een feit. ${ }^{2}$ Alvorens de onderzoeksvragen te expliciteren, wordt ingegaan op het historiografisch debat betreffende de relatie tussen de genese van de Flamenpolitik en het activisme.

\section{Een polemische geschiedschrijving}

In de literatuur wordt al meer dan een eeuw over dit thema geredetwist. Daarbij spelen drie vragen een rol. Allereerst, was de Flamenpolitik een breuk of een continuïteit binnen de Duitse politiek? Ten tweede, was het activisme een gevolg van de Flamenpolitik of een autonome evolutie binnen de ontwikkeling van de Vlaamse beweging? Ten slotte, wat was de aanleiding tot dit activisme? ${ }^{3} \mathrm{Bij}$ die laatste twee kwesties speelt de factor Duitse propaganda een rol. Al tijdens de oorlog stelden de activisten hun stroming voor als een voortzetting en aanpassing van de Vlaamse beweging. ${ }^{4}$ Daarbij werd dan zogezegd Duitse hulp aanvaard om rechtmatige Vlaamsgezinde eisen te verwezenlijken. Voor hun tegenstrevers was het activisme daarentegen een collaboratie van een kleine groep slechte vaderlanders. Of, zoals Belgisch-loyale Vlaamsgezinden zouden betogen: van misleide vrienden. De activisten 
werden, zo heette het, gemanipuleerd door de doelbewuste verdeel-en-heerspolitiek van de bezetter. Tijdens het interbellum ontstond er een propagandaoorlog tussen beide kampen. De oud-activisten schermden daarin met het argument dat de bezetter spontaan ingegaan was op hun vraag tot hulp tegen "franskiljonse" aanvallen, waarover straks meer. De activistische these werd na 1918 ondersteund door buitenlanders, van wie sommigen een rol gespeeld hadden in het activisme of in de Flamenpolitik. Om deze lezing van de feiten te bewijzen, werd benadrukt dat de Vlaamse beweging vóór 1914 niet germanofiel was, in de vooroorlogse periode niet door de Duitse regering gesteund werd en dat de Flamenpolitik een "improvisatie" was. 5 Otto Ebstein, een Duitse censor in België, en de diplomaat Oskar Von der Lancken-Wakenitz, het hoofd van de Politische Abteilung in Brussel, verdedigden deze laatste stelling resp. in 1919 en 1932.6 De Groot-Nederlander Pieter Geyl, die tijdens de oorlog buiten het gewoel stond maar wel met de radicale Vlaamsgezinden sympathiseerde, minimaliseerde in 1925 de impact van de Flamenpolitik. Hij betoogde dat de oorlog louter bestaande tegenstellingen verscherpt had. Ook ontstond er in Duitsland eind jaren 1920 een debat tussen zij die de Flamenpolitik als een instrument van het Duitse imperialisme beschouwden en anderen die beweerden dat het beleid enkel als oogmerk had het "zelfbeschikkingsrecht der volkeren" te implementeren. ${ }^{7}$ In België desolidariseerden Belgisch-loyale Vlaamsgezinden zich niet (altijd) van oudactivisten. Zo gaf het liberale en Vlaamsgezinde Julius Vuylsteke-Fonds in 1919 de anti-activistische maar apologetische documentaire verzameling Activisten uit om het activistische optreden te vergoelijken. Daarin werd op vermeende wallingantische en "franskiljonse" drijverijen vóór en tijdens de oorlog gewezen. Wel werd aangestipt hoe de Duitsers al spoedig bemerkten dat ze de taalkwestie konden gebruiken om "een werk van verdeling en verraad in gang te steken waarvan zij - voor hun politiek - succes verwachtten".

Anderzijds gaf in de nadagen van de bezetting de jurist Théodore Heyse een verzameling documenten uit betreffende de vernederlandsing van de Gentse universiteit door de bezetter om die na de oorlog te verhinderen. Naar Heyse betoogde, was de maatregel er schijnbaar gekomen om in te gaan op de verzuchtingen van de Vlamingen. In realiteit echter wilde de bezetter zijn eigen zaak dienen. ${ }^{9}$ Tien jaar later werden de Archives du Conseil de Flandre gepubliceerd door anti-Vlaamsgezinden. Die voerden een campagne tegen amnestie voor de activisten. De omvangrijke publicatie bevatte belangrijke uittreksels uit de archieven van de Raad van Vlaanderen. In 1929 betoogde de Belgische historicus Henri Pirenne dat de Duitse regering zich vóór de oorlog zowel voor de Vlaamse kwestie als voor de pan-Germanisten in eigen 
land desinteresseerde. Ook Vlaamsgezinden stonden volgens hem onverschillig tegenover pan-Germanistische strekkingen. Pirenne wees wel op het ontstaan van met Duits geld gesubsidieerde dagbladen in België tijdens het conflict. Die zouden dan de Duitse regering aansporen om de Vlamingen hun recht te geven. Vanaf 1915 werd, aldus de historicus, ook in Duitsland door dagbladen en brochures duchtig anti-Belgische propaganda gevoerd. ${ }^{10}$ Maar in hun voorstelling van zaken hielden de apologeten van het activisme (bewust) zeer weinig rekening met bovenstaand materiaal.

De liberale Vlaamsgezinde hoogleraar Maurits Basse betoogde in 1930 dat de Politische Abteilung in Brussel de "activistische molen aan het draaien gebracht" had. Volgens hem kreeg men de indruk dat de Duitsers nog vóór ze België binnenvielen, het plan van hun Flamenpolitik opgevat hadden. Het idee van een vooroorlogse inmenging van Duitsland in België wees hij daarentegen af. ${ }^{11}$ De documentaire verzameling Verraad of Zelfverdediging? (1933) van de Brusselse oud-activist Arthur Faingnaert vormde een invloedrijke apologie waarin de auteur beklemtoonde dat niet de Duitsers, maar wel de Vlamingen het initiatief namen. Tussen de lijnen gaf Faingnaert evenwel aan dat ook Berlijn actie ondernam. Zo noemde hij het een verdienste van de Duitse regering "dat zij dadelijk de grote betekenis van de Vlaamse beweging voor haar politiek in België gevat [had]". ${ }^{12} \mathrm{Na}$ de Tweede Wereldoorlog werden wetenschappelijke synthesewerken geschreven waarin Flamenpolitik en activisme aan bod kwamen. Die bleven echter een exclusieve zaak van personen die het activisme min of meer wilden vergoelijken. Gedurende drie decennia bleef het uitgangspunt de, weliswaar gepolijste en aangevulde, activistische propaganda. Een eerste belangrijk synthesewerk uit 1958 waarin het activisme aan bod kwam, was van de hand van Arie Wolter Willemsen, een promovendus van Geyl. In 1969 vulde hij zijn monografie aan met meer en nieuw bronnenmateriaal. Volgens de historicus hadden de Vlaamsgezinden geen echte vaderlandsliefde kunnen koesteren voor België. Enkel teleurstellingen waren immers hun deel geweest:

De nieuwe [Duitse] machthebbers zouden, zij het dan ook uit eigenbelang, meer begrip tonen voor de Vlaamse eisen. Wat was begrijpelijker dan dat vele Vlaamsgezinden de uitgestoken hand ten slotte aanvaardden ${ }^{13}$

Willemsen stelde dat het activisme bij Vlaamsgezinden in hoofdzaak een autonome ontwikkeling geweest was, die niet door de bezetter in het leven geroepen werd. Daarbij werd de toenadering tussen de bezetter en Vlaamsgezinden vergemakkelijkt, omdat Duitsland als tegenspeler van Frankrijk een 
zekere sympathie bij flaminganten bezat. ${ }^{14}$ De Duitse gedachte aan een blijvende heerschappij over België kon, aldus Willemsen, het best gewaarborgd worden indien de bezetter vriendschap met de bevolking sloot. Vandaar dat hij de communautaire kwestie uitbuitte. Die opvatting werd gestimuleerd omdat de Vlamingen als een Germaans broedervolk beschouwd werden, die door Romaanse overheersing bedreigd werden. Die visie leefde al vóór de oorlog in het Alldeutscher Verband ( $\left.{ }^{\circ} 1894\right) .{ }^{15}$ Die imperialistische pressiegroep was in 1891 onder de naam Allgemeiner Deutscher Verband in Duitsland opgericht. Toch beklemtoonde de auteur hoe die organisatie vóór de oorlog Vlaamsgezinden afgestoten had. Ten bewijze het wedervaren van het Vlaams-Duitse tijdschrift Germania, dat tussen 1898 en 1905 in Brussel verscheen en, aldus Willemsen, bij gebrek aan lezers verdween. ${ }^{16}$ Hendrik Elias legde in 1969 net als Willemsen de nadruk op de autonome genese van het activisme. Volgens hem wist noch de Duitse generale staf, noch het ministerie van Buitenlandse Zaken iets af van het bestaan van een Vlaamse kwestie in België. "De Vlamingen zelf zien wij overal het initiatief nemen." 17 "Het activisme", zo betoogde Elias, “...was van stonden aan en is ook tot het eind toe niets anders gebleven als een onderdeel van de traditionele Vlaamse Beweging". ${ }^{18}$

Dit was geen beweging die door de Duitsers in het leven werd geroepen. Het was [...] de logische uitgroei van het nationalisme dat steeds in de [Vlaamse] beweging verscholen lag en juist op de vooravond van de oor$\log$ zijn doorbraak zocht van het culturele naar het politieke. ${ }^{19}$

De auteur verwierp met klem elke vooroorlogse invloed van de Duitse regering in België en minimaliseerde de betekenis van Germania voor de Vlaamse beweging. Tijdens de jaren 1960 begon in West-Duitsland een grondig onderzoek naar de invloed van drukkingsgroepen op de Duitse politiek tot 1918. Aanleiding was Griffnach der Weltmacht (1961) van de Duitse historicus Fritz Fischer. De centrale these van dit meesterwerk was dat Duitsland in 1914 zelf een agressie-oorlog begonnen was en vervolgens gevoerd had om een Europese hegemonie te vestigen. Misschien onder invloed van wat er in Duitsland gebeurde, onderzocht de Franstalige historicus José Gotovitch in 1966 de archieven van de Duitse ambassade te Brussel. Hij meende dat daar geen spoor te bekennen was van een voorbereiding op de Flamenpolitik en besloot dat de oorlog een totale breuk in de Duitse politiek veroorzaakt had. Acht jaar later zou hij zich zeer duidelijk uitspreken tegen een invloed van de Alduitsers op de politiek van het keizerrijk. In 1969 poneerde Fischer 
dat het Alldeutscher Verband er louter in geslaagd was de stichting van Germania te bewerkstelligen. Nog dat jaar opperde de Duitse historicus Frank Wende dat er vóór de oorlog een planning noch voorbereiding bestond op de Flamenpolitik. De Duitse regering was, aldus Wende, niet op de hoogte van het Vlaamse vraagstuk. ${ }^{20}$ Horst Lademacher wees daarentegen in 1971 op de betekenis van vooroorlogse rapporten van de Duitse ambassade bij de opbouw van een Flamenpolitik. Wat de oorsprong van het activisme betreft, bevatten de Gedenkschriften van de katholieke voorman Frans Van Cauwelaert, die datzelfde jaar uitgegeven werden, de antithese van wat Elias beweerde. Volgens Van Cauwelaert immers was het activisme een vreemd gewas, "zorgvuldig voorbereid en kunstmatig door de Duitse veroveringspolitiek op de Vlaamse beweging ingeënt".21

\section{Verwetenschappelijking}

In 1974 verscheen het baanbrekende Flamenpolitik en aktivisme van de Leuvense hoogleraar Lode Wils. Het accent verschoof erin naar het Duitse lokken van de Vlaamsgezinden. Het activisme was in dit nieuwe verhaal slechts een "marionettenbeweging". ${ }^{22}$ Wils betoogde dat, gezien het belang dat Berlijn in 1914 plots hechtte aan "nationale bewegingen als middel om [zijn] tegenstanders te ontwrichten", Duitsland de Vlaamse beweging voor zijn kar zou proberen te spannen, al had de Duitse regering vóór de oorlog nooit pogingen in die zin gedaan. ${ }^{23}$ De Flamenpolitik kwam in het werk naar voren als een scharniermoment in de Belgische geschiedenis, daar ze kunstmatig een anti-Belgische stroming, het activisme, op de Vlaamse beweging entte. Tot daar kwam zijn conclusie overeen met die van Van Cauwelaert. Maar de historicus nuanceerde:

[De Duitsers] hebben dat maar gekund omdat de boom ontvankelijk was voor die nieuwe twijg, omdat er dus voldoende verwantschap bestond tussen beide, omdat het antibelgicisme geen volledig 'vreemd gewas' was voor de Vlaamse beweging van 1914.

Volgens hem was, behalve voor één kleine groep in Gent, het initiatief tot het activisme overal uitgegaan van de Duitsers. ${ }^{24}$ In 1985 vergeleek hij de impact van de Flamenpolitik op België met die van de Franse revolutie: Vlaanderen en België waren er voor eeuwen door geraakt. Wils bekeek het activisme binnen het raamwerk van een langetermijnpolitiek van de bezetter die België 
wenste te vernietigen. Bovendien legde de historicus de klemtoon op het feit dat het activisme door de Flamenpolitik in het leven geroepen was. Daarmee zette hij zich af tegen het klassieke geschiedbeeld. Het sprak dus vanzelf dat zijn these een reactie uitlokte. Velen weigerden zijn stellingen te aanvaarden. De voornaamste twistappel in de debatten werd naast de genese van het activisme, de al-dan-niet autonome ontwikkeling van die beweging. De Duitse historicus Frank Wende had daarover alvast een andere opvatting als Wils. Voor hem waren Flamenpolitik en activisme twee parallel verlopende, maar eerst van elkaar onafhankelijke processen. De Duitse inval in België ging zijns inziens niet met een "flamenpolitisch" programma gepaard. Dat de Flamenpolitik vóór het activisme begon - iets wat Elias overigens ook aangegeven had ${ }^{25}$ - betwistte hij.

Over het Vlaams-Duitse tijdschrift Germania schreef Bruno De Corte in 1982 een indrukwekkende licentiaatsverhandeling. Naar hij aangaf, vormde het tijdschrift een schakel in een bredere politiek van het Alldeutscher Verband en de Duitse geopolitiek. Daarbij speelde naast pan-Germanisten en grootindustriëlen ook de marine een grote rol. Rijkskanselier Von Bethmann-Hollweg was, aldus De Corte, slechts het "ventiel" op de imperialistische stoomketel. Inmiddels verkreeg Wils steun voor zijn these bij dr. Ilse Meseberg-Haubold, die datzelfde jaar het activisme een product van Duitse inmenging noemde. In 1989 betoogde Dolderer, die de improvisatie-these van Von der Lancken onderscheef, dat er geen directe lijn bestond tussen de Alduitse agitatie van de jaren 1890 en de Duitse Flamenpolitik. Wel stelde hij vast dat sommige van de personen die zich toen engageerden tijdens de oorlog een belangrijke rol speelden. Met Het Aktivistisch Avontuur (1991) van Daniël Vanacker verscheen een eerste en fraaie monografie over het Gentse activisme. De auteur beklemtoonde daarin sterk de autonome ontwikkeling van het activisme. Hij relativeerde het belang van de Flamenpolitik, die volgens hem een improvisatie was die de rijkskanselier eind 1914 ontdekte als oplossing om de nagestreefde afhankelijkheid van België te combineren met een vorm van politieke zelfstandigheid.

\section{Recente evoluties}

In 2002 stelde Antoon Vrints in Bezette Stad, een knappe synthese over het Antwerpse activisme, dat het initiatief in die stad uit leek te gaan van de Duitse bezetter. ${ }^{26}$ Ook hij beweerde dat de Flamenpolitik een improvisatie was. Wijzelf hebben in 2011 veel sterker de nadruk gelegd op de ideologi- 
sche continuïteit in het Duits-völkische denken waaruit de Flamenpolitik, onderdeel van een Niederlandepolitik, voortkwam. ${ }^{27}$ Drie jaar later gaf Wils een grondig herwerkte versie van zijn werk uit 1974 uit. Volgens hem was de Flamenpolitik een onvoorbereide improvisatie. Maar daarbij "en bij het bepalen van hun oorlogsdoelstellingen, maakten zowel de regeringskringen als de conservatieve Duitse elites [...] gebruik van de völkische opvattingen der Alduitsers". Ook benadrukte de historicus de invloed van allerlei imperialistische pressiegroepen op de Duitse (regerings)politiek. ${ }^{28}$ De ideeën van die nationalistische verenigingen heetten naadloos aan te sluiten bij wat voordien al in het tijdschrift Germania verkondigd werd. Volgens Wils was de Flamenpolitik, "zoals voor het Alldeutscher Verband al voordien [...] een middel tot de opslorping van de Lage Landen als geheel”. ${ }^{29}$

Dolderer trad in 2014 de onderzoeksresultaten van Wils bij voor wat de causaliteit van de Flamenpolitik betreft. Maar hij minimaliseerde enigszins het belang van Germania en betoogde, net als Wende vóór hem, dat de Duitsers bij hun inval in België geen blauwdruk voor een te voeren Flamenpolitik op zak hadden. De historicus meende wel dat de Duitse oorlogsdoeleinden "geheel en al op de leest geschoeid van het Alduitse programma van twee decennia voordien" waren. ${ }^{30}$ In zijn knappe Die Importierte Nation (2020) treedt de Duitse historicus Jakob Müller de visie van Dolderer op de Flamenpolitik als discontinuïteit in het Duitse beleid bij. De völkische retoriek was tijdens de oorlog, aldus de historicus, slechts propaganda. Een grote betekenis voor de Flamenpolitik legt hij bij de impulsen van het Duitse gezantschap in Den Haag. Voor hem provoceerde dit beleid tussen 1916 en 1918 het ontstaan van het Vlaams-nationalisme. ${ }^{31}$

\section{De ondermijnde Godsvrede}

De activistische voorstelling over de aanleiding tot het activisme werd onder meer gesynthetiseerd in Aan het Vlaamsche Volk (1917). Die anoniem uitgegeven brochure was van de hand van de activist H.D. Mommaerts. ${ }^{32}$ Die betoogde dat bij het uitbreken van de oorlog, de voormannen van alle politieke partijen stilzwijgend overeenkwamen voorlopig oude veten, waaronder die over de taalkwestie, te vergeten. De Vlamingen bleven die Godsvrede trouw, de "franskiljons" echter verbraken ze. Ze schandvlekten de Vlaamsgezinden als handlangers van Duitsland, vereenzelvigden de "Germaanse Vlamingen" met de vijand en schilderden de oorlog af als een strijd voor het Latijnendom. Dus moest in België van het conflict gebruikgemaakt worden 
om de vriendschap met de Franse "bondgenoot" (sic) te stimuleren. Om dat te bewijzen, werden enkele krantenuittreksels die begin augustus 1914 in de Franstalige pers verschenen waren, aangehaald. ${ }^{33}$ Zo ook citaten uit de katholieke en Antwerpse Métropole (22 augustus 1914). Sedert de Duitse bezetting, zo vervolgde de brochure, gaven de "Fransgezinden" meer dan ooit uiting aan hun vijandige gevoelens tegenover de Vlamingen. Ter illustratie: het pamflet La Vérité sur la Capitulation d'Anvers dat, blijkens het geschrift, meteen na de val van Antwerpen (9 oktober 1914) op een erg grote schaal verspreid was, om Antwerpen te schandvlekken. Voorts heette het buitenland met anti-Vlaamse aanvallen overstelpt te worden. Aan de hand van drie artikels uit de Belgische vluchtelingenpers (oktober 1914) werd dit geillustreerd.

De brochure haalde voorts een redevoering van de schrijver Maurice Maeterlinck, een artikel van de wallingant Gérard Harry (december 1914) en een van Raymond Colleye (juni 1915) aan als sprekende voorbeelden van die "anti-Vlaamse campagne". De auteur van de brochure beweerde ook dat al in de eerste oorlogsdagen vele "gekende franskiljons" de woorden "après la guerre on ne parlera plus du Flamand!" uitspraken. De publicatie en vooral de erin vervatte visie bleek bijzonder invloedrijk. Zo baseerde Activisten zich deels op wat Mommaerts geschreven had. ${ }^{34}$ Basse hernam op zijn beurt die informatie om te bewijzen dat de "franskiljons" de gelegenheid te baat wilden nemen om het Vlaams en de Vlaamse beweging uit te roeien. ${ }^{35}$ Dat deed ook Faingnaert en wel in nog grotere mate. ${ }^{36}$ Maar ook de loyale Vlaamsgezinde Frans Van Cauwelaert oordeelde ondubbelzinnig dat die anti-Vlaamse campagne de ontwikkeling van het activisme zichtbaar bevorderd had. ${ }^{37}$ Pirenne ging enigszins mee in die redenering. Hij beschreef hoe de Belgische vluchtelingenpers na de val van Antwerpen oude twisten oprakelde en sommige flaminganten ervan beschuldigde een grote verantwoordelijkheid te dragen voor de val van de vesting. Volgens die bladen zou het wel eens uit kunnen zijn met de Vlaamse zaak. Maar hij voegde er wel aan toe dat dit buitensporige taalgebruik zorgvuldig verzameld en becommentarieerd werd door de Duitse pers. Bovendien relativeerde Pirenne de impact van het polemiseren. Het ergerde slechts diegenen die niet het gezond verstand hadden het naast zich neer te leggen. ${ }^{38}$ Willemsen en Elias waren het erover eens dat de Walen en "franskiljons" in hun afkeer voor de Vlaamse beweging als eersten de Godsvrede doorbraken. Het heette dat er al in de eerste oorlogsweken een anti-Vlaamse stemming heerste, die zich uitte in Franstalige persartikels, aanplakbiljetten en fluistercampagnes. Toch stimuleerden die "anti-Vlaamse provocaties" blijkbaar slechts het ontstaan van het activisme. 
Volgens Willemsen zou het activisme zonder die campagne, in bescheidener vorm, ook ontstaan zijn. En Elias beweerde dat er al in november 1914 sprake was van het ontstaan van een "activistische geest", terwijl de meeste antiflamingantische teksten van nadien dateerden en als munitie voor de "activistische propaganda" fungeerden. ${ }^{39}$ Beide historici beriepen zich uitsluitend op Mommaerts, Activisten, Basse en Faingnaert. ${ }^{40}$ Het sprak vanzelf dat hun visie op de "anti-Vlaamse campagne" dan ook grotendeels het activistisch geschiedverhaal zou reflecteren.

Een bronnenonderzoek om te peilen naar het waarheidsgehalte van die "anti-Vlaamse (pers)campagne" werd niet ondernomen. Wils deed dat in 1974 wel. Hij betoogde dat het idee van een anti-Vlaamse campagne "voor méér dan 90 procent overdreven" was. ${ }^{41}$ Willemsen gaf een jaar later toe dat er van een anti-Vlaamse campagne geen sprake was. ${ }^{42}$ Andere auteurs, zoals Lammert Buning, die nog later en op grond van de apologetische propaganda van oud-activisten de stelling betreffende de "anti-Vlaamse campagne" bleven verdedigen, bestreden Wils' visie. ${ }^{43}$ Vanacker stelde in 1991 dat er in de aanloop naar het activisme "franskiljonse prikkels" te bespeuren waren. ${ }^{44}$ In 2012 legde Paul Van Velthoven de klemtoon op de "anti-Vlaamse campagne" als factor in het ontstaan van het activisme. ${ }^{45}$ Frank Seberechts schreef vijf jaar later dat de oproep van de Belgische overheden tot Godsvrede weldra botste op tegenstellingen tussen Vlamingen en Franstaligen die in alle hevigheid naar boven kwamen. ${ }^{46}$ Kortom, het al-dan-niet doorbreken van de "Godsvrede", is nog steeds voorwerp van een historisch dispuut. De eerste onderzoeksvraag behandelt dit beladen concept. Daarbij dient eerst gepeild te worden naar vooroorlogse factoren die een toekomstige Godsvrede konden hypothekeren. Die betreffen de spanningen tussen Vlaamsgezinden en hun tegenstrevers in de twee decennia vóór 1914 (hoofdstuk 1). Is het waar dat deze Godsvrede per definitie "van meet af aan tot mislukken gedoemd" was, zoals Vanacker dat gesteld heeft $?^{47}$ De activisten beweerden alleszins dat zij zich in eerste instantie slechts verdedigden tegen "de franskiljons" die vanaf de eerste oorlogsdagen met hun "anti-Vlaamse campagne" de Godsvrede doorbroken hadden. ${ }^{48}$ Ook vinden we in de (post-)activistische voorstelling van zaken terug dat "de tegenstanders van het Vlaamse recht" na de bezetting van België door Duitsland pas echt provocerend optraden. Klopt het dat vanaf de herfst van 1914 de anti-Vlaamse campagne die al in augustus begon, geïntensiveerd werd? Werd er na de val van Antwerpen in Belgische en Franstalige persorganen die in het neutrale Nederland, Frankrijk en het Verenigd Koninkrijk (her)opgericht werden een anti-Vlaamsgezinde perscampagne gevoerd? Of waren de Vlaamsgezinde gemoederen door de oorlog 
overspannen geraakt waardoor sommige flaminganten onbestaande zaken gingen zien en bestaande disproportioneel opblazen? Speelden daarbij herinneringen aan vooroorlogse twisten met hun tegenstrevers een rol? Of was die (vermeende) campagne een voorwendsel om te collaboreren? Ging het om een Duitse uitvinding $?^{39}$ Dit onderzoek werd zowel in de periode vóór als in die na de val van Antwerpen zeer grondig gevoerd. Daarvoor hebben we de Belgische (vluchtelingen)pers voor de eerste maal sedert 1974 aan een diepgaande analyse onderworpen en dit voor de periode van augustus 1914 tot juli $1915 .^{50}$ De synthese daarvan berust op de lezing van duizenden artikels in honderden dagbladedities.

We hebben ook nooit eerder onderzochte beweringen bestudeerd uit de activistische propaganda die een rol speelden in de beïnvloeding van de publieke opinie (hoofdstuk 2 en 3). Hierbij dient opgemerkt te worden dat Flamenpolitik en activisme tot nu toe voornamelijk vanuit louter politiek oogpunt geanalyseerd werden. Er was over het algemeen geen oog voor tekstkritiek en voor andere - filologische - invalshoeken die hier wel aan bod zullen komen. In deze studie werden ook egodocumenten en, vooral uitgegeven, archieven (onder andere de Rijks Geschiedkundige Publicatiën en de Tätigkeitsberichte van het Duitse gouvernement-generaal in Brussel) gebruikt. Respectievelijk voor buitenlandse inwijkelingen in België en voor het zogenaamde "verduitste" Antwerpen (hoofdstuk 1, par. 2) bieden de "vreemdelingendossiers" uit het Rijksarchief en de dossiers van het naoorlogse sekwester een interessante bron van informatie. Het streven naar bondigheid in het kader van het opzet van dit werk rechtvaardigde echter niet hun gebruik. In onze bibliografie werden evenwel de repertoria weerhouden.

\section{Flamenpolitik en activisme}

Wanneer en hoe de Duitse propaganda gericht op de Vlaamse beweging precies op gang kwam, vormt het onderwerp van de tweede onderzoeksvraag. Werden door de bezetter vóór de val van de vesting Antwerpen en in de nasleep ervan inbreuken op de Godsvrede of uitingen die kaderden in een anti-Vlaamse campagne uitgebuit? Want blijkens hun activiteitenverslagen vonden de Duitse diensten dat zij er geen enkel belang bij hadden om de uitdrukking van politieke twisten tussen de Belgen, inzonderheid die in verband met de nationaliteitenkwestie, te verhinderen. ${ }^{51}$ Werden daarbij dan met name in de pers die de bezetter vanaf september 1914 zelf oprichtte en leidde, maar als "Belgisch" of "Vlaams" doorging, alternatieve feiten verspreid? Zat 
er een lijn in deze propaganda? Op welke bronnen beriep ze zich? En hoe paste ze in de Flamenpolitik? Hiervoor werden er ook Duitse en Oostenrijks-Hongaarse dagbladen onderzocht. Tot op heden werd een mogelijke inbreng vanuit Wenen (en Boedapest) nooit bestudeerd. Overigens werd de Flamenpolitik over het algemeen te vaak vanuit een louter Duitse en een Vlaams-Belgische invalshoek benaderd. Dit terwijl de hele politiek gericht was op de Nederlanden (hoofdstuk 4).

Volgens de activisten was de verspreiding van het pamflet La Vérité sur la Capitulation d'Anvers belangrijk in de beroering der geesten. Werd dat schotschrift werkelijk al in oktober 1914 verspreid? Of dateert het van veel later ?5 In het vlugschrift werd het "verraad" van het Antwerpse stadsbestuur bij de capitulatie van de vesting gehekeld en aangekondigd dat de havenstad door de Britten bij de bevrijding verwoest zou worden. La Vérité dat eindigde met "l'ère du flamingantisme est finie", lijkt het toppunt van de beruchte anti-Vlaamse campagne te zijn. Antwerpen Boven, het blad van August Borms, de leraar en prominente activist, beweerde in april 1915 op grond van die kreet dat de "naamloze lasteraars" zichzelf verraadden als "franskiljons". ${ }^{53}$ Dat dit pamflet van Franstalige makelij is, wordt ook vandaag nog vaak aangenomen in de geschiedschrijving. Maar is dat wel het geval of hebben we hier te maken met een vernuftige Duitse vervalsing? Bouwde die misschien voort op Duitse propaganda in de nasleep van de val van Antwerpen? (hoofdstuk 5). In mei 1915 verschenen er nog twee voor de Vlaamse beweging provocerende Franstalige pamfletten. Het betreft La Politique Belge après la Crise - Un Parti National en het Appel aux Wallons. ${ }^{54}$

De samenhang ervan met La Vérité zal onderzocht worden. Zo ook wat de onderliggende betekenis was van die trits vlugschriften, die blijkbaar hetzij een uitkristallisering was van een anti-Vlaamsgezinde sfeerschepping, hetzij van een volgehouden Duitse inspanning in het kader van de Flamenpolitik. Tijdens de lente en de zomer van 1915 doken er nog geruchten op, die van dien aard waren om de Vlaamsgezinden te verontrusten. Bovendien begon de Flamenpolitik - anderen zullen zeggen: het ontwaken van de activistische gedachte - ook in Nederland voet aan de grond te krijgen. Wat was hier het kantelmoment? Speelden de vlugschriften waarvan sprake een rol in de uitbreiding van de Flamenpolitik en het activisme naar Nederland toe? Deden de Duitse diensten in dat land een beroep op bepaalde Nederlanders? Of namen Vlamingen en Nederlanders zelf het initiatief? Bestond er een ideologische verwantschap tussen het politiek denken van sommige Nederlanders en wat Duitsland in Europa voor ogen stond? Daarbij wordt de interactie tussen het beleid van de Politische Abteilung in Brussel en dat 
van het Duits gezantschap in Den Haag onderzocht (hoofdstuk 6). Vanaf de zomer van 1915 werd de kloof tussen activistische en loyale Vlaamsgezinden, door de activisten smalend als "passieven" of "passivisten" omschreven, steeds groter. Vanaf 1916 tot het einde van de oorlog toe werd in de Duits-activistische propaganda niet alleen beweerd dat het uit zou zijn met de taal van de Vlamingen indien de geallieerden de oorlog wonnen, maar ook dat de Vlaamse soldaten aan het front moedwillig uitgemoord werden. De stelling dat "Nederlandstalige soldaten sneuvelden omdat ze de bevelen van Franstalige officieren niet begrepen" sloot hierbij aan. Maakten al deze beweringen deel uit van wat de "franskiljons" vertelden en had Berlijn ze maar te recupereren voor eigen gebruik? Hoeveel Vlaamsgezinde, hoeveel activistische en hoeveel Duitse inbreng schuilde er in die stellingen? En kan men die steeds radicalere propaganda terugkoppelen naar eerdere propagandamotieven? (hoofdstuk 7) In ons algemeen besluit ten slotte worden de onderzoeksresultaten getoetst aan de gangbare visies binnen de historiografie over de aanleiding tot en de oorzaak van het activisme, kortom aan de verhouding tussen Flamenpolitik en activisme. Daarbij passen we het geheel in het debat over de (ideologische) continuïteit van de Flamenpolitik in. 



\section{HOOFDSTUK 1 HET VOOROORLOGSE SPANNINGSVELD}

Vóór de Eerste Wereldoorlog bestonden er in België spanningen tussen politieke stromingen die in het raamwerk van de parlementaire democratie opgevangen werden. Polarisatie tussen arbeid en kapitaal, vrijzinnigen en katholieken en rondom de taalkwestie werd zo gekanaliseerd. Het sprak voor zich dat de sterkte van de Godsvrede die tijdens de Eerste Wereldoorlog afgekondigd werd, gekoppeld was aan die binnenlandse politieke situatie. In dit hoofdstuk zullen we het vooroorlogse politieke spanningsveld onderzoeken, met oog voor de aspecten die zo'n Godsvrede konden ondermijnen. Cruciaal daarin is het geradicaliseerd nationaal-imperialisme dat sedert 1900 in heel Europa voelbaar werd. Dit versterkte het bestaande Duits-Frans antagonisme. Hoe verhielden völkische en imperialistische organisaties zich tot het Duitse staatsapparaat en de Vlaamse beweging? Want daarin was ook een germanofiele component aanwezig. Daartegenover stond een militante Waalse beweging. Verzwakte de polarisatie tussen beide stromingen de eenheid van België met het oog op een Godsvrede? Het zal blijken dat spanningen zich vooral uitkristalliseerden rond het bestaan van het tijdschrift Germania, de zogenaamd "verduitste" haven van Antwerpen, de pan-Latijnse agitatie van sommige wallinganten, de germanofiele acties van Vlaamsgezinden en het perspectief op een Belgisch-Nederlandse Entente. 


\section{Het völkische denken}

Vanaf de negentiende eeuw deed het völkische denken overal in Europa opgeld. ${ }^{1}$ Het ging ervan uit dat leden van eenzelfde taalgroep verbonden waren door bloed en "ras" en dat dit hun nationaliteit of "stam" bepaalde. Nergens waren deze gevoelens zo sterk aanwezig als in Duitsland. Dat land was in de periode tussen 1864 en 1871 verenigd door een trits oorlogen. De laatste daarvan werd gevoerd tussen een coalitie onder leiding van Pruisen enerzijds en Frankrijk anderzijds. De herinnering aan de vernederende nederlaag van 1870 die Frankrijk erdoor beleefde, versterkt door de afstand van Elzas-Lotharingen en torenhoge herstelbetalingen zorgden voor een opgekropt Frans revanchisme. Anderzijds was het nieuwe keizerrijk voor sommige Duitsers "onaf”. Want volgens de völkische definitie van een natie dienden ook kleine "Germaanse staten" als België - minstens Vlaanderen -, Nederland en Denemarken onder de ene of de andere vorm een deel van Duitsland te worden. Vanaf 1890 begonnen zulke stemmen weerklank te krijgen bij de elites van het Rijk. Wilhelm II, een jonge en ambitieuze keizer, had twee jaar eerder de troon bestegen. De voorzichtige diplomatieke koers die Duitsland sedert twee decennia voer, werd, samen met kanselier Otto von Bismarck, overboord gegooid. Deze onbehendige politiek had vérstrekkende gevolgen. Het keizerrijk kwam gaandeweg in een isolement terecht: de Frans-Russische Entente dateerde van 1892. Duitsland werd in de "Driebond" ( $\left.{ }^{\circ} 1882\right)$ bijgestaan door de relatief zwakke bondgenoten Oostenrijk-Hongarije en Italië. Dat laatste land was bovendien nog de facto door Frankrijk in 1902 uit de alliantie losgeweekt. Het zou tijdens de Eerste Wereldoorlog aanvankelijk neutraal blijven om zich in 1915 bij het kamp van de geallieerden te voegen. In 1896 begon het keizerrijk met een Weltpolitik, aangedreven door een imperialistisch vlootbeleid. Duitsland vervreemdde zo van het Verenigd Koninkrijk, dat op zijn beurt toenadering zocht tot Frankrijk (Entente Cordiale, 1904) en Rusland (Triple Entente, 1907). De nieuwe koers had ook enorme gevolgen voor het interne politieke bestel in Duitsland. Om te voorzien in een sterke vloot, moesten er immers hoge kredieten in de Rijksdag gestemd worden. Het compromis dat daarvoor bedacht werd, was de zogenaamde Sammlungspolitik. Die voorzag erin dat de Pruisische landadel de vlootkredieten stemde in ruil voor de toezegging van de lobbygroep van de grootindustrie om hogere toltarieven toe te laten. De volksmassa's moesten enthousiast gemaakt worden voor dit beleid en daarvoor bleken de Alduitsers - vanaf het begin waren die op de bres gaan staan voor de vlootagitatie - uitstekende gangmakers. Tussen 1899 en 1902 werkten ze 
hieromtrent samen met de Duitse regering. Tot hun frustratie verkoos die uiteindelijk (tijdelijk) goede relaties met het Verenigd Koninkrijk en werden er geen nieuwe kolonies verworven. De Alduitsers lieten zich evenwel niet ontmoedigen. Vanaf de laatste twee decennia van de negentiende eeuw hadden ze machtige pressiegroepen (mede)opgericht en ontwikkeld. Zo onder andere het Kolonialverein ( $\left.{ }^{\circ} 1882\right)$, het Alldeutscher Verband en het door de overheid gestichte Flottenverein $\left({ }^{\circ} 1897\right)$.

Het Alldeutscher Verband verenigde een koloniale en een völkisch-imperialistische stroming. Die laatste was gericht op de implementatie van een nieuwe en Duitse orde in Europa. Gaandeweg zou ze de eerste stroming overvleugelen. Met name tijdens de verkiezingscampagne van 1906 deden de Duitse conservatieven opnieuw en succesvol een beroep op de organisatie. Toen in 1909 een nieuw kabinet onder leiding van kanselier Von Bethmann-Hollweg aan de macht kwam, wilde de Verbandsleiter Heinrich Claß er "in stilzwijgende verstandhouding" mee samenwerken. Dat gebeurde in 1911 naar aanleiding van een ernstig incident tussen Frankrijk en Duitsland omtrent Marokko. Berlijn wilde immers niet toestaan dat Parijs daar meer invloed verwierf zonder zelf territoriale compensaties te verkrijgen. Hoewel een conflict afgewend werd, meenden vele Duitse, conservatieve krachten dat enkel een oorlog - ook binnenlands - orde op zaken kon stellen. In die overtuiging werden ze gesterkt toen in 1912 socialisten overtuigend de verkiezingen wonnen. Het Alldeutscher Verband vormde daarop een unie van "staatsbehoudende krachten". Die omvatte onder andere de Pruisische landadel en de industriëlen. Ze ging zwaar wegen op de regeringspolitiek. Het integraal-nationalistische denken begon zo nog sterker de Duitse elites te begeesteren. Er werden bovendien nieuwe organisaties opgericht, zoals het Wehrverein $\left({ }^{\circ} 1912\right)$, de tegenhanger van het Flottenverein. De sterke man daarin was August Keim, de latere militaire gouverneur van Belgisch-Limburg. Keim behoorde achtereenvolgens tot de top van het Flottenverein en van het Alldeutscher Verband. In 1911 was hij toegetreden tot de Jungdeutschlandbund. Die organisatie was gesticht door oorlogsveteraan en hervormer van het Ottomaanse leger Colmar von der Goltz. Een jaar later werd Moritz von Bissing lid. Ze zouden respectievelijk de eerste en de tweede gouverneur-generaal van bezet België worden. ${ }^{2}$ Het doel van de Alduitsers bestond erin om (via een oorlog) een door Duitsland gedomineerd Mitteleuropa te stichten. In het westen en het oosten zou een vergroot Duits Rijk "beschermd" worden door vazalstaten. Het sluitstuk in het westen daarop was een Duits Groot-Nederland, belangrijk door de kanalen, de kusten, de spoorwegen en - niet het minst - de havens van Antwerpen en Rotterdam. 
Die waren cruciaal met het oog op een oorlog met het Britse Rijk, met als inzet de wereldheerschappij. Met dat in het achterhoofd interesseerden Alduitsers zich vanaf de jaren 1890 voor de Vlaamse beweging. In de wagneriaanse Brusselse kring De Distel werden individuele contacten met Vlaamsgezinden gesmeed.

Maar het roekeloze optreden daar van de pan-Germanisten Harald Graevell en Hermann von Pfister, die in dat kader te uitdrukkelijk de lof van een verduitst Vlaanderen in een Alteutenbond bezongen, zorgde voor een breuk. Met name de Brusselse advocaat Alfons Prayon-Van Zuylen trok van leer tegen de pan-Germanistische ideologie. Eerst gebeurde dat zonder veel succes, maar op 16 mei 1897 slaagde hij er met enkele gelijkgestemden in een Manifest van de Vlaamsche Volksraad op te stellen. Die "Volksraad" was een soort studieparlement zonder enig mandaat. Maar blijkens het Manifest sprak hij in de naam van het Vlaamse volk. De annexionistische eisen van het Alldeutscher Verband werden erin afgewezen. Vlamingen waren Germanen, maar geen Duitsers. Hun taal was het Nederlands en niet het Hoogduits. Ze stonden erop de Belgische onafhankelijkheid te bewaren. De Duitsers heetten weliswaar stamverwanten, maar geen landgenoten te zijn. Het Duitse Rijk werd erin als een bevriende, maar vreemde mogendheid beschouwd. Elke Vlaming die het hier niet mee eens was, zo beweerde het Manifest, sprak louter in eigen naam. In België vond het schrijven geen weerklank, maar in kringen van het Alldeutscher Verband weerklonk woede en onbegrip. De semi-officiële Kölnische Zeitung gaf de ondertekenaars principieel gelijk, maar oordeelde toch dat ze de bedoelingen van het Alldeutscher Verband verkeerd inschatten. Op 4 juli 1897 onderstreepte Verbandsleiter Hasse opnieuw die goede bedoelingen. Maar dat de Vlamingen zich een volk waanden, beweerde hij niet te begrijpen: ze waren niet eens een aparte stam! Een tweede toenaderingspoging ging uit van de Alduitser Theodor ReismannGrone, de hoofdredacteur van de Rheinisch-Westfälische Zeitung, het orgaan van de grootindustrie te Essen. Hij onderhield zeer nauwe betrekkingen met de bedrijfswereld en dan inzonderheid met de staal- en wapenfabrikant Krupp. Reismann-Grone behandelde in een rapport uit 1897 dat ook Berlijn bereikte uitvoerig de Vlaamse beweging. In het document werd betoogd dat Nederland voor de "Duitse stam" veroverd moest worden door in België het Vlaamse element te stimuleren. Op 12 december 1897 werd op een vergadering van het Verband in Leipzig de stichting van het tijdschrift Germania goedgekeurd. Een tweede rapport (1898) werd door de voorzitter van het Alldeutscher Verband, Ernst Hasse, opgesteld als antwoord op een nooit uitgevoerd invasieplan van de Nederlanden door de Duitse marine. Een Duits 
België, zo betoogde hij, zou Nederland vreedzaam tot het Duitse Rijk doen toetreden. Op 18 april 1900 werd het schrijven naar de Duitse ambassade in Brussel gestuurd. Het idee van een Duitse omklemming van Nederland door België om de eerste staat in de Germaanse invloedssfeer te dwingen, was oorspronkelijk niet van Hasse afkomstig. Tenslotte had de germanist Carl Theodor Jaensch, die in contact stond met de kringen rond het radicaalrechtse Bayreuther Kreis en aan het eind van de negentiende eeuw door de Distel de Vlaamse beweging had leren kennen, in 1894 al opgemerkt:

Welke waarde echter een definitieve verbroedering met de Vlamingen voor ons moet hebben, komt al daaruit naar voren, dat dra ook Holland zich nauwelijks van zulks meer onttrekken kan; daar het tussen België en het keizerrijk gelegen is, zou een verdere isolering onder zulke omstandigheden [voor Nederland] steeds onnatuurlijker worden. ${ }^{3}$ [B.Y.]

Tussen 1898 en 1905 verscheen het tijdschrift Germania te Brussel. Naast Duitsers en enkele Nederlanders werkten er een aantal prominente Vlaamsgezinden aan mee (onder wie - de opportunistische? - Prayon-Van Zuylen). Het blad stelde zich voor als een cultureel orgaan, erop gericht om de Duits-Vlaamse betrekkingen aan te moedigen. Onder dat laagje vernis ging een Alduits propagandablad schuil, gefinancierd door Reismann-Grone en gepatroneerd door het Alldeutscher Verband. De eerste twee hoofdredacteuren van Germania waren baron A.J.A. von Ziegesar en zijn adoptiefzoon, de atheneumleraar en Brusselse flamingant Jozef Haller von Ziegesar. Die laatste nam van 1901, het jaar waarin de baron overleed, tot 1904 de taak op zich. Hij was actief in het vrijzinnige Brusselse flamingantisme, vooral in de kring rondom Frans Reinhard en Maurits Josson. In de laatste jaargang was de Arische racist Ludwig Wilser aan zet als hoofdredacteur. Doorheen de edities van Germania keerden verschillende thema's weer: een Duits Mitteleuropa; de Nederlanden als westelijk sluitstuk daarop; de Vlaamse beweging; de "rassenkunde" en, ten slotte, Zuid-Afrika en de Boeren. Tussen 1899 en 1902 woedde daar een oorlog tussen de Zuid-Afrikaanse republiek en Oranje-Vrijstaat enerzijds en het Verenigd Koninkrijk anderzijds. Het verzet van de kleine Boerenrepublieken kon op grote steun rekenen vanwege Alduitsers - zij droomden van een Duitse expansie in die contreien - maar ook van sommige Nederlanders en Vlaamsgezinden. Josson en Reinhard bijvoorbeeld ondersteunden de zaak van de Boeren. De eerste was tijdens de Boerenoorlog zelfs in Zuid-Afrika gaan vechten en werd er door de Britten gevangengenomen. De völkische aantrekkingskracht jegens hun "stamgenoten" was blijkbaar sterk aanwezig. 
Germania kon op dit gevoel appeleren om Vlaamsgezinden aan te trekken. Bij die bespeling van een Germaanse solidariteit voegde het een interesse toe voor de (havens van de) Nederlanden. Zodus kon Nederland, zo betoogden Duitse auteurs, maar beter vóór het uitbreken van een conflict eieren voor zijn geld kiezen en aansluiten bij een Duitse douane-, post- of maritieme unie. In het debat rond een Nederlands-Duitse tolunie rond de eeuwwisseling speelde Germania de rol van opzweper. Er werd op gehamerd hoe Nederland Duitsland zogezegd nodig had om zijn commerciële en koloniale belangen te vrijwaren. De Vlaamse beweging bleek dan weer geschikt om de twee in de middeleeuwen "ontstolen Duitse dochterstaten", Nederland en België, nader tot het Rijk te brengen. Natuurlijk was het kleine tijdschrift, in weerwil van wat Reismann-Grone gehoopt had, niet bij machte om in België de Franse invloed door de Duitse te neutraliseren. Het verdween uiteindelijk toen Reismann-Grone de geldkraan toedraaide.

In de historiografie verwijst men steevast naar het feit dat het blad niet lang verscheen en over weinig abonnees beschikte (dat laatste bezag de Duitse diplomatie trouwens niet als een obstakel voor het welslagen ervan). ${ }^{4}$ Maar het snijdt geen hout de invloed van het tijdschrift daaraan af te meten. Germania was een denktank die over een indrukwekkend aantal medewerkers beschikte. Bovenal konden de Alduitsers een netwerk opbouwen. Even belangrijk is de vaststelling dat Germania blijkbaar getolereerd en zelfs geprezen werd binnen de Vlaamse beweging, zoals in de katholieke Dietsche Warande en Belfort. ${ }^{5}$ Er werden geregeld titels van völkisch-racistische inslag uit Germania in besproken. Op zes jaar tijd verschenen er welgeteld drie artikels in het katholieke orgaan die het Duitse imperialisme bekritiseerden. En dat was dan nog meestal vanwege een gepercipieerde antikatholieke inslag. De directe invloed van de Germania-episode was het meest ingrijpend in Brussel, waar het blad over de sterkste basis beschikte. Op 27 mei 1906 behoorde Haller samen met Josson tot de kandidaten voor de Vlaamse Volkspartij ( $\left.{ }^{\circ} 1894\right)$ die bij de verkiezingen voor de Kamer van Volksvertegenwoordigers zonder succes een lijst neergelegd had. ${ }^{6}$ Ook nadien bleef de samenwerking tussen beiden bestaan. Net als een aantal andere Germania-medewerkers belandden ze in het activisme of in de Flamenpolitik. Een ander gevolg van de hele Germania-episode is dat de medewerking van een aantal flaminganten aan het tijdschrift de negatieve beoordeling van de Vlaamse beweging bij tegenstrevers versterkt heeft. Het Germania-verhaal had anderzijds de interesse voor Vlaanderen en de Vlaamse beweging in Alduitse kringen aangescherpt. Die waaierde uit naar Duitse en Oostenrijkse organisaties en personen. Verbandsleiter Hasse had zijn naam aan Germania 
verleend en zijn opvolger, Heinrich Claß, zou de Alduitse Westpolitik voortzetten. Invloedrijke personen als de econoom Arthur Dix en de Oostenrijkse academicus Paul Samassa - tijdens de oorlog zou die mee de Alduitse oorlogsdoelen opstellen - hadden aan het tijdschrift meegewerkt. Andere Duitse medewerkers bleven ook actief.

De historicus Karl Lamprecht zou bijvoorbeeld in 1914 en 1915 nog twee studiereizen naar België ondernemen en de bezetter informatie verschaffen. De advocaat Fritz Norden verzorgde dan weer oorlogspropaganda. Graevell en Von Pfister, die na 1898 door het Alldeutscher Verband gedesavoueerd waren, lagen in 1908 mede aan de basis van de stichting van het theosofische Guido von List-Gesellschaft, dat overigens nog Germania-medewerkers aantrok. Hun volgehouden contacten verklaren waarom ze nog gezamenlijk zouden optreden tijdens de Eerste Wereldoorlog. Germania had ook de banden met de Nederduitse traditie aangehaald, onder meer door het aantrekken van Karl Theodor Gaedertz, die het werk van Fritz Reuter uitgaf. In 1904 werd te Hamburg een vereniging opgericht van liefhebbers van de Nederduitse taal en literatuur. Twee jaar later nam die de naam Quickborn aan, een verwijzing naar de dichtbundel van Klaus Groth uit 1852. ${ }^{7}$ De kring oefende een zekere aantrekkingskracht uit op sommige Alduitsers.

Ook sociaal-darwinisten hadden interesse voor het blad betoond. Een daarvan, de econoom Julius Wolf, stichtte in 1904 het Mitteleuropäischer Wirtschaftsverein. Het werd door het Duitse hof en door toppolitici uit Oostenrijk-Hongarije gesteund. Omdat het Mitteleuropa-concept tijdens de Eerste Wereldoorlog enorm aan belang toenam, is het evident dat de figuren en organisaties die zich binnen dit netwerk bevonden, een sleutelrol zouden vervullen. Ook het Nederlandse aandeel binnen de deining die Germania teweegbracht, mag niet verwaarloosd worden. In de kolommen van het Zeitschrift für Sozialwissenschaft van het Verein für Sozialwissenschaft dat Wolf ook opgericht had, vinden we bijvoorbeeld de Nederlandse socioloog Sebald Rudolf Steinmetz terug. Tijdens de Eerste Wereldoorlog was die redactielid van het pro-Duitse tijdschrift De Toekomst van de journalist Valckenier Kips. Die laatste had als hoofdredacteur van het pro-Duitse Utrechtsch Dagblad omtrent de eeuwwisseling samen met Germania duchtig propaganda gevoerd voor een Duits-Nederlandse tolunie. Die vooroorlogse banden zijn belangrijk omdat er een verstrengeling bestond tussen de belangen van de Duitse regering en die radicale nationalisten. Na 1905 bleef de druk van alles wat völkisch was in Duitsland op de Nederlanden bestaan. Uit de vergaderingen van het Alldeutscher Verband bleek dat de Flamenfrage ook toen nog niet van de baan was. Wel begon rond 1910 een deel van de Alduitsers er zijn geduld 
onder te verliezen. Dat verwachtte niets meer van die Vlaamse beweging. Een oorlog moest orde op zaken stellen. In het massaal verkochte boek Wenn Ich der Kaiser Wär liet Heinrich Claß in 1912 België en Nederland in een onvermijdelijk gewaand conflict de "keuze" tussen de Entente en Duitsland. Het eerste scenario zou leiden tot een inlijving door Pruisen. Het tweede zou hen de plaats van bondsstaat in het Duitse Rijk toebedelen. Die toekomstvisie werd populairder, ook bij de Duitse elites. Want in het völkische denken was België een satellietstaat van Frankrijk en een vijandige toegangspoort tot Duitsland. Zo'n narratief sloot goed aan bij het Hollands-protestantse zelfbeeld, dat na de Belgische revolutie van 1830 gekrenkt was. In Duitsland was men daar ook van op de hoogte. Niet voor niets had Bethmann-Hollweg al vóór de oorlog opgemerkt dat de Nederlanders, ondanks alle tegenstrijdige verzekeringen, "1830" niet helemaal verteerd hadden. ${ }^{8}$

Tussen het Nederlandse nationalisme en zijn Duitse tegenhanger bestond er een onmiskenbaar verwantschapsgevoel. Het contrarevolutionair orangisme domineerde vanaf 1814 de Nederlandse politiek. De politici die gaandeweg de toon aangaven, bezagen "volkssoevereiniteit [als] een on-Nederlands fanatisme $[\ldots]$ in strijd met een rationele en tolerante verlichting, waaruit trouwens de katholieken uitgesloten moesten blijven". 'Toen de ancien régime-samenlevingen zich in moderne natiestaten transformeerden, kwam Nederland in het conservatieve kamp van de Duitse romantiek terecht. De Belgische revolutie heeft dit gegeven versterkt. ${ }^{10}$ Net als in de Duitse staten bestonden er in Nederland anti-Franse ressentimenten en werd België, conform het völkische gedachtegoed, beschouwd als een tegennatuurlijke staat met de Vlamingen als een soort halve Nederlanders. Ook na de revoluties van 1848 en het aannemen van een "liberale" grondwet door Nederland bleef dit het geval.

Bij vele Vlaamsgezinden was een völkisch verwantschapsgevoel met de Nederlanders aanwezig. De grootste afwijking tussen het Belgische geschiedverhaal en het Vlaamsgezinde werd in de negentiende eeuw dan ook de opvatting over het Verenigd Koninkrijk der Nederlanden, dat tussen 1815 en 1830 bestond. Dat werd in de Vlaamsgezinde versie afgeschilderd als een gezegend tijdvak, waarin de volkstaal algemeen verspreid zou geweest zijn. ${ }^{11}$ Zo beweerde de liberale hoogleraar Paul Fredericq dat de Belgische revolutie de "opbeuring der Nederlandse taal en der Nederlandssprekende bevolking van België" plotseling stuitte. Met zin voor overdrijving schreef hij dat nadien de overgrote meerderheid van die bevolking verkeerde "in een staat van volkomen verwildering, onwetendheid en onverschilligheid ten opzichte der gedachten die de overige beschaafde naties bezielden...." ${ }^{12}$ 
Tijdens de hele negentiende eeuw was er overigens amper belangstelling geweest van Nederlandse filologen voor de Vlaamse beweging. Pas rond de eeuwwisseling veranderde dit enigszins. De Boerenoorlog werkte als een katalysator in de betrekkingen tussen de Vlaamsgezinden en Nederland. Een Nederlands-Vlaamse uitkristallisering van het völkische denken was het Algemeen Nederlands Verbond dat de culturele samenhorigheid tussen Nederland, Vlaanderen, de Nederlandse kolonies en Zuid-Afrika wou versterken. ${ }^{13}$ Die organisatie had zich vanaf haar ontstaan vaak welwillend tegenover Duitsland opgesteld en positief over de Duits-Vlaamse contacten bericht. ${ }^{14}$ Volgens de lijst van buitenlandse abonnees op Neerlandia, het verbondsorgaan, was de belangstelling wederzijds. Zo waren er in 1908 meer dan een kwart abonnees afkomstig uit Duitsland of de kolonies van het keizerrijk. ${ }^{15}$

De völkische aantrekking van de flaminganten tot Nederland en Duitsland, mag niet doen vergeten dat de Vlaamse beweging als een soort Belgisch cultuurnationalisme in het kielzog van het enthousiasme rond de Belgische revolutie ontstaan was. Ze wou de volkstaal opwaarderen om de eigenheid van België tegen Frankrijk te accentueren. Maar anderzijds schreef ze zich al tijdens de late negentiende eeuw in binnen een Europese tendens, waarbij het criterium om tot een natie te behoren gaandeweg van gedeelde traditie, geloof en aanhankelijkheid aan de instellingen opschoof naar völkische criteria. Ze evolueerde tot een stroming die een gelijkberechtiging vroeg van een Vlaamse subnatie binnen België. Rond 1848 waren haar doelen dubbel. Enerzijds de vaderlandse "Nederduitse" taal verdedigen tegenover Frankrijk en anderzijds diezelfde volkstaal verheffen om te concurreren met de verfranste elites. Maar tijdens de katholiek-liberale strijd die vanaf de jaren 1860 intensiveerde, kwam ze voornamelijk terecht in het klerikaal-conservatieve kamp, dat het verst verwijderd was van de ideeën van de Verlichting die in Frankrijk haar oorsprong vond. Zo maakte ze eerst de liberale partij ( $\left.{ }^{\circ} 1846\right)$ en vervolgens ook de socialistische partij $\left({ }^{\circ} 1885\right)$ tot tegenstander. Tussen 1871 en 1916 kende België, zes jaar niet te na gesproken, onafgebroken homogeen-katholieke regeringen. Het was in die periode dat de taalwetten aan een verhoogd ritme tot stand kwamen. Tussen 1884 en 1901 zetelde er in de Belgische regering, in het beste geval, nooit meer dan één gekozene uit Wallonië. ${ }^{16}$ De taalwetgeving had niet langer als bedoeling om het Nederlands faciliteiten te verschaffen in Vlaanderen, maar wel om het wettelijk op basis van gelijkheid met het Frans te plaatsen. Een symbolisch hoogtepunt was de stemming van het wetsvoorstel, ertoe strekkende de twee grote landstalen wettelijk op gelijke voet te plaatsen in wetten en koninklijke besluiten. Dat werd in 1895 door de katholieke volksvertegenwoordigers Edward Core- 
mans en Juliaan De Vriendt ingediend en twee jaar later in de Kamer aangenomen. Maar in de Senaat werd het geamendeerd. Het Nederlands zou slechts het statuut van "officiële vertaling" toebedeeld krijgen. Dit bracht een enorm buitenparlementair verzet op de gang. In 1898 werd de "Gelijkheidswet" alsnog in de Kamer en de Senaat gestemd. Maar na 1900 ging de taalwetgeving trager vooruit. Dat had vooral te maken met de invoering in 1899 van de evenredige vertegenwoordiging. Het meerderheidssysteem, zoals dat vandaag bijvoorbeeld nog in het Verenigd Koninkrijk bestaat, werd daarmee afgeschaft. De klerikale regeringen zouden nog bijna twee decennia regeren, maar moesten steunen op socialistische of liberale volksvertegenwoordigers, die nu veel talrijker aanwezig waren in het parlement. Toch belandde de vernederlandsing van de universiteit van Gent op de parlementaire agenda en werd in 1914 een schoolwet gestemd. Die bepaalde dat de streektaal (i.c. de taal van de meerderheid der leerlingen) de voertaal was, behalve in Brussel en de taalgrensstreek. Voor sommige flaminganten was die wet een bittere teleurstelling, of dat verkondigden ze tenminste.

Er was in de laatste jaren vóór de oorlog alleszins een klimaat ontstaan waarin verschillende groepen gefrustreerd waren. Uiteraard de liberalen en socialisten, die reeds decennia van de uitvoerende macht verstoken waren. Maar ook de Vlaamsgezinden. Want uitgerekend op het moment dat hun beweging in bredere lagen van de bevolking begon door te breken, konden ze minder snel tegemoetkomen aan de eisen van hun kiespubliek. Mede uit dit ongenoegen kwam een spanning tussen hun Vlaams en hun Belgisch bewustzijn voort, die vóór de Eerste Wereldoorlog evenwel niet leidde tot de oprichting van een anti-Belgische partij, drukkingsgroep of persorgaan. Dat de sympathieën voor "1830" ondergraven werden, werkte die spanning in de hand. Mede daarom kon de schok van de oorlog een zeer kleine groep Gentse flaminganten eind oktober 1914 radicaliseren. Op 1 november vertrouwde één ervan, de Antwerpse geschiedenisstudent Leo Picard, zijn dagboek toe dat hij "anti-Belg" was en zijn hoop op een Duitse overwinning stelde. Zijn doel was het bekomen van een "Groot-Nederland". Picard voegde eraan toe: "Desnoods liever Duitser dan Belg." 17

Het is evident dat het bestaan van een gefrustreerde, linkse Waalse beweging, die de "taalwetterij" virulent bestreed en medeverantwoordelijk was voor de stagnering ervan, nog meer olie op het vuur van het Vlaamsgezind ongenoegen goot. Die Waalse beweging ontstond oorspronkelijk in Vlaanderen. Op de eerste Waalse congressen (1890-1893) was drie vierde van de aanwezigen dan ook afkomstig uit Vlaanderen en Brussel. Bij de eerste verkiezingen na de invoering van het algemeen meervoudig stemrecht, op 14 okto- 
ber 1894, werd er geen enkele liberale volksvertegenwoordiger meer verkozen in Vlaanderen. Zo kwam het vraagstuk van een politieke minorisering van Wallonië een eerste keer op de agenda te staan. In het kielzog van de stemming van de "Gelijkheidswet" kwam een wallingantische agitatie op gang. Een deel van de wallinganten bleef vasthouden aan het louter verzet tegen de taalwetten, een ander deel vroeg om de bestuurlijke scheiding. Ook doken er stemmen op die pleitten voor een aansluiting bij Frankrijk. Het Waals congres van 1905 weerspiegelde die versplintering, maar bleef niettemin het principe van de Franse eentaligheid van België verdedigen. Intussen begon men het Waals bewustzijn te definiëren tegenover de Vlaamse beweging en het idee van de âme belge. ${ }^{18}$ Toen de liberale wallingant Emile Dupont op 9 maart 1910 in de Senaat verklaarde ook in de openbare besturen het gebruik van het Nederlands te verwerpen en ingeval van zo'n "taaldwang" de administratieve scheiding van de "twee rassen" in België te vragen, was de Vlaamsgezinde reactie heftig. Julius Hoste onderstreepte in zijn Laatste Nieuws, een blad dat een flamingantisme beleed dat uitzonderlijk radicaal was voor een liberaal persorgaan, de vaderlandse bezieling van de Vlaamse beweging. Maar hij laakte wél tachtig jaar "onrecht" en "vernederingen". Omer Wattez, een oud-medewerker aan Germania, ging in het katholieke Antwerpse Handelsblad nog een stap verder door te verklaren dat als dit allemaal nog lang zou duren, Vlaanderen langzaam zou vergaan "in ontaarding, die men sinds bijna een eeuw voor het Vlaamse volk bewerkt, gelijk de Romein de Germaanse krijgsgevangenen drilde voor het vermaken van [het] circus". ${ }^{19}$

Vanaf 1911, toen het wetsvoorstel voor een geleidelijke vernederlandsing van de universiteit van Gent ingediend werd door de volksvertegenwoordigers Frans Van Cauwelaert (katholiek), Louis Franck (liberaal) en Camille Huysmans (socialist), won de gedachte aan een bestuurlijke scheiding meer veld in de schoot van de Waalse beweging. Nadat het kartel van socialisten en liberalen de parlementaire verkiezingen van 2 juli 1912 verloor, leek er voor sommigen geen einde te komen aan de katholieke dominantie. Niet toevallig schreef de Waalse socialist Jules Destrée toen zijn Lettre au Roi sur la séparation de la Wallonie et de la Flandre. Die open brief uit de Revue de Belgique wordt beschouwd als een mijlpaal in de geschiedenis van de Waalse beweging. Bij nader inzien ging het stuk nochtans nauwelijks over de ondertitel ervan. Slechts enkele zinnen werden gewijd aan wat Destrée van die bestuurlijke scheiding dacht. Allereerst beweerde hij de modaliteiten van zo'n scenario niet te kennen. Daarna volgden er nog een tiental lijnen om te zeggen dat de "volledige scheiding" (die dan neerkwam op een Zwitsers of Amerikaans federalisme) slechts een laatste toevlucht was die dan nog 
's lands eenheid zou versterken. De aanklacht (of klaagzang?) over wat de Vlamingen allemaal aan de Walen ontnomen zouden hebben (Vlaanderen, hun geschiedenis, kunstenaars, beambten enzovoort), vormde de echte kern van zijn epistel. ${ }^{20}$ Het Waals congres van 1912 nam niettemin het principe van de "bestuurlijke scheiding" aan. Het concept bestond dus reeds vóór de oorlog, al bleef het nog een randverschijnsel, zeker bij de Vlaamsgezinden. Maar het ongenoegen nam wel zichtbaar toe. Dat de Vlaamse beweging, met zijn epicentrum Antwerpen, vanaf 1900 in de context van binnenlandse en internationale spanningen om meerdere redenen onder vuur kwam te liggen, droeg daar nog toe bij.

\section{Een "Duits" Antwerpen?}

In het laatste deel van de negentiende eeuw groeide Antwerpen uit tot de op twee na belangrijkste haven van Europa. ${ }^{21}$ In niet geringe mate was dat het gevolg van de economische opmars van het Duitse Rijk. Sedert 1885 subsidieerde het keizerrijk de scheepvaart en dan inzonderheid de Norddeutscher Lloyd (Bremen). Die bekwam dat op haar intercontinentale reizen niet een Nederlandse haven, maar wel Antwerpen de rol van tussenhaven innam. Dertien jaar later werd dat contract verlengd. In het kielzog van de Norddeutscher Lloyd volgden andere lijndiensten, zoals de Hamburg-Amerika Linie. Beide verkregen ook gunstig gelegen kaaiplaatsen aan de haven (1903). De invloed van de Duitse scheepvaart steeg exponentieel. Aan de vooravond van de Eerste Wereldoorlog was ongeveer 30 procent van de totale lijnstoomvaart in Antwerpen Duits. Dat bevestigde de inhaalbeweging met de Britten (43 procent), terwijl het Franse aandeel tot ongeveer 20 procent slonk. Onder invloed hiervan en door de spoorwegverbindingen die Antwerpen met het Duitse Hinterland verbonden, veranderde de functie van de metropool. Ze werd een draaischijf voor de handel tussen West-Europa en de rest van de wereld. België sloot in 1891 en 1903 handelsverdragen af met Duitsland. Dat jaar tekenden beide landen ook een spoorwegconventie, hetgeen Franse argwaan opwekte. Vele tijdgenoten meenden dat Antwerpen verduitste. Niet alleen vanwege de vernoemde factoren, maar ook wegens de groei van het Duitse aandeel in de Antwerpse handel, de verhoging van het Duitse kapitaal in het Belgische bankwezen en vooral omdat er een welvarende Duitse kolonie in die stad aanwezig was.

In 1910 was 21 procent van de vreemdelingen in de havenstad van Duitse afkomst. Die Duitse kolonie organiseerde een bloeiend eigen verenigings- 
leven. Ze had een eigen sociaal vangnet, beschikte over scholen en (meestal katholieke) kerken. Deze inwijkelingen vielen ook op door hun specifieke feesten, bijvoorbeeld ter ere van Bismarck. Bovendien behoorden vele Duitsers tot de gegoede, liberale burgerij, met invloed in het stadsbestuur en de Kamer van Koophandel. Toen in 1881 de Belgische naturalisatiewetgeving versoepeld werd door vreemdelingen stemrecht te verlenen bij een naturalisatie, waren tal van katholieke kopstukken hiertegen gekant. ${ }^{22}$ De Duitse genaturaliseerden zouden, zo redeneerden ze, toch maar het liberale electoraat versterken en daarenboven nooit échte Belgen worden. Dat het Allgemeiner Deutscher Verband in 1891 een afdeling in de Scheldestad opgericht had, leek de argwaan nog te onderstrepen. In 1896 werd die wel ontbonden, omdat ze weigerde mee te stappen in de imperialistische politiek van de centrale leiding. Maar temeer daar Vlaamsgezinden zich met Germania inlieten, bleef het wantrouwen bestaan. ${ }^{23}$

In het Antwerpse zakenleven verwierven een aantal Duitse families ondertussen aanzien. Ook zij gaven de indruk dat in de "verduitste" Scheldestad een economische verovering de militaire voorafging. Tot de meest invloedrijke families in Antwerpen behoorde Rieth, die later in dit werk nog aan bod komt. Ze verwierf door een cruciale plaats in de petroleumhandel een economische machtspositie. Heinrich Peter Rieth sr. was een migrant van de eerste generatie. Hij werd in 1844 in het Pruisische Bonn geboren. De man was een veteraan van de Frans-Pruisische oorlog en vestigde zich nadien met zijn gezin te Antwerpen. Met zijn familiebedrijf, de SA pour la vente de pétrole ci-devant $H$. Rieth \& Co, verzorgde hij de olie-export en verkoop van Russische petroleum. ${ }^{24}$ Tussen 1894 en 1904 monopoliseerde de firma samen met American Petroleum en Rothschild de Belgische markt. ${ }^{25}$ Maar op 6 september 1889 werd de petroleumraffinaderij en -opslagplaats van Rieth, met de vaten incluis, volledig verwoest door de ontploffing van een munitiefabriek, toebehorende aan de fabrikant Joseph Corvillain. De explosies, die 's namiddags begonnen en tot in de nacht duurden, waren zo krachtig dat er schade tot in Antwerpen zelf toegebracht werd. Later werd Corvillain veroordeeld voor zijn nalatigheid. Hij had op onwettige wijze een stoomketel laten installeren, een gevaarlijke fabriek gebouwd en te grote hoeveelheden buskruit opgeslagen. Een eerdere explosie had al een man verbrand en een kind gedood. Tijdens het proces tegen Rieth was de advocaat van Corvillain de latere katholieke senator Alphonse Ryckmans. Volgens hem had een explosie in het bedrijf van Rieth de ramp veroorzaakt. In 1901 zou Rieth sr. consul van Rusland worden, een ambt dat hij tot 1907 bekleedde. ${ }^{26}$ In mei van dat jaar was de firma van Rieth onrechtstreeks betrokken bij de vor- 
ming van het eerste oliekartel ooit. ${ }^{27}$ Intussen had Rieth sr. nog een tegenslag moeten verwerken. Want in 1904 hadden Antwerpse zakenlieden 2 miljoen Belgische frank (vandaag zo'n 13 miljoen euro) veil gehad om een nieuwe werf te Hoboken in de steigers te zetten. Rieth sr., die aan het hoofd van de raad van beheer stond, moest echter lijdzaam toezien hoe de werf in vereffening ging. ${ }^{28}$ Zijn zoon, de geboren Belg Kurt Heinrich [roepnaam: Henri] Rieth, verging het beter. De jurist sprak thuis Frans en had familiale relaties in Nederland..$^{29}$ In 1910 werd hij gevolmachtigde voor de firma. ${ }^{30}$ De vader moet toen aan de opvolging van de wacht gedacht hebben en kocht in 1911 een schitterend landgoed te Mortsel, met kasteel en hovenierswoning, waaraan grootse verbouwingswerken uitgevoerd werden. Hij was blijkbaar niet zonder invloed en bekwam dat de geplande nieuwe fortengordel rond Antwerpen zijn domein niet zou doorkruisen. ${ }^{31}$

Speelden zijn contacten met Heinrich von Bary daarin een rol? Die vertegenwoordiger van de Norddeutscher Lloyd was de invloedrijkste persoon binnen de Duitse kolonie. ${ }^{32}$ In 1913 zetelde Rieth sr. samen met hem in een comité voor de versterking van de Duitse bewapening en het leger. ${ }^{33}$ Eind november van dat jaar werd in de Gesellenverein van Brussel en Antwerpen de honderdste verjaardag van de geboorte van de stichter der Vereine, Adolf Kolping, herdacht. In Antwerpen viel die viering samen met het zesjarige bestaan van de lokale afdeling. Niet alleen Rieth sr. was aanwezig, maar ook de priesters Ludwig Hürter (de voorzitter van de Antwerpse afdeling) en Carl Sonnenschein. Het katholieke deel van de Duitse kolonie hergroepeerde onder impuls van Rieth sr. en Hürter in de lente van 1914 de verschillende katholieke Vereine in nieuwe lokalen. ${ }^{34}$ Opvallend is dat al die figuren, op vader Rieth na, later in de Flamenpolitik terechtkwamen. ${ }^{35}$

\section{Het nieuwe Carthago}

Dat Antwerpen een verduitst oord heette te zijn, was maar een van de verdachtmakingen die de Scheldestad te verduren kreeg. Sedert 1859 was ze immers het Belgische réduit national. In geval van oorlog zou de overheid zich in die vesting terugtrekken. Maar de onneembaar gewaande fortengordel was rond de eeuwwisseling danig verouderd. Bovendien hinderde ze de economische expansie van de stad. ${ }^{36}$ In Belgische militaire kringen leefde de perceptie dat Antwerpen een "antimilitaristisch bastion" was, dat liever geen frank aan landsverdediging spendeerde. Zeker tot 1905 was die voorstelling op feiten gebaseerd. De Vlaamse katholieken waren gekant tegen legerlasten 
en de algemene dienstplicht in het bijzonder en dat gevoel leefde bijzonder sterk bij de Antwerpenaars onder hen. De wortels daarvan lagen bij de flamingantische Meetingpartij in de jaren 1860. Dat antimilitarisme, met de katholiek Edward Coremans als voornaamste Antwerpse woordvoerder, kende een hoogtepunt rond de eeuwwisseling. De invoering van het voluntariaat in 1902 werd dan ook beschouwd als een overwinning van die conservatieve tak in de over defensie sterk verdeelde katholieke partij. ${ }^{37}$

Voor de vestingen rond Antwerpen hing er na de Marokkocrisis van 1905-1906 verandering in de lucht. Wilhelm II had zich garant gesteld voor de Marokkaanse soevereiniteit en zo Frankrijk, dat een protectoraat over het land uitoefende, geprovoceerd. De spanningen tussen beide staten die tijdens de lente van 1905 begonnen, leidden zelfs tot een mobilisatie van troepen in Duitsland en Frankrijk. Op de Conferentie van Algeciras (van januari tot april 1906) werd het sluimerend conflict opgelost (of beter gezegd: uitgesteld). In België verschoof de politieke focus naar de interne veiligheid. In 1905 voorzag het wetsvoorstel De Smet-De Naeyer in een afbraak van de oude en de bouw van een nieuwe en meer uitgeruste Antwerpse fortengordel. Om de nationale veiligheid te verzekeren en om die forten te bemannen waren er meer troepen nodig. Tegen 1909 was er enige katholieke consensus over de nood aan versterking van de defensie. De oude conservatieve antimilitaristische garde klerikalen, zoals Woeste, was tegen dan vervangen door een jongere generatie christendemocraten zoals De Broqueville. In 1909 werd de persoonlijke dienstplicht ingevoerd. Het voornemen om de forten te bouwen had echter zowel in Frankrijk als in Duitsland argwaan gewekt. Het eerste land verdacht Duitsland ervan om met België samen te spannen. Vanuit Berlijn bezien, waren de forten dan weer een manier om Britse troepen, in geval van een ontscheping te Antwerpen, rugdekking te verlenen. ${ }^{38}$

De wrevel tegenover het "antimilitaristische" Antwerpen vond ook een weerklank in de literatuur. De roman La Nouvelle Carthage van de naturalistische schrijver Georges Eekhoud was daar een sprekend voorbeeld van. De eerste editie van dat werk verscheen in 1888 . Na de verschijning van twee herwerkte versies verkreeg zijn definitieve opus in 1893 de vijfaarlijkse Staatsprijs voor Letterkunde. ${ }^{39}$ Het boek, dat zich afspeelt in Antwerpen aan het eind van de negentiende eeuw, behandelt de belevenissen van de wees Laurent Paridael die samen met zijn oom in de voorsteden van de metropool leeft. De teloorgang van die oom is in La Nouvelle Carthage het gevolg van diens "kosmopolitische" relaties. Amerikanen, oosterlingen en vooral joden treden er als de grote gangmakers van Antwerpens neergang in op. ${ }^{40}$ Antwerpen was voor Eekhoud een ijdel nieuw Carthago dat aan haar mercantiele praalzucht zou ten onder gaan. 
Het xenofobe werk, badend in een typisch fin de siècle pessimisme, sloeg aan en niet alleen in België. Het werd vanaf 1898 meerdere malen in het Duits vertaald. De tweede vertaling (1903) was van de hand van de Luxemburger Tony Kellen, die tien jaar eerder al de vertaling van Kees Doorik (1883) van Eekhoud verzorgd had. Ze werd in de Rheinisch-Westfälische Zeitung van Reismann-Grone gepubliceerd. Kellen was een rassenkundige en publiceerde bijdragen aan het racistische tijdschrift Globus van Germania-medewerker Richard Andree. Die gingen over de bevolkingsverhoudingen in Elzas-Lotharingen, de noodzaak om de Polen die in het Ruhrgebied werkten te germaniseren (of te verdrijven) en België. ${ }^{41}$ Toen zijn vertaling van La Nouvelle Carthage verscheen, woonde hij al acht jaar in Essen en was hij een vaste medewerker aan Germania. ${ }^{42}$ Geen wonder dat Reismann-Grone hem in zijn dagblad de nodige bladruimte verschafte. Kellen had in Essen ook betrekkingen met de familie van Krupp. Getuige daarvan het feit dat in 1904 de firma zijn lovende artikelenserie over Friedrich Alfred Krupp in een Sonderausgabe uitgaf. Friedrich Alfred was de zoon van Alfred Krupp, een goede kennis van Reismann-Grone. Hij stond aan het hoofd van de firma vanaf de dood van Alfred in 1887 tot 1902. ${ }^{43}$ In november 1903 wijdde Kellen in Germania een studie aan Eekhoud. ${ }^{44} \mathrm{Hij}$ wees erop dat die laatste een van de weinige hedendaagse Belgische schrijvers was die in het Frans schreef en toch in het buitenland bekendheid genoot. Lemonnier, Rodenbach en Maeterlinck waren de andere gelukkige uitzonderingen. De Luxemburger stak zijn bewondering voor Eekhoud en diens bekroond werk bepaald niet onder stoelen of banken. Hij deelde zijn analyse betreffende de metropool: "Antwerpen ist eine kosmopolitische Stadt, die Eekhoud nicht mit Unrecht Neu-Karthago nennt, nicht bloss wegen ihre Machtstellung als Handelsstadt, sondern auch wegen der Sitten ihrer Bewohner."

\section{Het völkische element in de Waalse beweging}

Ook in de wallingantische propaganda lag Antwerpen onder vuur. Aanvallen op de stad gingen erin gepaard met uithalen naar het germanofiele element in de Vlaamse beweging. Voorbeelden daarvan vindt men in het tijdschrift La Jeune Wallonie: een literair blad, dat nogal wat aandacht besteedde aan scheldproza tegen Vlaamsgezinden in het algemeen en de Antwerpse flaminganten in het bijzonder. Zoveel maakt een lezing van de jaargangen 1911-12 wel duidelijk. Daarin werd betoogd hoe de haat van de Vlaamsgezinde de instinctieve en eeuwige afkeer van de Beotiër van de verfijnde rassen weer- 
spiegelde. ${ }^{45}$ Hoe opmerkelijk, zo betoogde het blad, was de toenadering tussen de enorme Duitse pretentie en die van de flaminganten. De "flamingantische epidemie" heette België, minstens gedeeltelijk, bij het Duitse Rijk te willen inlijven. Die flamingantische serpenten moesten het zwijgen opgelegd worden. Dat ze gingen tateren in de woestenij der Antwerpse forten, maar wegbleven uit het Franstalige Brussel! ${ }^{46}$ De wallingant Julien Delaitte verwoordde het als volgt: "le pangermanisme semble [...] guetter le mouvement flamingant." ${ }^{47}$ Omgekeerd werd Wallonië als een onderdeel van de Latijnse stam afgeschilderd: "dans vos veines [wallonnes] coule le sang frais et pur des races latines $[. .$.$] notre mère à tous, la France vous regarde et vous$ admire [...]." ${ }^{48}$ De filoloog Maurice Wilmotte beweerde dat vanaf de zevende eeuw de oriëntatie van Vlaanderen zuidwaarts gericht was: "la lumière est toujours venue de la France et les esprits saillants, les écrivains se sont toujours nourris des aliments précieux de la culture latine." ${ }^{49}$ Het monopolie van de "zogenaamde Vlaamse taal" aanvaarden, heette een inval volgens de Duitse methode in Elzas-Lotharingen te zijn. Het Frans was zogezegd een instrument tot verdediging tegen de zogenaamde "flamingantische beweging". Een Courrier de France drukte het als volgt uit:

Avec le Flamand, c'est l'Allemand qui vous [de Walen] envahirait [...] et je me disais que si l'Allemagne [...] venait à passer par votre pays, sous le regard des flamingants satisfaits et inactifs, vous seriez là Wallons, pour vous lever en une fière cohorte et leur barrer la route - et j'osais espérer qu'alors, vous souvenant de nos aïeux et de vôtres qui marchèrent ensemble à la prise d'Anvers (1832) vous sauriez, au chant de la Brabançonne et de la Marseillaise 'bouter' hors de chez vous, les 'casques à pointe' apportant avec eux le poids lourd de leur langue... ${ }^{50}$

Het tijdschrift stelde zich bij momenten uitermate radicaal op. Zo verheugde een medewerker zich erover dat de Vlaamsgezinde Brusselse Liberale Volksbond in maart 1912 een eigen lijst bij de wetgevende verkiezingen wou indienen als de liberale partij een ultimatum om an haar "legitieme eisen" over de taalkwestie tegemoet te komen, niet inwilligde. Een oorlogsverklaring, zo meldde hij, zij het dan een die tenminste het voordeel van de duidelijkheid bood:

ce n'est que le jour où la guerre sera sincère et claire entre ce clan de vendus et notre race belge patriotique, éclairée et active, que la Belgique pourra espérer se délivrer de ce brandon de discorde intestine, habilement entretenu et dirigé par les Allemands d'Anvers. ${ }^{51}$ 
Die Vlaamsgezinden bereidden immers, aldus deze schrijver, als echte samenzweerders, via de implementering van hun taal de afhankelijkheid van Nederland en het Duitse Rijk voor. ${ }^{52}$ La Jeune Wallonie besteedde in nog artikels aandacht aan de Duitse "infiltratie", met Antwerpen als mikpunt. ${ }^{53}$ Zoals de retoriek uit La Jeune Wallonie liet uitschijnen, was de Waalse beweging onderhevig aan een völkische aantrekkingskracht tot Frankrijk. Met name graaf Albert du Bois ontpopte zich tot de theoreticus van het pan-Latinisme in België. In 1897 begon hij aan een diplomatieke carrière als attaché bij de Belgische ambassade in Londen. Zijn publicaties over een aanhechting van Wallonië bij Frankrijk zorgden in 1903 voor een vroegtijdig einde aan die loopbaan. ${ }^{54}$ Hoe polemisch Du Bois schreef, bleek uit zijn vlugschrift $L e$ Catéchisme du Wallon van een jaar eerder. De Walen, zo betoogde hij daarin, waren onbetwistbaar Frans. Bloedbanden en hun hele geschiedenis verbonden hen met Frankrijk. ${ }^{55}$ Du Bois dreef de spot met België. Hij herinnerde de Walen aan hun napoleontisch verleden, toen ze de schitterende droom koesterden de natie te zijn die aan de spits van de mensheid zou staan. Wat een contrast met hun geschiedenis sedert 1830: daarin namen ze met hun "goede Vlaamse vrienden" deel aan... schietwedstrijden voor burgerwachten! ${ }^{56}$

Onverbloemd riep Du Bois de Walen op om de naam "België" te haten. Het land heette een Anglo-Franse uitvinding te zijn om Frankrijk na Napoleon te verzwakken. Vlamingen, "ennemis séculaires de notre âme française", en Walen hadden niets gemeenschappelijks. Bovendien waren de Walen dan nog verplicht om het Vlaamse "dialect" te leren. Men beledigde hun Franse nationaliteit door op de muren van Waalse steden tweetalige opschriften aan te brengen (hier zien we het effect van de uitbreiding van de taalwetgeving). "Si les Flamands sont trop stupides pour prononcer les noms de nos villes, ne peuvent-ils rester chez eux!” De Walen gingen, zo schreef Du Bois, gebukt onder het juk van een "Vlaamse" regering en moesten zich ertegen verzetten: "Mêler l'or latin au plomb germanique, cela peut sourire aux métis de Bruxelles, mais nous autres bons Wallons [...] nous devons conserver intacte notre nationalité [française]." De Walen heetten voorts in België het grootste deel van hun belastingen te betalen om de Vlamingen te verrijken. Daarvan getuigden de miljoenen die permanent in nutteloze kanalen en in dode steden geïnvesteerd werden. Of in de haven van Antwerpen. Die stad had de Walen sedert 1830 nog meer gekost dan de oorlog van 1870 aan de Fransen. De auteur omschreef ze weinig fijnzinnig als "cette ville vampire": de stad met een nefaste invloed op de natuurlijke afzetmarkt van de Waalse industrie, het zuiden. ${ }^{57}$

Een andere drijvende kracht in dit pan-Latinisme was de journalist Raymond Colleye. Die stichtte vanaf 1905 tijdschriften, waaronder La Revue 
Française en later Le Réveil Wallon en L'Action Wallonne. Aan de eerste twee tijdschriften werkte Du Bois mee. Colleye richtte ook de Jeunes Gardes wallonnes op, werd nationaal secretaris van het Comité National de Défense Wallonne en secretaris-generaal van La Ligue antipangermaniste belge. ${ }^{58}$ In de Revue Française van november 1906 omschreef hij Wallonië als "le bastion du Nord de la Latinité". Eens onder de knoet van de oosterbuur zette het Waalse land dus de poort naar Frankrijk voor het Duitse schorriemorrie open. Colleye wees Frankrijk op zijn verpletterende historische verantwoordelijkheid om een aanhechting van Wallonië bij het Duitse Rijk, door toedoen van de Vlamingen, te verhinderen. Voor hem was de Belgische revolutie een jammerlijk mislukte uiting van het Franse patriottisme van Wallonië. Overal en bij alle "rassen", die afhankelijk waren van een buitenlandse macht of die met een ander "ras" in dezelfde politieke entiteit leefden, zo betoogde Colleye, ontwaakten nationalismen. Streed Polen niet tegen de Teutoonse dwingeland? De trouw van de inwoners van het germanofobe Elzas-Lotharingen aan het Grote Franse Vaderland stond buiten kijf. Zo ook dat de instincten van de Vlamingen hen naar het Germaanse vaderland, wiens kinderen ze waren, dreven. Maar dat had een neveneffect. Want de belangen van het Latijnse "ras" in België werden zo bedreigd door de hegemoniale verzuchtingen van enkele Vlaamse fanatici en de eeuwenoude Teutoonse vraatzucht aan de Belgische grenzen. Een groot deel van de Vlaamsgezinden wilde, met medeplichtigheid van de "flamingantische" Belgische regering, net als de Duitsers in Elzas-Lotharingen dat met de Fransen deden, de Walen vervlaamsen. Toch vroeg hij (nog) niet om een aanhechting van de Waalse provincies bij Frankrijk. Zijn eis beperkte zich voorlopig tot regionale autonomie binnen België en praktische maatregelen, zoals een douane- en postunie tussen België en Frankrijk. ${ }^{59}$

Op 20 juli 1914 gaf Colleye het vlugschrift Wallonie! uit. Zijn bedoeling was om dat minstens 25 maal per jaar te laten verschijnen, maar de oorlog maakte een vroegtijdig einde aan die plannen. ${ }^{60} \mathrm{Hij}$ stelde het blad voor als een voortzetting van La Revue Française, die volgens hem het idee van een pan-Latijnse alliantie als tegenwicht voor het pan-Germanisme opgeworpen had. De auteur was op enkele jaren tijd geradicaliseerd. In het hoofdartikel beschreef hij hoe de Waalse beweging sedert 1905 stagneerde. Er was nood aan actie: "Qu'on envoie [...] balader par dessus la frontière linguistique les inscriptions flamingantes qui sont la honte de la Wallonie. Qu’on lynche proprement les députés wallons traîtres à leur patrie." Maar van een oningelichte bevolking verwachtte hij bitter weinig heil: "il n'y a pas dans l'Histoire l'exemple d'un peuple aussi lâche que le peuple wallon." Zelfs de Waalse 
comités hemelden het zogenaamde "Belgische" [aanhalingstekens Colleye, $B Y]$ patriottisme van Wallonië op, terwijl de centrale staat dat landsdeel stiefmoederlijk behandelde. De oplossing die hij de Walen aanbood, was eerst de bestuurlijke scheiding en daarna de annexatie bij Frankrijk. Net als Du Bois verheerlijkte Colleye de Waals-Franse banden. Voor de Vlamingen zag de toekomst er somber uit. Het beste wat ze konden doen, was rouwen om hun taalkundige ambities en zich laten opnemen in de Latijnse sfeer. Maar het waren niet alleen sommige wallinganten die provocerend optraden door hun voorliefde voor Frankrijk en afkeer van de flaminganten of zelfs de Vlamingen te berde te brengen. Radicaal-völkische uitingen vond men immers, ook na het verdwijnen van het tijdschrift Germania, terug aan Vlaamsgezinde zijde.

\section{De ophef rond Pol de Mont}

Zo bezongen sommige Vlaamsgezinden, zoals Pol de Mont, in niet mis te verstane bewoordingen hun völkische voorliefde voor een groter Duitsland. Daarbij hadden ze weinig vleiende bewoordingen over voor de Walen en Frankrijk. ${ }^{61}$

De Mont was vanaf zijn studententijd een germanofiele wagneriaan. Aan het begin van de jaren 1880 stond de Doornikse atheneumleraar in contact met de Platduitse dichter Klaus Groth, die hij toedichtte "kind van hetzelfde bloed" te zijn. Had het Platduits zijn dichterlijke aandacht getrokken, dan stond hij nog méér onder invloed van het Hoogduits en het Duitse Rijk. De bloei van de Duitse literatuur verklaarde hij door de identiteit van het Duitse volk. De Mont werd het belangrijkste aanspreekpunt in Vlaanderen voor Duitse auteurs en wilde bovendien in Duitsland interesse opwekken voor de Vlaamse beweging. In 1901 bracht dit voornemen hem in contact met het Duitse Insel Verlag en met Eberhard von Bodenhausen, die tussen 1895 en 1900 het kunst- en literaire tijdschrift Pan uitgaf. Na het falen van dit project was de Duitser opnieuw een studie in kunstgeschiedenis te Würzburg begonnen. Hij werd in 1906 plaatsvervangend commercieel directeur bij Krupp, trad vier jaar later tot de raad van bestuur ervan toe en bleef Insel Verlag financieel steunen. ${ }^{62}$

Inmiddels was De Mont in 1882 leraar aan het Koninklijk atheneum van Antwerpen geworden. De katholiek werd een overtuigd vrijzinnige en zetelde in de jaren 1890 als Antwerps provincieraadslid voor de liberale partij. Zijn denken was niet wars van racisme. Hij stond immers sterk onder de 
invloed van de "grote denker" Arthur de Gobineau en geloofde in pseudowetenschappelijke theorieën over de indeling van de wereld in hoofd- en onderrassen. ${ }^{63}$ Aan het eind van de negentiende eeuw ging hij in Duitsland voor verschillende Ortsgruppe van het Alldeutscher Verband toespraken geven. In 1899 zou het tijdschrift Germania, waaraan hij meewerkte, die bundelen. Tijdens de referaten voor het Alldeutscher Verband had hij "1830" betreurd, gesteld dat de revolutionairen België bij Frankrijk wilden aanhechten en gewezen op de historische banden tussen Vlaanderen en het Duitse Rijk. ${ }^{64}$ Ook nadat hij in 1904 benoemd werd tot conservator van het Antwerps Koninklijk Museum voor Schone Kunsten, en dus staatsambtenaar werd, bleef hij zijn openlijke sympathie voor het Alldeutscher Verband belijden.

Op 11 oktober 1905 verkondigde de dichter in een redevoering voor de organisatie te Dresden dat Vlamingen en Duitsers cultureel al bijna duizend jaar in nauwe betrekking tot elkaar stonden. Ze maakten deel uit van hetzelfde ras en spraken bijna dezelfde taal. De taalstrijd noemde hij een afspiegeling van de strijd tussen Frankrijk en het graafschap Vlaanderen, de Belgische revolutie was "door de Walen opgestart om de Vlamingen steeds meer onder hun heerschappij te brengen". De Mont besloot zijn redevoering met te wijzen op het annexionistische gevaar dat van Frankrijk uitging. "Duitsland moet België als het sterkste schild tegen Frankrijk beschouwen en daarom in zijn eigenbelang de Vlaamse beweging steunen." ${ }^{65}$ [B.Y.] De Vlaamsgezinde had zijn toespraak gegeven tegen de achtergrond van een internationale context waarin de gemoederen wegens de Marokkocrisis hoog opliepen. ${ }^{66}$ Dat verklaart mede de hevige reactie van de liberaal en redacteur van de Antwerpse Nouveau Précurseur, Frédéric Delvaux. Op 23 oktober 1905 publiceerde die een artikel over de voordracht van De Mont. Als reden voor de publicatie gaf hij aan dat het verslag een terechte opschudding verwekt had in Antwerpen. Diegenen die beweerden dat Antwerpen germaniseerde en een Duitse haven werd, konden zich, zo beklaagde de auteur zich, gesterkt voelen in hun stelling. In de internationale verwikkelingen (ten gevolge van die Marokkocrisis dus) die in een nabije toekomst aan de oppervlakte konden komen, mocht geen van de belanghebbende buurlanden in België een voorwendsel vinden om geweld aan te wenden. Bijdragen aan "een legende tegengesteld aan de Belgische geest en aan onze onafhankelijkheid" [B.Y.] moesten in het belang van het Belgische vaderland aan de kaak gesteld worden.

Delvaux onderstreepte dat de Anzeiger De Mont een der meest vermaarde verdedigers van de pan-Germanistische ideologie genoemd had (hetgeen enigszins klopte voor België). Blijkbaar waren er onder de Belgen dus lieden die niet konden begrijpen dat hun vaderland Belgisch was en wou blijven. 
De redacteur wees buitenlandse bemoeienissen in Belgische aangelegenheden met klem af. Hij nam aanstoot aan het feit dat De Mont de hulp van radicale pan-Germanisten inriep tegen een vermeende Franse annexatiestroming in België. Dat België, zo betoogde hij, door een paar heethoofden als een ongeluk van de geschiedenis beschouwd werd, kon best zijn, maar voor het overgrote deel van de bevolking ging het om het geliefde vaderland dat verdedigd moest worden tegen buiten- én binnenlandse aanvallen. Die laatste kwamen bovendien van een staatsambtenaar die in het buitenland een campagne voerde. Naast te wijzen op wat De Mont, afgaande op het verslag van de Dresdner Anzeiger in Duitsland, was gaan vertellen, maakte Delvaux gewag van een schrijven dat de ronde deed op de Antwerpse Beurs. Volgens de inhoud daarvan was De Mont, aldus Delvaux, nog verder gegaan door het patriottisme van de stichters van de Belgische nationaliteit in twijfel te trekken. De journalist vroeg zich af welk een idee buitenlanders wel moesten hebben van België wanneer een staatsambtenaar, op het moment dat de Belgen fier waren de 75 ste verjaardag van hun onafhankelijkheid te vieren, openlijk het bestaan zelf van hun land ging betreuren. Dat laatste had De Mont niet letterlijk gezegd, maar een tegenstander kon het wel uit het verslag van de Dresdner Anzeiger afleiden. ${ }^{67}$

De aanval van Delvaux was wellicht ook ideologisch geïnspireerd. Hij was immers voorzitter van de Association Libérale en De Mont, een lid van de Liberale Vlaamse Bond, was naar eigen zeggen al in 1890 om electorale redenen met hem in aanvaring gekomen. De liberale Chronique en Le Soir lieten zich in navolging van Delvaux niet onbetuigd. Het laatste blad meldde dat De Mont voor vreemdelingen ook de scheiding tussen Nederland en België was gaan betreuren. De dichter had zelfs gezegd dat de Walen en antiflaminganten het verlangen koesterden ons land aan Frankrijk over te leveren en, als klap op de vuurpijl, voormalig minister Rogier voor een landverrader versleten. ${ }^{68}$ De polemiek escaleerde: liberale dagbladen gingen zowaar aan een katholieke minister het ontslag van De Mont vragen. Nadat die Julius Sabbe, een redactielid van het liberale Volksbelang, gecontacteerd had, kwam een tegenreactie op gang. Allicht had laatstgenoemde hier een hand in. ${ }^{69}$ Steun verkreeg De Mont van een schare Vlaamse liberale bladen, maar ook van Le Petit Bleu en zelfs van het katholieke Handelsblad van Antwerpen. De onderlinge flamingantische solidariteit was dus groot, ook bij deze faux pas. Uiteraard stond ook de Liberale Vlaamse Bond van Antwerpen achter De Mont. Die organisatie wijdde op 7 november 1905 een vergadering aan de zaak. Ze verweet de Nouveau Précurseur de "gewetensvrijheid" der ambtenaars aan te vallen. De Mont had zogezegd enkel gebruikgemaakt van zijn 
grondwettelijk recht om feiten en personen aan een "geschiedkundige kritiek" te onderwerpen. Een slimme zet, want zo verschoof de aandacht van de aantijgingen aan het adres van De Mont naar een intentieproces tegen de Précurseur. ${ }^{70}$ Het conflict werd uiteindelijk bijgelegd op een onderhoud tussen redactieleden van de Précurseur en kopstukken van de Liberale Vlaamse Bond. ${ }^{71}$ Merkwaardig was wel dat De Mont, afgaande op de semi-officiële Temps, in september 1906 nogmaals voor het Alldeutscher Verband sprak. Naar aanleiding daarvan meldde de Berlijnse correspondent van dat Franse regeringsblad hoe "het hoofd van de Vlaamse beweging" op het congres van het Alldeutscher Verband zoveel bijval gekregen had, dat de pan-Germanisten hem gevraagd hadden een reeks lezingen te houden in Duitsland over de Germaanse expansie in België door de Vlaamse taal. ${ }^{72}$ We hebben het raden naar de motieven van de man die zijn broodwinning een jaar eerder nog bedreigd zag door een gelijkaardige actie. ${ }^{73}$ Hoewel zijn tweede optreden geen weerklank vond in België, wekte het wél de aandacht van de Franse ambassade in Brussel op. ${ }^{74}$ Binnen welke bredere context moeten we de actie van De Mont kaderen?

\section{Een Nederlands-Belgische Entente?}

In september 1905 vond in Luik het Congrès international pour l'extension de la culture et de la langue française plaats. Dit gebeuren werd achter de schermen door Frankrijk gesteund. ${ }^{75}$ Maurice Ansiaux, hoogleraar aan de ULB, hield er een redevoering over La pénétration allemande en Belgique. Hij omschreef de Vlaamse beweging als "essentiellement hostile à la langue française et se [rattachant] par un lien avoué au pangermanisme". Werd er in Brussel al niet sedert zeven jaar het tijdschrift Germania uitgegeven? Flaminganten zoals Pol de Mont prijkten er samen met Duitse pan-Germanisten op de lijst van redacteuren. Het maandblad betreurde, aldus Ansiaux, openlijk de Belgische omwenteling, waarvan Frankrijk zogezegd het succes verzekerd had en beweerde dat de Franse geest tegengesteld was aan de Vlaamse (of Belgische). De pan-Germanisten, zo betoogde hij aan de hand van Alduitse publicaties, beschouwden Vlamingen en Nederlanders als Nederduitsers. Ansiaux waarschuwde voor zulke imperialistische aspiraties: door omstandigheden konden ze voor een machtige staat - hij bedoelde natuurlijk Duitsland - een wapen worden. Wat eertijds slechts een geïsoleerde fantasie was, kon tijdens een oorlog tot een pseudowetenschappelijk geloofsartikel verheven worden. En een verstoring van het Europese machtsevenwicht kon de aanleiding tot 
zo'n conflict betekenen. Zonder twijfel had hij hierbij de Marokkocrisis in het achterhoofd, maar de Eerste Wereldoorlog zou hem gelijk geven. Nog volgens de spreker probeerde Duitsland België economisch te veroveren. Hij waarschuwde voor een gedwongen opname van België in het Zollverein. Dat werd in de hand gewerkt door het Frans en Brits protectionisme. Gaf België zijn economische autonomie op, zo betoogde hij, dan volgde daaruit een onvoorwaardelijke verzaking aan de politieke autonomie van het land. Een Franstalig volk werd desgevallend aan de Germaanse invloed overgeleverd. De groeiende economische activiteit door Duits toedoen speelde de Belgische industriëlen in de kaart en de Belgen gedroegen zich wel erg gastvrij. Ze zagen niet alleen geen vijand in de vreemdeling, maar drongen er zelfs op aan hem te naturaliseren. Het voornaamste doel van de economische Duitse pénétration pacifique heette Antwerpen te zijn, waar bijna 9000 Duitsers aanwezig waren in de groothandel, het bankwezen, het maritiem transport, de scholen enzovoort. De wil van de Belgen om weerstand te bieden tegen de Duitse bedreiging van hun Franse beschaving, hing samen met hun toekomstige taalkundig-culturele oriëntatie. ${ }^{76}$

Maurice Schwob, hoofdredacteur van de Phare de la Loire, borduurde in november in zijn blad voort op die redevoering. Ook volgens hem ging de Duitse bedreiging uit van Antwerpen, waar de Duitse aanwezigheid een economische verovering als voorafspiegeling van de militaire heette te zijn. Zijn studie over het Duitse scheepvaartwezen, een Duitse Rijnmonding, het Duitse bankwezen en de manieren om de stad te "germaniseren" was minutieus. Hij beweerde dat de pan-Germanisten op basis van etnografische en taalkundige argumenten de Vlamingen als Duitsers beschouwden. Zich beroepend op de Alduitse literatuur, waarin Nederland en België als kleine staten met een Germaanse nationaliteit afgeschilderd werden, trok hij de conclusie dat de pan-Germanisten de Vlaamse beweging ondersteunden. Die werd dan afgeschilderd als een gevaar, dat Wallonië wilde onderdrukken en België in twee vijandige kampen wou opsplitsen. Schwob noemde de woordvoerders van de Vlaamse beweging op Berlijn georiënteerd en duidde erop dat ze vergaderingen van het Alldeutscher Verband bijwoonden, een duidelijke allusie op De Mont. En hadden die flaminganten niet in Germania geschreven $?^{77}$ Kortom, Vlaamsgezinden en Alduitsers waren in die lezing van de feiten twee zijden van eenzelfde anti-Franse medaille.

In feite kon De Mont het tijdstip voor zijn redevoering nauwelijks slechter gekozen hebben. Niet alleen had het referaat van Ansiaux in Frankrijk weerklank gevonden, maar ook begon enkele dagen na de toespraak van De Mont de liberale journalist Eugène Baie in Le Petit Bleu te ijveren voor 
een Belgisch-Nederlandse Entente. Die zou een tegenwicht moeten bieden aan de vermeende Duitse expansiedrift. De bewuste artikelenreeks liep van 15 oktober 1905 tot december van dat jaar. Baie bestudeerde de kwestie, wees op het Duitse gevaar en riep op tot de vorming van een interparlementaire commissie om het vraagstuk onder de loep te nemen. ${ }^{78}$ De liberale journalist ondervroeg daarover Belgische en Nederlandse politici en persoonlijkheden uit beide landen. ${ }^{79} \mathrm{Zijn}$ oproep werd in bepaalde kringen positief onthaald. Zo publiceerde de Franse generaal en senator Langlois tijdens de zomer van 1906 een artikelenreeks in Le Temps. ${ }^{80} \mathrm{Hij}$ betoogde daarin dat een BelgischNederlandse douane-unie ook de Anglo-Franse belangen diende. Afgaande op de studie van Schwob, had Langlois ook gesteld dat Antwerpen door de Duitsers geïnfiltreerd werd en dat die zich in België voor hun propaganda bedienden van een volledig gegermaniseerde "flamingantische partij". ${ }^{81}$

Nog dat jaar verscheen in The Nineteenth Century and After het artikel met de veelzeggende titel The absorption of Holland by Germany van de Britse journalist Ellis Barker. In hetzelfde tijdschrift schreef de voormalige Franse minister Yves Guyot in september 1906, als antwoord op Barker, dat het beschermen van de onafhankelijkheid van België en Nederland de raison d'être was van de Entente Cordiale. Frankrijk, noch het Verenigd Koninkrijk konden toestaan dat Duitsland ooit beslag legde op zijn twee kleine buren. Ook hij waarschuwde voor de "germanisering" van België en prees een Belgisch-Nederlandse Entente aan als een middel tot vrijwaring van de vrede. ${ }^{82}$ In Londen was men eveneens beducht op een absorptie van België en Nederland in het Duitse Rijk, getuige daarvan de bespreking van het British Committee of Imperial Defence (juli 1905), waar de eerste minister Balfour verklaarde dat een Duits bezit van de Nederlandse havens niet met onverschilligheid bezien mocht worden. ${ }^{83}$ De artikelenreeks van Langlois wekte de argwaan op van het Auswärtiges Amt. In Berlijn werd op een van de knipsels uit Le Temps hierover genoteerd: "also müssen wir dagegen arbeiten." De Duitse ambassade in Brussel zou inderdaad tot januari 1912 proberen te bewijzen dat er een Franse intrige aan de gang was en dat het project op weerstand en wantrouwen stootte in België, inzonderheid bij de Vlamingen. ${ }^{84}$ Er werden in die periode 56 berichten over de kwestie naar het Auswärtiges Amt gestuurd. Officiële Duitse diensten lieten zich dus, net als de semiofficiële völkische Verbande, al vóór de Eerste Wereldoorlog in met de Vlamingen. Minstens interesseerde dat "broedervolk" hen. In Nederland was er evenwel weinig animo voor de Entente waarvan sprake. ${ }^{85}$ Toch kwam in november 1907 een eerste maal een Commission Hollando-Belge samen om "de economische toenadering tussen de landen te onderzoeken en de vriendschappelijke betrekkingen 
te bevorderen". [B.Y.] Ze was geen lang leven beschoren. Er werd tot 1910 driemaal vergaderd in Brussel en Den Haag, maar daarna verslechterden de Belgisch-Nederlandse betrekkingen. ${ }^{86}$ Meteen na de eerste commissiezitting haalde Le Temps overigens uit naar de Vlaamsgezinden. Het blad schreef dat de flaminganten die tegen de Entente hollando-belge campagne voerden onterecht volhielden dat de beweging ten gunste van de toenadering uitging van Frankrijk en het Verenigd Koninkrijk en anti-Duits was. De flaminganten waren, aldus Le Temps, de meest onbuigzame tegenstanders van dergelijke Entente omdat ze aan de Duitse invloed gehoorzaamden. ${ }^{87}$

Bovendien meldde de francofiele nationalist Léon Hennebicq, die de Nederlandse-Belgische Entente zeer genegen was, in Le Petit Bleu dat een dergelijke anti-pangermanistische Entente niet de achteruitgang van de Latijns-Franse cultuur mocht betekenen, maar integendeel haar uitdeining naar het noorden. Hennebicq voegde daaraan toe dat ook de expansie van de kwaliteiten van de Nederlanders in Wallonië in die context op prijs gesteld werd. ${ }^{88}$ Ondanks die nuancering kon een overprikkelde flamingant op basis hiervan die Entente als een anti-Vlaamse machinatie afdoen. Want sympathiseerde die Hennebicq niet met de société flamande pour la vulgarisation de la langue française? En had hij al in 1903 niet verklaard niet te willen dat zich rond Vlaanderen een soort "Chinese muur" optrok zodat het Vlaamse arbeiderskind de studie van het Frans ontnomen werd ? ${ }^{89}$ Overigens bestond er in de twee decennia die de oorlog voorafgingen een Franstalig en antiflamingantisch Belgisch nationalisme, dat weliswaar erg marginaal was, maar wel grotendeels links en francofiel. Het was in die kringen dat men neigde naar een regering van nationale unie, een verzaking aan de neutraliteitspolitiek en een alliantie met Nederland om de militaire gevolgen van het verlies van Nederlands-Limburg en Zeeuws-Vlaanderen ongedaan te maken. ${ }^{90}$ Geen wonder dus dat tegen die achtergrond Vlaamsgezinden achterdocht koesterden bij het perspectief op een Belgisch-Nederlandse Entente.

\section{Besluit}

Vanaf 1900 werd de landsverdediging een heet hangijzer in de Belgische politiek. In die context lag het voor de hand dat flaminganten en wallinganten de buitenlandse politiek voor binnenlands gebruik begonnen te instrumentaliseren met als ijkpunt de positie die tegenover de taalwetgeving ingenomen werd. België was sedert 1839 een door de grootmachten gegarandeerde "eeuwigdurende neutraliteit" opgelegd, hetgeen het voeren van een voorzichtige 
buitenlandse politiek impliceerde. Dat gold zeker nadat vanaf de eeuwwisseling de spanningen toenamen in het in twee machtsblokken verdeelde Europa. Men kan de instrumentalisering waarvan sprake vergelijken met de toestand die er bestond tijdens de Koude Oorlog, toen men mensen of groeperingen ervan verdacht te "heulen" met de Sovjet-Unie of, al naar gelang de zijde van het Ijzeren Gordijn waar men zich bevond, de Verenigde Staten.

De Waalse beweging bestreed in 1914 nog steeds de taalwetgeving, maar had enkel maar kunnen bekomen dat die minder snel vooruitgang boekte. Sedert decennia moest ze onafgebroken katholieke regeringen, die bovendien het ordelijke Duitse Rijk genegen waren, dulden. Zelf identificeerde ze zich echter tot op zekere hoogte met de Franse republiek en ontwaarde ze een Duitse hand achter de Vlaamse beweging. Wat de wallinganten verkondigden over die germanofilie was niet helemaal uit de lucht gegrepen, hoezeer het ook in hun propaganda overdreven werd. Er ging immers een Germaans verwantschapsgevoel schuil in de Vlaamse beweging. Die was tot op zekere hoogte ontvankelijk voor een völkische ideologie die tijdens het laatste kwart van de negentiende eeuw op grote schaal in het Duitse Rijk doorbrak. Ze nam er stilaan de vorm van een massabeweging aan. Door het bestaan en optreden van halbstaatliche organisaties, zoals het Alldeutscher Verband, ontstond er een synergie tussen de rijkspolitiek en dat völkische gedachtengoed. Dat zette de traditionele Duitse diplomatie in toenemende mate onder druk. Tegen die achtergrond flakkerden contacten tussen Alduitsers en Vlaamsgezinden vanaf de jaren 1890 op. Wanneer die Vlaamsgezinden aan het tijdschrift Germania meewerkten of het Alldeutscher Verband het hof maakten, werd er door hun tegenstanders aanstoot aan genomen. Aan het (vermeende) Duitse gevaar werd de Duitse expansie in het Vlaamsgezinde Antwerpen, met zijn goed georganiseerde en kapitaalkrachtige Duitse kolonie, gekoppeld. In de geesten van de Waalse beweging, maar ook in Frankrijk, ontstond een zeer negatieve beeldvorming over de "Duitse" havenstad. Maakte een Duitse economische overheersing van Antwerpen de weg niet vrij naar een Duitse politieke overheersing, met de flaminganten als wegbereiders van hun "Germaanse broeders"? Die kritiek werd dan gevoegd bij het antimilitarisme dat Antwerpen toegedicht werd en enigszins op feiten steunde. Ze was aanwezig in Belgische militaire kringen en vond haar weg naar de literatuur die op haar beurt in Duitsland gelezen werd. We hebben gezien dat de ergernissen bij de gallofiele radicalen binnen de Waalse beweging de vorm aannamen van scheldpartijen, waarin men enerzijds Frankrijk idealiseerde en anderzijds zowel België, de Vlaamsgezinden als de Vlamingen zelf kapittelde. De Vlaamse beweging voelde zich ook daarom bedreigd door de wallinganten. 
Vele Vlaamsgezinden vreesden immers dat die Waalse beweging de emanatie was van Franse kuiperijen. Ook hier zat een grond van waarheid in. Het is immers ontegensprekelijk zo dat de Franse staat acties en groeperingen ondersteunde tegen de Vlaamse beweging, die in Parijs als pro-Duits en antiFrans ervaren werd. ${ }^{11}$ Dat gebeurde bijvoorbeeld in de strijd rond de vernederlandsing van de Gentse universiteit. Hoewel de macht in de handen lag van katholieke regeringen die de flaminganten in principe welgezind waren, verloren die mede door de wijziging van het kiesstelsel aan slagkracht. Tot op zekere hoogte ondermijnde dat het Vlaamsgezinde vertrouwen in het overheidsbestel en scherpte het wellicht het wantrouwen tegenover de Belgische staat aan. Wat zou dat niet worden indien de Belgische regering een andere samenstelling zou kennen - waar anti-Vlaamsgezinde liberalen en socialisten ook deel van uitmaakten -, hetgeen in de lijn der verwachtingen lag bij een Godsvrede? Alleszins verzwakte de vooroorlogse polarisering tussen flaminganten en wallinganten tot op zekere hoogte de Belgische eenheid en dus zo'n Godsvrede.

De sfeer van internationale overprikkeling zorgde er bovendien voor dat de flaminganten in het voorstel van een Nederlands-Belgisch Entente een Franse dreiging ontwaarden. Bij uitbreiding was die dreiging zelfs Frans-Brits te noemen, want het heette dan dat het plan voor zo'n verbond tussen de twee kleine staten maakwerk was van Frankrijk en het Verenigd Koninkrijk om Duitsland het hoofd te kunnen bieden. De geboren Nederlander Marten Rudelsheim, die stadsbibliothecaris van Antwerpen was en later in het activisme terechtkwam, zou in 1907 een artikel van tientallen bladzijden wijden aan de ontmaskering van dit "complot". ${ }^{92}$ Een tijdlang werd ook op de Duitse ambassade te Brussel alles in het werk gesteld om te bewijzen dat die voorgestelde Entente een anti-Vlaamse machinatie was. De internationale toestand beïnvloedde de communautaire betrekkingen in België. Maar de Vlaamsgezinde agitatie ondermijnde ook de Nederlands-Belgische relaties. Op nog een ander punt waren die al danig vertroebeld. België vroeg Nederland dat het, in geval van oorlog, de Westerschelde vrij zou laten om Britse hulp toe te laten. Maar Nederland had in 1911 bij Vlissingen net forten gebouwd, die zo'n hulp konden hypothekeren. ${ }^{93}$ 


\section{HOOFDSTUK 2 DE GODSVREDE TOT DE VAL VAN ANTWERPEN}

Laat de Godsvrede dan al enigszins ondergraven geweest zijn door vooroorlogse spanningen, volgens de activisten en later verschillende historici was het de "anti-Vlaamse campagne" die ze doorbrak en aanleiding tot het activisme gaf. De bedoeling van dit hoofdstuk is om het waarheidsgehalte van verschillende incidenten die zich in dat kader vóór de val van Antwerpen afgespeeld zouden hebben, te analyseren. Meer concreet worden achtereenvolgens gallofiele artikels die begin augustus 1914 in de Belgische pers verschenen, onderzocht; vervolgens een flamingantische proclamatie van de Vlaamse Volksraad, blijkbaar gericht tegen Franstalige aantijgingen van pan-Germanisme; nadien een ophefmakend artikel uit La Métropole en, ten slotte, de Godsvrede in Gent tot de inname van die stad, op 9 oktober 1914.

We frissen eerst het geheugen op door het verloop van de eerste oorlogsweken bondig weer te geven. De moord op de Oostenrijkse troonopvolger en zijn echtgenote op 28 juni 1914 was het startschot voor het grootste gewapende conflict dat Europa sedert een eeuw gekend had. Op korte tijd sloegen de vonken uit de Balkan over naar de rest van het continent. Nadat Duitsland op 1 augustus de oorlog verklaard had aan Rusland, leidde het Europese alliantiesysteem tot een oorlog. Om die in zijn voordeel te beslechten, diende het Duitse Rijk eerst Frankrijk te verslaan (volgens het Von Schlieffenplan) om dan voluit Rusland te bekampen. Daarvoor was een vrije doortocht naar Frankrijk nodig. De Belgische regering wees, tot con- 
sternatie van Berlijn, het Duitse ultimatum van 2 augustus 1914 dat deze vraag bevatte, af. Toen Duitsland op 4 augustus 1914 België binnenviel - de Duits-Franse oorlog was een dag eerder begonnen -, bereikte het Belgische patriottisme een hoogtepunt. De vaderlandslievendheid die de massa's mobiliseerde, werd nog versterkt door het feit dat België, om de woorden van de Duitse kanselier in volle Rijksdag te gebruiken, een onrecht aangedaan was. ${ }^{1}$ Dat klopte. Want het Belgische grondgebied werd geschonden door een van de garanten van de Belgische neutraliteit. Dit gegeven vormde de aanleiding (of het voorwendsel) voor het Verenigd Koninkrijk om Duitsland de oorlog te verklaren. Op 4 augustus 1914 wees koning Albert I in een redevoering in de Kamer van Volksvertegenwoordigers erop dat een schending van het Belgisch grondgebied inhield dat het land gewapend de grootste offers zou brengen. Er heette nog één partij te zijn, die van het vaderland. ${ }^{2}$ Het concept "Godsvrede" lag in deze woorden besloten. Op 12 augustus weigerde België in te gaan op een tweede Duits verzoek tot wapenstilstand. ${ }^{3}$ Het keizerlijke leger begon daarop met het verwoesten van Belgische steden en het vermoorden van duizenden Belgische burgers. De Duitse soldaten verkeerden in de waan dat er, naar analogie met de Frans-Pruisische oorlog van 1870, Belgische "francs-tireurs" bestonden die Duitse troepen onder vuur namen. Wellicht kaderden de gruwelen ook binnen een strafexpeditie tegen dat balorige buurland. Het kleine België vermocht natuurlijk bitter weinig tegenover de Duitse pletwals. Achtereenvolgens vielen de stad Luik (7 augustus) en de omringende forten (16 augustus). Op 20 augustus 1914 werd Brussel door het Duitse leger veroverd. Vanaf 21 augustus werden de Naamse forten door het Duitse geschut verpulverd. Algauw werd het gouvernement-generaal onder leiding van Colmar von der Goltz, die op 23 augustus 1914 tot gouverneur-generaal van België benoemd werd, ingericht. Hij legde zijn ambt neer op 27 november 1914, waarna Moritz von Bissing hem opvolgde. ${ }^{4}$ De Duitse legers concentreerden hun krachtsontplooiing op de opmars naar Frankrijk, waardoor delen van België onbezet bleven. Het was daarom dat Antwerpen pas op 9 oktober in Duitse handen terechtkwam en Gent op 12 oktober viel.

\section{Francofilie en pan-Germanisme?}

De (post-)activistische propaganda besteedde nogal wat aandacht aan de vermeende gallofilie van de "Fransgezinde pers" in België tijdens de eerste oorlogsdagen. In de historiografie ging daar tot nu toe nochtans geen aan- 
dacht naar uit. Om welke stukken gaat het? Allereerst betrof het een editie van de liberale Petit Bleu van 2 augustus 1914 (dus nog vóór het uitbreken van de vijandelijkheden) die, wegens zijn Fransgezind karakter, door de Belgische regering in beslag genomen werd. ${ }^{5}$ Het blad titelde die dag naar aanleiding van het escalerende Balkanconflict: Honte à la Barbarie! Vive la France!. De redacteur van Le Petit Bleu beweerde dat het gepantserde "Germania" de wereld aan de dageraad van de twintigste eeuw, opnieuw in de barbaarsheid stortte. Het droeg als enige schuld aan deze misdaad tegenover de menselijkheid. Tegenover de woestheid uit het oosten stond België vol sympathie tegenover de koelbloedigheid van het vredelievende Frankrijk. Besluiten deed hij met een donderend: "Leve Frankrijk!" ${ }^{6}$ Vijf dagen later kwam Roland de Marès, de hoofdredacteur van L'Indépendance Belge (liberaal), woorden te kort om zijn liefde voor Frankrijk neer te pennen. Hij bezwoer dat de Belgische natie tot het einde der tijden niet zou vergeten dat Frankrijk, net als in 1831, het bloed van zijn zonen offerde om de Belgische onafhankelijkheid te verdedigen. ${ }^{7}$ In januari 1915 werd in de Duitsactivistische Gazet van Brussel uit dit artikel geciteerd om te illustreren hoe de "Fransdolle Belg" niet alleen gekenmerkt werd door een "haat jegens Vlaanderen" maar ook door een "gedweep met al wat Frans" was. ${ }^{8}$ Dat De Marès al vóór de oorlog bekendstond om zijn germanofobie en gallofilie en bovendien de vernederlandsing van de universiteit van Gent bestreed, maakte hem tot een dankbaar doelwit. ${ }^{9}$ Een ander artikel, van de hand van Camille Gutt, verscheen op 8 augustus in La Chronique (liberaal). De auteur beweerde in het zeer gallofiele stuk dat het blad zich een tijdlang bewust in stilzwijgen gehuld had, waar het de Franse hulp betrof. Het algemeen belang dicteerde dat. Er was immers nog niets onherstelbaars [een Duitse inval, $B Y$ ] gebeurd. Deze belangrijke nuance over de Belgische neutraliteit die het blad naleefde, werd in de activistische propaganda geschrapt. Wat wel weerhouden werd, was de volgende passage: "Mais maintenant! Avec quelle joie, avec quel orgueil, nous pouvons saluer ces amis fraternels en qui, toujours, nous avons vu s'incarner toute la droiture, toute la noblesse, toute la générosité!" ${ }^{10}$ De man die meer dan dertig jaar later als eerste aan het hoofd zou staan van het Internationaal Monetair Fonds (IMF), besloot zijn proza met het "gezegende Frankrijk" toe te roepen dat de Belgische harten klopten voor de natie die nimmer de schreeuw van een verdrukte onbeantwoord zou laten. ${ }^{11}$

Een laatste activistisch bewijsstuk kwam uit de liberale Soir van 9 augustus 1914. Daarin stond een brief afgedrukt van de oorlogsvrijwilliger en ingenieur Maurice Berger die de kinderlijke naïviteit behandelde 
van soldaten die dachten dat ze Duitsland tot aan de Rijn gingen annexeren.

Avec tout cela $[. .$.$] une façon de parler de leurs 'frères' qui combattent en$ ce moment, qui est vraiment émouvante. Depuis le premier jour de mobilisation, la haine pour l'Allemagne était féroce. Mais, par contre, il eût été difficile de nous faire marcher contre la France. ${ }^{12}$

Dergelijke annexatiedromen waren zeker niet voorbehouden aan Franstaligen. De Antwerpse advocaat Jozef Muls herinnerde zich immers ook dat hij en zijn huisgenoten tijdens de eerste weken van het conflict op de kaart keken naar de Duitse Rijnprovincie die ze tussen België, Nederland en Frankrijk zouden verdelen. ${ }^{13}$ Het was het andere deel van het artikeltje dat blijkbaar voor propagandadoeleinden dienst kon doen. Want vanaf begin 1915 beweerde de collaboratiepers dat indien Frankrijk eerst België was binnengevallen, er geen schot zou gevallen zijn. De "Fransdollen" hadden dan, integendeel, de Fransen met open armen ontvangen. ${ }^{14}$ Die stelling berustte op een verdraaiing van het verslag van Berger. Begin augustus 1914 waren er dus drie zeer pro-Franse artikels verschenen in een deel van de Franstalig-liberale pers, aangevuld met één lezersbrief. Van een massale en systematische gallofilie was er geen sprake.

In feite bouwde de Duits-activistische propaganda voort op het vooroorlogse wantrouwen van de Vlaamsgezinden voor de Belgische, Franstalige pers. Frankrijk had vóór de oorlog bij de Franstalige pers in België een gigantische voorsprong op Duitsland uitgebouwd. Rond de eeuwwisseling hadden de meeste Belgische dagbladen zelfs geen correspondent in Duitsland noch een redacteur die het Duits machtig was. De Franse aantrekkingskracht op de Franstalige pers werd versterkt omdat lange tijd het persagentschap Havas een feitelijk monopolie had op de berichtgeving. Door de beperkte taksen die de Parijse dagbladen moesten betalen, de aanleg van de telefoonlijn Parijs-Brussel aan het eind van de jaren 1880 en de Franse subsidiëring van kranten speelde Parijs voortdurend de eerste viool. Van alle dagbladen gold L'Indépendance Belge sedert decennia als het meest francofiele. Tot 1894 was de Britse liberale journalist Gérard Harry, die we later in de vermeende anti-Vlaamse campagne zullen ontmoeten, er (een tijdlang ook als hoofdredacteur) werkzaam. Daarna vertrok hij naar Le Petit Bleu waar hij tot 1908 bleef. L'Indépendance Belge werd quasi-permanent door het Quai d'Orsay en een tijdlang (in mindere mate) door Londen gesubsidieerd. Blijkens een lijst van het Belgische ministerie van Buitenlandse Zaken uit 1912 behoorde ook 
La Chronique tot het francofiele gezelschap. Volgens een Duits rapport gold dat ook voor Le Soir. ${ }^{15}$

Kortom, er bestond een francofiele pers in België die de Vlaamsgezinden ergerde. Die maakte van het uitbreken van de oorlog weliswaar geen gebruik om de Godsvrede in pro-Franse zin te verbreken, maar Vlaamsgezinden konden dat scenario wel vrezen. De besproken artikels konden later nuttig zijn voor de bezetter die, voor Vlaams gebruik, de oorlog afschilderde als een conflict tussen "Germanen" en "Latijnen".

De "proclamatie van de Vlaamse Volksraad" van 16 augustus (sic) 1914 dan. Was die er gekomen om de beschuldigingen van pan-Germanisme ten aanzien van de Vlaamse beweging te weerleggen, zoals we dat tot op vandaag lezen? ${ }^{16}$ In werkelijkheid had de Volksraad in Brussel op 6 augustus pamfletten opgeplakt, gericht aan de "Vlaamse Belgen". Twee weken later werd het bericht naar de pers opgestuurd. Op die plakbrieven viel te lezen hoe de Raad "namens het Vlaamse volk" en "ter bestrijding van alle pan-Germanisme" op 16 mei 1897 een brief had gericht met daarin het eerder besproken Manifest van de Vlaamsche Volksraad uit dat jaar. De inhoud daarvan werd gepubliceerd en aangevuld met een felle aanklacht tegen het Duitse Rijk dat, zo heette het, in weerwil van zijn verbintenissen (het traktaat van 1839), de Belgische neutraliteit geschonden had. Het pamflet maande de Vlamingen aan het "brutaal aangevallen vaderland" te verdedigen. In het oorspronkelijke Manifest werd beweerd dat het Duitse Rijk naast een bevriende natie, een vreemde mogendheid was. In augustus 1914 werd het Duitse Rijk natuurlijk de vijand van Vlamingen en Walen genoemd die "...allen uit al hun krachten en met alle middelen hardnekkig [...] bevechten" zouden. De "proclamatie" - het woord zelf is ontleend aan de apologetische propaganda, want het ging, net als in 1897 om een "manifest" - was dus eenvoudigweg een vaderlandslievend, anti-Duits schrijven. Hoogstens dient opgemerkt dat dit pamflet misschien op een impliciete manier de Vlaamsgezinden probeerde vrij te pleiten van hun vooroorlogse germanofilie. En dat ze bijgevolg bevreesd waren met die stroming vereenzelvigd te worden.

\section{Een vermeend anti-Vlaams artikel}

Er bestaat in de historiografie een zekere consensus over het anti-Vlaamsgezinde karakter van L'Avant-Guerre, le Pangermanisme - les Egarés. Soms leest men dat het een artikelenreeks betrof uit de katholieke Antwerpse Métropole. Dan weer wordt het als een artikel dat in dat blad op 22 augustus 1914 
gepubliceerd zou zijn, omschreven. Vreemd genoeg werden noch de inhoud, noch de context ervan ooit onderzocht. La Métropole publiceerde tussen 19 augustus en eind september 1914 een reeks van meer dan twintig artikels, onder de hoofding L'Avant-guerre, Contribution à l'invasion allemande en Belgique. Op 22 augustus verscheen die hoofding met als ondertitel Le Pangermanisme - Les Egarés. Zoals het blad aangaf, was die hoofding ontleend aan het in 1913 verschenen werk van Léon Daudet. Die rechts-conservatieve Franse publicist had met L'Avant-guerre: études et documents sur l'espionage juif allemand en France depuis l'affaire Dreyfus een controversiële bestseller geschreven. Het boek was een bundeling van zijn antisemitische en antidemocratische artikels uit de integraal-nationalistische Action Française, waarvan hij hoofdredacteur was. De joden werden erin afgeschilderd als Duitse handlangers. Zij hadden zich zogezegd meester gemaakt van de Franse grondstoffen, handel en strategische plaatsen. Mocht er een oorlog uitbreken, stond die vijfde colonne klaar om de Franse soldaten achter het front te saboteren. ${ }^{17}$ In de stukken van La Métropole nam die colonne de vorm van de Duitse kolonie te Antwerpen aan. In het eerste artikel uit de reeks luidde het dat de Duitsers in België en Antwerpen een verduitsende wolf in schaapsvacht geweest waren die een kwarteeuw lang het aanschijn van de stad grondig veranderd hadden. Ze werkten slechts in het Duitse belang en de Belgen moesten zich in een onderdanige positie schikken. Het pan-Germanisme maakte zo vóór de oorlog al zijn opwachting. ${ }^{18} \mathrm{Na}$ per artikel achtereenvolgens de "infiltratie", de "beïnvloeding" en de "verschillende instellingen" behandeld te hebben, kwamen in het vierde stuk (22 augustus 1914) de "misleiden" (les égarés) aan de beurt.

Het artikel begon eenvoudigweg waar het vorige gestopt was: bij het pan-Germanisme. Het blad beweerde dat de criminele samenwerking van enkele landgenoten, de pan-Germanisten, wellicht toegelaten had om een afdeling van het Alldeutscher Verband te Antwerpen op te richten. ${ }^{19}$ Toch waren de "misleide" landgenoten niet noodzakelijk Vlamingen. Sedert Jan Frans Willems - die het glas hief op het Duitse [sic, Dietse, $B Y]$ vaderland - waren er voldoende Duitsland-aanbidders, onder wie ook Walen zoals Jottrand en Delecourt. Die laatste had in de negentiende eeuw immers geijverd voor een toenadering tussen het Vlaams en het plattdeutsch. Jottrand was eertijds de hoofdredacteur van het pan-Germanistische blad De Broederhand. Door een merkwaardig toeval waren er tussen de pro-Duitse protagonisten overigens veel namen die duidelijk Franstalig waren, zo merkte La Métropole op. Delecourt (nom de plume: Van den Hove) en Jottrand maakten deel uit van het germanofiele deel van de Vlaamse beweging, maar in 1914 lagen 
hun activiteiten al zeventig jaar in het verleden. ${ }^{20} \mathrm{Kan}$ men in het gispen van die twee Waalse en weinig representatieve enkelingen een aanval op "de" Vlaamse beweging zien? La Métropole betoogde voorts dat Vlaanderen een grootse geschiedenis had en een mondiale artistieke reputatie genoot. Die schat moest het niet te grabbel gooien voor Duitsland dat zich, proportioneel gezien, niet op dezelfde historische glorie kon beroepen.

Feitelijk wou La Métropole net de eigenheid van de Vlamingen verdedigen. Zo werd het argument van de Duits-Vlaamse taalverwantschap, dat panGermanisten inderdaad te pas en te onpas gebruikten, de grond ingeboord. Het Vlaams was, aldus La Métropole, geen Duits dialect noch een verloren zoon van de Duitse familie. Ook wees het blad de etnische verwantschap tussen Duitsers en Vlamingen met klem van de hand. De Vlaamse beweging was niet, in tegenstelling tot wat vele Franse schrijvers beweerd hadden, door Duitsers geschapen noch had ze als doel de voorbereiding van de inlijving van de Vlamingen bij Duitsland. Er was Albrecht Rodenbach geweest en "bepaalde redevoeringen te Düsseldorf" die de overtuiging gesterkt hadden dat Vlaanderen Duitsland minstens als een bevrijder zou onthalen (een zinspeling op De Mont). Maar dat was het werk van enkelingen geweest. Net zoals een zwaluw de lente niet maakte, zo schreef La Métropole, kon een zwart schaap een nationale beweging die legitieme eisen beoogde [i.e. de Vlaamse beweging, $B Y]$ niet compromitteren, hoewel die beweging soms te duidelijk tegen Frankrijk was gericht. ${ }^{21}$ Het blad voegde daar aan toe: "Il ne faut plus chez nous de centenaire de la bataille des Eperons d'Or. Soyons Flamands tout simplement et fièrement."

La Métropole gaf hiermee uiting aan haar pro-geallieerde gevoelens. Maar een Vlaamsgezinde kon door de passage over de Guldensporenslag geërgerd worden. De schrijver Stijn Streuvels stoorde er zich op 19 september 1914 aan dat men het Brits geweld in Transvaal van vijftien jaar eerder vergeten was. Het eertijds corrupte en ongodsdienstige Frankrijk was nu een ridderlijke bondgenoot: “...en nu Frankrijk ons voor de zoveelste maal te hulp springt zullen we - Vlamingen vooral, wel best doen [...], voortaan te zwijgen met ons gezeur van Groeninge en 1302!"22

$\mathrm{Na}$ de publicatie van dit artikel begon het dagblad met het aanzwengelen van een spionnenneurose. De gekste geruchten deden in de reeks L'Avant-Guerre de ronde, tot zelfs verhalen over Duitse dominees in Antwerpen bij wie men zogezegd het uniform van officieren had aangetroffen. En stonden er op de reclameaffiches van bouillon-Kub (nota bene een Zwitserse firma) geen richtingaanwijzers voor Duitse soldaten? Zulke zaken hebben nu een onbedoeld komische bijklank, maar ook in mei 1940, bij de tweede Duitse inval, 
deed het gerucht de ronde als zouden Duitse soldaten hun instructies vinden op de achterkant van reclamepanelen van Chicorei-Pacha. ${ }^{23}$ Die voorbeelden schetsen de overprikkelde sfeer waarin het besproken artikel van La Métropole verschenen was, in een stad waarin sedert begin augustus spontane antiDuitse rellen uitgebroken waren. ${ }^{24}$ Wat er ook van zij, het bewuste artikel uit La Métropole was zeker niet "anti-Vlaams". Vandaar dat Het Laatste Nieuws het artikel op 26 augustus 1914 aanwendde om de flaminganten vrij te pleiten van de Duitsgezindheid die Franse auteurs hen aanwreven. ${ }^{25}$ Slechts door activistische en apologetische propaganda vond de visie van het artikel uit $\mathrm{La}$ Métropole als een anti-Vlaams artefact haar beslag. Die stelling werd daarna immers door de bredere historiografie aanvaard, daar latere auteurs niet meer de originele bron geraadpleegd hebben. ${ }^{26}$

\section{De Gentse Godsvrede}

Vanacker wijdde een grondige studie aan de Gentse pers in de periode vóór de bezetting van die stad, op 9 oktober 1914. Daarbij kwam hij tot het besluit dat de Godsvrede voor wat de taalkwestie betrof een illusie was. Zeker is dat het liberale Laatste Nieuws zich in die stad van 22 tot 26 augustus niet aan de Godsvrede hield, maar heftig polemiseerde. Drie factoren werkten dat in de hand: de schok die de val van Brussel teweeg had gebracht, de ontwrichte censuur en het feit dat Julius Hoste niet meer de feitelijke hoofdredacteur was, nu het blad enkel nog een Gentse en Antwerpse uitgave had. ${ }^{27}$ De nieuwe hoofdredacteur, de dichter Gustaaf van Hecke, trok zich van de Godsvrede blijkbaar een tijdje veel minder aan.

Het liberale persorgaan liet met name doorschemeren dat de geallieerden België in de steek gelaten hadden. Die gedachte stond niet op zich, want ook in andere dagbladen leest men hoe de Belgen wachtten op hulp. De "Vlaamse" vesting Antwerpen werd op 22 augustus 1914 door Het Laatste Nieuws als de nationale hoop omschreven. Maar de volgende dag strooide het blad het gerucht rond dat België de wapens neergelegd had. In dezelfde periode berichtte de socialistische Vooruit over de val van de vesting Luik. Daarbij werd een propagandabericht uit de Duitse pers overgenomen waarin stond dat er in de Luikse forten Franse soldaten gelegerd waren. Het blad kon dat maar verspreiden bij ontstentenis van de censuur die ten strengste verboden had de val der Luikse forten mede te delen. ${ }^{28} \mathrm{Het}$ christendemocratische Volk veroordeelde als regeringsgezind blad beide kranten. Het vroeg zich af of de demoraliserende houding van Het Laatste Nieuws ingegeven was 
door het "Neerlandisme". ${ }^{29}$ Later laakte de katholieke pers diplomatischer "zekere bladen" en "alwetende' personen" volgens dewelke de geallieerden niets deden. ${ }^{30}$ Ook Het Laatste Nieuws kreeg de volle laag van Vooruit over zich heen. Dat persorgaan had het over de persveldtocht van "het liberaal flamingantenblad" tegen zijn "bloedvijand" Frankrijk. Zo ver ging het liberale blad dat het kolommen volschreef over de moed der Vlaamse soldaten en de Vlaamse vesting Antwerpen, zonder met een woord te reppen over de dapperheid van de Walen! ${ }^{31}$ La Flandre Libérale gispte Het Laatste Nieuws in een artikel Patriotisme de certains flamingants getiteld. Daarin werd betoogd dat het Nederlandstalige blad in hatelijke artikels verkondigde dat de verdediging van Luik het werk geweest was van Vlamingen. Dat het Antwerpen een "Vlaamse vesting" genoemd had, heette een misdadig landverraad te zijn. ${ }^{32}$ In een ander artikel viel het blad "een zekere Vlaamse pers" aan, die het blijkbaar vaderlandslievend achtte om op een hatelijke wijze de geallieerden te bekritiseren. Het Laatste Nieuws verweet de confraters van La Flandre Libérale daarop "antiflamingantisch gekef", maar besloot de zaak te laten rusten. ${ }^{33}$

Op 26 augustus 1914 klaagde het liberale blad de kranten aan die "met vage, doch kwaadbedoelende verdachtmakingen ten opzichte der Vlaamsgezinden" voor de dag kwamen. In tegenstelling tot La Flandre Libérale en Het Vaderland (liberaal) had het, zo betoogde het, zelf nooit over de taalkwestie gerept. Waren die bladen er soms op uit de Vlaamsgezinden in Gent in een kwalijk daglicht te stellen? Zou dat in latere tijden de Vlaamse beweging geen schade toebrengen? Het Laatste Nieuws beweerde alleszins uit betere patriotten dan andere liberale dagbladen te bestaan..$^{34}$ Was hier een "Franstalige anti-Vlaamse hetze" aan de gang? Toch niet. Het Laatste Nieuws was wegens zijn Vlaamsgezindheid angevallen door La Flandre Libérale, maar ook door Vooruit en Het Volk. Dus door Nederlandstalige dagbladen. Zelfs het liberale Vaderland had Het Laatste Nieuws het verwijt van "fanatiek flamingantisme" naar het hoofd geslingerd. ${ }^{35}$ De Godsvrede in Gent was, voor wat de taalstrijd betreft, weliswaar geen absoluut gegeven. Maar ze was ook niet volledig "onmogelijk". Per slot van rekening draaide de polemiek enkel en alleen om de houding van één liberaal dagblad tijdens een korte periode in de tweede helft van augustus 1914. In september 1914 publiceerden alle gelezen bladen samen nauwelijks artikels die de taalkwestie behandelden. ${ }^{36}$ Integendeel verschenen er in de (Franstalige) pers stukken die de Vlaamse strijdliederen op het slagveld bejubelden. Dit motief werd meestal gebruikt om de eenheid van het Belgische vaderland in de verf te zetten. ${ }^{37}$ Wel laakte Het Laatste Nieuws Franse (geen Belgisch-Franstalige) bladen "waarin de fla- 
minganten nagenoeg worden afgeschilderd als handlangers van een Duitse inpalming..." [niet verwonderlijk voor wie de Franse houding vóór de oorlog kent, $B Y]$. Maar bijna 65 procent van het leger, zo stelde het blad, bestond uit Vlamingen en de meesten daarvan waren moedige flaminganten. ${ }^{38}$ Vandaar dat het ook aanstoot nam aan "onvaderlandse" praatjes van "bladen als $L e$ Soir" als zou een inval van andere zijde [i.e. Frankrijk] "waarschijnlijk niet met gelijke kracht geweerd worden" ${ }^{39}$ Daarmee verwees het blad naar de eerder besproken brief van de oorlogsvrijwilliger Berger die in Le Soir verschenen was.

\section{Besluit}

Gedurende de eerste twee maanden na de Duitse invasie werd de Godsvrede relatief goed nageleefd. Het was pas achteraf dat de activistische propaganda de draagwijdte van enkele artikels in het kader van een zogenaamde antiVlaamse campagne zou opkloppen. Toch kon de taalkwestie wrevel opwekken. Zeker toen, na de val van Brussel, het patriottisch enthousiasme een klap kreeg. De Godsvrede was geen absoluut gegeven en er moet rekening mee gehouden worden, dat in de algemene oorlogshysterie Vlaamsgezinden zelfs een schijn van verdachtmaking als een aanval op hun hele beweging konden percipiëren. We zagen hoe Vlaamsgezinden, toen De Mont in 1905 aangevallen werd, al overprikkeld reageerden. Wat moest dat dan niet worden in een conflict? Op dat moment kon zeker een Franstalige herinnering aan hun germanofilie door flaminganten als anti-Vlaams aangevoeld worden. Zoals we zullen zien, was de val van de vesting Antwerpen de spreekwoordelijke druppel die de emmer deed overlopen. De capitulatie van dat formidabel bolwerk door een onbevoegd burgerlijk bestuur, gevoegd bij het gegeven dat journalisten (en burgers) zowel binnen als buiten het bezette land verbleven, moest wel tot heibel leiden. 


\section{HOOFDSTUK 3 PERSPOLEMIEKEN IN DE NASLEEP VAN DE VAL VAN EEN "ONNEEMBARE" VESTING}

Veertien dagen na de Duitse inval trok het Belgische staatsapparaat zich terug in de vesting Antwerpen. Het "nationale bolwerk" was zo de feitelijke hoofdstad van België geworden. Het beeld dat de vesting onneembaar was, werd daardoor nog versterkt. ${ }^{1}$ Het immense vertrouwen van de publieke opinie in de vesting was ook het gevolg geweest van de houding van de overheid. $\mathrm{Na}$ de terugtrekking van het Belgisch leger naar Antwerpen, volgde een officiële mededeling dat de vesting onneembaar was. Zelfs werd beweerd dat de Duitsers niet naar de metropool zouden oprukken. ${ }^{2}$ Dat eerder ook gemeld was dat de forten van Luik onneembaar waren, werd blijkbaar snel vergeten. ${ }^{3}$ De Belgische pers heeft deze beeldvorming nog versterkt door tot op het laatste ogenblik die officiële visie te herhalen of minstens te wijzen op de lange weerstand die de forten konden bieden. Vele artikels deden een beroep op het Belgische patriottisme, riepen op tot verzet en minimaliseerden de Duitse opmars. Ze gingen gepaard met een overdreven vertrouwen in de forten, de Britse hulp en de Antwerpenaars zelf. ${ }^{4}$

De dagbladen konden evenwel niet volledig weten wat er aan de hand was. De berichtgeving liep immers vanaf 9 oktober mank omdat de communicatielijnen tussen de havenstad en de rest van België afgesneden waren. Hierover ontstond wel wat wrevel in de liberale en de socialistische pers. Toch werd nergens het optimisme getemperd, ook niet toen de inname van 


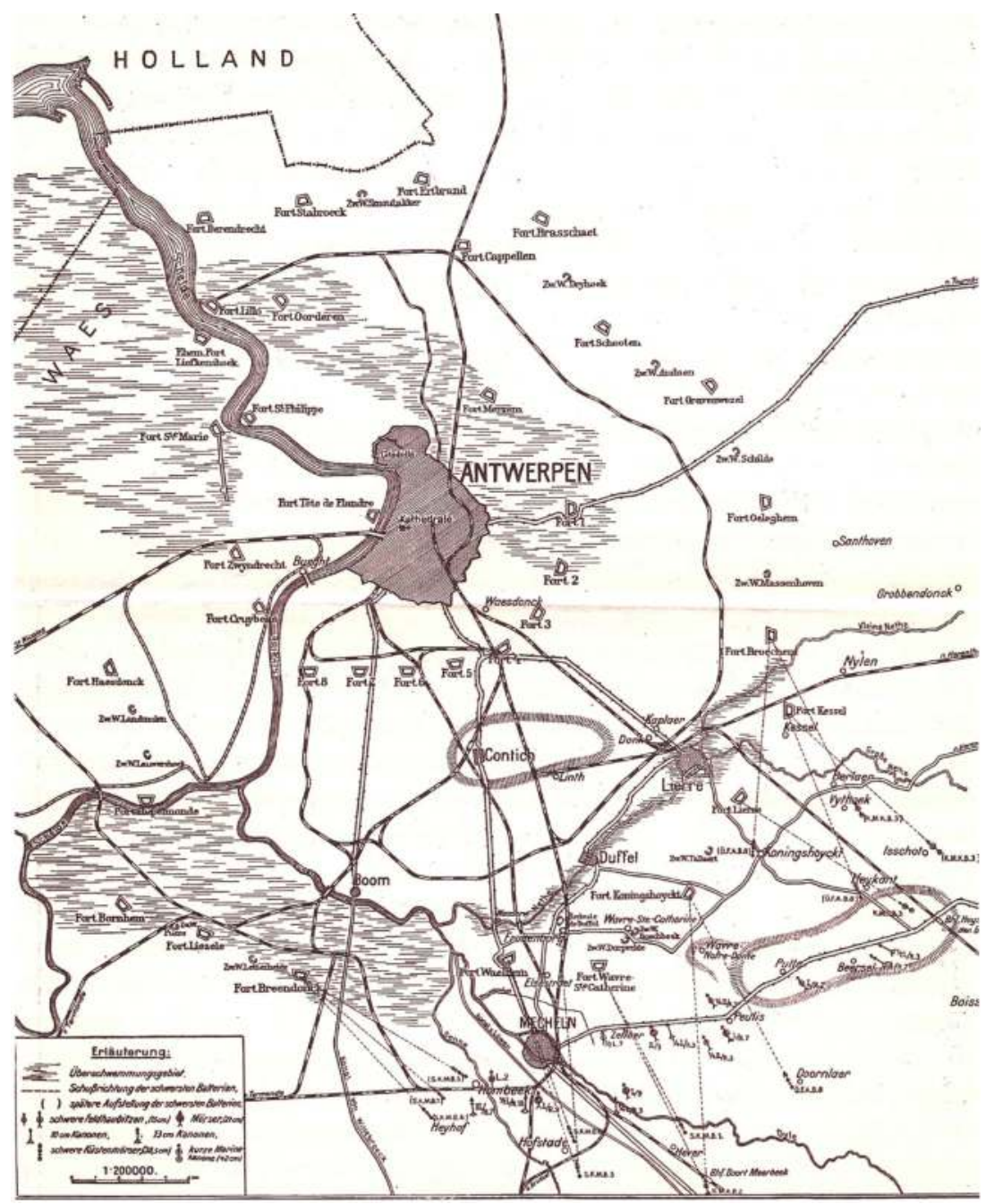

Afb. 1. De fortengordels rond Antwerpen

DE LOOZE, 295; KU Leuven Libraries Artes University Library MAGA1: Magazijn Y1205

de stad - waarvan pas 72 uur later gewag werd gemaakt - letterlijk voor de deur stond. Overschatting ging bij sommigen met een latente wrevel gepaard. Streuvels schreef op 23 september 1914 dat Antwerpen hem voorkwam als "de hoogdragende": de stad stelde zich wat egoïstisch op, wegens haar versterkte omheining. Ze was voor hem de onbereikbare, die zich boven Brussel plaatste omdat ze een schuilplaats kon bieden aan's lands bestuur en zo het 
vaderland in zijn uiterste toevlucht vertegenwoordigde. ${ }^{5}$ Dit relaas klinkt als een echo van wat Eekhoud twee decennia eerder verkondigd had.

Omdat het Duits offensief tot eind september 1914 gericht was op het afdwingen van een doorbraak in Frankrijk, hadden de Belgen aanvankelijk nog wat respijt gekregen. Bovendien kon het Belgisch leger uitvallen doen naar de Duitse aanvoerlijnen. De belangrijkste daarvan vonden plaats tussen 9 en 13 september. Twee weken later lanceerde het keizerlijke leger onder leiding van generaal Von Beseler een aanval op Antwerpen. Het sloeg met zijn zware artillerie een grote bres in de buitenste fortengordel. Het was duidelijk dat de erg verouderde binnenste fortengordel niet te verdedigen was. Op 2 oktober besloot de Belgische defensieraad dat een evacuatie aan de orde was. Drie dagen later stak het Duitse leger de Nete over. De weinige Britse troepen, vergezeld van de Britse minister van Marine Winston Churchill, boden geen substantiële hulp. Op 6 oktober besloot koning Albert om tot de terugtrekking van de troepen via het Waasland over te gaan. Generaal Deguise, de opperbevelhebber van de vesting, moest de nog intacte ringen tot het uiterste verdedigen. De snelle Duitse opmars, het gebroken moreel bij de troepen en de onophoudelijke bombardementen van het stadscentrum vanaf 8 oktober om middernacht, zorgden ervoor dat dit opzet mislukte.

Ondertussen was een Intercommunale Commissie opgericht, met als voorzitter het liberale gemeenteraads- en kamerlid Louis Franck. Die verbleef in Zuid-Afrika, maar keerde halsoverkop terug naar België. In de nacht van 6 op 7 september kwam hij in de Scheldestad aan. Daar stelde hij zich ter beschikking van de regering. ${ }^{6}$ De ondervoorzitter was de katholieke senator en schepen, Alphonse Ryckmans. Zij werden bijgestaan door andere bestuursleden uit de zaken- en bankwereld. De commissie telde 19 leden en incarneerde de Godsvrede, in die zin dat er negen liberalen en zes katholieken (maar geen enkele socialist) in zetelden. Dit stond in schril contrast met het bijna volledig liberale stadsbestuur van Antwerpen. Schepen Louis Strauss noch burgemeester Jan De Vos werd erbij betrokken. Nochtans had uitgerekend die eerste verzocht om een commissie als raadgevend orgaan op te richten. Spoedig bleek dat het om een bestuurlijke entiteit op zich ging waardoor de leiding van de 77 Antwerpse gemeenten de facto bij Franck kwam te liggen. Die werd zo de feitelijke burgemeester. ${ }^{7}$ Jozef Mertens veronderstelde dat het de regering was die druk uitgeoefend had op De Vos om Franck als zijn rechterhand te benoemen. Over de wettelijke regeling van de bevoegdheden, bestond er alleszins onduidelijkheid. Op 4 oktober, drie dagen vóór het vertrek van de koning, stelde 
men in de raadszitting van de stad voor om de stichting van de Intercommunale Commissie aan minister van Binnenlandse Zaken Berryer voor te leggen. De Vos bleef dagelijks in contact met de regering staan. ${ }^{8}$ De eerste bekommernis van de nieuwe bestuurlijke entiteit was het lot van Antwerpen, dat blootstond aan het zware Duitse geschut. De stedelijke overheid oordeelde dat het in die omstandigheden zinloos was om de strijd voort te zetten.

\section{Omtrent de val van Antwerpen}

Op 9 oktober 1914 onderhandelden Franck, De Vos en Ryckmans in het gezelschap van de consul van het neutrale Spanje te Kontich de capitulatie van de vesting tegen de volgende dag. ${ }^{9}$ Het alternatief was een onmiddellijke hervatting van de beschieting van Antwerpen. De volgende nacht trokken afgevaardigden van de burgerlijke overheid naar de forten om de Belgische bevelhebbers over de capitulatie in te lichten. Na de overgave aan het III. Reservekorps van Von Beseler ontmoetten de officieren elkaar te Antwerpen om het verdrag te bekrachtigen. In naam van generaal Deguise ondertekende generaal Werbrouck het document. Dat had hij persoonlijk ontvangen van de woordvoerder van Von Beseler, Oskar Von der Lancken-Wakenitz. Die trad op in de hoedanigheid van diplomaat bij het Duits bezettingsbestuur en vertegenwoordiger van het Auswärtiges Amt.

De val van de onneembaar gewaande vesting Antwerpen was een mokerslag die bij de bevolking waarschijnlijk nog harder aankwam dan die van Brussel anderhalve maand eerder. De bezetting was geen tijdelijk gegeven meer; de Duitse heerschappij was integendeel voor lange tijd over België gevestigd. Eind oktober 1914 stabiliseerde het front zich aan de IJzer. De loopgravenoorlog was begonnen. Inmiddels bevond de Belgische katholieke regering-de Broqueville zich in ballingschap in het Franse Saint-Adresse, dichtbij Le Havre. De koning bleef als opperbevelhebber bij zijn troepen, wat bijdroeg tot zijn enorme populariteit. Maar de verwarring na de val van Antwerpen was totaal. Een ooggetuige blikte vijf maanden na de val van de stad op de feiten terug:

De val van Antwerpen, de 'onneembare', na de hoop om eindelijk de geallieerden in groten getale op de Schelde te zien aankomen, wekte misschien een gevoel op dat pijnlijker was dan de eerste inval. [...] wat een angst! Alsof men de val van de eerste forten weigerde te geloven! ${ }^{10}$ [B.Y.] 
Een andere Brusselse ooggetuige beschreef eind november 1914 de sfeer toen men vernam dat Antwerpen gevallen was. Uit zijn verslag blijkt dat er een enorm ongeloof heerste. Men wist, zo herinnerde hij zich, dat de vesting Antwerpen, symbool voor het bestaan van België zelf, vernietigd kon worden. Maar indien een zegerijk verzet de stad tot asse herleidde, zouden alle Belgen toesnellen om haar in volle glorie herop te bouwen. De overgave van een stad, omringd door intacte forten, was niet bepaald eervol geweest. Een ander verslag van net na de overgave bevestigt dit ongeloof dat, toen de feiten waar bleken te zijn, omsloeg naar een irrationele woede:

Men spreekt van verraad en onbekwaamheid. Op slag worden de Antwerpenaars van veel verdacht en, zonder na te denken, beticht men ze al de verdedigers verplicht te hebben om zich over te geven om de gruwel van een bombardement niet te hoeven ondergaan! $!^{11}$ [B.Y.]

Algauw nam de irritatie onder de burgers en journalisten toe. De frustratie en het ongeloof over de capitulatie van de vesting leidden evident tot vragen naar de verantwoordelijken. Was Franck soms schuldig? Die incarneerde niet alleen het gezag, maar had ook mee de overgave van de vesting onderhandeld. En die capitulatie door afgevaardigden van de burgerlijke overheid was niet alleen juridisch betwistbaar, maar zelfs een unicum in de militaire geschiedenis. Had de Antwerpse gemeenteraad niet nog op 7 oktober unaniem verklaard bereid te zijn om alle gevolgen van een verdediging tot het uiterste te ondergaan en nooit te proberen om de beslissing van de militaire overheid, die verantwoordelijk was voor de verdediging te beïnvloeden? ${ }^{12}$ Was die Franck bovendien geen usurpator? De Belgische overheid zou alleszins pas laat haar vertrouwen in Franck en de Intercommunale Commissie uitdrukken, waardoor zelfs zijn eigen partijgenoten eind december 1914 nog aan de regering de vraag stelden op wiens gezag Franck en zijn Commissie nu eigenlijk hun "nefaste activiteiten" uitvoerden. ${ }^{13}$ Dat er journalisten in het bezette land én in het buitenland verbleven en elk op hun beurt polemieken zouden starten, werd een probleem op zich. In de exodus werden inderdaad vluchtelingenbladen gesticht en verschenen bestaande dagbladen opnieuw. Voor wat het Verenigd Koninkrijk betrof, ging het om La Métropole en L'Indépendance Belge, respectievelijk op 8 en 26 oktober 1914. Ook verscheen er vanaf 25 september 1914 onder hoofdredactie van de Vlaamsgezinde Floris Prims een nieuw weekblad: De Stem uit België. In Frankrijk verscheen vanaf 12 november opnieuw het officieuze katholieke regeringsblad Le Vingtième Siècle. 
Nieuwe dagbladen, die specifiek op vluchtelingen gericht waren, zagen vooral in Nederland het daglicht. De twee belangrijkste waren, vanaf 15 oktober 1914, het Journal des Réfugiés (liberaal), tien dagen later gevolgd door het liberale L'Echo Belge. Al deze persorganen, op De Vlaamsche Stem het Vlaamsgezinde persorgaan dat vanaf 1 februari 1915 te Amsterdam verscheen onder redactie van de socialistische hoofdredacteur Albéric Deswarte - Le Vingtième Siècle en L'Indépendance Belge na, werden geredigeerd door Antwerpenaren. Die wilden uiteraard met een meer dan gewone belangstelling het reilen en zeilen in hun moederstad volgen. In het bezette land viel de sedert 1831 florerende pers aanvankelijk grotendeels stil. Sommige dagbladen zouden gaandeweg opnieuw verschijnen, zoals vanaf 28 oktober 1914 Vooruit en 's anderendaags Le Bien Public (ultramontaans) in Gent. ${ }^{14} \mathrm{Al}$ op 26 augustus herverscheen in Namen het reactionair-katholieke L'Ami de L'Ordre "à la commande et sous le contrôle du général von Below". ${ }^{15}$ In Antwerpen betrof het, in november, drie liberale bladen. Vanaf 5 november 1914 La Presse, gevolgd door De Nieuwe Gazet (11 november) en de Vlaamsche Gazet (20 november). Ook gaven de stedelijke autoriteiten vanaf 21 oktober 1914 een nieuw en eigen persorgaan uit: Antwerpsche Tijdingen. Andere dagbladen waren niet zo Belgisch als ze op het eerste gezicht leken. Dat gold voor de hoofdstedelijke bladen Le Bruxellois (18 september 1914), La Belgique (5 november 1914) en de Gazet van Brussel (29 november 1914). Deze persorganen stonden onder controle van de bezetter. Ook L'Avenir (Antwerpen, 16 december 1914) en de Gentse Vlaamsche Post (21 februari 1915) stonden onder verborgen Duitse leiding. Vanaf 1 november 1914 gaf het Duitse hoofdkwartier in Noord-Frankrijk de Gazette des Ardennes uit. Die werd in bezet Frankrijk, maar ook in België verspreid. Het blad stelde zich voor als een onpartijdig persorgaan, maar gispte al in zijn eerste hoofdartikel bepaalde organisatoren van de titanenstrijd die foutief nieuws wereldkundig maakten. Zij voelden zich, zo beweerde het, in veiligheid, nadat ze de zwaarste taak aan hun bondgenoten en vazallentroepen uit Azië en Afrika [lees: de geallieerden en hun koloniale troepen, $B Y]$ overgelaten hadden. ${ }^{16}$ De lezer wist dus meteen vanwaar de wind waaide.

\section{De vluchtelingenkwestie als splijtzwam}

De val van Antwerpen had tot gevolg dat minstens 30.000 Belgische soldaten in Nederland geïnterneerd werden. ${ }^{17}$ De exodus had ook honderdduizenden Belgen naar het neutrale buurland gedreven. Moesten die daar blijven of 
huiswaarts keren? Franck opteerde voor een beleid dat de terugkeer van alle vluchtelingen aanmoedigde. Zonder hen was het immers onmogelijk om het leven in de metropool te normaliseren. Op 13 oktober deelde hij mede dat goederen en personen, de burgerwachters inbegrepen, in Antwerpen veilig waren. Winkeliers kregen twaalf dagen om terug te keren of de bezetter zou maatregelen treffen. Dit document was mede ondertekend door generaal Von Hüne, de Duitse militaire gouverneur van Antwerpen. Vijf dagen later sprak Franck in enkele Nederlandse grensgemeenten de vluchtelingen toe om hen aan te sporen huiswaarts te keren. Nog maanden later zou de Duitse propaganda trouwens verkondigen dat het in de eerste plaats de Duitse overheid was die de terugkeer van de vluchtelingen vergemakkelijkt had. ${ }^{18}$ Zulke mededelingen plaatsten Franck natuurlijk in een lastig parket.

De situatie in Nederland maakte de terugkeer der vluchtelingen alleszins noodzakelijk. Het land kon het aantal vluchtelingen eenvoudigweg niet aan en drong logischerwijs aan op de terugkeer van de Belgen, die trouwens vaak in erbarmelijke omstandigheden leefden. Overigens zullen wel niet alle Nederlanders even gelukkig geweest zijn met die toestroom van Belgen. Schreef de pro-Duitse Anna de Savornin Lohman niet dat ze nooit iets van de Vlaamse sympathie voor de Nederlanders gemerkt had "vóór ze als bedelaars (en tegelijk met een brutale toon erbij) hier in ons land invielen, om door ons gespijsd, gevoed, gekleed te worden" ? ${ }^{19}$ Ook de Belgische regering zat met de handen in het haar over de netelige kwestie.

Minister van Justitie Carton de Wiart verklaarde openlijk dat de Intercommunale Commissie, die propaganda voor een terugkeer voerde, geenszins de wil van de Belgische regering vertolkte. Volgens hem was een onmiddellijke terugkeer van openbare ambtenaren naar Antwerpen "onzeker en onwaardig”. Begin november 1914 stelde de regering (als compromis?) dat die "onzekerheid en onwaardigheid" enkel gold voor bepaalde staatsambtenaren. Op enkele uitzonderingen na, zoals magistraten en bedienaars van erediensten, werd het hen uitdrukkelijk verboden zich "ten dienste van de Duitsers" te stellen. ${ }^{20}$ Uiteraard beroerde die kwestie ook de vluchtelingenpers. Van alle dagbladen die we onderzochten, spraken enkel Le Vingtieme Siècle en De Stem uit België er zich niet over uit.

De andere waren unaniem in hun af wijzing van een terugkeer, al besteedde L'Echo Belge beduidend minder aandacht aan de zaak. ${ }^{21}$ De argumenten om tegen een terugkeer te pleiten, zocht men in de situatie te Antwerpen. De stad werd afgeschilderd als een oord met barre levensomstandigheden, een nijpend voedseltekort, zonder persoonlijke veiligheid, financiële zekerheid noch werkgelegenheid. Een ander tegenargument was dat uitgerekend 
de onbetrouwbare bezetter aan de vluchtelingen vroeg om terug te keren. Vluchtelingen die dat deden zouden, op de keper beschouwd, dienaars van de vijand worden. De lege stad die de bezetter aangetroffen had, was voor hem een ontnuchtering geweest. Moest men zijn vaderlandsliefde verzaken om daar via belastingen de Duitse oorlogskas tegen België te spijzen? Als de oorlog, zo werd geopperd, ten nadele van Duitsland beslecht werd, zou een tweede bombardement van Antwerpen - ditmaal door de geallieerden plaatsvinden. De bezetter zou de teruggekeerde vluchtelingen dan als levende schilden gebruiken. Was dit niet de ware reden waarom hij de vluchtelingen nodig had, zoals La Métropole dat op 24 oktober 1914 opperde? Meerdere vraagstukken werden met de bovenstaande kwestie verstrengeld. Sommige Antwerpse dignitarissen die pleitten voor een terugkeer, werd immers ook de ondertekening van het verdrag van Kontich verweten. Bovendien werkte de Intercommunale Commissie administratief samen met de bezetter. En dan was er de perskwestie: mochten dagbladen (her)verschijnen in bezet België? Toen op 21 oktober 1914 Antwerpsche Tijdingen, het officieuze orgaan van het stadsbestuur verscheen, was het hek helemaal van de dam. Dit blad beriep zich er immers op dat het geen Duitse censuur onderging en verscheen op uitdrukkelijk verlangen van het schepencollege en de Intercommunale Commissie. ${ }^{22}$ Zoals we zullen zien, zou het niet lang duren alvorens dit dagblad frontaal in aanvaring kwam met de vluchtelingenpers en in de eerste plaats met het Journal des Réfugiés uit Bergen op Zoom.

\section{Het Journal des Réfugiés verbreekt de Godsvrede}

Dat Journal des Réfugiés was een partiële voortzetting van de liberale, Antwerpse Matin. Andere medewerkers van dat laatste blad vervoegden zich in Amsterdam bij de rangen van L'Echo Belge. ${ }^{23}$ Het dagblad werd uitermate geprikkeld door de vluchtelingenkwestie en verbond er aanvallen op Franck, de Intercommunale Commissie en de Antwerpse pers mee. Ook stak het zijn ongenoegen over de wijze van overgave van de stad bepaald niet onder stoelen of banken. Het Journal was het eerste dagblad dat tegen Franck en de zijnen van leer trok en twee artikels ervan werden later in de activistische propaganda omschreven als staaltjes van de anti-Vlaamsgezindheid die zo kenmerkend zou geweest zijn voor de houding der Franstalige vluchtelingenpers. Het verdient dus onze bijzondere aandacht. In de redactie van het blad voorzag onder anderen de dramaturg Jacques Wappers menig artikel van een polemische ondertoon. Al een paar dagen na de val van Antwerpen 
verzette hij zich tegen de "verdachte" Duitse vraag om naar die "gevaarlijke" stad terug te keren. ${ }^{24}$ Op 17 oktober verklaarde een Britse schrijfster die te Antwerpen verbleven had in het blad dat de Belgen met een Duits spionnenvolkje samengeleefd hadden. ${ }^{25}$

Maar het was een gebeurtenis in het Verenigd Koninkrijk zelf die de vlam bij het Journal des Réfugiés pas echt in de pan deed slaan. Daar bereikte de spionnenneurose in oktober en november 1914 een hoogtepunt. Die ging gepaard met anti-Duitse rellen die meteen na de val van Antwerpen begonnen en tussen 14 en 24 oktober culmineerden. De val van de vesting werd over het Kanaal als een ramp beschouwd, die de Duitse invasie nabij bracht. Berichten die binnenkwamen over de Duitse opmars naar Calais, de Britse nederlagen, gevoegd bij de aankomst van duizenden Belgische vluchtelingen in Britse havensteden en hun verhalen over Duitse gruwelen en militaire macht, wakkerden er de oorlogshysterie aan. The Daily Mail begon in die context binnen de week na de val van Antwerpen met een campagne erop gericht om alle Duitse arbeiders te boycotten. Op 17 oktober 1914 ging het blad een stap verder met het artikel "Remember Antwerp!": een stuk dat op eenvoudige aanvraag door elke lezer gratis in affichevorm kon verkregen worden en een aantal maal opnieuw gepubliceerd werd. Nog eind oktober achtte het Britse ministerie van Binnenlandse Zaken de tekst ervan zó aanstootgevend dat het beval de aanplakbiljetten weg te halen. Het meende immers dat die anleiding gaven tot gewelddadige anti-Duitse agitatie. ${ }^{26}$

In "Remember Antwerp!" maande het blad elke gemeenteraad en stadsbestuur aan om onmiddellijk lijsten op te maken van alle vastgoedeigenaars met Duitse of Oostenrijkse namen, ongeacht het feit of ze genaturaliseerd waren. Voorts dienden er burgerwachten, bekleed met politionele bevoegdheden, te worden opgericht om hun eigendommen te onderzoeken. Aan het ministerie van Binnenlandse Zaken werd gevraagd om de lokale politie van elk district waar zulke genaturaliseerde Britse onderdanen leefden lijsten van elke sedert 1904 genaturaliseerde Duitser of Oostenrijker te verschaffen. Iedere Duitser, genaturaliseerd of niet, moest overigens achter slot en grendel geplaatst worden. Hij vormde, aldus het dagblad, een bedreiging in geval van een invasie. En in dit vlammende betoog luidde het: "Let every Briton remember the fate of Antwerp; how Germans established themselves in that city and betrayed it." ${ }^{27}$

Wappers hernam de titel uit The Daily Mail, noemde het artikel een les uit Engeland en citeerde de belangrijkste passages eruit onder de suggestieve hoofding: "Dédié à l'administration communale d'Anvers." Een tweede artikel dat hierbij aansloot werd "opgedragen aan de Belgische 
regering". Daarin bombardeerde Wappers Franck tot een onvaderlandse pan-Germanist. Met "zijn" Intercommunale Commissie had hij de echte burgemeester De Vos gemuilkorfd. Francks toespraak tot de vluchtelingen te Roosendaal, waarin hij hen aanmaande om terug te keren, moest het ontgelden. Dat hij daar verklaard had dat de Duitse overheid alles in het werk wou stellen om de veiligheid te Antwerpen te handhaven en dat "de hele wereld de ogen gericht had op dergelijke beloften gedaan aan zulke steden" [B.Y.] viel niet in goede aarde. De journalist opperde of Franck misschien eens aan de dagenlange verwoesting van Leuven door het Duitse leger kon denken. Voorts nam hij aanstoot aan het feit dat Franck meende in een officiële hoedanigheid te handelen. Zo ook dat er volgens hem voor de jonge mannen die niet tot het leger behoorden en de ontwapende burgerwachten niet meer reden tot angst zou zijn dan voor andere burgers. Daar getuigden de overeenkomsten met de bezetter van. Als klap op de vuurpijl had Franck dan nog de gevluchte Antwerpenaars verteld om "weer te keren naar betere dagen”! De man was veroordeeld, zo besloot Wappers. En op de volgende bladzijde publiceerde het dagblad een uitgebreide lezersbrief vanwege een persoon uit het bezette land. Die meldde dat Franck, in tegenstelling tot de gedeporteerde burgemeester Max van Brussel (die was eind september 1914 weggevoerd wegens zijn weigering de Duitse oorlogsschatting te betalen) die zich als goede Belg gedroeg, Duitse proclamaties ondertekende. "Et je suis fort surpris de constater que le texte de ces circulaires est à ce point conforme aux moindres désirs de l'autorité allemande que celle-ci se borne, sans plus, à mettre un cachet au bas de la prose de M. Ludwig Franck (sic)." ${ }^{28}$ Door de veiligheid van iedere Antwerpenaar die terugkeerde te waarborgen, zo vervolgde de lezer, nam de liberaal niet alleen een verpletterende verantwoordelijkheid op zich, maar ging hij zelfs verder dan de Kommandantur die enkel de veiligheid der dienstplichtigen garandeerde. ${ }^{29}$ Vier dagen later beweerde een Antwerpenaar in een "getrouw verslag" dat kwatongen Franck "der Oberbürgermeister dr. Ludwig Mark, alias Ludwig Franck" noemden. ${ }^{30}$

Verdachtmakingen tegen de sterke man in Antwerpen waren toen beslist niet van de lucht. Zo meldden op 20 oktober 1914 de Nederlandse leden van de Tweede Kamer Jan Van der Molen (Christelijk-Historische Unie) en B.J. Gerretson (Anti-Revolutionaire Partij) dat "hooggeplaatste Belgische personen zich over de onwaardige geruchten, die onder de Belgen liepen, als zou de heer dr. Louis Franck door de Duitsers zijn omgekocht" zeer verontwaardigd toonden. ${ }^{31}$ In zijn editie van 21 oktober uitte het Journal een wel erg zware beschuldiging aan het adres van Franck die een beroep deed op 
het patriottisme van de Antwerpenaars om hen te laten terugkeren. Het antwoord van een Belgisch patriot aan Franck moest, aldus het Journal, luiden:

Je suis parti d'Anvers, [...] parce qu'il avait été décidé de défendre la position jusqu'à la destruction complète de la ville s'il le fallait et que le devoir des civils, dans ce cas, était de laisser le champ libre à nos défenseurs. Après deux jours de bombardement, M. Franck se substituant au général Deguise, a rendu la ville. Pouvais-je prévoir cette défaillance?

Een goede patriot zou bovendien minachten wie nu in Antwerpen met de Duitsers verbroederde. ${ }^{32} \mathrm{Op}$ de volgende pagina werd er nog een schepje bovenop gedaan door de vergelijking met de zestiende-eeuwse godsdienstoorlogen en de hertog van Alva te trekken. Er waren toen mannen als Marnix van Sint-Aldegonde, zo heette het, die de vergelijking met de Brusselse burgemeester Max konden doorstaan. Maar er bestonden ook al "Francks". In plaats van de Oosterweelpolder onder water te zetten, zoals Willem de Zwijger dat gevraagd had, was hun devies: "Dat de Spanjaard maar doorkomt zolang onze koeien te grazen hebben." ${ }^{33}$ In diezelfde editie werd gemeld dat te Antwerpen een Duitse proclamatie hing waarop stond dat het voor mannen tussen achttien en veertig jaar verboden was om de stad te verlaten (om te suggereren dat het Duits leger hen zou opvorderen?). 's Anderendaags gaf de redactie toe dat dit bericht foutief was. Ze had haar bureau van Bergen op Zoom naar Rotterdam verplaatst, omdat, zo beweerde ze, er vanuit die stad een veel accuratere berichtgeving mogelijk was. ${ }^{34}$ In realiteit had de lokale overheid ingevolge een bevel van de commandant van het Nederlandse veldleger de verkoop van het Journal in de grensstreek verboden. ${ }^{35}$ Was het omdat het veelgelezen blad de vluchtelingen aanmaande om niet terug te keren? ${ }^{36}$ Wilde het neutrale Nederland Duitsland niet te zeer provoceren? Niet te vergeten dat het blad op amper twintig kilometer van de Belgische grens verscheen.

Naar aanleiding van de rancuneuze voorstelling van zaken van het Journal over Franck die in de plaats van Deguise opgetreden had, stuurde burgemeester De Vos op 23 oktober 1914 een verontwaardigde brief naar het Journal. Hij beweerde daarin dat, in tegenstelling tot wat het blad liet uitschijnen, de militaire overheid niet de mening was toegedaan dat de vesting nog verdedigd kon worden. De burgerlijke overheid was slechts tussengekomen nadat het leger de rechteroever verlaten had. Ze had de verantwoordelijkheid genomen om de stad een voortzetting van een bombardement dat al 36 uur duurde te besparen. Dat zou geëindigd zijn met een totale verwoesting van Antwerpen. 
Volgens de repliek van het Franstalige blad deed dat niet ter zake. Slechts de militaire overheid was gemachtigd om met de vijand te onderhandelen. De burgerlijke overheid had dus eigenhandig en zonder eerst de bevoegde instanties in te lichten gecapituleerd om Antwerpse "bakstenen" te redden. De Vos raadde het Journal aan de polemieken te staken. Er zou altijd tijd zijn om, zo nodig, later de kwestie van de verantwoordelijkheid te onderzoeken (een captatio benevolentiae?). Het dagblad besloot dat het uur der afrekening nog niet geslagen had. Voorlopig zou het zijn beweringen niet ten gronde bediscussiëren, hoewel het goed wist dat er schuldigen waren, die gestraft zouden worden. ${ }^{37}$ De door het blad becommentarieerde brief van De Vos verscheen echter pas op 27 oktober in het Journal, waardoor de Godsvrede nog enkele dagen naar hartenlust verbroken kon worden. Wat in het Journal des Réfugiés verscheen, werd ondertussen ook in de pers van de Centrale Mogendheden besproken. Zo becommentarieerde het Neues Wiener Journal op 28 oktober 1914 een artikel uit het Journal des Réfugiés van tien dagen eerder. Daarin had het blad aangegeven dat sommigen dachten dat na de val van Antwerpen de ramp een definitief karakter verkregen had. Deels weet het dat aan fatalistische meningen in de publieke opinie, zoals ontmoediging of karakterloosheid. Het Oostenrijks blad achtte die bijzonder interessant en onderstreepte een passage waarin stond dat nu de Antwerpenaren abrupt uit hun moederstad gedreven waren, de oorlog hen afschuwelijk en nutteloos scheen: "...et nous cherchons quelqu'un à accuser." ${ }^{38}$ Zulke beschuldigingen, die weldra in de Duits-Oostenrijkse propaganda geïnstrumentaliseerd werden, betroffen de verantwoordelijkheid voor de val van de vesting en de rol van vermeende verraders, waarvoor het Franstalige persorgaan gevoelig bleek.

Dat werd ook geprikkeld door het (her)verschijnen van dagbladen in het bezette land. Met name Antwerpsche Tijdingen verhitte de gemoederen nog meer. ${ }^{39}$ Dit blad beschouwde de blijvers als de ware patriotten en maande de vluchtelingen voortdurend aan naar Antwerpen terug te keren. ${ }^{40}$ Geen wonder dus dat het de confraters van het Journal des Réfugiés verweet de vluchtelingen in Nederland angst in te boezemen om dat niet te doen. ${ }^{41}$ Voorts beweerde Antwerpsche Tijdingen dat journalisten die de stad verlieten zich aan vaandelvlucht bezondigd hadden. ${ }^{42}$ Menig artikel was doordrenkt van een stedelijk patriottisme. ${ }^{43}$ Ettelijke stukken die uithaalden naar gevluchte Belgen vonden hun weg naar het blad. Ze heetten op kosten van de Britten een liederlijk te leiden en de meest hatelijke dingen over Antwerpen te vertellen: dat er hongersnood heerste, dat de stad aan besmettelijke ziekten ten prooi gevallen was of dat deportaties er aan de orde van de dag waren. De 
"blijvers" werden door hen als "idioten" gebrandmerkt. ${ }^{44}$ Tegen die achtergrond ging het Journal voorlopig door met polemiseren. Zo wrakte het in een artikeltje getiteld Les Pangermanistes d'Anvers drie Antwerpenaren "die met de Duitsers verbroederden": de journalisten Raf Verhulst en Lodewijk Mauw wegens hun medewerking aan het "pro-Duitse" Antwerpsche Tijdingen en Franck die weinig flatterend, in navolging van een eerder verslag, het etiket Oberbürgermeister opgekleefd kreeg. ${ }^{45}$

Op 24 oktober 1914 publiceerde het onder dezelfde titel een hoofdartikel dat een ereplaats in de activistische propaganda verwierf. ${ }^{46}$ De inslag ervan was inderdaad zonder meer anti-flamingantisch. Het blad betoogde dat de oorlog bewees dat er tussen de "apostelen van het flamingantisme" pan-Germanisten waren die een gevaar voor België vormden en de zijde van's lands ergste vijanden kozen. Aanleiding voor deze uithaal waren de journalisten die "onder toezicht van de Duitse overheid" Antwerpsche Tijdingen uitgaven. De Antwerpse Vlaamsgezinden hadden blijkbaar gedwee het hoofd gebogen om zich onder het gezag van "andere Germanen" te plaatsen. Koesterden de échte flaminganten niet reeds vóór de oorlog een haat tegenover Frankrijk en de Franstalige Belgen? Waren sommige door het pan-Germanisme verblinde Vlaamsgezinden niet bereid zich aan de Duitse heerschappij te onderwerpen indien ze over de zekerheid beschikten voorgoed komaf te maken met de Franstaligen te Antwerpen? Ze zouden niet aarzelen de gespreide vleugels van de Duitse adelaar als een scherm op te trekken voor de hen verblindende Franse zon! Het blad viseerde met name Verhulst, Franck en Van Cauwelaert. ${ }^{47}$ Allicht wist het Journal niet dat Van Cauwelaert op vraag van de Belgische regering de belangen der vluchtelingen behartigde, noch dat de Nederlandse regering hem gevraagd had zich bij Franck aan te sluiten..$^{48} \mathrm{De}$ Stem uit België ging wat dat betreft nog verder door te melden dat de Antwerpse overheid door de bezetter aangesteld was om vluchtelingen te laten terugkeren. Met dat doel zou de Duitse overheid lastigaards [Van Cauwelaert en Franck?, $B Y]$ naar Nederland gestuurd hebben. De Belgische regering, aldus De Stem, was "echter van mening dat men zich niet ten dienste te stellen [had] van de overweldiger". ${ }^{49}$ Nog op 24 oktober becommentarieerde het Journal in een voorpagina-artikel, La reddition d'Anvers, een brief van een oorlogscorrespondent "van een groot buitenlands blad". ${ }^{50}$ Die had opgemerkt dat een aantal dagen vóór de capitulatie de gemeenteraad een vertrouwensmotie ten voordele van Deguise gestemd had en zich daarin voor een verdediging van de stad tot het uiterste uitgesproken had. ${ }^{51}$ Terwijl Franck en zijn "satellieten" met Von Beseler onderhandelden en hem voorstelden om Antwerpen over te geven, bombardeerde Deguise nog de vijand, om hem 
te beletten de Schelde over te steken. De correspondent suggereerde dat het stadsbestuur het Belgisch leger verraden had. Wappers kon hem niet meer informatie verschaffen, maar sprak wel een dreigement uit:

aucun des actes posés en Belgique par des inconscients ou des criminels au cours des derniers évènements, ne restera impuni. $S$ 'il faut que la hautcour siège en permanence après la guerre, elle siègera tant que les traitres, s'il y en a, soient châties.

Het volgende salvo van het Journal kwam er naar aanleiding van een stuk in de Duitsgezinde Nieuwe Rotterdamsche Courant. Die beweerde dat de Antwerpenaars klaagden over dagbladen die op bevel van de Belgische militaire overheid een te negatief beeld opgehangen hadden van de Duitse soldaten. $\mathrm{Nu}$ nam men het de "verantwoordelijke mensen" kwalijk dat ze, in weerwil van hun plichten, op de vlucht geslagen waren. ${ }^{52}$ Wappers vroeg zich geprikkeld af of de pers misschien de Belgische bevolking en het leger nog vóór het beleg moest ontmoedigen. Hij voegde eraan toe:

Elle [la presse] aurait fait ainsi le jeu des pangermanistes, amis de M. Franck qui naguères appelaient par la bouche de M. Pol de Mont l'avènement des Prussiens en Belgique et qui s'occupent aujourd'hui de repeupler à leur profit la ville d'Anvers.

De breedsprakerige verhaaltjes die "dr. Ludwig Franck" [hier was weer die allusie, $B Y]$ in Nederland kwam vertellen, stemden volgens hem overeen met de mening van het Nederlandse persorgaan. Ook dit epistel kwam later in de activistische propaganda terecht. De redactie van het Journal was duidelijk overspannen, mede door de berichtgeving uit het bezette land. Dat was niet abnormaal, want in Nederland moest ze in volle oorlogsoverprikkeling uit Antwerpsche Tijdingen vernemen hoe onaangenaam het wel was dat Nederlandse dagbladen de Antwerpse plaatsnamen in het Frans weergaven. Dat werd trouwens de aanleiding tot een nieuwe uitval. Want blijkbaar maakte het niet uit, zo merkte het Journal des Réfugiés schamper op, dat België in vlammen opging, mits die Antwerpse namen maar in het Vlaams vermeld werden:

Nous avons dit et nous continuons de dire [...] que 'le flamingantisme' n'est inspiré en Belgique que par un seul sentiment: celui de la haine qu'une poignée de meneurs et de gloires locales [...] ont vouée à la France, à la culture française et à la langue de Voltaire. ${ }^{53}$ 
Vanaf 26 oktober 1914 reageerde de redactie van Antwerpsche Tijdingen. De Vos, Ryckmans en Franck waren in het narratief van dit blad ware helden die hun leven op het spel gezet hadden om een verdere verwoesting van Antwerpen te verijdelen. Dat leden van de Intercommunale Commissie "verkocht" waren aan de vijand, werd uiteraard van de hand gewezen. Het Journal, zo schreef het, dat door een drietal personen uitgegeven werd, riep de Antwerpenaren op om niet terug te keren omdat het zonder "réfugiés" niet kon bestaan. ${ }^{54}$ De redactie ontwaarde achter de tirades van het vluchtelingenblad blijkbaar wel winstbejag, maar geen ideologische agenda, in tegenstelling tot wat de activistische propaganda later zouden beweren. Maar net als het Journal hanteerde Antwerpsche Tijdingen een bijzonder agressieve toon waarbij het de Nederlandse overheid zelfs vroeg om de "uitbuiters van onzalige toestanden" te deporteren. ${ }^{55}$ De tegenaanvallen van Antwerpsche Tijdingen gebeurden zonder twijfel op aansturen van de stedelijke overheid. Die had overigens wel wat invloed op het Journal, want het hield woord en publiceerde na 27 oktober, de dag waarop de brief van De Vos verscheen, niets polemiserends meer over het verdrag van Kontich, op één artikel na, dat op 29 oktober 1914 verscheen. ${ }^{56}$

Daarin breidde Wappers de vijand uit tot alle "vaderslandslozen", onder wie de joden en de "halfbloeden". Hij maande de Belgen aan voor hen op te letten, want gedreven door geldzucht, zouden ze aansporen om onder het mom van pacifisme opnieuw handel te drijven met hun Teutoonse vrienden. In dat stuk verhaalde de redacteur ook over de overgave van Dendermonde in september 1914. Die heette het werk van Belgische notabelen geweest te zijn. Toen echter bleek dat de Belgische soldaten terugkwamen, kregen de burgers twee uur om de stad te verlaten waarna het oord in brand gestoken werd. De Duitse belofte bleek dus vals. ${ }^{57}$ Dit verhaal berustte grotendeels op fantasie, maar de weergave van de feiten was wellicht een onderhuidse sneer naar het Antwerpse stadsbestuur, dat ook met de Duitsers onderhandeld had.

Twee dagen later bracht het Franstalige dagblad de vluchtelingenkwestie in verband met de "Antwerpse pan-Germanisten". Het Journal meldde op basis van de berichtgeving uit L'Indépendance Belge dat het noch de plicht noch de wens van de (meerderheid van de) vluchtelingen was om huiswaarts te keren en zo de Duitsers in de kaart te spelen. Omdat het Londense blad beweerd had dat het de mening van de regering vertolkte, gaf het Journal een officieus tintje aan het bericht door erop te wijzen dat hoofdredacteur Roland de Marès in nauw contact stond met de Belgische regering: “...nous pensons que les pangermanistes d'Anvers ne vont pas tarder à se rendre compte 
d'où souffle le vent." ${ }^{58}$ In een tweede polemisch artikel, van 31 oktober, fulmineerde Wappers tegen de Belgische naturalisatiewetgeving en herinnerde hij aan het vooroorlogse Antwerpen. Het was een stad die letterlijk uitverkocht geweest was door "métèques" die de metropool "besmet" hadden. Het betrof de Duitsers en Oostenrijkers die hun fortuin slechts te danken hadden aan de Belgische onverschilligheid. De parallellen met wat vóór de oorlog over de vermeende Duitse infiltratie van Antwerpen beweerd werd en het fameuze artikel Le Pangermanisme - Les Egarés uit La Métropole van 22 augustus 1914, zijn hier onmiskenbaar aanwezig. Het artikel was doorspekt met beledigingen aan het adres van de Duitsers en beweerde: "C'est l'infériorité de la race germanique que de prendre constamment la vie au sérieux." Het spreekt voor zich dat zo'n zinsnede zonder bijkomende context een Vlaamsgezinde kon prikkelen.

Toch kan men de inspiratie van het Journal niet zonder meer als antiflamingantisch afdoen. Zo had het op 31 oktober nog zijn kolommen geopend voor een Franstalige bewerking van "De Vlaamse Leeuw", Le Lion Belge getiteld. ${ }^{59}$ Wel volgde er op 7 november nog een zijdelingse aanval op de flaminganten, naar aanleiding van een artikel in Het Handelsblad waarin de rol van de Duitse censuur geminimaliseerd werd. ${ }^{60}$ Volgens Wappers knoopte het Antwerpse dagblad - "lorgane attiré d'un parti dont le programme se résumait dans la formule: pas un sou, pas un homme, pas un canon" [de katholieke partij, $B Y]$ - aan met zijn vooroorlogse antimilitaristische houding. De katholieke krant was zogezegd totaal afhankelijk van de meest sektarische leiders van het separatistische flamingantisme. In een ander artikel beweerde Wappers hoe pijnlijk het was dat men het enige gebrek aan waardigheid in België aantrof in de Vlaamse steden. Een blik op de pers maakte dit duidelijk. ${ }^{61}$ Voorts kon het blad het niet laten om op de eerdere anval vanwege Antwerpsche Tijdingen in te gaan. Het beweerde erg verheugd te zijn over de beledigingen van dat orgaan. Aanvallen van een blad dat onder "Duitse tirannie" verscheen, bewezen immers hoe patriottisch het Journal wel was. ${ }^{62}$

Wils meldde dat hij in La Belgique (de nieuwe naam van het Journal des Réfugiés) vanaf 11 november 1914 geen aanvallen op de Vlaamse beweging meer terugvond. Franck werd sporadisch geloofd, maar ook aangevallen. ${ }^{63}$ Toch kwamen, aldus de auteur, ook de kritiek op de overgave en de "perscollaboratie" minder naar voren. Als verklaringsgrond daarvoor opperde hij dat de redacteuren misschien geschrokken waren van de reacties in de Antwerpse dagbladen. Of misschien speelde de houding van de Belgische autoriteiten een rol. Zetten ze druk op het blad om van koers te veranderen of door gewoonweg geen steun te verlenen aan de inbreuken van het blad 
op de Godsvrede ?64 Zeker is, dat naast het ordewoord van burgemeester De Vos, ook de Belgische autoriteiten hun invloed lieten gelden. Zoals we zullen zien, zou de Belgische regering de vluchtelingenpers, dus niet het Journal des Réfugiés alleen, eind november 1914 aanmanen om niet meer over Antwerpen te polemiseren. Maar Franck zelf moest veel langer op officiële erkenning wachten.

\section{Het beleid van Franck en het verdrag van Kontich}

Nochtans verdeelde de rol van Franck, zowel in zijn hoedanigheid van de facto burgemeester van Antwerpen als van mede-onderhandelaar van het verdrag van Kontich de pers. Zo onderstreepte L'Indépendance Belge dat De Vos burgemeester bleef. Het begroette de oprichting van de Intercommunale Commissie. Volgens het blad was de overgave van Antwerpen er in samenspraak met Deguise gekomen. Franck, De Vos en Ryckmans werden, net als in Antwerpsche Tijdingen, als helden geloofd. Zonder capitulatie - waarvoor ze overigens maar twee minuten bedenktijd kregen - zou het bombardement hernomen worden en was de totale vernietiging van de stad op enkele uren een feit geweest. Ook werden de gunstige capitulatievoorwaarden benadrukt. ${ }^{65}$ Als enig blad schreef het over de nobele bedoelingen van het stadsbestuur, dat de vluchtelingen wou laten terugkeren. ${ }^{66}$

Voor La Métropole daarentegen speelden "sommige Belgen" de vijand die middels gezanten de vluchtelingen wou laten terugkeren in de kaart. ${ }^{67}$ Franck werd op 30 oktober 1914 samen met andere leden van de Intercommunale Commissie als een van de "émissaires complaisants de l'ennemi" gebrandmerkt. ${ }^{68}$ Begin november schreef La Métropole over de verdachte motieven van de terugkeerpolitiek van een Belgische "bende": "Ajoutons qu’à côté de M. Franck, M. Frans Van Cauwelaert figure aussi parmi les émissaires des Allemands en Hollande." ${ }^{69}$ De socialistische volksvertegenwoordiger Terwagne had daarop zijn katholieke collega in L'Indépendance Belge geroemd wegens zijn werk voor de vluchtelingen en wees de beschuldiging als oneerlijk van de hand. ${ }^{70}$ Inzake het verdrag van Kontich benadrukte $L a$ Métropole dat de overgave er gekomen was nadat het stadsbestuur op eigen houtje gehandeld had. Nochtans had twaalf uur uitstel de terugtocht van het Belgisch leger kunnen vergemakkelijken. ${ }^{71}$ In haar verslag merkte ze in lijn met het Journal op: "Cela sera l'affaire du conseil de guerre plus tard de rétablir les faits dans leur pleine exactitude." ${ }^{72}$ In de eerste helft van november verschenen er in het persorgaan nog aantijgingen aan het adres van de Ant- 
werpse overheid. ${ }^{73} L$ 'Echo Belge trok met nog veel méér ijver van leer tegen dat verdrag en de Intercommunale Commissie. Op 3 november 1914 publiceerde het blad weliswaar nog een verslag waarin de moeilijke situatie waarin Franck en de zijnen zich bevonden, beklemtoond werd. ${ }^{74}$ Daarna werd de sfeer grimmiger en zou het persorgaan zich nog amper positief opstellen tegenover Franck. ${ }^{75}$ Aanleiding was een verslag waarin stond dat de onderhandelaars na de ondertekening van het verdrag van Kontich in het klooster van Tildonk met Von Beseler waren gaan dineren. ${ }^{76}$ L'Echo Belge bracht het vermeende incident meermaals in herinnering om Franck te discrediteren. ${ }^{77}$

Op 5 november verscheen in het blad een ophefmakend artikel waaruit moest blijken dat er in de schoot van het schepencollege en de Intercommunale Commissie een dubbele stroming bestond. De sterkste vleugel, die van de toegevingen aan de bezetter, werd vertegenwoordigd door Franck. Weerwerk kwam er van de meer patriottische stroming van schepen Strauss. Bovendien leverde die laatste volgens het blad resultaten op, ondanks tegenwerking van Franck en de zijnen. Het dagblad bracht in herinnering hoe Strauss de enige geweest was die zich tegen de ondertekening van het verdrag van Kontich verzet had. De burgerlijke overheid had toen de plaats van de militaire overheid ingenomen. ${ }^{78}$ Er bestond inderdaad een zekere animositeit tussen beide liberalen die in de nasleep van de val van Antwerpen ontstaan was. ${ }^{79}$ Voor Franck biedt de campagne van het Journal een verklaringsgrond, daar Strauss met Le Matin banden had. Ook Strauss had redenen om zich verongelijkt te voelen. Hij zetelde bijvoorbeeld (door toedoen van Franck?) niet in de Intercommunale Commissie, hoewel die zijn idee was, en stond erop dat die een raadgevend orgaan zou zijn. Ook had Strauss zich verzet tegen de overgave van Antwerpen door de burgerlijke overheid en waren zijn opmerkingen daaromtrent uit de akten van het gemeentebestuur geschrapt. Ten slotte was hij gekant tegen het verschijnen van dagbladen onder het bezettingsbestuur. ${ }^{80}$ Net als voordien, bij de twist tussen De Mont en Delvaux, kwamen hier spanningen tussen twee groeperingen binnen de Antwerpse vleugel van de liberale partij, naar boven drijven. Franck speelde immers de eerste viool in de Vlaamsgezinde Liberale Vlaamse Bond, terwijl Strauss bij de Association Libérale aangesloten was. ${ }^{81}$ De oorlog zou het gekissebis temperen, ook omdat Franck een krachtig bestuurder bleek voor de metropool. De Intercommunale Commissie reageerde trouwens op de twist door een gemeenschappelijke zitting met het Antwerpse schepencollege. Met eenparigheid van stemmen keurde ze een resolutie goed om te protesteren tegen de "schandelijke lastercampagne" die in den vreemde tegen haar gevoerd werd (het was ook op de herinnering aan dit soort retoriek dat 
de Duits-activistische propaganda later kon steunen). Strauss zelf keurde de inhoud van het artikel uit $L^{\prime} E c h o$ af en verklaarde ervan de auteur, noch bezieler geweest te zijn. Het bestaan van twee stromingen werd ontkend en het vertrouwen in Franck uitgedrukt. De Vos trad alweer in actie en zond het verslag op naar de Antwerpse pers, naar eigen zeggen ten gevolge van verschillende artikels die in La Métropole verschenen waren en de rol van de Antwerpse overheid en Franck verdraaiden. Eindigen deed hij door op te roepen de "steriele en gevaarlijke" redetwisten te staken. ${ }^{82}$ Kortom: de Godsvrede moest bewaard worden.

La Métropole, dat eerder nochtans het provocerende artikel uit L'Echo Belge overgenomen had, keurde op 26 november de houding van de burgemeester goed. Ze wees erop dat een vereniging van advocaten in het Verenigd Koninkrijk gewag maakte van een bericht van overheidswege. Daaruit bleek dat men en haut lieu wenste dat de ergerlijke discussies over Antwerpen meteen stopten. De regering had, vermoedelijk onder impuls van de koning, haar ongenoegen over de perspolemieken uitgedrukt. ${ }^{83}$ Wellicht wist ze iets af van een Flamenpolitik, getuige daarvan het feit dat Le Vingtieme Siècle op 24 november 1914 meldde hoe de Kommandantur vanuit Berlijn orders gekregen had met het oog op de intellectuele beïnvloeding van België. Het eerste doel daarvan was, aldus het dagblad, de Vlaamse bevolking ervan te overtuigen dat de Duitsers door bloed- en door taalverwantschap hun neven zo niet hun broers waren. ${ }^{84}$ La Métropole beloofde elke polemiek ter zake te zullen staken, wat ze - één editie niet te na gesproken - enkele maanden lang ook deed. ${ }^{85}$ Het katholieke blad zette een nieuwe lijn uit door expliciet eerdere beweringen over de kwestie van de terugkeer der vluchtelingen, het verdrag van Kontich en de Intercommunale Commissie te nuanceren. ${ }^{86} \mathrm{Op}$ 12 december 1914 sloeg het duidelijk mea culpa door erop te wijzen hoe men in hoge kringen vol lof sprak over Franck die de Duitse generaals meermaals te slim af was. ${ }^{87} L^{\prime} E c h o$ Belge weigerde daarentegen halsstarrig de brief van De Vos te publiceren. Zijn redactielid Charles Bernard merkte op dat de Antwerpse gezagsdragers maar hadden moeten reageren na de publicatie van het oorspronkelijke bericht over Strauss en niet na een overname ervan in La Métropole.$^{88}$ Het liberale blad zou in verschillende artikels de kritiek op Franck, diens beleid en de legaliteit van het verdrag van Kontich herhalen. ${ }^{89}$ Daarbij werden zelfs stukken gewijd aan de vergelijking tussen Antwerpen en Moskou. Die stad was tijdens de napoleontische invasie van 1812 op bevel van de militaire bevelhebber geëvacueerd en in brand gestoken om zo onbruikbaar te worden voor een Franse bezetting. ${ }^{90}$ Bernard, die nogal wat polemiserende hoofdartikels schreef, beweerde dat Franck en de zijnen daar- 
entegen in de Scheldestad hoogstens een hoop "bakstenen" gered hadden en daarover nog opschepten ook. ${ }^{91}$ De stelling van Wils dat L'Echo Belge zich heel gereserveerd betoond had inzake de overgave van Antwerpen, kunnen we niet bijtreden..$^{92}$ Het blad was integendeel ronduit ontevreden over de figuur en handelswijze van Franck. Het had geen goed woord over voor het verdrag van Kontich en polemiseerde erover, ook na de waarschuwing van de Belgische regering. Tot begin maart 1915 zou L'Echo Franck en vooral de inhoud van het verdrag van Kontich sporadisch blijven bekritiseren. ${ }^{93} \mathrm{Het}$ blad zou tijdens de oorlog geregeld in de activistische propaganda worden aangevallen, maar publiceerde - in tegenstelling tot het Journal des Réfugiés - geen artikel dat ook na de oorlog in de apologetische propagandamolen voortdurend aangehaald zou worden. Dat deed La Métropole wel.

\section{Een katholiek volksvertegenwoordiger in het oog van de storm}

Op 28 oktober 1914 had het katholieke blad immers La Vie à Anvers gepubliceerd. Daarin liet het zich ontvallen dat er te Antwerpen al snel een café heropend werd waar Duitsers met pan-Germanistische flaminganten verbroederden. Na een passage die hiermee volstrekt niets te maken had, volgde er een ander nieuwtje: “Les 'Antwerpsche Tijdingen' rédigées par les pangermanistes intvertébrés Karel Weyler, Raf. Verhulst et Louis Mauw [...] continuent de paraître." Terecht, zo schreef het, vervulde de houding van dat blad alle Belgen in Nederland met weerzin. Die bestempelden allemaal de krant, die amper enkele dagen na de vijandelijke inname van de stad al onder Duitse censuur verscheen, als een schande voor Antwerpen: "Les pangermanistes flamingants espèrent ainsi faire marcher leur boutique, ils sont loin de compte. On verra bien plus tard!"'44

Daarop schreef de katholieke volksvertegenwoordiger Adelfons Henderickx op 5 november 1914 in Antwerpsche Tijdingen de striemende aanklacht Ook Vaderlanders!. Hij beweerde dat toen België de oorlog werd aangedaan, de voorvechters van al de politieke partijen overeenkwamen voorlopig oude veten te vergeten. "Er zouden katholieken, liberalen, socialisten, Vlaamsgezinden noch franskiljons of walllinganten meer zijn - enkel Belgen. Allen bleven dat wachtwoord getrouw - allen, de Fransgezinde bladen uitgezonderd." Dit waren precies dezelfde woorden die later in de brochure van Mommaerts terechtkwamen en zo de hele apologetische propaganda beïnvloedden.

Daarop werd het artikel La Vie à Anvers besproken. Een van de bedoelingen van dat stuk was, zo beweerde Henderickx, het verdacht maken van 
de Antwerpenaren en in de eerste plaats van de flaminganten die gebleven waren. ${ }^{95}$ Weinig verwonderlijk, zo schreef hij, daar de oorlog de "franskiljons" een gelegenheid om de flaminganten klein te kriigen bood. Immers, "de Vlamingen zijn Germanen, de flaminganten moesten maar spijts hun protest tegen die beschuldiging pan-Germanisten zijn." Daarom diende men hen deelachtig te maken aan de afkeer van de bevolking tegen de Duitse overwinnaars. Bovendien stond de reputatie van "la grande patrie" (Frankrijk) van de "franskiljons" op het spel. Zo groot was hun bezorgdheid om dat land, dat het leek alsof ze meer beducht waren op een Duitse invasie van Frankrijk dan op de overweldiging van België. Naar Henderickx verhaalde, was het doel van de aanvallen op de Vlaamsgezinden te beletten dat die het hadden over de "zonderlinge wijze waarop 'la généreuse France' ons te hulp is gekomen". Hij vervolgde met te stellen dat ondanks de leugens van "verachtelijke Vlamingenhaters" de flaminganten zouden doorgaan met de verdediging van hun taalrechten tegen welke heersers dan ook (dus ook tegenover de Duitsers). ${ }^{96}$ Ook citeerde Henderickx uit Le Pangermanisme-Les Egarés (La Métropole, 22 augustus 1914), over de door het pan-Germanisme misleide Belgen. Volgens de volksvertegenwoordiger had het blad zo geschreven omdat Willems, Jottrand en Rodenbach "de wetenschappelijk bewezen verwantschap" tussen Hoog- en Nederduitsers (ergo tussen Vlamingen en Duitsers) bevestigd hadden of "met lof over het artistieke en wetenschappelijke Duitsland hebben gesproken". Zo'n verwantschap verhinderde volgens hem niet dat de Vlamingen een nationaliteit hadden die volledig van de Duitse verschilde. En ermee in oorlog was.

Hoe opzettelijk kwaadaardig [...] iemand voor 'verdwaald' [een vertaling van de "égarés" uit La Métropole, $B Y$ ] en 'pan-Germanist' [uit] te schelden, omdat hij zijn bewondering uitsprak voor al het grote, het goede en het schone waarvan ieder onbevooroordeeld mens, ook hij die tegenover Duitsland als vijand staat, het bestaan in dat land niet kan ontkennen!!

Henderickx was bij het schrijven van zijn artikel duidelijk overprikkeld en waarschijnlijk beïnvloed door de enorme ontgoocheling over de val van Antwerpen en het verloop van de oorlog. In die context reageerde hij als door een wesp gestoken op enkele artikels in de Franstalige pers die door hem disproportioneel uitvergroot werden. Zijn ontboezemingen wekten ergernis op in de vluchtelingenpers. La Métropole schreef hoe zijn stuk aantoonde dat haar artikel uit augustus over de "verdwaalden van het pan-Germanisme" volledig van toepassing was. ${ }^{97}$ Waarschijnlijk nog steeds geïnspireerd door 
het artikel van Henderickx, volgde er op 10 november in hetzelfde blad een sneer naar de Antwerpse pan-Germanisten, voor wie de brandschattende Duitsers slechts lammeren waren. Drie dagen later volgde er een uitval naar het "Duitse" blad Antwerpsche Tijdingen. Die gebeurde aan de hand van een uit de tekst van Henderickx overgenomen passage. Zijn woorden waren die van een "verrader" en "schurk" wiens schandelijke houding later bestraft zou worden. ${ }^{98}$ In één adem moest ook Pol de Mont eraan geloven, wegens zijn artikels in Antwerpsche Tijdingen en zijn vooroorlogse voordracht voor het Alldeutscher Verband te Düsseldorf (rond de eeuwwisseling dus). Ook hij zou later zijn straf niet ontlopen. Terecht had het blad dus eerder over de Antwerpse pan-Germanisten gesproken. Het sprak voor zich dat dit koren op de molen was van de activistische propaganda. Zes maanden later meldde die hierover dat La Métropole geschreven had dat men Henderickx maar moest fusilleren wegens zijn Vlaamsgezindheid: "Wij hebben het zelf niet gelezen, doch 't werd ons uit goede bron verzekerd." ${ }^{\prime 9}$ Het artikel uit La Métropole lokte enkele dagen na zijn verschijning een reactie uit van Edgar Vercruysse, die in 1919 katholiek senator zou worden. Hij beweerde dat La Métropole de flaminganten als pan-Germanisten afschilderde. Maar het blad verdedigde zich onder meer door te stellen dat het geen amalgaam gemaakt had tussen flaminganten en pan-Germanisten (wat klopte). Het waren "enkele" Vlaamsgezinden die zich in dat kamp bevonden en sommige van hun leiders compromitteerden de stroming door de Duitse belangen, al was het maar in beperkte mate, te dienen. ${ }^{100}$ Terwijl in de Belgische pers dit soort steriele twisten woedde, zaten de Duitse diensten niet stil. Ze lazen die pers om de berichtgeving in hun propaganda te absorberen. Zo publiceerde het door de bezetter gepatroneerde blad Le Bruxellois op 6 november 1914, de brief van burgemeester De Vos aan het Journal des Réfugiés, met commentaar:

Le Journal des Réfugiés du 27 octobre, insère une lettre de M. De Vos [...] dans laquelle il répond à deux articles du même journal ayant parus dans les numéros 4 et $5[$ sic $]$ dans lesquels M. Louis Franck et les personnes dirigeantes de l'administration communale d'Anvers sont traités de traîtres et de pangermanistes. ${ }^{101}$

De Vos had zoals gezien een brief gestuurd naar het Journal des Réfugiés om zich te beklagen over hoe de overgave van Antwerpen in dat blad op 21 oktober 1914 (i.e. nr. 6) werd weergegeven. Maar die verwees niét naar twee artikels over "verraders en pan-Germanisten", waarover overigens op die dag in het Journal niets te lezen viel. In de vierde editie en in latere nummers zou 
het dagblad wel terugkomen op de Antwerpse "pan-Germanisten", onder wie Franck en "verraders" (die later voor een rechtbank moesten verschijnen). Kortom, bovenstaande passage uit Le Bruxellois bewijst dat het gouvernement-generaal vrij vroeg begreep welke munt er te slaan viel uit wat het Journal des Réfugiés allemaal schreef betreffende de flaminganten. En bij uitbreiding over het polemiseren in de Belgische pers. Nog op 6 november redigeerde de Antwerpse correspondent van de Kölnische Zeitung het artikel Die Flamen und die deutsche Besetzung. Een week later werd dat in het officieuze regeringsdagblad gepubliceerd. ${ }^{102}$ De correspondent merkte op dat men niet moest geloven dat de Antwerpse Vlamingen de Duitsers anders bejegenden dan de Walen omdat ze zich als Vlamingen bewust waren van hun Nederduitse stamverwantschap. Toch klopte het dat de Antwerpenaar niet zoals de Brusselaar tegenover de Duitsers stiekem de vuist in de zak balde. Hij trad hen hoffelijk en correct tegemoet. En de Intercommunale Commissie werkte eerlijk met de bezetter samen ten behoeve van de stad en de ordehandhaving. De wijze waarop de Brusselse burgemeester Max meende het Duitse bestuur met advocatenknepen op het verkeerde spoor te zetten, vond bij de Intercommunale Commissie geen navolging. Toch ware het gevaarlijk, zo vervolgde de correspondent, achter deze houding pro-Duitse gevoelens te ontwaren. Die kon men ook niet verwachten van een bevolking die nog even tevoren door Duitse granaten in de kelders gejaagd was. Bovendien primeerde nationale trots en vrijheidsdrang bij de Vlamingen op hun Nederduitse stamverwantschap. Hij merkte op dat Henderickx zich daarover heel duidelijk uitgesproken had in "een van de dagbladen [Antwerpsche Tijdingen, $B Y][\ldots]$ die onlangs van het Duitse bestuur de toelating verkregen had om te verschijnen". [B.Y.] La Métropole echter, "één van de Franstalige bladen die in België verschijnen en in Franse dienst sedert jaar en dag professioneel een anti-Duitse hetze voert, zet dit mooie ambacht nu in dezelfde dienst en met dezelfde afkondiging van leugenmeldingen in Londen door". [B.Y.] La Métropole voerde dus sedert jaar en dag een campagne tegen Duitsland? Maar volgens de ambassade van het keizerrijk in Brussel nam het dagblad in de jaren vóór de Eerste Wereldoorlog net pro-Duitse standpunten in. ${ }^{103}$

De Duitse correspondent beweerde ook dat het katholieke dagblad onlangs een "giftig" artikel tegen de Vlamingen (sic) van Antwerpen [La Vie a Anvers, $B Y]$ gepubliceerd had. Daarin werden die zogezegd van "Alduitse verbroedering" beticht. Hij publiceerde het artikel van Henderickx in vervalste vorm. Daarbij werd het woord "verdwaalden" door het veel meer beladen "Überlaufer" [overlopers] vervangen. Een andere belangrijke wijziging was de volgende zin: "De Vlamingen zijn Germanen, de Vlamingen 
moesten [dus] [...] pan-Germanisten zijn." [B.Y.] De Vlamingen dus en niet, zoals Henderickx beweerd had, de flaminganten. De correspondent van de Kölnische Zeitung maande die Vlamingen voorts aan om "als Vlamingen" hun "politiek gewetensonderzoek" tegenover de personen en toestanden in België die hen in deze oorlog en Duitse overheersing meegesleept hadden, niet te vergeten. Dat betrof dan de schending van de Belgische neutraliteit die sedert jaren al moreel duidelijk was. Had de Frans-Belgische pers niet jarenlang een planmatige anti-Duitse campagne in dienst van Frankrijk en zijn regering gevoerd? Onlangs waren er door de Duitse overheid bovendien stukken gevonden in de geheime archieven van het Belgische ministerie van Oorlog die bewezen dat er een geheim akkoord bestond tussen België, Frankrijk en het Verenigd Koninkrijk betreffende een alliantie tegen Duitsland. Dit was een verwijzing naar de Conventions Anglo-Belges, vooroorlogse documenten van de Belgische overheid die de bezetter vervalste en als bewijsstuk gebruikte voor het bestaan van een geheime Belgische Entente met die landen, waarover straks meer. Inspelend op de Vlaamsgezinde retoriek besloot hij met: "Wat wals is, vals is."

Het stuk van Henderickx werd al als irritant ervaren in de vluchtelingenpers en was nu in vervalste en aangedikte vorm in een semi-officieel Duits blad gepubliceerd. Fernand Neuray, hoofdredacteur van Le Vingtième Siècle, spuwde in een editoriaal van 24 november 1914 zijn gal over de houding van de katholieke volksvertegenwoordiger. ${ }^{104}$ Daarbij ging hij louter af op de weergave van Henderickx' artikel in de Kölnische Zeitung. Dat verklaart ook waarom het officieuze Belgische regeringsblad pas twintig dagen nà het verschijnen van het oorspronkelijke artikel reageerde op Henderickx' stuk. ${ }^{105}$ Neuray noemde Henderickx een door de bezetter betaalde landverrader. Hij brandmerkte terloops Antwerpsche Tijdingen als een pseudo-Vlaams blad met een Duitse stempel erop. Had de Kölnische Zeitung de "hymne aan de Duitse cultuur" van Henderickx uit het Antwerpse blad niet met bloemen overladen? De vijand die Henderickx bestreed, was niet de meinedige Duitser. Nee, die Henderickx kende nog maar één ingebeelde vijand: de "franskiljon", tegen wie hij de Vlamingen wou opjutten. De verwoesting van Vlaanderen was blijkbaar bijzaak geworden. Henderickx, die slechts medelijden had met de Nederlandse taal in plaats van met de ongelukkige Vlamingen in hun exodus, had zijn plicht als burger en volksvertegenwoordiger verzaakt door de taalstrijd weer op de asse van het vaderland te doen herleven.

Die kritiek lag in lijn met wat het Journal des Réfugiés ook stoorde: was de oorlog nu een tijd voor flaminganten om over futiliteiten als Vlaamse straatnamen te spreken!? Dat Neuray als bron voor zijn overname de ver- 
valsing van de Kölnische Zeitung nam, gaf aanleiding tot misverstanden. Hij betoogde immers dat Henderickx de waarheid geweld aandeed door de Franstalig-Belgische dagbladen te verwijten de Vlamingen na het uitbreken van de oorlog voor pan-Germanisten versleten te hebben. De hoofdredacteur zette zijn kritiek kracht bij door tweemaal Henderickx' uitspraak "les Flamands sont des Germains!" vetjes te laten afdrukken. Een eerste maal liet hij die uitspraak volgen door de door de Kölnische Zeitung aan Henderickx toegeschreven klacht aan het adres van de Franstalige pers: "par conséquent, malgré leurs protestations, ils [i.e. "de Vlamingen"] devaient être des pangermanistes et partager ainsi la haine que l'on porte à l'envahisseur". Een tweede maal voorzag Neuray de uitspraak van de volgende, spottende commentaar: "Dès lors, rien de plus naturel que l'invasion et la conquête germaine..." Henderickx werd ook in L'Echo Belge van 1 december 1914 gekapitteld: "[cet] homme politique dont la fortune a eu comme piédestal les plus vils instincts de la foule [...] qui s'est fait l'insulteur des soldats français qui donnent leur sang pour nous comme nous donnons notre sang pour eux..... ${ }^{106}$

Op 11 december 1914 bracht Le Vingtième Siècle nogmaals het gewraakte artikel in herinnering. Daarbij voegde het dat de "beschermelingen van de Duitsers" een nog walgelijker stuk gepubliceerd hadden. Antwerpsche Tijdingen had namelijk het verblijf waar enkele dignitarissen vlak vóór het verdrag van Kontich gegijzeld werden, omschreven als een schitterend pand. Geen mens moest klagen dat hij er een paar uur doorbracht. ${ }^{107}$ Op basis hiervan werd het dagblad als Pruisischgezind gebrandmerkt, zowel in Le Vingtième Siècle als in L'Echo Belge. ${ }^{108}$ Het lijdt weinig twijfel dat het gebruik van woorden als "flaminganten" of "Vlamingen" gekoppeld aan "Germanen" en "panGermanisten" sommige flaminganten op stang joeg. Zo becommentarieerde frater Paul Impe, een scheutist uit Tielt, op 28 december 1914 in Londen het stuk van Neuray over Henderickx. Hij beweerde dat het te voorzien was dat de Vlamingen aangevallen zouden worden. De vijand, dat waren vanaf het begin van de oorlog de flaminganten. Het was, zo betoogde hij, voor de Fransgezinden, het moment om voor eens en voor altijd gedaan te maken met alles wat maar Vlaams was:

...en daarom hebben ze die reeds honderden keren weerkerende opmerking in [het] leven geroepen nu op [het] ogenblik dat die opmerking noodzakelijk voor alle Vlamingen een dodende invloed zou hebben: 'les Flamands sont des pangermanistes [dit bouwde voort op de propagandapraatjes uit de Kölnische Zeitung, BY] et donc ennemis de la Belgique. ${ }^{109}$ 


\section{De pers in het bezette land: een schietschijf}

Wie meende dat het normale leven in België onder geen beding mocht hernomen worden, zag natuurlijk elke activiteit die in die richting ging met lede ogen aan. Het mag dan ook niet verbazen dat de Belgische vluchtelingenpers het (her)verschijnen van de pers in België scherp veroordeelde. In die mening werd ze trouwens gesterkt door de regering. Kabinetschef De Broqueville verwoordde het op 5 november 1914 als volgt: “...s'il est une chose qui fait honneur à la presse belge [...] c'est la dignité dont tous, successivement, surent faire preuve vis-à-vis des Allemands. Tous, successivement, ont cessé de paraître, repoussant le joug de l'ennemi [...]" ${ }^{110}$ Anders gezegd, dagbladen die wel (her)verschenen, waren handlangers van de bezetter en maakten zich als dusdanig schuldig aan landverraad. Zoals L'Echo Belge het verwoordde, waren hun journalisten vijanden van België die voor de koning van Pruisen werkten. ${ }^{111}$ De Belgische Persbond te Londen veroordeelde eind november eveneens het "verraad" van redacties en journalisten van bladen die onder Duitse controle verschenen. ${ }^{112}$ Het wantrouwen tegenover de pers in bezet België werd nog méér in de hand gewerkt door wat men uit Duitse bladen vernam. Daarin werd immers gewezen op het vitale belang van de beïnvloeding van de Belgische publieke opinie door de pers. Het Duits bestuur wou de dagbladen die wilden verschijnen geen strobreed in de weg leggen. ${ }^{113}$

Antwerpsche Tijdingen kwam zo in de hele vluchtelingenpers onder vuur te liggen. Zo betreurde La Métropole nog vóór de publicatie van het artikel van Henderickx de "collaboratie" van Belgische redacteuren met de verafschuwde vijand inzake de vluchtelingenkwestie. ${ }^{114}$ De houding die de vluchtelingenpers tegenover dat blad aannam, is indicatief voor hoe ze dacht over kranten die in het bezette land verschenen. L'Echo Belge dat op 23 oktober 1914 Antwerpsche Tijdingen nog gefeliciteerd had met zijn initiatief, sloeg twee dagen later (beïnvloed door de negatieve publiciteit van het Journal?) een heel andere toon aan. In lijn met het Journal achtte het blad het artikel uit Antwerpsche Tijdingen betreffende de Antwerpse straatnamen die in het Frans gedrukt werden zeer irritant. De Vlaamsgezinde dichter Karel van den Oever stuurde daarop prompt een razende reactie naar het Nederlandse en katholieke dagblad Het Centrum. De redactie van het Franstalige dagblad stelde hij gelijk met de "stafoversten van het franskiljonisme". De Vlamingen werden door L'Echo Belge, zo betoogde hij, "in hun heiligste recht getroffen". De vijanden van de Vlaamse beweging hadden blijkbaar in de droevigste ogenblikken van Belgiës bestaan nog niet hun "hatelijke pen" neergelegd. Ze durfden blijkbaar Vlamingen hun rechten te ontzeggen, alsof die in oorlogs- 
tijd niet meer golden! ${ }^{15}$ Dat Van den Oever zo geprikkeld reageerde op een relatieve onbenulligheid typeert de oorlogsneurose die, net als iedereen, ook de Vlaamsgezinden in de ban hield. En in die sfeer bleef L'Echo Belge Antwerpsche Tijdingen aanvallen. Het blad heette "une feuille qui s'imprime sous la botte prussienne" te zijn. Het Franstalige blad wees op de Duitse censuur die het "blad van de Duits", zoals de bevolking het dagblad noemde, onderging, bestempelde het als een orgaan dat het misprijzen der Antwerpenaars opwekte en duidde de Duitsers als stichters aan, al dan niet met behulp van Franck en de zijnen. ${ }^{116}$

In het raamwerk van de vermeende anti-Vlaamse campagne kan overigens de hypothese dat enkel Nederlandstalige bladen geviseerd werden door de Franstalige vluchtelingenpers niet overeind blijven. Zelfs de negatieve houding tegenover Antwerpsche Tijdingen was niet taalgebonden. L'Indépendance Belge nam bijvoorbeeld veel minder aanstoot aan de verschijning van het blad. ${ }^{117}$ Anderzijds noemde ook De Stem uit België het persorgaan herhaaldelijk een leugenachtige "Duitse gazet". ${ }^{118}$

L'Echo Belge stoorde zich niet aan de Vlaamsgezindheid van Antwerpsche Tijdingen, wel aan het feit dat het dagblad bestond en geredigeerd zou worden door "[des] journalistes [...] qui travaillent à la solde de l'Allemagne". ${ }^{119}$ Maar dat gold in de ogen van de vluchtelingenpers voor elk blad dat in Antwerpen gepubliceerd werd. Zo viel op 13 november 1914 La Métropole Het Handelsblad aan omdat dit blad het waagde onder Duitse censuur te verschijnen. ${ }^{120}$ Nog in die editie kreeg La Presse uit Antwerpen ervanlangs, wegens een foutieve weergave van de regeringsmededeling over de vluchtelingen die (niet) mochten terugkeren. ${ }^{121}$ La Métropole noemde die een vervalsing en besloot daaruit dat La Presse de regering verraden had ten voordele van de bezetter, net als alle dagbladen die aanvaardden in bezet België te verschijnen. ${ }^{122}$ L'Echo Belge noch La Belgique (Journal des Réfugiés) spaarden trouwens La Presse. Met name een bericht uit dat blad waarin stond dat het bombardement van Antwerpen gelukkig meer lawaai dan kwaad aangericht had, lokte een felle reactie van dat eerste blad uit. Driehonderd doden en duizend vernietigde huizen, dat was dus "niets"? Straks ging men de Duitsers nog gelukwensen! ${ }^{123}$ De redacteuren werden als gewetenloos afgeschilderd en liepen, zogezegd, "aan de Duitse ketting”. De houding van "pseudo-journalisten" die het papier van die Antwerpse dagbladen vervuilden, heette onvaderlands te zijn. ${ }^{124}$

De totale afkeuring voor de pers in het bezette land ging erg ver. Zelfs toen De Nieuwe Gazet het aandurfde de redevoering van de Duitse kanselier voor de Rijksdag voorzichtig te bekritiseren - een half mirakel, gelet op de 
censuur - beschouwde L'Echo Belge dit als een handeling van een redactie die door de Duitse dwingeland beïnvloed was. Immers: "l'article manque de puissance pour réfuter les paroles du Chancelier." ${ }^{125}$ Ook de verschijning van de Antwerpse Vlaamsche Gazet door toedoen van een aantal "amateurjournalisten" die behoorden tot de "stadhuisflaminganten" werd op 12 december 1914 door La Métropole gehekeld: het proza erin was volgens het blad een schande. Terloops meldde het diezelfde dag ook hoe een van de drie "invertébrés" - Raf Verhulst - van de hoofding van Antwerpsche Tijdingen verdwenen was. ${ }^{126}$ Daarmee verwees La Métropole expliciet naar zijn fameus artikel La Vie à Anvers (28 oktober 1914). L'Echo Belge daarentegen noemde de Vlaamsche Gazet patriottischer dan de overgrote meerderheid van de Antwerpse bladen, zoals Het Handelsblad (omdat dat katholiek was?). ${ }^{127}$

Opvallend is hoe de vluchtelingenpers benadrukte dat de Brusselse pers niet opnieuw verscheen, ondanks de Duitse druk. De enkele bladen die verschenen waren, zo werd beweerd, gelegenheidsorganen. In het slechtste geval, zoals bij La Belgique en Le Bruxellois, heetten ze Duitsgezind of zelfs door de bezetter opgesteld te zijn. ${ }^{128}$ Dat klopte trouwens. Dat in andere steden dagbladen opnieuw van de persen rolden, wekte eveneens de wrevel op van de vluchtelingenpers. Vooral Le Bien Public (Gent) en L'Ami de L'Ordre (Namen), beide van katholieke signatuur, werden herhaaldelijk geviseerd. Meerdere berichten erin werden als ergerlijk ervaren: dat men in die bladen de mededelingen van de Duitse overheid weergaf als "regeringsmededelingen"; dat er verzet werd aangetekend tegen de hogervermelde resolutie van de Persbond; dat men met vijandelijke soldaten Belgische soldaten bedoelde; dat de Duitse censuur erin vergeleken werd met de Belgische. Ook dat het herverschijnen van Belgische dagbladen in de Duitse pers geloofd werd, irriteerde de vluchtelingenpers. Sporadisch werd die kritiek vermengd met partijpolitieke sentimenten. Waren de katholieke persorganen vóór de oorlog ook al niet tegen een versterking van het leger en daardoor schuldig aan het feit dat België zich onvoldoende kon weren? Was het dan niet logisch dat ze net als toen ook nu België verraadden, zoals L'Indépendance Belge op 5 december schreef ? ${ }^{129}$

Gebeurtenissen die in normale tijden empathie zouden hebben opgewekt, zorgden nu vooral voor hilariteit. Zo kwam L'Ami de L'Ordre in de schijnwerpers te staan door een opmerkelijk incident. Het drukte namelijk op 29 november 1914 een bericht af onder de onschuldig ogende titel La Guerre. Dat bevatte echter het minder onschuldige anagram: "M... pour les Allemands." Later verklaarde de redactie dat het stuk anoniem opgestuurd was geweest. De Duitse censuur had aanvankelijk ook niet door wat er aan 


\section{LA GUERRE}

Ma swar, yous souvient-1l qu'aax Joure do notre

Fin lisent les hauts faits do l'Hiatoire de Frasce,

Remplis d'admiration pour nos frères gaulois,

Dês gendranx fameax pous vantione les exploitst

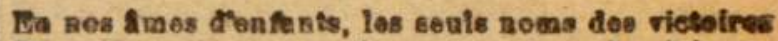

Prosaient un sens myotiquo, évocateur do gleicen

On ao rêsaít qu'assanute et combats : $₫$ nos year

Un gonoral vaiaçueur etait l'egal des dieux.

Risk zo semblait teruir l'delat do ces ennquator;

Lse batailles prenaient den sllurea de fôtes,

It noa ne songions pas qu'aux heurrss triomphento

S. môt aiens los saugiots dea mòres, des enfacts.

Aht nous la connaissone, helast thorrible gaerce,

Le fleau qui punit les crimes do la terre,

Le mot qui, fait trembler los màres à gaboux

Et qui séme le dosii ot la mort paraí noues

Mais oû sont les lauriers que rénerve l'Eistolte

A colui qui domain foreera la Vieoire?

$\mathrm{Nul}$ ne lea cueillers : les iasriers sont fetriby

Soul ua eyprès s'elève aux tombea de nes ad

Afb. 2. Een gedicht, gepubliceerd in L'Ami de L'Ordre uit Namen, verhult een anagram (de eerste letter van het eerste woord in elke zin van boven naar beneden met elkaar verbinden). L'Ami de L'Ordre, 29 november 1914, 1; UNamur-BUMP-Magasin SE001

de hand was. Pas 's anderendaags immers verbood baron Von Hirschberg, de militaire bevelhebber van de vesting Namen, het "voor de Duitse natie beledigend en aanstootgevend" bericht. De bezetter reageerde met draconische maatregelen. Zo werden de bestuurder en hoofdredacteur van L'Ami de L'Ordre achter slot en grendel geplaatst. Wie het gewraakte nummer ook maar in zijn bezit had, werd vervolgd. Het ging zover dat de burgemeester van Namen een proclamatie uitvaardigde waarin hij stelde dat hij voor al zijn stadsgenoten sprak wanneer hij formeel de "krenkende daad" afwees. De redactie drukte nadien haar diepe spijt uit over het "zeer ernstige incident" dat de "terechte" verontwaardiging van de militaire bevelhebber opgewekt had. De Duitse magistraten, zo verklaarde de redactie, hadden de goede trouw van de redacteuren erkend. 
Het dagblad en zijn redactie haalden zich de spot van de vluchtelingenpers op de hals. Toen L'Indépendance Belge het verhaal vernam, sprak het over L'Ami de L'Ordre... allemand: een krant die onder "bescherming" stond van personen die Belgen vermoordden. ${ }^{130}$ Kortom, het verschijnen van eender welk blad stuitte op verzet in de vluchtelingenpers omdat elke publicatie onder de Duitse censuur voor die dagbladpers gelijkstond met landverraad. De frequentie van de aanvallen lag voor Antwerpse bladen (en dignitarissen) in die periode duidelijk hoger in de grotendeels Antwerpse en Franstalige vluchtelingenpers. Echter, die bladen waren tot december 1914 - op $L a$ Presse na - allemaal Nederlandstalig.

Het feit dat nota bene Antwerpsche Tijdingen het blad van de "verdachte" Intercommunale Commissie was, heeft dit blad uiteraard nog ontvankelijker gemaakt voor kritiek. ${ }^{131}$ We mogen daarbij niet uit het oog verliezen dat de censuur die de Duitse bezetter oplegde, de volledige antithese was van de sedert 1831 grondwettelijk verankerde persvrijheid. Omdat het concept vrijheid een belangrijk onderdeel vormt van de Belgische publieke cultuur, is het weinig verwonderlijk dat dagbladen die zich aan een stelsel van censuur onderwierpen, op zeer veel wrevel botsten.

\section{Vier actoren uit de "anti-Vlaamse campagne" en een dreigement}

Wat de "anti-Vlaamse campagne" betreft, werd reeds tijdens het conflict verwezen naar de acties van vier figuren. Allereerst de schrijver Maurice Maeterlinck, die begin december 1914 in de scala van Milaan verklaarde dat België de Latijnse beschaving gered had. Dat gebeurde in een redevoering waarin hij de Belgen met de helden uit de oudheid vergeleek. België had de wereld - en dus ook de Latijnse beschaving - gered, goed wetende dat het zelf niet gered kon worden. Het had bovendien de kant van die beschaving gekozen met kennis van zaken, want meer dan de helft van de bevolking was Germaans. Daarna schetste Maeterlinck hoe België de uitputting nabij was. Als er geen onmiddellijke interventie kwam, zouden steden als Gent, Brugge en Antwerpen tot een puinhoop herleid worden. ${ }^{132}$ Wanneer men het bewuste "anti-Vlaamse" citaat uit zijn context licht, kan het inderdaad zeer pro-Frans klinken. Maar de Nobelprijswinnaar speelde met zijn dramatische weergave van Vlamingen die tegen hun Germaanse stambroeders hun bloed gaven natuurlijk in op de Latijnse sentimenten van Italië, dat toen nog neutraal was. De tweede figuur was Gérard Harry. Die liberale journalist publiceerde 
vanaf 18 december 1914 dagelijks een artikel in het Parijse Petit Journal. Op 21 december schreef hij L'Union Morale et Verbale des Races. Als we de activistische propaganda mogen geloven, pleitte hij daarin voor een "betoverend antigermaans verband van de Franse taal" dat Walen en Vlamingen zou verbinden. In werkelijkheid schreef Harry dat er voortaan enkel maar Belgen waren, geen Vlaamsgezinden noch wallinganten en pleitte hij voor "het gezaghebbende anti-Germaanse verbindingsteken van de Franse taal". [B.Y.] Hij opteerde voor een tweetalig Vlaanderen, niet voor een afschaffing van het Nederlands. En in zijn proza zat ook een oproep aan de neutrale Verenigde Staten, die Harry gevoelig wou maken voor het leed van België, verscholen. De Vlamingen hadden immers onder druk van de Duitse brutaliteit hun have en goed verlaten om in een buitenland terecht te komen waar men hun taal niet verstond en waar ze soms onheus behandeld werden omdat hun taal op het Duits leek (een correcte observatie).

Het duurde een tijdje alvorens de bezetter begreep dat hij munt kon slaan uit dit artikel. Vanaf eind januari 1915 werd het evenwel gebruikt in de Duits-activistische pers. Zelfs spendeerde de Gazet van Brussel liefst vijf opeenvolgende dagen aandacht aan het artikeltje van Harry om de theorie van de anti-Vlaamse veldtocht kracht bij te zetten. ${ }^{133}$ Natuurlijk was het nu ook weer niet zo dat iedereen zo'n complottheorie voor lief nam. Zo schreef het Antwerpse Handelsblad, daarin bijgetreden door het christendemocratische Volk, nuchter dat de aanvallen van Maeterlinck en Harry louter meningen weerspiegelden van afzonderlijke personen, die slechts de waarde van individuele gedachten hadden. Het blad riep op tot Godsvrede en werd er niet voor teruggefloten door de Duitse censuur (om de polemiek levendig te houden?). ${ }^{134}$ Maar om de tegenstellingen tussen de Belgen toch aan te wakkeren, viel de Duits-activistische Gazet van Brussel het stuk wel aan. Het hoofdstedelijke orgaan noemde het Antwerpse blad naïef. De Gazet wees erop dat wanneer zelfs in het buitenland de "franselaars" aan het "konkelfoezen" waren, er niets goeds kon verwacht worden voor de toekomst. "God weet wat zij al niet tegen ons in het geheim verrichten..." Dat moest snel veranderen, want anders zouden "er over vijftig jaar geen Vlamingen meer zijn". ${ }^{135}$ Zo ontstond via de Duitse propaganda het waanbeeld dat er een scheidslijn liep tussen de "passieve" Vlamingen die meewerkten aan de ondergang van hun eigen volk en de "actieven", die zich weerden tegen de aanvallen van "de franskiljons". Dat rijtje werd aangevuld met twee personen. Ten eerste de journalist Roland de Marès. Hij vertelde in januari 1915 op een bijeenkomst aan de Sorbonne ten voordele van de Latijnse beschaving dat de Belgen het diepe gevoelen bezaten van Latijnse solidariteit. Vlamingen en 
Walen hadden hetzelfde geleden en waren tot in het diepste van hun vezels Belgen. Die kenden alles waaraan ze de Latijnse cultuur schatplichtig waren en voelden zich innig verwant met het Franse volk.

Als kleine en neutrale natie, hebben we er steeds zorg voor gedragen om rigoureus het evenwicht tussen de politieke stromingen die ons omringden te bewaren, zoals onze internationale plicht dat vereiste. Maar neutraliteit impliceert geen onverschilligheid; ze verbiedt niet [...] te beminnen - en we beminnen Frankrijk, daar we ons erg dicht bij hem voelen en omdat het ons in zijn stralende helderheid onderdompelt. [B.Y.]

Daarna volgde een lofzang op de Franse taal, cultuur, het Franse geweten en de Latijnse beschaving. Door hun heroïsche daden en volkomen opofferingszin waren volgens De Marès de Belgen Latijnen. Ook dit was een oproep tot Latijnse solidariteit, naar het voorbeeld van Maeterlinck, maar dan nog sterker. Le Vingtième Siècle kopte in zijn verslaggeving over het gebeuren: $L a$ Civilisation Latine contre la "Kultur".136 Alleen al op basis daarvan kon de Duitse propaganda natuurlijk gemakkelijk opperen dat de Vlamingen bij het "Latijnendom" ingelijfd werden om tegen Germanen te strijden. De collaborerende pers bombardeerde die redevoering tot een referaat op een officiële vergadering. En ze vervalste de tekst. De heldhaftige strijd van de Belgen, zo stelde de Gazet van Brussel, werd blijkbaar enkel geleverd omdat die de Latijnse cultuur eerden. Ze beweerde op grond hiervan dat indien de Vlamingen na de oorlog weer begonnen te spreken over een Vlaamse hogeschool en dergelijke onder het "valse voorwendsel" dat ze evenveel of meer bloed dan de Franstaligen vergoten hadden, hun blijkbaar moest geantwoord worden:

Deze oorlog heeft ons integendeel bewezen dat de heldhaftigheid der Vlamingen aan de brok Latijnse cultuur hun opgedrongen te danken is; om die goede Vlamingen nog meer te veredelen, te verfijnen, gaan we ze nog een beetje meer latiniseren, een beetje meer verfransen. ${ }^{137}$

Colleye ten slotte ontmoetten we reeds als een voorvechter van de pan-Latijnse gedachte. We herdenken hem vandaag vooral wegens zijn beruchte uitspraak: "La Belgique sera latine ou elle ne sera pas." Die verscheen voor het eerst in een artikel in Le Cri de Londres van 15 juni 1915 en twee maanden later in The Nineteenth Century and After. In zijn stuk roemde hij de Vlaamsgezinden voor het vervullen van hun humanitaire plicht door zij aan zij met de Latijnen te strijden. Anderzijds dreef hij de spot met de "francofiele" 
revolutie van 1830. Hij laakte de Vlaamse beweging, die Wallonië toch maar wou vernederlandsen, terwijl Vlamingen de belangrijkste ministerambten in België bekleedden. Bovendien hielden die flaminganten toch niet zo van Frankrijk. Colleye bracht de germanofilie van Pol de Mont en de groep rond Germania in herinnering. Maar nu was België één geheel geworden. Hij verklaarde het flamingantisme dood (de Waalse beweging was door patriotten van morgen trouwens ook al vergeten). Voorts brak hij een lans voor administratieve taaleenheid, met dien verstande dat de Vlamingen "als ze dat wensten" hun taal mochten blijven spreken. Bovendien wou Colleye een Frans-Belgisch bondgenootschap, om zo een tegenwicht te bieden tegen de Belgische annexaties van Germaans (Duits) territorium na de oorlog. Hiermee ging hij door op zijn in juli 1914 in Wallonie! ingeslagen pad: de Vlamingen waren nog het best af in de Latijnse invloedssfeer. Bezield door een Belgisch patriottisme kwam zijn afkeer van het Nederlands en de Vlaamse beweging hier evenwel niet aan bod. Wel breidde hij zijn pan-Latinisme naar héél België uit. Het uur had geslagen, zo meldde hij, om het Franse België in de Latijnse sfeer te lanceren. België, zo besloot Colleye in The Nineteenth Century, zal Latijns zijn of niets zijn (in Le Cri de Londres stond: "La Belgique sera latine ou elle ne sera pas" en niet: "rien"). Of, anders gezegd: zonder Franse ruggensteun kon een Belgische grootmacht-in-wording zijn ambities nooit waarmaken. ${ }^{138}$

Dit artikel was vanzelfsprekend opruiend. In Le Vingtième Siècle (15 augustus 1915) werd de "wallingantische fanaticus" zwaar op de vingers getikt. Het dagblad stelde dat de publicist niet het minste gezag had om in naam van de Walen te spreken en nog minder om in het buitenland lovende stellingen te verkondigen die louter de Latijnse cultuur behelsden. Ze waren strijdig met het Belgisch belang. ${ }^{139}$ Colleye werd er ook voor gesanctioneerd door de Belgische overheid (die wel ook zal geoordeeld hebben dat zijn proza indruiste tegen de Godsvrede én 's lands neutraliteit). Zo werd er met succes bekomen dat het Verenigd Koninkrijk de publicatie van een boek van hem verbood en dat later L'Opinion Wallonne, het dagblad dat hij in Parijs stichtte, door toevoeging van een Belg aan de Franse censuur geboycot werd. ${ }^{140}$

Naast deze uitspraken vermeldden de activisten ook dat de "franskiljons" voortdurend het dreigement "après la guerre on ne parlera plus du flamand" zouden uitgesproken hebben. ${ }^{141}$ Zoals we in Het Laatste Nieuws lazen, maakten sommige flaminganten zich al in augustus 1914 zorgen over de latere potentiële schade van "franskiljonse" uitlatingen voor de Vlaamse beweging. Ze waren dus zeker ontvankelijk voor dergelijk dreigement. Opmerkelijk 
is ook dat een aantal Nederlanders al vroeg gelijkaardige uitlatingen in die zin deden, waardoor we niet kunnen uitsluiten dat de uitspraak daar zijn oorsprong vond. Zo schreef de Nederlandse stichter van de Wereldbibliotheek Leo Simons op 9 augustus 1914 in een brief aan de voorzitter van het Algemeen Nederlands Verbond, Kiewiet de Jonge dat de samenwerking met Frankrijk en de Nederlandse neutraliteit de hele Vlaamse beweging kon doden. ${ }^{142}$ Eind augustus betoogde de liberale Vrijzinnig-Democraat dat sommige Nederlandse dagbladen neutraal bleven omdat ze in de schending van de Belgische neutraliteit ("een der meest onrechtvaardige daden in de geschiedenis") geen Nederlands belang zagen. Onterecht, want hoe de oorlog ook aflopen zou, de Belgische volksziel zou voorgoed naar Frankrijk gewend zijn.

de Vlaamse beweging [zal] een geheel andere oplossing [...] krijgen dan iemand vóór enige maanden had kunnen denken. [...] Dat deze Vlaamse beweging jaren, tientallen van jaren is teruggezet, is duidelijk. En daarin ligt meer dan het spreken van Frans of Vlaams. Er is hierbij sprake, of België zich openen zal naar het noorden of naar het zuiden. ${ }^{143}$

In een artikel van 5 september 1914, getiteld Vlaamsche Beweging, drukte het Nederlandse oud-kabinetshoofd Abraham Kuyper (Anti-Revolutionaire Partij) zich in zijn dagblad De Standaard nog scherper uit. Volgens hem kon het niet ernstig genoeg beklaagd worden welke schade de oorlog al aan de Vlaamse beweging berokkend had. Hij beweerde te vrezen voor de positie van het Vlaams in België:

De wrevel tegen al wat van Germaanse oorsprong was - en dit is en blijft toch ook het Vlaams - nam in deze jongste maand op zo zichtbare wijze toe, dat de esprit Wallon, met de esprit Gaulois één, reeds 't triomflied aanhief. En de uiterst bittere ervaring, die het arme land in de jongste weken opdeed, stuwt nu natuurlijk heel de volksgeest naar al wat Frans is én Frans klinkt. ${ }^{144}$

In lijn hiermee schreef de Nederlandse historicus Cris te Lintum omtrent hetzelfde tijdstip in het sociaaleconomische tijdschrift De Handel dat de "Vlaamse beweging [...] moet lijden, hoe't ook loopt, én door de verwoesting des lands [i.e. van België] én door het Franse bondgenootschap". ${ }^{145}$ We herinneren ons ook dat Impe eind 1914 meldde dat voor "de Fransgezinden" het moment daar was om voor eens en voor altijd gedaan te maken met alles wat 
maar Vlaams was. De Nederlandse Nieuwe Courant nam begin januari 1915 een bericht op dat op 26 december 1914 in België geschreven was. Daarin maakte een "Vlaming" gewag van "franskiljons" die droomden van "l'écrasement du flamingantisme" en naamloze doodsbedreigingen aan het adres van "voormannen van de Vlaamse beweging" stuurden: "Honte et malédiction aux crapules flamingantes, payées par la Germanie pour nos imposer sa culture. Après la guerre ily aura la chasse; nous vous tuerons comme des chiens." ${ }^{146}$ Uit Duitse rapporten leren we dat de Nieuwe Courant op de lijst van dagbladen stond die de Politische Abteilung geschikt vond om in het bezette land te laten lezen. Al begin december 1914 liet de militaire gouverneur van Limburg, Keim, de germanofiele Limburger Koerier in zijn provincie verspreiden. ${ }^{147}$ Welnu, het was dit dagblad dat van het bericht over de "franskiljonse" hetze met doodsbedreigingen aan het adres der Vlaamse voormannen voorpaginanieuws gemaakt had. ${ }^{148}$ Maar van wie gingen die dreigementen uit? Omstreeks hetzelfde tijdstip legde de activist Leo Picard in een brief aan oud-Germania medewerker Karl Lamprecht de woorden "Ce sera fini avec le flamingantisme. Cette guerre lui portera un coup plus terrible que la révolution de 1830 " in de mond van professor Van Houtte. Volgens de flamingant was dat "de hoop van alle Fransgezinden". ${ }^{149}$ Is het hier niet aannemelijk dat de praatjes die eind 1914 opdoken door de Duitse propagandadiensten zelf verspreid werden en door sommige Vlaamsgezinden geloofd werden?

Inderdaad werd in een artikel uit de Duits-activistische Gazet van Brussel van 10 januari 1915 betoogd dat gezaghebbende Vlaamshaters de Vlamingen belaagden en het Nederlands wilden uitroeien. Sedert het uitbreken van de oorlog riepen tal van "Fransgezinden" uit: "C'est fini des Flamands et de leurs exigences quant à leur langue." Twee weken later dook de slagzin in zijn definitieve vorm op in het artikel Vlamingen, Waakt! van de atheneumleraar August Borms. Bij hem heette het: “Après la guerre, on n'en parlera plus, du Flamand [...] zei een Antwerps vulgarisateur [een lid van de anti-flamingantische Association flamande pour la Vulgarisation de la Langue française, BY] tot een onzer leiders." Deze uitspraak lijkt een echo te zijn van wat de Nieuwe Courant en later de Gazet van Brussel meldde. Nog in de editie van 10 januari titelde de Gazet van Brussel: Is het amen en uit met de Vlamingen? Veertien dagen later stond er in het Duits-activistische Vlaamsche Nieuws uit Antwerpen een soort antwoord: "Het [is] amen en uit met het Vlaams." ${ }^{150}$ Die voorstelling van zaken werd algauw nog meer aangedikt en vond haar weg naar het neutrale Nederland. Zo meldde het katholieke Centrum op 6 februari 1915 dat, toen de oorlog uitbrak, de Belgische pers van alle partijen verkondigde dat het "uit [was] met't Vlaams". ${ }^{151}$ 


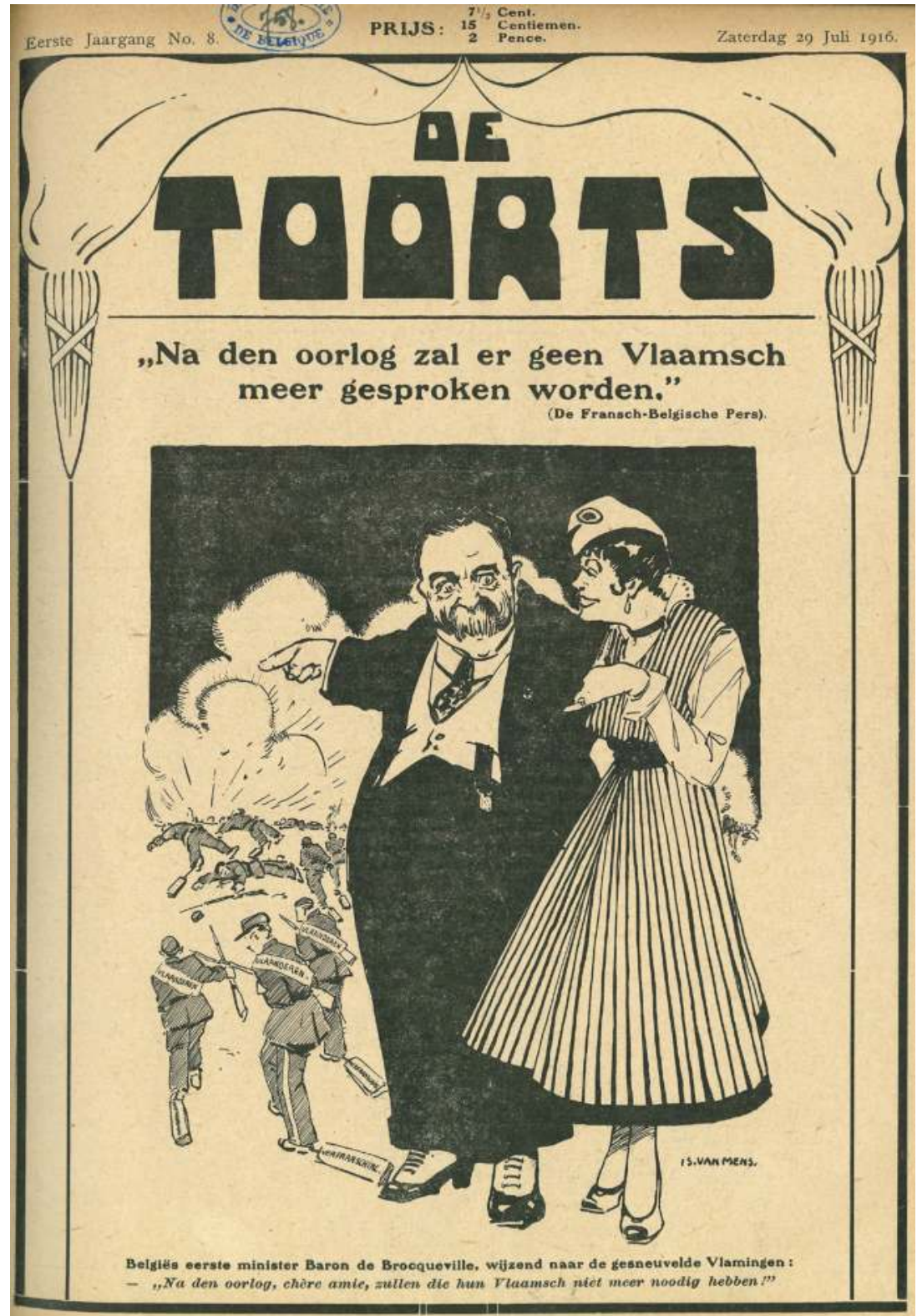

Afb. 3. Deze zogenaamd "franskiljonse" slagzin werd door de Duits-activistische propaganda tijdens de hele oorlog uitgebazuind.

De Toorts, nr. 8, 29 juli 1916; KBR BE-KBR00-Vi 7613 B 
Het verhaal over een anti-Vlaamse campagne borduurde ook voort op de vooroorlogse Vlaamsgezinde fraseologie. Schreef Het Laatste Nieuws op 17 juni 1907 niet hoe de "franskiljonsbladen" dagelijks beweerden dat er geen Vlamingen waren te Brussel? De krant laakte "onze Vlaamshatende gallomanen", maar deed dat in naam van onze "vaderlandse Vlaamse beweging". ${ }^{152}$ Hoewel de Flamenpolitik die Belgische bezieling in de Vlaamse beweging ondermijnde, beriepen ook de activisten zich erop die vaderlandse stroming voort te zetten. ${ }^{153}$

\section{Besluit}

De Godsvrede kreeg na de val van Antwerpen een fikse deuk. De vluchtelingenpers beschouwde elke aansporing vanwege Belgische dignitarissen om terug te keren naar het bezette land als onvaderlands. Vaak hysterische oproepen om niet terug te keren, werden vervlochten met geruzie over andere thema's, zoals de onduidelijkheid over de omstandigheden waarin de overgave van Antwerpen plaatsgevonden had. In het kielzog van die woordenstrijd kwamen er ook Vlaamsgezinden onder vuur te liggen. Soms werd daarbij gewezen op hun (vooroorlogse) pan-Germanisme. Het Journal des Réfugiés voerde als enige dagblad een soort antiflamingantische campagne door tussen 18 en 25 oktober 1914 vijf provocerende artikels in lijn hiermee te publiceren. Daarin deelden de zogenaamde Antwerpse pan-Germanisten en, in twee artikels, dé Vlaamse beweging in de klappen. Bovendien had het blad in dezelfde periode twee externe getuigenissen gepubliceerd met daarin verwijzingen naar "Ludwig Mark" en "der Oberbürgermeister dr. Ludwig Mark, alias Ludwig Franck".

Na 25 oktober haalde het blad nog eenmaal uit naar de Antwerpse "panGermanisten" (over de vluchtelingenkwestie) en eenmaal naar de flaminganten (over de perskwestie). Door zijn onbesuisde houding was het Journal onrechtstreeks medeverantwoordelijk voor de houding van La Métropole die op 28 oktober 1914 de "pan-Germanistische flaminganten" in Antwerpen hekelde. Na de door dat artikel geïnspireerde uitval van Henderickx in Antwerpsche Tijdingen (5 november 1914) volgden er drie tegenaanvallen van het katholieke blad. Ook hekelde La Métropole tweemaal een aantal Vlaamsgezinden als welwillende gezanten van de vijand. Het publiceerde in totaal een tiental voor Vlaamsgezinden prikkelende uitlatingen op vijf weken tijd. Die vertoonden amper een samenhang en vormden zeker geen onderdeel van een campagne. ${ }^{154}$ 
In Le Vingtième Siècle kan enkel het artikel dat Henderickx met de grond gelijkmaakte als mede door antiflamingantisme geïnspireerd beschouwd worden. In L'Echo Belge waren er twee artikels die aan dit criterium voldeden. De redactie van L'Indépendance Belge hield zich gedeisd. Wel heeft in dat blad de socialistische volksvertegenwoordiger Terwagne een aantal maal de Godsvrede niet onderhouden. In verschillende van zijn brieven uit Nederland die het dagblad publiceerde en waarvan twee vóór Nieuwjaar verschenen, verklaarde hij dat er onder de flaminganten pan-Germanisten waren en dat er in Duitsland een campagne aan de gang was om te doen geloven dat de Vlaamse bevolking het Duitse juk met genoegen op zich nam. Hij wist dus dat er een Flamenpolitik aan de gang was. Binnen de Vlaamse beweging bestonden er, zo merkte hij op, Duitse strekkingen in die mate zelfs dat de vijand er zich over verwonderde er niet met open armen ontvangen te zijn. Ook schreef Terwagne over kleine kringen flaminganten die "sedert geruime tijd" aan pan-Germanistische theorieën onderhevig waren. ${ }^{155}$ Aan het eind van de maand januari 1915 beweerde hij in L'Echo Belge dat iedereen die de Vlaamse taalrechten een warm hart toedroeg, luidop moest verklaren dat de Vlaamse bevolking niets te maken had met de kleine groep verdachte Duitse individuen die aan de oppervlakte kwam en sedert lange tijd de Belgen wilde verdelen. ${ }^{156}$ In zijn antwoord op Terwagne vroeg de in Nederland verblijvende Vlaamsgezinde advocaat Emiel Wildiers met aandrang om te stoppen met de "kwaadwillige insinuaties" die de Vlamingen in "sommige dagbladen" te beurt vielen. De advocaat had ook betoogd dat nooit één Duitser in een flamingantisch milieu het woord genomen had ten voordele van de Germaanse zaak. Waar waren, zo voegde hij er fijntjes aan toe, trouwens al die "ligues pour la vulgarisation allemande" in Vlaanderen? Wat we hier lezen, is karakteristiek voor de houding van veel Vlaamsgezinden, onder wie ook niet-activisten. Ze benadrukten dat zij zich niet schuldig gemaakt hadden aan een "pre-collaboratie" met de Duitsers. Maar de "franskiljons" papten wél van oudsher met Frankrijk aan!157

Het aantal stukken waarin een specifiek anti-flamingantische ondertoon aanwezig was, moet voor wat de vijf door ons onderzochte dagbladen betreft alleszins zeer sterk gerelativeerd worden. Tussen 15 oktober 1914 en 1 januari 1915 gaat het slechts om een twintigtal artikels, vooral uit het Journal des Réfugiés en, in mindere mate, uit La Métropole. In verhouding tot de honderden onderzochte dagbladedities is dat niet significant. Bij die artikels zitten er bovendien enkele van Terwagne, die duidelijk gespeend waren van een antiflamingantistische inspiratie, maar toch Vlaamsgezinden konden prikkelen. Dat de activistische apologeten zo weinig materiaal hadden om hun 
verhaal over een "anti-Vlaamse campagne" te bewijzen, toont de zwakte van die stelling aan. De artikels uit de vluchtelingenpers konden in de herfst en winter van 1914 en tijdens de hele oorlog trouwens enkel maar in het buitenland gelezen worden, tenzij de bezetter daar anders over besliste. Pas later werden ze in een apologetisch canon gegoten. ${ }^{158}$

Net als alle Belgen, waren Franstalige journalisten danig over hun toeren door de oorlog. Daarom publiceerden sommigen een aantal artikels waarin ze hun frustraties botvierden door vooroorlogse bedreigingen uit te vergroten. Het spookbeeld van het verduitste Antwerpen en de pan-Germanistische vijfde colonne, gevoegd bij de "flamingantische" handlangers daarvan, onder wie Franck, hoorde daarbij. Opvallend is dat die stukken vaak reacties waren op dagbladen die in het bezette land (opnieuw) verschenen. Ze waren dus zeker niet alléén door antiflamingantisme geïnspireerd.

Om een en ander in perspectief te plaatsen, wijzen we erop dat de hele Belgische vluchtelingenpers in Nederland in november 1914 vijf offensieve artikels publiceerde die de Vlaamse beweging of de "(Antwerpse) pan-Germanisten" aanvielen. Maar het katholieke Franstalige dagblad La Presse werd tussen 11 en 15 november 1914 ook in vijf artikels door drie Franstalige bladen gehekeld vanwege zijn vermeende onvaderlandse houding. Wie geloof hecht aan een anti-flamingantische campagne, kan dus met evenveel overtuigingskracht stellen dat "de Franstalige pers" een "antikatholieke hetze" had georganiseerd. Ook De Stem uit België had er trouwens op gewezen dat er Vlaamse gezanten waren van de Duitsers en dat sommige flaminganten meer pan-Germanist dan flamingant waren. Het beweerde dat die houding ook ingegeven was door de "onwaardige toon" van Antwerpsche Tijdingen. ${ }^{59}$ Voerde het blad van de flamingant Floris Prims, dat herhaaldelijk Antwerpsche Tijdingen veroordeelde voor zijn Duitsgezindheid, dan ook een antiVlaamse campagne? Vlaamsgezinden werden overigens zelfs sporadisch geëerd in de Franstalige vluchtelingenpers. ${ }^{160}$ Alle nuanceringen mogen ons evenwel niet blind maken voor het feit dat een aantal flaminganten geloofde dat er echt een anti-Vlaamse agitatie bestond. Op dit gevoelen konden de Duitse diensten inspelen. De eerste klachten over "franskiljonse" kuiperijen in de dagbladpers vinden we al eind oktober 1914 terug bij Karel van den Oever. In diens lezersbrief aan Het Centrum waar L'Echo Belge gekapitteld werd, wees hij er ook op hoe gevaarlijk het was, mocht de Franstalige pers de Vlaamse sympathie naar Duitsland verleggen: "Maar tegen die anti-Belgische houding moet elke [...] Belg bijtijds met beslistheid en kracht protesteren." ${ }^{161}$ In november 1914 reageerden ook Henderickx en de journalist Jacobs geïrriteerd op wat zij als anti-Vlaamse uitvallen bezagen. Blijkens een 
schrijven (14 november 1914) van Van Cauwelaert aan de katholieke volksvertegenwoordiger Van De Perre had die eerste gemeld dat Jacobs De Standaard wilde laten verschijnen. Desnoods moest dat vanuit het buitenland gebeuren. Zo wilde hij de werking tegengaan van de "Fransgezinden", die volgens hem onder andere via La Métropole de Vlaamsgezinden en de Vlaamse beweging verdacht trachtten te maken. Jacobs was - net als Van Cauwelaert en Van De Perre - een van de beheerders van de nv De Standaard bij haar stichting op 2 mei 1914. Het oprichtingsbesluit voor dat blad was toen genomen, maar wegens de oorlog werd de voor november geplande verschijning opgeschort. ${ }^{162}$

Er bestond alleszins een zekere gevoeligheid voor de taalkwestie bij de flaminganten, die begin november 1914 al aangezwengeld werd door de langzaam beginnende Duitse Flamenpolitik. Die zou de volgende maanden sterker worden en dus vertekende voorstellingen aan kracht doen winnen. De Duitse visie kon ook in het buitenland een impact hebben. Want via het neutrale Nederland circuleerden immers kranten uit het bezette België naar het Verenigd Koninkrijk en zo naar Frankrijk.

De irritatie van Vlaamsgezinden had ook de vooroorlogse situatie als voedingsbodem. Dit maakte hen in een situatie van oorlogsoverprikkeling ontvankelijker voor interpretaties die aan het beeld van een "anti-Vlaamse campagne" beantwoordden. Daarbij kwamen nog vragen over de Britse en Franse garanten: hoe betrouwbaar waren die? Hadden ze België in de steek gelaten? Hoe zouden ze de Belgische toekomst bepalen? Wellicht geloofden sommige flaminganten pas na verloop van tijd dat die "campagne" ook grootschalig en georkestreerd was. Zo schreef een lezer op 2 februari 1915 aan De Vlaamsche Stem uit Amsterdam hoe hij zich verontwaardigd voelde omdat sommige dagbladen die in Nederland verschenen de Vlaamsgezinden af en toe steken onder water gaven. ${ }^{163}$ Deze getuigenis stond veel méér in verhouding tot de realiteit dan de activistische bewering als zouden stukken in lijn met Harry dagelijks "in meer bedekte vorm" in de vluchtelingenpers herhaald worden. ${ }^{164}$ In feite konden Vlaamsgezinden nogal wat kwesties die de vluchtelingenpers aankaartte door een filter van "anti-Vlaamsgezindheid" bekijken. Zo bijvoorbeeld de administratieve collaboratie van Franck en de Intercommunale Commissie die in de meeste Franstalige dagbladen minstens tot eind november 1914 veroordeeld werd. Zonder twijfel hebben de verdachtmakingen over Franck die bij de overgave van Antwerpen de militaire overheid "vervangen" had, samen met de vraag in dagbladen om een tribunaal dat na de oorlog uit moest zoeken wie Antwerpen verraden had, daarbij nog méér olie op het vuur gegooid. 
Omdat een klein aantal provocerende persartikels verwijzingen naar de "Antwerpse pan-Germanisten" of "een aantal" Vlaamsgezinde verraders bevatte, was het mogelijk voor flaminganten om een haastige conclusie te trekken. Met name: Antwerpen en bij uitbreiding de flaminganten, ja de Vlamingen werden door "de Franstalige pers" aangevallen. Zelfs wie de vluchtelingen aanmaande om niet terug te keren, kon zo door associatie als "anti-Vlaams" bestempeld worden. Want was wie dat wenste, niet alleen tegen een hervatting van het normale leven, maar welbeschouwd ook voor de ondergang van Antwerpen? En was kritiek op de verschijning van eender welk Nederlandstalig dagblad in bezet België dan ook niet anti-Vlaams, omdat men de Vlamingen zo van informatie verstoken wou houden? In die context kan het voor Vlaamsgezinden pijnlijk overgekomen zijn te lezen dat een blad als het Journal des Réfugiés hekelde hoe enkel in Antwerpen of Vlaanderen dagbladen verschenen. Of dat L'Echo Belge meldde dat Antwerpsche Tijdingen een Pruisischgezinde campagne voerde. ${ }^{165}$ Zeker omdat er enkele artikels verschenen waren waarin telkens Brussel geloofd werd, omdat de pers daar niet meer zou verschijnen. Daarbij werd soms Luik bij de andere "goede" steden gerekend en af en toe het slechte voorbeeld van de Antwerpse pers gehekeld. ${ }^{166}$ Bovendien beschikten de Vlaamsgezinden net als iedereen in het bezette land maar over een beperkt aantal betrouwbare communicatiekanalen met het buitenland. Wie in België verbleef kon geen vluchtelingenbladen lezen, enkel wat de Duitsgezinde of gecensureerde pers eruit weergaf. Wel konden Belgen berichten lezen over vluchtelingen, onder wie journalisten, die op andermans kosten de tijd van hun leven in het buitenland doorbrachten. 



\section{HOOFDSTUK 4 DE DUITSE DIENSTEN TREDEN IN ACTIE}

In de nazomer van 1914 begon het Duitse propagandaoffensief over de val van Antwerpen. De Duitse diensten hebben er in dat kader alles aan gedaan om de Belgische haat tegen Frankrijk en, vooral, het Verenigd Koninkrijk aan te wakkeren. De val van Antwerpen toonde dan zogezegd aan dat met name de onbetrouwbare Britten België in de steek gelaten hadden. Rond die vermeende gebeurtenis zou de bezetter een mythe scheppen die in het raamwerk van de Flamenpolitik paste. Daarbij was het zijn bedoeling om, zoals oud-activist Faingnaert na de oorlog getuigde, "zekere maatregelen, aangaande het gebruik der Vlaamse taal" te nemen, Nederlandse dagbladen door te laten, "Vlaamsgezinde artikels" in de Duitse pers te publiceren, de Gazet van Brussel [en andere pseudo-Vlaamse bladen, $B Y$ ] in het leven te roepen en een "opvallende voorkomendheid van sommige Duitse beambten te Brussel en elders tegenover Vlamingen" te etaleren. ${ }^{1}$ Naast "Vlaamsgezinde artikels" publiceerden de Duitse diensten ook stukken over Antwerpen in de Duitse pers. De verhouding tussen dat soort artikels en wat de collaborerende pers in België schreef, dient onderzocht te worden. Wanneer schoten de door de bezetter gestichte en gepatroneerde persorganen in actie? Wat voegden ze voor nieuws toe aan het bestaande narratief? Welke propagandamotieven werden gebruikt? 


\section{De Flamenpolitik}

België wees niet alleen het Duitse ultimatum van 2 augustus 1914, maar ook het verzoek tot wapenstilstand van 9 augustus af. Het gevolg was zeer ingrijpend, want nu veranderde het Duitse Rijk het geweer van schouder. België zou de gevolgen van zijn houding moeten dragen en diende vernietigd te worden. Dat de Belgische regering begin september een nieuw verzoeningsvoorstel uit Berlijn naast zich neerlegde, werkte in Duitsland die gedachte vermoedelijk nog méér in de hand. ${ }^{2}$

Op 19 augustus 1914 werd op het Große Hauptquartier te Koblenz de Angliederung van Europese staten aan het Duitse Rijk besproken. Daarbij zouden België en Nederland Schutzstaaten worden. Een herstel van de Belgische neutraliteit achtte men onmogelijk en een toekomstige opname van België in een westelijke alliantie diende verhinderd te worden. Op 21 en 22 augustus kwam het Belgische probleem aan bod. Er werd voorgesteld het land te doen verdwijnen door een verdeling ervan tussen Frankrijk, Duitsland en Nederland. Dat was op dat moment de overtuiging van Von Bethmann-Hollweg en van Von Jagow, de Duitse staatssecretaris voor Buitenlandse Zaken. De kanselier vond dat op die manier een verzoening met Frankrijk nagestreefd kon worden. Zijn adviseur, Kurt Riezler, kantte zich daartegen. Met een integratie van de zuidelijke helft van België immers zou Frankrijk sterker zijn dan voordien. Zijn idee was België zonder Luik als Duitse Schutzstaat te laten bestaan, met toevoeging van Frans-Vlaanderen. Een deel van Limburg zou aan Nederland en een deel van Belgisch-Luxemburg aan het naburige groothertogdom geschonken worden. Hij stelde voor met Nederland, dat men volgens hem enkel kon verkrijgen wanneer men zijn vrijheid spaarde, een $S c h u t z$ - und Trutzbündnis aan te gaan. Eventueel kon het gezag over de Nederlandse kolonies gezamenlijk door Nederland en Duitsland uitgeoefend worden. Vijf dagen later sprak de kanselier zich na een verslag van admiraal Von Tirpitz uit voor een annexatie van de streek ten noorden van Antwerpen, Namen en Luik. (Als we zijn memoires mogen geloven, wenste Tirpitz overigens al bij het uitbreken van de oorlog een "zelfstandig" Vlaanderen met een Duits bezettingsrecht voor de haven van Zeebrugge). ${ }^{3}$ Het zuidelijke deel van België zou, zo zei Von Bethmann-Hollweg toen, als bufferstaat blijven bestaan. Maar ook dat vormde een probleem. Want een kleine en zwakke staat Wallonië zou, zoals Riezler dat opmerkte, naar Frankrijk neigen. ${ }^{4}$

Op 9 september 1914 legde de kanselier in zijn Septemberprogramm de Duitse oorlogsdoeleinden in het westen vast. Hij wenste een door Duitsland gedomineerd economisch Mitteleuropa. Frankrijk mocht zich nooit 
meer tot een grootmacht ontwikkelen en moest territoria in het oosten en het westen afstaan. Het Groothertogdom Luxemburg diende een Duitse bondsstaat te worden. Luik, Verviers en - misschien - Antwerpen zouden door Pruisen geannexeerd worden. België zou tot het niveau van een Duitse satellietstaat afzinken. De kanselier beschouwde Antwerpen als een soort troefkaart om Nederland in een "nauwere verhouding" met het Rijk te brengen, bijvoorbeeld door een Schutz- und Trutzbündnis met inbegrip van de kolonies. Daarvoor was hij bereid om de Antwerpse haven (met Duits bezettingsrecht) zonodig aan een "naar buiten toe onafhankelijk" Nederland (een satellietstaat dus) te schenken. Ondertussen riep de Marneslag (6-12 september 1914) het Duitse offensief een halt toe. De Duitse rechterflank liep bovendien vast in de modder van de IJzervlakte. De uitslag van de vijandelijkheden was nu onzekerder dan in augustus toen de Duitse troepen enorme overwinningen boekten. Het maakte Von Bethmann-Hollweg pessimistisch. Hij vertrouwde Riezler op 11 oktober toe dat het Belgische probleem bijna onoplosbaar was:

Die Niederlande werden nichts haben wollen. Frankreich vergrößern geht nicht an. Annexion, was die Militärs natürlich wollen, geht nicht an, 7 Millionen kann man nicht evakuieren [...] Während der Vernunft irgend eine Macht zuzutrauen, so müssten wir uns mit den Leuten verständigen, sur le dos du Belge - 1/2 Belgien gegen das Erzgebiet und die Kolonien, und stille Kooperation gegen England...5

Op 14 november 1914 noemde de kanselier het idee van een Belgische "Tributärstaat", zoals die in het Septemberprogramm voorzien was en op 18 oktober door hem wederom voorgesteld werd, een utopie. Het land moest op termijn opgedeeld worden tussen de buurlanden. Maar het voorlopige doel was "annexeren", hetgeen overigens de wens van het landleger en de marine was. ${ }^{6}$ Daarmee tekenden de oorlogsdoeleinden zich af: de directe of indirecte heerschappij over een verminkt België, dat samen met Nederland in een Germaans Mitteleuropa zou worden opgenomen.

De sleutel daartoe bleek de Flamenpolitik te zijn. Die liep parallel met een beleid van het Duitse keizerrijk, erop gericht om in te spelen op sociale, religieuze en nationale tegenstellingen in het Russische rijk en kolonies die tot de Entente behoorden. ${ }^{7} \mathrm{Al}$ vóór de oorlog had Von Bethmann-Hollweg het Vlaams-Waalse probleem grondig bestudeerd. Omdat hij vanaf zijn aantreden in 1909 minutieus ingelicht werd over de betekenis van de Vlaamse beweging in België, was er in augustus 1914 geen inleidende studie van het 
vraagstuk meer nodig. ${ }^{8}$ Dat die Flamenpolitik het licht zag, gebeurde mede omdat er een machtige Alduitse lobby bestond die gaandeweg de traditionele diplomatie zou overvleugelen. Zo ontstond er een völkische politiek, die door de schok van de oorlog aangewakkerd werd. Dit beleid sloot overigens aan bij wat een aantal Duitse deelstaten wensten, zoals een Duitse Rijnmonding. Zeker tegenover Nederland voerde Duitsland bovendien al veel eerder een imperialistische politiek. In 1899 schreef Wilhelm II onder invloed van de Alduitsers dat de kleine Nederlandse planeet uiteindelijk onder invloed van de grotere Duitse moest komen en hem toebehoren, zonder zijn zelfstandige bedrijvigheid te verliezen. ${ }^{9}$ En vanaf de eeuwwisseling tot 1909 werden pogingen ondernomen om een of andere unie met Nederland af te sluiten. ${ }^{10}$ Uit memoranda van Reismann-Grone en Hasse waar het Auswärtiges Amt al aan het eind van de negentiende eeuw kennis van had, was maar al te goed duidelijk geworden welke betekenis een Duits Vlaanderen of België kon hebben om de hele Nederlanden te veroveren. En dat de Vlaamse beweging daar dan een interessante rol in kon spelen. Vanuit ideologisch oogpunt moest de Flamenpolitik dus al niet geïmproviseerd worden. En in de Duitse en Nederlandse pers werd vanaf begin augustus 1914 het Belgische vraagstuk besproken. Zo schreef al op 12 augustus de correspondent van het Nederlandse katholieke dagblad De Tijd, vanuit Düsseldorf:

Op de intellectuelen in Duitsland heeft de menslievende handelswijze van Holland [tegenover de uit België verdreven Duitsers, $B Y$ ] een diepe indruk gemaakt. Velen, die niet onbekend waren met onze geschiedenis, verklaarden, dat Holland door de eeuwen heen altijd niets dan ellende van de Engelse en Franse zijde geleden had. Zij legden er vooral de nadruk op, dat België ons met hulp van Frankrijk ontnomen was. Er gingen veel stemmen op, die hoopten, dat na de oorlog Duitsland aan Holland zijn schuld dankbaar zou afbetalen, door Antwerpen en geheel Vlaanderen, dat toch eigenlijk Nederlands is, aan Holland terug te geven. Ik zou van dit [...] plan in het geheel niet reppen, als mij niet verschillende Rijksdagafgevaardigden, onder wie er waren met grote invloed, [...] hetzelfde gezegd hadden. ${ }^{11}$

Wat die correspondent meldde, is niet onmogelijk. Want er waren een aantal Duitse politici die, al dan niet via familiebanden, met België vertrouwd waren. In de komende weken en maanden werden gelijkaardige geluiden in de völkische Duitse pers gelanceerd. Ook begon het Duitse ministerie van Buitenlandse Zaken de Nederlandse publieke opinie rechtstreeks te bespe- 
len. Al op 15 augustus 1914 verscheen de eerste editie van het Duitse propagandablad De Toestand, waar ook Nederlandse medewerkers voor gevonden werden. Maar drie maanden later beweerde het blad dat "...de wereld rondom het Duitse volk [te kiezen zou] hebben [...] tussen de Duitse cultuur en de Duitse toorn". Dat leidde tot een diplomatieke rel, waarop het Auswärtiges Amt zijn subsidie aan het persorgaan stopzette. ${ }^{12}$ Pas maanden later zouden er opnieuw Duitse propagandabladen in Nederland verschijnen. Toch zal Duitsland tijdens de eerste oorlogsmaand nog wel meer olie op het vuur gegooid hebben. Want op 30 augustus achtte het Belgisch ministerie van Buitenlandse Zaken het nodig om te waarschuwen tegen geruchten van Duitse zijde, erop gericht om de betrekkingen met Nederland te schaden. ${ }^{13}$

Voor wat de beginnende Flamenpolitik betreft, springen twee Duitse instructies in het oog. Een eerste kwam van Von Bethmann-Hollweg op 23 augustus 1914. Betreffende de oprichting van het Duitse gouvernement-generaal in Brussel had die aan de staatssecretaris van Buitenlandse Zaken medegedeeld dat een goede kennis van het Frans voor Duitse ambtenaren in België absoluut noodzakelijk was. ${ }^{14} \mathrm{Op} 2$ september, dus nog vóór de bezetting van het grootste deel van Vlaanderen, droeg Berlijn het gouvernement-generaal op de Vlaamse beweging krachtig te ondersteunen, daar die ook een beweging voor de Hollandse taal was. Er waren Nederlandse elementen waarop Duitsland een beroep kon doen. De oorlog verdeelde de Nederlandse publieke opinie en het liberale kabinet in een pro- en een anti-Duits kamp. De meerderheid van de Nederlandse bevolking bracht sympathie op voor het geteisterde België, maar in sommige völkische milieus, waartoe gezaghebbende politici behoorden, in de officierenstand en in handelsmilieus, leefde een voorliefde voor Duitsland.

Het was vanuit Duits oogpunt natuurlijk belangrijk om een goede indruk te wekken in Nederland om daar die pro-Duitse elementen te ondersteunen en zo de inlijving van het land voor te bereiden. Aan het begin van de herfst van 1914 contacteerde generaal Von Ludendorff via een omweg de Nederlandse zaakgelastigde te Brussel. Hij stelde voor om, zoals men in Koblenz al besproken had, België te verdelen tussen Frankrijk en Nederland, waarbij dat laatste land daarna in het Duitse Rijk zou worden opgenomen.

Ondertussen werd het bezette België in drie delen opgedeeld. Het grootste deel van het land bestond uit het gouvernement-generaal. Het "etappegebied" had Gent als hoofdzetel en viel onder het gezag van het IVde leger. Het omvatte grotendeels de provincies Oost- en West-Vlaanderen alsook delen van Henegouwen. Het "operatiegebied", inclusief de hele kust en Brugge, viel onder het gezag van de Duitse Reichsmarine. Met name die Duitse zee- 
macht hechtte voor de langere termijn een bijzonder belang aan het bezit van de Belgische kust en de haven van Antwerpen. Dat verklaart waarom zij manschappen verzamelde die al na enkele weken ingeschakeld werden bij de verovering van de vesting Antwerpen en daarna mee naar het kustgebied oprukten. De Duitse admiraliteit werd, samen met de Alduitsers, een van de stuwende krachten in de annexatieplannen. Wanneer werden de eerste tekenen van een Flamenpolitik zichtbaar? De correspondent van de Nieuwe Rotterdamsche Courant meldde op 21 augustus 1914 dat er Duitse ulanen op de Brusselse Grote Markt met Nederlandstalige opschriften kampeerden..$^{15}$ Dat maakte indruk op Pieter Geyl, die vanuit Londen de oorlog met bijzondere interesse volgde. Nog eind 1942 schreef hij hoe het hem altijd bijgebleven was dat hij in grote ontroering en opwinding verkeerde "over de bezetting van Brussel door de Duitsers en over de Nederlandse opschriften op de Grote Markt - op zichzelf een onbeduidende kleinigheid van niets". ${ }^{16}$

Vanaf 25 augustus 1914 werden alle Duitse besluiten en affiches drietalig, waarbij het Nederlands na het Duits en het Frans kwam. ${ }^{17}$ In hun in 1919 uitgegeven oorlogskroniek schreven drie Brusselse journalisten evenwel dat de Duitse overheid op 26 augustus 1914 elke ochtend haar successen op Duits-Vlaams-Franstalige affiches meldde. Het Frans, zo meldden ze, was naar de laatste plaats verbannen. ${ }^{18}$ En al in de eerste editie van het Gesetz- und Verordnungsblatt für die Okkupierten Gebiete Belgiens (5 september 1914) werd de voorrang aan het Nederlands op het Frans gegeven. ${ }^{19}$ Op 8 september meldde de correspondent van de Nieuwe Rotterdamsche Courant: "er zijn daar aan het [Duitse] gouvernement[-generaal] ambtenaren werkzaam, die $\mathrm{u}$ in een volmaakt Nederlands te woord staan: slechts hun houding [...] duidt de oer-Germaan aan." ${ }^{20}$ Ook probeerde de Duitse bezetter het Belgische patriottisme de kop in te drukken. Op 19 september 1914 bijvoorbeeld zou baron Von Lüttwitz in Brussel het uithangen van de Belgische driekleur expliciet verbieden, onder het voorwendsel dat ze voor Duitse troepen een provocatie was. Hij beweerde de Duitse soldaten zo te beletten tot "zelfstandig optreden" tegen de Brusselse burgers over te gaan. ${ }^{21}$ Vanaf 6 oktober 1914 ging het Nederlands op alle officiële decreten en aanplakbiljetten van de bezetter het Frans vooraf. ${ }^{22}$ Inderdaad makte een correspondent van de Nederlandse Nieuwe Courant op 30 oktober gewag van uitgetikte Duitse proclamaties in "de drie talen Duits, Nederlands en Frans...." ${ }^{23}$ En op 1 november 1914 maakte Von der Goltz zelfs op Duits-Vlaamse affiches in Limburg kenbaar dat Belgische dienstplichtigen niet bij het Duitse leger zouden worden ingelijfd. ${ }^{24}$ Een maand later schreef de Gazet van Brussel, het hoofdstedelijk dagblad dat onder verborgen leiding stond van het Duitse 
gouvernement-generaal, hoe aangenaam verrast de Vlamingen enkele dagen geleden wel waren door het feit dat hun taal ditmaal vóór het Frans kwam op affiches. Deze maatregel waaruit bleek dat de Duitsers inzake de naleving der Belgische taalwetgeving een goed voorbeeld gaven, zo heette het dan, verstoorde vele "Belges de coeur" en sommige verfranste Vlamingen. ${ }^{25}$ In mei 1915 meldde de Henegouwse volksvertegenwoordiger Emile Buisset: “...une autorité d'essence allemande se croit autorisée à rechercher les voies politiques à s'attirer les sympathies d'une partie de la nation belge considérée ethnographiquement comme appartenant au rameau germanique." Een voorbeeld daarvan was, volgens hem, dat sedert het begin van de bezetting het Nederlands de voorrang kreeg op het Frans op de affiches van de Duitse overheid. ${ }^{26}$ Jean Massart, een hoogleraar aan de ULB die van augustus 1914 tot augustus 1915 in het bezette land verbleef, beweerde dat twee maanden na de Duitse bezetting van de hoofdstad de Duitsers de Vlamingen voor zich probeerden te winnen door te veinzen hun grieven te begrijpen en hun stamverwantschap poogden uit te buiten om ze van hun Waalse medeburgers te scheiden. Tijdens de eerste weken van de bezetting, zo schreef hij, werden officiële Duitse bekendmakingen slechts in het Frans en het Duits afgedrukt. En op 25 augustus 1914 begonnen officiële affiches te Brussel in drie talen te verschijnen (hetgeen klopte). Ten slotte kreeg, aldus Massart, vanaf 1 oktober het Vlaams de voorrang op het Frans. ${ }^{27}$ Brand Whitlock, de ambassadeur van de Verenigde Staten, schreef in 1919 over de "Nouvelles Publiées par le Gouvernement Allemand' - great white posters on all the walls in three languages, German, Flemish and French". Omdat Whitlock opmerkte dat op die affiches stond dat de troepen van generaal Von Kluck voor de poorten van Parijs stonden, lijkt het erop dat dergelijke affiches in de eerste septemberdagen van 1914 opdoken. ${ }^{28}$

In hun aantekening van 15 april 1916 herinnerden de drie eerder genoemde journalisten zich nochtans dat op de eerste Duitse affiches het Frans vóór het Nederlands kwam..$^{29}$ De proclamaties, bekendmakingen, verordeningen en nieuwsberichten die wij zelf onderzochten, tonen aan dat de bezetter tussen 20 augustus 1914 en 1 november 1914, althans in de hoofdstad, de volgorde Duits-Frans-Nederlands gebruikte. ${ }^{30}$ In Deinze, dus in het etappegebied, was er wel een aankondiging van de Duitse Kommandantur van 2 november 1914 die eentalig Nederlands was. ${ }^{31}$

$\mathrm{Al}$ tijdens de bezetting braken omtrent deze kwestie polemieken uit. Zo meldde de Duits-activistische Gazet van Brussel eind augustus 1915 dat de eerste Duitse aanplakbrieven louter in het Duits en in het Frans opgesteld waren. De taal van de Vlamingen werd volgens het blad miskend en 
wel wegens het stoken van de Walen bij de Duitse overheid. ${ }^{32}$ Een dag eerder had H. De Wandeleire in het vluchtelingenblad De Vlaamsche Stem uit Amsterdam, dat toen onder Duitse controle stond, beweerd dat na de Duitse inval de berichten van de Brusselse gemeenteraad eerst eentalig Frans en vervolgens Frans-Duits werden. Dit artikel werd in de pro-Duitse Nederlandse Nieuwe Rotterdamsche Courant overgenomen en lokte onmiddellijk een reactie uit van een naar Nederland uitgeweken Belg. ${ }^{33}$ Die schreef in het Nederlandse dagblad (terecht) hoe de bekendmakingen van het Duitse burgerlijke en militaire bestuur eerst op plakbrieven "in het Duits, Frans en Vlaams gesteld [...] over drie kolommen verdeeld" gepubliceerd werden. Volgens hem duurde het een drietal maanden (dus tot medio november 1914) na de bezetting, alvorens het Vlaams onmiddellijk na het Duits volgde en het Frans op de derde plaats kwam. Hij betoogde dat tijdens de periode dat hij in Brussel verbleef (tussen 20 augustus 1914 en 14 februari 1915) alle officiële berichten van de Brusselse gemeenteraad tweetalig waren. ${ }^{34}$

Er volgde een protest van "een Vlaamse lezer te Brussel" die deze beweringen van de hand wees. ${ }^{35}$ De Gazet van Brussel beklaagde zich op 4 september 1915 eveneens over de brief die blijkbaar geschreven was door een persoon die "steeds de Franse tekst van de plakbrieven leest, zodat het ontbreken van de Nederlandse vertaling hem zal ontgaan zijn". Het propagandablad wees erop dat pas de laatste maanden alle officiële bekendmakingen in Brussel opnieuw tweetalig waren. Het beweerde ook dat de affiches van de Duitse generaal Friedrich Sixt von Arnim in augustus 1914 tweetalig Duits-Frans waren. Wat het dagblad er niet bij vertelde, was dat die vóór de oprichting van het generaal-gouvernement verschenen. ${ }^{36}$ Uit al het voorgaande leiden we af dat de officiële affiches van de bezetter ten laatste op 25 augustus 1914 drietalig Duits-Frans-Nederlands werden en op 6 oktober officieel Duits-Nederlands-Frans om te tonen dat "die vlämische Bevolkerung und ihre Sprache dem deutschen Volke näherstehe als das Welschtum". ${ }^{37}$ Maar die maatregel werd blijkbaar pas consequent in november geïmplementeerd. Wel werd het Nederlands vroeger bevoordeeld, zij het dan nog niet systematisch (behalve in het Gesetz- und Verordnungsblatt). Later zullen we zien dat de Duits-activistische propaganda beweerde dat de bezetter in het begin van de bezetting louter het Frans gebruikte (omdat "de Walen" dat vroegen) en pas later aan het Vlaamse volk het zijne gaf.

De begunstiging van het Nederlands was niet in tegenspraak met de orders van de kanselier over het gebruik van het Frans. Uiteraard was dat van belang in België. Maar voor de Flamenpolitik was het gebruik van het Nederlands dat nog méér. Het waren personen als de Alduitser Robert-Paul 


\section{Gesetz- und Verordnungsblatt für die okkupierten Cebiete Belgiens.}

Wet- en Verordeningshlad roor de hezette streken van Belgiet.

Bulletin officiel des Lois et Arrêtés pour le territione helge oceuné.

BRLSSEL $\quad$ N $1 . \quad$ 5. SEPTEMBER 1914.

1.

Seine Majestat der Kaiser haben durch Allerhiechste Cabinetsorder d. d. Grosses Hauptquartier den 96. Angust 1914 Seine Excellenz den Herrn General-Feldmarschall Freiherrn von der Goltz zum Generalgouvernear in Belgien, und zun Verwalungschel bei dem Generalgouverseur Seine Excelleax den lieren Dr. von Sandt zu ernennen geruht.

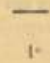

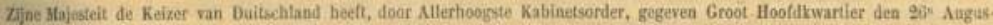
tas 1945, benoend tot Gouverneur Generaal in Belgin Zjue Excellentie dea Generaal-Veldmarschalk beer Barou von der Goltz, en

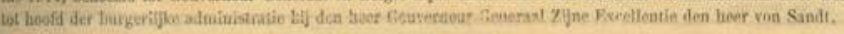

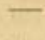

Par ordre du 20 aouit 1914, donné an Uuartier Gènèral de l'armie, Sa Majestè l'Empereur d'Allemagne a daigné nommer Gourerneur Gènéral en Bulgiquo Son Excellence M. Ie Feld-Maréchal Baron von der Goltz, et chef de rAdminiatration civile près le Gourerneur Getnéral Son Excellence M. von Sandt.

\section{2.}

PROKLAMATION.

Seine Majestat der Deutsche Kaiser haben gerult, mich mach Okkipierung belgischen Gebiets zum Generalgouverneur in BeIgien ni ernennen. Ich habe den Sitz des Generalgouvernements in Brüssel (Ministerium der sehōben Künste, rue de la Loi) aufgeseblagen. Aur Grund weiterer Anordnung Seiner Mfrjestit ist dem Generalgouverneur eine Zivilverwaltung angegliedert (Kriegsministerium, rue de Louvain) an deren Spitze Seine Exzellenz Herr von Sandt steht.

Die deutschen Hoere dringen siegreich in Vrankreich vor. Hier in bolgischen Gebiete Fuho und Ordaung aufrocht zu erhalten, ist dig Aufigabe des Generalgouvernements.

Jede feindsolige Hlandlung der Einwohnerschaft gegen Angehòrige des dentschen Heeres, jeder Versuch, ihren Verkehr mit der Ifeimat za stiren, Eisenbahnen, Telegraphea, Fernsprechverbindungen zu gefithrden, oder gar zu unterbrechen, wird unnachsichitich geahndet werden. Aufrubr oder Widerstand gegen die dentsche Verwaltung habea ricksichtslose Niedorwerfung zu gowsirtigen.

Die harte Notwendigkeit des Krieges bringt es mit sich, dass bei Bestrafung feindseliger Handlungen Unsehuldige mit dea Schutdigen teiden. Emsomelir ist es Palicht aller verstindig denkenden Rewohner Belgiens, die unruhigen Elemente in Lande von jeder Aussclireitung gegen die iffentliche Ordnung abzubalteo.

Kein belgischer Burger, der friedfertig seinem Erwerbe nachgeht, hat irgend etwas von soiten der deatschen Truppen und Behörden zu befirchten. Soweit irgend möglich, sollen IIandel und Wandel wieder aufgenommen, die industriellen Betriebe wieder in Gang geliracht und die Einbringung der Erate vollendet werten.

Afb. 4. Al vanaf de eerste editie van het Gesetz- und Verordnungsblatt für die okkupierten Gebiete Belgiens werd voorrang aan het Nederlands verschaft. Gesetz- und Verordnungsblatt, 5 september 1914, 1; KU Leuven Libraries Artes University Library LOP: Government Publications BE* Staatsblad 
Oszwald, assistent aan het historisch instituut van de universiteit te Leipzig en vanaf medio 1915 de Antwerpse perscensor, en later de historicus Franz Petri die beklemtoonden dat de bezetter in het begin van de oorlog zogezegd "louter" het Frans gebruikte. Dertien jaar later beweerde Oszwald dat de nadruk op de exclusieve kennis van de Franse taal bewees dat men in Duitse regeringskringen niet de minste kennis had van de binnenlandse strijd tussen Vlamingen en Walen. ${ }^{38}$ In 1937 - hij was inmiddels bekeerd tot het nationaalsocialisme - verhaalde Oszwald dat hij op 26 augustus 1914 naar aanleiding van de instructie over het taalgebruik aan Von der Goltz geschreven had om in de Vlaamse provincies naast het Duits slechts het Nederlands te gebruiken. Die dag had hij zijn twee maanden oud opstel uit de Preußische Jahrbücher naar gouverneur-generaal Von der Goltz opgestuurd. Daarin werd betoogd dat tussen de "verdrukte Vlamingen" en de "francofiele Walen" een rassenstrijd woedde. ${ }^{39}$ Wellicht wou Oszwald in 1937 zijn eigen rol in de Flamenpolitik in de verf zetten. Alleszins moest die voorstelling van zaken Duitsland van elk vooraf beraamd imperialisme vrijpleiten.

Naast Oszwald achtten ook andere Alduitsers hun moment gekomen. Zo benadrukte Heinrich Claß, de voorzitter van het Alldeutscher Verband, op 28 augustus 1914 voor het Geschäftsführende Ausschuß van de organisatie het belang van België, dat onder Duitse heerschappij geplaatst diende te worden. Een verschillende behandeling van Vlamingen en Walen was, aldus Claß, daarbij noodzakelijk. Op 18 september 1914 rolde het document waarin de oorlogsdoelen van Claß geëxpliciteerd werden van de persen. Het werd op circa 3000 exemplaren verspreid. België zou onder Duitse voogdij worden geplaatst en in een Vlaamse en een Waalse Mark gesplitst worden. Een dictatoriaal regime zou de Vlamingen voorbereiden op hun eventuele opname in het Rijk. Nederland zou zijn kolonies "wellicht" niet kunnen behouden en daarom uiteindelijk de Duitse zijde kiezen. Op 30 augustus 1914 stuurde Max Robert Gerstenhauer, toen Oberleutnant aan het Franse front, zijn Denkschrift naar Von Bethmann-Hollweg op. Volgens Gerstenhauer regeerde het bezettingsbestuur de Vlamingen nog Franser dan het Belgisch bestuur. Dat beschouwde hij als een gemiste kans. Want bij de juiste behandeling zouden de Vlamingen, zo betoogde hij, Duitsland als "redder en bevrijder van de verfransing" begroeten. De rest van België kon dan "zonder strijd" veroverd worden. Hij verwees voorts naar de talloze contacten die hij met Vlamingen gelegd had, daar hij rond 1900 an het tijdschrift Germania meegewerkt had. Gerstenhauer vernoemde daarbij drie namen: Pol de Mont, Hippoliet Meert en Haller von Ziegesar. Op 8 september 1914 stuurde de kanselier het geschrift op naar Von Sandt, het hoofd van 
de Zivilverwaltung. ${ }^{40}$ Diezelfde dag verzond Graevell in samenspraak met Von Pfister vanuit Zwitserland een aantal documenten over een Flamenpolitik naar gouverneur-generaal Von der Goltz. Hij opperde het idee om een kosteloos dagblad te stichten en leeszalen in te richten waarnaar Duitse uitgevers hun kranten konden opsturen. Aan de nog niet vervulde Vlaamse aanspraken moest gevolg gegeven worden. Het Vlaamse volk diende in Gent en Leuven twee Duits-Vlaamse universiteiten te verkrijgen. Voorts moest in de administratie, op school, in de rechtbanken, in de kerken en de dagbladen het Vlaams de enige taal worden in Vlaanderen. België diende in "Vlaamse" en "Waalse gewesten" opgedeeld te worden, elk met hun eigen hoofd. Die splitsing moest dan met een eigen Vlaams (en Waals) leger en aartsbisdom gepaard gaan. ${ }^{41}$

Op 9 oktober 1914 vertelde de germanist Borchling, die we moeten situeren in de kringen rond de Quickborn, op een voordracht in Hamburg ongeveer hetzelfde als Oszwald, maar hij drukte zich nog scherper uit. Met het door een rassenstrijd verziekte België kwam het niet meer goed en dus moest Vlaanderen een "onafhankelijke" Nederduitse staat worden, eventueel verbonden met Nederland en ingekapseld binnen een Germaanse Bond. Ook de publicist Fromme was in de Quickborn actief. Hij benadrukte in de Deutsche Rundschau de "bloedverwantschap" tussen Vlamingen en Nederlanders, hun onderdrukking door de Walen en de noodzaak van een "onafhankelijk" Vlaanderen. De prominente Alduitse antisemiet Fritz Bley had intussen ook zijn weg naar die organisatie gevonden. Aan het einde van de negentiende eeuw was hij binnen het Alldeutscher Verband nog een van de voorvechters geweest van de inlijving van de Nederlanden in een Duitse Germanenbond. ${ }^{42}$ In oktober 1914 bezong hij de Vlaams-Nederlanse eenheid en bezag hij de Walen als bron van alle kwaad. Op 4 november 1914 titelde zijn Zeitfragen: Heraus mit den vlämischen Hochschule!.

Met het verlies van de Marneslag veranderde de functie van de Flamenpolitik. Ze werd vooral - sommigen zullen zeggen: uitsluitend - een instrument voor na de oorlog. Zo kon België na een onderhandelde vrede verdeeld worden tussen zijn buurlanden. Duitsland kon dan compensaties krijgen door de afstand van Frans grondgebied en door een vergroting van zijn koloniale rijk. Het doel bleef: België intern vernietigen. Ook wanneer het land volledig door Duitsland ontruimd en hersteld moest worden - dat wilde noch de marine, noch het landleger, noch de gouverneur-generaal in Brussel, noch de kanselier (die in mei 1915 in besloten kring zelfs verklaarde dat zijn annexatiewensen in België groter waren dan die van de zeer annexionistische 
generaal Von Hindenburg) -, dan nog kon er een een pro-Duits regime aan de macht komen. ${ }^{43}$ Het sprak vanzelf dat België niet openlijk kon vernietigd worden, met het oog op het niet hypothekeren van een compromisvrede met het Verenigd Koninkrijk. Tenminste, dat was de mening van de regering in Berlijn. Sommige militairen, daarin gesteund door de Alduitsers, waren echter voortvarender. Op 16 december 1914 schreef kanselier Von BethmannHollweg aan Von Bissing dat allereerst alle vraagstukken in verband met het "Vlaamse vraagstuk" door een bijzondere daarmee belaste dienst behandeld moesten worden. Duitsland zou zich bovendien de rol van "trouwe beschermer en vriend" der Vlamingen aanmeten. Wat dat precies inhield, drukte hij als volgt uit:

die weitesgehende Forderung der flämischen Sprache unter Verzicht darauf, in den flämischen Landesteilen der deutschen Sprache eine übergeordnete Rolle zuzuteilen, ferner die Ausgestaltung der Universität Gent zu einer rein flämischen Lehranstalt und die Herstellung einer für die militärischen Interessen annehmbaren publizistischen Verbindung zwischen Holland und den flämischen Gebieten. ${ }^{44}$

In een gesprek tussen Reismann-Grone en Von Bissing 's anderendaags liet die eerste zich ontvallen dat Duitsland België wellicht moest ontruimen, maar het land diende te vernietigen door de ondersteuning van de Vlamingen. ${ }^{45}$ De gouverneur-generaal sprak hem niet tegen. Verschillende historici hebben zich later afgevraagd of dit op een stilzwijgende beaming van Von Bissing duidde. Dolderer en Müller wijzen er terecht op dat die laatste in het openbaar "allesbehalve de vernietiging van België [...] voorstond". Pas in 1916 stemde hij, op aandringen van de kanselier, zo betogen ze, uiteindelijk in met de bestuurlijke scheiding. ${ }^{46}$

Von Bissing wilde enerzijds het hele Belgische territorium behouden, maar anderzijds het land intern ontwrichten. $\mathrm{Al}$ in zijn antwoord op de instructies van de kanselier, op 10 januari 1915, meldde hij dat België in 1830 als een "onnatuurlijke staat" geschapen was. Op 11 januari 1915 werd een Dienst voor Vlaamse aangelegenheden opgericht. Een maand later werd die geïntegreerd in de Politische Abteilung van het gouvernement-generaal. Die stond onder leiding van Von der Lancken, die aan Von Bissing geopperd had om België te verbrokkelen in een Vlaams en een Waals deel. ${ }^{47}$ De gouverneur-generaal nam de desintegratie van België dus toen al in overweging. 


\section{De oorsprong van de Duitse voorstelling van zaken}

Parallel met de beginnende Flamenpolitik voerde het Duitse Rijk propaganda tegen de Entente. In dat kader werd op 12 oktober 1914 aan de Brusselse muren een bekendmaking van het gouvernement-generaal geplakt, met als hoofding "ENGELAND EN BELGIË" ${ }^{48}$ Daaruit moest blijken dat er in het Belgisch ministerie van Oorlog een dossier bestond, De Britse interventie in België getiteld. Daarin stond dat er reeds in 1906 voorzien werd in het sturen van een Brits expeditieleger naar België in geval van een Frans-Duits conflict. Op Brits initiatief had het hoofd van de Belgische generale staf een gedetailleerd project uitgewerkt voor gezamenlijke acties tegen Duitsland, waarbij honderdduizend Britten het Belgisch leger zouden bijstaan. Deze Conventions Anglo-Belges werden, zo stond er te lezen, voorafgegaan door gelijkaardige militaire akkoorden tussen België en Frankrijk. Correspondentie van baron Greindl, de Belgische ambassadeur te Berlijn, over een mogelijke aanval van de Entente doorheen België tegen Duitsland werd als bijkomend bewijs afgeschilderd voor de echtheid van de Duitse stelling. België had, zo heette het, verzuimd om gelijkaardige overeenkomsten met het Reich af te sluiten en als dusdanig zijn neutraliteit "verloochend". Over de documentatie luidde het: "Dat ze de ogen opene van de Belgische bevolking over diegenen, die schuldig zijn aan de catastrofe die zich over het arme land heeft ontketend." De semi-officiële Kölnische Zeitung had in haar artikel over Henderickx op 13 november 1914 gelijkaardige bewoordingen gebruikt. ${ }^{49}$

De Duitse beweringen klopten niet. In werkelijkheid waren er slechts officieuze gesprekken geweest tussen België en de Entente. Die behandelden dan nog de mogelijkheid tot een geallieerde bijstand na een schending van de Belgische neutraliteit. De Duitse overheid kende er in 1906 de inhoud al van. Koning Albert had de feiten immers zelf aan de Duitse militaire attaché te Brussel medegedeeld. ${ }^{50}$ In de herfst van 1914 kon de bezetter dus inderdaad schrijven dat zijn "bevoegde instanties" het wisten. Op 16 oktober en op 25 november 1914 bracht de conservatieve en semi-officiële Norddeutsche Allgemeine Zeitung de inhoud van die vermeende Conventions naar buiten. De Duitse voorstelling van zaken werd in de collaborerende "Belgische" pers overgenomen. Begin december 1914 noemde kanselier Von Bethmann-Hollweg in de Rijksdag op grond van die stukken de Belgische neutraliteit een "masker"."1

Het lag voorts voor de hand dat de Duitse diensten munt zouden proberen te slaan uit de val van de "onneembaar" gewaande vesting Antwerpen, waar de Britten ook bij betrokken waren. Al op 10 oktober 1914 begon de 
propaganda in het Berliner Tageblatt. Dat zette de toon door te beweren dat de Britten hun veto uitspraken, terwijl de Belgen dachten aan het ontkomen aan een doelloze verwoesting van en bloedvergieten voor Antwerpen. "Gehoorzamen moesten allen, ook de koning." Ook de Berlijnse en nationalistische Tägliche Rundschau beweerde dat de ramp die de havenstad te beurt viel, slechts een gevolg was van de Belgische gehoorzaamheid aan de Britse wil..$^{52}$ In lijn hiermee schreef de Vossische Zeitung, een toonaangevend liberaal orgaan uit Berlijn, dat de Belgen zelf de vesting waarschijnlijk al veel vroeger hadden overgegeven, omdat de nutteloosheid van een verzet tot het uiterste duidelijk was. De Britten echter beletten de overgave en wisten de Belgen te overhalen om het nog langer vol te houden. "Dit was een volkomen nutteloze tegenstand, die slechts tot onnodig bloedvergieten heeft geleid en de stad onberekenbare schade heeft berokkend." De Belgische regering had verstandiger moeten handelen door met de echte krachtsverhoudingen rekening te houden en zo de Antwerpenaren van het bombardement te sparen. ${ }^{53}$ De Deutsche Tageszeitung spaarde evenmin de roede. Geen wonder ook: het dagblad was een integraal-nationalistisch persorgaan van de Bund der Landwirte, een organisatie die nauw samenwerkte met het Alldeutscher Verband. ${ }^{54}$ Het beweerde dat de "verblinde Belgen" zich onder de (overigens waardeloze) Britse bijstand waanden. ${ }^{55} \mathrm{Nog}$ in de Tageszeitung verscheen een stuk van de völkische redacteur (en latere nationaalsocialist) Ernst Graf zu Reventlow over Antwerpen. Ook hij legde de volledige schuld voor de ellende die Antwerpen ondergaan had bij Engeland. Dat kunstwerken beschadigd en mensenlevens verloren gegaan waren, heetten allemaal "offers" geweest te zijn die het Verenigd Koninkrijk op zijn geweten had:

Reeds enkele dagen geleden beweerden Nederlandse bladen, dat in Antwerpen verwensingen werden gehoord tegen de Engelse en Franse vrienden die België tot de oorlog hebben gedreven en het Belgische volk door leugens over de stand van zaken tot verder verzet aanspoorden, maar nooit op het juiste moment hielpen.

Zelfs, zo betoogde hij, dwongen de Engelsen koning Albert te Antwerpen weerstand te bieden, hoewel de Belgen, zich bewust van de nutteloosheid van het verzet, de stad wilden overgeven. ${ }^{56}$ De gelijkenissen tussen wat de Tageszeitung en de Vossische Zeitung meldden, waren treffend. Opvallend zijn ook de persreacties uit Oostenrijk-Hongarije die parallel liepen met wat de lezer uit de Duitse pers vernam. Zo brandmerkte het Weense Fremdenblatt het gebeuren als een schande voor Engeland. Het Neues Wiener Tageblatt 


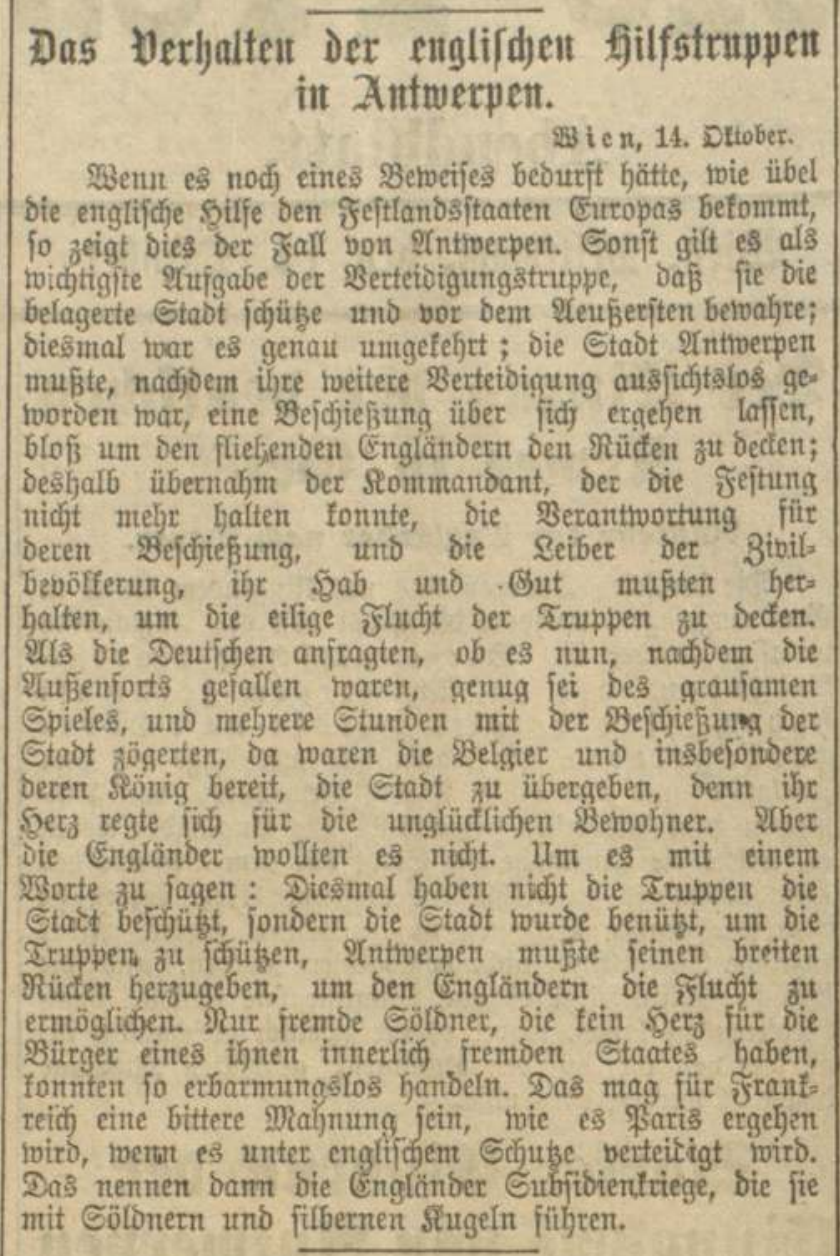

Afb. 5. De anti-Britse propaganda omtrent de val van Antwerpen begon al enkele dagen na de val van de vesting, ook in de Weense Neue Freie Presse.

Neue Freie Presse, Abendausgabe, 14 oktober 1914, 2; Universitätsbibliothek Wien Hauptbibliothek Magazin: (NT 11) III-5246

beschouwde België als "het eerste offer" van de Britse minister van Buitenlandse Zaken Grey. De Neue Freie Presse, het meest invloedrijke dagblad in de Donaumonarchie, beschreef dan weer hoe de val van Antwerpen een voorbeeld was van hoe het Verenigd Koninkrijk en Frankrijk vrienden die op hen vertrouwden, in het ongeluk stortte. ${ }^{57}$ In bezet België drukte het Duitse blad Le Bruxellois op 14 oktober 1914 een gefingeerd interview af met een 
zeer hooggeplaatste Belgische dignitaris dat hiermee in lijn lag. Volgens hem diende België als buffer voor de anderen (de geallieerden). Het bloed van Belgische jongens was vergoten en het arme land verwoest. Maar de beloofde geallieerde hulp was uitgebleven $!^{58}$

De Weense Neue Freie Presse ging op dat elan door. Het blad beschikte over correspondenten die hun berichtgeving rechtstreeks haalden bij het Duitse Große Hauptquartier in Charleville-Maizières. In een bericht dat op 14 oktober 1914 te Wenen opgesteld was, beweerde het dagblad hoe de val van Antwerpen een zoveelste bewijs was van het euvel dat het Verenigd Koninkrijk over het vasteland bracht. Toen de buitenste forten gevallen waren, hadden de Duitsers uit humanitaire redenen uren geaarzeld om de stad te beschieten. De toestand was uitzichtloos. De Belgen en vooral de koning waren bereid tot een overgave. De Britten weigerden. In plaats van de stad te beschermen hadden ze de Belgen gebruikt om door rugdekking te verschaffen, hun vlucht mogelijk te maken. De Duitse beschieting was de verantwoordelijkheid van Deguise, die de vesting niet langer kon houden en de bevolking niet ontzag. ${ }^{59}$ Op 18 oktober 1914 verscheen in het Oostenrijks blad In Antwerpen nach dem Fall, van de hand van de Duitse oorlogsverslaggever en koloniale expert Oscar Bongard. Vóór de oorlog onderhield hij nauwe relaties met het Pruisische ministerie van Cultuur. ${ }^{60}$ Afgaande op de informatie van het Duitse hoofdkwartier schreef hij:

De bewoners van de provincie [sic] Vlaanderen, waartoe Antwerpen behoort, zijn van Germaanse oorsprong. Aan de Germaanse cultuur en [het Germaans] vernuft is het te danken, dat Antwerpen is wat het is. De strijd tegen de Franse invloed werd er hardnekkig gevoerd, maar geleidelijk verkregen de franskiljons de overhand, ofschoon de landstaal nog steeds het Vlaams is. In het licht van deze omstandigheden, kan heel goed worden uitgelegd hoe het komt dat de in Antwerpen achtergebleven mensen de Duitsers vriendelijk [...] bijna kameraadschappelijk, ontvangen. [B.Y.]

De Antwerpenaars beschouwden, aldus het Oostenrijks dagblad, de Duitsers zelfs als hun redders. $\mathrm{Zij}$ hadden hen immers van de rampspoed bespaard die de volledige vernietiging van de stad teweeg zou hebben gebracht. "Het betreft [...] een stamverwante en volkomen andere soort mensen als in Brussel." [B.Y.] Want daar koesterde men een verbitterde haat tegen de Duitsers. ${ }^{61}$ In het Nederlandse dagblad De Tijd werd op 21 oktober 1914 dezelfde klok geluid. Een Duitse correspondent uit Aken beweerde erin dat de Belgen in Vlaanderen het Duitse volk nader stonden dan ze zelf thans beseften en 
voegde daar een variatie op een gekend thema aan toe: "De Belgen hebben [...] de terugtocht der Engelsen uit Antwerpen moeten beschermen [...] Hoe [het Belgisch leger] zich ook weerde: Franse en Britse hulp bleef uit!” Churchill was in Antwerpen wel komen "decreteren" dat de stad moest standhouden, maar de Britse daden spraken anders. In plaats van tijdig voor hulp gezorgd te hebben, liet men de Belgen in de steek. Volgens de correspondent was Antwerpen niet uit militaire overwegingen prijsgegeven, maar ter wille van Frankrijk en Engeland opgeofferd. De Belgische soldaten waren geëvacueerd om de geallieerden, die enorme verliezen leden, in Frankrijk te hulp te snellen. ${ }^{62}$

Er zat een lijn in de Duits-Oostenrijkse propaganda. De schuld voor de val van Antwerpen, de verwoesting en het bloedvergieten lag bij de Britten. $\mathrm{Zij}$ eisten immers verzet tot het uiterste van de Belgen en hun koning-opperbevelhebber, die ze dan eerloos in de steek lieten. Op 21 november 1914 borduurde Erwin Scherl in het artikel Das Betrogene Antwerpen voort op de besproken themas. ${ }^{63}$ Scherl was een Oostenrijkse correspondent in Boedapest voor de Neue Freie Presse, die medio november in Antwerpen verbleef. ${ }^{64}$ Zijn artikel verscheen in de Pester Lloyd, het toonaangevende blad uit het Hongaarse deel van de Donaumonarchie. In lijn met Bongard beweerde hij dat Antwerpen de meest vreedzame stad was van België. Wat een verschil met Brussel, waar de inwoners de oorlog maar kenden van horen zeggen. De Antwerpenaars waren ook na het bombardement de meest vreedzame, eerlijke, welgezinde en dankbaarste mensen gebleven. Het is interessant om deze oorlogspropaganda te vergelijken met de inhoud van de Duits-activistische Gazet van Brussel van 11 december 1914. De intertekstualiteit tussen wat dat blad toen beweerde en wat Scherl schreef, is immers te groot om als louter toeval afgedaan te worden. De Gazet van Brussel verhaalde hoe een medewerker die zich kort na de val van Antwerpen van de hoofdstad naar de havenstad begaf, daar optekende hoe een Waal zijn bewondering voor de Duitse troepen niet verborg. De man was getroffen door het Antwerpse pragmatisme: "de Duitser was nu baas, men moest zich daar maar in schikken en zijn burgerplicht doen. Wat ik overal hoorde, was de stem van het gezond verstand; Iedereen wenste van verdere verschrikkingen van de oorlog bevrijd te zijn."

Want hierin bestaat het onderscheid tussen mensen die door de oorlog beproefd zijn en anderen die hem maar van horen zeggen kennen, dat de eersten zich niet met ijdel gepraat bezighouden en niets dan vrede wensen, terwijl de tweeden dikwijls maar al te lichtzinnig over oorlog, verwoesting, ondergang van handel en nijverheid enzovoort wauwelen. Het is zo gauw gezegd: liever het ganse land vernield zien dan te buigen voor 
de Duitser! Maar de arme lieden die geleden hebben, die have en goed verloren hebben, spreken anders, of liever zij spreken niet, maar herleven nu ze uit die vreselijke nachtmerrie verlost zijn. Zij kennen nog één wens: vrede, vrede tot alle prijs! ${ }^{15}$

Wat vertelde Scherl nog meer? Allereerst dat de Duitsers die vóór de oorlog in de metropool verbleven en nu in Duitse dienst getreden waren, door de Antwerpenaars als oude vrienden begroet werden. De Germaanse stamverwantschap was daar natuurlijk niet vreemd aan: "de Antwerpenaar is zuiver Vlaams in taal en karakter. De Brusselaar is een Waal van een slecht Frans aftreksel." [B.Y.] Terwijl de Brusselaars op straat bustes van koning Albert en burgemeester Max verkochten, onthielden de Antwerpenaars zich wijselijk van elke patriottische oprisping. Vergeleken met de sfeer in Brussel was het in de Scheldestad bijna aangenaam vertoeven. Vervolgens borduurde de auteur voort op wat de Neue Freie Presse op 14 oktober beweerd had. Want uitgerekend Antwerpen, zo schreef hij, viel ten prooi aan de grootste Britse gemeenheid van de oorlog: "De machtigste havenstad van Europa [werd] aan het verwoestende Duitse geschut prijsgegeven [...] [en] de meest conservatieve bevolking van België [...] brutaal opgehitst [...] opdat alleen de Engelse verdedigers zich snel in veiligheid konden brengen." [B.Y.] En dat ondanks de dure eden van Churchill! Vierhonderd beschoten of verbrande huizen en honderdmaal méér mensen die have en goed moesten achterlaten om naar Nederland te vluchten, waren het offer van het Britse bedrog geweest; 25.000 Belgische soldaten waren met Britse boten gevlucht. De zogenaamde "verdedigers" hadden bij "Nacht und Nebel" Antwerpen verlaten en 400.000 vreedzame burgers waanden zich in volkomen zekerheid toen het bombardement begon. Verhaald werd hoe de burgerlijke overheid door de Britten niet op de hoogte gesteld was van de situatie opdat ze zo niet op eigen initiatief de stad kon overgeven. Er was meer. Want volgens de correspondent meldden de Belgische dagbladen in authentieke vorm dat de regering de beschieting van de stad ronduit had uitgelokt om de germanofiele gevoelens van haar inwoners te temperen en te vergiftigen:

Om de Duitsvriendelijkheid uit deze stad te bannen, dwong men de Duitsers om de vreedzame burgers uit hun schuilplaats te jagen en een hele stad op de vlucht te jagen. De Belgische pers stelt voorts met voldoening vast dat er voortaan, door het bombardement van Antwerpen, een wig gedreven is tussen de Vlaamse en Duitse stambroeders en dat die daar voor altijd zal blijven. Het plan was bedacht met herostratische arglistigheid. [B.Y.] 


\section{Entilletort. \\ (1)uer Durd Dent Weltkrieg. \\ Das betrogene \&ntwerpen. Bon Grwiu eherf. \\ If ntwerpen, Mitte Rovember.}

intmex nidyt bergefien. Wenn biejes bunfle Ungetüm jiber ber Etaot fonpebte und Berberben fpie, ba exfasite

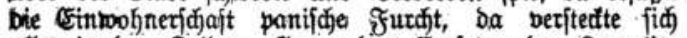
alles in ben feillern. Begen bass Entietien ber Bespelins:

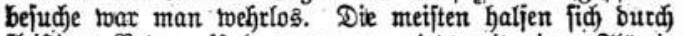

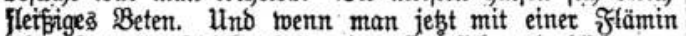
biber Beppelin jpridgt, befreuzigt fie fing und blidt er froden gegen ben Simutel.

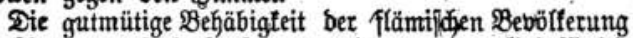

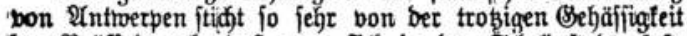

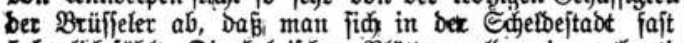
bejoglifi fühlt. Die belgifiden slätter melben in autbenti=

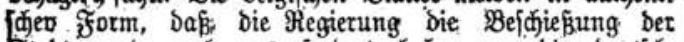
Staot gerabezu herausaeforbent habe, umi bie beutidy.

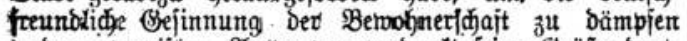

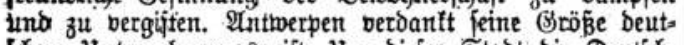
Whem Unternehmungaggeijt. IIm Diejer Etaot bie Deutid): teunolidjteit augzutreiben, zwang man Die Deutiden;

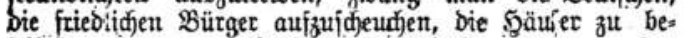

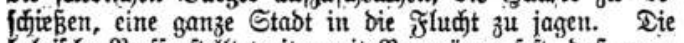

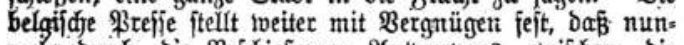

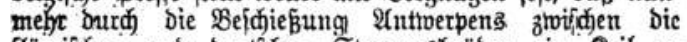

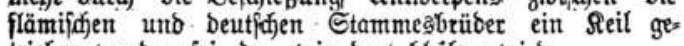
trieben worden jei, der elwig bort bleiben wiro.

Der \$llait twat mit berojtratifder Tüđe erionnen,

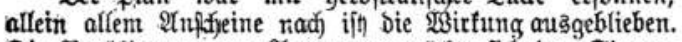
Die Bebölferung von $\mathscr{U}$ nttwerpen mödfte fid Den ভiegern am liebiten anjeunden. Wäfrent in Brififiel bie Buijten

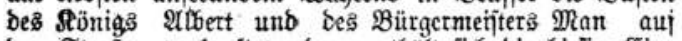

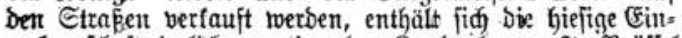
mohnerfidaft jeglidjer nationtulen Sunogebung. In Brüffel erliés Der Millitärgouberneutr einen Direften Bejehl an bie

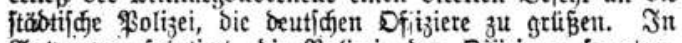
Intmerpen falutiert die Folijei Den Ditizieren fpontan.

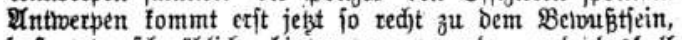

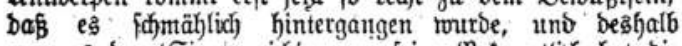
mag eకె bem 'Greger nidjt grain fein. Setanntlidy hat bie Deutjd)e Regiering Belgien nad) Dev (Eimuahme von Rüttid ein Frtiebensangebot gemadt. Bon biejem \&ntrag

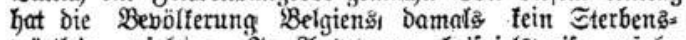
wörtlein eriahten. In 2 (ntwerpent beijpielșveife erjugr man bon biejer hodherzigen Initiative erit nad) ber (Ein.

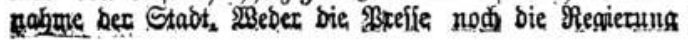

Afb. 6. De Oostenrijkse correspondent van de Pester Lloyd schetste medio november 1914 het tragische lot dat de Belgische overheid voor Antwerpen in petto heette te hebben. Pester Lloyd, 21 november 1914, 1-2; National Széchényi Library — FM3/775 
Herostratos had in 356 voor Christus de Griekse tempel van Efeze, een der zeven wereldwonderen, in brand gestoken. Het woord "herostratisch" betekent hier "uiterst eerzuchtig". ${ }^{66}$ De straf die de Belgische regering Antwerpen opgelegd had, was dus haar aan een moedwillige Duitse beschieting over te laten om de Vlamingen voor hun germanofilie te straffen. Tevergeefs, aldus Scherl, want het gemene plan kende geen gevolg. Integendeel. De Antwerpenaars gaven immers dankbaar toe dat generaal Von Beseler in de 36 uur van het bombardement slechts de lichte artillerie liet schieten. Toen het zware geschut klaarstond, traden drie burgers op die de stad uit eigen beweging overgaven. Zij werden vandaag als redders van de stad erkend: burgemeester De Vos, senator Ryckmans en gemeenteraadslid Franck. ${ }^{67}$

Op dezelfde dag dat Das Betrogene Antwerpen wereldkundig gemaakt werd, schreef de Brusselse correspondent van de Vossische Zeitung een opmerkelijk bericht, dat op 26 november 1914 onder de titel Nachklänge zum Fall von Antwerpen gepubliceerd werd. ${ }^{68}$ Toen in de nacht van 8 oktober het Belgisch leger, zo begon hij, op aansporing van de "moedige" (aanhalingstekens in tekst) Engelsen van de Zeebrigade van Churchill zonder slag of stoot de stad verliet en de bevolking aan de gevaren van een bombardement overgelaten had, meende de burgerlijke overheid terecht dat ze bevoegd was de stad over te geven. Daarom liet burgemeester De Vos op de kathedraal de witte vlag hijsen en begaf hij zich, samen met Ryckmans en "Frank" [sic, Franck, $B Y]$, naar Kontich om met Von Beseler de overgavevoorwaarden te onderhandelen. In het eerste deel van deze Brusselse correspondentie vindt men twee elementen terug die tot dan nog nooit in de pers voorgekomen waren: de foutieve schrijfwijze van de naam van Franck en de onware verwijzing naar een witte vlag op de kathedraal. ${ }^{69}$ De correspondent vervolgde door te stellen dat men niet goed wist wat minister van Oorlog De Broqueville bezield had toen hij zijn troepen liet uitrukken. Dacht hij dat de bevolking maar overhoop moest geschoten worden en de soldaten de eer konden opstrijken?

Man könnte dies beinahe meinen, denn jetzt wird bekannt gegeben, das von Le Havre aus die beiden Politiker Ryckmans und Frank [sic] vor das Tribunal geschleppt worden sind um sich hier [in Le Havre, $B Y]$ in einem Prozess wegen Hochverrats zu verantworten.

Twee partijkopstukken, de katholieke minister van Staat Cooremans - sic, Cooreman; was deze foutieve schrijfwijze het gevolg van een verwarring met de andere katholieke politicus Coremans? - en de liberaal Hymans hadden zich, zo vervolgde de correspondent, vorige week naar Den Haag begeven 


\section{Dachklänge zum Fall von Antwerpen.}

Bon unferem Rorreiponbenten.

Bxïff̆er, 21. November.

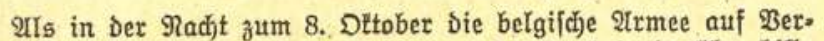
anlaffung Der "mutigen" Ënglänber von Der Seebrigabe Churdills fang: und Hlanglos bie Stabt verlaffen und bie Bevölferung ihrem Shidfal und ben Gefabren eines Bombarbements - iiber.

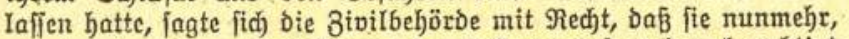
von Den berufenten Berteibigern Der Feftung aufgegeben, beredjtigt fei, bie Stabt zu überliefern. Der Bürgermeijter De Dos ließ̧ Deshalb auf Der Rathedralc Die weiß̧e Fahne hod)ziehen und begab fich), beglcitet von zwei Mitgliebern ber Stabtverwaltung, Dem fatbolifáben Senator Rydmans uno Dem Iiberalen Deputierten Grant, nach) Contid), um mit bem Belagerungstommandanten, General von Bejeler, Die Uebergabebebingungen feftzujeben.

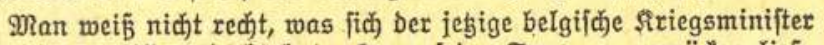
De Broqueville gebadht hat, als er feine ฐruppen ausrüden Iiȩ́.

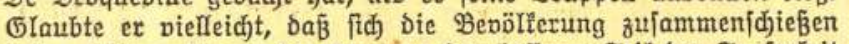
Iaflen follte, mährend bie Truppen ben befferen Teil ber Tapferfeit ermählten? Dian tönnte Dies beinabe meinen, Denn jebt wixb

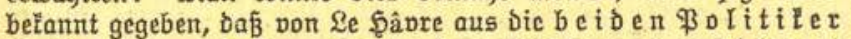
Rydmans und Frant oor bas Tribunal gefd̆leppt

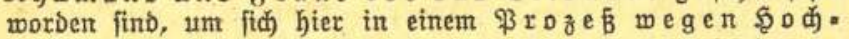
verrats zu verantworten.

8 wei ßaxteifübrer, Der Staatsminifter $\mathcal{C}_{0}$ oremans, ber ber fatholifdjen \$artei angehörte unb Der liberale Führer \$D.

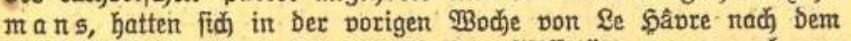
$5 \mathrm{a} a \mathrm{~g}$ begeben, um bort bie beiben Wiffetäter of vernehmen. Der jehr nervöje . Gerr Symans foll feinem Freunde Franf ben Bormur eines Berräters ins (5efid)t gefdhleubert haben. Diejer

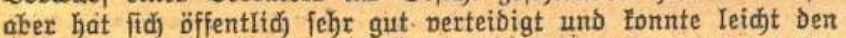
Bemeis liefern, Dab er mahrhaft patriotifí) handelte, als er Dafür Sorge trug, niōt nur, Daß̄ Die Bejojiebung Der Stabt cingeftellt wurbe, Die volftändig zmed = und ftunlos war, fonbern baß̄ auch bine geflïh)teten Sanosleute aus Solland zurïdfebrten, Damit Das normale Qeben wieber einfeben tonnte. Die Bevölterung Int= werpens hat biejes Grant aud zu banten gewübt, Denn Grant ift beute Der populärite Mann in Untwerpen, uno es gereījt

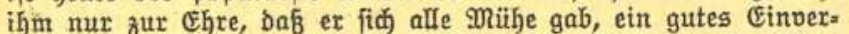

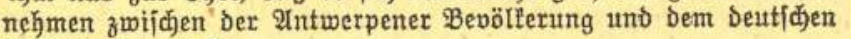
Militär herzuftellen.

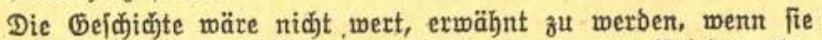
nicht Den Beweis exbräd)ten, Daß̧ Dic Seute, Die jebst Belgiens Ge. fachiďe Ienten, naiv uno obne Renntnis ber internationalen Ber. einbarungen finb, bie ihre berufenen Bertreter im Şaag getroffen baben.

Afb. 7. Het fantasieverhaal over het verhoor van twee Antwerpse dignitarissen, op

21 november 1914 opgesteld door de Brusselse correspondent van de Vossische Zeitung. Vossische Zeitung, Morgen-Ausgabe, 26 november 1914, 4; UCL-JEL 128 
om daar de twee misdadigers te verhoren. De zeer nerveuze Hymans zou daar zijn vriend "Frank" een verrader genoemd hebben. Maar die had zich publiekelijk goed verdedigd en kon gemakkelijk aantonen dat hij patriottisch gehandeld had. Hij had immers niet alleen gezorgd voor een beëindiging van de zinloze beschieting van de stad, maar ook dat zijn gevluchte landgenoten uit Nederland terugkeerden. De correspondent besloot met te stellen dat de Antwerpse bevolking "Frank" dankbaar was en dat hij met reden de populairste persoon in de stad was. Terecht strekte het hem tot eer de goede verstandhouding tussen de Antwerpenaars en de Duitse militairen op touw te zetten.

Het verhaal over de vermeende ontmoeting vond zijn oorsprong in het feit dat Franck en Ryckmans op 2 november 1914 in Den Haag waren om er zaken te regelen betreffende de terugkeer der Belgische vluchtelingen. Cooreman en Hymans bevonden zich op datzelfde tijdstip op dezelfde plaats "om zich van het lot van [hun] landgenoten [...] te vergewissen" ${ }^{70}$ Het besproken stuk uit de Vossische Zeitung van 26 november speelde in op de verdeeldheid tussen diegenen die het beleid van Franck huldigden, zoals de Vlaamsgezinden van Antwerpsche Tijdingen en zijn tegenstanders. Het suggereerde dat de Belgische regering volledig onbekwaam was om het land te leiden. Ze heette zelfs geen kennis te hebben te hebben van de "overeenkomsten" die haar eigen gevolmachtigden, Hymans en Cooreman, in Den Haag waren gaan afsluiten. Af te gaan op zulke berichtgeving vonden de twee ministers van Staat dat Franck en Ryckmans inderdaad verraders waren die gestraft moesten worden. Maar dat er verraders waren, hadden vluchtelingenbladen als het Journal des Réfugiés en La Métropole óók beweerd. Nadat het fabeltje op 26 november wereldkundig werd gemaakt, bleef het anvankelijk muisstil in de Belgische pers. Maar drie dagen na de publicatie van het artikel in het Duitse dagblad schreef de Gazet van Brussel in zijn eerste editie een polemisch artikel, waarin het opperde dat België door zijn bondgenoten (sic) in de steek gelaten was: "Naar het schijnt, was koning Albert met enkele verlichte staatslieden en legeroversten voor de vrede; de druk [...] van Engeland en Frankrijk sloeg dit wijs raadsbesluit in duigen. Wij kennen het verder rampzalig verloop" - met onder meer de val van de vesting Antwerpen. De gelijkenissen met wat de Duitse en Oostenrijkse pers al vlak na de overgave van Antwerpen schreef, springen in het oog. Het blad vervolgde dat het in het hele land herhaaldelijk had horen zeggen dat België na de val van Luik vrede had kunnen en moeten sluiten: "Wie zijn nu de beste vaderlanders: zij die het land aan verwoesting en ondergang wilden prijsgeven of zij die na de verdediging van Luik het vaderland wilden sparen en een eervolle vrede sluiten?"71 
Omtrent hetzelfde tijdstip, ging ook het pro-Duitse blad Le Bruxellois resoluut in de aanval, nadat het de schijn van neutraliteit meer dan twee maanden na zijn eerste publicatie min of meer had opgehouden. Constant Goffinet, ondervoorzitter van het officieel Belgisch Comité voor het Verenigd Koninkrijk, meldde later aan The Times dat het Brussels blad een verachtelijke publicatie was, uitgegeven door de bezetter, vol tendentieuze berichten en Duitse verzinsels die als "inlichtingen" doorgingen. ${ }^{72}$ De nummers van 26 november en 1 december 1914 waren alvast niet van dien aard om die stelling te ontkrachten. In het eerste nummer werd namelijk geveinsd dat Belgische gezagsdragers door het blad ondervraagd geweest waren. Vele van deze hoge heren gedroegen zich echter als lafaards. Sommigen spraken, maar ontliepen hun verantwoordelijkheid door het persorgaan te verzoeken hun naam niet te publiceren; die zwakkelingen wilden pas na de oorlog praten. De Belgen zouden zulk gedrag fel veroordelen. ${ }^{73}$ Op 1 december publiceerde het blad een opzichtig voorpagina-artikel, getiteld $A$ Propos de la Capitulation d'Anvers. ${ }^{74}$ Het uur der afrekening had nog niet geslagen ["L'heure de régler les comptes n'a point sonné encore”], zo meldde Le Bruxellois. Daarmee werd bijna woordelijk herhaald wat het Journal des Réfugiés op 27 oktober geschreven had over "het uur der afrekening" ["l'heure de la reddition des comptes n'est pas venue"] in verband met de "ware toedracht" omtrent de overgave van Antwerpen. We weten dus waar Le Bruxellois vermoedelijk de mosterd haalde. ${ }^{75}$ Het witwassen van de schuld zou, zo vervolgde het pro-Duitse blad, niet gebeuren onder de ogen van de vreemdeling, hoewel sommige journalisten, profiteurs en vluchtelingen die veilig samenhokten in een vergulde schuilplaats de Godsvrede tussen de partijen probeerden te verbreken op de kap van hun tegenstanders. Niettemin liet het blad niet na de sensationele "nieuwsfeiten" (aanhalingstekens in tekst) die de Belgen direct aanbelangden en de grote bladen in het buitenland rondbazuinden ter wille van de "waarheid" aan het licht te brengen. Het citeerde het "feitenrelaas" uit de "opmerkelijke correspondentie" van de Vossische Zeitung:

On sait que la nuit du 8 octobre dernier la brigade navale Churchill avait quitté les forts et la ville [...]. Le bourgmestre De Vos arbora le drapeau blanc sur la tour de la cathédrale Notre-Dame et, accompagné de deux de ses échevins [sic, Franck was in 1914 gemeenteraadslid, $B Y$ ] M. le sénateur catholique Ryckmans et M. le député libéral Franck, se rendit à Contich, où il négocia avec le général von Beseler les conditions de la reddition de la place. Celle-ci avait été abandonnée par les renforts anglais et par l'armée belge que le Gouvernement et les Alliés voulaient faire échapper 
à une capitulation possible. La population civile jugea, avec raison, qu'elle avait le droit d'éviter d'être massacrée et d'arrêter le bombardement [...]. C'est pourquoi l'administration civile d'Anvers, se faisant son interprète, se soumit à la nécessité et qu'en son nom et mandatés par elle à cette fin, les trois fondés de pouvoirs remirent la cité aux vainqueurs. C'était leur droit, cétait leur devoir; les innocents et les non-combattants ne pouvaient être davantage sacrifiés. ${ }^{76}$

Le Bruxellois voegde nieuwe elementen toe aan de eerdere Duitse propaganda, die de Belgische lezer uiteraard niet kon verifiëren. Zo bijvoorbeeld hoe Franse en Engelse dagbladen schreven dat "Ryckmans en Franck gesommeerd waren om voor een uitzonderingsrechtbank in Le Havre terecht te staan" en dat er sprake van was om "hen in een proces voor hoogverraad aan te klagen":

Deux ministres d'Etat, M. Gérard Cooremans [sic, Cooreman; het betreft hier dezelfde taalfout als in de Vossische Zeitung, BY], catholique, et M. Paul Hymans [...] se seraient même rendus la semaine dernière à La Haye, tout exprès pour 'entendre' les 'inculpés'.

Het blad meldde dat Hymans zijn oude vriend Franck als "landverrader" bestempeld had. Dat was een versterking van de "verrader" die hij in de Vossische Zeitung heette te zijn. Bovendien werd hier niet alleen gemeld dat Franck patriottisch gehandeld had: het drietal had dat gedaan "en arrêtant un bombardement désastreux et en rendant une cité que l'armée belge et les Alliés eux-mêmes avaient dû renoncer à défendre davantage". Ook schreef Le Bruxellois dat de Belgische staatslieden Franck ten laste legden dat hij de vluchtelingen die in Nederland verbleven, aangemaand had om terug te keren. Het schreef over wat er zich te Den Haag afgespeeld had: "Des feuilles hollandaises narrent tout au long les détails de cette entrevue historique qu'on eût dû tenir au moins secrète." Een laatste subtiel verschil betrof de houding van de Belgische regering. Waar de Vossische Zeitung beweerde dat de regering blijkbaar niets afwist van de handelingen van haar afgevaardigden in Nederland, liet Le Bruxellois een ander geluid horen:

...nous avons le droit de conclure que les dirigeants de nos vieux partis gouvernementaux n'ont aucunement le droit de parler de 'haute trahison', eux qui ont trahi leur mission par crainte - comme les élus du Meeting anversois notamment - de perdre leur clientèle électorale en exigeant 
et en votant les impôts et les sacrifices militaires nécessaires, ou, comme certain vieux leader de la droite conservatrice [bedoeld werd: Woeste, $B Y]$, en supposant, depuis trente ans, de tout le poids de son excessive influence, aux réformes inéluctables...

Misschien werd voor die beweringen inspiratie opgedaan in het Journal des Réfugiés van 7 november 1914. In een artikel van die dag werd, zoals gezien, het antimilitarisme en het flamingantisme van de katholieke partij op de korrel genomen. ${ }^{77}$ Alleszins blijkt uit de berichtgeving van het Franstalige persorgaan dat, in tegenstelling tot wat de Vossische Zeitung geschreven had, de actie van de twee ministers van Staat in Nederland door de Belgische regering zelf gemandateerd was. Want het waren de "oude regeringspartijen" die over hoogverraad spraken. Kan uit het voorgaande niet besloten worden dat de oorspronkelijke Brusselse correspondentie uit de Vossische Zeitung vanuit het gouvernement-generaal naar het Duitse blad was gestuurd? En dat de opsteller, een Duitse correspondent verbonden aan het gouvernement-generaal, het daarna in licht gewijzigde vorm in Le Bruxellois opnam?

Die stelling wint nog aan kracht, wanneer men de tweede editie van de Gazet van Brussel (3 december 1914) erbij neemt. ${ }^{78}$ Het blad publiceerde toen op zijn eerste pagina een artikel met de provocerende titel $Z i j n$ de Vlamingen goede Belgen?. Dat was een becommentarieerde compilatie van meerdere artikels. Het begon met de samenvatting van een aan de Nederlandse Nieuwe Courant van 2 november 1914 ontleend artikel, getiteld In Duitsch-Antwerpen. Dat betrof een verslag van zijn oorlogscorrespondent en was op 30 oktober te Antwerpen opgesteld. Die had het over hoe de bezetter wou waken over een "zeker soort geschrijf dat onverantwoordelijken deden". Dat klopte trouwens. Want vanaf het eind van de maand oktober 1914 werd de pers strakker gecontroleerd. Zo liet generaal-majoor Von Bodenhausen, de militaire gouverneur van Antwerpen, toen via een proclamatie weten dat iedereen die dagbladen die door de Duitse censuur niet goedgekeurd werden, uitgaf of (ver)kocht volgens de oorlogswetten gestraft zou worden. Die maatregel zou vooral diegenen treffen die dagbladen bezaten met een antiDuitse strekking, zoals het Journal des Réfugiés. ${ }^{79}$

Tussen de observaties in de Nieuwe Courant door volgden er complimenten over het hoffelijk gedrag van de Duitse militairen. Iedereen meende zogezegd persoonlijk veel minder van de Duitse troepen te hebben geleden dan verwacht, af te gaan op wat Belgische dagbladen schreven over de gebeurtenissen elders. "Een Brusselaar" zou aan de correspondent gezegd hebben dat "de Antwerpenaren en de Vlamingen óók geen Belgen waren". Ze verzoenden zich immers te 
spoedig met de toestand. "De Antwerpenaren, aldus mijn zegsman waren altijd voor 90 procent Duitsgezind." ${ }^{80}$ Het is mogelijk dat een Brusselaar dit laatste verteld had, de commentaren die in de hoofdstad meteen na de val van de vesting de ronde deden in acht nemend. In de Gazet van Brussel werd van dit deeltje de essentie gemaakt. In verschillende nummers, aldus het dagblad, wezen "Hollandse bladen" erop dat de Antwerpenaren heel wat jovialer met de bezettingstroepen wisten om te gaan dan de Brusselaars. Vormde dat geen bewijs dat ze praktische mensen waren? Bovendien was het een vaderlandse plicht om het werk op te nemen, niet om op geheimzinnige wijze allerlei valse geruchten te verspreiden [zoals de aantijgingen tegen het Antwerps stadsbestuur?, $B Y$ ].

In lijn met de kritiek van Antwerpsche Tijdingen op de vluchtelingenbladen werd daaraan toegevoegd: "Wie kan het hun [de Antwerpenaars] ten kwade duiden dat zij, na een beleg van twaalf dagen en een bombardement van 36 uren doorstaan te hebben, naar kalmte, rust en vrede snakken?" De Sinjoren en Vlamingen waren wél goede Belgen, in de traditie van Breydel en De Coninck. Hadden de Vlamingen niet onder het zingen van de Vlaamse leeuw net als hun illustere voorouders het land verdedigd? De meest "Vlaamshatende gazetten" stonden er zelfs voor in bewondering. [De bezetter had de pers vanaf augustus 1914 blijkbaar gelezen, want de Franstalige dagbladen hadden dit inderdaad ook aangehaald, $B Y]$. De redacteur van de Gazet had dergelijke "anti-Vlaamse" geruchten trouwens eveneens te Brussel gehoord, zo schreef hij. Besluiten deed het blad met zijn echte intenties te onthullen:

Wanneer men met de nodige kalmte en onbevooroordeeld nagaat dat de Duitsers en Vlamingen van hetzelfde Germaanse ras zijn en dat Duitsland daarenboven steeds onze belangen heeft behartigd [...] dan zal men geredelijk [i.e. redelijkerwijs] toegeven dat het een beetje onze sympathie verdiende.

De Vlamingen zouden eerder, zo heette het, "een zeker gedeelte van de Belgische natie" [het Franstalige dus, $B Y$ ] kunnen beschuldigen. Want dat had gedurende de laatste driekwarteeuw gauw een al te grote genegenheid betuigd aan "naburen [Frankrijk en het Verenigd Koninkrijk, $B Y$ ] die ons [de Vlamingen, $B Y$ ] sedert vele eeuwen van onze vrijheid beroofd hebben of dreigden het te doen". Dit stukje herhaalde het motief van de Nederduitse of Germaanse stamverwantschap, dat ook in de Neue Freie Presse (18 oktober 1914), de Kölnische Zeitung (13 november 1914) en de Pester Lloyd (21 november 1914) aan bod kwam. Hier speelde mogelijk ook de invloed van het boek Frankrijk, de eeuwenoude vijand van Vlaanderen en Wallonië 
een rol. Dat was in 1913 door Maurits Josson geschreven. De bezetter was zeker met het werk vertrouwd. Josson had het vóór de oorlog zelfs naar de keizer proberen op te sturen. ${ }^{81}$ Het taalgebruik zal de flaminganten alleszins bekend in de oren geklonken hebben. Daarna volgden twee artikels "die hierbij aansloten”. Een eerste was getiteld Ware en Valsche Patriotten. Dat bundelde uittreksels uit twee stukken uit Antwerpsche Tijdingen, misschien om dat blad (nog meer) te compromitteren tegenover de Franstalige vluchtelingenpers. Het eerste was een oproep om de orde te handhaven en zich te schikken naar de oorlogssituatie (lees: de wetten van de bezetter). Het tweede riep de bevolking op om terug naar Antwerpen te keren nu de situatie veilig was. ${ }^{82}$ Dat was, aldus de Gazet, "vaderlandse taal". Tegenover de "ware patriotten" stelde het blad "valse patriotten", die België naar de ondergang dreven. Dat waren de bladen die vluchtelingen aanzetten om niet huiswaarts te keren en die met alle middelen wilden beletten dat rust en orde in België terugkeerden. Die "hatelijke veldtocht" werd vooral gevoerd door La Métropole, L'Indépendance Belge, een blad dat de Franse belangen heette te dienen en (natuurlijk) het Journal des Réfugiés dat "reeds verboden werd in Holland" (sic). De eerste twee kranten kwamen later op het lijstje van de Politische Abteilung van provocerende en anti-Duitse dagbladen die zogezegd de Godsvrede ten nadele van de Vlamingen doorbraken terecht. ${ }^{83}$

Daarna volgde Eene Franskiljonsche Beschuldiging dat zich voorstelde als een samenvatting van het door ons besproken artikel van Henderickx in Antwerpsche Tijdingen. De Gazet van Brussel meldde daarin hoe La Métropole "onlangs" een artikel tegen de Vlamingen schreef - dat stuk vormde inderdaad de aanleiding tot het epistel van Henderickx -, waarin die van "pan-Germanistische verbroedering" beschuldigd werden. Die aantijging vindt men niet terug in het fameuze La Vie à Anvers uit La Métropole van 28 oktober 1914 maar wel in de herwerkte versie daarvan uit de Kölnische Zeitung van 13 november 1914. Dat blad had inderdaad gemeld hoe La Métropole "een korte tijd geleden" de Vlamingen van "alldeutsche Verbrüderung" beticht had (quod non, La Métropole had het over enkele Vlaamsgezinden). Dat het bewuste nummer van La Métropole "onlangs" verscheen, kon men op 6 november, toen de correspondent van de Kölnische Zeitung het bewuste artikel redigeerde, wel beweren, maar natuurlijk niet meer op 3 december 1914 toen de Gazet van Brussel dit stuk publiceerde. Vervolgens onthield de Gazet uit het artikel van Henderickx dat sommige leiders van Vlaamsvijandige bladen de Godsvrede doorbroken hadden. Ze "hadden de droeve moed de Vlamingen van pan-Germanisme te beschuldigen (sic). Hoewel wij Germanen zijn [...] zijn wij nog geen landverraders!". De "frans- 


\section{A propos del lacapitulation d"Anters}

Pourquoi a-t-on livré la Mètropole ? Pouvaitelle tenir plus longtemps ? Pourquoi parler de haute trahison? Incurie passée.

L'heure de régler les comptes n'a point sonné encore. Le lessivage des responsabilités ne se fera point sous les yeux de l'étranger. C'est entendu, quoique certains journalistes profiteurs, réfugiés prudemment dans un exil doré, aient cru déjà pouvoir rompre la « trêve du silence des partis », pour politicailler sur le dos de leurs adversaires.

Nous ne pouvons pas, néanmoins, ne point signaler au public belge les a nouvelles n sensationnelles que les grands journaux de l'extérieur colportent librement et qui nous intéressent trop directement pour que nous ne leur fassions pas écho, en nous efforçant de rétablir la vérité.

Ces jours-ci - le jeudi 26 ,novembre - la KGazette de Voss publiait une remarquable correspondance belge sur les détails de la reddition de notre fameux a réduit national s.
Or, voici que des journaux de France et d'Angleterre publient que MM. Ryekmans et Franck auraient été cités à comparaître devant un tribunal d'exception au Hâvre et qu'il serait question de leur intenter un procès en haute trahison. Deux ministres d'Etat, M. Gérard Cooremans, catholique, et M. Paul Hymans, le brilfant leader libéral, se seraient même rendus; la semaine dernière, à La Haye, tout exprès pour a entendre s les a inculpés ».

Au cours de cet interrogatoire, M. IIymans, très nerveux, aurait traité son vieil ami M. Franck de a traître à la patrie n!:

Des feuilles hollandaises narrent tout au long les détails de cette entrevue historique, qu'on eût dû tenir au moins secrète.

M. Franck s'est aisément justifié. Il a prouvé, à l'évidence, que les trois magistrats civils d'Anvers ont agi patriotiquement en arrêtant un bombardement désastreux et en rendant une cité que l'armée belge et les Alliés eux-mêmes avaient dû renoncer à défendre davantage. En outre, il a tenu à légitimer pleinement son attitude ultérieure. M. Franck a, en effet, conseillé aux fuyards et aux réfugiés de la province, qui, par centaines de mille, étaient à charge de la Hollande, de rentrer dans leurs foyers et de contribuer à faire revivre Ia vie normale et le mouvement des affaires. Or, on lui en faisait un nouveau grief.

Afb. 8. De Duitse diensten voerden hun propaganda ook via zogenaamd Belgische dagbladen, zoals Le Bruxellois.

Le Bruxellois, 1 december 1914, 1; KBR J.B. 28

kiljons" grepen de oorlog aan om de Vlaamsgezinden klein te krijgen. "Zij hoopten door de Vlamingen te beschuldigen deze te beletten erop te wijzen hoe het 'edelmoedig Frankrijk' ons is komen helpen."

Men vindt dezelfde tekstuele varianten - "verdwaalden" i.p.v. "landverraders"; pan-Germanistische Vlamingen i.p.v. pan-Germanistische flaminganten... - ook terug in de Kölnische Zeitung. Dat blad had eveneens beweerd dat de Franstalige pers in België aan Frankrijk verkocht was. Dat "de Vlamingen [wisten] met welk geld dit droevig werk betaald wordt" uit de Gazet van Brussel was dus ook aan de Kölnische ontleend. Overigens besloot het hoofdstedelijk orgaan zelf met te melden dat de Kölnische Zeitung het artikel van Henderickx uit Antwerpsche Tijdingen letterlijk vertaald had (sic) om daarna opmerkingen uit het Duitse blad over de herinnering aan "wat wals is, vals is", het onderzoek naar de vijanden van de Vlamingen, de anti-Duitse politiek van de Belgische regering enzovoort te citeren. Was de opsteller van Die Flamen und die deutsche Besetzung uit de Kölnische Zeitung enerzijds en 
Zijn de Vlamingen goede Belgen? uit de Gazet van Brussel niet dezelfde persoon? Misschien ging het om dr. Wien. Uit een Duits rapport blijkt dat deze correspondent van de Kölnische Zeitung ook voor het gouvernement-generaal werkte. ${ }^{84}$ Men merkt alleszins dat er een methode toegepast werd, gelijkaardig met diegene die de Vossische Zeitung en Le Bruxellois over hetzelfde onderwerp hanteerden. Berichten werden door correspondenten in bezet België naar de Duitse pers opgestuurd en daarna door de collaboratiepers in het bezette land overgenomen.

\section{De propagandamolen komt op toerental}

Het hele verhaal over de aanklacht tegen Franck en de zijnen uit de Duitse en de collaboratiepers had aanvankelijk een beperkte impact op de Belgische pers. Verschillende dagbladen in het bezette land maakten wel gewag van het bericht uit het Duitse blad, zoals op 3 december 1914 Le Bien Public uit Gent. ${ }^{85}$ Vooruit meldde dat het bekend was dat Franck de vluchtelingen hielp terugkeren en het leven in de stad hersteld had, maar niet dat men hem daar "links en rechts ook een grote grief van gemaakt heeft, zodat er later nogal wat woorden de nek zullen gebroken worden over deze ingewikkelde kwestie". ${ }^{86}$ L'Echo Belge uit Amsterdam had wel al op 30 november als enige dagblad het integrale bericht uit de Vossische Zeitung overgenomen. Het reageerde vol ongeloof op wat het Duitse dagblad schreef en beweerde dat onder de censuur in België Duitse dagbladen en met name de Vossische Zeitung in groten getale verspreid werden waardoor het manoeuvre van de bezetter om de Belgische regering te discrediteren duidelijk werd. ${ }^{87}$ Op 9 december 1914 publiceerde de Düsseldorfer General-Anzeiger een nieuw bericht vanwege zijn bijzondere medewerker te Brussel. Dat luidde als volgt:

De beide Vlaamse leiders, senator Ryckmans en volksvertegenwoordiger Franck $[. .$.$] moeten [. .$.$] wegens hoogverraad voor een krijgsraad verschij-$ nen, die in Le Havre samenkomt. Ze worden ervan beschuldigd door de Belgische regering niet toegestane akkoorden tussen het Antwerpse stadsbestuur en de Duitse vijand betreffende de overgave van de stad Antwerpen en een niet door de Belgische regering gemachtigde overeenkomst tussen dat stadsbestuur en de Duitsers onderhandeld te hebben. [B.Y.]

De Anzeiger verhaalde over hoe de beklaagden in Den Haag door twee Belgische staatslieden (Hymans en Cooreman), die in de hoedanigheid 
van onderzoeksrechter optraden, ondervraagd werden. Het blad meldde laconiek dat de Belgische regering blijkbaar "op zoek naar werk" was. Net als in Le Bruxellois ging de impuls voor de actie dus uit van de Belgische regering. De inhoud van wat de Anzeiger schreef, was ontleend aan de Deutsche Tageszeitung. ${ }^{88}$ Die hernam blijkbaar de kern van het bericht uit de Vossische Zeitung. Wohlmann, een te Brussel gevestigd Duits professor, was als correspondent van de Tageszeitung en de conservatieve Kreuzzeitung aan het gouvernement-generaal verbonden. ${ }^{89}$ Ook dat laatste blad had het artikel in licht gewijzigde vorm gepubliceerd. Het heette daarin dat er in Le Havre een proces wegens hoogverraad tegen Ryckmans en Franck opgestart was, omdat beiden de overgave van Antwerpen zonder de toestemming van de regering onderhandeld hadden. "De beide onderhandelaars van het Antwerpse stadsbestuur", aldus de Neue Freie Presse die het artikel overnam, "zijn, zoals bekend, met de onderhandelingen begonnen, nadat de stad door het Belgische en het Engelse leger in de steek gelaten was". ${ }^{90}$ [B.Y.]

In België zelf deed het Antwerpse blad L'Avenir zijn duit in het zakje van de propagandacampagne. Dit Franstalige persorgaan verscheen voor het eerst op 16 december 1914. Volgens La Métropole ging het om een blad dat men te Antwerpen zuiver Duits noemde, enkel de ideeën van de invaller weergaf en gedrukt werd onder leiding van een rabiaat-flamingantische wisselagent. ${ }^{91}$ Was het inderdaad "un journal germanophile de langue française", zoals $L e$ Vingtieme Siècle beweerde??2 Een revelerend bericht daaromtrent verscheen op 13 december 1914 in de liberale Nieuwe Gazet uit Antwerpen. Daaruit leren we dat er binnenkort te Antwerpen een nieuw Franstalig dagblad zou verschijnen (L'Avenir dus) en dat de bestuurder ervan, "dezelfde [was] als die van 'Le Bruxellois". ${ }^{33}$ Anders gezegd, de beheerder van L'Avenir was dezelfde als die van een dagblad waarvan we weten dat het van Duitse signatuur was. $\mathrm{Al}$ in zijn eerste nummer, doorbrak het de Godsvrede.

L'Avenir se mettra [...] au premier rang dans la défense des revendications linguistiques des provinces flamandes. Si notre journal ne se publie pas dans le premier idiome national du pays, c'est que précisément nous avons pris à tâche de convaincre la partie wallonne de la Belgique que le moment est venu de donner satisfaction [dans son entièreté] aux Flamands dans les griefs nombreux que depuis 84 ans ils dénoncent... ${ }^{94}$

Deze programmaverklaring vertoont opvallende gelijkenissen met hoe Duits-activistische bladen zich voorstelden. Zo publiceerde de Gazet van 
Brussel tussen 18 en 25 december 1914 op haar eerste bladzijde een Verklaring. De ogenschijnlijk Vlaamsgezinde intenties werden er expliciet in kenbaar gemaakt:

Wie zal er ons een verwijt [...] maken dat wij eerst en vooral de belangen van ons Vlaamse volk voor ogen hebben en sommige zaken door een Vlaamse bril beschouwen? [...] Onze leus is en blijft: voor God, taal en volk! $!^{95}$

In zijn eerste nummer zou later ook de radicaal-activistische Vlaamsche Post uit Gent verklaren erover te willen waken dat geen duimbreed van het verworven Vlaamse recht verloren zou gaan en dat ze het Vlaams gevoel wakker wou houden. Kortom: "Vlaanderen boven al en in Vlaanderen Vlaams." De eerste editie van L'Avenir bevatte voorts een uittreksel uit het "reisverslag" naar Antwerpen dat de Gazet van Brussel op 11 december 1914 gepubliceerd had. Daarin werd de klemtoon op het propagandamotief uit het hoofdstedelijke persorgaan gelegd:

Tout ce que nous y [in Antwerpen, $B Y$ ] entendions prouvait l'appréciation saine du peuple: tout le monde désire être préservé de plus amples terreurs de la guerre, car la différence entre les gens éprouvés par la guerre et ceux qui ne la connaissent que par oü dire consiste en ce que les premiers [...] ne demandent que la paix, tandis que les autres ne discourent [...] de guerre, dévastation, anéantissement du commerce et de l'industrie.

L'Avenir zong in zijn hoofdstedelijke kroniek opzichtig de lof van de Gazet van Brussel, die "in een stijl en taalgebruik de Academie waardig" [B.Y.] opgesteld heette te zijn. ${ }^{97}$ Het Duitsgezinde blad bedankte op zijn beurt de Franstalige confrater voor die "vleiende beoordeling". ${ }^{8} \mathrm{Net}$ als in de Gazet van Brussel en Le Bruxellois werd elk artikel in L'Avenir ondertekend met pseudoniemen. ${ }^{99}$ De drukker van het blad, De Vos-Van Kleef, die tijdens de oorlog in Leiden verbleef, weigerde overigens om ook maar de minste naam van een medewerker kenbaar te maken. ${ }^{100}$ Ook de inhoud van het Franstalige blad stemt overeen met wat we in eerder vernoemde Duitse en collaboratiebladen aantreffen. Het Verenigd Koninkrijk werd zijn kolonialisme verweten. Inzonderheid haalde het uit naar de Vlaamsgezinden die in Zuid-Afrika, waar een anti-Britse rebellie woedde, propaganda gingen voeren. Allerlei verwijten werden Frankrijk naar het hoofd geslingerd: dat het zich "geprostitueerd" had aan het autocratische Rusland bijvoorbeeld. 
(Niet toevallig kwamen ook revolutionaire stromingen daar uitgebreid aan bod. Het lag immers in lijn met de Duitse oorlogsdoeleinden om die te stimuleren.) Zo ook dat oorlogen Frankrijk in het verleden financiële rampspoed hadden gebracht en dat het Duitsland met zijn bondgenoten "omsingelde". Pacifistische artikels wisselden stukken af waarbij de orde van het Duitse leger tegenover de zwakheid van het Belgische geplaatst werd. Belgisch bloed werd, zo heette het, voor vreemde landen vergoten. Ook werd propaganda gevoerd voor een Duits-Europese blokvorming. Het taalgebruik van rapporten van de in februari 1915 opgerichte Politische Abteilung herkent men eveneens in het blad, bijvoorbeeld over de vooroorlogse francofiele "mentalité franco-belge". ${ }^{101}$ Pers, socialisten en Kerk werden gehekeld voor hun aandeel in de oorlog. Nee, de oorlogskansen keerden niet in het voordeel van de "militaristische" Triple Entente, maar wel in dat van Duitsland.

Bovendien ging L'Avenir vanaf zijn allereerste editie een bitse polemiek aan over de vermeende berechting van Ryckmans en Franck. ${ }^{102}$ Het blad schreef hoe de Düsseldorfer General-Anzeiger gemeld had dat Ryckmans en Franck wegens hoogverraad voor een Belgisch militair gerechtshof in Den Haag zouden moeten verschijnen. Men verweet hen dat ze overgegaan waren tot de overgave van de stad alsook tot overeenkomsten met de Duitsers voor het stadspersoneel zonder eerst de raad van de Belgische regering ingewonnen te hebben. De Anzeiger had echter gemeld dat beiden in Le Havre voor een oorlogsrechtbank zouden moeten verschijnen. L'Avenir schreef ook volgende foutieve bewering aan de Anzeiger toe: "Nos deux concitoyens seront entendus par deux délégués belges envoyés du Havre." Nochtans had de Anzeiger bericht dat dergelijk verhoor al in Den Haag plaatsgevonden had. L'Avenir beweerde dat de Anzeiger zich van tijdstip vergiste. Het feit waarvan sprake, speelde zich volgens dat Antwerps blad drie weken in het verleden af (eind november 1914 dus) toen beiden zich in Den Haag over de overgave van Antwerpen moesten verantwoorden. In het Franstalig blad viel het proces in Le Havre waarvan eerder in de Duitse pers sprake, blijkbaar weg. Wat overbleef, was het verhoor in Den Haag. Daar hadden de "helden", aldus L'Avenir dat zich blijkbaar op de eerdere berichtgeving uit de Vossische Zeitung en Le Bruxellois beriep, moeiteloos elke schuld van zich kunnen afwimpelen. Indien men de stad niet volledig wou verwoesten na de terugtocht van hen die haar tot het uiterste wilden verdedigen, kon men uiteraard niet anders handelen. L'Avenir zaaide dus nog méér verwarring door een eerdere propagandafabel met nieuwe onwaarheden te "corrigeren". Had het de lont opnieuw aan het kruitvat 
gestoken omdat het gouvernementgeneraal meende dat het eerdere stuk uit Le Bruxellois onvoldoende weerklank gevonden had? Hoe dan ook kon niemand vermoeden dat achter de subtiele verschillen in berichtgeving tussen dagbladberichten de Duitse diensten de échte aanstokers waren. Het Antwerpse gemeentebestuur reageerde via Antwerpsche Tijdingen. Dat blad stelde (gecursiveerd) dat de aanwezigheid in Den Haag van Franck en Ryckmans en hun onderhoud met hoge overheidspersonen heel wat anders tot doel had dan hetgeen het Duitse en het Franstalige blad beweerden. Het schreef hoe de Anzeiger en L'Avenir gewag maakten van iets wat nooit gebeurd was. "Het tweede [L'Avenir, BY] versterkt de onwaarheid [over het verhoor van Franck en Ryckmans] door [aan de berichtgeving van het Duitse blad] een zogezegde verbetering [...] toe te voegen", zo merkte het scherpzinnig op. Toch blijft de vraag waarom het persorgaan de correcte datum (begin november in plaats van eind november) en vooral het echte doel van het onderhoud - de vluchtelingenkwestie - er niet aan toevoegde.
MM. Franck et Ryckmans

Un confrère anversois taxe d'inexacte la rectification que nous avons donnée d'un article du "Düsseldorfer General Anzeiger " disant que MM. Franck et Ryckmans allaient être traduits devant une Cour militaire a La Haye pour s'expliquer sur la reddition d'Anvers.

Nous avons rectifié cette information en disant que l'entrevue en question avait déjà eu lieu et que nos deux honorables concitoyens en étaient revenus la tête haute.

L,e dit confrère qui cite le journal allemand sans même mentionner notre titre a nous (pourquoi?) affirme que l'événement n'a pas eu lieu, et que nous confirmons la contre-vérité en la rectifiant.

N'en đéplaise à notre confrère, nous devons maintenir l'exactitude de nos renseignements. Les faits se sont bien passés comme nous les avons rapportés. Eit si notre confrère insistait nous serions amenés à y ajouter quelque précision qui jetterait un jour étrange sur la façon dont certaines personnalités haut placées et actuellement a l'étranger envisagent l'intérêt et le bien-être de notre ville d'Anvers.

Pour le reste, nous avons rendu hommage au dévouement des trois héros anversois De Vos, Ryckmans et Franck qui ont sauvé la ville du désastre final et ce que notre confrère dit des attaques dont ils sont l'objet ne saurait done nous être imputable.

Afb. 9. Het behoorde tot de opdracht van het Duitse propagandablad L'Avenir uit Antwerpen om de propaganda rond de Scheldestad levendig te houden. L'Avenir, 18 december 1914, 1; KU Leuven Libraries Special Collections BRES: Tabularium - Magazijn VH055/018a

Dit ondanks het feit dat het stadsbestuur blijkbaar wel kon melden dat beiden in Nederland contact zochten met Belgische ministers, zonder te riskeren door de bezetter gestraft te worden. Waren er contacten geweest tussen Franck en de Belgische regering die misschien dacht dat men nu beter zweeg over de gebeurtenissen? De verdediging van L'Avenir (18 december 1914) klonk ongeloofwaardig. Het Franstalige blad ging niet in op de kri- 
tiek van Antwerpsche Tijdingen, maar herhaalde zijn eerdere bericht over het gebeuren. En L'Avenir voegde er enigmatisch aan toe:

Et si notre confrère insistait nous serions amenés à y ajouter quelque précision qui jetterait un jour étrange sur la façon dont certaines personnalités haut placées et actuellement à l'étranger envisageaient l'intérêt et le bien-être de notre ville d'Anvers. [B.Y.]

Pogingen van het Antwerpse stadsbestuur om het Franstalige blad op andere gedachten te brengen, draaiden op niets uit. Zo had het stadsbestuur een ongetekend verweerschrift naar LAvenir gestuurd waarin stond dat de regering geen enkel gerechtelijk onderzoek over de val van Antwerpen geopend had. En dat het onwaar was dat ze Cooreman en Hymans naar Nederland gestuurd had om hierover een onderzoek in te stellen. Ryckmans en Franck moesten zich dus niet verantwoorden voor een tenlastelegging. L'Avenir publiceerde dit en kaatste de bal terug door zich af te vragen wat nu eigenlijk de bedoeling was van die logenstraffingen en wie de opdracht daartoe gegeven had: "en attendant disons que les récriminations et les accusations, dont l'écho nous est parvenu et de Hollande et de Londres, rendent vraisemblable l'événement que nous avons relaté...". Dit is een duidelijke nagalm van wat er begin december 1914 in Le Bruxellois stond.

Hoezeer de Duitse campagne ondertussen verwarring in de geesten gesticht had, werd duidelijk toen Antwerpsche Tijdingen het Journal des Réfugiés als de ware schuldige voor al die laster met de vinger wees. Het blad herinnerde eraan hoe het destijds te Roosendaal verschijnende orgaan Franck en Ryckmans als verraders afgeschilderd had. Het beweerde dat de "Réfugiés" al enkele dagen in het buitenland zaten, waar ze van dit "geschiedkundig feit" (de ware toedracht betreffende de val van Antwerpen) niets wisten, toen Antwerpsche Tijdingen de puntjes op de i zette. Na het verbod op de uitgave van het "lasterblad" in Roosendaal, zo ging het voort, had men van dat lasterende "kliekje vluchtelingen" niets meer gehoord - tot nu. Antwerpsche Tijdingen kwam tot die conclusie omdat de verdachtmaking uit de Anzeiger "uit Brussel" kwam (inderdaad meldde de Anzeiger dat zijn bericht vandaar kwam). ${ }^{103}$ Het blad van het stadsbestuur leidde daaruit af dat het Journal des Réfugiés nu zijn antivaderlands werk voortzette door het plaatsen van lasterend proza in een Duits blad opdat dit in België zou overgenomen worden. Er werd dus een onterecht maar geen onbegrijpelijk amalgaam gemaakt tussen het (eerdere geschrijf van het) Journal des Réfugiés en (dat van) de General-Anzeiger. 
De Tageszeitung en zijn doorgeefluik de Anzeiger hadden dus dezelfde techniek toegepast tegenover L'Avenir als de Vossische Zeitung eerder tegenover Le Bruxellois. Het Duitse bericht was immers in beide gevallen in de pro-Duitse pers in België overgenomen uit een Duits blad met een correspondent die aan het gouvernement-generaal verbonden was en van daaruit berichten stuurde. De berichtgeving kon op nog een andere manier een ruimere weerklank vinden. Verscheidene Nederlandse dagbladen makkten immers vanaf medio december gewag van de twist tussen Antwerpsche Tijdingen en L'Avenir, waarbij het artikel uit de Anzeiger geciteerd werd. Ze namen daarvoor verbatim over wat er stond in de pro-Duitse Nieuwe Rotterdamsche Courant, waarvan de bezetter de verspreiding in België toeliet. ${ }^{104}$ Toch besteedde de Belgische pers - met Antwerpsche Tijdingen dus als uitzondering - (alweer) nauwelijks aandacht aan het gebeuren. ${ }^{105}$ Le Vingtieme Siècle, voor wie het "germanofiele" L'Avenir schuldig was aan het opnieuw beginnen van de polemiek omtrent de val van Antwerpen, deed dat wel. Het wilde naar eigen zeggen niet tussenkomen in een twist tussen de drie "germanofiele" bladen [Antwerpsche Tijdingen, de Anzeiger en L'Avenir, BY], maar verklaarde dat Cooreman en Hymans in Den Haag Franck en Ryckmans ontmoet hadden. Het was heel goed mogelijk dat ze zich onder andere over de situatie te Antwerpen onderhouden hadden. Wat ze gezegd hadden, zou het publiek ongetwijfeld later te weten komen, "quand on s'efforcera de dissiper les obscurités qui entourent encore l'histoire de la reddition d'Anvers". ${ }^{106}$

De regering weigerde blijkbaar openlijk haar vertrouwen in Franck uit te spreken. ${ }^{107}$ Opmerkelijk, want uiterlijk eind november 1914 wist ze dat er een Flamenpolitik aan de gang was. ${ }^{108}$ Bovendien had ze de pers toen al met aandrang verzocht om de polemieken over Antwerpen te staken. En een maand later verscheen in Le Vingtième Siècle een voorpagina-artikel onder de titel Les Allemands veulent tromper les Flamands. In dat stuk was de briefwisseling uit september 1914 vervat die de pan-Germanist Harald Graevell naar gouverneur-generaal Colmar von der Goltz opgestuurd had. De houding van de Belgische regering gaf uiteraard speelruimte aan de bezetter. ${ }^{109}$

\section{Antwerpen moet kapot!}

Van die speelruimte werd duchtig gebruikgemaakt. Zo schreef de Gazet van Brussel op 5 december 1914 hoe "de gedurige verwoesting van ons land" wel het ergste was voor "ons, Belgen”. Daarbij hadden de Britten zich ook niet onbetuigd gelaten: hun scheepsgeschut had volgens het dagblad immers 
Middelkerke, Westende, Oostende, Zeebrugge en Heist verwoest. "Wie had zoiets verwacht van de Engelse 'vrienden'? Maar gaven ze Antwerpen ook niet prijs aan de beschieting door de Duitsers?" Het beeld van vernielzuchtige Britten, dat overeenstemt met wat de Duits-Oostenrijkse propaganda eerder meldde, herhaalde het blad nog diezelfde dag in een ander bericht. Afgaande op The Times, meldde het dat Zeebrugge vernietigd was. Bernard Shaw, aldus de Gazet van Brussel, schreef "met bitterheid dat de Engelse granaten in België juist hetzelfde uitwerksel hadden als de Duitse. Toch één Engelsman [sic] die België zou willen sparen!'. Lees: de Britten wilden België blijkbaar verwoesten. Zulke onzin zette het blad dan twee dagen later kracht bij door een parallel te trekken tussen Britse bombardementen op Kortrijk en Gent, waarbij verscheidene inwoners gedood werden (en geen enkele Duitser, zo cursiveerde de Gazet) en Duitse op Antwerpen. "Wanneer vroeger de Duitse vliegers boven Antwerpen kwamen dat dan nog eens een versterkte stad is, spraken de Antwerpse bladen steeds van 'sluipmoordenaars'. Wij hopen dat zij nu ook het gepaste woord zullen vinden." En in een "reisverslag", dat kort na de overgave van de stad zou geredigeerd zijn en op 9 december in het hoofdstedelijke blad verscheen, werd betoogd dat de Duitse troepen in Mechelen niets verwoest hadden en de eigendom eerbiedigden. De "begeleiders" van de auteurs wilden België zoveel mogelijk gespaard zien. Ze legden de schuld voor al het gebeurde bij het Verenigd Koninkrijk, "dat België tot de strijd gedwongen had". ${ }^{110} \mathrm{Op}$ 12 december rapporteerde de Gazet van Brussel over een gerucht dat verspreid werd aangaande de verwoesting van het overblijvende deel van (bezet) België, mochten de Duitsers zich uit Frankrijk terugtrekken. Dat werd dan toegeschreven aan "zonderlinge patriotten", die in Brussel door mondelinge en schriftelijke leugens die met vreemd geld betaald werden, de bevolking ophitsten. Zij zouden de verantwoordelijkheid dragen voor de ondergang van Brussel en werkten "onafgebroken voort om over Brussel ergere rampen te trekken dan iemand zich inbeeldt" ${ }^{111}$ En een week nadien beweerde het blad een brief ontvangen te hebben, waarin stond dat volgens de "franskiljons" de "goedheid" van de "bondgenoten" (sic) van België bleek uit het feit dat ze uit bezorgdheid om de Belgen de Duitsers niet uit Frankrijk wilden terugdrijven. Want moesten de Duitsers achteruit, zouden ze zich wederom op Belgisch grondgebied begeven: “...en dan wordt ons land helemaal verwoest." Maar volgens een bericht toegeschreven aan The Times - die kon deze zogenaamde schrijver blijkbaar ongestoord ontvangen - was het doel van de geallieerden net om Duitsland binnen te dringen. Het Britse blad wou de bezetter dus door België verjagen, volgens deze briefschrijver. "Of weet de Times soms een andere weg om de Duitsers terug naar hun land te drijven?" 12 
In De Rol van Engeland (Gazet van Brussel, 14 december 1914) werd een artikel uit het Britse Daily News van 1 augustus 1914 dat voor een onvoorwaardelijke neutraliteit pleitte, onder de loep genomen. ${ }^{113}$ Die berichtgeving heette van een "toonaangevend regeringsorgaan" (quod non) te komen. In Engeland, aldus de commentaar van de Gazet, had het gezond verstand niet gezegevierd, met als gevolg een Europese kettingreactie. Het was overigens een leugen dat het Verenigd Koninkrijk voor België vocht. Waarom had het land dan wel het zwaard getrokken? Het antwoord illustreerde het blad met de commentaar van de Nieuwe Rotterdamsche Courant van 15 augustus 1914 op een artikel uit de linkse Manchester Guardian. Daarin stond dat met het voorlopige einde van de Duitse uitvoerhandel, Britse zakenlieden gaandeweg inzagen dat dit een markt voor de Britse nijverheid kon openen. $\mathrm{Nu}$ kon er met de Verenigde Staten gedongen worden naar de groothandel van Duitsland met het Verre Oosten of Zuid-Amerika. De Nieuwe Rotterdamsche Courant had het artikel hernomen en eraan toegevoegd: "de Engelsen treffen het ook [...] dat de Belgen ook geduchte concurrenten waren van de Engelsen op de wereldmarkt, nu aan geen zaken doen kunnen denken..."114

De Gazet van Brussel leidde daaruit af dat het Verenigd Koninkrijk Duitsland "kapot" wou hebben, omdat het een al te gevaarlijke handelsconcurrent werd. Daarmee was het antwoord gegeven op de vraag waarom Albion oorlog voerde. Dat gebeurde vanwege zijn "business". Om die te bevorderen, deed het al eeuwenlang conflicten ontstaan, zoals het "vermoorden van onze taalbroeders in Zuid-Afrika". Het was "grotendeels verantwoordelijk voor de ongelukken die ons arme land overstelpen. En ondanks dit alles zijn er nog talrijke Vlamingen die Engeland in hun hart dragen, dat staat immers op het programma van het schijnpatriottisme tegenwoordig in de mode". ${ }^{115} \mathrm{Het}$ woord "schijnpatriottisme" klinkt als een echo uit de Gazet van Brussel van 3 december 1914, waar het eerst over Antwerpen gesproken werd. Van de beweringen over die Britse eigenbaat vindt men overigens een nagalm in de Gazette des Ardennes van 1 februari 1915. Dat propagandaorgaan beweerde immers dat in de industriële centra van het Verenigd Koninkrijk bijna niemand zich had opgegeven als oorlogsvrijwilliger voor het conflict in Frankrijk: "La raison est cependant bien simple, c'est que l'Angleterre pense, en première ligne, au 'business'..." Dat blad voegde daar, volledig in lijn met de propaganda in de Gazet van Brussel, aan toe dat de Britten met name hun industriële producten duurder wilden verkopen aan hun bondgenoten waarvan ze voor lange tijd de buitenlandse handel vernietigd hadden. ${ }^{116}$

Dat de Gazet van Brussel in december 1914 vier maanden oude artikels ging oprakelen en becommentariëren, was geen toeval. De Duitse diensten 
vonden er blijkbaar allusies in over de verwoesting van handelsconcurrenten die het Verenigd Koninkrijk niet zinden. Later werd dit narratief in de Duitse propaganda rond de val van Antwerpen verwerkt. Parallel hiermee werd het door toedoen van de Duitse (en Oostenrijkse) propaganda doorkruist met artikels over hoe Antwerpen aan zijn lot overgelaten was.

Nog andere bladen tapten uit hetzelfde vaatje. Zo beweerde de völkische Duitse kunstverzamelaar en mecenas Karl Ernst Osthaus in een open brief gericht aan de Antwerpse kunstschilder Henry Van de Velde, samen met de Duitsers mee te hebben gevoeld voor het lijden van de beproeving die Antwerpen beleefd had toen de vesting viel. "En de verontwaardiging over de eigenzuchtige handelswijze der Engelse troepen die, om hun vlucht te verzekeren, de beschieting der stad afdwongen, is in Duitsland algemeen." En nog in die brief heette het:

gij zijt Vlaming en onze stamgenoot. [...] De cultuur berust [...] op het Bloed en niet op de Staatsinrichting; het is derhalve onzinnig het Duitse karakter van uw werk te loochenen. Een Belgische cultuur zal eeuwig ondenkbaar blijven; want er is geen Belgisch volk. [...] De Belgische staat is een kunstmatig product der Europese diplomatie, hij kan weggevaagd worden, gelijk hij plots ontstond.

Dit schrijven verscheen op 12 december 1914 in de Frankfurter Zeitung, een blad met een permanente correspondent, Fritz Schotthöfer, die voor het gouvernement-generaal werkte. Het is veelzeggend dat de Vlaamsche Gazet op 22 december 1914 door een integrale overname van dit schrijven deze anti-Belgische retoriek wereldkundig maakte. Zoals we straks zullen zien, was dat dagblad toen al zeer waarschijnlijk in Duitse handen. Ondertussen bleven er provocerende berichten gepubliceerd worden. Want de dag na de publicatie in het Antwerpse dagblad, meldde de Neue Freie Presse dat de Britten Antwerpen aan een zware beschieting overgeleverd hadden om Calais te beschermen. ${ }^{17}$

Bovendien schreef de Gazette des Ardennes omtrent hetzelfde tijdstip dat een Brits-Belgisch geschil dagelijks verergerde. Er werden volgens het blad tal van brieven naar Belgische kranten gestuurd, waarin lezers hun ongenoegen uitten over het feit dat België zo dom geweest was om het grootste deel van zijn leger aan de Britse belangen op te offeren, terwijl de Britten het kleine land bij Antwerpen toch in de steek gelaten hadden. ${ }^{118}$ Het bleef daar niet bij, want op 30 december gispte de Brusselse medewerker van de Duits-activistische Vlaamsche Gazet de verstokte "Vlaamshaters" "die zelfs in deze treurige ogenblikken hun kwaadwilligheid [bleven] ten toon spreiden", 
door het gerucht te verspreiden dat Franck en Ryckmans van hoogverraad beschuldigd werden. ${ }^{119}$ En 's anderendaags publiceerde de Gazet van Brussel onder lovende woorden het antwoord van Antwerpsche Tijdingen op wat de Anzeiger en L'Avenir geschreven hadden over de ontmoeting van Franck en Ryckmans met de twee Belgische ministers van Staat. Het Duits-activistische blad merkte op dat de Brusselse bladen tot nu toe zwegen over die logenstraffing. Het lijkt duidelijk dat de Gazet van Brussel na de eerdere geruchten, verspreid door de Duitse en door Duitsland gesubsidieerde pers over het vermeende verraad van de Antwerpse dignitarissen, de geruchtenmolen daaromtrent opnieuw wou aanzwengelen. Temeer daar de rest van de Belgische pers inderdaad de Godsvrede onderhield. De Gazet benadrukte wat Antwerpsche Tijdingen geschreven had betreffende een 'zekere 'kliek' (rondom het Journal des Réfugiés) die haar proper werk voortzet". ${ }^{120}$

In een volgend en spectaculair hoofdartikel, Antwerpen moet kapot! - een voorlopig hoogtepunt in de Duitse propaganda - dat de Gazet van Brussel op 5 januari 1915 publiceerde, gaf het dagblad een eigen invulling aan uit wie die "kliek" bestond. Volgens het blad bestond er een groep, een "partij", anti-Vlaamse drijvers "die zelfs in deze trieste omstandigheden hun haat voor al wat Vlaams is niet konden onderdrukken". Dat Antwerpen "kapot" moest, kwam volgens het blad omdat die stad vertegenwoordigster was van alle Vlaamse gewesten. Dit voornemen kaderde in een "lasterveldtocht" tegen het Vlaamse volk die al tijdens de eerste oorlogsdagen begonnen was. Het blad beweerde dat er onder de eigen landgenoten vijanden waren. Zoveel bleek uit een mededeling die "een bevriend en betrouwbaar persoon" onlangs had gedaan. Die had, zo heette het, van "een Vlaming van aanzien" vernomen dat een Waalse soldaat - in het openbaar, en toevallig in het bijzijn van die Vlaming - verklaarde dat hij gelukkig was over wat te Leuven en te Dendermonde was geschied (de verwoesting van die steden dus) en dat hij hoopte dat Antwerpen, Gent enzovoort hetzelfde lot zouden ondergaan.

Gedurende de beschieting van Antwerpen konden sommige dweepzieke heerschappen te Brussel hun vreugde nauwelijks verbergen. Ook hoopten zij stellig dat men de stad niet zou overgeven en dat ze bijgevolg tot gruis zou gemaakt worden. Gelukkig viel het anders uit. Ook kende de woede van velen, die van de krijg persoonlijk niets onaangenaams hadden te verduren paal noch perk. Onmiddellijk werd de wens uitgesproken dat de legers der verbondenen, om Antwerpen terug te nemen, niets zouden ontzien en dat zij de Scheldestad met de grond zouden gelijk maken. Nu, daar Antwerpen een eersteranghaven is, en derhalve een geduchte mededinger 
van buitenlandse [lees: Britse] zeehavens, zou die wens weleens kunnen verhoord worden.

Het artikel beweerde ook dat in de allereerste dagen van de oorlog een antiVlaamse lasterveldtocht was begonnen. Onder de "geruchten" die men toen rondstrooide, hoorde men dat de Vlamingen zich jegens de soldaten onmenselijk gedroegen, bijvoorbeeld door hen slaapplaatsen te weigeren. ${ }^{121}$ In een artikel uit de Gazet van Brussel van 21 januari 1915 werd dezelfde klok geluid, zij het dat nu de "franskiljons" vertelden hoe Vlaamse landbouwers zich schandelijk opstelden tegenover Belgische soldaten, maar zeer gedienstig waren voor de Duitsers. Daaraan werd dan de "getuigenis" van een Brabantse dorpsbewoner gekoppeld. De puinhopen overschouwend, verklaarde die er bijna spijt van te hebben dat Brussel gespaard was gebleven: "wij mogen over de oorlog meespreken, het is niet zoals uw Brusselaars, die enkel het kanon van verre gehoord hebben en die ons, op de koop toe, komen beschimpen." 122

Uit de beeldvorming van de Gazet van 5 januari 1915 viel af te leiden dat de lijdensweg van de havenstad nog niet voorbij was. De bevrijding van de geallieerden zou niet alleen een uitroeiing van het Nederlands met zich meebrengen, maar ook de verwoesting van het "Mekka van de Vlaamse beweging", omdat de metropool een concurrent was van het perfide Albion. Dat was een thematische variatie op wat de Gazet van Brussel op 14 december 1914 beweerd had, namelijk dat de Britten Duitsland wilden vernietigen omdat het land een geduchte handelsconcurrent was. In dat licht wordt het duidelijk wat L'Avenir op 18 december bedoeld had toen het sprak over de "verduidelijking" die een vreemd licht zou werpen op hoe sommige hooggeplaatste persoonlijkheden die in het buitenland verbleven tegen het welzijn van Antwerpen aankeken. Ze wensten blijkbaar de verwoesting van de havenstad. De Duitse propaganda inspireerde zich in de constructie van die bewering blijkbaar (ook) op buitenlandse berichten zoals het geciteerde voorbeeld uit de Nieuwe Rotterdamsche Courant uit augustus 1914 aantoont. Een ander voorbeeld hiervan had ook met Nederland te maken. Want in het Journal des Réfugiés (1-2 november 1914) - dat door de Duitse diensten gelezen werd verdedigde redacteur Wappers de Nederlandse gastvrijheid tegen de aanvallen van de Italiaanse journalist Gino Calza Bedolo, de Londense correspondent van Il Giornale d'Italia. Die had een week eerder het vermeende wangedrag van de Nederlanders jegens de Belgische vluchtelingen gegispt en hen ervan beschuldigd om, gedreven door een laag gevoel van naijver op de handel, met vreugde het ongelukkige lot van Antwerpen en haar bewoners aan te zien. Het leverde hem een officieel protest op van de Nederlandse legatie in Italië. ${ }^{123}$ 


\section{Antuerpen moet kapot !}

Een nuedewerker sedrijif ons :

Itovenstaande vitroep as die leus van ene gansche partij geworden. En men ledoelt met Antwropen niet alleen die trotsche sinjorimstad op zichzelf, maar neel zict in foar de vertegenwoordigster ran de Vlatamsehe gewesten altegater.

Dal de partij waarop bierboven gezinspeelal wordi niet isene der vier politieke purtijen onzer Statenkamers is, zal dke lozer roeds wel vermoed hobben. Neen, het geifl it groep trijwers, die zelfs in de huwige, droevige onstandigiseden, hem hast voor al wat Vlaamsch is nicl kunner tuderibuklien.

In ife allewerate dingen vall den oorlug is een lastervelultocht traen ons wolk hezonnen. Eerst heeft men alkelwege ite geructiten rondgestrooud, tat de Vamingen in slad en iorj onmensdolijk warion jegens te Pelisische soldaten, dat zij an onze landrerdedigers stros weigerden om op te slapen en water on zich te waserhen, dat zij tot vijftig centienen eisehten toor ren kon kowite of rent glas bier. enz.. enz. Pergelijke

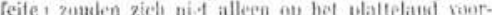

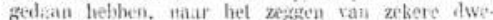

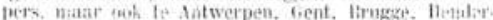
mond: Leusen, en was onk niet al. Voor de burzers bloven daarentegel de gawone prijzen bestaan.

hat wij hior $\mathrm{n}$ al verzonnes in kwasdwilligi ver-

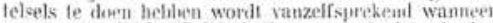
men nagatat dat het Belgizehe leger voor de drie vierden uit Vlamingen lestant. Daarbij is het schier niet denkhas dat talrijke bonten van zewapende soldaten zich

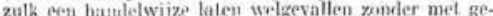
wollt hum rovolwardiging to uiten. Wij lebben trou-

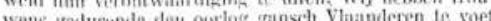

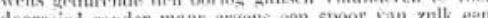
dontreist zomser me

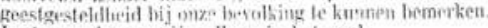
Laster en lengen ziin allewn in liet spel.

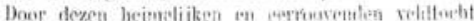

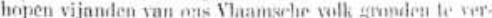
krijgen om ons klein te maken. Ons groeien en hlocien

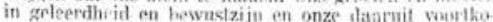
mende toeseming van invloed stann hun revis lang in den wes: zij willen onze nafuurlijke onlwikkeling or krachtonfsourving fnuiken en liefst mef de medehulp der gewapente machl. Daarlogen staat ons fogenworerdig sledits een enkel mudtel van tregenwere ter beschikkinks. en dat is aan al onze stamgenocten zon hard wi kummen toe te roenen : "Een nog in 't zeil houden! Ook hoeven dokunkenten vorzameld to worilen om den laster den kop in te druktien.

Dat men van zekere zijde dezen oorlog heeft willen gebruken onl de Vlamingen te kort te doen is aam velen onmuddellijk opgexallen bij bet lezen der FransehBeigiscle uicuwsibladen. Inmets, de strijdleuze van deze pers was is Los op de Germanen! stijuleuze yal op de Duitsethers! " Upzettelijk Iselitici onze Franside op de Duifsethers! "Opzetlelijk lebliben onze Fransche selirijvelatirs Vlamingen en buitsehers willen vereenzel-
vagen. baarlsij worea wij zoo goed als ontuachtig, want zegien wij dat wi nettegenstaande alles gok bermanet zijn, dan waren wij uit den booze. Lieten wij intpgendiel gevelen dat wij geen Gormanen zijn, dan verloochemelen wij onszelven, hetgeen exene lafheid ou ziclizal

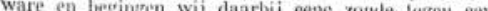

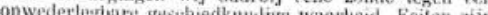
feiten, an de vlamurgut leblen bloed in hun ten van hun anderen. dau de bevolking van vele bewesdersan Dnitschland of Skandinavię. Ook is onze moederspratiak dene der allerzuiverste Germatansche talen. Dat alles neemt erhter niet weg, dal wij ten slotte evenmin buitschers zijn, als deze laatsten Vlamingen en dat wij, hoe deze oorlog ook eindige, met onverzethelijken wil zullen soortgaan met eigen taal en kultuur te ont. wikkelen en desnoods te verdedigen.

Afb. 10. Op 5 januari 1915 donderde het in de Gazet van Brussel: "ANTWERPEN MOET KAPOT!"

Gazet van Brussel, 5 januari 1915, 1; KBR J.B. 117 bat wij ondet onze eigen landigmonten vijanden heb-

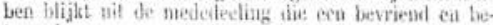
trouwbaar persoon ons kortalings heeft gedaan. Van een Vlaming vais aanzien heeft hij inderdaad vernomen dat een Balgische soldaat, die tevens Waal is en student, in bict openhasr, en toevallig in het bijzijn van voormelden Vlaming, verklaarde dat hij gelukkig was van wat te Leaven en te Dendermonde was geschied en dat hij wel hoopte dat Antwerpen, Gent, enz., hetzelfde lot zouden ondergaan. Na den oorlog kreeg Holland ook zijn deel, blijklaar alleen omdat het door een fier-

Gedurende de besehicting van Antwerpen konden sommige dweepziekte heersehappen te Irussel hun vreugde nauvelijks verbergen. Ook hoopten zij stellig dat men de stad niet zou overgeven en dat ze bijgevolg tot gruis zou gemaakt worden. Gelukkig viel het anders uit. Ook kende de woele van velen, die van den krijg persoonlijk niets onaangenaams hadden te verduren, paal noch perk. Onmiddellijk werd de wensch uifgesproken dat de Jegers der verbondenen. om Antwerpen terug te nemen, rists zouden ontzien en dat zij de Schelilestad met den grond zouden gelijk maken. Nu, daar ditwerpen eene eersteranghayen is, en iferhalve

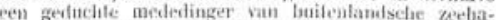

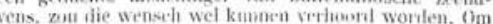
do sinjoren te Irosstem zou men aan hane slerie dan

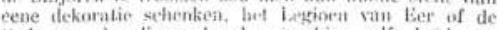

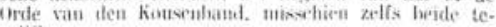
zelijk.

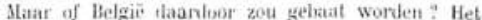
veclies rall ecue groole havemolad is smoter dan dat

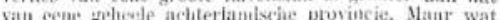
kan dal dian sormmige drijvers wed scholetn? Zij willen zalfs personalijk benadeelal worden, indien de VIamingen maar tog grooter shate ondergaan. Haat is blind.

Onzen wetrseit is dat de Vlamingen oogen en ooren wijd openzetten en dat zij nict aarzelen de lasteraars aan to pakken en opentijk gan te klagen. Ons blad zal daartoe met al zijne krachten medehelpen.

GOYERD, mansch volk bewoond wordt. 
Op 13 januari publiceerde de Gazet van Brussel een gefingeerde lezersbrief, onder meer als "reactie" op Antwerpen moet kapot!. Daarin werden de Brusselse "budgetvreters" in verschillende ministeries en gemeentebesturen - "steunpilaren" van de ligues wallonnes en associations wallonnes - gehekeld. Toen Antwerpen viel, had onze "lezer" sommigen onder hen verschillende malen "honte à Anvers" horen uitroepen. Deze woorden lijken door het artikel La Vie à Anvers (28 oktober 1914) uit La Métropole geïnspireerd te zijn. Daarin werd het verschijnen van Antwerpsche Tijdingen immers een "schande voor Antwerpen" genoemd. De "pan-Germanistische" Antwerpse flaminganten kregen erin te horen: "On verra bien plus tard!" Die laatste "waarschuwing" werd blijkbaar in de Duitse beeldvorming bewaarheid: Is het amen en uit met de Vlamingen? was immers, zoals gezien, een titel in de Gazet van 10 januari. Maar om terug te komen op de praatjes uit dat blad van drie dagen later: de "briefschrijver" verhaalde dat hij deze week bij vrienden een Waal ontmoette die wist te vertellen dat bij een Duitse terugtocht Oosten West-Vlaanderen verwoest zouden worden. Dat lot zouden de geallieerden ook Antwerpen te beurt doen vallen. Die rampen hadden, volgens de "Waal", vermeden kunnen worden, indien men Antwerpen niet had overgegeven: "Men had die stad dus tot gruis moeten laten schieten..." 124

Waarschijnlijk was het Antwerpse stadsbestuur intussen niet alleen geërgerd door al die geruchten over de overgave van de stad, maar wist het ook wie de aanstokers ervan waren. Getuige daarvan het schrijven dat burgemeester De Vos op 11 januari 1915 stuurde naar de Antwerpse pers én het collaboratiedagblad La Belgique. Daarin wees hij de ingebeelde beweringen over de inname van Antwerpen die in "een deel van de pers" verschenen waren van de hand. Hij betoogde dat het gemeentebestuur de forten niet had overgegeven. Ze waren ingenomen en de stedelijke overheid kwam pas nadien tussen. Bovendien waren ze grotendeels onbruikbaar gemaakt. Voorts had Antwerpen zich twee dagen laten beschieten om het Belgisch leger te redden. Ten slotte was de berichtgeving over de Belgische regering die het Antwerpse gemeentebestuur aansprakelijk stelde voor zijn tussenkomst en ministers van Staat naar Nederland gestuurd had om ter zake een onderzoek in te stellen, volledig foutief. Hij meldde ook dat hij zijn medeburgers de volledige inlichtingen wou geven omdat die onder de indruk van "de spoedige val [van de] vesting welke onneembaar heette" verhalen konden geloven die slechts verzinsels waren. ${ }^{125}$ Het verdere verloop van de gebeurtenissen bewees dat die bezorgdheid terecht was. Zo meldde het pro-Duitse La Belgique op 16 januari 1915 dat de geruchten waarover de burgemeester sprak "naar verluidt" hun oorsprong vonden in een Nederlands dagblad 
[een allusie op De Tijd. Er waren inderdaad exemplaren van La Vérité die zich voorstelden als een uittreksel uit dat blad, $B Y]$. Daarin was een artikel verschenen dat Franck, Ryckmans en De Vos in een kwaad daglicht gesteld had. Een nota die het blad "uit zekere bron" ontvangen had, beweerde dat het verhaal van die Nederlandse krant (sic) volledig ingebeeld was ${ }^{126}$. Vijf dagen later, op 21 januari 1915, publiceerde de Gazet van Brussel een hoofdartikel, getiteld Luik en Antwerpen. De beide steden werden erin tegen elkaar uitgespeeld. ${ }^{127}$ Over de heldendaden van de Vlamingen werd volgens het blad niet gerept. Integendeel werd de stad die zich meer offers dan Luik getroost had, zelfs gelasterd. De Antwerpenaren hadden zogezegd de koning tot onmiddellijke overgave willen dwingen en waren aan Duitsland verkocht (een variatie op wat het blad eind november 1914 al schreef). ${ }^{128}$

Verleden week nog werd in Brussel een vuil papiertje [lees: La Vérité sur la Capitulation d'Anvers, BY] heimelijk verkocht met een hoop bijzonderheden omtrent de overgave van Antwerpen, en waaruit moest blijken, dat de hele Antwerpse bevolking voor hoogverraad zou moeten ter dood veroordeeld worden!

En dat alles, zo vervolgde de redacteur, omdat Antwerpen Vlaanderen vertegenwoordigde en Luik de "hoofdstad" van Wallonië was. Haalde het blad hiervoor inspiratie uit de korte perspolemiek waarin Het Laatste Nieuws in augustus 1914 verwikkeld was? Of uit bepaalde artikels uit de vluchtelingenpers waarin Luik geloofd werd als een stad waar de pers niet herverscheen, terwijl Antwerpse dagbladen dat wel deden? Daarna volgden de gebruikelijke aantijgingen. Bijvoorbeeld dat voor de "franskiljons" de "Fransgezinden" het alleenrecht op vaderlandsliefde bezaten of Vlamingen onbetrouwbaar waren, wegens Germanen in deze oorlog tegen het "Germanendom". Dagelijks, zo verklaarde het blad, groeide de haat van de Vlaamshatende "franskiljons" die de Vlamingen voor landverraders wilden laten doorgaan. Deze stellingen vonden we al terug in de Kölnische Zeitung van 13 november en de Gazet van 3 december 1914. In hetzelfde artikel werd naar de redevoering van Maeterlinck in Milaan verwezen en nogmaals het beruchte artikel La Vie à Anvers uit La Métropole in herinnering gebracht, zo ook het antwoord daarop van Henderickx in Antwerpsche Tijdingen. In een ander artikel van 21 januari dat zich als een "mededeling" voordeed, was er nogmaals sprake van naamloze papiertjes die in Brussel heimelijk verkocht werden: "Ofschoon al de 'uittreksels, [...] van een rijkdom aan scheldwoorden getuigen, die een viswijf zou doen verstommen, toch hadden wij tot nog toe nooit een hatelijk stuk 
gelezen als dit Métropole-pamflet, dat echter onmogelijk van dat blad kan voortkomen." Het ging over Antwerpen, viseerde De Vos, Franck en Ryckmans en had een naamloze schrijver. "Het stuk eindigt met de voorspelling, dat Antwerpen eerlang in as zal worden gelegd en dat op het slangennest een nieuwe stad zal worden gebouwd, die geheel naar de zin van de walgelijke scribent zal zijn." ${ }^{129}$

Niet toevallig werd Luik en Antwerpen uit dezelfde editie geflankeerd door een uittreksel van het schrijven dat burgemeester De Vos tien dagen eerder aan de pers gericht had. Daarin stond een opmerkelijke zin: "Het gezegde, volgens hetwelk het Gouvernement de tussenkomst der gemeentelijke overheden zou hebben gevraagd [...] is volstrekt vals." Maar in de Franstalige tekst stond "gewraakt" ["incriminé"]. Was dit een typfout? Of werd hier impliciet verwezen naar de inhoud van La Vérité dat, zoals we in het volgende hoofdstuk zullen zien, ook meldde hoe de overheid om de tussenkomst leden van de gemeenteraad vroeg om nog 36 uur stand te houden? ${ }^{130}$ Inpikkend op hetgeen De Vos wou bestrijden, reageerde enkele dagen later een "lezer". Die was zogezegd verheugd om de publicatie van de burgemeester. Volgens hem werd het "boze vertelsel" over Antwerpen ijverig rondgestrooid, ja zelfs kosteloos in de Brusselse brievenbussen gestoken. De "kliek" was echter onhandig geweest en dat had de ogen geopend: "Wanneer men Antwerpen beliegt en bevuilt, dan is het wellicht om de aandacht van Luik af te keren" (dit stemde natuurlijk overeen met wat de Gazet eerder al schreef). Daarna kwam een passage, die later onder andere vormen meermaals in de activistische propaganda opdook:

Uit hetgeen thans gebeurt valt voor de Vlamingen te leren, dat zij zich niet [...] in slaap mogen laten sussen, maar dat zij meer dan ooit op hun hoede moeten zijn. Want terwijl zij [...] hun bloed voor het gemeenschappelijke vaderland vergieten, worden hen door sommige hardvochtige bestrijders [onder wie officiële dignitarissen] hinderlagen gelegd. ${ }^{131}$

Het ongeluk dat de Vlamingen nu te beurt viel, illustreerde deze Brusselse "lezer" door te beweren dat in Parijs "weldadigheidssermoenen" ingericht werden waar de bevolking uit de provincie Henegouwen met open armen ontvangen werd, in tegenstelling tot de Vlamingen. Een Brusselse lezer die in het bezette België op de hoogte was van wat er zich te Parijs afspeelde? Dit herinnert aan de lezer die zogezegd The Times kon verkrijgen en zegt alles over de geloofwaardigheid die we aan het woord "lezer" moeten hechten. Op 15 januari 1915 mengde ook Le Bruxellois zich in de debatten, naar 
aanleiding van de vernoemde brief van burgemeester De Vos. Het beloofde zeer binnenkort een officieel document te publiceren dat overduidelijk zou bewijzen dat de versterkingen rond Antwerpen duidelijk ontoereikend en onvoltooid waren. De situatie aan de vooravond van de vijandelijkheden moest wel leiden tot een gemakkelijk bombardement van de zogenaamd "onneembare" vesting. ${ }^{132}$ Dat "officiële document" verscheen nooit: het bestond enkel in de fantasie van de Duitse propaganda. Maar, belangrijker, ook Le Bruxellois zaaide, net als de Gazet van Brussel omtrent hetzelfde tijdstip, verwarring over het lot van Antwerpen.

Het pro-Duitse La Belgique besteedde op haar beurt eveneens aandacht aan de val van Antwerpen, onder het voorwendsel dat "men" er opnieuw over praatte (en dat was natuurlijk zo, de collaborerende pers bleef het vuur oppoken!). In een artikel van 27 januari 1915 van de Antwerpse correspondent van het blad, dat blijkbaar als antwoord op La Vérité sur la Capitulation d'Anvers bedoeld was, werd het optreden van de burgerlijke overheid verdedigd. ${ }^{133}$ Hetzelfde stuk vindt men drie dagen later terug in L'Avenir dat het met een officiële luister bekleedde door het aan "une plume autorisée et qui émane de personnalités belges mêlées aux négociations" toe te schrijven. ${ }^{134}$ Ondertussen werd het vlugschrift La Vérité verspreid. Op 1 februari ontving de Gentse hoogleraar Paul Fredericq van Hippoliet Meert het lasterschrift, dat hij als "walgelijk" omschreef. ${ }^{135}$ En 's anderendaags schreef de Gentse correspondent van de Nieuwe Rotterdamsche Courant hoe de "Fransgezinden" de huidige toestand voor hun zaak trachtten uit te buiten.

Daarvoor echter moeten de Vlaamse leiders eerst geschandvlekt. Zij vallen nu mr. Louis Franck, [...], Ryckmans en burgemeester De Vos [...] heftig aan in een klein smaadschrift. Antwerpen wordt verder hevig aangevallen en uitgescholden - het is immers de Vlaamse veste bij uitnemendheid - en zelfs voorgesteld als de enige vlek op de heldhaftige naam der Belgen! En dan komt de aap uit de mouw: in 't herstelde België zullen de flaminganten voor altijd afgedaan hebben! ${ }^{136}$

Vier dagen later schreef de liberale journalist Auguste Monet in de Nederlandse en pro-geallieerde Telegraaf dat in "Antwerpen, te Brussel, en te Gent - te Gent vooràl! - een brochure verspreid [werd] die als titel [...] 'Manuel du Patriotisme' (!!!) [droeg]”. Ze begon met een uitval tegen de Duitse "barbaren", waarna "al de vervloekingen van het verwoeste België ingeroepen [werden] op de Vlaamse leiders". In het bijzonder ging het volgens Monet om Franck (die Antwerpen aan de Duitsers had "overgeleverd"), Ryckmans 
en De Vos (die hem daarbij geholpen hadden). "Dan heet het dat Antwerpen [...] de enige vlek is op de heldhaftigheid van België, en het slot van de historie is, dat in het herstelde België de flaminganten voor altijd afgedaan zullen hebben en dat het Frans de énige landstaal zal zijn!" Bepaalde elementen uit het door Monet beschreven vlugschrift, zijn aanvullingen op de versies van La Vérité die wij onderzochten, wat erop wijst dat er bewerkingen van het pamflet circuleerden. De journalist benadrukte dat het schimpschrift een Duitse list was. Het werd door de bezetter gedrukt en vervolgens gratis uitgedeeld. ${ }^{137}$

De heisa over het pamflet kwam Franck bijzonder ongelegen, daar hij al problemen genoeg had met de voedselbedeling en het herstel van het dagelijkse leven. ${ }^{138}$ Maar via het stadsbestuur reageerde hij toch. Op 8 februari 1915 drukte het Antwerps schepencollege, de burgemeester en de Intercommunale Commissie een verklaring af, getiteld De Inneming van Antwerpen - La Prise d'Anvers, waarin de inhoud van het pamflet weerlegd werd. Ook werd gemeld dat een klacht neergelegd was wegens laster. ${ }^{139}$ Toen De Vos op 11 januari 1915 de pers probeerde in te lichten inzake de berichtgeving over de capitulatie van Antwerpen, kon hij zich niet beroepen op een goedkeuring van de Intercommunale Commissie door de regering. ${ }^{140}$ Daarentegen meldde De Inneming van Antwerpen op 8 februari wel dat de daden van het gemeentebestuur volledig door de regering gedekt waren. Als we La Belgique mogen geloven, loofde de regering pas medio maart 1915, bij monde van minister van Onderwijs Poullet, openlijk de Antwerpse stedelijke autoriteiten. Tijdens een verblijf in Nederland vertelde hij hoe de regering in oorlogstijd niet bij alle perspolemieken kon tussenkomen (dit stemt overeen met wat Le Vingtième Siècle voordien beweerde). Maar het stadsbestuur van Antwerpen en de Intercommunale Commissie wisten zeer goed dat hun handelingen door de regering gedekt werden. ${ }^{141}$ Toch bleef het officieuze regeringsblad Le Vingtieme Siècle van februari tot mei 1915 sporadisch de goede trouw van Franck in twijfel trekken. ${ }^{142}$

Door het gebrek aan krachtdadigheid of inzicht van de Belgische overheid (en een onderschatting van de situatie?) bleef de visie van de bezetter onaangevochten. En dat terwijl de bezetter niet alleen het rumoer errond bleef stimuleren, maar ook bewust tegengestelde signalen de wereld instuurde. Zo gaf het Duitse burgerlijke bestuur van de provincie Antwerpen een week na de publicatie van het gemeentelijk vlugschrift toestemming om deze verklaring in de provincie openbaar te maken: "U kan erop rekenen [...] dat de Antwerpse toelichting in de pers op de grootste schaal verspreid zal worden." ${ }^{143}$ De bezetter steunde uiteraard propaganda tegen 
een verborgen Duits pamflet. Ze had de bedoeling La Vérité als een "franskiljons" vlugschrift voor te stellen en dus wou ze er er méér ruchtbaarheid aan geven om zich vervolgens aan de kant van "de Vlamingen" te scharen. Ook L'Avenir besteedde artikels aan de kwestie. Eind januari heette het dat men in bepaalde milieus in Brussel en Parijs de meest felle aantijgingen tegen Franck, De Vos en Ryckmans bleef uiten. De Brusselse correspondent van het dagblad schreef op 29 januari 1915 dat er pamfletten met artikels die zogezegd uit Le Temps afkomstig waren en waarin het drietal openlijk als verraders behandeld werd, verspreid werden (sommige versies van $L a$ Vérité stelden zich inderdaad voor als een uittreksel uit dat Franse dagblad). Daarna volgde het langste uittreksel uit La Vérité dat tot dan toe verschenen was. In lijn met de Gazet van Brussel die op 21 januari 1915 meldde dat het stuk niet uit La Métropole afkomstig was, beweerde L'Avenir dat dit pamflet niet in Le Temps gestaan had, maar het werk was van Brusselse boulevardmilieus. ${ }^{144}$ Op 18 februari publiceerde L'Avenir het artikel Une campagne antiflamande. ${ }^{145}$ Een "lezer uit Brussel" had het blad, zo heette het, gemeld dat er sedert een tijd een campagne aan de gang was tegen alles wat Vlaams was. Die was indirect aanbevolen door de Maeterlincks (waarvoor het blad eerder al ter staving een artikel uit de Gazet had overgenomen), Harry's en anderen. ${ }^{146}$ L'Avenir betoogde dat men in conversaties, getypte geschriftjes en kleine affiches de Vlamingen en dan vooral hun leiders aanviel, door hen allerlei beledigingen en bedreigingen naar het hoofd te slingeren. Zo heette het dat de clerus thans verkondigde dat door de Vlaamse eisen een Germaans spoor liep: "Le clergé, par peur d'un danger imaginaire, celui de voir les Flamands se jeter dans les bras de l'Allemagne, crée un danger très grand et pousse directement le pays dans les bras de la France." Uit angst dat de Vlamingen zich in Duitse armen wierpen werd, aldus L'Avenir, België in de Franse invloedssfeer gestuwd. De Vlamingen werden geboycot door hun te vertellen dat Vlamingen en Duitsers hetzelfde waren. En zo trok het blad van leer tegen de "franco-Belgische" chauvinisten (hier zien we weer de hand van het gouvernement-generaal). Vlak naast dit artikel drukte het persorgaan La Prise d'Anvers af, het officiële protestschrift van de stad Antwerpen tegen La Vérité, blijkbaar om te suggereren dat het stadsbestuur zijn stem verhief tegen die "anti-Vlaamse campagne". ${ }^{147}$ Een artikel gebaseerd op een schrijven dat Het Vlaamsche Nieuws van 13 maart 1915 beweerde "uit Brussel" ontvangen te hebben, makt de verstrengeling van de propaganda in de proDuitse pers verder duidelijk. Die "zegsman" van het dagblad meldde onder andere dat nooit een Vlaming pan-Germanist was geweest, maar mocht men evengoed zeggen dat de Walen nooit van een inlijving bij Frankrijk 
gedroomd hadden? Om die bewering te staven, verwees hij naar het Waals Congres van 1905. Voorts heette het:

Wat er thans gebeurt [...] kan heel erg zijn voor de Vlamingen. De Walen gaan nogal in alles te ver en Frankrijk toonde zich altijd buitengewoon behendig om van een volksmening voordeel te halen. De hogere geestelijkheid, misschien om een ingebeeld gevaar, Vlaamse welwillendheid voor Duitsland, te voorkomen, sticht een werkelijk en tevens zeer groot gevaar door het land in de armen van Frankrijk te willen werpen. Niet een inlijving alleen, maar een nauwe aaneensmelting met Frankrijk, zou de ondergang wezen van het Vlaamse volk in heel België!.

Het fragment bevatte een letterlijke passage uit wat L'Avenir eerder ook gemeld had. En die passage was niet de enige. Deels werd het schrijven uit Het Vlaamsche Nieuws trouwens in de oorspronkelijke taal - het Frans weergegeven. Wie beide stukken naast elkaar legt, merkt hoe de twee dagbladen gewoonweg uit wat dezelfde bron - het gouvernement-generaal - hen medegedeeld had, citeerden. ${ }^{148}$ Zoals we later zullen zien, was de flamingantische vrees voor een aansluiting van België bij Frankrijk een thema waarop de Duitse propaganda nog zou inspelen.

Op 4 maart 1915 drukte de Gazet van Brussel, in navolging van L'Avenir, het document De Inneming van Antwerpen af. Het collaboratiedagblad beweerde naar aanleiding hiervan met voldoening vast te stellen dat zijn stem tegen de anti-Vlaamse campagne weerklank vond. ${ }^{149}$ Uitgerekend op die dag publiceerde L'Avenir een artikel, getiteld Haro sur Anvers, dat meer duidelijkheid verschaft over de verbinding tussen het gouvernement-generaal en het Franstalige dagblad. ${ }^{150}$ Het stuk was geschreven naar aanleiding van een brief vanwege de hoofdredacteur van $D e$ Tijd, waarin die verklaard had dat $L a$ Vérité nooit in zijn krant verschenen was. De ontkenning werd door L'Avenir als aanknopingspunt genomen om het denkbeeldige relaas van de overgave van Antwerpen te bespreken. Het blad gaf het besluit van La Vérité weer als een voorbeeld van gallofiele hysterie, die in sommige Belgische milieus zou leven: "ces énormités ont vraiment cours parmi une partie de la société boulevardière de Bruxelles, comme nous l'avons déjà dit dans nos articles sur la campagne anti-flamande." In het door het dagblad aan La Vérité ontleende stuk, heette het: “...les Belges reviendront, appuyés par leurs alliés [...] et ils reprendront les forts [rond Antwerpen, $B Y$ ] et cette destruction [van Antwerpen, $B Y]$ ce sont les boulets anglais qui l'accompliront." Om zijn argumenten te staven, citeerde L'Avenir verbatim uit Antwerpen moet kapot! van 


\section{Haro sur Anvers}

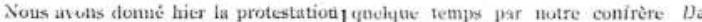
du Tijd d'Anster.am, disant qu'il $\mathrm{n}^{\prime}$ a réligé ni reprodnit l'article "La vérité sur la capitulation d'Anvers $n$, qu'um peruphlet anonyme propage comme rant parn dans ee journal.

L'article da pampnlet durige sur notro morable boturgmestre De vios et sur

A. Y. Rranck et Ryckmans les accusations les plus ignobles si elles n'śtaicnt grotesques et donne une relation fautsisiste de la reddition d'Auvers, qui a éc suff.ssmunent rectifice et démentie par les conmunigues officiels et officienx ct les relations des journaux.

Nons avons donué il $y$ a quelque temps tn petit extrait du pamphlet cua I'on traite notre cher Anvers de villo infame, couverte de houte fternelle.

Voici la conclusion de ce petit exem. ple de ce que pent l'hystéric gallophile qui atvit dans quelques milieux cliez notus :

Il est un chatiment, Anvers, auquel It n' chappera pas. Les Equnements ne sont pas encore accomplix, Cotte ceiti

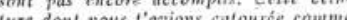

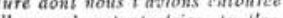
d'une arine probelnice, in pras wendue at l'ennemi of miantenant Pennemi va s'en servir conlre les enfants de la palrie belge, car les Belges reviendront, ap. puyes par leurs allies, defonseurs du droit, de lit verrilte, de la justice, et its refrendront les forts, offerts par loi an Allemands, if celte destruction, par-les monlets eninc

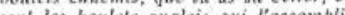
sonl les ront. Tu scras un amas de ruincs, Ansers, et c'est loi-même qui l'atiras voulh. Neus fouillerons ton nid de vipires tentonnes, nous enteverouf le dard de cors bêtes malfaisontes, nous purgerons labcìs unverseis de tous ces pus allemands qu'il coationt. Sur ces ruines immondes s'elevera anc ville nouvelle, whe ville surée de ces álémunts malsains. unc ville belge que nous ouvrirens indislinctement a toutes les nations du mow-
de, squs la laisser dominer bar aucune. Petulelve alors, cel Ansers fulur, gHe uous aurons rédific, barriendra-t-il at force de grandeur, d'satrile of d'honneur, a faire oublise oc que fit Anvers en 1914 ?

(itre sugger if $\mathrm{d}+$

ANTWERPEN MOET KAPOT

C'ct article signale une campagne de alomnies cntamée contre nos poptila. fons flamaules en général et la villo 'Anvers en particulier.

¿Ce n'cst plus aux Allemands seuls gu'on en vent; mais a tont ce qui est de race germainc. On ne crie plus os sus ux Allemands \#, mais "sus aux GerHains ", nous mettant ainsi cntre l'endume et le martean. Quand les Fl. culs disent gutits wont Gernains anatwhe tout ré tont, ils som vonts ats getinomies ils renicnt cette origine, ils renient len ropre indiv,dualite, ce qui serait d'une nsigne lache: 6 , tont en ctant in contrnliction formelle avee l'histoire, Lex faits ont les faits et le sang des Flamanús st plus purement germain que celui do a population de fiverses regions de l'd cmagne of de la Scandinavie Notr innes taranich ermancuch les phis pures. Cela n'entéche pas que nots ne sommes pas plus Allemands que ceux-ci ne sont Flnaunds of que, quoi qu'il arrive, nous unintiendrons laut notre individualits, nostre idiome et notre culture propres.

$$
*^{*} *
$$

Notth apprentong que MM. De Vos ranck et Rycknans ont déposé unc lainte contre les auteurs anonymes du sumphlet. Nous espérons que la justice atura dícouvrir les counables et leur infligera la punition qu'ils méritent. Cula uettrit fin une bonne fojs atux attaques lígéces contre certains de nos administratcurs of contre la ville meme.

Anvers $n$ 'a rien à st rejrocher dans is evenements tragiques dont elle a cte le théstre. D'elle conme de toute la Bel. ginue on peut íre qu'an point de vue les allicis elle a fait son devoir et mème las que soln devoir. Qu'ou compare son atitude ì celle de Liége củ le troisième forr dis siege 1a pupulation signa des hétitions pour utue la ville ne fut pos certis ift aux troupes attemandes. I ge dift aux troupes allenandes. Le genéra Letuan déclara lui-mêtue que la ville Stait libre d'agir combe clle le voulait, wats que les forts résisteratent jusqu'a la dertitero extrónite.

II en fut fait ainsi et e'est de ta ville mêtue que certains forts furent attaqnés ct réduits au silence.

Anvers s'est ¿one comportée d'une façon vraiment clicyaleresqute en se soutucttant au bombardement.

Quant au flamingantistue anversois, cc the sont ni des pamphlets, ni des malkdietions de ecrtaines tétes chatudes qui fercnt aliandouner a notre chère ville Claunande eon caractero pronre et son individualis contre tous.

A cette occision nous venons de met tre la main sur un article public il $y$ a VERTTAS

Afb. 11. Begin maart 1915 lichtte L'Avenir onbedoeld een tipje van de sluier over de Duitse propaganda-campagne

L'Avenir, 4 maart 1915, 1; KBR III 41.703 D [M-SLZ] 
twee maanden eerder uit de Gazet van Brussel. Dat artikel signaleerde, aldus L'Avenir, een lastercampagne tegen de Vlaamse bevolking in het algemeen en Antwerpen in het bijzonder. Maar daarnet lazen we dat in Antwerpen moet kapot! (Gazet van Brussel, 5 januari 1915) óók beweerd werd dat Antwerpen bij de bevrijding door de geallieerden verwoest zou worden, zonder dat er (al) over een pamflet gesproken werd. Er bestond dus een duidelijk verband tussen het vlugschrift La Vérité, Antwerpen moet kapot! en Haro sur Anvers. Of, anders gezegd, tussen (de dagbladen van) het gouvernement-generaal en het schotschrift. En net als voordien de Gazet van Brussel en de Duits-Oostenrijkse propaganda beweerde, schreef L'Avenir hoe de Britten voorstander waren geweest van het "verzet tot het uiterste". Bij monde van een "Brusselaar" meldde het Antwerpse blad volledig in lijn met de Gazet van Brussel:

Les journaux hollandais ont raconté quau début de la dernière semaine du siège un parlementaire allemand était venu encore faire des propositions de paix que le Roi Albert était d'avis de les accepter; mais que les Anglais qui siégeaient dans l'état-major avaient fait rejeter toute proposition. ${ }^{151}$

Naar analogie met het Brusselse persorgaan beweerde L'Avenir in Haro sur Anvers dat Antwerpen zich niets te verwijten had en dat haar houding met die van Luik vergeleken kon worden. Wat het Antwerpse flamingantisme betrof, waren het noch pamfletten, noch bedreigingen van enkele heethoofden die de "dierbare Vlaamse stad" haar Vlaams karakter en eigenheid zouden laten verliezen. ${ }^{152}$

\section{Andere vlugschriften}

Het artikel Une campagne antiflamande dat op 18 februari 1915 in L'Avenir gepubliceerd werd, is om nog een andere reden belangrijk. Het bevatte immers de tekst van een pamflet van Reinhard en Josson van zes dagen eerder. Opmerkelijk is dat L'Avenir het eerste dagblad was dat dit schrijven afdrukte, nog vóór de Gazet van Brussel, Het Vlaamsche Nieuws, De Vlaamsche Post en Antwerpsche Tijdingen. ${ }^{153}$ Het stuk begon met een lofzang op de roemrijke verdediging van België door de Vlaamse soldaten. De "franskiljons" daarentegen vormden een "antinationale partij" die er niet voor terugdeinsde om zelfs in oorlogsomstandigheden haar "verachtelijke veldtocht" tegen de Vlaamse nationaliteit voort te zetten. Beiden verweten aan die "franskiljons" dat ze 
zich verheugden over de rampen die Vlaanderen teisterden en zelfs hoopten dat het door nog ergere rampen getroffen zou worden (een verwijzing naar de gevoerde propaganda omtrent de val van Antwerpen en La Vérité). Ook verspreidde die

antinationale partij [...] in de dagbladen en door middel van strooibriefjes, de hatelijkste lasteringen tegen de Vlamingen, die zij voor lafaards en verraders uitscheldt; zij laat kleine berichten aanplakken, waarop men deze woorden kan lezen: 'schande over de Vlamingen!' Zij heeft tot verschillende voormannen van de Vlaamse Partij naamloze brieven gericht, die met deze woorden eindigen: TER DOOD.

De kroon op het werk was zogezegd de miskenning van het taalrecht op elk gebied die deze "antinationale partij" voorspelde. Het pamflet bewijst hoe sommige Vlaamsgezinden geloof hechtten aan de zogenaamde anti-Vlaamse campagne. Ze kwamen zo in een vicieuze cirkel terecht. Zo meldde op 26 februari 1915 L'Echo Belge dat het uit goede bron wist dat Graevell, Reinhard en Josson voor bewezen diensten door Von Bissing voorgedragen waren voor ontvangst van de Pruisische Kroonorde, vierde klasse. ${ }^{154}$ Misschien een schertsend bericht, maar een geprikkelde flamingant kon er zeker een "antiVlaamse aanval" in zien. Temeer daar La Métropole het voor waar aannam en op grond daarvan zichzelf feliciteerde:

On sait avec quelle fureur après notre départ d'Anvers nous fûmes attaqués dans une feuille allemande d'Anvers [door Henderickx in Antwerpsche Tijdingen, $B Y]$ pour avoir osé regretter que nous ayions compte des pangermanistes en Belgique. Encore notre regret n'allait-il pas jusquà l'accusation puisque nous admettions en les appelant les 'égarés' que leur conduite n'était pas suspecte. ${ }^{155}$

Afgaande op de inhoud van het pamflet van Reinhard en Josson poneerde Wils dat dreigbrieven aan de bezoekers van het Vlaams Huis in Brussel en de strooibiljetten tegen Vlaamsgezinden uitingen waren van de "machteloze woede" van de Brusselaars tegenover de Gazet van Brussel. ${ }^{156}$ Dat collaboratiedagblad had inderdaad op 13 december 1914 te kennen gegeven dat al zijn nummers in de drukkerij van het dagblad of in dat vooroorlogs ontmoetingsoord voor Brusselse flaminganten op de Grote Markt besteld konden worden. ${ }^{157}$ Daar bleef het niet bij, want de Gazet van Brussel nam tussen 10 februari en 15 maart 1915 dagelijks en ook daarna regelmatig aankondi- 
gingen voor het Vlaams Huis in haar kolommen op. ${ }^{158}$ Het is dus waarschijnlijk dat de bezoekers ervan, onder wie Reinhard en Josson, geviseerd werden. Alleszins wekte niet alleen de verschijning van het Nederlandstalige blad de toorn van de Brusselaars op.

Zo gaf Le Bruxellois al in de herfst van 1914 meermaals toe dat lezers het blad ervan betichtten een Duits orgaan te zijn en dat het daarom op weerstand van publiek gestoten was. Die verdenking wilde het overigens wel héél uitdrukkelijk afwimpelen. Al in zijn eerste editie van 18 september 1914 stelde het blad zich uitdrukkelijk voor als een door Belgen opgesteld persorgaan. Naar eigen zeggen hoopte het op advertenties. In realiteit bleven die beperkt, wat al argwaan moet wekken over de echte financiering van het dagblad. Le Bruxellois bleef voortdurend de verdenking een Duits dagblad te zijn van zich afschudden, getuige daarvan het opschrift "Le Bruxellois est un journal belge", dat algauw de eerste bladzijde tooide. Al na twee dagen wees het blad op het "begrijpelijke wantrouwen" van het publiek tegenover "nieuwe dagbladen": "encore un journal des Allemands..." Dat het door Belgen opgesteld werd, konden de lezers volgens de redactie vaststellen. ${ }^{159}$ Maar wie die waren, daar werd in alle talen over gezwegen. Meermaals heette het dat er kritiek was bij het publiek op het zogenaamde Duitse karakter van het blad. ${ }^{160}$ Op 4 november 1914 kondigde het dagblad aan vanaf's anderendaags op een groter formaat te verschijnen; goed twee weken later verscheen het op vier bladzijden. Dit bleef zo, ondanks het feit dat op 23 december de verkoopprijs gehalveerd werd, zogezegd om de lezers de hoogste kwaliteitsjournalistiek aan de laagste prijs te bieden. ${ }^{161}$ Een dagblad met nauwelijks reclame, op groot formaat en vier bladzijden gedrukt met kolommen geschreven door anonieme redacteuren werd door de publieke opinie allicht argwanend bekeken.

Nog op 1 maart 1915 beklaagde het persorgaan er zich over dat het anonieme brieven ontving: "elles ne se comptent pas plus que les épîtres injurieuses ou calomniatrices." ${ }^{162}$ Bijna vier maanden later heette het opnieuw dat de redactie "des lettres de grossières injures" ontving. ${ }^{163}$ Die boodschap kreeg het ook te horen via een vlugschrift dat medio 1915 in de Brusselse agglomeratie uitgedeeld werd. Dat kantte zich tegen de pers die onder Duitse censuur verscheen en gaf inzonderheid de journalisten die daar uit eigenbelang aan meewerkten een veeg uit de pan. Het heette erin dat het merendeel van de dagbladen de Duitsers toebehoorde (wat slechts deels klopte). Het geschrift riep op om dagbladen als de Gazet van Brussel en Le Bruxellois te boycotten. ${ }^{164} \mathrm{Net}$ als bij de naamloze geschriften waarover $L e$ Bruxellois klaagde, ging het hier over anonieme Belgische briefschrijvers die inderdaad collaborateurs (of wat zij als dusdanig beschouwden) aanvielen. 
Dat deden ze wellicht ook ten aanzien van de Gazet van Brussel en dus tegen de bezoekers van het pand waar men dat blad kon bestellen. Maar Reinhard en Josson interpreteerden die aantijgingen als anti-Vlaamsgezinde aanvallen. De Duitse bezetter gooide in dat proces olie op het vuur, zoals de ouddaensist Léonce du Catillon en Le Vingtième Siècle aanstipten. Op 11 maart 1915 schreef dat blad hoe Josson en Reinhard niet begrepen hadden dat de anonieme brochures met daarin laag-bij-de-grondse anti-Vlaamse aanvallen die in Brussel verspreid werden, duidelijk het werk waren van scribenten die voor de Duitsers werkten. ${ }^{165}$

Een voorbeeld daarvan was waarschijnlijk de repliek op het manifest die tegen Reinhard gericht was. Die heette uit te gaan van "des Belges". We beschikken niet over het origineel, maar aan de hand van wat Reinhard er op 28 februari 1915 op antwoordde, kan de inhoud gereconstrueerd worden. In het stuk, dat naar meerdere personen opgestuurd werd, stond onder meer dat Reinhard de taalkwestie oprakelde, een onderscheid maakte tussen de Belgische soldaten en dat hij Walen en Fransen zou haten. Bovendien bevatte de brief een uittreksel uit de Düsseldorfer General-Anzeiger, hetzelfde blad dat begin december 1914 onwaarheden over de val van Antwerpen verspreid had. De redacteur van de Anzeiger meldde te hopen in België de politieke voorkeur aan de Vlamingen op de Walen gegeven werd. Dat Franstaligen naar meerdere personen opruiende pamfletten met daarbij knipsels uit de Anzeiger zouden sturen, is onwaarschijnlijk. Dat Duitse diensten dat deden, lijkt logischer. De brief aan Reinhard die ondertekend was door "Belgen" kan dus ook een Duitse zet geweest zijn. Zoals we later zullen zien, verscheen er in de lente van 1915 nog een ophefmakend Duits vlugschrift dat ondertekend werd door "des vrais Belges". In zijn antwoord op deze tweede naamloze brief schreef Reinhard dat het de vijanden van de Vlamingen waren, die opnieuw begonnen waren met de taalkwestie te beroeren. Hij beweerde dat zij hen met alle middelen bestreden en dit sedert het begin van de oorlog: "nous avons fini par leur riposter." ${ }^{166} \mathrm{~W}$ ils gaf aan dat Reinhard hier "niet onoprecht" was. Want "sinds het begin van de oorlog" waren er de polemieken geweest over Antwerpen, de rede van Maeterlinck, het artikel van Harry enzovoort. "Maar dat de dreigbrieven en de rest zouden dateren van vóór de Gazet van Brussel, schreef hij niet." ${ }^{167}$ Die analyse klopt: Reinhard had het hier alleen over (vermeende) aanvallen i.v.m. de taalkwestie. Uit het eerder besproken bericht uit de Limburger Koerier (6 januari 1915) weten we dat door Duitse diensten gefabriceerde naamloze doodsbedreigingen en verwensingen aan het adres van flamingantische voormannen al in december 1914 - dus na de stichting van de Gazet van Brussel - in het bezette land circuleerden. 
De Duitse diensten publiceerden nog geschriften om de gemoederen te verhitten. Want vanaf februari 1915 werd een een brochure verspreid, met als titel Lettre Ouverte au peuple belge par un philanthrope. Of, in de Nederlandstalige versie, Open Brief aan het belgisch Volk door een Menschenvriend. ${ }^{168} \mathrm{De}$ "filantroop" betoogde daarin op basis van achttiende-eeuwse principes van het volkenrecht en een brochure van de collaborerende Belgische majoor Girard uit 1889, La Belgique et la Guerre prochaine, dat Duitsland het recht had om door het Belgisch grondgebied te trekken. Het betrof, aldus de schrijver, een noodzaak. België, verscheurd als het was tussen Vlamingen en Walen, stond toch op het punt zich in de armen van Frankrijk te werpen. Bovendien was het sedert 1906 niet meer echt neutraal geweest (de stelling die Duitsland vanaf de herfst van 1914 verkondigde), maar stond het land in het Frans-Brits kamp. De "filantroop" hekelde het gedrag van de Belgische overheid: die beschikte niet over een leger die naam waardig, weigerde de Duitse doortocht en ten slotte het Duitse vredesaanbod. Hij verzocht de koning om onmiddellijk vrede te sluiten. Congo moest als prijs fungeren voor het bewaren van de Belgische onafhankelijkheid. Door de oorlog toch voort te zetten, zou het lijden slechts verlengd worden en riskeerde België van de Europese landkaart te verdwijnen. "De Duitser, met zijn patriottisme, zijn rijkdom en zijn organisatie, zelfzeker, zeker van zijn leger en marine, twijfelt niet aan zijn succes." [B.Y.] De geallieerden werden er eenzijdig negatief in afgeschilderd: hoogmoedige Fransen, gesteund door de Russen die bij hen voor tientallen miljarden in de schulden stonden en de egoïstische Britten. En daar had België rugdekking aan verschaft.

In zijn rapport uit mei 1915 schreef Von der Lancken-Wakenitz dat deze brochure "met een openlijk germanofiel karakter", die de laatste tijd op grote schaal verspreid werd, door een Belg, die uiteraard anoniem wou blijven, geschreven was. De drukker die hij gevonden had zette er evenwel zijn naam niet onder, hoewel dat wettelijk nodig was. Daarna vond die een stroman die zijn naam wilde geven. Maar toen die laatste merkte dat de brochure op de boulevards kleinschalig verkocht werd, werd hij bang, trok hij zich terug en liet hij alle exemplaren weghalen. De drukker moest op zoek naar een nieuwe persoon die zijn naam aan de zaak leende. De oplossing werd gevonden door het adres van een Oostendse drukker op te geven. ${ }^{169}$ Dat wekte achterdocht in de vluchtelingenpers. Zo vroeg $L^{\prime} E$ cho Belge zich op 12 juli 1915 af waarom die persoon een brochure liet drukken in Oostende, een stad die ontoegankelijk was, behalve dan voor de Duitsers. ${ }^{170}$ Een maand later stelde het sluikblad La Libre Belgique zich de vraag hoe die "Duitse schrijver" aan een drukker was geraakt: "De deux choses l'une: ou l'impri- 
meur a été forcé de s'exécuter ou il s'agit de plein gré et, en ce dernier cas, il n'y a qu'un jugement à émettre, c'est qu'il forme le 'pendant' du 'philanthrope." ${ }^{171}$ De schrijver van de brochure was in realiteit Arthur Limet, een Belgische arts die tweemaal met een Duitse getrouwd was en later in het Waalse activisme terechtkwam. ${ }^{172}$

Het parket van Brussel stelde een onderzoek in naar de identiteit van de geheimzinnige drukker en kwam snel tot twee conclusies. Ten eerste dat de brochure verwees naar een onbestaande straat in Oostende. Ten tweede dat de echte drukker Paul Kropp was, een Duitser gevestigd in Sint-Jans-Molenbeek [sic, Anderlecht, $B Y]$. Vóór de oorlog werd daar al het weekblad de Brüsseler Zeitung gedrukt. Het regeringsorgaan Le Vingtieme Siècle omschreef het als de drukker die door de Duitse Kommandantur aangewezen was. Zowel in edities van Le Bruxellois als in de Gazet van Brussel troffen we sporadisch hetzelfde adres aan dat overeenstemde met dat waarop volgens het parket die provocerende brochure gedrukt werd. In Brussel werden de dagbladen en de vlugschriften van het gouvernement-generaal blijkbaar op dezelfde, met die Duitse instantie verbonden plaats gedrukt. ${ }^{173}$

\section{De ontwikkeling van het activisme in het bezette land}

De stichting van de Gazet van Brussel en L'Avenir, de Duitse overname van de Vlaamsche Gazet - waarover straks meer -, de verschijning van provocerende stukken in Duitse en Oostenrijkse kranten en Belgische collaboratiedagbladen over de overgave van Antwerpen vonden allemaal plaats in de tijdspanne tussen medio november en medio december 1914. Het was omtrent dat tijdstip dat de Flamenpolitik intensiveerde. Begin 1915 bereikte dit beleid een eerste kookpunt. Hoe ontwikkelde het activisme zich ondertussen? Onze bijzondere aandacht gaat daarbij uit naar Brussel. Over het hoofdstedelijke activisme missen we na al die tijd nog steeds een monografie, naar het voorbeeld van die van Vanacker over Gent en Vrints over Antwerpen. Nochtans zou de "Flamenpolitik van het gouvernement-generaal" zich net "[daar] het eerst openlijk manifesteren". ${ }^{174}$ In Gent, de hoofdplaats van het etappegebied gebeurde méér dan twee maanden niets. ${ }^{175}$ Pas na contact tussen de Nederlandse pastor Domela Nieuwenhuis en Duitse militairen, in het bijzonder de hem goedgezinde generaal Von Werder, kwam er wat beweging in de zaak. Domela werd de Duitse vertrouwensman in het etappegebied, kreeg Duitse paspoorten en kon vanaf 23 oktober 1914 van militaire treinen gebruikmaken om zijn anti-Belgische boodschap te verspreiden. 
De dag nadien stichtte hij een groepje dat zich "Jong-Vlaanderen" noemde. Het bestond uit tien leden, onder wie vier vrijzinnige flaminganten die vóór de oorlog het blaadje De Bestuurlijke Scheiding uitgegeven hadden. Dat schold vooral op Vlaamsgezinde voormannen uit de traditionele partijpolitiek, maar pleitte nergens voor de opheffing van België. Het had ongeveer evenveel te maken met de bestuurlijke scheiding als de brief van Destrée met de séparation administrative. Domela werd onmiddellijk tot "leider" van Jong-Vlaanderen uitgeroepen en drukte zijn anti-Belgisch programma door: een Vlaamse staat, Noord-Frankrijk inbegrepen, als deel van een Algermanenbond. Wanneer de Nederlander zijn gedachtegoed in buitenlandse tijdschriften verkondigde, ging hij overigens veel verder dan wat in het groepje besloten was. Het heette dan onder meer dat het Duits in het lager onderwijs moest ingevoerd worden en dat enkel Nederland een gelijkberechtigde plaats naast het keizerrijk zou innemen. Vlaanderen zou waarschijnlijk een deel van Duitsland worden, voorzien van Duitse oorlogshavens. ${ }^{176}$ Tot eind november 1914 volgden nog drie vergaderingen, zonder concreet resultaat. ${ }^{177}$

Het keerpunt kwam er toen Hermann Felix Wirth, een pan-Germanistische filoloog met een Duitse vader en een Nederlandse moeder, rond 20 november 1914 te Gent aankwam. Want binnen de week legde hij contact met de groep. Opmerkelijk is dat de Vlaamsche Gazet uit Antwerpen begin december aankondigde dat Wirth in het Duitse leger dienst genomen had. ${ }^{178}$ Zegt dat iets over de strekking die dat blad toen al had aangenomen? Uit een strooibrief die in november 1915 in het bezette land rondgedeeld werd en waarin we details terugvinden die pas later voor de historiografie bekend werden (zoals het feit dat Domela zich naar Nederland begeven had om geld voor De Vlaamsche Post in te zamelen), leren we meer over zijn rol: "Dr. Wirth spreekt goed Nederlands en geeft zich uit voor 'Grootnederlander' en vriend van de Vlaamse beweging. Tevergeefs trachtte hij betrekkingen aan te knopen met de leiders der Vlaamse beweging te Gent. Domela kon hem alleen jongens van de eerste broek aanbrengen." ${ }^{179}$ De actie van Wirth stemde dus (aanvankelijk) overeen met hoe het hoofd van de Zivilverwaltung, Von Sandt, op 13 februari 1915 de taak van de bezettende macht omschreef. Die nam immers “...mit hervorragenden Führern der vlämischen Bewegung [...] in aller Stille Verbindung auf...." ${ }^{180}$

Wirth werd lid van Jong-Vlaanderen of stelde zich toch zo voor. Het groepje vergaderde soms zelfs bij hem thuis. Als Mitarbeiter des Pressedelegierten der Etappeninspektion der 4. Armee bepleitte hij begin 1915 te Brussel succesvol de oprichting van het dagblad De Vlaamsche Post, waarvan hij de verborgen hoofdredacteur werd. ${ }^{181} \mathrm{Hij}$ vertaalde het beginselprogramma en 
twee hoogdravende brieven van de groep. Het proza werd naar de Duitse keizer opgestuurd. Die geschriften waren doordrenkt van een bombastisch pan-Germanisme. In de eerste brief (19 december 1914) drukte het groepje de hoop uit om na de "ure der bevrijding" [door Duitsland, $B Y$ ], wanneer Vlaanderen verlost zou zijn van "alle Romaanse dwang" op te bloeien "als frisse loot van de Germaanse stam". Dan zouden de Jong-Vlamingen als "echte Nederlanders van Kales tot de Maas [...] onder de hoge leiding van Uwe Majesteit trouwe grenswachters van het machtig Germanendom [worden]". De tweede brief werd in januari 1915 opgestuurd en bevatte onder meer de wens dat Vlaanderen in een federatief verbond met het keizerrijk zou mogen treden. De Jong-Vlamingen beweerden dat achter hen duizenden Vlamingen die nog niet openlijk optraden stonden. Toch spraken ze "deels met hun medeweten en goedkeuring" (sic). Wilhelm II heette de "herschepper van de oeroude en toch altijd jonge Teutonenvolkerenmaagschap, die de geschiedenis van ongeboren eeuwen de weg wijst en de Germanen der toekomst de baan opent" te zijn. Op 19 januari 1915 besliste Domela om deze brief ook naar alle leden van de Rijksdag te sturen. ${ }^{182}$

Er was vanaf eind oktober 1914 dus een anti-Belgisch groepje in Gent, maar dat modderde maar wat aan, zoals de (niet anti-Belgische) Antwerpse Groeningerwachten dat deden. Die hielden volgens Borms vanaf 29 november 1914 óók gesprekken, waarvan de oud-activist Hendrik Mommaerts later getuigde dat het "eenvoudige onderonsjes [waren], waar geen actie van uitging en [die] beperkt bleven tot het enge kringetje". ${ }^{183}$ Domela bracht wekenlang geen verandering in de situatie, hoewel de Duitse militairen zijn pogingen van meet af aan een warm hart toedroegen. Pas na de interventie van Wirth kwam de zaak in een stroomversnelling. Het gouvernementgeneraal in Brussel ging regelmatig op de rem staan. Het stoorde zich aan de onstuimige militaire etappe-overheid en haar radicaal Jong-Vlaams verlengstuk. Toch was er ook sympathie voor de groep. Von Bissing omschreef Jong-Vlaanderen niet voor niets als "der Vortrupp, die vorauseilende leichte Kavalerie einer Bewegung, [...] die einer Lösung des flämischen und belgischen Problems in deutsch-freundlichen Sinne zustrebt" ${ }^{184}$ De "lichte cavalerie" was natuurlijk niet de drijvende kracht achter het Duitse optreden, al had de groep zichzelf misschien wel graag die rol aangemeten. Zo eiste op 25 januari 1916 burgerlijk ingenieur Reimond Kimpe, die al in de herfst van 1914 lid was van Jong-Vlaanderen, in de Nederlandse Nieuwe Courant zelfs het geestelijke vaderschap van de vernederlandsing van de universiteit van Gent voor Jong-Vlaanderen op. De bezetter had die op 31 december 1915 bekend gemaakt. Binnen de 24 uur reageerden de Duitse diensten op het 
artikel. In hun repliek werd geponeerd dat Von Bissing onmiddellijk na het aanvaarden van zijn ambt, eind november 1914, de opdracht gegeven had om de kwestie van de vernederlandsing te onderzoeken. Het besluit was "eenvoudig het resultaat van dit [...] onder geen buitenwaartse [externe, Vlaamse, $B Y]$ invloeden gedane onderzoek van die kwestie [...]".185

Hoe evolueerden Flamenpolitik en activisme in het gouvernement-generaal? Op 13 februari 1915 sprak het hoofd van de Zivilverwaltung, Von Sandt, in zijn Arbeitsplan ter uitvoering van de instructies van december 1914 over de Flamenpolitik enkel van Duitse initiatieven. ${ }^{186}$ Drie maanden later schreef Von der Lancken aan Berlijn dat de Vlamingen louter met de Duitse administratie samenwerkten voor het goed van het land, zonder bun eigen politieke overtuiging op te geven. ${ }^{187}$ Anders gezegd, na negen maanden oorlog was er nog geen activistische fractie afgescheurd binnen de Vlaamse beweging, maar er waren wel Duitse initiatieven. Het is binnen die context dat we de ontwikkeling van het activisme moeten situeren. ${ }^{188}$

Voor Brussel bestaan er weinig bronnen. Het betreft vooral losse getuigenissen en de lijvige apologie van de oud-activist Faingnaert uit 1933. Ook is er informatie betreffende de Duitse agent Kurt-Heinrich (Henri) Rieth, die minstens even invloedrijk was als Wirth te Gent, omdat de Gazet van Brussel "de tolk dr. Rieth" ondergeschikt was ["unterstellt ist"], zoals we dat in een Duits verslag uit februari 1915 lezen. Zijn familie kwam al in het eerste hoofdstuk ter sprake. Voor heel wat materiaal over hem moet men zich beroepen op de Belgische pers. Die dient kritisch gelezen worden, wegens haar evidente partijdigheid. ${ }^{189}$ Voor het gezin Rieth betekende de oorlog een dramatisch keerpunt. Twee dagen na de Duitse inval in België werd ter wille van de landsverdediging het fraaie kasteel van Rieth sr., dat in een zone van 500 meter rond de Antwerpse forten lag en het gezichtsveld van een fort hinderde, met de grond gelijkgemaakt. ${ }^{190}$ De verwoesting nam twee dagen in beslag. Onder luid protest werd Rieth sr. net als zijn landgenoten uit Antwerpen verdreven. Uiteindelijk kwam hij via Nederland in Wiesbaden terecht. Op 71 jaar werd de nieuwbakken Rittmeister der Landwacht Kavalerie de oudste luitenant in het Duitse leger. ${ }^{191}$ Volgens een ooggetuigenverslag riep zoon Henri Rieth al op 20 augustus 1914 geüniformeerd in Brussel rond. In oktober begaf hij zich, afgaande op een verslag uit L'Echo Belge, naar Antwerpen. Hij zou nauwelijks enkele uren nadat het bombardement er gestopt was - dus begin oktober - de stad bereikt hebben. ${ }^{192}$ Het Belgisch Dagblad uit Den Haag meldde dat Rieth secretaris was van Von der Goltz en van Von Bissing. In de wandelgangen van de Zivilverwaltung noemde men hem Doktor Rieth. ${ }^{193}$ Deze informatie stemt overeen met die uit het gekende Duitse 
stuk uit februari 1915. Naar Le Vingtième Siècle op 2 februari 1915 schreef, stond Rieth samen met de journalisten Hackenbroich en Wertheimer, waar we in ons vijfde hoofdstuk nog uitgebreider op terugkomen, toen aan het hoofd van de censuur. ${ }^{194}$ Afgaande op informatie uit L'Indépendance Belge, was Wertheimer het hoofd van het bureau dat de Duitse affiches te Brussel vervaardigde. Het blad had enkele daarvan afgedrukt, waarvan de meest recente van 31 oktober 1914 dateerde, zodat we over een chronologisch houvast beschikken over zijn activiteiten. ${ }^{195}$

Volgens beweringen die in de Belgische vluchtelingenpers circuleerden, werd Rieth er door de bezettingsoverheid mee belast om een document van de hand van Trimborn, de katholieke referent voor onderwijszaken in België, in Keulen aan kardinaal Von Hartmann en de Zentrum-politicus Julius Bachem voor te leggen. Het was gericht tegen kardinaal Mercier. ${ }^{196}$ In het geschrift stonden inlichtingen om de kardinaal te kunnen bestrijden en werd aangezet om te antwoorden op het vaderlandslievende herderlijk schrijven (Patriotisme et Endurance) dat hij eind 1914 opstelde. Dat Trimborn katholiek was en Rieth in Leuven gestudeerd zou hebben, kan daar een rol in gespeeld hebben. ${ }^{197}$

De Amerikaanse ambassadeur Brand Whitlock bevestigde na de oorlog dat Rieth in 1915 een medewerker bleef van Von der Lancken, het hoofd van de Politische Abteilung. Op 11 december 1915 werd een nieuw organisme in het leven geroepen: de Vermittlungsstelle. Daarin werd Rieth tot vertegenwoordiger van de Politische Abteilung benoemd. Die Vermittlungsstelle regelde het dagelijks beheer van de betrekkingen tussen de Duitse overheid en het Comité National de Secours et d'Alimentation (opgericht op 1 september 1914). Dat orgaan stond, als verlengstuk van de Commission for Relief in Belgium, in voor de voedselvoorziening in bezet België. Dr. Rieth en dr. Schachs waren door de bezetter aangeduid om met Emile Francqui, voorzitter van het Comité national, over het werk en het statuut ervan te overleggen. ${ }^{198}$ Begin 1916 had het gouvernement-generaal te kennen gegeven dat het wenste dat het Comité National de lijsten verstrekte van Belgische werklozen. Vanaf oktober 1916 begon inderdaad hun verplichte tewerkstelling in Duitsland. Ook hierin speelde Rieth een rol. Vermoedelijk was hij toen niet meer in legerdienst, want het was de Amerikaan niet ontgaan dat hij op het gouvernement-generaal als burger gekleed ging. ${ }^{199}$ In oktober 1916 zou Rieth sr. met zijn gezin van Duitsland naar Dordrecht verhuisd zijn. ${ }^{200}$ Hij overleed in 1918 in het Zwitserse Sankt-Moritz. ${ }^{201}$ Tot 1918 bleef Henri Rieth werken op de Politische Abteilung. Na de oorlog stuurde het Auswärtiges Amt hem nog naar Darmstadt, het Quirinaal, Parijs en Wenen. ${ }^{202}$ In 1934 trok hij zich terug uit de 
diplomatie, nadat hij betrokken geweest zou zijn bij de moord op de Oostenrijkse kanselier Dolfuss. ${ }^{203}$ Later werd hij in de Verenigde Staten op verdenking van spionage gearresteerd. ${ }^{204} \mathrm{Na}$ zijn deportatie door de Amerikanen kwam hij eind 1941 in Zuid-Amerika aan. ${ }^{205}$ In de zomer van 1942 stond hij aan het hoofd van het Duitse consulaat te Tanger ${ }^{206} \mathrm{Na}$ de geallieerde invasie van Marokko tijdens de Tweede Wereldoorlog (in november 1942) speelde Rieth in op de islam als "vriend" van Duitsland bij de inheemse bevolking (speelde hier zijn ervaring met de Flamenpolitik geen rol?). ${ }^{207}$ Twee jaar later verliet hij Tanger. ${ }^{208} \mathrm{Na} 1945$ werd hij gestraft, maar in 1954 volgde de Wiedergutmachung. Hij kreeg naast eerherstel ook zijn titel terug: "Botschafter a.D."209

Op wie kon de bezetter nog een beroep doen? Zeker is dat Hans-Friedrich Blunck, een lid van de Quickborn, sedert eind september 1914 aan de Kommandantur verbonden was, waar hij de rol van justitieofficier vervulde en verbindingsman met Vlaamsgezinde kringen zou worden. ${ }^{210} \mathrm{Op} 22$ november leerde hij Justizanwalt en oud-Germania medewerker Fritz Norden kennen, een tot Belg genaturaliseerde Duitser die in Brussel woonachtig was. Norden bracht Blunck in contact met de liberale flamingant Frans Bogaerts. In december 1914 schreef Norden een memorandum over het "Vlaamse vraagstuk". Dat deed ook Frans Bogaerts. Begin januari 1915 werden die naar Blunck verstuurd. ${ }^{21}$

Nog belangrijker lijkt ons evenwel de rol van Haller von Ziegesar te zijn. ${ }^{212}$ Hoe kwam de bezetter erbij hem in te zetten? We weten dat op 8 september 1914 Von Bethmann-Hollweg een Denkschrift van Gerstenhauer, naar Von Sandt opstuurde, waarin hij Haller had aanbevolen. ${ }^{213}$ Haller, die in augustus 1914 in het buitenland verbleef, kwam pas op 8 november 1914 in Brussel aan. Dat had hij grotendeels aan Reismann-Grone (wiens dagboeknotities we kennen) te danken. ${ }^{214}$ Die laatste had in november de onderstaatssecretaris van de rijkskanselarij ontmoet en een Denkschrift over een te voeren Flamenpolitik opgesteld. Dat bereikte verschillende Duitse ministeries en het gouvernement-generaal in België. ${ }^{215}$ Op 14 december 1914 reisde Reismann-Grone naar de Belgische hoofdstad, waar hij Haller bezocht. Laatstgenoemde sprak hem over Von Bissing. Hij had het ook over Von Sandt en diens medewerker Trimborn en sprak lovend over Rieth. ${ }^{216} \mathrm{Hij}$ kende toen dus de man die de verborgen leiding had over de Gazet van Brussel. Anders gezegd, ten laatste medio december, maar vermoedelijk vroeger, had Von Sandt inderdaad contact met Haller opgenomen. Toen Picard begin januari 1915 Brussel bezocht, noteerde hij in zijn dagboek: "Haller von Ziegesar; Gazet van Brussel." 217 Het lijkt dus aannemelijk dat het gouvernement-generaal in Haller von Ziegesar de geknipte man zag om in de redactie daarvan te zetelen en er zelfs de (verborgen) hoofdredacteur van te zijn. Tenslotte 
had hij Germania tussen 1901 en 1904 geleid. ${ }^{218}$ Eind februari 1915 bezocht Reismann-Grone Haller von Ziegesar opnieuw. Die wist zijn vriend toen te bevestigen dat er op 11 januari 1915 een Ausschuß für vlämische Angelegenheiten opgericht was (hij wist dus dat die instelling bestond), waar hij met Dirr, waarover straks meer, samenwerkte. ${ }^{219}$ Uit de briefwisseling van de Antwerpse perscensor Gerstenhauer uit september 1915 met Sleeswijk, een redacteur van het met Duits geld gesubsidieerde Nederlandse tijdschrift $D e$ Toekomst komen we nog meer te weten over de rol van Haller von Ziegesar. ${ }^{220}$ De Nederlander had Gerstenhauer een proefdruk opgestuurd van het Oorlogsdagboek van Domela Nieuwenhuis, met de vraag aan de bezettingsoverheid om er enkele duizenden exemplaren van te financieren. ${ }^{221}$ Ook vroeg hij Gerstenhauer om de verspreiding van De Toekomst in Brussel onder Duitse officieren en Duitsgezinde Vlaamse en Nederlandse kringen. Dat moest dan gebeuren middels de inschakeling van "tussenpersonen" in België. "Maar geen officiële, openlijke aanbevelingen!" (het mocht naar buiten toe natuurlijk niet Duits ogen). Volgens Sleeswijk was Haller von Ziegesar misschien de aangewezen vertrouwenspersoon.

Volgens L'Echo Belge van 11 september 1915 "publiceerde" Haller von Ziegesar op dat moment de Gazet van Brussel. ${ }^{222}$ Op 1 januari 1916 noemde ook Het Vlaamsche Nieuws in een artikel Haller de opsteller (lees: de hoofdredacteur) van de Gazet van Brussel. ${ }^{223}$ Waarschijnlijk was zijn aandeel in de redactie van de Gazet van Brussel toen vergroot omdat Rieth zich vanaf eind 1915 op de Vermittlungsstelle zou toeleggen. Door op 1 januari 1916 het artikel waarvan sprake te laten afdrukken, had perscensor Gerstenhauer een fout gemaakt, waar Haller mee verveeld zat. Twee dagen later schreef die laatste een brief naar hoofdredacteur Borms om er zich over die "dwaling" te beklagen. Zoals verzocht, publiceerde Het Vlaamsche Nieuws zijn rechtzetting. ${ }^{224}$ Dat Haller op dat moment de hoofdredacteur was, was nochtans correct: nog in 1917 vermeldde een Duits archiefstuk dat hij en Emiel Van Bergen (was die er ook al eind 1914 bij?) de Gazet van Brussel leidden. ${ }^{225}$ Van Bergen was een katholieke Vlaamsgezinde en had samen met zijn broer vóór de oor$\log$ de Kriegsnovellen van Detlev von Liliencron vertaald. In 1917 noemde hij zich in een verzoekschrift van katholieken uit het bisdom Mechelen aan de paus de "gewezen beheerder van de Belgische Anti-Vrijmetselaarsbond".226 Afgaande op het Belgisch Dagblad van 26 oktober 1915 was hij vroeger vertaler van het Anti Maçonniek Bulletijn en toen redacteur van de Gazet van Brussel. Bovendien verzorgde hij op dat moment de Nederlandse vertalingen van de officiële Duitse mededelingen. ${ }^{227}$ Omdat we weten dat Wertheimer bevoegd voor die affiches was, lijkt het duidelijk dat Van Bergen toen ook 
voor hem werkte. Op 14 maart 1915 maakte die laatste zich kenbaar toen de Gazet van Brussel hem als hoofdredacteur vermeldde. Drie maanden later bevestigde een Duits document deze functie.

Een volgende spilfiguur op het gouvernement-generaal was de vermelde Pius Dirr. Dirr zou bij de gevechten te Hazebroek in oktober 1914 gewond geraakt zijn. Hij werd in de streek gaandeweg ingelicht over de Vlaamse beweging. ${ }^{228}$ Von der Lancken meldde in zijn memoires dat het Beierse Armee-Kommando VI waar Dirr in ondergebracht was, voeling zocht met de bevolking en vooraanstaande persoonlijkheden, om door waarschuwingen oorlogsmisdaden te voorkomen. Dirr stelde daaromtrent rapporten op. Daaruit ontstonden dan enkele maanden later geschriften over een te voeren Flamenpolitik. ${ }^{229}$ Zonder twijfel was de Duitse nationalist Dirr bijzonder geschikt voor de taak. Hij zetelde in het Beierse Lagerhuis, verdedigde er de Beierse en Duitse bewapening en kwam in contact met de invloedrijke Alduitser generaal Keim. De door die laatste beoogde legerwet was in 1913 door de Rijksdag goedgekeurd. ${ }^{230}$

Op bevel van het hoofd van de generale staf van kroonprins Rupprecht van Beieren legde Dirr na enkele maanden oorlog de Vlaamse kwestie in een bijzondere lezing uit. Eind november vatte hij, als we Von der Lancken mogen geloven, zijn opgedane kennis samen in een Denkschrift voor de Beierse minister-president Von Hertling. De vraag was hoe de Vlaamse publieke opinie in pro-Duitse zin gestuurd kon worden. Vanuit het Armee-Kommando VI zond Von Hertling het Denkschrift naar de Rijksleiding en het Auswärtiges Amt op. In het schrijven beval Dirr een voorzichtige propaganda in het etappegebied en in het gouvernement-generaal aan. Op 14 december zond het Armee-Kommando VI het document terug naar Dirr, met de aanbeveling het meteen aan het generaal-gouvernement te overhandigen. Een meer gedetailleerd Denkschrift zond Dirr overigens ook naar kroonprins Rupprecht op. Daarin stond de vraag naar propaganda in België centraal. Nadat Von Bissing Von der Goltz opgevolgd had, verkreeg hij een kopie van het bericht van Dirr. De nieuwe gouverneur-generaal wenste over de daarin opgenomen suggesties een mondeling onderhoud. Op 24 december 1914 vond dat plaats. De suggesties van Dirr waren, volgens Von der Lancken, opgebouwd op grond van ervaringen in het operatiegebied met Vlaamse voormannen en legden het accent op twee noodzakelijkheden. Allereerst de aanwending van een voorzichtige, maar doelbewuste actie om voeling met Vlaamsgezinde leiders te bekomen en zo de mogelijkheid van een inwerking op de Vlaamse bevolking te verkrijgen. Zo moest de door de oorlog verlamde Vlaamse beweging opnieuw op gang getrokken worden. Bovendien beval Dirr een onderzoek aan om te analyseren in hoeverre de Duitse belangen met de Vlaamse parallel 
liepen. Anders gezegd, om te bekijken hoe de Vlaamse beweging het best in de Duitse oorlogsmachine ingeschakeld kon worden. Zo konden de volgende stappen van de Flamenpolitik gezet worden. Inzonderheid moest onderzocht worden in welke mate men door de uitvoering van bestaande, maar nog onuitgevoerde Belgische wetten en wetsontwerpen, zoals de schoolwetten, de Vlamingen kon "tegemoetkomen" - lees: lokken. ${ }^{231}$ Wat was de impact van de Duitse activiteiten op de Brusselse Vlaamsgezinden?

Op 22 juli 1915 schreef Emiel Van Bergen, toen de hoofdredacteur van de Gazet van Brussel, hoe het "Vlaams geestesverkeer" vanaf augustus 1914 stilviel en de Vlamingen de Godsvrede naleefden, onlangs de "drieste" provocaties van de verfransers. Dat deden ze nog toen men "van Waalse zijde" na de val van Antwerpen openlijk en bedekt schande sprak van de overgave van Antwerpen, de ondergang van de stad wenste en dreigde dat dit bij de terugkeer van de geallieerden zou gebeuren. Toen men echter de verfransing in Brussel "schrikbarend" zag toenemen en de "Vlaamshaters" stappen zetten om van Brussel een Franstalige stad te maken onder Duits bestuur, zag - aldus Van Bergen - de Gazet van Brussel het daglicht. ${ }^{232}$ Het pamflet La Vérité zou pas in januari 1915 verschijnen en het verhaal over die "stappen" van Franstaligen bij de Duitse bezetter behoorde tot de Duitse oorlogspropaganda. Deze getuigenis doet reeds uitschijnen dat er van een Vlaamsgezinde actie niets in huis kwam.

Faingnaert beweerde dat na de bezetting van Brussel (20 augustus 1914) de Vlaamsgezinden regelmatig in het "Vlaams Huis" op de Grote Markt samenkwamen. Hij had het over vergaderingen die meermaals per week plaatsvonden. Maar was het wel zo'n levendige bedoening in het Vlaams Huis? Jef Herremans, een redacteur bij het Duits-activistische Vlaamsche Nieuws, merkte op 3 oktober 1915 gelaten op hoe toen men in Brussel het Vlaams Huis gesticht had - dus vóór de oorlog - enkel in het begin alles heel goed verliep. Maar weldra bleef een categorie Vlamingen er weg. De redenen waren volgens hem dat er mensen kwamen van een andere politieke overtuiging en dat sommigen het Huis niet "voornaam" genoeg vonden. Zij gingen liever naar "de grote koffiehuizen der boulevards, waar zij in 't Frans bediend werden”. Tenslotte kende hij er ook die wegbleven "omdat sommige jongeren bekritiseerden wat te bekritiseren was [...] en zij zulks niet konden verkroppen [...] En zo begon stilaan het Vlaams Huis op krukken te springen, en de duivel weet wat er na de oorlog mee zal gebeuren".233 Blijkbaar rommelde het dus al vóór de oorlog in het Vlaams Huis. Maar dat er na de bezetting van Brussel van daaruit opnieuw een (intense) activiteit uitging, schreef Herremans niét. Hoe dan ook, volgens Faingnaert heerste er bij de 
flaminganten een "verwarring in de geesten". Was die het gevolg van de oorlogsomstandigheden? Of van het Duitse aandringen? Of van beide?234 $\mathrm{Als}$ we de schrijver mogen geloven, tekenden er zich tussen de deelnemers "al dadelijk" drie richtingen af. De eerste zou onvoorwaardelijk loyaal gebleven zijn aan de Belgische staat. De tweede vormde een "middengroep". De "radicalen" ten slotte hadden gebroken met de Belgische staat.

Dat Vlaamsgezinden elkaar ontmoetten, valt niet uit te sluiten, wel dat er meteen een georganiseerde groepsvorming was. Omdat we weten dat de eerste polemieken in de vluchtelingenpers pas van medio oktober 1914 dateerden en de eerste "pro-Vlaamse" maatregelen van de bezetter pas de volgende maand merkbaar werden, was er voordien wel stof tot gesprek - het verloop van de oorlog - maar geen reden om voordien tot een discussie over de Vlaamse kwestie over te gaan. Maar wat Faingnaert weergeeft is in hoofdzaak geen historische, maar (grotendeels) wel een post factum constructie. Getuige daarvan bijvoorbeeld volgende passage over "...de voorwaardelijke loyalen, die verkondigden dat de onderdaan niet alleen plichten had tegenover de staat, doch ook in alle omstandigheden zijn recht van de staat mag opeisen". 235 Deze formulering om een groep uit 1914 te definiëren is ontleend aan de zogenaamde "loyauteitstheorie" die de Groot-Nederlander Gerretson pas in de lente van 1915 zou verkondigen. ${ }^{236}$ De stijlfiguur dat "al dadelijk" verschillende meningen tot uiting kwamen, zou de auteur trouwens nog gebruiken voor gebeurtenissen die zich pas maanden later afspeelden. ${ }^{237}$ Hij baseerde zich voor het tijdstip en het gebeuren voornamelijk niet op zijn eigen herinneringen, maar wel op de activistische propaganda. Daarin lezen we al in 1917 hoe de meeste Vlaamsgezinde kringen bij het uitbreken van de oorlog hun werkzaamheid staakten:

Echter niet allen. In de grote centra Brussel, Antwerpen, Oostende en vooral te Gent, werden de koelgebleven Vlaamse koppen weer spoedig bijeen gestoken. De voor Vlaanderen nieuwe toestanden werden in besloten kringen besproken en toen de kringen met de dag in sterkte toenamen, werd besloten de strijd weer aan te binden. ${ }^{238}$

Slechts een aantal beweringen van Faingnaert kunnen kloppen, bijvoorbeeld dat er ongenoegen was over "anti-Vlaamse" uitlatingen in de Franstalige vluchtelingenpers. Dat zal pas ten vroegste vanaf november 1914 geweest zijn. Bovendien ging het dan om verdraaiingen van de bezetter, want in België kon men geen vluchtelingenbladen lezen. Sommige van de vermeende meningsverschillen in het Vlaams Huis behoren ook tot de latere Duitse 
oorlogspropaganda. Inzake La Vérité bijvoorbeeld zit de chronologie volledig fout. Ook beweert Faingnaert meermaals in zijn boek dat de Waalse volksvertegenwoordiger Buisset bij Von der Goltz was gaan protesteren over het gebruik van de Nederlandse taal (op officiële Duitse bekendmakingen), tegen de gelijkheidswet van 1898, zelfs was gaan vertellen dat het Frans de enige officiële taal in België was. En dat Walen en Fransgezinden toen reeds "op onbeschaamde wijze" handel dreven met de vijand. Ondertussen weten we dat het verhaal over Buisset berust op een Duitse propagandaleugen, waar we in hoofdstuk 5 nog uitgebreid op terugkomen. En dat de beweringen over die "oorlogswoekeraars" hun oorsprong vinden in de apologetische propaganda die de activistische voorstelling opklopte. 239

Niettemin is het interessant om op te merken dat Faingnaert beweerde dat het eerste wantrouwen van de "loyalen" tegenover de anderen er kwam, toen advocaat Willem Thelen kwam vertellen "dat Buisset en andere Walen" zich tot Von der Goltz hadden gewend om te protesteren tegen het gebruik van het Nederlands. Volgens Faingnaert opperden de "radicalen" toen, tegen het advies van de "loyalen" in, het idee om de Duitsers over de taalwetten en de Vlaamse taalrechten in te lichten en was dit het begin van de tweespalt in de groep. "Sedertdien", zo beweerde hij, "werd het Duits bestuur langs een omweg voorgelicht en gedocumenteerd nopens het talenvraagstuk en de toestand van het Germaans element in België, vooral door bemiddeling van de heer Haller von Ziegesar" ${ }^{240}$ Het vermelde verhaal over het activistische initiatief na de vermeende actie van Buisset ontstond al tijdens het conflict. Zo schreef Het Vlaamsche Nieuws op 13 oktober 1918 dat

nadat de Waalse volksvertegenwoordiger Buisset gepoogd had de bezettende macht [met name Von der Goltz, $B Y$ ] te misleiden, door het Frans als enige officiële taal in België voor te stellen, [...] de Vlaamse activisten, de Duitsers op hun plicht ten opzichte der Vlaamse bevolking gewezen [hadden]. ${ }^{241}$

Maar de mogelijkheid dat de bezetter al onder Von der Goltz geruchten rondstrooide over Waals stoken tegen het Nederlands, mag niet uitgesloten worden. Ook niet dat hij daarvoor een beroep deed op personen als Haller en Thelen. ${ }^{242}$ Blunck schreef immers in zijn propagandawerk dat ten laatste in juli 1915 verscheen: ${ }^{243}$

Die, die dich zuerst in ganz Belgien an die deutsche Regierung drängten, waren Wallonen. Haben sie nicht in Brüssel viel hundert Mal versucht 
uns zu überzeugen, es gebe keine Vlamen mehr. Haben sie nicht überall unter dem Sand das verhaßte Dietsch wieder auszulöschen versucht, nur weil's jetzt leichter beim Gesetz vorbeiglitt. ${ }^{244}$

Thelen was een geboren Nederlands-Limburger die tot Belg genaturaliseerd werd. Hij was zoon van een Nederlands majoor-op-rust en een Duitse moeder. Rond de eeuwwisseling fungeerde hij als medewerker aan het tijdschrift Germania. Net als Josson was hij advocaat aan het hof van beroep te Brussel. Voorts was hij voorzitter van het Algemeen Nederlands Verbond-België. Eind april 1914 stuurde Thelen in die hoedanigheid een brief naar de kandidaten voor de verkiezingen van 24 mei 1914 met daarin een protest tegen de eisen van de Assemblée Wallonne. De man behartigde aan het begin van de oorlog als rechtskundig raadsman meermaals de belangen van zijn Nederlandse cliënten op de Kommandantur. In 1915 zou die hem aanbevelen om processen van de Duitsers in Brussel te bepleiten. ${ }^{245}$ Overigens kende Thelen Haller goed en niet alleen via Germania. Het contact tussen beiden overleefde de teloorgang van het tijdschrift en ze zouden samen nog kandideren voor de Kamerverkiezingen van 27 mei 1906 op de lijst van de Vlaamse Volkspartij. ${ }^{246}$

Faingnaert beweerde dat op 16 november 1914 de voormalige anarchist August Vermeylen voor de eerste keer in het Vlaams Huis verscheen om daar een onvoorwaardelijke loyauteit te eisen aan koning en vaderland. Daarop zou een twist gevolgd zijn, vooral tussen Vermeylen enerzijds en journalist Grosemans en ambtenaar De Raet anderzijds. Die mondde dan, aldus Faingnaert, uit op een breuk in de groep. ${ }^{247}$ Vermeylen zou, aldus een naoorlogse getuige, "de geheime vergaderingen van Vlamingen, om het activisme te bestrijden" voorzitten. Volgens Faingnaert gebeurde dat vanaf de breuk. ${ }^{248}$ De Raet overleed op 24 november $1914 .{ }^{249}$ Bij de jurist Derk Hoek die als correspondent van het christelijk-historische dagblad De Nederlander omtrent dat tijdstip in België verbleef, vernemen we meer informatie over August Vermeylen. Af te gaan op zijn briefwisseling, bevond Hoek zich op 7 december 1914 in Gent en vijf dagen later te Brussel. Hij tekende de verschillende stromingen in België op, vernoemde daarbij op 12 december de naam van Jong-Vlaanderen (op een moment dat de groep zich nog niet aan de buitenwereld kenbaar had gemaakt) en zette Vermeylen daarentegen op één lijn met Paul Fredericq en Karel Van de Woestijne. Hoek omschreef hem als een "Fransgezinde" en een "Duitshatende" [Hij was dus Belgischgezind, $B Y]$. De Vlaamsgezinde Brusselaar zou hem opgeworpen hebben dat er geen moderne Duitse beschaving bestond, buiten die van de macht. ${ }^{250}$ Naar Picard 
op 24 december 1914 in zijn dagboek noteerde, had ook Eugeen De Bock, zijn jeugdvriend die toen op de Antwerpse stadsbibliotheek werkte, Vermeylen als een "Deutschenhetzer" omschreven. Nog volgens De Bock was De Raet "zeer Duitsgezind". ${ }^{51}$ Die laatste bewering moeten we niet aannemen, maar dat Vermeylen zo hevig anti-Duits was, kon De Bock niet uit de pers vernomen hebben. Het verslag van Hoek daarover verscheen immers pas nadien in De Nederlander. Ageerde Vermeylen toen al tegen de Flamenpolitik?

En over wat ging het vermeende dispuut waarvan Faingnaert gewag maakte? Constant De Sadeleer, die volgens Faingnaert bij de groepsvorming betrokken was, beweerde op 13 augustus 1915 - hij was toen redacteur bij de Gazet van Brussel - dat De Raet na verschillende weken bezetting opmerkte dat er Franstalige nieuwsbladen verschenen. Toen ijverde hij, volgens De Sadeleer, voor een Vlaams dagblad. Vermeylen zou zich tegen het initiatief verzet hebben. De Raet had enkele vrienden samengeroepen om over de toestand te beraadslagen en naar de uitgever van een bekend Vlaams dagblad te stappen om het te doen herverschijnen. Vermeylen was volgens de redacteur niet "vatbaar voor rede" en drong erop aan dat "de Vlamingen zich ondanks alles en ten koste van alles moesten schuilhouden". De krantenuitgever antwoordde De Raet cum suis dat hij gebonden was tegenover de Persbond (omdat die omtrent dat tijdstip de verschijning van dagbladen in het bezette land expliciet had afgekeurd?) en er in de huidige omstandigheden geld aan zou verliezen. Een van de door De Sadeleer aan De Raet toegeschreven motieven was dat hij er bezwaar tegen had dat de bevolking de domme praatjes slikte die de ronde deden. Maar die praatjes gingen niet over antiVlaamse drijverijen van de "franskiljons". Immers, "[er] was nog niets bekend van het hatelijk gekonkelfoes van de franskiljonse kliek tegen het Vlaamse volk en de Scheldestad". 252 Men kan hieruit afleiden dat het geruzie tussen de Vlaamsgezinden medio november 1914 nog niet ging over geruchten rond een anti-Vlaamse campagne in het algemeen noch over de "ware toedracht" betreffende de val van Antwerpen in het bijzonder. Of, anders gezegd, de Duitse propaganda daarover vond pas daarna in Brussel ingang. Inderdaad verschenen de eerste cruciale stukken over de capitulatie van Antwerpen tussen 26 november en 9 december 1914 in de Duitse pers en in de collaboratiepers. Dit bevestigt de suggestie van Wils dat de geplande uitgave van de Gazet van Brussel (op 29 november 1914) door de Duitse bezetter de (of een?) echte aanleiding was tot onenigheid. ${ }^{253}$ Pas nadien zal er waarschijnlijk gesproken zijn over de "anti-Vlaamse campagne" en over Duitse geruchten over "de Walen" die het Nederlands wilden afschaffen. Ten laatste medio 
december 1914 zullen vele Brusselse Vlaamsgezinden wel geweten hebben hoe laat het was omdat de bezetter vanaf toen het "Vlaams Huis" als uitvalsbasis gebruikte voor de verspreiding van zijn propagandaorgaan, de Gazet van Brussel.

De reactie van de Brusselaars en Josson daarop kennen we, maar ook Karel Van de Woestijne had het op 28 december 1914 over verdachtmakingen tegen Vlaamsgezinden, hoewel "de voornaamste daaronder" de Godsvrede onderhielden. ${ }^{254}$ Niet iedereen dus. Ten laatste op 7 januari 1915 begon Constant de Sadeleer, die voordien geen rol van betekenis speelde in de Vlaamse beweging, voor de Gazet van Brussel te schrijven. ${ }^{255}$

Begin februari 1915 waarschuwde dat blad de Brusselse flaminganten die aan een "gevaarlijke slaapziekte" leden. ${ }^{256}$ Van groepsvorming was er toen dus nog steeds geen sprake. ${ }^{257}$ Wel van individuele collaboratie van personen als Rieth, Bogaerts, Von Ziegesar, Norden, Thelen en De Sadeleer. Waarschijnlijk ook van Van Bergen en misschien van Lambrichts. Die laatste was een geboren Nederlander die de Belgische nationaliteit aangenomen had. Hij was voorzitter van de Brusselse afdeling van de Katholieke Vlaamse Landsbond. ${ }^{258}$ Het ging voornamelijk over personen die familiaal op Duitsland of Nederland gericht waren, waardoor hun trouw aan België zwakker was. Voor wat de Gazet van Brussel betreft, is er geen reden om aan te nemen dat de enkele medewerkers die het Duitse blad vanaf november 1914 had, Vlaamsgezind waren, op Haller en - misschien - Van Bergen en Lambrichts na. Het betrof zeer waarschijnlijk vooral collaborateurs die om den brode bereid waren te schrijven voor een dagblad dat door de bezetter gesubsidieerd was. ${ }^{259}$

Dat te Brussel het Vlaamsgezind leven stil lag, werd overigens door de hoofdstedelijke correspondent van De Vlaamsche Post uit Gent bevestigd. Op 27 februari 1915 schreef die naar het blad dat het Vlaamse geestesleven in Brussel zich in een "verderfelijke slaap" bevond en hekelde hij de onwerkdadigheid van de Vlaamse middens. ${ }^{260}$ Die visie werd bevestigd in een artikel dat uit België naar het Nederlandse Algemeen Handelsblad (17 maart 1915) gestuurd werd. Daarin vindt men de overname van activistische geluiden die in Antwerpen te horen waren. ${ }^{261}$ "Hoe komt het", zo merkte De Vlaamsche Stem uit Amsterdam aan de hand hiervan op, "dat nog alléén uit Antwerpen en Gent stemmen van willende en werkende levenden opgaan?"262 Dat waren de activisten, van wie het Belgisch-loyale dagblad dat toen blijkbaar nog niet wist.

Op 14 mei 1915 publiceerde Het Vlaamsche Nieuws uit Antwerpen een verslag van een redevoering van August Borms van twee dagen eerder. Die beweerde dat de Vlamingen in Brussel nog "voorzichtig onder hun schelp" zaten. Dat gold met name voor Vermeylen en Van de Woestijne (omdat ze 
zich verzetten tegen de Flamenpolitik?). ${ }^{263}$ "Te Brussel zien we slechts Frans Reinhard die van nu af het aangekondigd Antivlaams Schrikbewind durft te trotseren en Maurits Josson, tegen wie reeds doodsbedreigingen [een duidelijke verwijzing naar hun manifest, $B Y$ ] werden uitgesproken."264 Dit stuk inspireerde Le Vingtieme Siècle drie weken later tot een vermanend artikel waarin zowel naar Borms en Josson als naar Reinhard uitgehaald werd. Over die laatste twee meldde het dagblad: "[ils] sont traités, comme des pestiférés, et à bon droit, par leurs compatriotes Flamands et Wallons révoltés de leur servilisme à l'endroit des Prussiens." ${ }^{265}$ Op 6 juni 1915 meldde Het Vlaamsche Nieuws dat in Brussel sinds tien maanden de "talrijke Vlaamse maatschappijen" ingesluimerd waren. ${ }^{266}$ De Brusselse correspondent van $D e$ Vlaamsche Post drukte in verschillende brieven zijn ongenoegen daarover uit. Op 18 juni 1915 betreurde hij hoe de "commandobrug der Vlaamse beweging" er sedert elf maanden verlaten bijlag, blijkbaar omdat de vroegere leiders zwegen. ${ }^{267}$ Vier dagen later herhaalde hij die klacht en werd eraan toegevoegd hoe de Duitsers verklaarden dat Vlaanderen vrij moest zijn, met een eigen bestuur, ja als autonome staat [de bezetter voerde dus zeer duidelijk een Flamenpolitik, BY]. De meeste Vlaamse "ezels" echter stremden de vooruitgang van de zelfstandige ontwikkeling van Vlaanderen. Ze maakten, aldus de correspondent, geen gebruik van de door de bezetter geschonken taalvrijheid om de Vlaamse zelfstandigheid te vestigen. En zij niet alleen, maar ook de bestuurders van Vlaamse verenigingen die "te Brussel [...] het ganse raderwerk der Vlaamse beweging stil" gelegd hadden. ${ }^{268}$ Het initiatief ging dus blijkbaar enkel van de bezetter uit, wat de correspondent op 29 juni 1915 ook uitdrukkelijk bevestigde. Hij schreef immers dat het "ingrijpen vanwege het Duitse bestuur [ten voordele van de Nederlandse taal in Brussel, $B Y$ ] [...] zonder Vlaamsgezinde medehulp" tot stand kwam. ${ }^{269}$ Sterker nog, Vlaamsgezinde kringen en bonden in Brussel, zo werd begin juli door hem gemeld, vertikten het zelfs om te waken over de stipte toepassing van de Duitse verordening om in de bioscopen verplicht het Nederlands te gebruiken. ${ }^{270}$

Toch startte de georganiseerde collaboratie op initiatief van Paul Simons van het Alldeutscher Verband in Brussel op 18 juni 1915 met een vergadering. Van Bergen was er als journalist voor de Gazet van Brussel aanwezig, zo ook anderen onder wie zijn overste Rieth en Blunck, voor de Politische Abteilung. Later zou het collaborerende groepje zich de Vrienden van de Vlaamsche Zaak noemen. ${ }^{271}$ Haller werd afgevaardigde bij deze organisatie. ${ }^{272} \mathrm{Hij}$ hield zich ook met het Gentse activisme in. Daarom kon men in de notulen van Jong-Vlaanderen op 3 juni 1915 melden dat Haller voor De Vlaamsche Post een redacteur gevonden had, de oud-Germania medewerker Jef Hinder- 
dael. ${ }^{273}$ Het is overigens pas in een brief die de Brusselse correspondent van De Vlaamsche Post een week nà de vergadering te Brussel schreef, dat voor het eerst een optimistische toon doorklonk. De aanleiding daartoe was blijkbaar dat Josson een klacht wegens eerroof neergelegd had tegen L'Echo Belge. Volgens de correspondent van het Duits-activistische blad uit Gent kon die actie van Josson in Brussel op bijval rekenen: “...vele onder de Brusselse Vlamingen beschouwen het gebeurde als een les, een bittere les, waaruit blijkt dat braaf toezien [...] de Vlamingen meer kwaad dan goed berokkent." Het artikel waarop Josson het gemunt had, was het eerder vermelde stuk uit $L e$ Vingtième Siècle dat naar hem, Borms en Reinhard uithaalde. Het was inderdaad op 15 juni 1915 door L'Echo Belge overgenomen. ${ }^{274}$ Omdat De Vlaamsche Post pas op 8 juli als enige in bezet België het artikel uit L'Echo Belge gepubliceerd had en Josson in België geen Franstalige bladen uit Amsterdam of Le Havre kon lezen, moeten we ervan moeten uitgaan dat de Duitse diensten het stuk voordien in Brussel verspreidden. ${ }^{275}$ Lode Wils noemde het "ontstaan van het activisme in Brussel [...] de vrucht van negen maanden Duitse propaganda”. ${ }^{276}$ Ons eigen onderzoek bevestigt deze stelling.

Voor wat de Antwerpse Flamenpolitik betreft, was het belang van Max Robert Gerstenhauer onmiskenbaar. Hij werd vermoedelijk gewond aan het front en misschien was dat de reden waarom hij pas in januari 1915 door het generaal-gouvernement naar België geroepen werd. De Antwerpse perscensor sympathiseerde als enige binnen de Politische Abteilung met de radicalen van Jong-Vlaanderen. ${ }^{277} \mathrm{Nog}$ twee figuren wekken er de aandacht. Allereerst de protestantse dominee August Schowalter. Medio november 1914 kwam die in de Scheldestad aan. Daar werd hij provinciaal Gouvernementspfarrer. Schowalter interesseerde zich al rond de eeuwwisseling voor de Vlaamse beweging. In 1902, na de laatste Boerenoorlog, gaf hij de memoires uit van Krüger, de voormalige president van de Zuid-Afrikaanse republiek. In november 1914 probeerde hij vanuit bezet Antwerpen het Duitse publiek te mobiliseren voor de anti-Britse Zuid-Afrikaanse rebellie. Hij zou zich vrijwillig opgegeven hebben om naar België te komen. Bij zijn komst stonden hem "bepaalde doelen voor ogen". ${ }^{278}$ Was hij daarvoor door de Duitse overheid gemandateerd? Vanaf januari 1915 werkte hij op de Ausschuß für vlämische Angelegenheiten. De Politische Abteilung was niet ontevreden over zijn werk, maar in de herfst van 1915 werd hij toch bedankt voor bewezen diensten. ${ }^{279}$ Als Alduitser had hij te veel openlijke sympathie betoond voor de groep Jong-Vlaanderen hetgeen, aldus Von der Lancken, niet aansloot bij een voorzichtige politieke activiteit. Terug in Duitsland bleef hij het vertrouwen van de tactisch meer radicale militairen genieten. 
De tweede figuur, priester Lüdwig Hürter, ontpopte zich tot de katholieke tegenhanger van Schowalter. Sedert 1907 verbleef hij in de provincie Luik. In de eerste oorlogsmaanden schreef hij een artikel waarin stond dat de Vlaamse beweging als oogmerk "die Befreiung der alten germanischen Kultur Flanderns von diesem Fremden Zwange” had. Vanaf oktober 1914 werd hij aalmoezenier van het Duitse garnizoen en Gouvernementspfarrer. In februari 1915 trad ook hij tot de Ausschuß toe. Hij schreef twee völkische propagandawerken over de "Vlaamse kwestie". Maandenlang viel het Duitse lokken in flamingantische dovemansoren. August Borms vond het na een tijdje zelfs niet meer de moeite om de vergaderingen van de Antwerpse Groeningerwachten bij te wonen. ${ }^{280}$ In 1930 zou diezelfde Borms getuigen dat geen enkele Vlaamsgezinde tot eind januari 1915 de Godsvrede doorbrak. Van een flamingantisch initiatief kwam niets in huis. Toch haalde perscensor Gerstenhauer, die als dusdanig de verborgen leiding over Het Vlaamsche Nieuws uitoefende, in februari 1915 August Borms tot collaboratie over. ${ }^{281}$

Het eerste openbaar optreden van Borms kwam er naar aanleiding van een bericht van 2 februari 1915 uit de Berlijnse Deutscher Kurier. Dat blad meldde hoe vóór de oorlog Vlamingen en Duitsers, die het Nederlands minachtten, en tot de hogere burgerij behoorden, bijna vijandig tegenover elkaar stonden. Het sprak de hoop uit dat zulke toestanden tot het verleden behoorden en dat er met het "ontwaken" van het Vlaamse volk rekening zou gehouden worden. Om te beginnen moest dus de taalwetgeving aangepast worden. Maar naar Borms in Vlamingen, waakt! in Het Vlaamsche Nieuws (17 februari 1915) - en meer uitgebreid in het Handelsblad en de Gazet van Brussel van enkele dagen later - meldde, was er niets veranderd. Staatsambtenaren verkregen Duits-Franse formulieren "waarop het Nederlands gebannen was". Bovendien moest het postverkeer tussen België en zijn buurlanden uitsluitend in het Frans plaatsvinden.

Ge ziet, zoals het vroeger was vóór de oorlog, zo is het nu onder de bezetting; maar dat zal geen enkel van die heren Vlaamshaters aan de Amstel, aan de Thames of waar ook beletten van achter onze rug, geheim en bedektelijk, rond te lopen om te zeggen dat de flaminganten aanspannen met de Duitsers! ${ }^{282}$

Le Vingtième Siècle vergeleek Borms' artikel daarop met wat Henderickx eerder geschreven had. "Allez donc parler aux soldats belges, dans les tranchées, de Wallons et de Flamands, pour voir s'ils se prêteront à cette querelle... 
d'Allemand!" Niemand dacht er volgens het katholieke blad aan de rechten van het Vlaamse volk na de oorlog te schenden. Mocht het na afloop toch gevaar lopen, dan was dat omdat Henderickx, Het Handelsblad, kortom de onruststokers die in de kaarten van de vijand speelden het gecompromitteerd hadden door tijdens het conflict landgenoten aan te vallen. ${ }^{283}$ Dit versterkte de Duits-activistische propaganda die eerder al verkondigde dat de Vlamingen een "oog in 't zeil" moesten houden, daar de "wapenstilstand" die de Godsvrede heette te zijn, ervoor zorgde dat hun tegenstanders het Vlaamse volk in den vreemde verraderlijk bleven aanvallen. ${ }^{284}$ Perscensor Gerstenhauer corrigeerde 's anderendaags het bericht van Borms: Nederlandstalige brieven naar het buitenland werden na controle door de censuur bijna allemaal afgeleverd, binnen België zelf was er geen enkel probleem en het gebruik van de Vlaamse taal was onvoorwaardelijk toegelaten voor de correspondentie met krijgsgevangenen in Duitsland. Voorlopige beperkingen vonden hun oorsprong in het feit dat het door de oorlog niet vanzelfsprekend was om veel Duits personeel (voor de censuur) te verzamelen dat het Nederlands machtig was. De Gazet van Brussel publiceerde op 21 februari 1915 het artikel van Borms, samen met het antwoord van Gerstenhauer. ${ }^{285}$ Drie dagen later vernam het blad uit "goede bron" dat het Duits bestuur beslist had in alle Belgische postkantoren de briefwisseling in de Vlaamse taal toe te laten. Nu de moeilijkheid van het ontoereikend aantal censuurbeambten die het Nederlands machtig waren overkomen was, zouden, volgens het dagblad

de Vlamingen over heel het land [...] met genoegen ervan kennis nemen, dat aan hun wensen [...], die ook in ons blad herhaaldelijk ter uitdrukking gekomen zijn, nu voldoening is gegeven [...] Wij herinneren bij deze gelegenheid er aan, dat de briefwisseling in de Vlaamse taal met de gevangenen in Duitsland van bij begin af van dit postverkeer toegelaten is geweest $[s i c] .{ }^{286}$

$\mathrm{Al}$ in de herfst van 1914 wist de Duitse bezetter dat er uit de taal van de correspondentie met krijgsgevangenen munt te slaan viel. Want op 25 november 1914 had het liberale Nationaal Vlaams Verbond zich tot de toen voor taalvraagstukken bevoegde specialist Trimborn gewend. De reden voor die demarche was dat het toen nog verboden was voor Belgische soldaten in krijgsgevangenschap in het Nederlands te corresponderen. ${ }^{287}$ Trimborn had daarop Josson en Reinhard voor een gesprek uitgenodigd, maar die wezen dat af. In de plaats daarvan, kwam het wel tot een ontmoeting tussen Trimborn en Lambrichts. ${ }^{288}$ (Werd die daar tot collaboratie overgehaald?) Hoe 
dan ook, het vermelde bericht uit de Gazet van Brussel was duidelijk een commentaar op de correspondentie tussen Borms en Gerstenhauer. ${ }^{289}$ Sterker nog werd een en ander in Het Vlaamsche Nieuws uitgedrukt. Een Vlaming, zo heette het, hoefde niet nederig te doen tegenover een Duits soldaat. Beiden waren Germanen, met een nauwe taalverwantschap. Daarom kon de Duitser het beter met zijn mentaliteit vinden dan met die van een Waal. De Duitsers behandelden de Vlamingen ook beter: de Vlaamse grieven verdwenen in de openbare besturen "als bij een toverslag" [door de Flamenpolitik dus, $B Y] .290$

Ook na de gepubliceerde correspondentie tussen Borms en Gerstenhauer kwamen er nog klachten over Duits onbegrip aangaande de taalkwestie. In een Brief uit Antwerpen die op 21 maart 1915 in De Vlaamsche Stem uit Amsterdam verscheen, stelde de schrijver dat in Oost- en West-Vlaanderen de uitwijkelingen ontsnapten aan de Duitse eis om naar bezet België terug te keren. De reactie van de "franskiljons" was het aantekenen van verzet bij Von Bissing om "deze begunstiging, die uit taal- en stamverwantschap gesproten is". Dat klopte volgens de auteur om verschillende redenen niet: zo heerste er in Vlaanderen een drietalig regime en kreeg men geen gehoor bij de overheid in het Nederlands. Dit in tegenstelling tot Wallonië waar het stelsel tweetalig was en men zich in het Frans tot Duitse officieren kon richten. "Thans is het Vlaanderen dat kapot geschoten wordt en geteisterd en evenwel klagen de franskiljons en trachten iedereen tegen de Vlamingen op te zetten. Het zijn troebelverwekkers [...] die men, wij hopen het, de kogel zal gunnen!" Nog in het bericht lezen we een klacht tegen dezelfde "franskiljons" die hun haat voor alles wat Vlaams was steeds luider lieten klinken. Daarna volgde een verwijzing naar het pamflet La Vérité, dat hiervan dan een voorbeeld heette te zijn. Vervolgens berichtte de schrijver hoe te Brussel prominente Vlaamsgezinden dagelijks via "brandbrieven" met de dood bedreigd werden (een duidelijke verwijzing naar het strooibiljet van Reinhard en Josson).

Vlaanderen, dat het meest geleden heeft, wordt door de franskiljons voor deze oorlog verantwoordelijk gesteld. Brussel dat bijna nooit dan wittebroodsweken telde, staat grammig te blazen op het Vlaamse Antwerpen, de stad die al de gruwelen van de oorlog heeft gekend. ${ }^{291}$

Uit het bovenstaande leiden we af dat in de eerste maanden van 1915 de Duitse propaganda geruchten verspreidde waarvoor deze schrijver blijkbaar ontvankelijk was. Een ervan luidde dat de Vlamingen niet alleen door de "franskiljons" in hun taalrechten bedreigd werden, maar dat ook de Duitse 
bezetter hun taal miskende. Pas in de zomer van 1915 zou die laatste verduidelijken hoe het zo ver was kunnen komen.

Naast het rondstrooien van pamfletten of, in dit geval, geruchten speelde het stichten (of opkopen) van dagbladen een rol in de Flamenpolitik. Wat was de precieze verhouding van die pers tot de Duitse overheid?

\section{Omtrent de Duitse pers in bezet België}

Het valt op dat Von der Lancken in een rapport uit mei 1915 de loftrompet stak over Le Bruxellois, de Gazet van Brussel en La Belgique. ${ }^{292}$ De eerste twee werden in de hoofdstad het meest gelezen, golden als uiterst germanofiel en publiceerden artikels die door het gouvernement-generaal zelf geschreven konden zijn, zo merkte hij op. Bovendien vond het ministerie van Oorlog te Berlijn ze zeer geschikt als literatuur voor Belgische krijgsgevangenen. De synergie tussen het pro-Duitse Le Bruxellois en de Gazet van Brussel wordt duidelijk wanneer men in rekening neemt dat Von der Lancken in zijn verslag suggereerde om ze op dezelfde persen te laten drukken. De drukpers van Le Bruxellois was immers verouderd. Men heeft blijkbaar vrij vlug zijn raad opgevolgd, want vanaf 15 augustus 1915 werden de dagbladen op dezelfde drukpers uitgegeven. Dat gebeurde binnen dezelfde drukkerij, Kropp: de geliefkoosde onderneming van het gouvernement-generaal.

Het is opvallend dat het Antwerpse L'Avenir dezelfde politieke oriëntatie als Le Bruxellois volgde, blijkbaar dezelfde bestuurder had (Rieth?), dezelfde bewoordingen gebruikte als het gouvernement-generaal (en later de Politische Abteilung) en zich een cruciale speler zou tonen in de Duitse propagandacampagne rond de val van Antwerpen. Volgens Von der Lancken was La Belgique behendig opgesteld. "Ze tracht", aldus Von der Lancken, "naar het Belgische publiek toe, haar onafhankelijkheid en haar nationaal Belgisch karakter te bewaren. Niettemin verandert ze op tijd haar strekking en wanneer de [Duitse] dwang zich laat gevoelen, voert ze loyaal de verbintenissen uit die ze opgenomen heeft". [B.Y.] ${ }^{293}$ Dat La Belgique een "verbintenis" met het gouvernement-generaal had aangegaan, is revelerend. Het gouvernement-generaal stelde in dat dagblad blijkbaar méér vertrouwen dan in De Vlaamsche Post. Want blijkens de notulen van Jong-Vlaanderen d.d. 5 februari 1915 had "de Duitse regering [het gouvernement-generaal, $B Y$ ]" verklaard "geen overeenkomst met de Jong-Vlamingen te willen sluiten, doch vrij te willen staan”. De bezetter wou dus geen overeenkomst aangaan waarbij het eigendomsrecht van Jong-Vlaanderen over een blad dat met Duits geld gesubsidieerd 
werd, erkend werd. ${ }^{294}$ Kunnen we hieruit afleiden dat La Belgique, dat ook met Duits geld gefinancierd werd, wel een overeenkomst verkreeg zonder haar eigendomsrecht aan het gouvernement-generaal af te staan? Uit Duitse archiefstukken is bekend dat dit dagblad onder de verborgen leiding stond van de Duits-Belgische bankiers Hütt. Volgens Du Catillon was vóór de oorlog de stiefvader van Haller, baron Haller Von Ziegesar, de zaakwaarnemer van de broers. ${ }^{295}$ Heeft Haller met hen contact gelegd?

Er bestaat onduidelijkheid over het tijdstip waarop de Vlaamsche Gazet in Duitse handen terechtkwam. Von Sandt schreef in februari 1915 naar Berlijn dat het gelukt was om de controle over een aantal Vlaamse dagbladen te verwerven. ${ }^{296}$ Onder "verwerven" moet hier vooral "oprichten" verstaan worden, naar het voorbeeld van de Gazet van Brussel. Wel werd, zoals zal blijken, de Vlaamsche Gazet door de bezetter verworven. ${ }^{297}$ In een rapport van de Politische Abteilung van 14 mei 1915 werd Het Vlaamsche Nieuws, de nieuwe titel die het blad inmiddels aangenomen had, "durchaus germanophil" genoemd. ${ }^{298}$

Het bureau van de redactie van het blad was vanaf de eerste editie gevestigd in de Rodestraat 44 te Antwerpen en dit tot het einde van de oorlog. Vanaf begin november 1915 zou op precies hetzelfde adres de Antwerpse administratie van het Duits-Grootnederlandse propagandatijdschrift Dietsche Stemmen zetelen. ${ }^{299}$ Opvallend is, dat het Duitse propaganda-orgaan L'Avenir vanaf 23 december 1914 óók daar gevestigd was. Anders gezegd, ten laatste op die datum was het Nederlandstalig blad volledig in Duitse handen, hetgeen overigens verklaart waarom het zeven dagen later een provocerend artikel over de overgave van Antwerpen publiceerde.

Bij de eerste publicatie van de Vlaamsche Gazet in oorlogstijd (20 november 1914) noemde het blad zwijgen over het verleden een laffe struisvogelpolitiek. Vroeger had het, zo heette het, "alleen ter wille van de grootheid van ons volk" voor de algemene dienstplicht geijverd. Indien men toen geluisterd had, was de situatie van de bevolking wellicht anders geweest. "Zij die, door allerhande middelen, die noodzakelijke hervorming jarenlang hebben tegengehouden [de conservatieven dus, $B Y$ ], dragen alleen de verantwoordelijkheid van de laatste gebeurtenissen. Wij hebben ons niets te verwijten." Het beklemtoonde dergelijke kwesties niet te verzwijgen, noch de bespreking naar latere, meer gepaste tijden te verschuiven. ${ }^{300}$ Opvallend is de gelijkenis tussen deze passage en het besproken artikel uit Le Bruxellois van 1 december 1914 over de val van Antwerpen. Daarin stond weliswaar dat het "uur der afrekening [dus van te 'spreken'] nog niet geslagen" had, maar werd de verre van volmaakte staat van de forten die Antwerpen moesten verdedigen, 
gelaakt. De conservatieve partijen hadden door een kleinzielig electoralisme drie decennia lang verzuimd om hier iets aan te doen. ${ }^{301} \mathrm{Op} 23$ november 1914 beklaagde Paul Van Ostaijen zich in de Vlaamsche Gazet over het gebrek aan "rasfierheid" en het "snobisme" van de Nederlanders die in hun dagbladen artikels met als "pretentieuze titel" Chronique pour les Belges lieten verschijnen, aankondigingen in het Frans plaatsten, de Vlaamse straat- en plaatsnamen verfransten enzovoort. ${ }^{302}$ Op 3 december betichtte de Vlaamsche Gazet de "franskiljons" ervan de Godsvrede doorbroken te hebben. Terwijl ze de Vlaamsgezinden om een "wapenstilstand" vroegen, maakten ze zelf van het ogenblik gebruik om "achterduims" hun campagne tegen het Vlaams voort te zetten. De Walen daarentegen hadden zich daarentegen sedert het uitbreken van de oorlog waardig gedragen en onmiddellijk elke polemiek gestaakt. Ook L'Avenir meldde op 18 februari 1915:

Les Flamands, s'ils n'y font pas attention se laisseront encore une fois duper et [...] faisant état d'un armistice, ils [...] se font refouler du terrain de leurs justes revendications. Ce ne sont pas les Wallons qui se sont jamais opposés à ses revendications mais bien quelques énergumènes soldés et décorés qui reçoivent leur mot d’ordre de Paris... ${ }^{303}$

"Wij, Vlamingen", aldus de Vlaamsche Gazet, "hadden gehoopt op een eerlijke wapenstilstand, maar vermits wij ons nu aangevallen voelen, verdedigen wij ons ook". En op 8 december 1914 verkondigde het blad uitdagend: "Wat ook oorlog en bezetting verandering brachten in de toestanden de franskiljons ontwapenen niet... maar, men vergete het niet, wij evenmin.."304 Deze klanken kondigden blijkbaar een openlijke koerswijziging aan.

Rond Nieuwjaar was er inderdaad iets op til. Vanaf 1 januari 1915 begon de Vlaamsche Gazet op vier bladzijden te verschijnen, zoals Le Bruxellois dat vanaf 17 november 1914 en de Gazet van Brussel vanaf 3 januari 1915 eveneens deden. In oorlogstijd is een dergelijke verhoging van het aantal bladzijden enkel te verklaren door een kapitaalinjectie van de bezetter. Op 8 januari 1915 kondigde het blad bovendien een naamsverandering aan. Het meldde dat het persorgaan vanaf 11 januari de titel Het Vlaamsche Nieuws zou aannemen met de belofte om nog "verbeteringen" aan te brengen. ${ }^{305}$ De naamsverandering liet iets langer op zich wachten, maar op 14 januari was het toch zover. Toen kwam de lezer te weten wat die "verbeteringen" inhielden. Het bleek dan dat het dagblad zich voorstelde als het orgaan van de vooruitstrevende liberalen (hetgeen het vóór de oorlog was). Maar vooral, dat het hardnekkiger dan ooit wou strijden, zonder "wapenstilstand" ("een half verraad") 
welteverstaan. Het Vlaamsche Nieuws verkondigde onafhankelijk te zijn en niet "laf" te "heulen" met "vijandelijke gezindheden". ${ }^{306}$ Maar het stond wel onder Duitse controle. Antoon Van Opstraet, de Antwerpse hoofdagent van Julius Hoste sr., beweerde in 1936 dat die hem in november 1914 de toelating gegeven had om een eigen, plaatselijke uitgave van de Vlaamsche Gazet op te starten. ${ }^{307}$ Toen het blad als nieuwe titel Het Vlaamsche Nieuws aannam en de Godsvrede openlijk doorbrak, bleef de latere activist Van Opstraet "beheerder" en dit tot eind april 1915. ${ }^{308}$ Anders gezegd, hij werkte voor een blad dat de bezetter toen "durchaus germanophil" noemde. ${ }^{309} \mathrm{Zijn}$ verhaal is betwistbaar en werd nooit door Hoste onderschreven. La Métropole meldde op 12 december 1914 dat Hoste niets te maken had met dit dagblad. ${ }^{310}$ Minder dan een maand later stuurde Julius Hoste jr. een verontwaardigde brief naar het katholieke persorgaan waarin hij beweerde dat het blad een titel (de Vlaamsche Gazet) die zijn vader toekwam, geüsurpeerd had. "Le vague pamphlet", zo schreef La Métropole, "séditant à Anvers, sous la censure allemande, n'a, comme nous l'avons fait prévoir, rien à voir avec le journal de M. Hoste, dont le patriotisme ne fut du reste jamais suspecté. Mais comment trouve-t-on le procédé des 'journalistes' anversois, capables de semblables vilenies?"311

Op 31 januari 1915 gaf Julius Hoste jr. in een brief aan Le Temps te kennen dat een Antwerpse journalist beslag gelegd had op twee van zijn dagbladtitels (de Vlaamsche Gazet en Het Laatste Nieuws). Hij schreef dat er nooit sprake van zou zijn om zijn dagbladen opnieuw in bezet België te laten verschijnen. Volgens Van Opstraet gebeurde de naamsverandering naar $\mathrm{Het}$ Vlaamsche Nieuws in volle vriendschap. Volgens Hoste jr. kwam die er omdat hij zijn verontwaardiging over de daad van kwade trouw van Van Opstraet uitgedrukt had. ${ }^{312}$ Waarschijnlijk hebben zowel vader als zoon Hoste op een verandering van de titel aangestuurd, omdat ze vreesden (of wisten) wie het blad écht uitgaf. Zonder twijfel was het dagblad na Nieuwjaar in handen van de bezetter. Was dat twee maanden eerder ook al zo? Was de herverschijning van de Vlaamsche Gazet ook geen resultaat van een Duitse interventie en dit al vanaf november $1914 ?^{313}$ Dat de Vlaamsche Gazet drie maanden wachtte om de Godsvrede openlijk op te zeggen, betekent niet noodzakelijk dat ze drie maanden vrij was van elke Duitse invloed. Ook Le Bruxellois onderhield maandenlang (relatief) de Godsvrede. Wellicht wou de Politische Abteilung voor haar beleid niet alle eieren in het Brusselse mandje leggen. Daarom werden elders persorganen in het leven geroepen, zoals L'Avenir en later Antwerpen Boven in Antwerpen. Andere organen, met name de Vlaamsche Gazet werden opgekocht. ${ }^{314}$ 
Opmerkelijk is alleszins dat de bezetter zijn Flamenpolitik niet alleen via Nederlandstalige bladen voerde. Hij deed dat ook via Franstalige persorganen en dit zowel in Antwerpen als Brussel. Gelet op de nauwe verbindingen tussen de Gazet van Brussel enerzijds en L'Avenir en Le Bruxellois anderzijds - niet het minst over wat daar allemaal in verscheen over de capitulatie van Antwerpen - is het mogelijk dat de Antwerpenaar Henri Rieth een coördinerende functie uitoefende over die drie persorganen. Was hij niet de persoon die de Gazet van Brussel controleerde en, allicht, ook "beheerder" was van Le Bruxellois en L'Avenir?

Ook in Gent, en dus in het etappegebied, wou het gouvernement-generaal een vinger in de pap te brokken hebben. In een rapport dat Wirth begin 1915 opmaakte, gaf de perscensor zijn ongenoegen te kennen. ${ }^{315}$ Hij beweerde dat de anpak van de overheid danig tekortschoot. Het Duitse beleid, zo heette het, miskende het bestaan van een "sterke germanofiele stroming" binnen de Vlaamse beweging. Die had nochtans de vereniging met Duitsland tot doel en verwachtte nu van het keizerrijk en in het bijzonder van de Duitse keizer de verlossing. Wirth schilderde de Jong-Vlaamse beweging veel machtiger af dan ze in werkelijkheid was. Zo werd het zeer bescheiden groepje rond De Bestuurlijke Scheiding "een grote bond die zelfs een bijzonder dagblad te Gent uitgaf". [B.Y.] Hij verweet het commando van het Duitse leger niets met de Jong-Vlaamse keizersbrief van 19 december 1914 gedaan te hebben, hoewel die toch het Duitse belang diende. Een doorslaggevende rol speelden de aangehaalde argumenten alleszins toen nog niet, hetgeen mede verklaart waarom men op het gouvernement-generaal zo lang is blijven twijfelen over de levensvatbaarheid van De Vlaamsche Post. Wirth toonde zich nochtans optimistisch: "Indien Duitsland de zaak van Vlaanderen tot de zijne maakt, wint het heel Noord-Europa." [B.Y.] De militaire veiligheid vereiste volgens hem dat men de separatistische Jong-Vlamingen in heel Nederlandstalig België, en zelfs in delen van Luik organiseerde. Die organisatie had meerdere doelen, waaronder de publicatie van een "bijzonder dagblad". Daarmee zouden "we geen openbare contacten onderhouden". [B.Y.]

Het was dus de bedoeling om De Vlaamsche Post als een zuiver "Vlaams" initiatief voor te stellen. Tijdens een vergadering rond 1 februari 1915 met leden van het gouvernement-generaal, tekende Wirth op dat de Gazet van Brussel alleen al vanwege zijn naam nooit een landelijke uitstraling kon hebben. Gent was dus een betere uitvalsbasis voor een dagblad, zo luidde de redenering. Wirth - of moeten we zeggen: het etappebestuur - haalde zijn slag thuis, want twintig dagen later werd de eerste editie van De Vlaamsche Post gedrukt. Het militaire bestuur van de etappe in Gent heeft het persmo- 
nopolie van het gouvernement-generaal doorbroken. Dat gebeurde door De Vlaamsche Post te financieren. Bovendien ondernam het etappebestuur een poging om het blad te laten "versmelten" (door het bij dezelfde uitgever onder te brengen?) met Het Vlaamsche Nieuws van Gerstenhauer zoals we dat in de notulen van Jong-Vlaanderen (8 april 1915) lezen. Dit plan kon "op zeer veel bijval" rekenen, maar werd een week later toch opgeborgen, omdat het gouvernement-generaal dwarslag. ${ }^{316}$ Het etappebestuur deed dus hetzelfde als het gouvernement-generaal: het stichten, financieren en - in het geval van Het Vlaamsche Nieuws - (proberen) opkopen van dagbladen.

Medio 1915 moest Gerstenhauer gedwongen ontslag nemen bij dat dagblad. Hij had namelijk een artikel van Raf Verhulst in Het Vlaamsche Nieuws van 19 juli 1915 doorgelaten. Het stuk in kwestie was een kritiek op het vertaalde artikel Wünsche und Befürchtungen der Vlamen dat Gerstenhauer in de Deutsche Tageszeitung en in de Rheinisch-Westfälische Zeitung gepubliceerd had. ${ }^{317}$ Daarin had hij beweerd dat Duitse en Vlaamse belangen evenwijdig liepen. Verloor Duitsland de oorlog, dan waren alle Germanen en in de eerste plaats de Vlamingen die door de "Latijnse beschaving" zouden verzwolgen worden, tot de ondergang gedoemd. Won Duitsland daarentegen, waren alle Germanen gered. Verhulst had daarop gerepliceerd dat men niet kon wensen dat Duitsland de oorlog won. De flaminganten hadden geen kans tegen het Hoogduits en zouden hetzelfde lot als de Nederduitsers ondergaan. Indien de Duitsers het onderspit zouden delven, dan zouden de Vlamingen van hun regering zelfbestuur, een eigen hogeschool en taalrechten krijgen. Op 20 juli werd Gerstenhauer afgezet en zou hij naar het front overgeplaatst worden. Na protest van Borms werd hij overgeplaatst naar Gent. Werd Gerstenhauer gewoonweg niet bekwaam geacht om Het Vlaamsche Nieuws te leiden? Begin dat jaar was door zijn toedoen ook al de naam van de (verborgen) hoofdredacteur van de Gazet van Brussel (Haller von Ziegesar) in Het Vlaamsche Nieuws onthuld. Vrints beschrijft het incident terecht als een voorwendsel "om de perscensor met Jong-Vlaamse sympathieën weg te kunnen sturen”. Zijn opvolger Robert Oszwald "beantwoordde in elk geval wel aan het gewenste profiel van de Politische Abteilung". ${ }^{318}$

De problemen tussen het bestuur te Brussel en het etappebestuur te Gent dat de Jong-Vlamingen instrumentaliseerde, waren evenwel niet ideologisch van aard. Waar het gouvernement-generaal vanuit strategische overwegingen al te openlijk pan-Germanistische en anti-Belgische stukken in De Vlaamsche Post wou afremmen, hielden de militairen in Gent zich niet aan de (voorlopige) richtlijnen van gematigdheid. Dit liep uit op een tweespalt binnen de groep Jong-Vlaanderen en het ontslag van hoofdredacteur Picard - de man van het gouvernement-generaal in de redactie van De Vlaamsche Post ${ }^{319}$ - in 
de zomer van 1915. Er barstte ook een conflict over het eigendomsrecht van het blad los. Marcel Van de Velde, die de notulen van het groepje in 1941 uitgaf, beschreef de situatie in augustus 1915 als volgt: "De moeilijkheid, waarvoor de Gentse Groep [...] stond, was deze, dat haar blad nog steeds in de handen was van hen, die met haar beginsel hadden gebroken." ${ }^{20}$ Anders gezegd, De Vlaamsche Post was eigendom van het gouvernement-generaal, dat niet de radicale koers van Domela en zijn militaire vrienden wilde varen. Uiteindelijk werd het dispuut tussen het gouvernement-generaal en de militaire overheid van het etappegebied in maart 1916 in het voordeel van het eerste bestuur beslecht. ${ }^{321}$ L'Avenir was ondertussen een jaar eerder om onduidelijke redenen gestopt met te verschijnen.

\section{Besluit}

De Duitse geruchtenmolen rondom de val van Antwerpen kan niet los gezien worden van een bredere anti-Britse campagne. Ze werd, versterkt door de aanhoudende Duitse geruchten over een vermeende anti-Vlaamse campagne, in de Flamenpolitik ingeschakeld. Vermoedelijk heeft dit manoeuvre het wantrouwen tegen het Belgisch overheidsbestel bij sommige flaminganten aangescherpt. Zo zou Frans Reinhard in december 1914 Derk Hoek toevertrouwd hebben dat de Conventions de "grove en gevaarlijke eenzijdigheid van wie het land ten beste heetten te besturen", belicht hadden. ${ }^{322}$

Die Conventions Anglo-Belges vormden het startschot van die anti-Britse campagne en moesten ook de Duitse kanselier van munitie voorzien. Want op 2 december 1914 integreerde hij die Conventions in zijn redevoering voor de Rijksdag om Duitsland van alle schuld voor de inval in België vrij te pleiten. De semi-officiële Norddeutsche Allgemeine Zeitung had ze eerder in twee delen gepubliceerd: het eerste op 16 oktober, het tweede op 25 november 1914. Het valt op dat de eerste datum samenviel met de eerste golf van geruchten in de Duitse en Oostenrijkse pers over Antwerpen. De tweede luidde het begin in van het intensiveren van de Duitse perscampagne over het aandeel van het Antwerpse stadsbestuur in de val van Antwerpen. De rol van Oostenrijk-Hongarije in België is zonder meer opvallend. Veelzeggend in dat opzicht is dat de eigenaar van het Franstalige hoofdstedelijke collaboratieblad L'Information zowel Duitse als Oostenrijkse subsidies ontving. ${ }^{323}$ Ook dient opgemerkt dat Berchtold, de Oostenrijkse minister van Buitenlandse Zaken, zich vanaf september 1912 via de ambassade van de Dubbelmonarchie in Brussel over de Vlaamse beweging liet informeren. ${ }^{324}$ 
De Duitse propaganda rondom de val van Antwerpen en zijn nasleep concentreerde zich op twee thema's: enerzijds de "verwoesting" van de Scheldestad en anderzijds het fantasieverhaal over het verhoor van Antwerpse dignitarissen in Den Haag en hun proces in Le Havre. Later zullen we zien dat die twee thema's in La Vérité tot een geheel gesmeed werden. Het thema van de "verwoesting" is het oudste. In de Oostenrijkse en Duitse propaganda werd al vanaf oktober 1914 gesuggereerd dat Antwerpen door de geallieerden in de steek gelaten was en de stad aan een beschieting overgeleverd werd. Zulke berichten gingen onder meer van het Duitse Große Hauptquartier uit. Dat Antwerpen moedwillig aan het Duitse geschut overgeleverd werd om de germanofilie uit de Scheldestad te bannen, werd al op 21 november 1914 in dat verhaal geïntegreerd.

Vanaf eind oktober 1914 werd het voor de bezetter duidelijk dat hij de polemieken die in de Belgische vluchtelingenpers na de val van Antwerpen aan bod kwamen, voor zijn propaganda in de Flamenpolitik kon aanwenden. Vooral het Journal des Réfugiés trok zijn bijzondere aandacht. Vanaf medio november ging het gouvernement-generaal aan de slag met zijn Brusselse correspondenten die aan Duitse dagbladen verbonden waren. Daarbij kon hij óók berichten lezen aangaande het gekissebis over de mogelijke verwoesting van Antwerpen. De voorstanders van het verdrag van Kontich makten zich immers sterk dat Franck, De Vos en Ryckmans de stad van een gewisse ondergang gered hadden. Sommige tegenstanders beweerden dan weer dat zo'n lot te verkiezen was boven de overgave van een hoop "bakstenen" aan de Duitsers. In die context speelde de Duitse propaganda ook in op kreten als "on verra bien plus tard" uit La Métropole van 28 oktober 1914. In het blad was dat van toepassing op de redacteuren van Antwerpse Tijdingen. Maar geïsoleerd bezien, kon het als een dreiging voor het stadsbestuur, zelfs voor heel Antwerpen, geherinterpreteerd worden. Van dat tijdstip dateert ook de bewering van de journalist Calza Bedolo, die de Nederlanders ervan beschuldigde, gedreven door hun jaloersheid op de handel, zich om het lot van Antwerpen te verheugen. De campagne bereikte een voorlopig hoogtepunt in Antwerpen moet kapot! (Gazet van Brussel, 5 januari 1915), dat beweerde hoe Antwerpen door de Britten verwoest zou worden omdat ze een geduchte handelsconcurrent was van buitenlandse havens (en dat sommigen dat al tijdens de beschieting van de stad hoopten). Dat artikel hernam de retoriek van het blad van 14 december 1914. Toen werd immers beweerd dat de Britten Duitsland wilden verwoesten, omdat het land een geduchte handelsconcurrent was. Maar waar in december Duitsland het slachtoffer was van het Britse imperialisme, werd die rol in januari aan Antwerpen toebedeeld. Het blijkt 
trouwens uit Britse rapporten dat Duitse officieren stelden dat, indien Duitsland militair teruggedrongen werd, de Duitsers België als een woestenij zouden achterlaten..$^{325}$

Het was niet abnormaal dat die vertelsels over verwoesting in België aan kracht wonnen. Belgische steden - en voor Antwerpen gold dit deels ook waren immers al tot puin herleid. In feite was de propaganda die de Duitse bezetter rondstrooide vergelijkbaar met zijn inspelen tijdens de Tweede Wereldoorlog op de vrees van de bevolking voor Anglo-Amerikaanse bombardementen en de mogelijke verwoesting en bloedvergieten die een "bevrijding" zou meebrengen. Op 5 december 1914 had de Gazet van Brussel het over de mogelijke verwoesting van België. Zeven dagen later en opnieuw op 19 december, bracht het blad die verwoesting in verband met een Duitse terugtocht uit het bezette land. En op 14 december koppelde het de vernietiging van Duitsland aan Britse economische naijver. Ongeveer een maand later verkondigde het blad dat "een Waal" zei dat een bevrijding de verwoesting van Antwerpen, West- en Oost-Vlaanderen tot gevolg zou hebben.

Welke artikels uit de Belgische vluchtelingenpers kon de bezetter aanwenden om zijn propagandaverhaal over de gerechtelijke perikelen van Franck en Ryckmans eerst in de Vossische Zeitung en daarna in Le Bruxellois, de Tageszeitung, de Düsseldorfer General-Anzeiger en L'Avenir op te bouwen? De onduidelijke omstandigheden waarin de overgave zich afgespeeld had, gaven aanleiding tot polemieken in de vluchtelingenpers. Had Franck de plaats ingenomen van Deguise, zoals het Journal des Réfugiés al op 21 oktober 1914 beweerd had en burgemeester De Vos in zijn op 27 oktober 1914 in dat blad verschenen brief had proberen te weerleggen? Ook L'Echo Belge had op 5 november de bewering van het Journal herhaald. Terwagne maakte in L'Indépendance Belge van 19 november 1914 gewag van een polemiek tussen de Belgen in Nederland en zij die te Antwerpen gebleven waren. Eén van de twistpunten daarin was dat, volgens de eersten, de gemeentelijke overheid haar boekje te buiten was gegaan door zonder militaire toestemming de vesting over te leveren. ${ }^{326}$ Ook had het Journal des Réfugiés op 24 oktober geschreven dat als er in het gemeentebestuur naar aanleiding van de overgave van Antwerpen verraders waren, die na de oorlog gestraft moesten worden door een hooggerechtshof. Op 27 oktober heette het in dat blad dat er schuldigen waren en dat die hun straf niet zouden ontlopen. Op 5 november uitte $L a$ Métropole een gelijkaardige stelling. Onder de "verraders" waren er blijkens sommige stukken in de Franstalige vluchtelingenpers ook Vlaamsgezinden, met name Franck, Van Cauwelaert, de redactie van Antwerpsche Tijdingen, de "Antwerpse pan-Germanisten", Pol de Mont en Adelfons Henderikcx. De 
basis voor het fantasierijke vertelsel over de overgave van Antwerpen werd onder het bestuur van Colmar Von der Goltz gelegd. Dat wijst op het vroege intensiveren van de Flamenpolitik.

Op 21 januari 1915 werd het bestaan van het vlugschrift La Vérité in de Gazet van Brussel angekondigd en vanaf eind januari werd het verspreid. Zoals besproken, hielden ook ook andere door Duitsland gesubsidieerde bladen als L'Avenir en Het Vlaamsche Nieuws de propagandamolen draaiende. Omdat de collaborerende dagbladen in België en de Oostenrijks-Duitse pers intens samenwerkten, was de intertekstualiteit tussen wat er beweerd werd, uiteraard erg groot. Dat wordt erg duidelijk in de vergelijking van Antwerpen met Brussel, die maandenlang herhaald werd. In de Neue Freie Presse van 18 oktober 1914 stond hoe de Antwerpenaars, in tegenstelling tot de Brusselaars, van Germaanse oorsprong en dus Duitsvriendelijk waren. Op 13 november had ook de Kölnische Zeitung het over de Nederduitse stamverwantschap van de inwoners van Antwerpen wier correcte houding tegenover die van de Brusselaars stond. Acht dagen later roemde de Pester Lloyd het vreedzame Antwerpen en wees het op de Germaanse stamverwantschap van de inwoners met de Duitsers. In het veel minder aangename Brussel daarentegen kenden de inwoners de oorlog maar van horen zeggen. Wat in de Kölnische Zeitung stond, werd dan op 3 december in de Gazet van Brussel hernomen en aangevuld. Een week later schreef hetzelfde blad hoe joviaal men in Antwerpen met de bezetter omging en dat men te Brussel de oorlog maar van horen zeggen kende. Op 16 december 1914 nam L'Avenir dit stuk over en in de Gazet van Brussel werd op 5 januari 1915 eens te meer gesproken over diegenen die van de oorlog persoonlijk niets onaangenaams te verduren hadden. Zestien dagen later heette het in dat blad hoe de inwoners van de hoofdstad "enkel het kanon van verre gehoord hadden". En nog in maart 1915 meldde een Antwerpse correspondent van De Vlaamsche Stem hoe Brussel bijna enkel wittebroodsweken had gekend, terwijl Antwerpen de gruwelen van de oorlog ten deel vielen. De auteur Karel Angermille had het in 1931 over een variant hierop die men ook al in Luik tegen Antwerpen uit de Gazet van 21 januari 1915 leest: "Het was een dankbare tegenstelling: het heldhaftige, Waalse Luik, tegenover het vuige, Vlaamse Antwerpen."327

Er bestaan andere voorbeelden van zo'n intertekstualiteit. Zo was het, in de Belgische collaboratiepers, niet zelden "een Brusselaar", "een Brusselse lezer" of "een Brusselse vriend" die bepaalde "feiten" onthulde. Een ander voorbeeld hiervan is het thema "slapen" en "waken", "zwijgen" of "spreken" of anders gezegd: de Godsvrede naleven of niet. Later werd dit vertaald naar "actief" versus "passief". Op 20 november 1914 beweerde de 
Vlaamsche Gazet dat men ondanks de omstandigheden niet moest "zwijgen", maar "spreken". Op 1 december schreef Le Bruxellois dat men net door die omstandigheden nu nog niet moest "spreken" (maar het deed dat zelf wel). Op 5 januari 1915 drukte de Gazet van Brussel de wens uit dat de Vlamingen ogen en oren wijd openzetten. ${ }^{328}$ Op 13 januari maande in hetzelfde dagblad een "lezer" de Vlaamse voormannen aan te "waken". ${ }^{329}$ Het artikel Vlamingen waakt! (23 januari 1915) van August Borms hernam dit thema. Zo ook de Gazet van Brussel die de Vlamingen twee weken later aanmaande zich niet in slaap te laten wiegen. ${ }^{330}$ Op 2 februari 1915 drukte het blad zich nog sterker uit door te beweren dat de flaminganten in Brussel aan een "gevaarlijke slaapziekte" leden. En op 17 februari 1915 publiceerde Borms wederom een hoofdartikel, getiteld Vlamingen waakt! in Het Vlaamsche Nieuws. Begin maart had De Vlaamsche Post het over de "verderfelijke slaap" van het Vlaamse geestesleven te Brussel. En drie maanden later hekelde Het Vlaamsche Nieuws de ingesluimerde Vlaamse maatschappijen te Brussel ${ }^{331}$. Een ander voorbeeld van deze techniek. Op 5 november 1914 had Henderickx de houding gelaakt van de Frans-Belgische bladen, "die in de hachelijke omstandigheden welke wij doorworstelen" de Vlamingen en hun leiders aanvielen. Dat werkte inspirerend. Op 30 december 1914 immers klaagde de Brusselse medewerker van de Vlaamsche Gazet de "verstokte Vlaamshaters" aan, die zelfs tot in deze "treurige ogenblikken" hun kwaadwilligheid bleven tentoonspreiden. Op 5 januari 1915 berispte de Gazet van Brussel de anti-Vlaamse drijvers "die zelfs in deze trieste omstandigheden hun haat voor al wat Vlaams is niet konden onderdrukken". Iets meer dan twee weken later lezen we in een ander artikel uit hetzelfde blad hoe de franskiljons "tot zelfs in deze droeve tijden toe" de Vlamingen bevuilden. Op 4 maart 1915 combineerde de Gazet van Brussel twee motieven. Ze herhaalde enerzijds meermaals "gewezen [te hebben] op het konkelfoezen van zekere naamloze kliek die van de droevige tijden welke wij doorleven probeert misbruik te maken" om de Vlamingen nog méér onder de knoet te krijgen. En anderzijds maande ze "de voormannen" aan "te waken". 332

Moet men hier niet uit afleiden dat de schrijvers van die teksten vanuit het gouvernement-generaal hun redactionele richtlijnen kregen? Zonder twijfel putte die Duitse propaganda inspiratie uit de woorden van Henderickx, wiens artikel achtereenvolgens door de Kölnische Zeitung en de Gazet van Brussel vertekend werd. Zowel in Antwerpen, Gent als Brussel verspreidde de bezetter via Nederlands- en Franstalige dagbladen die hij opkocht of (meestal) stichtte op grote schaal deze onwaarheden over een "anti-Vlaamse campagne”. Wat hij over Antwerpen orakelde, werd maandenlang intensief 
herhaald. Een en ander werd ook duidelijk voor de Belgische regering, die ten laatste vanaf eind november 1914 wist wat er aan de gang was. De maatregelen die de bezetter in het kader van zijn Flamenpolitik nam, kwamen in de semi-officiële Vingtieme Siècle uitgebreid aan bod: het verbieden van Franse opschriften en briefwisseling in het etappegebied, provocerende artikels in de Duitse pers, het hernemen van stukken in diezelfde pers uit "Vlaamse" germanofiele organen, het geven van Nederlandse lessen aan Duitse officieren en het wedervaren van de radicaal-activistische groep Jong-Vlaanderen in Gent. ${ }^{33}$ Daarbij werden ook (vermeende) activisten bij naam aangevallen. ${ }^{334}$ Begin maart 1915 meldde het blad over de pogingen van de Duitse bezetter om de taaltwisten weer te doen oplaaien:

Von Bissing s'est attelé à la besogne, offrant de transformer immédiatement l'Université de Gand en Université flamande et demandant à certaines personnalités du mouvement flamand d'examiner avec lui les moyens de donner satisfaction aux aspirations du peuple flamand.

Parallel daarmee voerden de Duitse diensten, aldus Le Vingtième Siècle, een perscampagne in enkele dagbladen die in het Nederlands onder controle van de Duitse censuur werden gepubliceerd. En ze verspreidden te Brussel anonieme pamfletten om de Vlamingen aan te vallen. Voorts bestonden er dagbladen die onder Duitse bescherming uitgegeven werden. ${ }^{335}$ Ook buiten regeringskringen werd de beginnende Flamenpolitik steeds duidelijker. Terwagne maakte er zich op 22 december 1914 al zorgen over. Karel Van de Woestijne gaf zes dagen later aan dat sommigen de Vlaamsgezinden verdacht maakten (omdat een aantal zich niet aan de Godsvrede hield). ${ }^{336} \mathrm{Op} 8$ januari 1915 schreef Floris Prims dat van Duitse zijde de "gemoedstoestand" van de Vlamingen door de Duitsers in het oog gehouden, misschien wel bewerkt werd. ${ }^{337}$ Op 14 januari noemde de filoloog Antoon Jacob de "pan-Germaanse lokstem" een "Duitse actie" die in "de laatste weken" vernomen werd en het grootste gevaar voor "ons volksbestaan" uit de geschiedenis van de Vlaamse beweging vormde. ${ }^{338}$ Begin februari meldde de Nieuwe Rotterdamsche Courant dat de Duitse bezetter een poging ondernam om in België sympathie op te wekken. Er werden volgens het persorgaan door het Duitse bestuur maatregelen genomen, die veel beter in staat schenen om de gevoelens van de Vlaamsgezinden tegemoet te komen. $\mathrm{Zij}$ dienden als eersten "met de voorkomendheid der Duitsers" kennis te maken door de pro-Duitse Gazet van Brussel en het gegeven dat "verschillende leiders der [Vlaamse] beweging die in België zijn gebleven [...] bezoek [kregen] van een heer". Volgens het 
dagblad praatte die met hen over de "noodzakelijkheid van een Nederlandse hogeschool te Gent [...] Weldra liep het gesprek over de behoefte om de propaganda voort te zetten...." ${ }^{39}$ Of nog, de Duitse bezetter kwam de Vlaamsgezinde voormannen die hij contacteerde, vertellen dat ze hun activiteiten tijdens de oorlog niet mochten staken. Het hoofdargument was dan dat de "franskiljons" hen aanvielen. Hoe eenzijdig de "sympathie" was die de Duitsers probeerden op te wekken, was ook de journalist Auguste Monet niet ontgaan, toen hij op 6 februari 1915 meldde dat het toch wel opmerkelijk was dat tot dusver "alleen maar de Vlààmse kunst en de Vlààmse artiesten de begeerlijkheid van de wevers van de Duitse cultuur" wekten. Volgens hem probeerde de bezetter op verschillende manieren zijn voordeel te halen uit de Belgische taalstrijd. Zo beloofde hij twee Vlaamse universiteiten "onder de vleugels van de Pruisische adelaar" aan een door Duitsland "bevrijd" Vlaanderen. Ook wenste hij bekende en gezaghebbende Vlamingen te compromitteren. Daarmee werd, aldus Monet, een dubbel doel beoogd: die Vlamingen voor zich te winnen en het uitlokken van verwijten van "Fransgezinde Belgen, die [...] allicht, door veralgemening, àlle Vlamingen grieven en beledigen kunnen". Onder die personen bevond zich de "tienderangsjournalist" Harry. Volgens Monet had hij zich aan de Duitse tactiek laten vangen. Dat was niet zo, maar het bewijst wel dat Monet vermoedde dat de Flamenpolitik al in december 1914 - toen Harry zijn stuk schreef - volop bezig was. Ten slotte werd, volgens Monet, het Manuel du Patriotisme (La Vérité sur la Capitulation d'Anvers dus) in alle grote steden verspreid. ${ }^{340}$ Tien dagen later wijdde de filosoof en priester Albert Decoene in De Vlaamsche Stem een heel voorpagina-artikel aan de Flamenpolitik. Hij betoogde dat hij op grond van persoonlijke ervaringen en onderzoek tot de overtuiging gekomen was dat enkele Vlaamsgezinden dachten dat Duitsland de Vlaamse kwestie zou oplossen en waarschuwde voor een annexatie van Vlaanderen bij Duitsland. ${ }^{341}$ Misschien had de Duitse campagne rondom de val van Antwerpen in de kiem gesmoord kunnen worden indien de Belgische regering eerder het werkelijke gevaar van de Flamenpolitik erkend had en ernaar zou gehandeld hebben. Nu wisten de rijksambtenaren slechts in de lente van 1915 dat de regering van hen vroeg de directieven van Franck en Ryckmans op te volgen. Waarom duurde het zolang alvorens de Belgische overheid zijn vertrouwen in de Intercommunale Commissie en in Franck uitsprak? Zocht de koning misschien graag in Franck een zondebok voor de val van Antwerpen? Werd Franck (aanvankelijk) niet in bescherming genomen omdat hij een liberaal was? $?^{342}$ Of waren het zijn oproepen tot de vluchtelingen om huiswaarts te keren die de Belgische overheid een lange tijd zwaar op de maag lagen? 
Hoe dan ook, de Duitse campagne rond Antwerpen kon vooral zo'n impact krijgen omdat de bezetter geduldig en planmatig op de Vlaamse beweging inwerkte. Er werd zo verwarring gesticht bij sommige Vlaamsgezinden over het optreden van de "franskiljons". Eind januari woedde er al vijf maanden een Duitse campagne, waarin Antwerpen een centrale rol vertolkte. En het hoogtepunt hiervan was La Vérité sur la Capitulation d'Anvers. 



\section{HOOFDSTUK 5 DE WAARHEID OVER LA VÉRITÉ}

Volgens de Duits-activistische propaganda was La Vérité sur la Capitulation d'Anvers een "franskiljons" vlugschrift. Later werd deze zienswijze in apologetische werken en in de historiografie hernomen. In 1974 schreef Wils dat het bijna zeker tot de Duitse propaganda behoorde. Hij werd daarin vier jaar later bijgetreden door Mertens die de oorsprong van het pamflet zocht in een bericht uit de Düsseldorfer General-Anzeiger van 9 december 1914. Daarnet hebben we dit beeld grondig bijgestuurd. Historici als De Schaepdrijver, Saerens en Vrints namen de hypothese van Wils over. Anderen, zoals Molenaar en Vanacker, bleven erbij dat het vlugschrift van "franskiljonse" makelij was. In 2010 onderzochten we het document en wezen we op nieuwe elementen die aantoonden dat de Duitse propagandadiensten de echte auteurs waren. Müller liet in het midden of het vlugschrift van Duitse of Franstalige oorsprong was. ${ }^{1}$ Zoals dit hoofdstuk zal aantonen, was het pamflet het resultaat van de maandenlange Duitse campagne die voordien gevoerd werd. Daarbij werden elementen uit de meest diverse bronnen verwerkt, werkelijkheid met fantasie vermengd en, bovenal, een "bewijs" geformuleerd om eerdere beweringen van Duitse zijde over de vermeende anti-Vlaamse campagne in het algemeen en de "ware toedracht" omtrent de val van Antwerpen in het bijzonder, kracht bij te zetten. $\mathrm{Na}$ de inhoud ervan ontleed te hebben (par. 1), worden motieven die in het vlugschrift aanwezig waren, onderzocht (par. 2 en par. 4). Tevens analyseren we het verband tussen dit vlugschrift en de Duitse cultuurpolitiek (par. 3). Welke personen op het gouvernement-generaal hielden zich bezig met de constructie hiervan? Wie waren de mensen achter de schermen van de voorafgaande perscampagne over de uitzonderingsrechtbank waarop het pamflet verder bouwde (par. 5)? Ten slotte wordt een verwant document bestudeerd (par. 6). 


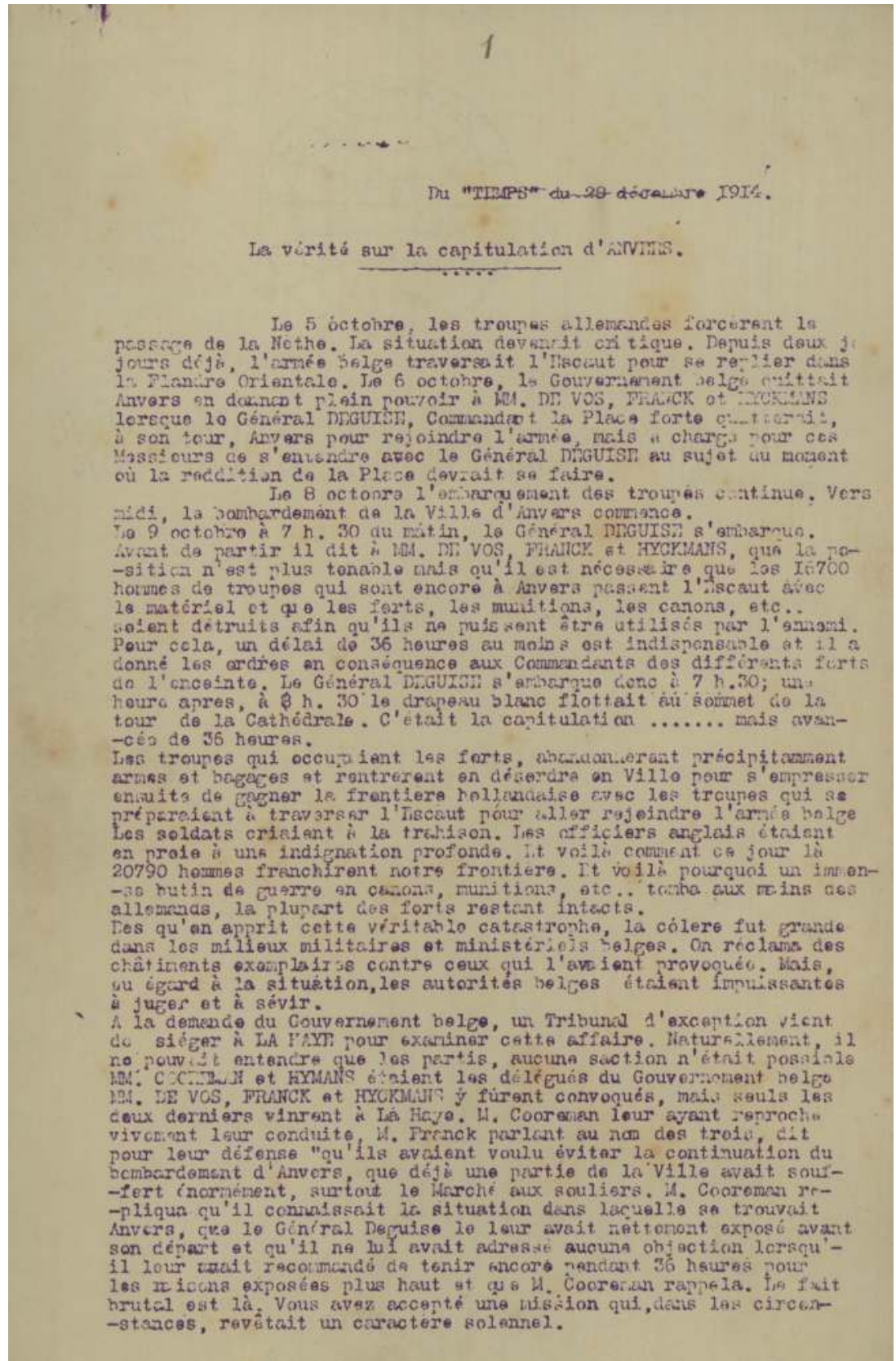

Afb. 12. De Gentse versie van het vlugschrift La Vérité sur la Capitulation d'Anvers

University Library Ghent, Book Tower; BHSL.HS.III.0023.001691 


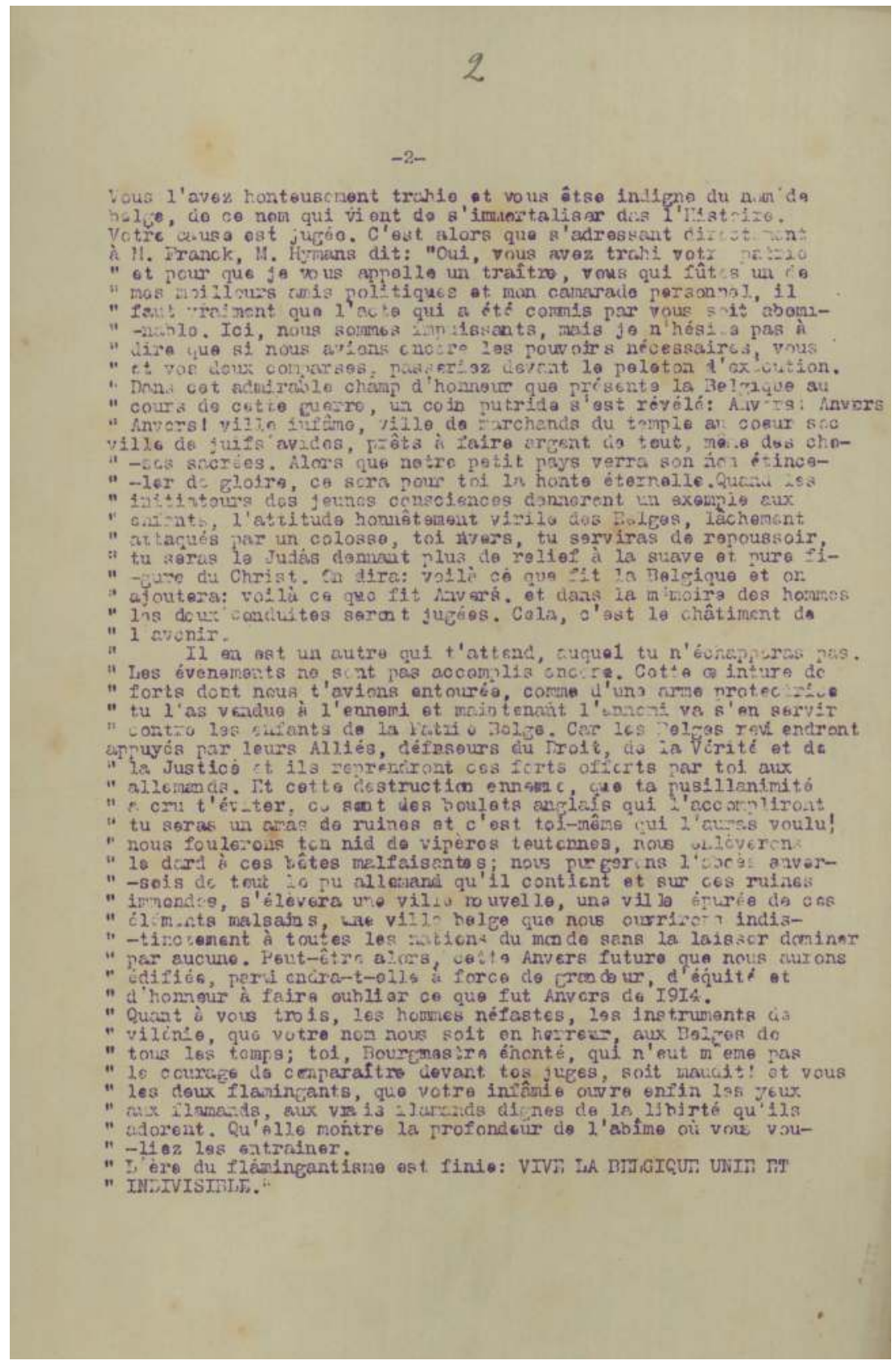




\section{Ontleding van een mysterieus vlugschrift²}

Van het pamflet bestaan er verschillende exemplaren. Voor deze studie konden we een beroep doen op drie exemplaren. Twee zijn afkomstig uit de Koninklijke Bibliotheek van Den Haag, een ander uit Gent. De "Nederlandse" versies doen zich voor als een toespraak die de liberale minister van Staat Hymans te Den Haag gegeven had. Hun identieke en plechtige opmaak, beiden zijn omzoomd met bloemen op de eerste bladzijde, bewijzen dat de auteurs van deze versies dezelfde waren. De eerste "Nederlandse" versie draagt als titel La Vérité sur la Capitulation d'Anvers, met daarbij: "Extrait du journal 'le [!] Tijd' du 28 décembre 1914”. De tweede versie draagt geen datum. Beide versies hebben als ondertitel: "Anvers, Ville infâme, Ville des Juifs" en "Discours prononcé par M. Hymans à La Haye". Vergelijken we deze versies met die uit Gent, valt vooral het verschil in titel op: "[extrait] Du 'Temps' du 28 décembre 1914”. Inhoudelijk zijn er weliswaar nog kleine verschillen, die evenwel niet de betekenis veranderen. ${ }^{3}$ Er bestonden nog varianten. Zo maakte op 14 februari 1915 De Vlaamsche Stem gewag van het feit dat er in België op grote schaal een pamflet verspreid werd dat de handtekening van "een zekere Hijmans [sic, Hymans, $B Y]$ " droeg. "Dat de staatsminister hiermede geen betrekking heeft, bewijst de waanzinnige woede waarmede men Antwerpen aanvalt en de... flaminganten." Wat de inhoud betreft, treft men in deze versie elementen aan, die enerzijds voorkomen in de "Gentse" en anderzijds in de "Nederlandse" versies. ${ }^{4}$ Nog een andere versie van $\mathrm{La}$ Vérité, waarvan de Nieuwe Courant gewag maakte, stelde zich voor als "[un] Article extrait du Tijd d'Amsterdam, reproduit et confirmé par La Métropole". 5 Voor een inhoudsanalyse van het pamflet baseerden we ons op de twee "Nederlandse" versies. Het vlugschrift begon met de weergave van een "feitenrelaas". Op 5 oktober staken de Duitsers de Nete over, de dag erna verliet de Belgische regering Antwerpen. Het gezag werd aan "Devos", "Frank" en "Rijckmans" overgedragen. "De Guise" zou op 9 oktober aan de dignitarissen gezegd hebben dat Antwerpen nog 36 uur stand moest houden om de inscheping van 16.000 manschappen met bruikbaar materiaal toe te laten. Deze bevelen werden ook aan de forten van de eerste gordel gegeven. Om 7.30 uur scheepte "De Guise" in. Een uur later wapperde de witte vlag op de kathedraal. "C'est la capitulation, mais avancée de 35 heures..." Het verhaal over de overdracht van bevoegdheden an het drietal noch de opdracht om 36 uur stand te houden of het relaas over de witte vlag die op de kathedraal gehesen werd, stemmen overeen met de werkelijkheid. Het relaas over de vlag treft men wel voor het eerst in de Vossische Zeitung van 26 november 1914 en, 
vervolgens, in Le Bruxellois van 1 december 1914 aan. Die 36 uur zal de lezer overigens wel bekend in de oren geklonken hebben: het was het aantal uren dat Antwerpen was beschoten.

Blijkbaar gaf het pamflet een concrete inhoud aan de zogenaamd onwettige overgave van Antwerpen, die de reden vormde waarvoor Franck en Ryckmans, volgens die dagbladen, door Belgische ministers van Staat ondervraagd waren.

Het burgerlijk bestuur, zo meldde het, had de stad te vroeg overgegeven, met als catastrofaal gevolg dat tienduizenden Belgische soldaten geïnterneerd werden. Het pamflet verkondigde dat op de overgave door het burgerlijk bestuur een ongeordende terugtrekking van de troepen uit de forten volgde. De soldaten spraken van verraad, de Britse officieren waren diep verontwaardigd. Naast de oorlogsbuit en de intacte forten die in Duitse handen vielen, staken 20.720 Belgische militairen de Nederlandse grens over. Deze passage verwees naar een artikel uit het Journal des Réfugiés van 21 oktober 1914 waarin stond, zoals we in hoofdstuk 3 zagen, dat Franck de plaats van Deguise had ingenomen en de stad overgegeven had, terwijl het een patriottische plicht was om de stad desnoods tot aan haar volledige verwoesting te verdedigen. Zo ook naar de brief van burgemeester De Vos gericht tegen dit gestook van het Journal des Réfugiés. Die werd op 27 oktober in het Journal gepubliceerd en van een dubieuze commentaar in het collaboratieblad Le Bruxellois (d.d. 6 november) voorzien. In de brief luidde het: "Vos articles sont de nature à faire supposer qu'alors que l'autorité militaire était d'avis que la défense de la position pouvait être prolongée encore, l'autorité civile, et Mr. Franck en particulier, serait intervenue pour rendre la ville." ${ }^{6}$ En in een artikel uit La Métropole van 5 november 1914 werd eveneens geklaagd over het feit dat de Belgische soldaten beter waren gevaren bij meer uitstel.

Het pamflet vervolgde met te stellen dat hoewel de ramp de woede van militairen en parlementairen opwekte, net als de roep om straffen die tot voorbeeld strekken zouden, de Belgische autoriteiten niets konden doen. De "woede van militairen en parlementairen" [B.Y.] lijkt ontleend aan de passage uit de Gazet van Brussel van 5 januari 1915 waarin stond dat na de capitulatie van Antwerpen "...de woede van velen paal noch perk" kende.

Op vraag van de Belgische regering, zo ging het vlugschrift voort, had daarna een rechtbank te Den Haag gezeteld. Die moest de zaak uitzoeken, zonder evenwel te kunnen bestraffen. De Vossische Zeitung, Le Bruxellois en de Tageszeitung hadden gemeld dat een tribunaal in Le Havre zou zetelen en dat er sprake was van een verhoor in Den Haag. Maar zoals gezien had L'Avenir medio december 1914 in zijn verhaal verteld dat er in Den Haag 
een verhoor plaatsgevonden had en was de verwijzing naar het proces in Le Havre geschrapt. "Cooremans" en Hymans waren er, zo lezen we in La Vérité, aanwezig in de hoedanigheid van afgevaardigden van de Belgische regering. "Devos", "Frank" en "Rijckmans" werden opgeroepen, maar die eerste gaf niet present. "Frank", aldus het vlugschrift, sprak dan in naam van de drie [een allusie op het feit dat hij een advocaat was, $B Y$ ] en vertelde "Cooremans" dat ze een voortzetting van het bombardement van de al zo fel getroffen stad wilden vermijden. Blijkbaar was dit ook ontleend aan de brief van De Vos, die de lof van het gemeentebestuur zong: "elle a épargné à la ville la prolongation d'un bombardement qui durait déjà depuis 36 heures [et] avait causé des ravages énormes." "Cooremans" herinnerde aan de opdracht van "De Guise". U hebt, zo zei hij, schandelijk uw plechtige missie verzaakt en bent de naam Belg die in de geschiedenis onsterfelijk gemaakt is, onwaardig. Vervolgens leest men in het vlugschrift een terechtwijzing van Hymans aan het adres van "Frank":

Oui, vous avez trabi votre patrie, et pour que je vous appelle un traître, vous qui fûtes un de mes meilleurs amis politiques et un camarade personnel, il faut que l'acte accompli par vous soit abominable. Ici, nous sommes impuissants, mais je n'hésite pas à dire, que si nous avions encore les pouvoirs nécessaires en Belgique, vous et vos deux compagnons, vous passeriez au peloton d'exécution.

Hier dient opgemerkt dat van een twist tussen Franck en Hymans voor het eerst in de Vossische Zeitung van 26 november 1914 gewag gemaakt werd. De beschuldiging van landverraad troffen we eerder in Le Bruxellois van 1 december 1914 aan. In dezelfde editie van het Franstalige persorgaan lazen we hoe het verhaal over de uitzonderingsrechtbank in Nederlandse, Franse en Britse bladen besproken werd. Geen wonder dus dat La Vérité zich voorstelde als een pamflet overgenomen uit dagbladen in die landen. Voorts is het frappant dat niet minder dan vijf van de zes namen van Belgen fout gespeld waren. In één "Nederlandse" versie werd ook "Rijkmans" i.p.v. Ryckmans geschreven. En in de versie waarover De Vlaamsche Stem het had, werd "Hijmans" geschreven daar waar Hymans moest staan. Sommige fouten vertonen overigens een grammaticale gelijkenis: tweemaal $k$ en niet ck. Dit op zich wijst in de richting van een Duitse opsteller. In het Duits kan immers na een $\mathrm{n}$ of een lange klinker nooit een ck volgen (cf. "Rijkmans", "Frank"). In de tekstuele weergave van de versie waaruit Borms in de lente van 1915 tijdens een voordracht citeerde, stond dan weer "Ryckmann", hetgeen al evenzeer 
een Duitse bijklank heeft. ${ }^{9}$ Belangrijker is evenwel dat men de foutieve spelling van de namen "Frank" $[s i c]$ en "Cooremans" $[$ sic $]$ enkel in het genoemde artikel van de Vossische Zeitung - en voor wat "Cooremans" betreft ook in Le Bruxellois - aantreft.

Er werd in La Véritévervolgens beweerd dat op het bewonderenswaardige Belgische ereveld een verrotte plek lag: "Antwerpen". De auteurs spaarden de roede niet. Antwerpen werd afgeschilderd als een eerloze stad van kooplieden, van mensen met een dor hart en joden die bereid waren uit alles munt te slaan, zelfs uit de meest heilige zaken. ${ }^{10}$ Volgens het vlugschrift stak het aura van België af tegen de eeuwige schande die Antwerpen te beurt viel. Wanneer mensen die de jonge gewetens zouden onderrichten aan de kinderen het voorbeeld zouden geven van de eerlijke en manmoedige houding van de Belgen, zo laf overvallen door de Duitse reus, zou Antwerpen als repoussoir dienen.

Tu seras le Judas donnant plus de relief à la suave et pure figure du Christ et on dira: 'Voilà ce qui fut la Belgique' et on ajoutera: 'Voilà ce quifit [sic] Anvers' et dans la mémoire des hommes les deux conduites seront jugées, cela est le châtiment de l'avenir.

De morele berisping was echter maar de eerste straf. Want er werd een andere in het vooruitzicht gesteld die de Scheldestad wachtte en nog veel onheilspellender klonk. De gordel van forten die Antwerpen omringde als een beschermer had de stad aan de vijand verkocht, zo luidde het. Nu zou diezelfde vijand er zich van bedienen tegen de kinderen van het Belgische vaderland. Want de Belgen, gesteund door hun bondgenoten $(s i c)$, verdedigers van het recht, de waarheid en de rechtvaardigheid zouden komen en de forten, die Antwerpen aan de Duitsers "aangeboden" had, opnieuw innemen. De vernietiging door vijandelijke kogels die het "laffe" Antwerpen dacht te vermijden, zou nu door Engelse kogels voltrokken worden. De stad zou tot een hoop ruïnes herleid worden: het was haar eigen wens geweest. Die stelling bouwde uiteraard voort op waar de Gazet van Brussel al eind 1914 op zinnespeelde en zeer duidelijk in januari 1915 orakelde. Op zijn beurt putte het verhaal over de verwoesting, net als dat over de uitzonderingsrechtbank, uit sommige analyses die na de val van Antwerpen in de Belgische vluchtelingenpers opdoken en die in het besluit van het vorige hoofdstuk besproken werden. De zinsnede over de terugkeer van de "verdedigers van het recht, de waarheid en de rechtvaardigheid" ging zeer waarschijnlijk terug op het Journal des Réfugiés van 22 oktober 1914. Dat had toen een vertoog van het gemeentebestuur van Le Havre aan de Belgische regering afgedrukt. Het beschouwde het ver- 
blijf van de regering in de Franse stad als het bewijs van de vriendschap die de Franse bevolking met het heroïsche België en zijn illustere monarch verbond en eindigde als volgt: "Interprète de la population havraise toute entière, il [...] salue l'espoir des réparations prochaines, qui amèneront le triomphe de la civilisation, de la justice et du droit." ${ }^{11}$

Bovendien konden de Duitse diensten zich voor de bewuste passage ook laten inspireren door de bewering van La Métropole van 24 oktober 1914 als zouden de vluchtelingen zeker niet moeten terugkeren, omdat de Duitsers hen bij een beschieting door de geallieerden als levende schilden zou gebruiken. Of, zoals volksvertegenwoordiger Terwagne het op 28 oktober 1914 in L'Indépendance Belge stelde: "Anvers serait la meilleure protection allemande contre les Alliés." ${ }^{12}$ En was het gedrag van het stadsbestuur niet ronduit laf geweest, zoals sommige dagbladen dat gemeld hadden? De vernietiging van de stad die het vlugschrift voorspelde, zou komaf maken met de Duitse kolonie in Antwerpen:

Nous fouillerons ton nid de vipères teutonnes, nous enlèverons le dard à ces guêpes malfaisantes et sur ses ruines nous reconstruirons une ville ouverte à toutes les nations du monde sans la laisser dominer par aucune [lees: niet door de Duitse natie, $B Y$ ]. Peut-être alors [sic, qu'alors, $B Y$ ] cette Anvers future que nous aurons réédifiée parviendra-t-elle encore à force de grandeur d'équité et d'honneur à faire oublier Anvers [sic] de 1914.

De Duitse propaganda bouwde in dit fragment blijkbaar voort op de Duitse "infiltratie" van de stad waar La Métropole in haar fameuze artikel van 22 augustus 1914 op had gewezen. Met dit beeld bestond bovendien al jaren vóór de oorlog een zekere vertrouwdheid. En dan waren er nog, in lijn hiermee, twee polemische artikels uit het Journal des Réfugiés die eveneens dienst konden doen. In het eerste (29 oktober 1914) werden de vaderlandsloze handelaars, die door geldzucht gedreven met de Duitsers na de oorlog handel zouden drijven, gegispt. In een tweede (31 oktober 1914) werd beweerd dat Antwerpen door een lakse nationaliteitswetgeving vóór de oorlog door Duitsers en Oostenrijkers besmet was geweest. En dus, impliciet, dat men de stad daarvan moest zuiveren. ${ }^{13}$ Het schimpschrift vervolgde met een uithaal naar de drie mannen: "moge uw naam ten eeuwigen dage door de Belgen verafschuwd worden. Vervloekt zij de burgemeester [De Vos, $B Y]$ die niet eens de moed had om zich voor de rechtbank te komen verdedigen." [B.Y.] En het besloot: 
Et vous les deux flamingants, que votre infamie ouvre les yeux aux flamands, aux vrais flamands [sic, "Flamands", BY] [...] Qu elle [sic, "Qu'elle", $B Y][\ldots]$ leur montre l'abomination de l'abîme ou [sic, "où”] vous vouilliez les entraîner. L'ère du flamingantisme est fini [sic, "finie", $B Y]$. Vive la Belgique unie et indivisible.

Dat deze slotpassage als doel had de flaminganten de gordijnen in te jagen, behoeft geen betoog.

\section{Apocalyps van een nieuw Carthago}

Het laatste deel van het vlugschrift vormt het meest intrigerende. Wat waren de bronnen? Het thema van de straf die uitgesproken werd, werd later nog herhaald. Zo noemde Le Bruxellois, in het kader van herhaaldelijke aanvallen op de Belgische politiek, op 20 april 1915 wat België overkomen was geen onverdiende straf. Door het klerikaal-liberale vooroorlogse steekspel en het electorale opbod heette België niet klaar geweest te zijn voor de oorlog:

Hélas! Cinq milliards de ruines et de vies fauchées par milliers payèrent cet aveuglement. Nous avions péché contre nous-mêmes et l'expiation est venue, châtiment $[. .$.$] non immérité et qui nous servira pour l'avenir de$ sanglante et inoubliable leçon... ${ }^{14}$

Het motief van de verwoesting van de stad, desnoods te verkiezen boven een eerloze overgave, kwam zoals vermeld herhaaldelijk in de Belgische vluchtelingenpers voor. ${ }^{15}$ Ook schreef de Duits-Oostenrijkse propaganda in de nasleep van de val van Antwerpen hoe de Britten en de Belgische regering niet geaarzeld hadden om de stad aan de verwoestende Duitse artillerie over te laten. En die daad heette door motieven, die nauw aanleunen bij wat we in dit vlugschrift lezen, ingegeven te zijn: het germanofiele Antwerpen mores leren. Opmerkelijk is voorts de pseudoreligieuze ondertoon in de slotpassage van het pamflet. Vermoedelijk werd hiervoor ook inspiratie geput uit de evangeliën. Had Christus de geldwisselaars en handelaars niet uit de tempel verdreven ${ }^{16}$ In het Evangelie volgens Mattheüs zei Jezus aan de Farizeeën:

Wee u, schriftgeleerden en Farizeeën, huichelaars! [...] Wat staat dan hoger: het goud of de tempel die het goed heilig maakt? [...] Slangen, adderengebroed, hoe zult ge het hellevonnis ontkomen? [...] Jeruzalem! 
Jeruzalem [...] Hoe dikwijls heb ik uw kinderen willen verzamelen [...] maar gij bebt niet gewild. ${ }^{17}$

Volgende voorspelling van Jezus Christus aan zijn discipelen vindt men in alle synoptische evangeliën terug: "Ziet ge die grote gebouwen [van de tempel]? Geen steen zal op de andere gelaten worden. Alles zal worden verwoest." ${ }^{18}$ Er bestaat een tweede gelijkenis tussen bovenstaande passages en het Nieuwe Testament: de afkeer van het aardse en de komst van het hemelse Jeruzalem, zoals voorspeld in Openbaringen, hier vertaald naar het nieuwe Antwerpen. ${ }^{19}$ Een derde parallel betreft de passage over het "nid de vipères". Die vond zijn oorsprong in het Oude Testament. In het boek Jesajah vindt men naast een visioen over de verwoesting en de eerloosheid van Jeruzalem niet alleen het volgende stuk: "Luister, jij rumoerige, levendige, vrolijke stad [Jeruzalem]! Je bewoners zijn niet eervol met het zwaard gedood in de strijd! Nee, al je aanvoerders zijn laf gevlucht", maar ook een contrasterende passage over het toekomstige Koninkrijk Gods. ${ }^{20}$ Die luidt als volgt: "Bij het hol van een adder speelt een zuigeling, een kind graait met zijn hand naar het nest van een slang." 1

In de Duits-activistische propaganda werd tijdens de oorlog de inhoud van het pamflet met Bijbelse thema's in verband gebracht. Zo insinueerde Raf Verhulst, naar aanleiding van een voedseltekort, op 1 oktober 1917 in Het Vlaamsche Nieuws dat "Havere het Vlaamsgezinde Antwerpen ter dood veroordeeld" had en dat de "komiteiten onzer franskiljons [het patriottische Nationaal Hulp- en Voedingskomiteit, $B Y$ ] de strafuitvoerders waren". Naar aanleiding daarvan bracht hij La Vérité in herinnering, waaruit dan de laatste passage werd geciteerd. Verhulst becommentarieerde die als volgt:

dat is de Jeruzalemse vloek op Antwerpen geworpen! Doch daar Titus Joffre [de Franse opperbevelhebber, $B Y$ ], Titus French [de opperbevelhebber van de Britse troepen in Frankrijk, $B Y$ ] en Titus Haig [de Britse generaal, $B Y]$ met al de andere woorden-Tituskens, van Churchill tot Lloyd George en Asquith [de twee opeenvolgende Britse eerste ministers vanaf $1908, B Y$ ], nu drie jaar de Jeruzalemse verlossing [i.e. van het Ottomaanse Rijk, $B Y]$ beloven, zonder met één kilometer hun doel te naderen, nu worden wij de hongersnood overgeleverd! ${ }^{22}$

Met Titus verwees Verhulst hier naar de gelijknamige Romeinse keizer, die Jeruzalem belegerde en vernietigde in 70 na Christus. Op dat thema borduurde de auteur voort in december 1917, toen Jeruzalem door de geallieer- 
den op de Turken werd ingenomen. Hij beweerde met name dat de Britse generaal Allenby daar zelfs wat voor keizer Titus onbereikbaar bleek, zou verwoesten en hoopte daarom op een redding van de Heilige Stad door de Duitse keizer. Terloops uit Jesajah citerend, verhaalde hij hoe de kunstschatten van de stad het British Museum zouden verrijken. Op de Olijfberg zou een Palace Hotel verrijzen en mocht Christus nog in zijn graf rusten, hij zou - aldus Verhulst - naar Madame Tussauds overgebracht worden. ${ }^{23}$

Het antisemitisme dat we ook in de ondertitel van La Vérité ("ville infâme, ville des Juifs") aantreffen, lijkt ons aan het pamflet toegevoegd te zijn om het vertrouwde beeld van de jood als christusmoordenaar kracht bij te zetten. Was het doel van de passages in La Vérité die een verwantschap met de Bijbel vertonen, niet om de herkenbaarheid van het pamflet voor een katholiek publiek te verhogen? Poogden de opstellers met zulke fragmenten de christelijke eschatologie, waarvan het bewustzijn door de wereldoorlog aangewakkerd was, te recupereren? Er waren overigens priesters die de oor$\log$ en het lot van Antwerpen als een straffe Gods aanzagen. Op 8 november 1914 beklaagde Stijn Streuvels zich hier in zijn dagboek over. Hij beschreef hoe een pastoor uit West-Vlaanderen voorspelde welke steden er vernietigd zouden worden "uit straf van het verderf" [...] "Antwerpen heeft alreeds het lot onderstaan" (i.e. zijn verdiende straf gekregen). ${ }^{24}$ Eind oktober 1914 was het in de vluchtelingenpers bekend dat Streuvels zijn dagboek zou uitgeven, maar pas in februari 1915 bevond hij zich met zijn manuscript in Nederland. De polemieken omtrent zijn dagboek, dat deels in De Vlaamsche Post (Gent) gepubliceerd werd, dateren van nog later. ${ }^{25}$ Als directe bron voor de Duitse propaganda kunnen we zijn dagboek uitsluiten.

Van cruciaal belang om het laatste deel van La Vérité te begrijpen, is alleszins wat de Gazet van Brussel op 5 en 13 januari 1915 beweerd had. In het persorgaan treft men de eerste maal aan hoe de verwoesting van Antwerpen in de kaart speelde van de Britse havens. Het heette toen dat "dweepzieke heerschappen" in oktober 1914 hoopten dat Antwerpen vernietigd zou worden en dat de geallieerden dat zouden doen bij de terugname van de stad. Die laatste bewering leest men dus in het Brusselse persorgaan van het gouvernement-generaal én in La Vérité, wat ons meteen iets leert over wie het pamflet opstelde. Het thema leefde blijkbaar door, want jaren later vinden we het opnieuw expliciet terug. Het artikel Antwerpen's Straf, dat het Duits-activistische tijdschrift Door Vlaanderen Heen naar aanleiding van een Britse luchtaanval op Antwerpen op 28 oktober 1917 publiceerde, beschreef namelijk hoe La Vérité zich liet lezen als een voorspelling. Het beweerde dat de Britten weliswaar tot hun ergernis de Antwerpse forten niet hadden kunnen 


\section{Donr Vlaganderen hagn}

\section{Geillustreerd bijblad}

\section{Engelsche luchtaanval op Antwerpen} Zondag, 28 Oktober 1917.

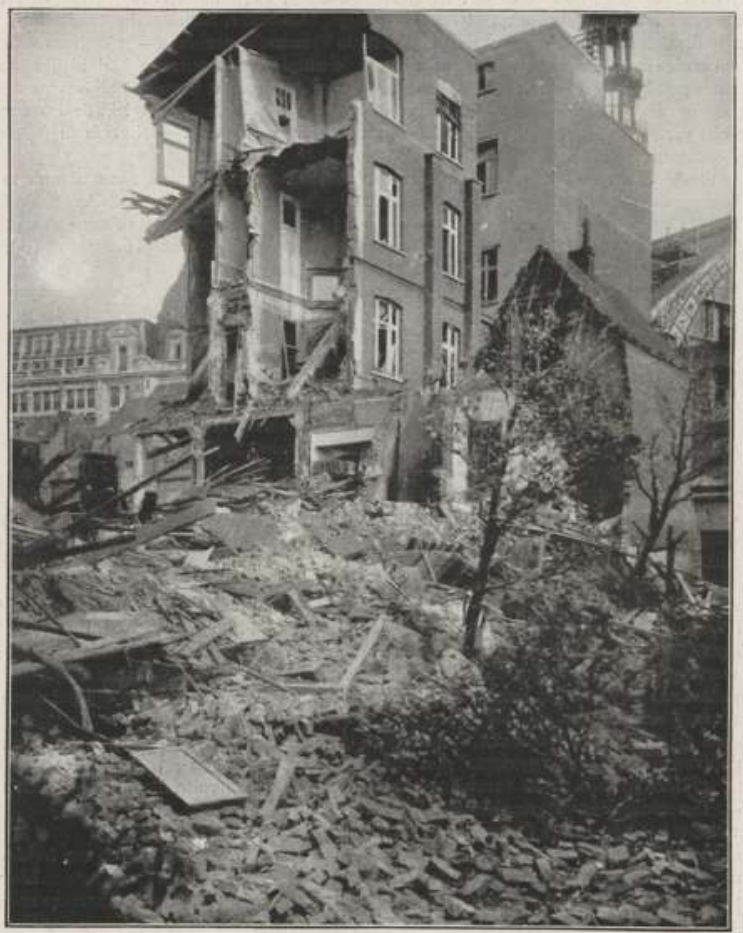

Huis nabii de „Diamantbeurs“ te Antwerpen.

Afb. 13. Nog in 1917 bleef de Duits-activistische propaganda beweren dat de geallieerden Antwerpen zouden verwoesten, ditmaal vanuit de lucht. Door Vlaanderen Heen, 1917, z.p.; EHC: B 105036:37 [C2-585 d] 
terugnemen, maar wellicht de vernietiging van de stad met luchtaanvallen wilden voltrekken. Men leest hier dus een variatie op wat Verhulst in Het Vlaamsche Nieuws stelde: enkel zou Antwerpen hier niet gestraft worden door hongersnood, maar wel door bombardementen. En waar in de Gazet van Brussel Antwerpen zou verwoest worden, omdat het een concurrent was van "buitenlandse" havens, diende de Scheldestad in Door Vlaanderen Heen gekastijd te worden, omdat zijn nieuwe toekomstmogelijkheden die van Londen bedreigden. "Want Antwerpen is 'het nieuwe Carthago', de geduchte mededingster." ${ }^{26}$ Inderdaad vormde het verhaal van het nieuwe Carthago een constitutief onderdeel in de constructie van La Vérité ${ }^{27}$ Zoals gezien was het Georges Eekhoud die deze beeldvorming over Antwerpen aan het begin van de jaren 1890 neerpende. Een aantal thema's die in zijn boek voorkomen, treft men ook in de slotpassage van La Vérité aan.

Zo was La Nouvelle Carthage, meer nog dan La Vérité, doordrenkt van antisemitisme. ${ }^{28}$ Antwerpen werd in het werk afgeschilderd als een verwaand oord dat de voorvaderlijke waarden de rug toegekeerd had. Daarom had de stad haar deugd verloren. De schuldigen waren de joden en de "verjoodste" Belgen. Tegenover de corrupte industriëlen, beurshandelaars en zakenlieden, onder wie de criminele miljonair Béjard, een petroleumhandelaar op het Kattendijkdok, stelde Eekhoud de wijsheid van de oudere bestuurders: de traditionele burgerij en Antwerpse aristocratie, die zich enkel door autochtonen liet omringen. Het werk was ook de kroniek van een aangekondigde verwoesting, naar analogie met die van Carthago door Rome in de oudheid. Die verwijzing naar de Punische oorlogen is op nog een ander punt relevant. Zoals de socialistische en antisemitische senator Edmond Picard, een vriend van Eekhoud, beweerde, waren de oorlogen tussen Rome en Carthago een van de belangrijkste gebeurtenissen in de eeuwenlange strijd tussen Semieten en Ariërs. Kortom, de verwijzing naar Carthago was er ook één naar de gevolgen van het "joodse gevaar". Groot was de invloed van de Franse antisemiet Edouard Drumont op deze karikatuur. Die schilderde de jood af als iemand die in de eerste plaats een handelaar was in menselijk vlees, nu eens een parasitair schepsel, dan weer een bedreigend insect dat zich toelegde op "le mal de l'or" (een element dat voorkwam in het vlugschrift). ${ }^{29} \mathrm{Op}$ de Antwerpse Beurs, symbool van alle kwaad, voelde de jood, die voor geld - en hier lezen we weer een overeenkomst met La Vérité - zogezegd "tot alles" bereid was, zich in het narratief van Eekhoud in zijn sas. De schrijver brandmerkte dat oord als een synagoge waarin rabbijnen en gelovigen als onmenselijke roofvogels wereldrijken inpikten en handel dreven met de zielen van de Vlaamse landbouwers. Voor de personen die dit oord des verderfs in de 
handelsstad frequenteerden - "la meute avide de curée" - had hij geen goed woord over.

Het gebouw omschreef hij als "ce temple du Dieu Commerce", met zijn "aride rite commercial". De beschrijving van Eekhoud was niet van Bijbelse beeldspraak gespeend. Zo karakteriseerde hij de plaats waar de grote handelaars samenkwamen als volgt: "Là trônent, pontifient, les mages billionaires, les grands prêtres. Piliers même du négoce, aussi solides que les colonnes [philistines] de leurs temples [...] contre lesquelles l'honnête Samson ne prévaudrait jamais!"30 De schrijver bestempelde de beurshandelaars als kapelaans van de godheid die het muntstuk van honderd stuivers symboliseerde. De jood werd afgeschilderd als een wrede egoïst die zich overleverde aan een materialistische cultus. Toonbeeld van die corruptie waren de industriëlen en de financiers die bezig waren met Antwerpen in hun klauwen te grijpen. ${ }^{31}$

Een ander thema in het boek was de fatalistische houding over Antwerpen. Daarbij waren aantijgingen over het "antimilitaristische" karakter van de Belgische havenstad niet van de lucht. Volgens de schrijver vervulde de metropool, hoogmoedig in plaats van strijdlustig, als handelsstad met tegenzin haar rol van militair bolwerk. De stad had al een concessie bekomen van een ouder fort en droomde ervan om ook alle verschansingen en ringmuren die haar omwalden te kunnen omvormen tot hangars, haven- en droogdokken. Ze vervloekte als een verfoeilijke dienstbaarheid de omheining van doorheen de eeuwen uitgebreide vestingwerken, bedoeld om hen onneembaar te maken. De oorzaak voor die afkeer van de fortengordel zocht Eekhoud in het verleden. In plaats van de stad te beschermen, had ze net de ergste plagen aangetrokken, zoals maandenlange belegeringen, bombardementen, invallen, plunderingen, brandschattingen en verwoestingen door vreemde soldateska. Met name tijdens de Spaanse Furie in 1585 was Antwerpen ternauwernood ontsnapt aan een volledige verwoesting, die haar nooit meer uit haar asse zou doen opstaan en tot haar verdwijning zou geleid hebben. Maar door de Schelde kon ze elke keer mooier en begeerlijker herboren worden. Naarmate de stad evenwel rijker werd, werd ze ook zelfzuchtiger. Zou ze nieuwe rampen vermoeden? Hoe meer haar handel bloeide, des te fanatieker werd haar haat tegen die schadelijke forten. Die werkten niet alleen haar bloei tegen, maar duidden haar in geval van oorlog ook aan als theater van een wanhopig strijdtoneel:

Et la ville en arrive à envelopper dans la même animadversion les bastions qui l'étranglent et la garnison oisive et parasite qui semble insulter à son activité et dont elle conteste jusqu'au courage patriotique. Ainsi Carthage exécra jadis ses mercenaires. 
Eekhoud omschreef die vooroordelen tegen, de afkeer, ja de haat van Antwerpenaren voor het leger als een onverzoenlijkheid van zeden, een historische rancune die de Antwerpenaar erfde als een traditie die van nature aanwezig was in de lucht die hij inademde. Een laatste thema in het boek betrof de ondergang en verwoesting. Met name in het laatste hoofdstuk van het boek ontdekte de protagonist hoe Béjard kinderen in een buskruitfabriek liet werken (onder meer om de patronen leeg te maken), waar dan nog een stoommachine draaiende gehouden werd naast opslagplaatsen van petroleum. Op dat moment had onze hoofdrolspeler een apocalyptisch visioen. Hij ontwaarde daarin een explosie waarbij afgerukte ledematen te zien waren. Daarna volgde de echte ontploffing. ${ }^{32}$ De auteur beschreef hoe die in een oogwenk plaatsvond en zo hevig was dat ze kilometers verder verwoestingen aanrichtte. Als een eenvoudige lucifer stak ze 50.000 petroleumvaten aan. "Et tels étaient les progrès de la déflagration, telle fut la furie de cette marée incendiaire quelle paraissait devoir submerger la métropole..." ${ }^{33}$ Antwerpen heette zowel bij Eekhoud als in La Vérité dus een hebzuchtige, egoïstische, verjoodste en materialistische stad te zijn, een antimilitaristisch en modern spiegelbeeld van Carthago. Een stad die bovendien haar fortengordel verachtte, het leger geen blik waardig gunde, kortom laf was. In het verleden was de stad reeds verwoest, maar steeds mooier herrezen (vgl. de allusie op het nieuwe Antwerpen in het laatste deel van La Vérité). In de beschrijving van Antwerpen volgens Eekhoud valt overigens niet alleen een inhoudelijke, maar zelfs een stijlverwantschap met La Vérité op. Die wordt erg duidelijk wanneer men de twee volgende passages naast elkaar legt. De eerste komt uit La Nouvelle Carthage:

Ah! [Anvers] ville superbe, ville riche, mais ville égoïste, ville de loups si âpres à la curée qu'ils se dévorent entre eux lorsqu'il n'y a plus de mouton à tondre jusquaux os. Ville selon le coeur de la loi de Darwin. Ville féconde, mais marâtre. Avec ta corruption hypocrite, ton tape-à-l'oeil, ta licence, ton opulence criarde, tes instincts cupides, ta haine du pauvre, ta peur des mercenaires; tu mévoques Carthage... ${ }^{34}$

De tweede komt uit La Vérité:

Anvers, Ville infâme, Ville des Juifs [...] Anvers, [...] ville de marchands, [ville] du peuple au coeur sec, ville de juifs avides, prêts à faire argent [sic] de tout, même des choses les plus sacrées! Alors que notre petit pays verra son nom étinceler dans une aurore de gloire, ce sera pour toi la honte 
éternelle. [...] toi, Anvers, tu serviras de repoussoir [...] Tu seras un amas de ruines: $\mathrm{O}$ Anvers, et c'est toi qui l'auras voulu...

Eekhouds boek verscheen tussen 1888 en 1893 in verschillende versies die telkens aangevuld werden. Soms gebeurde dat met hoofdstukken die feitelijke gebeurtenissen bevatten. Zo werd in 1891 het hoofdstuk La Bourse toegevoegd, met daarin een verwijzing naar het afbranden van de Antwerpse Beurs in 1858. Het hoofdstuk La Cartoucherie uit hetzelfde jaar putte dan weer inspiratie uit de in hoofdstuk 1 besproken explosie van de kruitfabriek van Corvillain op 6 september 1889. Blijkbaar was het personage Béjard een alter ego daarvan. ${ }^{35}$ Welnu, zowel Peter Heinrich Rieth sr., wiens petroleumraffinaderij en -opslagplaats door een explosie bij (de later veroordeelde) Corvillain vernietigd was, als Ryckmans, de toenmalige advocaat van die Corvillain, waren daarbij betrokken. Wat ons hier interesseert, is de rol van de zoon van Heinrich Peter: Henri Rieth. Die patroneerde immers de Gazet van Brussel, het propaganda-orgaan van het gouvernement-generaal. Heeft hij door het gebruik van het werk van Eekhoud ook geen unieke kans gezien om Ryckmans te viseren en zo via het vlugschrift terloops ook zijn vader te wreken?

La Nouvelle Carthage was overigens niet de enige literaire bron voor het laatste deel van $L a$ Vérité. Het stukje over het uittrekken van de angel uit de kwaadaardige Teutoonse wespen in het pamflet, lijkt immers ontleend te zijn aan La Vie des Abeilles (1901) van Maeterlinck. De schrijver verhaalde daarin over zijn herinnering aan de lessen van een oude Zeelandse liefhebber van bijenkorven: "J'y appris les noms et les habitudes des indépendantes butineuses que nous ne regardons jamais, les prenant pour [...] des guêpes malfaisantes $[. ..] .{ }^{36}$

Maar wat bracht de Duitse diensten tot het idee om deze motieven in hun pamflet te verwerken? Welke personen speelden een rol? En waren er misschien nog bronnen die ons meer leren over het vlugschrift?

\section{In het spoor van de Duitse cultuurpolitiek}

Waarschijnlijk was het de Luxemburger Tony Kellen die al vóór de oorlog vertalingen van het werk van Eekhoud in Duitsland verspreidde, die het gouvernement-generaal erop wees dat er uit La Nouvelle Carthage garen te spinnen viel. Tijdens de Eerste Wereldoorlog was hij met de Zivilverwaltung verbonden. ${ }^{37}$ Speelde Reismann-Grone hier een rol in? De vooroorlogse ban- 
den zijn bekend en tijdens de oorlog liet Kellen zijn propaganda-artikels en -werken in Essen, de thuishaven van Reismann-Grone, drukken. Daaronder waren er meerdere over België, zoals Aus der Geschichte des Zeitungswesens in Belgien (1915). ${ }^{38}$ Ook verzorgde hij voor Belgien sonst und jetzt (1915) de redactie en het voorwoord. Dat was een boek met vooroorlogse foto's van België en de Belgische kunst, alsook afbeeldingen van de Duitse verwoestingen tijdens de oorlog. ${ }^{39}$ In 1916 schreef hij Die vlämische Hochschule in Gent (1916) en het jaar erop Das vlämische Volk (1917). We moeten ook opmerken dat de man een bijenliefhebber was, wat zijn interesse voor La Vie des Abeilles van Maeterlinck kan helpen verklaren. ${ }^{40}$

In een propaganda-uitgave over België van de Süddeutsche Monatshefte uit april 1915 wijdde Kellen als "neutrale Luxemburger" een artikel aan de Belgen, die hij een "Mischlungsvolk" noemde. ${ }^{41}$ Het was bovendien een bevolking met een laag cultureel ontwikkelingspeil, hetgeen de Belgische "gruweldaden" aan het begin van de oorlog verklaarde. Volgens hem bestonden er grote antropologische verschillen tussen Vlamingen en Walen. De volgende passage verraadt Kellens Alduitse inspiratie:

Gemiddeld zijn de Vlamingen groter dan de Walen, hebben ze een langere schedel en een lichtere huids- en oogkleur [...] men kan ze uiterlijk [...] als Germanen herkennen, maar ook de wezensaard van hun karakter getuigt van hun Germaanse afkomst [...] Hun taal is een Nederduits dialect. [B.Y.]

Beide "volksstammen" vormden volgens Kellen geen natie. De Walen wensten een aansluiting bij Frankrijk, die echter enkel via een oorlog mogelijk was. De Vlamingen wilden, ondanks hun afkeer voor de Walen, dan weer geen aansluiting bij Nederland noch Duitsland. Kortom, België was een verstandshuwelijk. Het Vlaams-Waalse antagonisme zette zich ook in de Belgische literatuur door. Vóór de jaren 1880 was er in het Frans volgens hem maar één werk verschenen dat van belang was, namelijk La Légende d'Ulenspiegel (1867) van Charles De Coster. Naast dit boek bestonden er enkele lezenswaardige werken: Happe-Chair (1886) van Camille Lemonnier, $\mathrm{La}$ Nouvelle Carthage natuurlijk en ten slotte Kees Doorik (1883) ook van de hand van Eekhoud. De rest moest men maar in enkele verzamelbanden bundelen. Het valt op dat Kellen in zijn artikel de naam van Eekhoud zesmaal liet vallen. Men moet daarbij opmerken dat het werk van deze drie schrijvers niet gespeend was van een antisemitische ondertoon. Dat geldt zeker voor Eekhoud en Lemonnier. ${ }^{42}$ 
In januari en februari 1915 publiceerde Kellen zijn eerdere vertaling van La Nouvelle Carthage uit de Rheinisch-Westfälische Zeitung opnieuw in de Düsseldorfer General-Anzeiger (was dit toeval, gelet op het feit dat de verspreiding van het pamflet La Vérité toen begon?). Twee jaar later verscheen ze in boekvorm. Net als bij Kees Doorik (maart 1918) was de uitgever Insel Verlag. ${ }^{43}$ Anton Kippenberg, het hoofd van die uitgeverij, meldde in oktober 1914 aan Eberhard von Bodenhausen, de kunstkenner en sterke man binnen het Krupp-bedrijf, dat de Duitse uitgevers de strijd moesten aanbinden met diegenen die tegen het "Germanendom" samenspanden. Wat de overste van Von Bodenhausen, Gustav Krupp, die tussen 1906 en 1943 het bedrijf leidde, wenste, liep min of meer parallel met het radicale programma van Heinrich Claß, de voorzitter van het Alldeutscher Verband. ${ }^{44}$ Krupp had in november 1914 zijn oorlogsdoeleinden aan de staatssecretaris voor Buitenlandse Zaken Von Jagow en aan een paar van zijn vrienden in de Duitse regering kenbaar gemaakt. Het blijkt dat de industrieel zich op de radicale en Alduitse lijn plaatste. Hij verwierp elke vredesconferentie, het Deutschtum noemde hij het hart van Europa, Frankrijk moest als grootmacht uitgeschakeld worden en inzonderheid het Verenigd Koninkrijk was de echte vijand. Daarom moest België en misschien het noordoosten van Frankrijk, militair bezet blijven. Dat alles bezag hij binnen het raamwerk van een Duits Mitteleuropa dat ook Nederland omvatte. ${ }^{45}$ In een brief die Kippenberg op 31 mei 1915 naar Von Bodenhausen verstuurde, toonde hij zijn interesse in de Flamenpolitik:

Indien we nu België willen "behouden", "beschermen" [...], dan is het absoluut noodzakelijk dat we in die richting [...] zo snel mogelijk intellectuele relaties aanknopen en hen, vooral via de boekhandel, die in dit opzicht veel politieker zou moeten worden, een echte basis geven. Zo staat me een Duits-Belgische (of Duits-Vlaamse?) uitgeverij voor ogen, politiek - artistiek en literair gericht, met een soort Insel-Bibliotheek [...] In Vlaanderen. [...] Wat weten de zo nauw verwante Vlamingen over ons, wat weten wij over hen? [B.Y.]

Kippenberg wist Von Bodenhausen, en later Von der Lancken, ervan te overtuigen dat de belangen van zijn uitgeverij en die van de Duitse politiek parallel liepen. Von Bodenhausen beschikte over goede contacten met de hoogste leger- en regeringskringen. Hoe ver zijn arm reikte, wordt duidelijk wanneer we weten dat Kippenberg door toedoen van de grootindustrieel vanaf augustus 1915 (amper twee maanden na de brief) als eerste-luitenant 
in het etappegebied te Tielt gelegerd werd en daar de officiële Kriegszeitung uitgaf. Dat vernoemde boeken bij Insel Verlag zouden verschijnen, was van die actie de verdere neerslag. Er werd heel wat voorbereidende arbeid in die flämische Serie gestoken. Medewerkers van Kippenberg, verbonden aan het gouvernement-generaal, contacteerden de betrokken auteurs. ${ }^{46}$ Verschillende Duitse uitgevers zouden tijdens de oorlog, onder invloed van de Flamenpolitik, een competitie aangaan om het werk van Vlaamse schrijvers in het Duits uit te geven. Eekhoud zelf werd meermaals gecontacteerd door Friedrich-Markus Huebner, een literator die in België deel uitmaakte van het gouvernement-generaal. Hij was een medewerker van Kippenberg en spande zich tijdens de oorlog in voor de Duits-Vlaamse cultuurpolitiek. ${ }^{47}$ $\mathrm{Na}$ een eerste bezoek van Huebner gaf Eekhoud op 10 december 1915 aan Insel Verlag schriftelijk de toestemming om zijn werk te publiceren. Nochtans kondigde in mei 1916 het officiële Börsenblatt für den deutschen Buchbandel de Duitse publicatie aan van twee werken van Eekhoud bij de uitgever Georg Müller. Naar aanleiding daarvan bezocht Huebner opnieuw persoonlijk de Belgische schrijver. Op 3 juni 1916 bracht Kippenberg hun eerdere overeenkomst in herinnering. Müller drong echter aan en beriep zich op het feit dat de vertaling van Kellen van La Nouvelle Carthage in verschillende bladen verschenen was. Op 16 juli ontving Eekhoud een brief van Kellen. Die schreef dat de dubbelzinnigheid draaide om het principe van de "toegelaten vertaling". Indien Eekhoud de toelating gegeven had om La Nouvelle Carthage in die bladen uit te te geven, gold dat dan ook voor de boekvorm, zo vroeg hij zich af. Na veel vijven en zessen werd toch een akkoord bereikt: Insel Verlag mocht La Nouvelle Carthage uitgeven, mits zeer grondige herwerkingen. ${ }^{48}$

De hele episode leek de reputatie van Eekhoud na de oorlog te zullen schaden, temeer daar hij in 1918 medewerker was van het activistische weekblad Vlaamsch Leven. Hij diende dan ook zijn ontslag als leraar in. Toch volgde er eerherstel voor de schrijver. In augustus 1920 werd hij door de koning benoemd aan de Koninklijke Academie van de Franse taal- en letterkunde. ${ }^{49}$ Maar hoe verklaart men dat de Duitse diensten plots het werk van Eekhoud zo interessant vonden voor hun vlugschrift over de val van Antwerpen? Was dit louter de verdienste van Kippenberg en Kellen geweest? Speelde het feit dat enkele maanden vóór het uitbreken van de oorlog La Nouvelle Carthage opnieuw uitgegeven werd door de uitgeverij van de Mercure de France een rol $?^{50}$ Dat kan de belangstelling wel aangewakkerd hebben. Maar er was toch meer aan de hand. 


\section{Caveant Consules}

Zo lijkt het duidelijk dat de Duitse diensten gebruikgemaakt hebben van een ander stuk om La Vérité met motieven over Carthago te verrijken. Het betreft een artikel van 25 januari 1911 uit La Jeune Wallonie. ${ }^{51}$ In het licht van de strijd rond de vernederlandsing van de Gentse universiteit titelde het blad: Caveant Consules. Deze Latijnse spreuk verwijst naar een formule die de Romeinse gezagsdragers aanspoorde erop toe te zien dat de staat geen schade berokkend wordt. Wat België bedreigde, maakte de anonieme auteur in niet mis te verstane bewoordingen duidelijk: het was de "pretentieuze" en "tirannieke" "vierde partij" van Vlaamsgezinden. Die achtte hij verantwoordelijk voor de politieke crisis die België doormaakte. Die flaminganten en dan inzonderheid de liberale volksvertegenwoordiger Franck, zijn katholieke collega Van Cauwelaert en het socialistische kamerlid Huysmans, wilden zogezegd Wallonië de wet opleggen: "les exigences de ce parti, égaré par des sectaires, augmentent chaque jour." De Vlaamsgezinden vormden, zo heette het, een bende fanatici die aanzetten tot de verbrokkeling van de natie. Niettemin was hun streven tot falen gedoemd. Hij waarschuwde Waalse volksvertegenwoordigers om niet, net als bij de stemming van de Gelijkheidswet, hun partijen te verraden voor "le péril flamingant". Daarna volgde een sneer naar Antwerpen:

La ville d'Anvers est devenue le centre de ce flamingantisme entêté, impitoyable et sectaire. Cela ne peut nous étonner. La nouvelle Carthage - égoïste, mercantile et orgueilleuse, celle-là qui ne connaît que ses hommes, ses affaires, ses artistes - est conquise par l'Allemagne financière, juive et commerciale.

Pol de Mont zou zich hier wel over verheugen, want die ging over de Rijn voor een vergadering Teutonen verklaren dat de hele Vlaamse bevolking pan-Germanistisch was (sic). Zijn oproep had een weerklank gevonden: "L'Allemagne veut Anvers. Elle rêve d'en faire à son tour un pistolet braqué sur le coeur d'Angleterre." ${ }^{52}$ Vandaag al stuurde Duitsland zijn bankiers, beste handelslieden en spionnen naar de welvarende metropool. Langzaamaan voltrok zich de verovering en groeide de buitenlandse invloed: "la juiverie de la finance active dans l'ombre un mouvement qui servira parfaitement les intérêts de l'Empire [allemand]. Elle prépare une guerre de races... Elle ne l'aura pas." ${ }^{33}$ De economische overheersing van dat mercantiele en egoïstische Antwerpen ging in dit verhaal dus de Duitse verovering vooraf, met alle clichés over sektarische flaminganten die met hun vrienden van over de Rijn 
meeheulden, en over verjoodsing van dien. Het literaire thema van Eekhoud werd dus politiek geïnstrumentaliseerd.

De gelijkenissen tussen dit artikel en de Duitse propaganda die men in $L a$ Vérité leest, zijn treffend: de aanval op de Vlaamse beweging, op drie flaminganten onder wie Franck, op Antwerpen (volledig in de stijl van Eekhoud) en op het jodendom met de benadrukking dat de havenstad geïnfiltreerd was door gevaarlijke Duitsers incluis. Zelfs het antagonisme tussen Antwerpen en het Verenigd Koninkrijk vindt men erin terug. In de slotpassage werd beweerd dat de fiere Vlaamse bevolking zich niet zou laten vangen aan het discours van die flamingantische oproerkraaiers. Indien het vaderland in gevaar was, zouden de Belgen in één klap al hun twisten vergeten en zich tot heil van de natie verenigen: "Du calme, de la bonne volonté, de la patience et de la politesse aussi, suffiront aux Flamands et Wallons à régler une bonne fois un conflit dont le résultat confondra surtout le Teuton rapace..." Werd de Duitse propaganda uit La Vérité ook niet door deze passage, die dan vertaald werd naar het antagonisme tussen de "échte Vlamingen" wier ogen geopend zouden worden en "de flaminganten" wier tijdperk uit was, geïnspireerd? Een concrete aanwijzing dat het generaal-gouvernement bekend was met dit artikel komt uit Belgien als Französischen Ostmark (1917) van Pius Dirr. Die wijdde een heel hoofdstuk aan de "Hochschulstreit", met alle Franse en wallingantische tegenkanting van dien en liet dat beginnen met een vergadering van Van Cauwelaert, Franck en Huysmans. Te Antwerpen hadden die in december 1910 (de maand vóór het verschijnen van het besproken artikel in La Jeune Wallonie dus) een eed gezworen niet te rusten alvorens de vernederlandsing van de Gentse universiteit in het parlement goedgekeurd was.

Verderop in zijn boek citeerde hij twee passages uit La Jeune Wallonie. De eerste ging over de reden van de antipathie van de "Latijnse" Walen tegenover de "Germaanse" Duitsers. Het gevaar van de Duitse economische, industriële en commerciële infiltratie, waarvan het "verduitste" Antwerpen een smadelijk voorbeeld heette te zijn en het flamingantische gevaar, slechts een voorloper van het Duitse, speelde daarin een rol. De tweede was een overname uit Caveant Consules. ${ }^{54}$ Dirr leidde die als volgt in: "Der Zeitschrift La Jeune Wallonie [...] ist Antwerpen vor allem auch als vlämischer Vorort verdächtig." Daarna volgde de passage uit Caveant Consules die de meeste verwantschap vertoonde met wat we in La Vérité lazen:

Die Stadt Antwerpen ist der Mittelpunkt dieser hartnäckigen, unerbittlichen und sektiererischen vlämischen Bewegung geworden. [...] Das neue Karthago, eigensüchtig, handelsfleiszig und stolz, dieses Karthago, das 
nichts gelten laßt, als sich selbst, seine Geschäfte, seine Halbgötter [dit stond niét in La Jeune Wallonie, maar zou een toespeling kunnen zijn op "le Dieu Commerce" die in het werk van Eekhoud de joden op de Antwerpse Beurs zo dierbaar heette te zijn, $B Y$ ], seine Künstler, ist durch das geld- und handelsmächtige jüdische Deutschland erobert worden. Deutschland will Antwerpen haben. Es träumt damit seinerseits eine geladene Pistole auf das Herz Englands zu richten. [...] Schritt auf Schritt geht die Eroberung vorwärts.

Omdat Dirr pas begin 1915 aan het gouvernement-generaal gehecht werd, kon hij natuurlijk onmogelijk bij de constructie van het hele pamflet, waarvan de grondslagen al vroeger gelegd werden, betrokken zijn. Maar wie dan wel?

\section{De mensen achter de schermen}

Om die vraag te beantwoorden moeten we de actoren betrokken bij de aan het pamflet voorafgaande perscampagne nader bestuderen. De reorganisatie van de Belgische dagbladen door de Duitse diensten gebeurde al onder de eerste gouverneur-generaal, Von der Goltz. Von Sandt, het hoofd van de Zivilverwaltung, gaf hem hieromtrent raadgevingen, zo bijvoorbeeld over het verbod op het Franse persagentschap Havas en de suggestie om in Brussel een filiaal van het Duitse Wolff-bureau te openen. Van daaruit werden persberichten in het Nederlands, Frans en het Duits kosteloos verspreid. Daarna konden enkele bestaande redacties hun bedrijvigheid hervatten. $\mathrm{Na}$ een onderhandeling met de Duitse uitgever en journalist Wertheimer stelde Von Sandt meerdere dagbladen voor die in aanmerking kwamen om verspreid te worden. Zouden die weigeren onder Duitse censuur te verschijnen, dan behield het gouvernement-generaal zich het recht voor om een eigen dagblad uit te geven. ${ }^{55}$ Von der Lancken was, zoals besproken, in oktober 1914 bij de ondertekening van het verdrag van Kontich aanwezig. Als we de memoires van de Duitser mogen geloven, had Franck tijdens de onderhandelingen de vrees geuit dat hij later voor zijn daden zou veroordeeld worden. ${ }^{56}$ Zeer waarschijnlijk heeft Von der Lancken de juridisch erg betwistbare capitulatie van de vesting Antwerpen uitgebuit voor propagandadoeleinden. De aristocraat geeft ons ook een goed beeld van hoe die propaganda functioneerde. In zijn rapport aan Berlijn uit mei 1915 schreef hij dat enkele van de voornaamste Duitse dagbladen de toestemming kregen om hun correspondenten in België, met zetel te Brussel, te vestigen. Weliswaar dienden zij 
hun artikels aan de Duitse persdienst voor te leggen. De bedoeling daarvan was om tussen henzelf en de Duitse overheid een zo nauw mogelijke band te smeden. "Aldus zouden ze uit zichzelf de bijzondere voorwaarden van hun werk onder een vaderlandslievend [Duits, $B Y$ ] oogpunt beschouwen.” [B.Y.] Natuurlijk moesten ze dan ook spontaan afzien van in Duitsland informatie te verspreiden die niet in overeenstemming was met de doeleinden die de Duitse administratie in België nastreefde. Of, positief uitgedrukt, propaganda verspreiden die de Duitse oorlogsdoeleinden diende. In ruil daarvoor kregen de correspondenten de garanties dat belangrijke informatie voor hen niet zou verdonkeremaand - lees: aan hen doorgespeeld - zou worden.

Von der Lancken meldde aan Berlijn dat acht vertrouwenspersonen voor de volgende perskanalen weerhouden waren: het Wolff-agentschap en de Vossische Zeitung; de Frankfurter Zeitung; de Kölnische Zeitung; de Lokalanzeiger; de Kölnische Volkszeitung; de Kreuzzeitung en, ten slotte, de Deutsche Tageszeitung. Natuurlijk, zo schreef hij, waren alle andere dagbladen buiten dit systeem gebleven. ${ }^{57}$ Voor wat de constructie van de geruchtenmolen, die aan La Vérité voorafging betreft, springen een aantal figuren die aan het gouvernement-generaal verbonden waren, in het oog. Een eerste was de vernoemde Hackenbroich van de Kölnische Volkszeitung. In 1906 was hij redacteur voor Le Patriote (katholiek) en de Kölnische Wochenzeitung. Ook werkte hij op het persbureau van Congo-Vrijstaat. ${ }^{58}$ Wertheimer was sedert 1908 verbonden aan de Vossische Zeitung en het Wolff-agentschap..$^{59} \mathrm{Al}$ in 1912 had hij een studie aan de Belgische pers gewijd. ${ }^{60}$ In juli 1914 zou hij de Belgische hoofdstad verlaten hebben, maar na de bezetting van Brussel, werd hij bij de Duitse censuurdiensten tewerkgesteld en dit tot $1918 .{ }^{61}$

Op 6 november 1914 schreef Wertheimer een artikel dat een week later verscheen in de Vossische Zeitung, het blad dat de geruchtenmolen over de berechting van het Antwerps driemanschap aan het draaien bracht. Daarin publiceerde hij een erg gedetailleerd overzicht van de Belgische pers, met een korte beschrijving ervan sedert het uitbreken van de vijandelijkheden. De uitgever merkte op dat het in Antwerpen gemakkelijker was om dagbladen te doen herverschijnen. Daar hadden de Britten, waar niemand in de Scheldestad een goed woord voor over had, wel voor gezorgd (het gekende motief). $\mathrm{Na}$ de dagbladpublicaties in de grote steden te hebben besproken, besloot hij:

Für die allgemeinen Verhältnisse in Belgien ist es von größter Wichtigkeit, daß die öffentliche Meinung durch die Presse aufgeklärt wird. Die deutsche Verwaltung wendet deshalb der Presse ihr ganz besonderes Wohlwollen zu und Sie zeigt volles Verständnis für diese ihre Aufgabe. ${ }^{62}$ 
La ville d'Anvers est devenue le centre de ce flamingan tisme entêté, impitoyable et sectaire. Cela ne peut nous étonner. La nouvelle Carthage - égoiste, mercantile et orgueilleuse, celle-fla qui ne connait que ses homines, ses affaires, ses hếros, ses artistes - est conquise par l'Allemagne financière, juive et commerciale. Monsieur Polde Mont s'en réjouit sans doute, lui qui s'en fut prêcher la bonne cause un jour sur les bords du Rhin où il affirma solennellement, au millieu d'une assemblée de Teutons, que tout le peuple flamand était pangermaniste!

Une telle déclaration n'est pas restée sans écho chez nos uissants voisins. L'Allemagne veut Anvers, "Elle rêve d'en faire à son tour un pistolet braqué sur le cceur de PAngleterre. $=$ Déjà elle envoie dans cette ville si prospère, et ses bariquiers et ses meilleurs commercants, ses espions aussi, et petit à petit la conquête se fait et l'influence étrangère grandit. La juiverie de la finance active dans l'ombre un mouvement qui servira parfaitement les intérêts de l'Empire. Elle prépare une guerre de races... Elle ne l'aura pas.
- AhI ville superbe, ville riche, mais ville égoiste, ville de loups si âpres a la curéequ'ils se dévorent entre eux lorsqu'il n'y a plus de mouton a tondre jusqu'aux os. Ville selon le cour de la loi de Darwin. Ville féconde mais maratre. Avec ta corruption hypocrite, ton tape-a.l'ceil, ta licence, ton opulence criarde, tes instincts cupides, ta haine du pauvre, ta peur des mercenaires; tu m'evoques Carthage... N'avez-vous pas ete frappés, vous autres, du préjugé qu'ils entretiennent, ici, contre le soldat? Meme les Anversois qui ont de leurs garçons à Parmée, sont impitoyables et féroces à l'égard des troupiers. Nulle part en Belgique on n'entend parler de ces terribles bagarres entre militaires et bourgeois; de ces guet-apens on des assommeurs tombent dessus au permissionnaire ivre, rega. gnant la caserne faubourienne ou le fort perdu à l'extrémité de la banlieve....

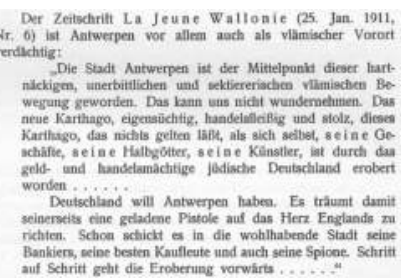

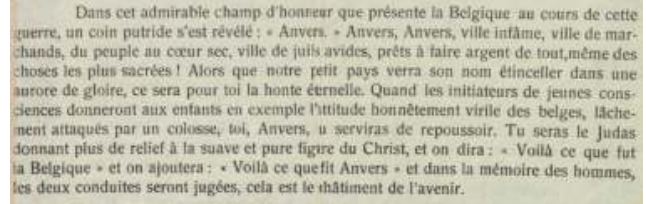
les deux conduites seront jugées, cela est le thatimeat de l'avenir.

If en est un autre qui t'attend et auquel tu ntéchapperas pas. Les évènements ne se sont pas encore accomplis.

Afb. 14. De wallingantische propaganda van La Jeune Wallonie (1911) (bovenaan, links) inspireerde zich op La Nouvelle Carthage van Georges Eekhoud (1893) (bovenaan, rechts). Pius Dirr, die op het gouvernement-generaal werkte, hernam de bewuste passage uit het wallingantische tijdschrift in Belgien als französische Ostmark (1917) (onderaan, links). Onderaan rechts: een fragment uit La Vérité sur la Capitulation d'Anvers, waaruit een stijlverwantschap met het gepubliceerde stuk uit de roman van Eekhoud blijkt.

1) La Jeune Wallonie, 25 januari 1911, 1-3; KBR III 99.537 A; 2) EEKHOUD, 1893, 111; KU Leuven Libraries Artes University Library MAGA5: Magazijn 3A4; 3) DIRR, 270; Ligplaatsnummer: KU Leuven Libraries Artes University Library MAGAK: Magazijn A15163; 4) KB Den Haag 1419 B 10

Dat waren geen loze woorden, want dezelfde dag vervalste de Antwerpse correspondent van de Vossische Zeitung het artikel van Henderickx in het kader van de Flamenpolitik. Wertheimer, allicht gesteund door Rieth en Hackenbroich, die tot 1915 op post bleef, speelde waarschijnlijk een rol in een deel van de propaganda die voorafging aan La Véritée. ${ }^{63}$ Met name dan voor wat betreft het artikel dat in de Vossische Zeitung van 26 november 1914 verschenen was en door Le Bruxellois hernomen werd. Een volgende actor was de al vermelde dr. Wien, die voor de Kölnische Zeitung werkte. Medio november 1914 had dat blad inderdaad een provocerend artikel over Antwerpen laten verschijnen, dat later in de Gazet van Brussel hernomen werd.

Ook wijzen we nog op de eerder besproken rol van Wohlmann van de Deutsche Tageszeitung, het blad dat het bericht over de uitzonderingsrechtbank begin december 1914 onder licht gewijzigde vorm opnieuw wereldkun- 
dig gemaakt had. Ten slotte dient de naam J.P. Lippert vermeld te worden. Deze Luxemburger had zich in december 1891 te Brussel gevestigd. Hij werd redacteur bij Le Soir en, vanaf 1897, bij de Kölnische Zeitung. De vrijzinnige Lippert genoot een hoog aanzien op de Duitse ambassade. In 1906 meldde hij de Duitse zaakgelastigde dat hij van plan was om een germanofiel dagblad in Brussel op te richten. Dat zou om te beginnen tweemaal per maand verschijnen en tot doel hebben "de ophitsingen van de door Parijs betaalde pers te neutraliseren”. [B.Y.] De Duitse zaakgelastigde reageerde in een schrijven aan rijkskanselier Von Bülow terughoudend en besloot voorlopig de kat uit de boom te kijken. Toen in 1906 enkele nummers van het dagblad van Lippert, de Gazette Internationale, uitgegeven werden, viel hij blijkbaar toch in de gunst van Berlijn. Er werd de Brusselse ambassade immers een geldsom toegestuurd om hem te steunen. Maar in januari 1907 verwoestte een brand de lokalen van zijn blad. Lippert probeerde vervolgens een persagentschap op te richten, waarvoor de som van 10.000 mark nodig was. Hij werd hierin gesteund door de rijkskanselarij, die het geld vergeefs probeerde in te zamelen bij de Duitse kolonie in Antwerpen. De financiële middelen bleven uit en bij de Kölnische Zeitung werd hij bedankt voor bewezen diensten. Lippert bleef wel tot 1914 Brussels correspondent voor de Neue Freie Presse en de Pester Lloyd. ${ }^{64}$ Blijkens een verslag van het Belgisch Dagblad van 26 februari 1916 werkte deze "intrigant" tijdens de oorlog mee aan L'Echo de la Presse. Dat was een blad dat op 3 november 1914 voor het eerst verschenen was. Het stelde zich als neutraal voor. Ook was hij "waarschijnlijk" nog correspondent van de Neue Freie Presse. ${ }^{65}$ Werkte hij mee aan de Oostenrijkse propaganda ${ }^{66}$

\section{Een opmerkelijk stuk van Harry}

In mei 1915 publiceerde Gérard Harry een artikel, getiteld L'Agonie d'Anvers, in het Parijse maandblad La Grande Revue. ${ }^{67}$ Naar eigen zeggen gebeurde dit aan de hand van "het belangrijkste fragment" van notities van een Belgisch artillerieofficier, waarvan hij beweerde dat die de commandant van zijn vrienden was. De gepubliceerde aantekeningen van de bevelhebber van een fort van de binnenste gordel rondom de vesting Antwerpen gingen vooral over de dagen vóór de val van de vesting. Harry voorzag het geheel van een inleiding en besluit en beloofde de naam van de man bekend te maken, op het moment dat de voorschriften die de anonimiteit oplegden aan soldaten, opgeheven werden (een belofte die hij overigens niet nakwam). Zulke voorschriften bestonden. Zo verscheen in 1919 in De Legerbode een geanonimiseerd ver- 
slag over de val van Antwerpen, "volgens 't verhaal van luitenant-kolonel $\mathrm{X}$. ${ }^{68}$ In de door Harry gepubliceerde notities stond achtereenvolgens een gedetailleerd relaas over de vernietiging van de buitenste fortengordel, de terugtocht van de soldaten, de aankomst van de Britse versterkingen en het begin van de Duitse beschieting van Antwerpen. Vervolgens het verhaal van de commandant die met enkele manschappen afgesneden werd van de troepen die zich over de Schelde terugtrokken, de heraansluiting bij het Belgisch leger en de aftocht naar Oostende. De volgende passage van 7 oktober 1914 trekt de aandacht:

Anvers va payer, comme les autres malheureuses villes belges, son ruineux tribut à la guerre. Mais on devra reconnaître que c'est un châtiment mérité. Cette ville ne s'était-elle pas laissé germaniser depuis longtemps? Toutes les sympathies y allaient naguère à ceux qui devaient nous attaquer et nous trahir. Et Anvers fut aussi la ville de l'égoïsme et du mercantilisme à outrance, la Carthage qui haïssait l'armée et s'opposait à toute dépense et défense militaires. Tout le pays paye la lâcheté des boutiquiers anversois... ${ }^{69}$

Men merkt dat deze zinnen elementen bevatten die men in het boek van Eekhoud, de vooroorlogse wallingantische propaganda, en later in het slot van La Vérité aantreft. Daar leest men ook hoe Antwerpen de laffe, verduitste stad van kooplieden was. Naar analogie met het vermelde "egoïsme" in bovenstaande passage, heette Antwerpen in het vlugschrift "hebzuchtig" te zijn. Het pamflet beweerde eveneens dat de verwoesting een straf was. Een analogie met de inhoud van die notities vindt men in ook in het pro-Duitse dagblad Le Bruxellois van 20 april 1915, waarin de straf die door de oorlog over België kwam "niet onverdiend" heette te zijn. ${ }^{70}$

Een aantal indicatoren wijzen erop dat het stuk van Harry apocrief is. Zo werd de bewuste passage over de niet onverdiende straf die Antwerpen te beurt zou vallen, ingeleid door een problematische passage. Daarin stond dat er op 7 oktober 1914 een Brits detachement, bestaande uit 1000 mariniers, zich aangemeld had. Die wilden zich niet ingraven, maar ten aanval trekken. Daarvoor kwamen de versterkingen, aldus de officier, acht dagen te laat. ${ }^{71}$ Dat was een vreemde bewering, wetende dat het laatste Belgische offensief in werkelijkheid bijna twee weken eerder plaatsvond, op 25 september 1914.

De eerste Britse troepen waren op 4 oktober 1914 geland. ${ }^{72}$ Volgens de officier ging het toen om minstens 4 tot 5000 man. "Pour la plupart fusiliers de marine, d'un entrain endiablé."’3 In zijn naoorlogse verslag van wat 
er zich op 4 oktober 1914 afspeelde, meldde "luitenant-kolonel X" in De Legerbode de aankomst van slechts 2000 man Britse marine-fuseliers. ${ }^{74}$ Volgens hem kwamen die zonder materiaal. John Buchan, de oorlogscorrespondent van The Times schreef, in lijn met het verslag in De Legerbode: "their equipment was very imperfect." 75 Ook de officiële Britse rapporten geven aan dat er op 4 oktober 2085 marinetroepen aankwamen te Antwerpen. ${ }^{76}$ Buchan citeerde eenzelfde cijfer. ${ }^{77}$ Waarom was de commandant in het stuk van Harry zo enthousiast geweest over die troepen die geen substantiële hulp boden ${ }^{78}$ Een tweede ontplooiing van de Britse troepen in de binnenste fortengordel gebeurde niet, zoals we in het verslag lezen, op 7 oktober, maar wel op 6 oktober $1914 .^{79}$

Voorts vertelde de officier hoe hij op 7 oktober 's namiddags de nieuw aangemelde Britse troepen naar de loopgraaf tussen twee forten begeleidde. Maar de Britse mariniers hadden hun posities in de loopgraven van de binnenste fortengordel al in de nacht van 6 op 7 oktober ingenomen. ${ }^{80}$

Ook lezen we in de notities van 7 oktober: "Les journaux nous apportent la proclamation du général de Guise $[s i c]$ avertissant la population de l’imminence du bombardement de la ville." ${ }^{81}$ De enige proclamatie van Deguise was op 3 oktober 1914 in de pers verschenen. Daarin stond dat de vesting Antwerpen tijdens de belegering aan vijandelijke projectielen kon blootgesteld worden en werd een beroep gedaan op het patriottisme van de inwoners. ${ }^{82}$ Op de dag van de dagboekaantekening echter had Deguise gemeld dat het bombardement van de agglomeratie Antwerpen imminent was. Burgers konden de stad derhalve verlaten. Dit betrof geen "proclamatie", maar wel een brief aan de burgemeesters van alle gemeenten die de dagbladen opnamen. ${ }^{83}$ Voorts is de naam van Deguise fout gespeld in het stuk van Harry. Is het aannemelijk dat een officier niet wist hoe de naam van zijn generaal te spellen? Hij hanteerde alleszins de schrijfwijze die men ook in La Vérité sur la Capitulation d'Anvers aantreft.

In de notities van 8 oktober leest men hoe om 4 uur's namiddags een Britse generaal aankwam die de bevelhebber vroeg om nog een tijd stand te houden en beloofde twee divisies, gewapend met mitrailleurs, te sturen. Dit om de soldaten te helpen om de Duitse aanval die op het bombardement zou volgen, te weerstaan. Maar de Britten kwamen niet. ${ }^{84}$ Vond die gebeurtenis echt plaats? Welnu, die ochtend werd met generaal Dossin overeengekomen dat indien er enkele forten van de tweede lijn zouden vallen die niet opnieuw ingenomen konden worden, de verdedigingslijn onhoudbaar was. Rond vijf uur in de namiddag vertelden twee Belgische officieren dat dit voor twee van de forten van de tweede lijn het geval was. Op dat moment 
meldde de Britse aanvoerder Archibald Paris dat de Britse troepen zich na valavond zouden terugtrekken. ${ }^{85}$ In het verslag dat Harry publiceerde stond inderdaad dat om halfacht de Britse generaal kwam melden dat elk verder verzet nutteloos was. Hij nodigde de commandant dan ook uit om zijn troepen te vervoegen. Die antwoordde hem dat hij dat bevel enkel van zijn oversten kon ontvangen en dat hij op hen zou blijven wachten. Toen hij's avonds om 22 uur een soldaat naar het Britse hoofdkwartier uitzond, trof die er niemand aan. Hij beklaagde zich over de situatie: ze waren met hun vieren alleen gelaten, zonder bevelen van hogerhand. Op de Britse compagnieën en mitrailleurs moesten ze niet meer rekenen. Het Duitse bombardement intensiveerde:

Et à chaque secousse, je ferme les yeux et pense aux êtres aimés, avec la certitude de ne plus jamais les revoir. Je conçois que plusieurs officiers de forteresse, à Liège, Namur, Anvers même, aient, en de pareils moments, perdu la raison. ${ }^{86}$

Was het waarschijnlijk dat een Britse generaal, die de toestand kende nog 's namiddags twee nieuwe divisies beloofd had? En dat de troepen waarvan sprake bij Harry geen deel uitmaakten van de acht vestingsregimenten die om 18.30 uur de Schelde overstaken? Deguise had immers een uur eerder het bevel tot aftocht geblazen. ${ }^{87}$ Berustte dit dramatische gebeuren over in de steek gelaten soldaten op feiten? Of behoorde het, net als bovenstaand citaat, tot de demoraliserende, Duitse propaganda? De volgende passage van 8 oktober doet ook de wenkbrauwen fronsen:

Je me décide à tenter de quitter nos abris pour aller réoccuper les postes les moins exposés [...] ayant mis mes deux coupoles de de 7 c. 5 en action, je tire à obus brisants sur la tour de l'hôtel de ville et le clocher d'E... ${ }^{88}$

Dat een Belgische officier die Belgische gebouwen bestookte, is ongeloofwaardig. In de notities van die dag werd ook gemeld: "Nous sommes sans communication téléphonique avec l'extérieur. C'est désormais pour nous l'isolement." ${ }^{89} \mathrm{Na}$ de oorlog schreef de Franse officier-op-rust Bujac: "Les installations électriques et téléphoniques faisaient défaut partout, un seul fort excepté." ${ }^{90}$ En dat betrof dan nog de meer gemoderniseerde fortengordel van de eerste lijn. Deguise beweerde in 1921 zelfs dat er geen telefoonsysteem aanwezig was. ${ }^{91}$ Het is derhalve zeer onwaarschijnlijk dat er in de oude vestingsforten ooit een telefoon gefunctioneerd heeft. 
Misschien was het schrijven van de commandant inderdaad authentiek en bestond het al die tijd zonder dat de Duitse diensten er weet van hadden. We weten tenslotte dat het beeld van Antwerpen niet bijster positief was in militaire kringen en dat aantijgingen over het vermeende antimilitarisme van de stad er zeker niet vreemd waren. Maar hoe had Harry het dan in handen gekregen? Een positieve verklaring dat wat hij vertelde over die vrienden niet met de werkelijkheid overeenstemde, blijkt uit het feit dat hij beweerde het stuk door een "gelukkig toeval" (en dus niet door kennissen) in handen gekregen te hebben. ${ }^{92}$ Uiterst onwaarschijnlijk is dat het een authentiek document betrof dat in Duitse handen terechtkwam. Ze hadden dan beslag moesten leggen op de notities van een officier die niet krijgsgevangen was gemaakt. Veel waarschijnlijker is dat het hier om een stuk gaat van Duitse makelij, naar analogie met de gefingeerde "soldatenbrieven" die in de Duits-activistische pers gepubliceerd werden. ${ }^{93}$ Harry liet zich er blijkbaar aan vangen. De kwestie van de capitulatie van Antwerpen en de "Britse perfiditeit" bleef overigens in de Duitse propaganda aanwezig. Zo meldde de Groot-Nederlandse agent in Duitse dienst, F.C. Gerretson, op 14 mei 1915 in De Vlaamsche Post dat de beloofde Britse hulp uitbleef, toen die nodig was: “...bij de verdediging van Antwerpen verschenen 8000 halfgeoefende mariniers, die, na 35 man aan doden te hebben verloren, zich haastig in Holland in veiligheid stelden". " En volledig in lijn hiermee schreef Le Bruxellois op 11 december 1915: "Une armée anglaise aurait [...] dû débarquer chez nous le 3 août pour nous aider à repousser les Allemands, et non pas une pauvre division de 8.000 hommes à Anvers, et qui s'est rembarquée avant la capitulation de la forteresse." 95

In de Belgische vluchtelingenpers bleef de aandacht voor het relaas dat Harry publiceerde beperkt. La Métropole nam er op 2 juli 1915 een heel fragment uit over, zonder evenwel de netelige passage te vermelden. Dat deed L'Echo Belge vier dagen later ook. ${ }^{96}$ Het in het Verenigd Koninkrijk verschijnende Antwerpse commerciële persorgaan Neptune protesteerde wél zeer heftig tegen die passage. Dit protest werd op 25 augustus 1915 overgenomen in L'Echo Belge, die het eens was met zijn confrater. ${ }^{97}$ Neptune beweerde dat de volkomen foute beweringen van de commandant overeenstemden met die van vele officieren van het Belgisch leger. Het blad had naar eigen zeggen zeer verstandige mensen horen zeggen: "On aurait dû détruire Anvers de fond en comble." Dit lijkt wel overgenomen uit de propaganda van de Gazet van Brussel van 13 januari 1915. En had L'Avenir niet op 16 december 1914 in zijn verslag over het vermeende verhoor van Franck en Ryckmans in Den Haag gemeld: "A moins de vouloir que la ville [Antwerpen, $B Y]$ ne fut détruite de 
fond en comble après le départ de ceux qui avaient décidé la résistance à outrance, on [bedoeld wordt: de drie Antwerpse dignitarissen die het verdrag van Kontich onderhandelden, $B Y]$ ne pouvait évidemment agir autrement"?98 De Duitse propagandavoorstelling was blijkbaar tot in het Verenigd Koninkrijk doorgedrongen. Dit was het resultaat van het feit dat Belgische bladen en andere Duitse desinformatie via het neutrale Nederland ook daar kon worden gelezen en dat artikels derhalve naar believen becommentarieerd werden. Neptune nam de verdediging van Antwerpen op zich. Het riep met aandrang op deze "campagne" te staken (er zal dus wel nogal wat over de capitulatie van Antwerpen gesproken zijn). Het blad hoopte dat zijn artikel gelezen werd door zij die onterecht Antwerpen verfoeiden en door diegenen die een vredesconferentie voorzaten "afin qu'ils mettent Anvers dans la position d'être tout à fait belge!!". Het blad haalde ook uit naar de vooroordelen tegen Antwerpen die, aldus Neptune, zelfs zozeer in de massa doorgesijpeld waren dat een groep belangrijke mensen zegden dat ze voor die Antwerpenaars, "Allemands de coeur", niets meer zouden doen op commercieel vlak. Dat men de Antwerpenaars in sommige kringen ervan betichtte germanofiel te zijn, had te maken met de vooroorlogse situatie. Maar de oorlogstoestand heeft dit beeld versterkt. Zo beklaagde eind januari 1915 een redacteur van Antwerpsche Tijdingen zich erover dat de in Antwerpen verblijvende Brusselaars de Antwerpse postbodes verweten laf "voor de Duitsers te werken" (omdat ze hun werk hervat hadden), hetgeen de Brusselse ambtenaars niet deden. En die voorstelling werd natuurlijk gedramatiseerd door de uitwerking van de Duitse propaganda: "over een paar dagen nog zegde mij een hunner 'dat de heren De Vos, Ryckmans en Franck de stad te vroeg hebben overgegeven'; 't oude, zo dikwijls en zo vaak weerlegde praatje, dat - dankzij het lichtzinnig gezwets der Brusselaars - nog immer blijft voortwoekeren." Die bedenkingen werden dan aangevuld met de klacht dat de meeste Brusselaars in Antwerpen de Sinjoren als Duitsgezind aanzagen. En de redacteur beweerde hoe die Brusselaars telkenmale herhaalden: "'t is een flamingant", ge moet dus niet vragen welke kant zijne gezindheid gaat!" 99 Weinig verwonderlijk werd dit artikel in de Gazet van Brussel overgenomen. ${ }^{100}$ Want in de Duits-Oostenrijkse propaganda die zoals gezien in de collaboratiepers hernomen werd, hamerde men op de tegenstelling tussen beide steden. De verspreiding van La Vérité moest in dat kader ook bewijzen dat dit antagonisme erg scherp was. Daarom schreef Het Vlaamsche Nieuws op 10 april 1915 dat de Belgische pers die in het buitenland verscheen die tegenstelling maakte. En dat Antwerpen in "geheime vlugschriften" voor het allerlelijkste uitgescholden werd. Te Brussel werd, aldus het blad volgend "praatje" alge- 


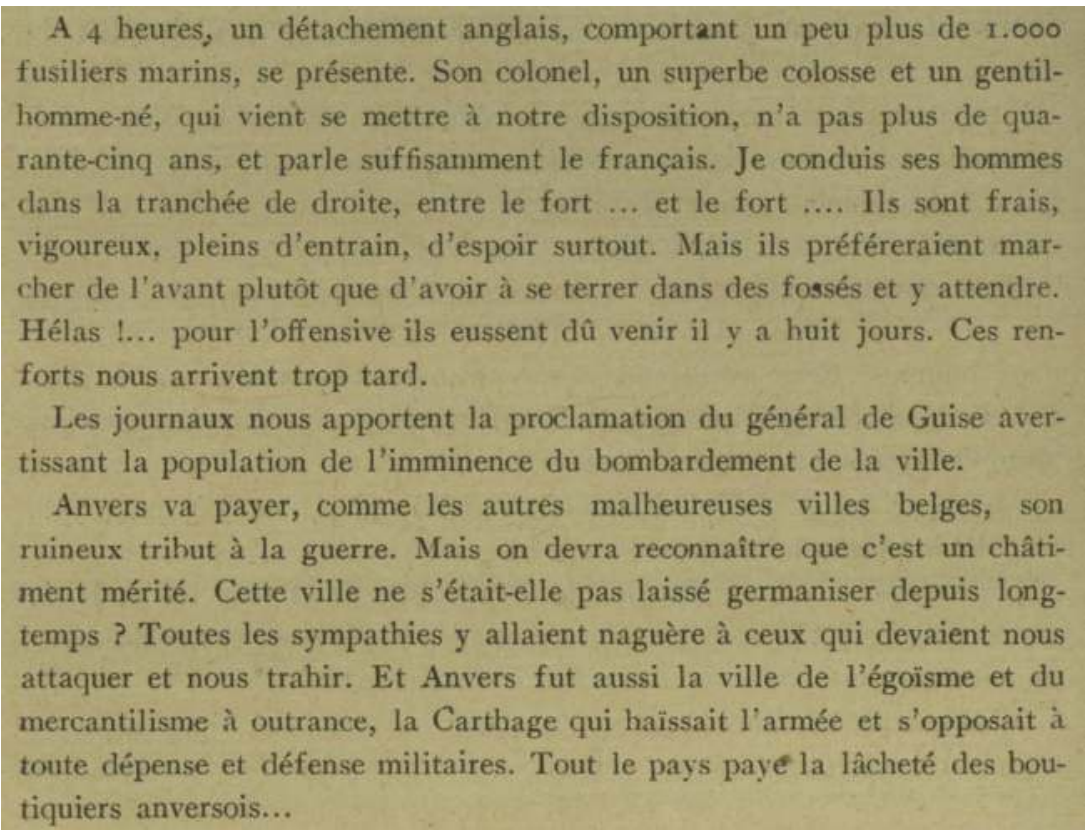

Afb. 15. Een fragment van de door de Britse journalist Gérard Harry afgedrukte "soldatenbrief" La Grande Revue, mei 1915, 360; Gentse universiteitsbibliotheek; BIB.P.002829

meen verspreid: "De Antwerpenaars! Een volk van koopliê, van sjacheraars en ikzuchtigen!" ${ }^{01}$ Dat "praatje” was natuurlijk ontleend aan La Vérité.

\section{Besluit}

La Vérité sur la Capitulation d'Anvers vormde een eerste hoogtepunt van een grootschalige Duitse propaganda-inspanning. Zelfs zonder de in dit hoofdstuk aangereikte elementen zijn er nog aanwijzingen die bewijzen dat het pamflet van Duitse oorsprong was. Zo zijn de taalfouten tegen het Frans indicatief voor het apocriefe karakter van het vlugschrift: van fout geschreven woorden tot het door en onder elkaar gebruiken van de tegenwoordige en verleden tijd. Bovendien had het pamflet een extreme inslag die de meest radicalen van de Waalse beweging ver voorbij stak. Waarom zou een Franstalige Belg bovendien ijveren voor een vernietiging van Antwerpen met alle Franstaligen incluis? En waarom zou die amper een naam van zijn landgenoten correct spellen ${ }^{102}$ 
Toch miste La Vérite zijn effect niet. Deels kwam dat ook omdat die propaganda putte uit de vluchtelingenpers. Dat zorgde ervoor dat La Vérité er voor sommige flaminganten kon uitzien als een soort uittreksel uit het Journal des Réfugiés. En dus voor hen geloofwaardiger kon overkomen. Een en ander werd literair verfraaid door motieven die de bezetter in de Belgische literatuur en dan met name in La Nouvelle Carthage vond. Wanneer we dit boek in synopsis lezen met Caveant Consules uit La Jeune Wallonie, blijkt dat er een inhoudelijke en stijlverwantschap bestaat tussen het Duits pamflet, het artikel en het boek. Interessant is hoe La Vérité ook een nieuw licht werpt op de culturele dimensie van de Flamenpolitik. Naast journalisten speelden ook uitgevers, zoals Wertheimer en Kippenberg, een rol in de constructie van de Duitse propaganda. Met name via Kippenberg liepen lijnen naar Alduitsers die zich vóór de oorlog al in de Vlaamse beweging interesseerden enerzijds en de Duitse grootindustrie anderzijds. De spilfiguur was hier zeer waarschijnlijk Tony Kellen, de Eekhoud-kenner die met het gouvernement-generaal verbonden was en, net als Kippenberg, contacten met Krupp onderhield. Zoals gezien vindt men bij Dirr concrete aanwijzingen over de constructie van het pamflet terug. Hij werd door Von der Lancken hoog ingeschat. Die laatste schreef aan Berlijn dat Dirr de taak op zich genomen had om de vooroorlogse dossiers en documenten uit Belgische ministeries te bestuderen voor propagandistisch gebruik (in het diplomatenjargon van het hoofd van de Politische Abteilung: "om de Duitse belangen te verdedigen" [B.Y.]). Het gelukte die laatste na "lange inspanningen" een aanzienlijk deel geschriften verspreid over "gangen, hoeken, kantoren en zolders" van de gebouwen van de ministeries te verzamelen. Daaronder bevonden zich dossiers van het Belgische ministerie van Buitenlandse Zaken en van het ministerie van Oorlog. ${ }^{103}$ Zo zette Dirr het werk voort van de Duitse diensten die de Conventions Anglo-Belges gepubliceerd hadden. Er kan geen twijfel over bestaan dat Pius Dirr zich grondig in "het Belgische vraagstuk" ingewerkt had. Daarvan getuigen niet alleen zijn rapporten over de Vlaamse beweging, maar ook twee artikels van zijn hand uit de Frankfurter Zeitung (20 en 24 april 1915). In een eerste hekelde hij de hypocrisie van Maeterlinck en Destrée die in Italië pro-Belgische propaganda voerden. Vóór de oorlog heetten die zich niet om de Belgische natie te bekommeren. Destrée pleitte voor de bestuurlijke scheiding van België en Maeterlinck dweepte niet alleen met Frankrijk, maar schimpte ook nog op zijn stamgenoten. Het tweede zeer gedetailleerde artikel was volledig gewijd aan het vooroorlogse vraagstuk van de bestuurlijke scheiding en het wallingantisme, waarbij gewezen werd op het feit dat de wallinganten in hun strijd konden steunen op een sterk en 
machtig Frans broedervolk. ${ }^{104}$ Die laatste opmerking is belangrijk. Want hoe belangrijk het afgelopen half jaar ook geweest was om de Flamenpolitik op gang te brengen, de inspanning van de bezetter was in 1915 zo mogelijk nog omvattender. Het zal blijken dat in die desinformatie La Vérité maar de top van de ijsberg was, een schakel in een veel groter offensief. En daarin speelde met name de Duitse recuperatie van wallingantische en pan-Latijnse propaganda een rol. 



\section{HOOFDSTUK 6 DE TOP VAN DE IJSBERG}

Begin 1915 circuleerden meerdere pamfletten van Duitse hand in bezet België. Dat bleef blijkbaar aanhouden, want in augustus van datzelfde jaar schreef een redacteur van het sluikblad La Libre Belgique:

J'ai ici, devant moi, des papiers anonymes sortant [...] d'une antichambre de la Kommandantur; voici une relation mensongère de la reddition d'Anvers [La Vérité, BY], ayant pour but de faire accroire que la ville a trahi la patrie, que la population flamande s'y est comportée en traître, relation radicalement fausse [...] Voici d'autre part un chant soi-disant national!!! [La Politique belge après la Crise - Un Parti National, BY] dans lequel l'auteur anonyme célèbre le jour où la langue flamande sera bannie de la Belgique, où le français sera l'unique langue du pays. De malheureux égarés wallons, des fanatiques à la conscience obscurcie ont répandu cette triste littérature, au nom du patriotisme belge.

Dat het vlugschrift La Vérité door de Duitse diensten vervaardigd werd, is bekend. Maar ging het tweede schimpschrift waarover de redacteur van $\mathrm{La}$ Libre Belgique het had van wallinganten uit? Of behoorde het tot de vele anonieme geschriften, waarvan Fernand Passelecq, de directeur van het Bureau Documentaire in Le Havre, in de nazomer van 1915 opmerkte dat die in februari van dat jaar verspreid werden? Volgens hem waren ze van tweeerlei aard. In sommige werd de Vlaamse beweging gekapitteld en in andere de Waalse. Blijkbaar was het de bedoeling van de Duitsers om Vlamingen en Walen tegen elkaar in het harnas te jagen. De schrijvers van die schotschrif- 
ten, aldus Passelecq, deden zich uiteraard voor als Belgen en meer bepaald als flaminganten, wallinganten of "unionisten". Onbekende handen (onbekend, behalve dan voor de Duitsers) verspreidden exemplaren van deze brochures en zorgden ervoor dat Vlaamsgezinden de zogezegd "wallingantische" lectuur in hun bus kregen en vice versa. ${ }^{1}$ Inderdaad verspreidden de Duitse diensten, zoals Von der Lancken dat schreef, "mit Hilfe unseres Vertrauensmänner-Systems im ganzen Lande” geschriften. ${ }^{2}$ Die brede verspreiding van de pamfletten, werd door de Duits-activistische propaganda dan weer afgeschilderd als "... het beste bewijs, dat die werking tegen alles wat Vlaams is, systematisch geschiedt en bij de Vlaamshaters van het hele land steun vindt". De Duits-activistische pers hield mee de geruchtenmolen draaiende. En dat gebeurde ook na februari 1915. Zo vestigde in april 1915 Antwerpen Boven (dat onder leiding stond van Borms) in een artikel, getiteld Onze moederstad gewroken, de aandacht op La Vérité sur la Capitulation d'Anvers. Het Antwerps driemanschap, verantwoordelijk voor de redding van de Scheldestad, werd erin opgehemeld. Er werd gegispt hoe men Antwerpen tegen Luik uitspeelde. Ten slotte bezwoer het blad nooit te zullen toegeven aan het stoken der "franskiljons" die beweerden dat er na de oorlog geen Vlaams meer zou gesproken worden. ${ }^{4} \mathrm{~W}$ ils schreef hierover:

Is het aan te nemen dat het fameuze pamflet over de overgave van Antwerpen twee maanden na zijn verspreiding nog zo'n verontwaardiging wekte, dat de redactie [van Antwerpen Boven] moest starten met een wrekende kop en een gloeiend hoofdartikel 'Onze Moederstad gewroken'?'

De beroering die de verspreiding van het pamflet veroorzaakt had, was alleszins sterk genoeg om het liberale, Brusselse persorgaan Le Progrès Libéral nog op 1 april 1915 onder de ronkende titel Ce qui sest passé à Anvers de helft van zijn aantal bladzijden te laten besteden aan de gebeurtenissen van oktober 1914. Naar eigen zeggen deed het dat om de waarheid te vertellen over het fantasieverhaal betreffende de Antwerpse burgerlijke overheid die zogezegd uit plaatselijk egoïsme het land verraden had: "Cette accusation fut répandue par un journal anversois réfugié à Londres; des extraits de l'article [...] furent distribués à profusion." [het blad geloofde blijkbaar dat La Métropole echt het artikel waarvan La Vérité een uittreksel heette te zijn, gepubliceerd had]. ${ }^{6}$ Waar Le Progrès Libéral nog maanden na de initiële verspreiding van het pamflet meende de puntjes op de i te moeten zetten, was de commentaar op La Vérité in Antwerpen Boven niet alleen een actie, erop gericht om nog méér verontwaardiging op te wekken, maar vooral als een zet bedoeld om 
aan te tonen dat La Vérité slechts een schotschrift uit een reeks anti-Vlaamse pamfletten was. Het bleef daar inderdaad niet bij, want in juni pakte het blad uit met de schreeuwerige titel: De Strop om den Hals. In die uitgave werd de inhoud van het vermelde pamflet La Politique Belge après la Crise - Un Parti National weergegeven. Daarin werd voor de oprichting van een nationale partij na de oorlog gepleit. De tekst ervan werd gekruid met een frontale aanval op de Vlaamse beweging en de bewering dat België "onder bescherming" van Frankrijk geplaatst zou worden. ${ }^{7}$

Ten slotte was er in juli de publicatie van het Appel aux Wallons met daarin gallofiele citaten. Dat werd door Antwerpen Boven aan de "franskiljons" en leiders der Waalse beweging die ook in Antwerpen zouden rondlopen, toegedicht. ${ }^{8}$ De inhoud ervan was zonder meer irritant voor Vlaamsgezinden. ${ }^{9}$

Dit hoofdstuk onderzoekt niet alleen de onderlinge samenhang tussen de vlugschriften, maar ook het mogelijke verband tussen deze propaganda en de Flamenpolitik in Nederland. Ondanks de instructies van december 1914 uit Berlijn had die daar maandenlang nog geen vaste voet aan de grond gekregen. Door intriges bij het Belgisch-loyale dagblad De Vlaamsche Stem werd tijdens de lente van 1915 een kentering ingezet (par. 2 en par. 3). Een doorbraak vond plaats in de zomer van 1915 (par. 4). Ook werd de verdere Duitse agitatie in het bezette land geconcentreerd rond een vervalsing van een demarche van de Henegouwse volksvertegenwoordiger Buisset (par. 5). Ten slotte bestuderen we de ideologische basis van de Groot-Nederlandse beweging (par. 6).

\section{La Politique Belge après la Crise - Un Parti National}

$\mathrm{Al}$ in de laatste week van mei maakte de activistische pers gewag van het pamflet La Politique Belge après la Crise. ${ }^{10}$ Het werd blijkbaar, zoals Passelecq aangaf, ongevraagd opgestuurd. Zo signaleerde Alphonse Ryckmans op 4 juni 1915 in Antwerpsche Tijdingen hoe de redactie van het blad een achttal dagen geleden in een gesloten omslag en "zo geheimzinnig mogelijk" een omzendbrief opgestuurd werd, getekend "un groupe de vrais Belges". Het stuk in kwestie was in de laatste week ook door meerdere personen ontvangen, zo getuigde hij. ${ }^{11}$ En inderdaad, acht dagen later, schreef ook de liberale Nieuwe Gazet uit Antwerpen hoe het vlugschrift de redactie "in handen [viel]". ${ }^{12}$ Antwerpen Boven publiceerde het in juni 1915 in de twee grote landstalen. De redactie beweerde dat ze het pamflet via "een vriend uit Brussel" bemachtigd had. In Brussel en later ook te Antwerpen werd het zogezegd 
"in zekere middens" van hand tot hand doorgegeven, "evenals vroeger het beruchte smaadschrift betrekkelijk de overgave van onze stad". Dat vertelt ons al iets over de echte oorsprong ervan.

Het vlugschrift begon met de aankondiging dat de Centrale Mogendheden spoedig zouden instorten. Daarom was het wenselijk om nu al te overwegen, welke politiek er in het naoorlogse België gevoerd diende te worden. Die moest "uitsluitend nationaal" zijn. Het vlugschrift meldde eerst dat in de "hachelijke stonden" volgend op de inval van de Duitse troepen in België tussen al de partijen "stilzwijgend" een echte Godsvrede gesloten werd. Die manier van verwoorden lijkt geïnspireerd door het gekende artikel van Adelfons Henderickx van 5 november 1914 dat door de Duitse diensten vervalst werd. De volksvertegenwoordiger meldde hoe toen België de oorlog aangedaan werd, de voorvechters van alle politieke partijen "stilzwijgenderwijze" overeengekomen waren voorlopig oude veten te vergeten, ofwel een Godsvrede af te sluiten. Volgens het pamflet moest die Godsvrede ook nà de oorlog doorgezet worden. De voorwaarden daartoe werden als vervuld beschouwd. De sociale kwestie had, net als de liberaal-katholieke strijd, haar beslag gekend respectievelijk door de implementering van de sociale wetgeving en de schoolwet. ${ }^{13}$ Zo ook de taalkwestie. De Vlamingen hadden immers het recht bekomen om in hun eigen taal gevonnist en bestuurd te worden. De wallinganten die de bestuurlijke scheiding predikten, moesten bestreden worden. Als het pamflet zich beperkt had tot de bovenstaande analyse, was de inhoud ervan niet abnormaal. Het sprak vanzelf dat tijdens de oorlog mensen nadachten over hoe België er morgen moest uitzien. Dat men daarbij een nationale pacificatie langsheen de drie klassieke breuklijnen binnen de Belgische samenleving in overweging nam, is evident. Aan zoiets konden de Vlaamsgezinden zich wel ergeren maar niet meer dan de socialisten of katholieken. ${ }^{14}$ Plots echter veranderde de toon omtrent de taalkwestie abrupt. Het heette dat er op meedogenloze wijze en voorgoed een einde gesteld moest worden aan het oprichten van een Nederlandstalige universiteit. Officieren, ambtenaren, noch rechters mochten "gedwongen" worden om in het Nederlands te spreken. Men hoefde zich

niet bovenmatig onrustig te maken over wat men in zekere schriften en redevoeringen, de ingrijpingen [= het ingrijpen] van het flamingantisme noemt. Die ingrijpingen, voor zoveel [= in zoverre] ze al bestaan, zullen tegengehouden worden en geheel en al wegvallen op de dag dat de nieuwe schoolwet haar vruchten zal afgeworpen hebben, zowel op de buiten als in de steden, waar de Franse taal in al de volkslagen zal doordringen. 

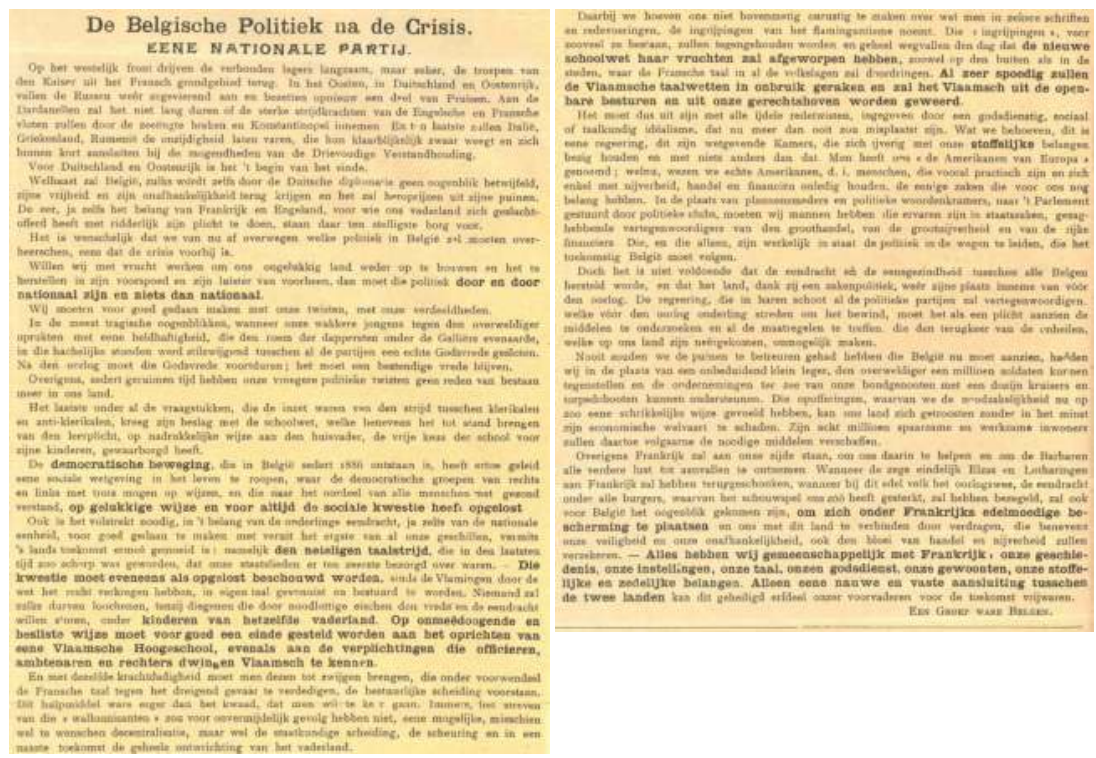

Afb. 16. Het vlugschrift La Politique Belge après la Crise, Un Parti National

Antwerpen Boven, juni 1915 (b), 2; Universiteitsbibliotheek Gent; BIB.J.003946

Zulke uitlatingen waren uiteraard meer dan gewoon ergerlijk voor Vlaamsgezinden die al niet gelukkig waren met de schoolwet die een paar maanden vóór het uitbreken van de oorlog gestemd was. Daarover werd in het becommentariërende artikel in Antwerpen Boven ook nog eens, heel subtiel, een artikel van Frans Van Cauwelaert in herinnering gebracht. Die was een half jaar eerder in het Antwerpse Handelsblad van leer getrokken tegen het later verbeterde ontwerp van de nieuwe schoolwet. Antwerpen Boven gaf toe dat de aangepaste en definitieve tekst "wat beter" was, maar in kwade handen toch nog steeds een verschrikkelijk wapen tegen het Vlaamse volk bleef: “... vele Vlaamsgezinden bleven vrezen, dat onze vijanden er zouden gebruik van maken om de verfransing op grote schaal door te drijven. De 'Groep ware Belgen' bewijst ons hoe gegrond hun vrees was." "De Strop om de Hals" was dus de schoolwet. Het lag natuurlijk in lijn met de Duitse propaganda om de Vlaamsgezinden voor te houden dat na de oorlog hun taalstrijd decennia zou achteruitgeslagen worden, ja dat hun taal zou verdwijnen. De tekst van het vlugschrift ging vervolgens nog radicaler door op het ingeslagen pad: "Al zeer spoedig zullen de Vlaamse taalwetten in onbruik raken en zal het Nederlands uit de openbare besturen en uit onze gerechtshoven worden geweerd.” De nuchtere lezer kon opmerken dat in hetzelfde schotschrift waarin de verwor- 
ven taalwetten aangeprezen werden als het ultieme middel tot beslechting der taalstrijd ook stond dat het de bedoeling was om het Nederlands uit het openbaar leven te verbannen: een duidelijke contradictie. Was dit overigens het vooruitzicht dat een Nationale Partij, bestaande uit "ware Belgen" na de oorlog bood? Of veeleer een poging die kaderde in wat Le Vingtième Siècle omschreef als "la manoeuvre tentée par M. Von Bissing dans le but de séparer le peuple flamand de la nation belge" ?16 Het vlugschrift beweerde ook dat Frankrijk aan de zijde van België zou staan tegen de invallen der "Barbaren". Meer nog:

Wanneer de zege eindelijk Elzas en Lotharingen aan Frankrijk zal terug geschonken hebben, [...] zal voor België het ogenblik gekomen zijn om zich onder Frankrijks edelmoedige bescherming te stellen en zich met dit land te verbinden door verdragen, die, benevens onze veiligheid en onafhankelijkheid, de bloei van onze nijverheid en onze handel zullen verzekeren.

Impliciet werd hier dus de boodschap verkondigd dat de Belgen voor het Franse revanchisme en imperialisme streden. De zogezegd "Nationale Partij" besloot met te stellen dat de Belgen

alles [...] gemeenschappelijk met Frankrijk [hebben]: onze geschiedenis, onze instellingen, onze taal, onze godsdienst, onze gewoonten, ["nos moeurs" in de Franse tekst, dus "zeden", BY] onze stoffelijke en zedelijke belangen. Alleen een nauwe en vaste aansluiting tussen de twee landen kan dit geheiligd erfdeel onzer vaderen voor de toekomst bewaren.

Maar waarom zou een Nationale Partij pleiten voor de herleiding van België tot een Frans wingewest en de Belgische geschiedenis, instellingen, cultuur enzovoort reduceren tot een doorslagje van de Franse? Dit alles vertolkt wel de toenmalige Duitse visie op het land: "une dépendance française" om de woorden van de activistische propaganda te hernemen. Die "dépendance" was de voor Vlaams gebruik vertaalde Duits-völkische visie van de französische Ostmark die België heette te zijn. ${ }^{17}$

Voor de verspreiding van de hierboven opgesomde kenmerken die Frankrijk zogezegd gemeenschappelijk had met België, putte ook dit pamflet uit geschriften van de vooroorlogse Waalse beweging. Met name ging het om de pan-Latijnse propaganda van graaf Albert du Bois. In 1902 had die een roman gepubliceerd, met als titel Waterloo (Belges ou Français?). Daarin betoogde hij dat Walen en Fransen tot dezelfde natie behoorden, omdat 
ze zeven hoofdkenmerken deelden: taal, wetten, zeden, religie, geschiedenis, hetzelfde ras en de wil om samen te leven. ${ }^{18}$ Die stellingname was een uitbreiding van wat hij in zijn gallofiele brochure Le Catéchisme $d u$ Wallon uit hetzelfde jaar (zie hoofdstuk 1) betoogd had. Daarin omschreef hij een natie als een groep mensen, die typerende kenmerken gemeenschappelijk had. Die onderscheidden haar van leden van andere naties: "Le premier est le plus important, c'est la langue; le second, c'est la race; le troisième, c'est le caractère national; le quatrième, c'est le passé commun." 19

Bij de constructie van La Politique Belge werden verschillende kenmerken die moesten bewijzen dat Wallonië bij Frankrijk hoorde, geëxtrapoleerd naar héél België en dus ook naar Vlaanderen. Zo lag de teneur van het pamflet in lijn met de woorden die de Duits-activistische pers in de mond van Maeterlinck en van De Marès gelegd had: dat België bij het "Latijnendom" ingelijfd zou worden. Naast wat Du Bois schreef, werd dezelfde inspiratiebron als bij La Vérité gebruikt: het tijdschrift La Jeune Wallonie (1911). In de jaargang, die ook Caveant Consules bevatte, bevond zich een redevoering van Destrée, waarin hij de spot met de âme belge dreef, beweerde dat België uit twee volkeren bestond en de Nederlandse taal kleineerde. Ook haalde hij uit naar de politieke partijen die allemaal door het flamingantisme "geïnfecteerd" heetten te zijn. ${ }^{20}$ Destrée beweerde eveneens het volgende:

Ils [Les Flamands] disaient nous voulons être jugés en notre langue. C'était légitime, cela leur a été accordé [...] Ils ont dit: nous voulons être administrés dans notre langue. C'était aussi légitime. On a donc nommé chez eux des fonctionnaires connaissant le flamand. Ainsi leurs légitimes désirs ont été satisfaits.

Kortom, alle legitieme desiderata van de Vlamingen waren volgens Destrée vervuld. In La Politique Belge après la Crise werd dit als volgt geherformuleerd: "Depuis le vote des lois qui ont garanti aux Flamands le droit d'être jugés et administrés dans leur langue, cette question là [...] est résolue." De wallingant had trouwens in 1911 nog wel meer te zeggen dat de Duitse diensten vier jaar later nuttig achtten: “...l'oppression de la langue française commence. On a dit: 'Tout fonctionnaire doit connaitre les deux langues." Daarna viel Destrée een wetsontwerp aan om het officierenkorps te "vernederlandsen”. Ook wilden de flaminganten volgens hem de ambtenarij vernederlandsen, om de tweetalige petite-bourgeoisie van Gent, Antwerpen en Brugge die dan alle ambten in de administratie kon bekleden te paaien: "...la suite fatale du triomphe des flamingants", aldus Destrée, "serait l'obligation de tous 
les Belges de connaître le flamand". [...] "Et maintenant ils veulent supprimer l'Université française de Gand. Eh bien! Je le dis nettement, je suis hostile à toute espèce d'université flamande." Daarvan maakten de Duitse diensten vier jaar later in hun vlugschrift La Politique Belge: "La création d'une Université flamande, les mesures imposant aux offciers, aux fonctionnaires des administrations publiques et aux magistrats des tribunaux et cours, l'obligation de connaître le Flamand doivent être irrévocablement écartées." Destrée vervolgde in de in La Jeune Wallonie hernomen redevoering:

Si le Roi Albert me faisait l'honneur de demander mon avis, [hij zou die uitnodiging niet afwachten, zoals we nu weten, $B Y]$ je lui dirais: la question des langues est la plus grave que vous aurez à connaître durant votre règne. [...] J'entends dire, dans cette Wallonie qui lutte contre le protectionnisme des grandes puissances: si nous étions réunis à un grand pays, quelle prospérité pour notre industrie! [...] on parle de séparation administrative! Ce serait la fin de la Belgique. ${ }^{21}$

De gelijkenis met de inhoud van het pamflet is treffend. Allereerst wat het gallofiele deel betreft. De "rattachistische" "union intime et durable entre les deux pays [België en Frankriik, $B Y$ ]" werd in La Politique Belge in de verf gezet. En de andere woorden van Destrée werden er als volgt in herwerkt:

Avec non moins d'énergie d'ailleurs il faut réduire au silence ceux qui [...] préconisent la séparation administrative. Ce serait là un reméde pire que le mal qu'on veut combattre. Les efforts de ces 'wallonisants' auraient pour aboutissement fatal [...] la séparation politique...

Inzake de economische, militaire en politieke evolutie van het naoorlogse België meldde het pamflet overigens dat de regering en Kamers zich enkel nog met economische belangen onledig moesten houden. Op zich kaderde ook dat in de filosofie van nationale eenheid. Het is echter de invulling die aan dit streven gegeven werd, die uitermate radicaal was:

In de plaats van plannensmeders en politieke woordenkramers, naar ' $t$ Parlement gestuurd door politieke clubs, moeten wij mannen hebben die ervaren zijn in staatszaken, gezaghebbende vertegenwoordigers van de groothandel, van de grootnijverheid en van de rijke financiers. Die [...] alleen, zijn werkelijk in staat de politiek in de wegen te leiden, die het toekomstig[e] België moet volgen. [B.Y.] 
In een oorlog die in de propagandistische beeldvorming van de westelijke geallieerden en van de Belgen draaide om de strijd tussen de parlementaire democratie en de autocratische keizerrijken naar het Duitse en OostenrijksHongaarse model, werd dus door "ware Belgen" gepleit voor een kortwieking van het partijenstelsel ten voordele van een parlement waarin onder anderen "rijke financiers" de toon zouden aangeven?22

Hier moeten we aan toevoegen dat al in november en december 1914 de propaganda van het gouvernement-generaal rancune tegenover de Belgische politieke klasse probeerde op te wekken. ${ }^{23}$ Deze afrekening in het pamflet met de "politieke clubs" van het vooroorlogse politieke bestel ligt in lijn hiermee. Over het militaire aspect lezen we in La Politique Belge:

Le gouvernement, représentant dans son sein tous les partis politiques, qui avant la guerre se disputaient les rênes du pouvoir, [dit was alweer een contradictie, daar het pamflet eerder een lans brak voor de afschaffing van politieke partijen, $B Y]$ a pour devoir de rechercher les moyens et de prendre les mesures qui rendent impossible le retour des calamités qui se sont abattues sur notre pays. Jamais nous n'aurions eu à déplorer les ruines qui la désolent si la Belgique, au lieu de disposer d'une armée insignifiante par le nombre, avait pu opposer un bon million de soldats à l'envahisseur.

Desgevallend had België zijn bondgenoten (sic) ter land en ter zee krachtig kunnen ondersteunen. Net als in de Duitse propaganda werd er gesproken over "bondgenoten" daar waar België slechts "garanten" had. De antiparlementaire fraseologie in het algemeen en de laatste geciteerde passage in het bijzonder zijn belangrijk om de oorsprong van het pamflet te achterhalen. Ze leiden allereerst opnieuw naar Destrée en dan met name naar zijn Lettre au Roi uit 1912. De Duitse diensten waren uiteraard bekend met de open brief van Destrée, al had de Duitse ambassade in Brussel vóór de oorlog weinig aandacht besteed aan zijn scenario dat ze onrealistisch achtte. ${ }^{24}$ Een van Destrée's aantijgingen in zijn brief betrof de bewering dat de Vlamingen de veiligheid van de Walen afgenomen hadden. Ze stonden immers, zo heette het, afkerig tegenover de algemene dienstplicht:

Anvers, réduit national, s'il n'est pas aux mains des Alllemands qui y sont déjà installés en maîtres, laissera passer l'orage à l'abri de ses forts, mais nous, Wallons, nous serons livrés aux horreurs du combat. [...] Ah! si [...] on nous laissait libres d'organiser nous-mêmes la garde de nos frontières! La seule Wallonie, avec le système suisse de la nation armée pourrait mettre 
en ligne une armée de 200.000 hommes, supérieure à tout ce que pouvait donner l'organisation militaire de la Belgique entière à l'heure actuelle...25

De vervlechting tussen het flamingantisme, de afkeer van het leger en het "verduitste" Antwerpen valt op. Maar de aandacht wordt hier getrokken door de passage over de "gewapende natie". Dit concept, dat uit de Franse Revolutie dateerde, werd in 1889 door de Tweede Internationale unaniem aangenomen. ${ }^{26}$ In dat opzicht is het artikel $A$ Propos de la Capitulation d'Anvers (Le Bruxellois, 1 december 1914) dat mede aan de basis lag van La Vérité belangrijk. Het Franstalige blad had in dat stuk omtrent de val van Antwerpen immers uitgehaald naar de vooroorlogse Belgische politiek, inzonderheid naar de "conservatieven" die zich al decennialang tegen de noodzakelijke legerhervorming verzetten. ${ }^{27}$ Het artikel uit Le Bruxellois vervolgde met de stelling dat de geschiedenis zou uitwijzen dat Antwerpen door de schuld van het decennialang beleid van de katholieke partij onvoldoende verdedigd was: "...Avec la nation armée, 800,000 hommes à la frontière, jamais le sol de la patrie n'eut été envahi et conquis et nous n'aurions pas les millions de francs de ruines semées de l'Yser à Visé." Wat er in het pamflet stond, was dus afgeleid uit Le Bruxellois, die op zijn beurt uit het schrijven van Destrée geput had. Een andere onthullende aanwijzing vinden we in het hoofdartikel van $L e$ Bruxellois van 29 maart 1915. Dat besloot immers met de volgende passage:

Au surplus, nous expliquerons prochainement pourquoi [...] la Belgique de demain ne devra plus connaître qu'une politique d'affaires et de réformes sociales, et qu'un seul parti nationaliste réformiste, les vieux partis ayant eux-mêmes par leur impéritie et leur sectarisme étroit contresigné leur lamentable faillite. ${ }^{28}$

Le Bruxellois bleef die uitleg verschuldigd, net als eerder toen het ondanks zijn belofte niets publiceerde over de onvolkomenheid der Antwerpse forten. ${ }^{29}$ Belangrijker is dat uit dit fragment een duidelijke verwantschap met La Politique Belge blijkt. Enkele dagen later hernam de Gazet van Brussel in het artikel Zakenpolitiek dit stuk. ${ }^{30}$ Op 8 en 20 april 1915 verschenen in Le Bruxellois twee artikels in lijn met dat van 1 december 1914. In het eerste werd beweerd dat de rekening later zou vereffend worden. Antwerpen was "le réduit national fameux, réputé imprenable, mais hélas! si dérisoirement armé que la vérité à ce sujet [...] restera éternellement le scandale inexpiable de notre parlementarisme bourgeois". In het tweede schreef hoofdredacteur François Belvaux een vernietigende kritiek op het Belgische parlementa- 
risme. België was daardoor onvoorbereid toen de oorlog uitbrak, met als gevolg "vijf miljard frank aan rünes" en duizenden verwoeste levens (alweer een verwantschap met wat in het vlugschrift stond). ${ }^{31} \mathrm{Op} 5$ mei 1915 meldde Le Bruxellois dat Antwerpen nog geen tien dagen (sic) standgehouden had, terwijl de vesting Verdun dat nog steeds deed. ${ }^{32}$ Daarna stopte de controverse in het blad. Stilte voor de storm, want ten laatste vanaf eind mei werd het pamflet La Politique Belge après la Crise verspreid. ${ }^{33}$ Belangrijk is hier dat vanaf 1 december 1914 in Le Bruxellois de kritiek op de slechte staat van de vestingen, de miljarden aan ruïnes (en de roep om een "gewapende natie") vermengd werd met een virulent antiparlementarisme en antidemocratische lokroepen. Elementen daarvan werden in La Politique Belge geïntegreerd. De bronnen aan de basis van La Vérité en La Politique Belge overlappen en doorkruisen elkaar dus.

Een woord nog over die antidemocratische tendens. Die vindt men niet alleen terug in Le Bruxellois. Zo publiceerde de Gazette des Ardennes op 1 februari 1915 een striemende aanklacht tegen het parlementarisme van de geallieerden en van België. Met name de kritiek op de Franse republiek ligt in lijn met wat we in La Politique Belge après la Crise lazen: "Quelques avocats, arrivistes et intrigants, soutenus par l'argent de collègues anglais, ont réussi à s'emparer du pouvoir..." ${ }^{34}$ En 's anderendaags drukte de Gazet van Brussel een vermeend interview af dat koning Albert I aan het Amerikaanse persbureau Associated Press zou gegeven hebben. Daarin zou hij verklaard hebben dat zijn inmiddels gedemoraliseerd leger discipline ontbeerde omdat de Belgen "te democratisch" waren. Het Belgisch leger had, ten koste van ontzettende verliezen, Duinkerke en Calais gered. Deze opmerking ligt in lijn met wat in Le Bruxellois en in La Politique Belge après la Crise stond. Dergelijke demoraliserende en aan buitenlandse bronnen toegeschreven praatjes kwamen overigens wel vaker voor in de Duitse berichtgeving. Zo meldde de Gazette des Ardennes op 8 november 1914 dat minister van Oorlog De Broqueville in een interview met het Italiaanse Tribuna de situatie van het Belgisch leger als hopeloos omschreven had. ${ }^{35}$ Een maand later meldde het Duitse propagandablad hoe uit een in The Times gepubliceerde brief van een Britse majoor bleek dat het Belgisch leger geïnfecteerd was door een tyfusepidemie waardoor het binnenkort gedecimeerd kon worden. ${ }^{36}$ Het gefingeerde Duitse propagandabericht dat aan Associated Press toegeschreven werd, stond eind januari in de Duitse en Oostenrijkse pers. Op 5 en op 7 februari 1915 werd het respectievelijk in Het Vlaamsche Nieuws en L'Information gepubliceerd. ${ }^{37}$ Uit dit "interview" leiden we ook af dat, in lijn met wat de Gazet van Brussel en dus het gouvernement-generaal beweerde, Vlaams bloed vergoten 
werd om Frankrijk te redden. ${ }^{38}$ Dat idee dook al in de herfst van 1914 in de Duitse propaganda omtrent de val van Antwerpen op. Het bleek bestendig. Tijdens de vergadering van de Raad van Vlaanderen op 20 januari 1918, waar het orgaan de "zelfstandigheid" van Vlaanderen bekend maakte, die het op 22 december 1917 achter gesloten deuren uitgeroepen had, herinnerde August Borms aan de "vloed van laster, van beledigingen tegen Antwerpen, die veldtocht van hatelijkheden". Hij verklaarde er dat "de Entente-machten [...] te Parijs [vergaderden]" (Borms doelde hier op de Conférence Economique des Gouvernements Alliés in juni 1916 om een tegenwicht te bieden aan het Duitse Mitteleuropa-project) en "[er] besloten werd tot de handelsoorlog na deze bloedige strijd. Zij bedreigden daardoor Antwerpen en heel ons land. Maar wat gaf men om Antwerpen als Parijs maar gered was?". Sommige Vlaamsgezinden geloofden het misschien (of wilden het geloven). Zo beklaagde Faingnaert zich er nog in 1933 over dat de "Fransgezinde Belgen" graag Antwerpen opofferden om Parijs te redden. ${ }^{39}$

\section{Het Appel aux Wallons}

De studie van het Appel aux Wallons, een ander Duits pamflet, legt een verdere synergie tussen de vlugschriften bloot. Antwerpen Boven, dat er in juli 1915 een samenvatting van publiceerde, gaf te kennen dat het "ons enkele dagen geleden te lezen gegeven werd, door een onzer abonnenten [geabonneerden], die, omdat hij Antwerpenaar [vgl. met de Brusselaar uit La Politique Belge après la Crise, BY] is, zijn korstje in Wallonië [...] verdienen moet.... Ook hier heette het dat de exemplaren in Wallonië (volgens Het Vlaamsche Nieuws door "Walen en Fransgezinden" in Brussel) van hand tot hand overgeleverd werden. Die "enkele dagen geleden" moet wel met een stevig korreltje zout genomen worden, vermits De Vlaamsche Post het al in haar Brusselse correspondentie van 16 mei 1915 in extenso gepubliceerd had. Het Vlaamsche Nieuws maakte op 1 juni gewag van het bestaan van het pamflet. ${ }^{40}$

Antwerpen Boven voorzag het Appel van een commentaarstuk, getiteld $A$ dixpas... En joue... Feu!!!!: de oproep voor een vuurpeleton. ${ }^{41}$ De uitvoerders van die executie heetten "sommige zeer eigenaardige patriotten, alias franskiljons" te zijn. Die wilden de opstellers, abonnees en verkopers van alle bladen die tijdens de bezetting verschenen, neerkogelen. Die uit de lucht gegrepen bewering werd geïnspireerd door een vertekening van bepaalde overprikkelde reacties sedert oktober 1914 van sommige Belgische journalisten in het buitenland op de (her)verschijning van dagbladen in het bezette land. 


\section{- OPROEP TOT DE WALEN!}

"Walen! Raymond Colleye, die echte Waal, dien gij sillen hebt geketud ala selkretaris van liet Nationaal Komiteit cor Waalschn Verdediging on als vocrzitter van het Verbond der Wralicho Junge Wachten van Belgio, sehreef op lunie, bet orgaan der Walea, die, bewut van hun ware nationalit it, uit al huu krschten de inlijving van Wallonie bij ons meederland Prankrijk venschen en inruepen

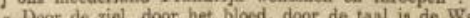

- een zoon van Frasicrijk. En de Waal van Henegouwen,

- van Luik, van Luxemburg is een Franschman, gelijk de

Waal van Mnubeuge, van Atrecht een Franschman is.

- Alleen de grillighedeu der Europeesehe diplomatio heb.

- ben op den Wailsohen grond een brutale grens geworpen.

n Voor de Frunacian, welke deze grens naar ingebeelden

* vora naar linles on reohts van mekaar scheidde, zal sij

- nooit meer dan oen bedrieglijke afsluiting zijn... Drie

- milhoea zielen wachion er op dat frankrijk zich herinnere

n en vooral weto dat de - pr

Franschen zijn,

"Granf Albert du Bois, die andere echte Wasl, duidde tezelider tijd, eveneens in Wallonie, derplichten van het exht Wanlach patriotisme aan :

- Vaderlandor zijn, - zoo achreef hij, - beataat or niot - in to zeggen : Ik ben burger van zulken Staat, was - deze Stani eerbemijaen our geld uitdeolt. Ik ga dua mijn * liefde voor dezen Stsat bewijen, en het zou me org loed - doen, indien ik ues gelijk het overige der tuitgehongerdá - bende happen kon in deu hoop eerbewijzen en geld. Neen, - vaderlander zijn bostauk erin to verklaren : Ik ben lid - van zulke natie. Deze natie bestast tiit oen groep men- schen die dezelfde taal, hetzelfde geloof, dezelfde hoop " on dezalide goden hobben. Dezelfdo zodelijke belangen, dezelfde reestelijks genousten hebben voor gevolg, dat " dezelfde goestelijko genougten hebben voor gevolg, dat " vadrs - eeta grooto, cene onuitroeibare verstandhouding a beataat. Dat consgerinde voslen, ik draag het in mij, ik bevestig het, ik wil het uiting goven, ik wil het dienen. Met andere woorden, de belangen der natie overtrelten de bolangen van den Staat, werk van menseben, slecht werk, wanneer het laantast het werk van God, het werk der natuur. Er bestaut gean Beigischo natio; maar er - bentant door den wil der diplomiten van 1830 can Bel.

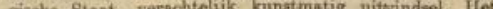
- giacbe Staat, jerankrijk vich eindelijk terinnere dat

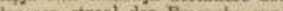

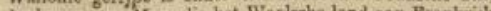
dstik aan gaze Maas die hot Wasioche land aan Frankrijk * verbindt, zooals de navelatseng het kind aan zijne moedor.

* Walen 1 Rogier, Gendebien, Surlet de Chokior en hun anhangers warren de siorlijke toliten der Walon. Zij poog. den van Belgie een Fransohe provineie te maken en zij wilden dit land van. Fransche gedaubte, ondanks het verzet der Vlamingen, tot glorio ran Frankrijk doen groeien. Om

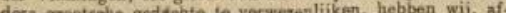
dewo groptacase gedachto to vorwente acheiding, vervolgea do inlijving bij Frankrijk govraagd. acheiding, vervolgean do inlijving bij Frankrijk govaagd. * Walen 1 Ongeveer cene eeuw gelerten itreden de Walen te Quatre-Bras on Waterloo tegen Fraukrijk, zooala Aleer du Boia het 200 welsprekend zogt. Hun handeiwijzo te dien dage was cen monsterachtige misdasd, onvergeefijk, yer.
zaking aan den hoiligaten on odeloten picht $;$ den plicht

\section{Afb. 17. Het Appel aux Wallons}

Gazet van Brussel, 28 juni 1915, 1; EHC: B 32000 [C3-253 b] jegens het vaderland. Zij gingen hun afstammelingen gedurende jarenlang bet reolit ontaeggen nog langer den naam van Franschman to dragen, dien naam mot fierheid bekroond, die een hoofd boven alle hoofden der barbaarache rassen uitsteekt. Dank aan hen dit gruwelijke uur waarin gansch Europa opstond en het volk bedreigde... Zij hadden deel aun dat afachuwelijk feit : de atandasarden der vijas. den van Frankrijk ntonden zegepralend geplant in den Franschen grond van Wallonie

"Ten einde den terugkeer van dergelijke rampen te sermijden, ten einde te voorkomen dat onbewruste Walen de wapena tegen Frankrijk, bervid tot heilige toewijding, antdeu opnemen, ints wat wij, bewuste Wslen, zouden geweigevd hebben, is het noodzakelijk dat we de inlijving van allonib bij Franktijlk vischen.

-Walen I Tusschen Walen en Vlamingen grotnt sedert ceuwon een rassenhast, nooit gedoofd os even noodlottig als din hast tusechen vuru en wator. De besteruning vau bun verschillenden oorsprong, van hun tegenstrijdige belangen, van hun vijandige kulturen, vin hum zich onderling tegrosprekendo nationale gevoelens, stellen ze wederrijda in tegenovergestelde kampen.

- De omatandigehden, veel meer dan hun wil, hobben niging met Vlaanderen hoeft slechta ntand geboaden doordat do alzomeene toestand van Europa de ontbinding nlet tosliet. Het uur der scheiding in eindelijk nungebroken. De goachiodenis der Walon is de tegensprank der groshiedenis hunner Vlaamiche landgenooten, Dcre lsatste, ingelijfd bil Francrijk, pogen zich ervan to ontvoogden, terwijl wif, Walen, gescherden van Frankrijk, streven nair vereeniging ermes.

"Het zegevierende Prankrijk zal zich herinneren dat Wallonie eene Franiche provineie is, de rijkste en getrouwste der Fransehe provincies.

- Soest het zegevierendo Prankrijk do wanhopige kreton sijuer Waalsche sonen niet aanhooren, zijn vorantwoordelijkchicid tegenover het Latijneadam sou groot. zijn. " Reve de inhijving van Wallonie bif Brankrijk! Leve Frimikrijk:

Het vlugschrift deed zich mysterieus voor, met een "uniek” nummer 519 en de melding: "Confidentiel!!! Ne peut être communiqué qu'aux Wallons sincèrement soucieux de notre race." Het vervolgde met een citaat van Raymond Colleye uit Wallonie! van 20 juli 1914. Dit tijdschrift dat maar één keer verschenen was (zie hoofdstuk 1), werd in het vlugschrift prompt gepromoveerd tot het orgaan van de Walen, die, "bewust van hun ware nationaliteit, uit al hun krachten de inlijving van Wallonië bij ons moederland Frankrijk wensen en inroepen". In het tijdschrift werd Colleye in zijn hoofdartikel $\mathrm{La}$ 
Neurasthénie Wallonne - Le Remède voorgesteld als "l'ancien secrétaire [...] du Comité National de Défense wallonne. ${ }^{42}$ Ancien Président de la Fédération des jeunes gardes wallonnes de Belgique". Met precies die woorden werd "die echte Waal" ook in het Appel ingeleid. Het vlugschrift dichtte hem de verklaring toe dat door de ziel, de taal en het bloed, de Waal een zoon van Frankrijk was. Alle Walen heetten even Frans te zijn als de inwoners van de Hexagoon zelf en slechts de grillen van de Europese diplomatie hadden op Waalse grond een brutale grens getekend:

Voor de Fransen, welke deze grens naar ingebeelde vorm naar links en rechts van mekaar scheidde, zal zij nooit meer dan een bedrieglijke afsluiting zijn... Drie miljoen zielen wachten erop dat Frankrijk zich herinnere en vooral wete dat de Fransen van Wallonië steeds Fransen zijn.

Bovenstaand stukje uit het vlugschrift was ontleend aan Le Devoir Wallon \& La France van Colleye in Wallonie!. Daarin schreef hij inderdaad: "Par l'âme, par le sang, par la langue, le Wallon est fils de France. Et le Wallon [...] est un Français comme le Wallon de Maubeuge, d'Arras et d'Avesnes, est un Français." Zonder twijfel had Colleye zich hier laten inspireren door de völkische retoriek van Du Bois. Die had in 1902 beweerd dat de Walen precies dezelfde aard hadden als de Fransen uit het oosten en de Franse Ardennen, ja dat het bloed van Romeinen, Galliërs en Franken in Wallonië in dezelfde verhouding verdeeld was als in het Frans gebied ten noorden van de Loire. ${ }^{43}$ Colleye vervolgde in Le Devoir Wallon met het stuk dat in het Appel aux Wallons hernomen werd:

Seules, les fantaisies de la diplomatie européenne ont jeté sur la terre wallonne une frontière brutale. Pour les Français qu’elle séparera fictivement à gauche comme à droite, cette frontière ne sera jamais qu'une illusoire barrière. Mais à présent, écartés de la vie de la Nation [française], dont ils sont les fideles enfants, [deze gecursiveerde zin werd niet weerhouden in het pamflet, $B Y]$ trois millions d'hommes attendent que la France se souvienne. Qu'elle sache toujours que les Français de Wallonie sont toujours des Français.

"Graaf Albert du Bois", zo vervolgde het Appel aux Wallons, "die andere echte Waal duidde tezelfdertijd, eveneens in Wallonie!, de plichten van het echt Waals patriottisme aan". In Wallonie! van 20 juli 1914 verscheen naast Le Devoir Wallon ook het artikel Le Vrai Patriotisme Wallon, waarin dit stond. Vandaar de "tezelfdertijd": beide artikels waren toen in hetzelfde blad gepubliceerd. Le 
Vrai Patriotisme Wallon was eigenlijk de inleiding van Du Bois op Une Nuit Florentine, een in boekvorm uitgegeven theaterstuk dat Colleye samen met de esoterische kroniekschrijver Maurice Boué de Villiers geschreven had. ${ }^{44}$ In Wallonie! werd die prefacering door Colleye enthousiast omschreven als "[une exaltation du] véritable patriottisme wallon", een bewoording die overeenstemt met die in het Appel. Du Bois had in het stuk betoogd dat het boek de Franse helderheid weergaf, te vinden bij "d'âmes profondément françaises". Bovendien was een van de auteurs - Colleye - een onbuigzaam patriot. Tussen het patriottisme en de literatuur zag Du Bois een raakvlak:

[...] être patriote - autrement que ne l'est le troupeau répugnant de quémandeurs de places $[. .$.$] en effet, ne consiste pas à se dire: 'je suis citoyen$ de tel Etat. Or, cet Etat distribue des honneurs et de l'argent. Je vais donc affirmer mon amour à cet Etat, et j'aurai bien du malheur si je ne finis point par pouvoir, comme le reste de la meute affamée, donner mon coup de gueule dans le tas d'honneurs et d'argent.'

Bovenstaande passage werd grotendeels in het pamflet overgenomen, als de beschrijving van dat Waals patriottisme:

'Vaderlander zijn', - zo schreef hij [Du Bois], 'bestaat er niet in te zeggen: ik ben burger van zulke staat, waar deze staat eerbewijzen en geld uitdeelt. Ik ga dus mijn liefde voor deze staat bewijzen, en het zou me erg leed doen, indien ik niet gelijk het overige deel der uitgehongerde bende, happen kon in de hoop eerbewijzen en geld'.

En nog in Le Vrai Patriotisme Wallon én in het Appel aux Wallons volgde dan wat een patriot wél moest doen. Allereerst bevestigen dat hij deel uitmaakte van een natie. Het bestaan van dezelfde zedelijke belangen en een gedeeld intellectueel vreugdebesef leidde tussen broeders van dezelfde nationaliteit, aldus de voormalige diplomaat, tot een onverwoestbare solidariteit. De patriot voelde en bevestigde die, wou ze verheerlijken en dienen. Du Bois had dat onder meer nog aangevuld met de plicht van een patriot om de (Franse) natie te verdedigen tegen hypocriete landen (lees: het Duitse Rijk) die miljoenen zielen aan het vaderland wilden ontrukken. In het pamflet zelf werd deze anti-Duitse passage niet weerhouden.

Het vlugschrift vervolgde: "Met andere woorden, de belangen der natie overtreffen de belangen van de staat, werk van mensen, slecht werk, wanneer het aantast het werk van God, het werk der natuur." Die passage, die niet in 
Wallonie! stond, is een commentaar van de Duitse opstellers van het vlugschrift op wat Du Bois schreef.

Daarna volgde in het Appel een aan Du Bois toegeschreven uitspraak: België was geen natie, maar enkel een door diplomaten gewild en verachtelijk uitvindsel. Die bewering was geconstrueerd op basis van wat Colleye geschreven had in La Neurasthénie Wallonne. Daarin beweerde hij dat de ame belge kunstmatig was. Zo ook bestond er geen Belgische literatuur of kunst. Zoiets kon volgens hem immers maar bestaan als spontane inspiratie van een ras, gevoed door een enkel ideaal dat zich uitdrukte in één enkele taal, opgesmukt in één enkele haard van beschaving:

\begin{abstract}
Allons! Trouvez-moi cela dans ce pays, qui est tout ce que vous voudriez, sauf une patrie: combinaison financière, Etat-tampon, création due à la politique égoöste d'un Palmerston [de Britse minister van Buitenlandse Zaken in 1830, $B Y$ ] au lendemain de 1815. Trouvez-moi cela ici où gronde depuis des siècles une haine des races [...] fatale comme la haine $\mathrm{du}$ feu et de l'eau. Elements latins et germaniques s'associeront, peut-être, mais ils ne fusionneront jamais au point de s'abâtardir totalement.
\end{abstract}

En ook in de literaire rubriek in Wallonie! stond er: "s'il n'existe pas de nation belge il existe un Etat belge." Volgens het Appel aux Wallons beweerde Du Bois dat het nodig was dat Frankrijk zich eindelijk herinnerde dat Wallonië onder de stralende Franse zon gerijpt was door de Maas die het aan Frankrijk verbond. Ook die uitspraak kwam in werkelijkheid uit La Neurasthénie Wallonne van Colleye:

Nous avons donné à l'Humanité notre part de Génies. Et c'est encore parce que la Wallonie mûrissait dans un rayon du soleil français, nourrie par les grandes pensées qui venaient de Paris, grâce à notre Meuse qui rattache le pays wallon à la France...

Het Appel aux Wallons vervolgde met:

Walen! Rogier, Gendebien, Surlet de Chokier en hun aanhangers waren de sierlijke tolken der Walen. Zij poogden van België een Franse provincie te maken en zij wilden dit land van Franse gedachte, ondanks het verzet der Vlamingen, tot glorie van Frankrijk doen groeien. Om deze grootse gedachten te verwezenlijken, hebben wij [...] eerst de bestuurlijke scheiding, vervolgens de inlijving bij Frankrijk gevraagd. 
Deze aan Du Bois toegeschreven woorden waren in werkelijkheid een aaneenrijging en bewerking van twee beweringen van Colleye uit La Neurasthénie Wallonne. De eerste luidde:

Les Rogier, les Gendebien, les Surlet de Chokier étaient les éloquents porte-paroles des Wallons. Ils s'efforcèrent de faire de la Belgique une province française sous un règne français et ils auraient fait mûrir ce pays de pensée française, à la Gloire de la France - en dépit des protestations flamandes.

In de tweede heette het: "La situation créée aux Wallons, en Belgique, exige une solution rapide $[\ldots]$ nous ne voyons cette solution que dans la séparation administrative... d'abord, [et] l'annexion à la France ensuite." Vervolgens verkondigde het Appel aux Wallons strijdvaardig: "Walen! Ongeveer een eeuw geleden streden de Walen te Quatre-Bras en Waterloo tegen Frankrijk, zoals Albert du Bois het zo welsprekend zegt." Dat werd dan als een monsterachtige en onvergeeflijke misdaad tegen het Franse vaderland omschreven. Om te vermijden dat in de toekomst onbewuste Walen tegen Frankrijk zouden strijden, moesten bewuste Walen de inlijving bij de Hexagoon eisen. Hoewel men deze passage niet letterlijk terugvindt in Wallonie!, is ze er wel op gebaseerd. Zo schreef Colleye in La Neurasthénie Wallonne: "Hier et avant hier nous combattions encore sous les étendards français pour la gloire de leurs Aigles et jusqu’à Waterloo." En in het stukje Le Monument belge à Waterloo stond hoe Walen in de slag bij Jemappes en Waterloo aan de Franse zijde stonden en werd er uitgehaald naar Edmond Picard die in Waterloo een nieuw monument wou oprichten ter nagedachtenis van Nederlands-Belgische soldaten bij Quatre-Bras. Het blad bezwoer zelf een Waals monument opgedragen aan de Walen te Waterloo op te richten (een idee dat door Du Bois bestudeerd werd). Bovendien waren de Duitse diensten, zoals een studie van La Politique Belge après la Crise aantoont, op de hoogte van het feit dat die Du Bois een roman getiteld Waterloo, (Belges ou Français?) geschreven had.

Het Appel aux Wallons besloot opruiend met: "Leve de inlijving van Wallonië bij Frankrijk! Leve Frankrijk!” Die hartenkreet werd door twee passages voorafgegaan. De eerste was een herwerking van het eerder geciteerde stukje over de "eeuwenoude rassenhaat" tussen Vlamingen en Walen, waarover Colleye het in Wallonie! had, nogmaals ingeleid met een donderend "Walen!".

In de tweede werd betoogd dat het zegevierende Frankrijk zich zou herinneren dat Wallonië een Franse provincie was, de rijkste en trouwste van de Franse provincies. Mocht Frankrijk daarentegen geen gehoor geven aan de wanho- 
pige kreten van haar Waalse zonen, zou haar verantwoordelijkheid tegenover het Latijnendom groot zijn. Die woorden waren ontleend aan twee afzonderlijke stukjes die men terugvindt in Le Devoir Wallon \& La France. Een eerste was een vingerwijzing naar Frankrijk dat scheen toe te kijken terwijl Wallonië door toedoen van de Vlamingen in het Germaanse Rijk opgeslorpt werd. "La France, alors, qui n’écouta pas les appels désespérés de ses fils wallons [...] serait la grande responsable." En, in lijn hiermee: "Pourquoi donc a-t-elle [la France] oublié que cette [...] Wallonie est bien la plus admirablement française de toutes ses provinces et la plus riche et la plus belle et la plus fidèle de toutes!"

Het eerder besproken werk van Pius Dirr uit 1917 laat geen twijfel bestaan over wie de echte auteurs van dit vlugschrift zijn. ${ }^{45}$ Het meldde: "Raymond Colleye wiederholte im Coq Wallon (15. Jan 1914) und später in Wallonie seine schon im Jahre 1906 [...] zum ersten Male niedergeschriebenen Sätze." Daarna gaf Dirr de passage weer van Colleye uit Wallonie! waarmee het Appel aux Wallons begon. Zoals gezien, was die afkomstig uit het artikel Le Devoir Wallon \& la France. Maar revelerend is wat níet in het Appel aux Wallons stond, maar wél bij Dirr. Om te weten dat Colleye het artikel (in een langere versie) al in november 1906 in La Revue Française geschreven had, volstond het om Wallonie! - waarin die gegevens vermeld waren - te lezen. Maar Dirr kon onmogelijk weten dat het artikel ook in Le Coq Wallon van 15 januari 1914 stond, zonder dat tijdschrift zelf te hebben gelezen: Wallonie! bevatte die informatie immers niet. Hij gaf daarop, in tegenstelling tot het Appel, een deel van het artikel van Colleye vollediger in de doorlopende tekst weer. De ambtenaar vervolgde: "Graf Albert du Bois setzte zu gleicher Zeit in einem offenen Briefe sein Landsleuten auseinander das Patriot sein nicht bedeutet, sich bedingungslos irgendeinem Staate zu verschreiben, sondern mit klarem Bewusstsein einer Nation zugehören." Dat was een samenvatting van hoe het deel van Du Bois (en van de aan hem toegeschreven woorden) in het pamflet ook begon. Het stuk was, zoals vermeld, "zu gleicher zeit" met dat van Colleye gepubliceerd: niet in een open brief aan zijn landgenoten, zoals Dirr het wilde doen geloven, maar wel in Wallonie!. Het was geen toeval dat Dirr eerst het stuk van Colleye en vervolgens dat van Du Bois gepubliceerd had. In die volgorde stonden ze immers ook in het pamflet afgedrukt. De inhoud van wat $\mathrm{Du}$ Bois in die open brief zou geschreven hebben, volgde grotendeels wat er in het Appel aux Wallons stond, al was niet alles weerhouden. Men leest er eerst de plichten van een patriot in (uit Le Vrai Patriotisme Wallon), vervolgens de bewering over de natie als een goddelijk werk; dat er geen Belgische natie was; dat Frankrijk zich eindelijk de banden met Wallonië moest herinneren, gevolgd door het deel over de eeuwenoude Vlaams-Waalse rassenhaat. 
Eindigen deed de "brief", net als het pamflet, met: "Das siegreiche Frankreich wird daran denken, dass Wallonien eine französische Provinz ist, die reichste und treueste." De passage was een aan Du Bois toegeschreven stuk dat verbatim uit het Appel aux Wallons afkomstig was. Het stond niet in Wallonie!, maar was, zoals gezien, een voor dat Duitse vlugschrift bestemde herwerking van een artikel van Colleye uit Wallonie!. Maar van Colleye had Dirr anderzijds correct in het deel dat aan de passage van Du Bois (of de woorden die hem in de mond gelegd werden) voorafging de volgende woorden, die niet in het Appel aux Wallons maar wel in Wallonie! stonden, geciteerd: "Warum denn hat es [Frankrijk] vergessen, dass dieses heldenhafte wallonisch-französische Gebiet im Herzen am meisten französisch ist von allem seinen Provinzen und dazu die reichste, schönste und treueste von allen!" Door beide passages zo te publiceren, wordt het nog duidelijker dat de eerste een bewerking is van de laatste.

Dat de Duits-activistische propaganda voortbouwde op vooroorlogse wallingantische propaganda, wordt verder bewezen door een lezing van het pamflet De Walen en de Statenbond van Vlaanderen en Wallonië. De uitgave van dat vlugschrift werd door de Politische Abteilung gefinancierd en in 1916 door de Brusselse en activistische Vlaamsche Landsbond verspreid. ${ }^{46} \mathrm{Het}$ betrof een chronologische verzameling van tientallen citaten uit wallingantische tijdschriften en dagbladen uit de periode 1910-1914 om aan te tonen dat ook prominente Walen de bestuurlijke scheiding vroegen. Hierin werd niet toevallig uit de Revue Française van november 1906 geciteerd, waarin Colleye de eerste versie van Le Devoir Wallon geschreven had. Zo ook uit Wallonia, L'Express, La Défense wallonne en, natuurlijk, uit Le Coq Wallon met het nummer van januari 1914 waarin hetzelfde artikel van Colleye opnieuw stond. Er loopt overigens nog een verbinding van de geschriften van Albert Du Bois naar La Politique Belge en de Politische Abteilung. Zoals gezien was dit pamflet geëindigd met enkele kenmerken op te sommen, waarvan het beweerde dat België en Frankrijk die gemeenschappelijk hadden. Die waren op hun beurt partieel ontleend aan de these die Du Bois verkondigd had in Waterloo (Belges ou Français?) uit 1902. Welnu, in het annexionistische tijdschrift Les Marches de L'Est (juli 1914) herhaalde Du Bois die stelling. Uit Belgien als Französische Ostmark blijkt dat Pius Dirr zich ook uitgebreid gedocumenteerd had over de inhoud van dat tijdschrift, met inbegrip van de jaargang waarin Du Bois zijn stellingen verkondigd had. ${ }^{47}$

Met de publicatie van het in omloop zijnde Appel aux Wallons in juli 1915 sloot Antwerpen Boven de reeks af die in april met Onze Moederstad Gewroken begonnen en in juni met De Strop om den Hals vervolgd was. Op 
26 juni 1915 publiceerde de Brusselse correspondent van de Vossische Zeitung, Wertheimer dus, Wallonische Zukunftsgedanken in dat blad. Daarin betoogde hij hoe een "Waals-Franse brochure", La Politique belge après la Crise, waarin de Vlamingen met hun ondergang bedreigd werden, groot opzien in Vlaamse kringen gebaard had. Het toekomstige België, zo heette het "...müsse ein nationaler und sprachlicher Einheitsstaat mit rein französischem Charakter sein. Deshalb sei das flämische Volk, das zu den Germanen gehöre, mit allen Mitteln zu entnationalisieren”. Na een summiere weergave van de inhoud besloot hij: "Schließlich erklärt die Flugschrift, Frankreich sei Belgiens natürlicher Beschützer, deshalb müsse sich das künftige Belgien an Frankreich anlehnen." ${ }^{48}$

Dit artikel werd de volgende dag hernomen in de Kölnische Volkszeitung. ${ }^{49}$ Van dat blad weten we dat zijn journalist Hackenbroich voor de Politische Abteilung werkte. Die dienst was op dreef, want niet toevallig verschenen er eind juni onder de titel Ondermijners aan 't Werk in de Gazet van Brussel twee synthese-artikels. In het eerste (28 juni 1915) werd kort teruggekomen op La Vérité en werd het Appel aux Wallons in extenso gepubliceerd. In het tweede (29 juni 1915) gebeurde hetzelfde voor La Politique Belge après la Crise. In dit dubbelartikel trekt volgende passage onze bijzondere aandacht:

Sedert de allereerste dagen van de oorlog is een geheime kliek onophoudelijk bezig met het bezwadderen van al wat Vlaams is. [...] Talrijk zijn de ongetekende drukwerken die van hand tot hand worden rondgegeven, waarvan drie stukken de bijzondere aandacht der Vlamingen verdienen. Tegen het eerste [La Vérité, BY] hebben wij met kracht onze stem verheven (zie Gazet van Brussel van 5 januari laatstleden)..$^{50}$

Zoals gezien kaderde Antwerpen moet kapot!, het voorpagina-artikel uit de Gazet van Brussel van 5 januari 1915, in de perscampagne die aan La Vérité voorafging. In het artikel stond niets over een vlugschrift, maar wel (onder meer) dat "dweepzieke heerschappen" te Brussel in oktober 1914 hoopten dat de geallieerden Antwerpen tot gruis zouden laten schieten. En dat sommigen vonden dat de geallieerden dat moesten doen bij het heroveren van de stad. Dat er een verband bestaat tussen deze beweringen en La Vérité zelf, werd reeds aangetoond. Maar door op 28 juni 1915 te schrijven dat het artikel uit de Gazet van Brussel van 5 januari over het later gepubliceerde pamflet La Vérité ging, legde het blad van het gouvernement-generaal zélf (onbedoeld) dit verband. Overigens werd nog in de Gazet van Brussel van 5 januari 1915 voor de eerste keer gewag gemaakt van een "partij” van Vlaamshaters 
die sedert het begin van de oorlog een lasterveldtocht begonnen was. ${ }^{51} \mathrm{Het}$ idee van een anti-Vlaamse "nationale partij", zoals we dat in de lente van 1915 bij de "ware Belgen" van La Politique Belge zien opduiken, was dus geen nieuwigheid. Nieuw was dat die concepten door Duits toedoen ook in Nederland verspreid zouden worden. Een ideologische koerswijziging van het dagblad De Vlaamsche Stem uit Amsterdam plaveide daarvoor de weg.

\section{De koers van De Vlaamsche Stem}

Typerend voor de evolutie was hoe het blad over die "franskiljonse" vlugschriften sprak. Zo meende het op 3 april 1915 dat La Vérité het werk was van een naamloos schrijvertje van twijfelachtig allooi. De klacht die De Vos, Franck en Ryckmans ertegen neergelegd hadden, was voor ernstige lieden "misschien wel de moeite niet waard". 52 Tien dagen later beweerde de Gazet van Brussel niet te kunnen begrijpen dat mensen als Deswarte aan de leiding stonden van een orgaan dat schimpte op alles wat Germaans was. ${ }^{53}$ Maar op 19 juni noemde de socialistische hoofdredacteur van De Vlaamsche Stem de pamfletten toch het misdadige werk van wallinganten en werd hij voor zijn stellingname in de activistische pers gelauwerd. ${ }^{54}$ Blijkbaar was De Vlaamsche Stem toen het activisme gunstig gezind.

Het blad had een hele evolutie meegemaakt, want initieel was het geprikkeld geweest door het vereenzelvigen van Vlaamsgezindheid met collaboratie. Het programma-artikel in het eerste nummer (2 februari 1915) maakte dit al duidelijk. De redactie verklaarde dat alle Vlaamsgezinden in vredestijd verkondigden dat Belgiës toekomst in nauwe samenhang was met de Vlaamse beweging. Ze beweerde "wars van alle vreemde inmenging" te willen bevestigen dat de Vlaamse beweging louter nationaal bleef. "Door een echt Vlaams rondborstig optreden zullen wij weten te verijdelen dat over einddoel en beweegreden de minste twijfel zou ontstaan." 55 Die bedenking valt ook te verklaren door een vrees voor reputatieschade van de Vlaamse beweging na de oorlog. Daarom ook dat De Vlaamsche Stem schreef dat de bezetter de Vlamingen een slechte dienst bewees door in België als bevorderaars van het Vlaams op te treden. Na de oorlog, konden de "Fransgezinden" daaruit profijt proberen te trekken. ${ }^{56}$ De hoofdredacteur Deswarte probeerde in meerdere artikels het verwijt "ook nu nog de Vlaamse beweging aangewreven", namelijk dat ze met het pan-Germanisme had geheuld, te weerleggen. ${ }^{57} \mathrm{Hij}$ verwierp het perspectief van een toekomstige inlijving van Vlaanderen bij het Duitse Rijk en de onvermijdelijke verduitsing die het Vlaamse land dan 
te beurt zou vallen. Op 17 maart 1915 wilde hij daarover Klare Wijn schenken. Hij stelde de Vlaamse beweging wit te willen wassen van "de ergerlijke aantiiging" dat de leiders ervan ooit met Duitsland heulden. ${ }^{58}$

Deswarte schreef liefst vier artikels met als titel Vive la France! om te bewijzen dat de Vlaamsgezinden helemaal niet anti-Frans waren, ja dat ze zelfs unaniem de Franse cultuur hoogachtten. ${ }^{59}$ Meermaals leest men in zijn blad hoe de Duitsers zich vóór de oorlog niet in de Vlaamse beweging interesseerden of die onbelangrijk vonden. ${ }^{60}$ Tegelijk benadrukte De Vlaamsche Stem hoe onbenullig klein het aantal flaminganten wel was dat tijdens de oorlog een Vlaamse heropbloei verwachtte van de bezetter. Als er een enkele keer werd toegegeven dat er een afwijking op de regel bestond, werd de "goede trouw" van die "verdwaalden" benadrukt. Zo ook het feit dat ze niet tot de leiders van de Vlaamse beweging behoorden. ${ }^{61}$ Alle vergoelijkingen ten spijt was het dagblad niet vrij van ideologische contaminatie door de Flamenpolitik. Zo werd La Vérité gepubliceerd. Aandacht werd besteed aan La Politique Belge en het Appel aux Wallons. Het zogezegd anti-Vlaamse karakter van de uitlatingen van Harry en Maeterlinck werd voor waar aangenomen. ${ }^{62} \mathrm{Zo}$ ook de bewering dat in Antwerpen de "vulgarisateurs" meer dan ooit overmoedig waren in hun pogingen om het Vlaamse volk te "versmachten". Dat "franskiljons" beweerden dat er na de oorlog geen sprake meer zou zijn van het Vlaams kwam meermaals voor, ook dat kardinaal Mercier de lieve vrede op de kap van de Vlamingen wou behouden. Het blad strooide de aantijging rond dat er in het Antwerpse gerechtshof geen taalwetten meer te bespeuren waren en dat de "franskiljons" in het buitenland tegen alle Vlamingen een lasterveldtocht begonnen waren. Daarbij werd dan gevoegd dat ook in het bezette land anti-Vlaamse praatjes en leugens rondgestrooid werden, in het bijzonder sedert de val van Antwerpen. ${ }^{63}$

De Vlaamsche Stem nam ook klachten op betreffende het briefverkeer tussen België en het buitenland, dat enkel in het Duits en het Frans opgesteld mocht worden. Het artikel Vlamingen, waakt! van Borms dat dit thema behandelde, werd zelfs tweemaal in een licht verschillende vorm gepubliceerd. Borms werd in De Vlaamsche Stem trouwens een "kranige", door-endoor Belgische leider en een "dappere redenaar" genoemd, zijn Antwerpen Boven heette een kranig weekblad te zijn, de Gazet van Brussel een "sociaaldemocratisch" dagblad. ${ }^{64}$ Soms zullen zulke beweringen wel uit onwetendheid gebeurd zijn. Zo schreef L'Echo Belge, dat net als De Vlaamsche Stem te Amsterdam verscheen, aanvankelijk ook zonder commentaar over het ontstaan van Antwerpen Boven. ${ }^{65}$ Toch valt het op dat, De Vlaamsche Post niet te na gesproken, geen enkel dagblad dat in bezet België verscheen door 
De Vlaamsche Stem aangevallen werd. Dit ondanks een brief uit Antwerpen (14 februari 1915) waarin stond dat de meeste gepubliceerde dagbladen in België pro-Duits waren en in weerwil van de correcte bewering van het blad dat het gouvernement-generaal sommige ervan subsidieerde. ${ }^{66}$ Opvallend is hoe slechts enkele auteurs waarschuwden voor de Flamenpolitik en het activisme. Zo betoogde Julius Hoste jr. expliciet dat enkel de annexionistische Duitsers er voordeel bij hadden om de Belgen onderling te verdelen en het nationaal gevoel te verzwakken. Hij waarschuwde de Belgen op hun hoede te zijn voor het betwisten van het bestaansrecht van België omdat de vijand door hemzelf opgewekte meningsverschillen tot een enorme staatszaak verhief. Of nog, annexionistische Duitsers "kunnen er op dit moment op uit zijn de taalkwestie tot een broedertwist op te drijven". Hoste minimaliseerde ook de uitlatingen van Harry en Maeterlinck.$^{67}$ De journalist Johan Demaegt ergerde zich aan de personen die de Vlamingen aanvielen en uitscholden voor pan-Germanisten, maar beklemtoonde wel het daar pas na de oorlog over te willen hebben. ${ }^{68} \mathrm{Du}$ Catillon wees erop dat de naamloze aanvallen die gebeurd waren op enkele flamingantische leiders misschien niet het werk waren van "franskiljons", maar wel van Duitse opstokers. ${ }^{69}$

Slechts in Gent, waar het activisme in zijn meest radicale vorm tot uiting kwam, werd de stroming door het blad ondubbelzinnig bestreden. Aanvankelijk hadden zowel de redactie van De Vlaamsche Post uit Gent als die van De Vlaamsche Stem elkaars verschijnen nochtans instemmend begroet. ${ }^{70}$ Maar tussen begin maart en begin juni barstte een polemiek los tussen $D e$ Vlaamsche Stem en de spreekbuis van het Gentse activisme. De band tussen De Vlaamsche Post, de Duitse censor Wirth en Domela Nieuwenhuis (die zich al in oktober 1914 "in de armen der Germaanse wapenbroeders geworpen [had]"), moest het daarbij ontgelden. Zo ook de inhoud van De Vlaamsche Post en zijn medewerkers, met name Minnaert en Picard die hun "zonderlinge vaderlandsliefde" uitten door "voor België niets [te] gevoelen, maar alles voor Vlaanderen". Kwamen daarbij nog aan bod: het flamingantisch verzet tegen De Vlaamsche Post, maar - omgekeerd toch weer - ook de vermeende houding van de "franskiljons" die heetten te jubelen over wat er zich bij de Gentse flaminganten afspeelde omdat ze hun kans schoon zagen om een "geheim lasterschrift" over de val van Antwerpen te verspreiden. ${ }^{71}$ Domela en zijn vader Jacob, aan wie De Vlaamsche Stem een vrije tribune verschafte, reageerden op de aantijgingen. ${ }^{72}$ Zo ook "verschillende Vlamingen" die in het dagblad uit Amsterdam de boodschap verspreidden dat de "franskiljons" de goede trouw der Vlamingen in twijfel trokken. Dat bewezen hun pamfletten over de val van Antwerpen en het gegeven dat ze de meest beza- 
digde Vlaamsgezinden op "proscriptielijsten" zetten. De Walen wachtten slechts op het geschikte ogenblik om de Vlamingen voorgoed de doodsteek te geven. ${ }^{73}$ Picard schreef twee stukken om te polemiseren met Deswarte. Een eerste op 10 maart 1915, met daarin een apologie van Domela Nieuwenhuis en vooral een aanval op De Vlaamsche Stem. Publiceerde die geen artikel over een pan-Latijnse bijeenkomst te Parijs, waar Roland de Marès - die wilde zogezegd heel België bij het "Latijnendom" inlijven - aanwezig was, zonder enig protest?

Hij spoorde Deswarte aan om de Vlamingen tegen al hun belagers (dus tegen de "franskiljons" en hun zogenaamde anti-Vlaamse campagne) te verdedigen. In zijn repliek beklemtoonde laatstgenoemde hoe De Vlaamsche Stem, net als de overgrote meerderheid van de leiders van de Vlaamse beweging, de Vlaamse aan de Belgische zaak koppelde (lees: Picard en de zijnen dus niet). Domela werd afgeschilderd als een "Hollander die thans te Gent met de Duitsers" heulde. Beweren, zo schreef Deswarte, dat De Vlaamsche Stem niet opgetreden had tegen het "pan-Latijnse gedrijf" van De Marès, Maeterlinck, Harry, heel het kliekje "slechte vaderlanders..." was onwaar. Zijn blad heette zich te verdedigen tegen strijdgenoten en tegenstrevers die zich voor de Duitse of de Franse "afgod" vernederden. Maar die tweede groep schatte hij toch hoger in, want die was in tegenstelling tot Minnaert en Picard wars van alle vreemde inmenging. Picard beweerde in zijn verdediging dat hij en de zijnen al vóór de oorlog voorstander van de bestuurlijke scheiding waren (veel later zou hij dat, voor wat zichzelf betrof, ontkennen). ${ }^{74}$ De oorlogsomstandigheid, zo schreef hij, bracht met zich mee dat alle Europese zaken, en dus ook de Vlaamse, besproken moesten worden. Na de oorlog moest een harde strijd gevoerd worden, hetzij tegen het "Belgische regime", hetzij tegen een zekere "centraliserende richting" in de Duitse politiek. Lees: hij aanvaardde een mogelijke permanente Duitse bezetting van België. In zijn repliek keurde Deswarte die optie af. Hij sloot daarna de pennentwist af, maar kwam er begin juni nog op terug naar aanleiding van wat hij persoonlijke aanvallen vanwege De Vlaamsche Post noemde, uitgaande van Picard en de zoon van Domela Nieuwenhuis. ${ }^{75}$ Een andere bron van onrust was de verhouding van De Vlaamsche Stem tot L'Echo Belge. Het is niet zo dat De Vlaamsche Stem vanwege haar uitgesproken Vlaamsgezindheid meteen op geen krediet kon rekenen in de Franstalige pers. ${ }^{76}$ Maar de artikels over die vermeende "antiVlaamse campagne” lokten bij Charles Bernard, de redacteur van L'Echo Belge, ergernis uit. Naar aanleiding van zo'n polemiserend artikel uit $D e$ Vlaamsche Stem schreef Bernard dat veel van zijn landgenoten een beetje te veel met hun "dierbare Vlaamse beweging" bezig waren. Stond het welzijn 
van België en Vlaanderen niet op de eerste plaats? En dan volgde een bedenking die gelijk loopt met wat we eerder al in sommige Franstalige dagbladen aantroffen, namelijk dat de klaagzang van de Vlaamsgezinden verbleekte bij de gruwelen van de oorlog. Of, zoals Bernard het uitdrukte:

Parce que, devant l'odieuse agression allemande, deux ou trois personnalités ayant en vue certaines intelligences que le clan pangermaniste entretenait chez nous, ont à propos du mouvement flamand prononcé des paroles qui dépassent certainement leur pensée, ça été une explosion d'indignation autrement grande que devant les fusillades de Dinant ou le sac de Louvain. Sans doute ils voyaient déjà leurs prébendes en péril, et le plus prudent c'est de sauver la caisse.

Waren er soms flaminganten die verkozen dat ons leger zich onderwierp aan Duitsland onder het voorwendsel dat tegen macht geen weerstand opgewassen was!? Na een lofzang op de eeuwenoude Belgische lotsgemeenschap en het schitterende verzet van Vlamingen en Walen tegen de Duitse overweldiger, betoogde hij dat het een dwaze fabel was van de flaminganten dat het recht om het Nederlands te spreken en zich aldus tot een hogere cultuur te verheffen, bedreigd was. Moesten ze nu nogmaals van de gelegenheid gebruik maken om tegen Frankrijk, een land dat toch ook voor de bevrijding van België en het vrijheidsideaal vocht, ten strijde te trekken? Daarnaast betichtte Bernard sommige flaminganten van sympathieën voor, minstens van toegeeflijkheid tegenover de bezetter. Vervolgens richtte hij zijn pijlen op een artikel uit De Vlaamsche Stem. Hij nam met name aanstoot aan het feit dat een correspondent van dat blad het had over een anti-Vlaamse campagne van "franskiljons" en de situatie van de Vlamingen in België als lamentabel beschreef. Zo ook dat die correspondent vergoelijkend over de flamingantische pan-Germanisten sprak. Diezelfde verslaggever had ook gemeld dat Vlaamse jongens zich niet voorstelden, op welke wijze het volk jonge intellectuele leiders zou ontvangen die het waagden het wijs te maken dat alle heil van over de Rijn moest komen. Bernard gaf hem gelijk: de vrees dat de Vlaamse beweging ten onder zou gaan, wanneer ze zich naar Duitsland zou keren, was correct. ${ }^{77}$ Die bewering stemt overeen met wat Le Vingtième Siècle eerder ook gemeld had: nee, de Vlaamse beweging liep geen gevaar, tenzij natuurlijk de Bormsen en Henderickxen van deze wereld ze zélf zouden compromitteren! Men merkt hoe gemakkelijk Duitse propagandisten op basis hiervan konden betogen dat er inderdaad een "anti-Vlaamse campagne" gaande was. 
Maar wanneer L'Echo Belge anderzijds berichtgeving uit De Vlaamsche Stem gunstig onthaalde, werd het laatste blad op zijn flamingantische flank bedreigd. Volgend op een lezersbrief over de "eenzijdige" ophemeling van Frankrijk in de Belgische kring te Amsterdam in De Vlaamsche Stem, betoogde Bernard bijvoorbeeld geïrriteerd hoe er nog steeds anti-Franse maniakken, redeloos en ondanks de huidige toestand Frankrijk als de eeuwenoude vijand van Vlaanderen bleven beschouwen. Dat was nu al van vóór 1302 aan de gang. Maar:

il nous plaît $[. .$.$] de rappeler que l'éminent vice-président de l'Union$ Belge, notre confrère Albéric Deswarte, a répondu d'avance à la diatribe du correspondant [sic] de la 'Vlaamsche Stem', lorsqu[...] il rendit luimême, et cela dans un langage que nous mettons au défi quiconque d'incriminer, un hommage éclatant au génie français... ${ }^{78}$

Maar zeker in een sfeer waarin de Duits-activistische propaganda hoogtij vierde, was een associatie met "le génie français" niet even gemakkelijk te verteren voor elke Vlaamsgezinde. Sterker nog, sommige medewerkers aan De Vlaamsche Stem hadden het in de geschetste context moeilijk om de Godsvrede stipt na te leven. Dat gold zeker voor de dichter René De Clercq. Begin april 1915 verkondigde hij in een hoofdartikel Germanen dat een zekere pers en publiek op de Germanen in het algemeen schold en dat ook Belgen aan dit gevaarlijke spelletje deelnamen. Zo ook waren er, volgens hem, personen die in Nederland voortgingen met de Nederlandse taal te minachten en bestrijden. ${ }^{79}$ Eind mei 1915 besprak hij de vernederlandsing van de Gentse universiteit met zijn "Vlaamshatende professoren": "Wat talent, wat genie is er in België niet gestikt omdat de hogeschool te Gent door een vreemde geest werd uitgezogen, en haar praalcultuur [voor] de Vlaming bleef een lokkende vrucht in gesloten hoving?" ${ }^{00}$ Een maand later beweerde De Clercq dat de Vlamingen blijkbaar dwaalden als ze geloofden te strijden voor de gezamenlijke vadergrond van Vlamingen en Walen, de eigen taal, het goede recht der kleine volkeren: "...we strijden tegen het Germanendom tot behoud van de Latijnse cultuur [...] De wereld moet verlatiniseerd, Vlaanderen verfranst." Tegen wat hij blijkbaar als het offensief optreden van "ultra-Fransgezinden" beschouwde, schreef hij: “...we hebben al water genoeg gedaan in onze wijn; nu willen wij wijn in ons water." ${ }^{\prime 1}$

Op zijn beurt ging een andere medewerker aan het blad, de filoloog Antoon Jacob, vanaf eind februari tot begin april 1915 een pennentwist aan met de wallingant en medewerker aan L'Echo Belge Louis Piérard. Die laat- 
ste had zich in een patriottisch artikel in De Amsterdammer laten ontvallen dat Vlamingen en Walen elkaar door het gemeenschappelijk lijden tijdens de oorlog beter zouden begrijpen. Hij voegde daaraan toe: "Sans abdiquer jamais devant certaines exagérations ridiculement gallophobes, pourquoi les Wallons [...] n'apprendraient-ils pas plus volontiers le néerlandais qui a une littérature aussi riche que l'allemand?" Van de opmerking over de "gallofobe overdrijvingen" werd door Jacob de essentie gemaakt en tekst en uitleg gevraagd. ${ }^{82}$ Piérard zou er eind maart bij Jacob persoonlijk op aandringen om tijdens de bezetting niet te kibbelen tussen de Belgen. Zijn oproep viel echter op een koude steen en werd als een Open Antwoord in De Vlaamsche Stem gepubliceerd. ${ }^{83}$ In L'Echo Belge (30 maart 1915) kwam Piérard terug op de zaak. Hij lichtte zijn eerdere bewering als volgt toe. In België bestond er een soort flaminganten die maar een handvol "slechte Belgen" uitmaakte. Die deinsden er niet voor terug de Franse "bondgenoot" (sic) schaamteloos aan te vallen. De Vlamingen, zo beweerde hij, hadden het recht in de eigen taal berecht, bestuurd en onderwezen te worden. Hij sprak zich echter uit tegen de Nederlandse eentaligheid van Vlaanderen. ${ }^{84}$ Dit artikel noopte Jacob tot een offensief optreden. In de kolommen van De Vlaamsche Stem betoogde hij dat de Vlamingen zich met "onverwoestbare kracht" tegen de "invloeden die de verfransing" meebrachten, zouden blijven verzetten. Piérard heette aan de zijde van de verfranste Vlamingen te staan: "Dat de Waalse broeders, die [...] zich de bondgenoot tonen van de verfranste kaste in Vlaanderen, denken [aan] de gevolgen van zulk een verbond voor de zedelijke eenheid van het nieuwe Belgie." ${ }^{85}$ Laat Jacob zich dan al in een polemiek begeven hebben met L'Echo Belge, tot eind juni 1915 bleef de animositeit tussen beide vluchtelingenbladen beperkt. Wel vonden er nog twee incidenten plaats.

Een eerste draaide rond de socialist Camille Huysmans. L'Echo Belge meldde begin mei 1915 dat die een Brusselse schepen zou opvolgen en voegde eraan toe dat hij eertijds een wetsvoorstel getekend had tot vernederlandsing van de Gentse universiteit. Die vernederlandsing, zo voegde $L ' E c h o$ Belge daar fijntjes aan toe, werd door de Duitse bezetter bestudeerd. Volgens het blad wou hij die aan het eind van het jaar verwezenlijken. Na het bericht inhoudelijk gecorrigeerd te hebben, beschreef de redacteur van De Vlaamsche Stem hoe die "zijsteek" er gekomen was om de vervlaamsing van de universiteit van Gent hatelijk te maken. ${ }^{86}$ Een andere "zijsteek" kwam twee weken later, toen L'Echo Belge zijn Nederlandstalige confrater impliciet van Duitsgezindheid verdacht. In een berichtje meldde het dagblad namelijk hoe $D e$ Vlaamsche Stem L'Echo verzocht had zijn adresverandering mede te delen. Het Franstalige blad deed dat, met tussen haakjes erbij: "même immeuble 
que le Norddeutscher Lloyd" ${ }^{87}$ De Vlaamsche Stem repliceerde geprikkeld en ontkende eender wat gevraagd te hebben. Een bijgevoegde lezersbrief stelde dat L'Echo Belge de flaminganten verdacht maakte. Geenszins verwonderlijk, zo ging de brief voort, wanneer men aan de talrijke artikels dacht uit de beginperiode van het dagblad die over de Vlaamse kwestie en de overgave van Antwerpen handelden (hier was ze weer). ${ }^{88}$ L'Echo Belge antwoordde dat het bericht enkel een vaststelling betrof. De Vlaamsche Stem wou blijkbaar het debat ontwijken. Van de gratuite belediging dat L'Echo de Vlamingen aanviel was niets aan:

nous sommes trop sincèrement Flamands nous-mêmes, mais personne ne nous empêchera de dire ce que nous pensons [...], des Reynaert [Reinhard], des Josson et de ceux qui les défendent, pour ne pas parler des Minnaert et autres Léo Picard [leden van Jong-Vlaanderen dus, $B Y$ ], qui ne sont plus des Flamands mais des Allemands. ${ }^{89}$

Pas op 7 juni 1915, nadat De Vlaamsche Stem uitgebreid, met de nodige verwijten en in twee artikels, gereageerd had op de aantijgingen van $L ' E c h o$ Belge, kwam er een einde aan de twist. ${ }^{90}$

Sommige medewerkers van de De Vlaamsche Stem reageerden dus geprikkeld op berichten van de Franstalige confrater en hechtten deels geloof aan de praatjes over een anti-Vlaamse campagne. Dat verzwakte bij enkele redactieleden misschien het Belgische patriottisme. Bepaalde activistische voorstellingen werden alleszins slechts door individuele medewerkers bestreden. Bij Jacob en De Clercq heerste duidelijk een nauwelijks verholen ongenoegen over de Godsvrede. Die situatie was een gunstige voedingsbodem voor het Duitse lokken.

\section{Een Duits programma voor Nederland}

Vanaf de lente van 1915 gingen de Duitse diensten zich steeds meer roeren in het neutrale Nederland. Die acties kaderden binnen de oorlogsdoelstellingen van het keizerrijk. Dat wou immers het hele Groot-Nederlandse blok in de Duitse invloedssfeer drijven. Instructies daarover waren zo oud als de Flamenpolitik zelf. Na meer dan een half jaar oorlog deden zich kansen voor. Want in Nederland kwam er sleet op de verontwaardiging die de Duitse inval van België gewekt had. Bovendien was er onbehagen over het optreden van de Britten tegenover de neutrale landen - in maart 1915 meldde het Duitse 
gezantschap zelfs dat men in Nederland rekening hield met een Britse landing op de Nederlandse kusten - en voerden de Duitse diensten propaganda door hun subsidies aan dagbladen als de Nieuwe Rotterdamsche Courant en De Tijd.${ }^{91}$ Maar er was ook een probleem. Want vanaf 8 mei 1915 maakte het Duitse gezantschap in Den Haag Berlijn opmerkzaam op het feit dat de gedachte aan een Duitse annexatie van België in Nederland voor onrust zorgde. De situatie was zelfs gevaarlijk, daar er stemmen opgingen die pleitten voor een toetreding van Nederland tot de Entente. ${ }^{92}$ Alleszins was Duitsland van plan om een versnelling hoger te schakelen in Nederland. Cruciaal daarin was de benoeming van Richard Von Kühlmann tot nieuwe Duitse gezant in Den Haag. Berlijn, zo schreef de Britse ambassadeur in Nederland, verwachtte immers "meer doortastendheid"..$^{93}$ Of zoals baron Fallon, de Belgische ambassadeur in Nederland, het verwoordde: “...l'Allemagne désire employer la manière forte dans ses relations avec les Pays-Bas. [Von Kühlmann] est un partisan décidé des théories pangermanistes." ${ }^{\text {94 }}$

Twee maanden na zijn aanstelling in april 1915, werd door de nieuwe Duitse gezant een Hilfsstelle opgericht, die onder leiding kwam te staan van Friedrich Wichert, een met een Nederlandse gehuwde kunsthistoricus uit Mannheim. Deze instelling was aan het Duitse gezantschap in Den Haag gehecht. Bedoeling was de Nederlandse publieke opinie in pro-Duitse zin te bewerken. Het oogmerk was "die großen Gedanken der holländischen Vlamenpolitik, nämlich ein Vlämisch-Holländisches Bollwerk zu schaffen".95 Von Kühlmann, zelf een kunstliefhebber en een vennoot van Insel Verlag van Von Bodenhausen, speelde een belangrijke rol bij het voeren van een Duitse cultuurpolitiek die op de Nederlandse massa gericht was. ${ }^{96}$ Maar voor de verwezenlijking van de politieke doeleinden van het Duitse Rijk zou niet de hele massa maar wel een germanofiel segment ervan, bewerkt worden. Een rapport dat Wichert op 6 september 1915 opstelde, onthult wat de Duitse legatie precies voor ogen stond. ${ }^{97} \mathrm{Hij}$ schreef aan Berlijn dat er in Nederland een "soort Groot-Nederlandse beweging" bestond die zich bezighield met het "lot van stamgenoten" die buiten de eigenlijke rijksgrenzen leefden, onder wie de Boeren in Zuid-Afrika maar ook de Vlamingen in België. Volgens hem was die beweging qua programma in het Algemeen Nederlands Verbond verenigd. Het beperkte aantal leden deed niets af van de invloed ervan. Het telde immers een schare intellectuele en politieke persoonlijkheden onder zijn financiers. Laat de beweging, aldus de schrijver, dan wel cultureel van aard geweest zijn, in turbulente tijden - zoals tijdens de Boerenoorlog of met de oorlogsomstandigheden in België - leek ze als vanzelf warm te lopen voor een verreikende politieke activiteit. Een aantal factoren zorgde onmiskenbaar 
voor een aantrekking van die stroming tot het Duitse Rijk. Ten eerste het gegeven dat die Nederlanders een organische staatsvorm aanhingen. Bovendien waren ze tegenstanders van het "liberaliserende individualisme" en sterk antidemocratisch. Ten slotte (en niet onbelangrijk) waren ze als Groot-Nederlanders ook "Groot-Germanen". En dus tegenstanders van de opmars van het Latijnse ras en, vanwege de "Franse invloed" in België, anti-Frans. Wegens de Boerenoorlogen waren ze tevens anti-Brits. Kortom, in zoverre de Duitse politieke belangen gericht waren tegen het Verenigd Koninkrijk en Frankrijk, vielen ze in veel gevallen samen met die van de Groot-Nederlanders. Dat was ook het geval voor wat de Vlaamse beweging betrof. Waar Wichert op zinspeelde, was dat Duitsland de völkisch-culturele aantrekkingskracht tussen Vlaamsgezinden en Nederlanders in het raamwerk van een Niederlandepolitik kon instrumentaliseren. Het rapport vervolgde met de bedenking dat

het uiteindelijke doel van deze beweging [...] voor de Vlamingen [de activisten, $B Y]$ en Groot-Nederlanders de bevrijding van Vlaanderen van België [is], ongeacht de wijze waarop. Het is in het belang van Duitsland om deze vernietiging van de Belgische eenheid in ieder geval in zulke mate te ondersteunen, dat ze een toekomstig Duits beleid in België niet kan schaden. [B.Y.]

Er bestonden volgens Wichert twee groepen Vlaamsgezinden. Enerzijds de "deloyalen" die min of meer Duitsgezind waren met als orgaan De Vlaamsche Post uit Gent. Dat streefde "eventueel met behulp van de Duitse overwinnaar" [B.Y.] naar een bevrijding van de "Belgisch-Franse onderdrukking", een bestuurlijke scheiding en zelfbestuur. Ten tweede, de loyale "regeringsgetrouwen", met als orgaan De Vlaamsche Stem uit Amsterdam. Zij wilden de doelen van de Vlaamse beweging slechts bereiken, zo ging hij voort, binnen het raamwerk van de onverbreekbare eenheid van België. Hun blad voerde een grove "anti-Duitse hetze" en moest alleen al daarom bestreden worden. Temeer daar in tegenstelling tot andere Franstalig-Belgische dagbladen, die bij de Nederlanders geen groot aanzien genoten, De Vlaamsche Stem een redelijke invloed op de Nederlanders had. Maar hoe kon het persorgaan het best bestreden worden? Van Duitse zijde had men, zo getuigde Wichert, vernomen dat het blad in financiële moeilijkheden verkeerde. ${ }^{98}$ Men kon het zelfs zonder veel moeite overnemen. Maar daarna gewoon De Vlaamsche Stem de nek omwringen, was geen optie. Naar zijn oordeel zou het blad dan toch op een andere manier zijn "haatdragend werk" voortzetten. Het echte doel moest zijn: “...het dagblad zo te modelleren dat het voor zijn abonnees 
nog steeds de oude Vlaamsche Stem bleef, maar verder op een ongemerkte manier de Duitse belangen diende." [B.Y.]

De overname waarvan sprake kon slagen wegens de vermelde financiële moeilijkheden en het feit dat hoofdredacteur Deswarte ideologisch onstandvastig was. ${ }^{99} \mathrm{Bij}$ hun manoeuvre konden de Duitse diensten rekenen op Frederik Carel Gerretson. Deze Nederlandse historicus, dichter en politicus kwam vóór de oorlog al in aanraking met de Vlaamse beweging. ${ }^{100}$ Op 24 april 1915 had hij in een brief aan de Groot-Nederlander Derk Hoek gevraagd of die hem desnoods via Valckenier Kips kon introduceren op de Duitse legatie. ${ }^{101}$ Goed vier maanden later herinnerde Wichert zich inderdaad dat, om de overname van De Vlaamsche Stem uit te voeren, Gerretson "der uns durch Professor Valckenier Kips empfohlen wurde" zich vrijwillig aanbood. Gerretson stelde gedetailleerd aan de Duitse legatie zijn plan van aanpak voor. Allereerst zou hij de meerderheid van de aandelen van het dagblad verwerven en de redactie van het blad veranderen. Net als zijn Duitse vrienden, was hij de mening toegedaan dat dit allemaal zeer omzichtig moest gebeuren. Het moest overkomen "als een symptoom van de verandering in houding van het tot nu toe pro-gouvernementele deel van de Vlamingen onder de Belgische vluchtelingen" [B.Y.], aldus Wichert. Die doelstelling halen lukte. Want de activisten, apologeten en later zelfs historici, zouden tot decennia na de oorlog volhouden dat de houding van "de Vlamingen" in Nederland (rond De Vlaamsche Stem) tegenover de Belgische regering spontaan en zonder Duitse inmenging veranderde. ${ }^{102}$ Het hoofd van de Hilfsstelle wist wel beter. Hij schreef dat Gerretson van de Duitse legatie volledig de vrije hand kreeg, met dien verstande natuurlijk dat de Nederlander nauwgezet de Duitse richtlijnen zou volgen. Het hele opzet was natuurlijk te gevaarlijk voor de legatie om zichzelf bloot te stellen. Op 9 mei 1915 deelde het Duits gezantschap aan Gerretson, Hoek en Valckenier Kips mede dat het geld "ter beschikking" stond. De stromannen, aldus Gerretson aan Hoek, moesten zich nu beschikbaar houden voor het "passeren der akten". ${ }^{103}$ Over wat er daarna gebeurde, getuigde André de Ridder, een gewezen redacteur van De Vlaamsche Stem, op 22 augustus 1915 in de pro-geallieerde Telegraaf. Het kapitaal van de opgerichte vennootschap ter exploitatie van het dagblad bedroeg 5000 gulden (vandaag zo'n 48.000 euro), verdeeld over honderd aandelen. Van die aandelen werden er slechts 40 geplaatst ( 2000 gulden): een te kleine som. Op het moment dat een faillissement van het noodlijdende blad nabij bleek, zo vervolgde de redacteur, verscheen Gerretson ten tonele. Die deed zich aan Deswarte voor als een vriend der Vlamingen en kocht 60 procent van de overgebleven aandelen op, maar "onder duidelijk beding 
dat hij van de daardoor verkregen overmacht nooit gebruik maken zou om invloed uit te oefenen op de richting van het blad". ${ }^{104}$ Inderdaad verwierf Gerretson op 18 mei voor 1200 gulden aandelen. Die werden verdeeld over door Wichert gecontroleerde "vertrouwenspersonen". Dat kon, zo meldde hij aan de Duitse legatie, omdat hij zijn eigen zwager verplichtte om eveneens aandelen te nemen.

Het eerste wat Gerretson na de overname deed, was een raad van commissarissen oprichten die aan hem ondergeschikt was. Daarna liet hij Deswarte samen met hem een nieuw programma op papier zetten. Na de eigendomsoverdracht werd uiteraard een pro-Duitse koerswijziging opgelegd. ${ }^{105}$ Bovendien moest De Vlaamsche Stem Antoon Jacob in de redactie opnemen. Dat zal wel geen toeval geweest zijn, want blijkbaar was die er al vroeger van overtuigd geraakt dat de Godsvrede ondergeschikt was aan het voortzetten van de taalstrijd. Blijkens het rapport van Wichert verkreeg Jacob een loon van de Duitse ambassade. De Duitse legatie kreeg waar voor zijn geld, want naar De Ridder getuigde, ontstond er met Jacob al vanaf de eerste dag ruzie. Die laatste wenste immers in het blad artikels te plaatsen die, scripsit De Ridder, in lijn met De Vlaamsche Post lagen en bedreigingen aan het adres van de Belgische regering uitten. De gewezen redacteur erkende dat het blad onder druk van Jacob op een zeker ogenblik al zo ver was gegaan "dat bijna met recht aan onze vaderlandsliefde getwijfeld mocht worden". ${ }^{106}$

Welk waren de concrete doeleinden die de Duits-Grootnederlandse werking beoogde? Gerretson wist Deswarte te vertellen dat er niet meer over de "onbewezen" Duitse gruwelen in België geschreven mocht worden. Inderdaad had Wichert ook als eerste doel aan Berlijn gemeld dat het schimpen op Duitsland in het dagblad gestopt of minstens gematigd moest worden. Zeker moest de redactie zich van dergelijke "misbruiken" onthouden. Wel behielden medewerkers voorlopig het recht om hun "natuurlijke gevoelens tegen Duitsland" binnen bepaalde grenzen te ventileren. Maar dat was natuurlijk tactisch als bescherming tegen de bewering dat men onder Duitse invloed stond. ${ }^{107}$ Bovendien moest in het blad de Vlaamse zaak van de geallieerde losgekoppeld worden. Wichert merkte op dat uiteindelijk de anti-Duitse toon in een anti-Britse en een anti-Franse moest veranderen. Ook mocht $D e$ Vlaamsche Post niet meer aangevallen worden. ${ }^{108}$ Dat kaderde in wat Gerretson als plan op de Duitse legatie had voorgesteld: "dass das Blatt [De Vlaamsche Stem, BY] sein Programm langsam dem der 'Vlaamsche Post' annähere, d.h. sich mit der Zeit zu dem Grundsatz der nur bedingten Loyalität gegenüber der belgischen Regierung bekenne." Het was inderdaad met het concept "voorwaardelijke loyauteit" dat Gerretson de koerswijziging van het blad zou 
verdedigen. Later zou de Nederlander deze retoriek aan zijn Duitse vrienden als "bombast" omschrijven en stellen dat het ware doel de vernietiging van België was. ${ }^{109}$ Maar naar de buitenwereld toe heette het dat de Vlamingen slechts loyaal aan België mochten zijn indien de Belgische regering hun eisen inwilligde. Dit verhaal had Gerretson in mei 1915 in De Vlaamsche Post al uit de doeken gedaan. ${ }^{110}$

Hij betoogde toen dat er een onlosmakelijk verband bestond tussen de schending van de Belgische neutraliteit door Duitsland en de Vlaamse zaak. Duitsland, aldus Gerretson, had de neutraliteit van België (het traktaat van 1839) maar één keer geschonden, België schond daarentegen voortdurend de taalwetten. En die neutraliteit heette dan nog een pro-Franse noodoplossing te zijn. België kon, zo beweerde hij, wegens binnenlandse tweedracht, zijn onzijdigheid niet verdedigen. De Vlamingen droegen immers de Belgische staat die hen "verdrukte" middels de door Frankrijk gesteunde "franskiljons" geen warm hart toe. Het onrecht aan de Vlamingen aangedaan maakte een binnenlandse eendracht dus onmogelijk. Dit onrecht moest weggenomen worden. Dat was, naar Gerretson beweerde, de voorwaarde voor een duurzame vrede en bijgevolg de internationale betekenis van het Vlaamse vraagstuk. Uit die redenering volgde dat de Vlaming dus op twee fronten moest strijden: tegen het "accidentele" onrecht van Duitsland tegenover de Belgische staat en tegen diegene die "chronisch en opzettelijk uit vijandige gezindheid tegen zijn ras, zijn taalrechten vertrapt en zijn volksziel vermoordt".

In De Vlaamsche Stem werkte Albéric Deswarte deze "loyauteitstheorie" in drie artikels uit: Spreken is Plicht, Diagnosis en Het Redmiddel. Deze artikels, die de koerswijziging eind juni 1915 definitief vormgaven, waren de neerslag van het nieuwe programma dat Gerretson hem opgedrongen had. De hoofdredacteur gaf in Spreken is Plicht - dat op dezelfde dag als het eerste deel van Ondermijners aan 't Werk uit de Gazet van Brussel verscheen - aan dat hij op 23 mei (dus enkele dagen nadat Gerretson en de zijnen 60 procent van de aandelen verworven hadden) geschreven had dat de Vlamingen het behoud van het onafhankelijke België wensten. Anderzijds wou hij het herstel van België als een federatie van twee autonome delen. Le Vingtième Siècle had dit artikel betreurd, maar wilde niet antwoorden omdat het alles uit de weg wou ruimen wat België tijdens de oorlog verzwakte. Deswarte nam dit als aanleiding om artikels te wijden aan wat België zogezegd echt verzwakte en wat het redmiddel in de toekomst was. Spreken ten voordele van een zelfstandig Vlaanderen moest men alleszins, want zij die zich weinig bekommerden om België, de Groot-Nederlanders en de Alduitsers, deden dat immers óók. ${ }^{111}$ Deswarte beweerde in Diagnosis dat de zwakte van België 
in het "unitaristisch centralisatiestelsel" lag. Al dadelijk na 1830 voerden de Belgische regeringen zogezegd een "uitroeiingspolitiek" tegen het Vlaams, de taalwetten waren maar niet of gebrekkig nageleefde doekjes voor het bloeden. Het resultaat was "wrijving, verbittering, verdenking, ontaarding van taalstrijd in rassengeschil [...] een misselijke, onhoudbare atmosfeer, waarin de patiënt tevergeefs hijgt naar een radicaal ingrijpen". ${ }^{12}$ Het Redmiddel was de vervanging van het "staatsunitarisme" door een "volksdualisme". Nieuw was die gedachte voor Deswarte niet. In 1913 reeds had hij ervoor gepleit om de wallingantische uitdaging tot bestuurlijke scheiding te aanvaarden. ${ }^{113} \mathrm{Nu}$ ging hij dat begrip uit de weg, naar eigen zeggen door de negatieve connotatie ervan. Hij verkoos "dubbel zelfbestuur" dat de eenheid van België ten goede heette te komen. Om zijn betoog te ondersteunen had Deswarte bijna enkel op Waalse auteurs gewezen die vóór de oorlog de séparation administrative geprezen hadden. ${ }^{114}$ In de niet-activistische Vlaamsgezinde propaganda, die de activisten probeerde te vergoelijken, dook deze propagandatechniek na 1918 overigens ook op. ${ }^{15}$ Op 1 juli 1915 volgde er een vierde artikel, getiteld Dubbel Zelfbestuur. Dat was niet van de hand van Deswarte, die de publicatie ervan de dag tevoren wel aankondigde. Het betrof een herwerkte overname van een opiniebijdrage uit het katholieke weekblad Hooger Leven van 31 januari 1914, getiteld Zelfbestuur? (mét vraagteken). Het tijdschrift had het toen afgedrukt "zonder vooralsnog stelling in te nemen over het vraagstuk". In de overname door De Vlaamsche Stem werd meer dan een derde van het oorspronkelijke artikel geschrapt. Maar dan nog is het opvallend dat in het gepubliceerde deel van het vooroorlogse artikel de klemtoon lag op de vernederlandsing van het Vlaamse land en dat er niet expliciet gesproken werd over wat die "bestuurlijke scheiding" nu precies inhield. ${ }^{116}$

De Vlaamsche Stem probeerde nu duidelijk de beweging op Duits-GrootNederlands aansturen ten voordele van "federalisme" en een verbrokkeling van België tijdens de oorlog in te schrijven in wat de vooroorlogse Vlaamse beweging voor ogen zou gestaan hebben. Later zou Wichert de programma-artikels die Deswarte "onder druk van dr. Gerretson [besloten had] om te schrijven" [B.Y.] een grote stap voorwaarts noemen. Volgens hem bracht de hoofdredacteur op een "ongehoord dappere manier" voor de Vlaamse beweging tot dan toe nieuwe principes en eisen naar voren. De activistische principes, die onder Duitse druk tot stand kwamen, waren dus zeker geen "onderdeel van de traditionele Vlaamse beweging". ${ }^{117}$ Ze kwamen, zoals Wichert dat verwoordde, welhaast neer op een "afwijzing van de Belgische regering". Daarmee komen we tot de kern van de Flamenpolitik: het scheppen en uitdiepen van de kloof tussen Vlaanderen en België. Natuurlijk werd 
in de activistische propaganda de koerswijziging van De Vlaamsche Stem anders voorgesteld. Zo beweerde Het Vlaamsche Nieuws in september 1915 dat De Vlaamsche Stem in januari van dat jaar gesticht was "om te antwoorden op de toen reeds ontelbare aanvallen die Vlaanderen van Franse [sic] zijde te verduren had". Het Antwerpse dagblad wees op de "zware financiële moeilijkheden" waarmee De Vlaamsche Stem te kampen had. Het dagblad werd bovendien, "dagelijks [...] door de Echo Belge als een verdacht blad voorgesteld en bekampt" (quod non). En zo werden "enige van de bijzondere aandeelhouders" het beu: "deze groep wist, begin juni [1915] [...] Deswarte te overtuigen een meer Vlaams karakter aan het blad te geven." ${ }^{118}$ De drie artikels van Deswarte waren in deze voorstelling van zaken dus gewoon een uitdrukking van een voortschrijdende Vlaamsgezindheid. Dat L'Echo Belge zou reageren lag voor de hand. Het wachtte het eerste opruiende artikel van Deswarte zelfs niet af om zijn ongenoegen te uiten. Hoewel het na het afsluiten van de discussie over de vestiging van De Vlaamsche Stem in de gebouwen van de Norddeutscher Lloyd wekenlang niets provocerends meer geschreven had, publiceerde het op 26 juni 1915 Les Importuns. Daarin werden de flaminganten ervan beschuldigd misbruik van de oorlog te maken. Ze schilderden zich als slachtoffers af en noemden zich de Polen of Tsjechen van België. Maar diezelfde Vlaamsgezinden misbruikten volgens het Franstalige dagblad de Belgische wetgeving om ambten, vergoedingen en subsidies te verkrijgen. De enige "onderdrukking" die ze voelden was dat zij de anderen (de Walen en een Franssprekende minderheid Vlamingen) niet konden verdrukken. Daartegenover werd dan door L'Echo Belge de massa Vlamingen gesteld die dat niet wilde, maar in het bezette land niet kon spreken. En dus deed een categorie flaminganten die in het binnenland gebleven was en een die uitgeweken was, alsof zij voor iedereen sprak: "Les flamingants élèvent donc la voix en Belgique? Hélas oui, et comment! Ils sont une clique qui saluent les Allemands - leurs frères germains - comme des libérateurs." En dat allemaal om het Frans in België te verbannen! ${ }^{119}$

Een antwoord van De Vlaamsche Stem bleef niet uit. In de kolommen van het blad namen twee personen het woord. Allereerst de liberale volksvertegenwoordiger Arthur Buysse, die erop wees geen polemiek te willen aangaan. Na de oorlog diende de Vlaamsgezinde strijd met de vernederlandsing van de universiteit van Gent door te gaan. Johan Demaegt schreef hoe Vlaanderen in een vrij België heel zijn ziel moest kunnen geven aan de "heroprichting" van het naoorlogse land. Het kon dat enkel door zelf door en door Vlaams te zijn. Demaegt beweerde dat de situatie der Vlamingen nog erger was dan die van Polen, Elzassers en Tsjechen, daar de Vlamingen, 
hoewel een onoverwonnen meerderheid in België, zich volgens hem moesten plooien naar de eisen van de "Fransgezinden". ${ }^{120}$ De polemiek duurde voort. De dag zelf nog dat het Nederlandstalige blad dit publiceerde, viel L'Echo Belge René De Clercq aan met als reden (of onder het voorwendsel) dat die gefeliciteerd, ja verafgood werd door De Vlaamsche Post uit Gent. Hij kreeg aanlokkelijke voorstellen om zijn werk in het Duits uit te geven en had hij eertijds niet geschreven: "Wat doen wij voor U, arm Diets, arm Diets?" Volgens het blad was het Diets de taal, eertijds gesproken van de Baltische kusten tot de Noordzee: "Diets = Duits" (sic). Bovendien had die De Clercq ook de volgende zin op papier gezet: "à la porte, la concubine, l'étrangère, le français." Weg met het Frans? Maar met die woorden kon men de hele "flamingantische beweging" samenvatten! Geen wonder dat De Vlaamsche Post de dichter bewierookte. De beweringen van het Franstalige blad waren niet uit de lucht gegrepen, maar gingen inderdaad voort op het artikel René De Clercq in Holland, dat enkele dagen eerder in De Vlaamsche Post verschenen was. Daarin beweerde de verslaggever van het dagblad hoe de houding van sommige "franskiljons" de dichter diep gegriefd had: "Hij, de rechtgeaarde en rondborstige Vlaming, is verontwaardigd over de sluiperige en oneerlijke handelswijze van zekere Vlaamshaters die [...] hun Fransdolle kuiperijen niet willen staken en vals van de gelegenheid gebruik maken om te trachten het [Vlaams] voorgoed te versmachten." ${ }^{21}$

De redactie van L'Echo Belge was zichtbaar geïrriteerd door de artikels van de dichter, die een inbreuk op de Godsvrede waren. Minister Poullet had op 29 juni 1915 aan De Vlaamsche Stem en aan L'Echo Belge gevraagd om de polemiek te staken. ${ }^{122}$ Maar voorlopig bleef dat zonder gevolg. Een (indirect) antwoord van L'Echo Belge op de artikels van Deswarte kwam er op 1 juli 1915. Toen titelde het blad: Les Impudents. Nu werden de handelingen berispt van een "boosaardige kliek" in Nederland die in het bezette land het bewonderenswaardige Vlaamse volk - dat vocht en leed - discrediteerde. Zolang er een Belgische zaak bestond, aldus het blad, mocht er geen Vlaamse zijn. De "luidruchtige minderheid" flaminganten in het bezette land dreef de haat tegen het Frans zover dat ze de Duitse brandstichters op een vreugdekreet onthaalde. En ze voerde een campagne die de nationale eenheid in gevaar bracht. ${ }^{123}$

De Vlaamsche Stem antwoordde op 2 en 3 juli met de publicatie van twee stukken. In een eerste publiceerde De Clercq zijn gedicht Ons Dietsch en hekelde hij diegenen die uit dwaasheid "Diets" met "Duits" gelijkschakelden. "Wij zullen [...] niet rusten", zo schreef hij, "eer ons Vlaams [...] het hoogste en enig woord mag voeren in wetenschap, onderwijs, en het hele bestuur 
van Vlaanderen". In een tweede haalde het blad zwaar uit naar het "onterend werk" van L'Echo Belge. Het persorgaan stelde dat na de bevrijding van België ook Vlaanderen gered moest worden van de ziekte van de tweetaligheid en de miskenning van het Vlaams. ${ }^{124}$ L'Echo Belge had al in Les Impudents beloofd de polemiek te staken. ${ }^{125}$ Dat deed het ook, al werd niet nagelaten om op 5 juli 1915 nog zonder commentaar te signaleren dat De Vlaamsche Post "drie interessante artikels" van Deswarte gepubliceerd had. ${ }^{126}$ De Duits-activistische propaganda recupereerde natuurlijk de inbreuken op de Godsvrede van het Franstalige dagblad en zette daarbij in de verf dat Charles Bernard van $L ' E c h o$ Belge, "en zijn kliek onophoudelijk en zonder genade de Vlamingen aanvallen en tekortdoen”. ${ }^{127}$ En uiteraard werden de artikels van Deswarte die het Franstalige persorgaan prikkelden, gunstig ontvangen in de Duits-activistische pers, van de Gazet van Brussel die Deswarte als de verloren zoon onthaalde tot De Vlaamsche Post die naar aanleiding van haar speciaal 11 juli-nummer op de reeks van Deswarte reageerde. Volgens het blad was die eindelijk tot het inzicht, de bestuurlijke scheiding, gekomen, waar alle échte flaminganten ooit toe moesten komen. Naar het Jong-Vlaams blad beweerde, was er nog een punt dat het blad, en dus de groep Jong-Vlaanderen van De Vlaamsche Stem scheidde. Immers, de groep uit Gent wilde de Vlaamse kwestie "internationaliseren" en niet laten afhangen van de Belgische regering. En aangezien er geen Vlaamse macht was om op een vredesconferentie de Vlaamse belangen te behartigen, moest men steunen op een "buitenlandse mogendheid". Die moest logischerwijs behoren tot de Centrale machten of de Entente. De Belgische regering "die steeds de rechten van de Vlamingen heeft miskend” en die zich bij dat laatste bondgenootschap aangesloten had (sic), mocht niet voorgoed de houding der Vlamingen bepalen. ${ }^{128}$ Voor de goede verstaander: Vlaanderen kon zich (bij een vredesconferentie) enkel maar op Duitsland beroepen.

Het staatkundig programma dat we hier in de De Vlaamsche Post lezen, was een impliciet antwoord van het Gentse blad op wat Deswarte eerder geschreven had. In zijn replieken op Picard had hij immers geweigerd om rekening te houden met een scenario waarin Duitsland blijvend Vlaanderen overheerste. Wat De Vlaamsche Post betoogde, stemde overeen met wat Wichert blijkens een bespreking met Gerretson op 4 september 1915 voor De Vlaamsche Stem wenste. Daarin meldde hij dat er een aantal "bijzonder principiële standpunten [waren] voor de behandeling van de redactie". [B.Y.] Het eerste daarin luidde: "Het staatsverband, waarin het zelfstandige Vlaanderen opgenomen zal worden, wordt bepaald door de uitkomst van de oorlog." In eerste instantie, aldus Wichert, moest De Vlaamsche Stem 
het principe verdedigen dat deze zelfstandigheid binnen een hersteld België bewerkstelligd diende te worden. Het dagblad moest het voortouw nemen in de reeds genomen maatregelen die tot doel hebben die "zelfstandigheid" van de Belgische regering af te dwingen. Weigerde de Belgische regering - en dat was wel erg zeker! - moest men zich wenden tot de koning en daarna tot de vredesconferentie. "Als er niets wordt bereikt, gaat men over naar de oude positie van De Vlaamsche Post: zelfstandigheid van Vlaanderen, in eender welk [dus ook het Duitse, $B Y$ ] staatsverband." [B.Y.] ${ }^{129}$ Als laatste "redmiddel" moest er constant verwezen worden naar gewapende weerstand. Met name moesten eerdere opstanden $(1572,1789,1830)^{130}$ in herinnering gebracht worden alsook de verwijzing naar hun legaliteit. Een absorptie van Vlaanderen door Duitsland mocht blijkbaar ook door het opnemen van de wapens tegen de staat in een anti-Belgische revolutie bewerkstelligd worden.

\section{De zomer van 1915: een doorbraak}

Begin juli 1915 gaven Deswarte en Jacob voor de redacteuren en medewerkers aan De Vlaamsche Stem tekst en uitleg bij de ideologische ommezwaai van het blad. Waar Jacob het "Belgische regime" hekelde, benadrukte Deswarte dat men zich moest verdedigen tegen de "anti-Vlaamse uitlatingen". Van Cauwelaert verdedigde de onvoorwaardelijke loyauteit aan België. Julius Hoste jr. was het eens met hem, De Clercq uiteraard niet. ${ }^{131}$ In april 1915 bestond er enigszins een breuklijn binnen De Vlaamsche Stem waarbij Jacob en De Clercq al op de rand van de Godsvrede balanceerden, blijkbaar omdat ze ervan overtuigd waren geraakt dat "de franskiljons" met een anti-Vlaams offensief begonnen waren. Het was dus gemakkelijker om hen naar het activisme te doen overhellen. Belangrijk voor het verdere verloop der gebeurtenissen was het 11 juli-feest te Bussum. ${ }^{132}$ Het betrof, zoals we dat bij Wichert lezen, een “...durch die [...] Utrechter Studentenabteilung des Algemeen Nederlandsch Verbond [und die] Redaktion der 'Vlaamsche Stem' und unsere Vertrauensleute inscenierte Fest". Anders gezegd, achter dit gebeuren ging ook de hand van de Duitse diensten schuil.

Het werd een bijeenkomst die uitblonk in völkisch radicalisme. Slechts Nederlandse driekleuren en Vlaamse vlaggen wapperden er. Onder de aanwezigen telde men activisten en Groot-Nederlanders. Deswarte had het over de verbroedering van de Nederlandse stam in barre oorlogstijden en het verdrukken in België van de Nederlandse taal. "We leggen hier de basis van een nieuwe politiek: het pan-Neerlandisme." Het ging erom te weten 


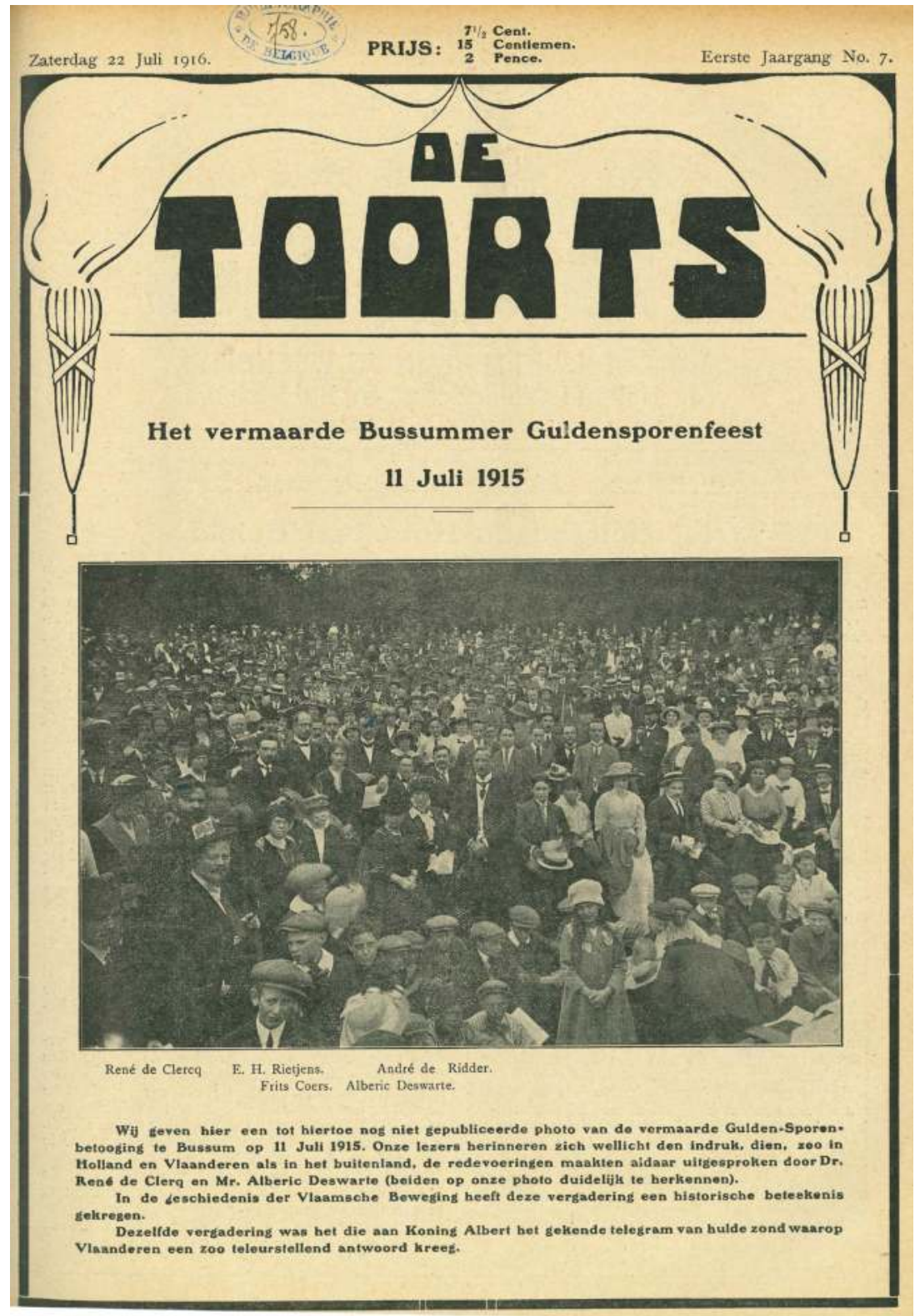

Afb. 18. Het Guldensporenfeest te Bussum

De Toorts, 22 juli 1916; KBR BE-KBRO0-Vi 7613 B 
of Vlaanderen daarvan het bolwerk zou blijven. Ook René De Clercq sloeg een dreigende toon aan. Hij eiste meermaals en met hamerende vuist de onmiddellijke vernederlandsing van de Gentse universiteit. Deze inbreuk op de Godsvrede was blijkbaar ook bedoeld als een chantagemiddel tegen de Belgische regering in ballingschap. Voorts dreef De Clercq de spot met de vooroorlogse taalwetterij en de partijen die "lapjes" toewierpen, waaruit dan het kleed waarin de Vlaamse beweging zou worden gehuld, moest gemaakt worden:

Ons kleed is als een vastenavondpak, ons wordt daarvoor door de katholieken een gele, door de liberalen een blauwe, door de sociaaldemocraten een rode lap toegeworpen. Maar wij willen een schoon wit kleed! Ik zweer [...] dat wij dit kleed zullen terug hebben, of ik ga niet terug.

Profetische woorden, gelet op zijn levenslange ballingschap na de oorlog. ${ }^{133}$ Op de bewuste viering richtte Deswarte samen met René de Clercq, in naam van De Vlaamsche Stem, een telegram aan koning Albert I. Daarin stond dat Vlamingen en Nederlanders die "in duizendtallen te Bussum verenigd", de Guldensporenslag herdachten aan Zijne Majesteit hun huldegroet brachten en hun vertrouwen uitbrachten "in Zijn wijs beleid om het zelfstandige Vlaanderen in het onafhankelijke België te vrijwaren”. De koning antwoordde hierop dat 's lands overheden alle maatregelen zouden nemen, erop gericht om de verzuchtingen en belangen van zijn volk te behartigen wanneer België zijn soevereiniteit herwonnen had. Het telegram besloot met een dringende oproep aan alle Belgen om voor de vijand geen ander doel te hebben dan de bevrijding van het grondgebied. ${ }^{134}$ Dat was natuurlijk een beleefde oproep om de Godsvrede na te leven.

Elias zou in 1969 optekenen dat 's konings antwoord op dit "huldetelegram" (sic) voor velen een ontgoocheling was. "Door de radicalen zou het in de nabije toekomst samengevat worden in het lapidaire: Vecht en Zwijgt!"135 Maar het telegram van een overigens volstrekt niet door de bevolking gemandateerde groep en zijn effect was een zelf vervullende profetie. Zoveel leiden we tenminste af uit wat Deswarte schreef in het blad waarvan hij de machteloze hoofdredacteur geworden was. Want al op 28 juni 1915 had hij beweerd dat van heden af aan Walen en Vlamingen het recht, ja de plicht hadden tot alle politici en leden van de regering met klem de vraag te stellen:

Wij die voor België thans goed en bloed, lijf en leven veil hebben, wat zal het ons geven $[\ldots]$, wanneer we door ons strijden en lijden [...] Belgiës 
bestaan zullen gered hebben? [...] zal men het aandurven die vraag te ontduiken met het benauwde antwoord: 'eerst uw bloed vergieten jongens, daarna zult gij weten wat gij eraan hebt?' - is dàt de taal van staatsmannen?"136

Inderdaad wist Deswarte - of, accurater gezegd: de Groot-Nederlanders en Duitsers die hem aanstuurden - natuurlijk zeer goed dat koning en regering nooit de eisen van hem en De Clercq zouden en konden inwilligen. Het parlement, dat wetten moet stemmen, kwam immers niet in oorlogstijd samen. Maar abstractie makend hiervan zou de koning, indien hij niet instemde met hun wensen, zogezegd "de Vlamingen" afwijzen (in de Duits-activistische beeldvorming werden "de activisten" gelijkgeschakeld met "de Vlamingen"). Maar wanneer hij het tegengestelde deed, werd de activistische collaboratie de officiële regeringspolitiek. Daardoor kan het beruchte telegram enkel maar gelezen worden als een vooraf beraamde provocatie om tweedracht te zaaien tussen de Vlaamsgezinden onderling enerzijds en tussen de Vlaamsgezinden en de Belgische overheid anderzijds. Die stelling wordt bevestigd door Wichert die hierover het volgende rapporteerde: "Dit telegram, dat niets anders betekenen kan als een in vleiende vorm uitgeschreven opstand-ultimatum ["Aufruhrultimatum"], heeft de aanleiding gegeven tot een verdere ontwikkeling [...] van de Vlaamse beweging in de voor de Belgische regering ongewenste zin." [B.Y.] Sterker nog, het geld dat de Duitse legatie tot dan toe geïnvesteerd had en alle intriges waarmee ze zich gedurende al die maanden had beziggehouden, had voor de leider van de Hilfsstelle zichzelf al terugbetaald wanneer er niets anders bereikt was dan het feest te Bussum en dat "anti-Belgische huldetelegram" ["antibelgische Huldigungstelegramme"], om zijn woorden te gebruiken. ${ }^{137}$

De evidente ergernis die het gebeuren bij de Belgische overheid verwekte, werd vertolkt door Le Vingtième Siècle van 21 juli 1915. Dat blad hernam enkele uittreksels (waaronder het bovenstaande) van de fameuze stukken van Deswarte van eind juni 1915. Het was dus niet meer, aldus het dagblad, de plicht van onze soldaten om goed te strijden, maar wel om voorwaarden te stellen aan hun eigen regering om tegen die Pruisen te blijven vechten!? De verdrukking van de Vlamingen werd als romantisch pathos afgedaan. We zijn hier toch niet in Polen! Bovendien gebood het ongeluk van het vaderland de regering al haar tijd aan de oorlogsvoering en de administratie van onbezet België te besteden, in plaats van aan het taalprogramma dat een groepje flaminganten rond De Vlaamsche Stem formuleerde. ${ }^{138}$ In zijn rapport van 1 augustus 1915 aan Berlijn noteerde Von der Lancken over dit arti- 
kel: "we hebben ervoor gezorgd dat deze ontboezemingen [van de Belgische regering, $B Y$ ] hier [in bezet België, $B Y$ ] de grootste ruchtbaarheid kregen." [B.Y.] ${ }^{139}$ Of nog, de Duitse diensten verspreidden maar al te graag wat er in Le Vingtieme Siècle stond als "anti-Vlaamse propaganda".

In de nasleep van de gebeurtenissen omtrent de 11 juli-viering werd in de Nederlandse pers aangekondigd dat er aanstonds een manifest zou verschijnen van bekende Vlaamsgezinden waarin ze het opwerpen van taalstrijddiscussies afkeurden, verklaarden niets te maken te willen hebben met $D e$ Vlaamsche Post dat slechts een Duits werktuig was en de tactiek van de Duitse regering veroordeelden. Die wilde hen compromitteren door de Vlamingen ongevraagde voordelen op taalgebied te schenken. Ten slotte maanden ze aan om de Vlaamse strijd na de oorlog binnenlands en door Vlamingen zelf verder te zetten. ${ }^{140}$ August Borms benutte Het Vlaamsche Nieuws om de aanstaande "oekaze" van de bekende Vlaamse leiders - "geen trekkende locomotieven, doch remtoestellen" in de Vlaamse beweging - belachelijk te maken. ${ }^{141}$ In een brief (17 juli 1915) van de ingenieur Hippoliet Meert naar aanleiding van de aanstaande publicatie van het manifest stond dat de Vlaamsgezinden toch niet konden zwijgen. Immers, beambten drongen volgens hem het Frans op, de verfransing woekerde voort in Vlaamse scholen, "heel de bende van de handlangers der Franse propaganda, Maeterlinck, Destrée, De Marès, Harry" ging in het buitenland tekeer om de flaminganten te bestrijden en men hoorde vertellen dat Vlaanderen in de armen der Latijnse cultuur geworpen zou worden. Voorts had Colleye verklaard: "la Belgique sera latine ou elle ne sera pas!" Ook beklaagde Meert zich over de achterstelling van het Nederlandstalig hoger onderwijs bij Belgische geïnterneerden en de "gewelddadige" verfransing van kinderen van Vlaamse vluchtelingen in Frankrijk. ${ }^{142}$ Hij had zijn brief naar de Nieuwe Rotterdamsche Courant verstuurd, die een opname weigerde. ${ }^{143}$ Het schrijven zou later evenwel nog van belang blijken.

Het eigenlijke manifest, dat naast door Van Cauwelaert en Julius Hoste jr. door elk redactielid van De Vlaamsche Stem ondertekend werd - Jacob en De Clercq daargelaten -, trok in naam van de Vlaamse beweging (en uitdrukkelijk in naam van gezaghebbende flaminganten die onder Duits bestuur niet konden spreken) van leer tegen de Flamenpolitik. ${ }^{144}$ Daarbij wees het op het belang van taalgelijkheid en Nederlandstalig onderwijs, maar dan wel binnen de context van de Belgische wetgeving:

De Vlaamse beweging is uit Vlaanderen zelf opgekomen, alleen gedragen door Vlaamse beweegredenen [...] Nooit hebben wij aan steun noch ingeving van Duitsland iets te danken gehad, en voor zover invloedrijke 
Duitse ingezetenen zich in België vóór de oorlog met ons binnenlands leven hebben bemoeid, stonden zij alvast niet aan onze zijde.

Wat bedoelde men hiermee? Allereerst dat het activisme geen natuurlijke uitwas van de Vlaamse beweging was. Ten tweede ontkenden de Vlaamsgezinden impliciet het bestaan van vooroorlogse germanofilie binnen hun rangen. En collaboreren had niets te maken met de Vlaamse beweging. De ondertekenaars wilden geen afbreuk doen aan de staatkundige eenheid van België (versta: hun tegenstrevers wél) en wezen de openlijke of bedekte annexatie van België af. Wie handlanger was van de vijand, was niet alleen een verrader van België, maar ook van de Vlaamse beweging. Slechts in een onafhankelijk België zou het Vlaamse volk tot zijn recht komen. ${ }^{145}$ Van Cauwelaert, die ondertussen de ware toedracht omtrent de intriges rond De Vlaamsche Stem kende, eiste een vergadering om Gerretson cum suis ertoe te dwingen zich uit het dagblad terug te trekken. Maar die bleef zo'n zitting verdagen. Wichert beschreef het verzet van Van Cauwelaert en de zijnen als een felle anti-Duitse campagne waaraan "Regieringungsvlamen" deelnamen. Daarachter ontwaarde hij de hand van de Belgische overheid. Als gevolg van de 11 juli-viering te Bussum, zo meldde hij, was die bij monde van Van Cauwelaert en de zijnen met dit manoeuvre begonnen. Deswarte werd naar zijn aanvoelen "geïntimideerd" en veranderde van kamp. Gerretson wees op het programma dat moest worden nagekomen. Maar volgens de loyalisten werd De Vlaamsche Stem nog niet door de Nederlandse staat als onderneming erkend; het dagblad kon dus schrijven wat het wou, zonder zich aan het programma te houden. Het hoofd van de Hilfsstelle noteerde dat Gerretson, nadat dit "drijven" van zijn tegenstrevers een korte tijd geduurd had, tot hardere maatregelen besloot. Hij beriep een vergadering van aandeelhouders en leidde de liquidatie. ${ }^{146}$

Op 31 juli 1915 kwam inderdaad een aanmaning bij deurwaardersexploot om vóór 16 augustus een algemene vergadering bijeen te roepen. Het programmapunt was: "Ontslag van de beheerraad, ontbinding der vennootschap." Het schrijven was ondertekend door Gerretson, Van Vessem - de secretaris van het Utrechtse Algemeen Nederlands Verbond -, De Clercq alsook de juristen Brulez en Eggen. Op de bewuste vergadering verscheen Gerretson met "volkomen onbekende heren" (stromannen), zo vertelde oud-redacteur De Ridder nadien. Die droegen de aandelen van de Nederlander [dus van het Duits gezantschap, $B Y$ ] bij zich. Deswarte zou dan zijn tussengekomen om de aandelen van Gerretson terug te kopen en van het blad opnieuw een Belgische onderneming te maken. Zonder twijfel gebeurde dit onder invloed van Van Cauwelaert en Hoste. Naar Wichert verhaalde, boden die Gerretson 
geld aan en bedreigden ze hem met schandalen van allerlei aard, wanneer hij het waagde De Vlaamsche Stem "aan te randen". Gerretson hapte echter niet toe. Door zijn meerderheid van de aandelen zorgde hij voor een afzetting van de redactie en de ontbinding van de vennootschap door een liquidatiecommissie. Diezelfde commissie zorgde ervoor dat de volgende dag al De Vlaamsche Stem opnieuw verscheen, maar nu zonder de namen van de oude redactie maar mét die van De Clercq en Jacob. "Wij zijn verraden en verkocht", zo klaagde De Ridder. De redacteur vertelde dat hij er zeker van was dat Gerretson er nooit aan gedacht had rechtstreeks in het belang van Duitsland te handelen (geloofde hij dat echt?). Wel bestond er een groep Nederlanders die zich met de interne aangelegenheden van de Belgische staat wilde inlaten:

Moest deze oorlog onbeslist blijven en tot een verdeling van België leiden, dan zou het volstrekt niet onmogelijk zijn, dat de mogendheden overeenkwamen om het Waalse gedeelte van België aan Frankrijk te schenken en het Vlaamse gedeelte bij Nederland te voegen, om van dat 'GrootNederland' dan een staat te maken waarin Duitsland de vrije hand zou hebben. ${ }^{147}$

Die laatste zin van De Ridder was de kern van de zaak: de schepping van een Groot-Nederlandse satellietstaat onder Duitse voogdij. Nadat de loyalisten met De Vlaamsche Stem hadden gebroken, stichtten ze onder leiding van Van Cauwelaert en Hoste jr. een nieuw Vlaamsgezind en pro-Belgisch weekblad: Vrij België. ${ }^{148}$ Terugblikkend op de gebeurtenissen, beoordeelde Vanacker het wedervaren van De Vlaamsche Stem als volgt:

De redactie van dit blad had stilaan de indruk gekregen dat de Godsvrede misbruikt werd om de Vlaamse beweging te bestrijden en begon op een 'bevrijdend woord' van de Belgische regering aan te dringen. Gerretson versnelde deze evolutie door via stromannen de onverkochte aandelen op te kopen, met geld dat hij van de Duitse legatie gekregen had. ${ }^{149}$

We kunnen het hier moeilijk mee eens zijn. In De Vlaamsche Stem verschenen inderdaad artikels, gericht tegen de vermeende anti-Vlaamse campagne en het is onloochenbaar dat een aantal redactieleden vóór de overname verhalen over het doorbreken van de Godsvrede door "de franskiljons" aannamen en daarover geïrriteerd waren. Maar slechts de "nieuwe redactie" zou om een "bevrijdend woord" vragen. ${ }^{150}$ De Duitse diensten zetten in feite langs twee zijden druk op De Vlaamsche Stem: hun propaganda over een anti-Vlaamse 


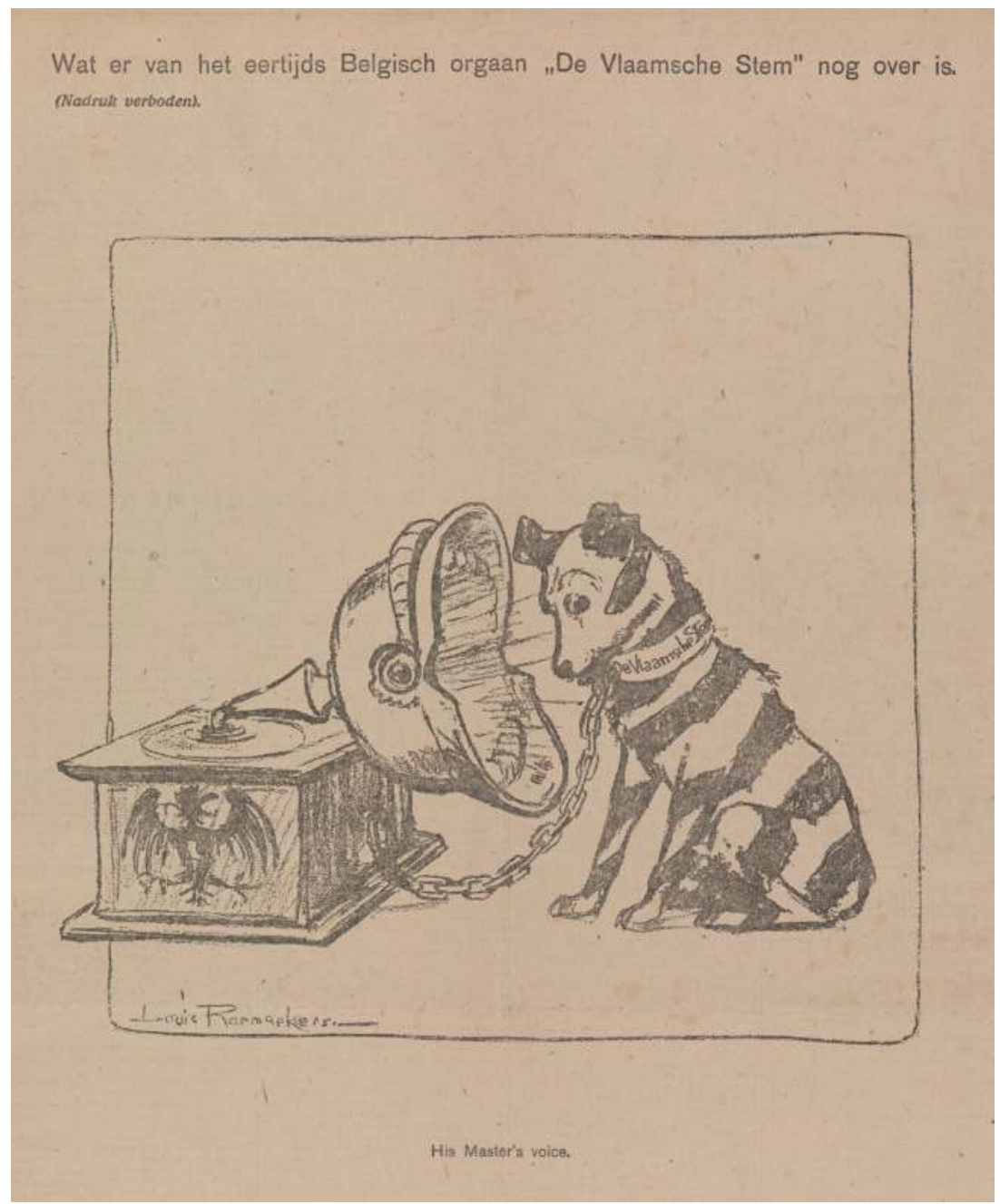

Afb. 19. De cartoonist Louis Raemaekers maakte begin september 1915 in de pro-geallieerde Nederlandse Telegraaf duidelijk van wie het dagblad De Vlaamsche Stem voortaan afhing. De Telegraaf, Tweede Blad, 1 september 1915, 1; Koninklijke Bibliotheek Den Haag - C 98

campagne circuleerde in Nederland en maakte sommige redactieleden nerveus. Een beperkt aantal keren zochten ze het conflict op met L'Echo Belge. Anderzijds kochten die Duitse diensten vanaf medio mei aandelen op om gaandeweg het dagblad over te nemen, met de koerswijziging van De Vlaamsche Stem eind juni 1915 tot gevolg. Uit wat Vanacker schrijft, zou men kun- 
nen afleiden dat Gerretson de spilfiguur hierin was. Tot op zekere hoogte terecht, want hij voltrok behendig een manoeuvre. Maar in werkelijkheid voerde hij Duitse bevelen uit. De koerswijziging van het dagblad werd niet door de hele redactie gedragen, maar wél door De Clercq en Jacob. Zij waren het die, samen met Deswarte, het meest onstandvastig bleken en het was dan ook weinig verwonderlijk dat ze, Deswarte daargelaten, de redactie vormden van de "nieuwe" Vlaamsche Stem.

\section{De zaak-Buisset: een Duitse tegenzet}

De Vlaamsche Stem was in Duitse handen, maar dat was niet zonder slag of stoot gebeurd. Wichert verbloemde het niet:

Dr. C. G. [C. Gerretson], und seine Freunde haben nun von Mai bis September [1915] unermüdlich und in beständiger mittelbarer Fühlung mit der Gesandtschaft an der Umwandlung der Zeitung gearbeitet und gegen deren Hintermänner gekämpft. Dieser Kampf war ungewöhnlich schwer und liess immer wieder neue Schwierigkeiten hervortreten. ${ }^{151}$

Die moeilijkheden kwamen niet van de Nederlandse pers. Want zoals Wichert vaststelde, had op al die tijd enkel De Telegraaf het aangedurfd om op ondubbelzinnige wijze het verband tussen De Vlaamsche Stem en de Duitse belangen duidelijk te maken. In dat blad was namelijk een spotprent van de Nederlandse cartoonist Louis Raemaekers verschenen met daarop een hond aan de leiband - De Vlaamsche Stem - geketend aan een Duitse grammofoonspeler. Het veelzeggende opschrift daaronder was: His master's voice. De echte weerstand kwam van de Belgisch-loyale Vlaamsgezinden die het manifest-Van Cauwelaert ondertekenden. Om dit verzet in de kiem te smoren, deden de Duitse diensten een tegenzet op basis van twee brieven over de situatie van de Belgische krijgsgevangenen in Duitsland. Vanaf 16 februari 1915 had het ministerie van Oorlog in Berlijn het bevel gegeven om Vlamingen en Walen van elkaar te scheiden in de krijgsgevangenkampen. ${ }^{152}$ De bedoeling was om de Vlamingen zo meer onderhevig te maken aan de Flamenpolitik. Op 23 maart 1915 meldde de Antwerpse correspondent van de Nederlandse Nieuwe Courant die in België gelezen kon worden, hoe hem uit zekere bron bevestigd werd dat het Duitse bestuur in België de Vlaamse beweging gunstig gestemd was, zonder dat de Vlamingen hierom gevraagd hadden. De uit Duitsland naar België teruggezonden 
burgerlijke krijgsgevangenen, zo vervolgde hij, waren - zo werd hem verteld - uitsluitend Vlamingen. Bovendien kwam op de officiële bekendmakingen en verordeningen uitgaande van de Duitse overheid na het Duits de Nederlandse tekst en dan pas het Frans. ${ }^{153}$ Dit bericht werd twee weken later in $D e$ Vlaamsche Post hernomen en bleef niet zonder gevolg. ${ }^{154}$ Op 13 april 1915 immers had Franck zich tot Von Bissing gewend om de ongelijke behandeling van Vlaamse en Waalse gevangenen aan te klagen. Hij nam aanstoot aan het feit dat, naar men hem mededeelde, de Waalse burgerlijke gevangenen nog steeds in Duitse gevangenschap zaten, terwijl de Vlaamse al op vrije voeten zouden zijn. Hij of iemand uit zijn omgeving was dus op de hoogte van de berichtgeving uit het Nederlandse dagblad of De Vlaamsche Post. Niets zou pijnlijker zijn, zo beweerde Franck, dan in de tragische omstandigheden die België doormaakte een politiek te voeren die zich liet leiden door "taalof rassenkundige overwegingen" en daarvan het lot van de inwoners deed afhangen. ${ }^{155}$ Op 5 mei 1915 uitte de Henegouwse volksvertegenwoordiger Buisset in een brief aan Von Bissing dezelfde klacht. Enkele maanden later werd dit laatste schrijven door de Duitse propaganda verdraaid.

Op het moment dat hij zijn brief schreef, was Buisset geen onbekende voor het gouvernement-generaal. Want toen Von der Goltz eind augustus 1914 in België aankwam, hadden hij en Devreux, de burgemeester van Charleroi, zich naar Luik begeven, waar de eerste gouverneur-generaal resideerde. Ze lichtten hem daar in over de gevolgen van een brand in Charleroi na een Frans-Duits gevecht. Na een volgend onderhoud bekwamen ze op 6 september 1914 van Von der Goltz dat de Duitse vorderingen van voedsel zouden stoppen. De streek rond Charleroi werd immers met hongersnood bedreigd. Von Sandt, het hoofd van de Zivilverwaltung, raadde hen aan om naar Nederland te gaan: de Duitse bezetter bevoorraadde enkel zijn eigen troepen. Omdat ze ook daar bot vingen, gingen ze naar het Verenigd Koninkrijk. In de hoedanigheid van vertegenwoordigers van het Belgian National Relief Committee, verkregen ze van de Britse overheid eind oktober 1914 een zending van duizend ton levensmiddelen voor de geteisterde regio. De Britse overheid had eerder al ingestemd met een voorwaardelijke opheffing van haar vlootblokkade, waar het civiele voedselleveringen betrof.

In zijn vermelde brief aan Von Bissing, had Buisset zich ook uitgelaten over een onderwerp dat de Nieuwe Courant eveneens had aangeraakt. Hij beklaagde zich er immers over dat sedert het begin van de bezetting [de gecursiveerde passage stond niet in de Nieuwe Courant, BY] het Nederlands op Duitse aanplakbiljetten voorrang kreeg op het Frans "malgré la conception constitutionnelle qui avait institué le français comme langue officielle du 
pays". ${ }^{156}$ Besluiten deed hij zijn schrijven met de vaststelling dat toen Von der Goltz in België aangekomen was, hij en Devreux met hem gesproken hadden. Hij had, zo schreef hij, de gouverneur-generaal met goed gevolg gewezen op diverse desiderata, noodzakelijk om "hun lijden te verlichten" (over de brand in Charleroi dus). Buisset beweerde er niet aan te twijfelen dat ook Von Bissing aan de huidige "irritante maatregelen" [over de gevangenen en, in mindere mate, de voorrang van het Nederlands, $B Y]$ een einde zou stellen. Welnu, enkele dagen na de aankondiging van het manifest-Van Cauwelaert in de Nieuwe Rotterdamsche Courant van 13 juli 1915 - waarin ook de brief van Franck gepubliceerd was -, schoot de Politische Abteilung in actie. ${ }^{157}$ Dat gebeurde allereerst, erg subtiel, door de publicatie van een boekbespreking in de Gazet van Brussel (17 juli 1915) van Belgien und die niederdeutsche Frage van Hans-Friedrich Blunck. Daarin werd opvallend veel aandacht besteed aan zijn eerder besproken bewering (zie hoofdstuk 4, paragraaf 6) als zouden de Walen de Duitsers ervan hebben proberen te overtuigen dat er geen Vlamingen meer waren. Die passage werd dan als volgt becommentarieerd:

Iets wat wij reeds tevoren hadden horen zeggen [...], vinden wij in het werk [...] volledig gedrukt. [...] Is het misschien daaraan te wijten, dat op vele Duitse plakbrieven in den beginne [van de bezetting, $B Y$ ] onze taal geheel ontbrak? Laat ons hopen dat wij er eens meer van zullen vernemen. ${ }^{158}$

Het bleef niet bij die wens, want zes dagen later meldde het persorgaan dat al in de eerste dagen van de bezetting het "gerucht" vernomen werd dat "zekere Waalse heren" geprobeerd hadden het Duits bestuur ervan te overtuigen dat het onnodig was het Nederlands te gebruiken. En volgens de Gazet van Brussel kon het nu die bewering via een officiële Duitse mededeling staven. ${ }^{159}$ Wat was er dan gebeurd? Welnu, op 18 juli had de Politische Abteilung in verband met de brief van Franck een rechtzetting naar de pers opgestuurd. Daarin stond, als antwoord aan Franck, dat de vrijlating van burgerlijke gevangenen vooral van de militaire overheid in Duitsland afhing. Voorts was er "geen redelijke grond [...] voor de mening dat het Duits bestuur in België Vlamingen en Walen verschillend behandelt". De gouverneur-generaal, zo heette het, streefde er beslist naar ook aan het Waalse gedeelte volkomen recht te doen wedervaren. Het was bovendien niet door de brief van Franck dat de gouverneur-generaal tot die opvatting was gebracht. Dat bleek duidelijk uit het antwoord dat hij eerder aan een verzoek van een "Waals leider" uit Charleroi gaf. Die nam overigens ook aanstoot aan het feit dat het gouverne- 
ment-generaal in zijn mededelingen ook (sic) de Nederlandse taal gebruikte, omdat naar zijn mening slechts (sic) het Frans de officiële taal van België was. En in zijn antwoord aan Buisset had Von Bissing medegedeeld dat de Duitse autoriteiten inzake de taalkwestie voortaan ook naar recht zouden handelen. Het Vlaamse volk en de Nederlandse taal konden er aanspraak op maken dat de gelijke behandeling, gewaarborgd door de wet, ook werkelijk doorgevoerd werd. Voortaan ook naar recht handelen? Anders gezegd, tevoren werd, althans volgens de Duitse propaganda, de rechtsgelijkheid van de Vlamingen voor de wet blijkbaar niet of onvoldoende door de Duitse overheid gegarandeerd. ${ }^{160}$

De bezetter, die zich naast de tussenkomst van Buisset bij Von der Goltz in augustus waarschijnlijk ook zijn interventie met Devreux in september 1914 herinnerde, speelde heel handig in op de taalkwestie in de brief van de volksvertegenwoordiger. Die had dan, zo luidde het intentieproces, "lafhartig" en al in 1914 aan de "overweldiger" verzocht "geen Nederlands meer te gebruiken", zoals August Borms dat op 25 juli 1915 in Het Vlaamsche Nieuws schreef. ${ }^{161}$ Dát was blijkbaar het "lijden" dat Von der Goltz aan het begin van de bezetting "verlicht" had. Borms was later nog duidelijker:

$\mathrm{Nu}$ begrijp ik ook hoe het komt dat [...] toen ik einde oogst [augustus 1914] naar Brussel ging, op alle plakbrieven en openbare berichten het Nederlands was verdwenen en alles enkel in het Duits en in ' $t$ Frans was opgesteld! Zeker naar de 'wenken' van de heer Buisset en consoorten, die volgens een vriend uit Brussel ons mededeelde aan de gouverneur-generaal [Von der Goltz] het programma van de wallonisanten en vulgarisateurs, [...] dat o. a. de afschaffing van al onze [...] taalwetten voorziet, moet overhandigd hebben, opdat de Duitse overheid daarin de 'desiderata' der bevolking zou leren kennen. ${ }^{162}$

Die voorstelling van zaken paste in de eerdere Duitse propaganda. Want zoals vermeld werden in de herfst van 1914 in Brussel misschien Duitse geruchten verspreid over "de Walen" die het Nederlands wilden afschaffen. Ook had de bezetter het beeld verspreid dat de Duitse bezetting niets aan de bevoordeling van het Frans in België veranderd had. Maar anderzijds botste de propaganda rond Buisset op de werkelijkheid van de Flamenpolitik en zelfs op eerdere voorstellingen van de Duitse bezetter. Want al op 10 januari 1915 had de Gazet van Brussel triomfantelijk gemeld dat de toenemende vijandigheid bij Franstalige landgenoten ten opzichte van het Vlaamse volk des te grievender was "bij het vaststellen van de achting voor onze taal aan de dag 
gelegd door het nieuwe [Duits] bestuur, dat in alles aan deze de haar toekomende plaats toekent". ${ }^{163}$ En, zoals gezien, schreef Het Vlaamsche Nieuws op 4 maart 1915 dat de Vlaamse taalgrieven "als bij een toverslag" verdwenen onder het Duitse bestuur.

De propagandamolen begon te draaien en op minder dan een maand wijdde alleen al de Gazet van Brussel niet minder dan zeventien artikels aan de zaak-Buisset. ${ }^{164}$ Intussen was begin augustus een nieuw manifest verschenen, dat in lijn lag met dat van Van Cauwelaert. Het schrijven ging uit van Brusselse Vlaamsgezinden, onder wie Vermeylen, de dichter Hegenscheidt en (de Antwerpenaar) Franck. Ze verklaarden dat het onaanvaardbaar was dat de Duitse regering gunsten aan een deel van de bevolking wou verlenen en dat sommige bladen die in België verschenen "onder de dekmantel van Vlaamse taalstrijd andere belangen dienden dan de Belgische". Ook dit manifest eindigde met een oproep om de taalgeschillen te laten rusten. ${ }^{165}$ Dat was blijkbaar een aanleiding om de propaganda rond Buisset nog op te drijven. Daarbij hadden de Duitse diensten het geluk dat de man er zijn geduld onder verloor. Op 14 augustus reageerde hij immers met twee brieven naar Het Vlaamsche Nieuws. De ene was een kopie van zijn schrijven naar Von Bissing, de andere een toelichting. Ze werden twee weken later in het blad gepubliceerd. ${ }^{166}$ In zijn toelichting betoogde Buisset terecht: "J'apprends que votre organe s'est occupé de mon intervention auprès du Gouverneur Général [...] à propos de la question flamande. Inutile d'ajouter que vous avez dénaturé totalement mes sentiments, et, ce qui est pis, tronqué le sens de ma lettre [...]."

De volksvertegenwoordiger vervolgde met te stellen dat het niet het moment was om, zoals "enkele" Vlaamsgezinden dat deden, over de irritante taalkwestie te polemiseren. Na herhaald te hebben dat hij over het lot der gevangenen geprotesteerd had, schreef hij de wenselijkheid om het Nederlands vóór de Franse tekst te publiceren, betwist te hebben. De Belgische wetgeving had immers steeds de voorrang der Franse taal erkend. Besluiten deed hij met te protesteren tegen de bewering dat hij afbreuk wou doen aan de rechten der Vlamingen en de wens uit te drukken dat de karaktermoord op zijn persoon goed gemaakt werd door zijn brief en die aan Von Bissing te publiceren. Maar als Buisset dacht de gemoederen zo te bedaren, dan sloeg hij de bal wel erg mis.

Het Vlaamsche Nieuws becommentarieerde de gewraakte passage uit zijn brief en beweerde op grond daarvan eens te meer dat Buisset de bezetter wou wijsmaken dat het Frans door de Grondwet tot enige landstaal uitgeroepen was. De Waalse beweging wou dus de "enkele kruimels" die de Vlamingen de laatste 84 jaar bekomen hadden, afnemen en dan moesten de Vlamingen nog 
eens zwijgen! ${ }^{167}$ Op 27 augustus publiceerde De Gazet van Brussel de brief van Buisset om die de volgende dag te bespreken. Volgens het blad stond het buiten kijf "dat er [in het begin van de bezetting, $B Y$ ] ook wenken [de "desiderata" waarvoor Buisset zich blijkens de Duitse interpretatie van zijn brief tot Von der Goltz gewend had, $B Y]$ op taalgebied zullen bij geweest zijn". Als reden haalde het daarvoor "de [bekende] gezindheid van de Waalse volksvertegenwoordiger" aan, die "trouwens nogmaals uit zijn eigen brief" zou blijken. ${ }^{168}$ Om het verhaal over Buisset geloofwaardig te maken, werd voorts beweerd dat de volksvertegenwoordiger vóór de oorlog het Nederlands in het atheneum van Charleroi als tweede taal had proberen te vervangen door het Duits. Dat was onwaar. In werkelijkheid had hij de huisvader er de keuzevrijheid tussen het Nederlands, Duits of Engels willen geven. ${ }^{169}$ De woorden die Buisset in de mond gelegd werden, steunden ook op een verdraaiing van zijn artikel uit de Revue de Belgique (1913), getiteld Le français, langue officielle de la Belgique. Die titel dekte de lading niet, want in dat stuk pleitte hij niet voor de afschaffing van het Nederlands, maar voor een tweetalig Vlaanderen. Wel betoogde hij dat de wet vereiste dat minstens de Franse tekst in wetten en koninklijke besluiten vóór de Nederlandse kwam. De aantijgingen tegen Buisset moesten uiteraard het beeld van een anti-Vlaamse campagne kracht bijzetten. Het waren - zo heette het - de Walen die zich "aan de Duitse regering [in België] opgedrongen hadden" en van de oorlogssituatie gebruik hadden proberen te maken om sedert het begin van de bezetting "het gehate Vlaams" weer uit te schakelen. Zowel de Gazet van Brussel als Het Vlaamsche Nieuws verwees voor die beweringen naar het gekende propagandawerk van Blunck. ${ }^{170}$

De fabel rond Buisset hielp, net als het verspreiden van provocerende vlugschriften, om een nieuwe fase in de Flamenpolitik mogelijk te maken. Met name: het vaste voet aan de grond krijgen ervan in Nederland. Ook hier konden de Duitse diensten zaaien op de vruchtbare akker van de völkische stamverwantschap. Zo schiepen ze een Groot-Nederlandse beweging. Op welke traditie kon die bogen en hoe paste de uitvoering van het Duitse beleid in Nederland hierin?

\section{De Groot-Nederlandse beweging}

In het Duitse machtsspel in Nederland speelde de Duitse agent Gerretson een cruciale rol. De loyauteitstheorie die hij bepleitte, was een concept dat uit het ancien régime dateerde. ${ }^{171}$ Die gedachten werden door hem verweven met een Nederlands nationalisme, dat aanleunde bij de conservatief-pro- 
testantse ideologie uit het midden van de negentiende eeuw. Na de oorlog vertelde Gerretson de Groot-Nederlander Pieter Geyl dat de ideologie van de conservatief Guillaume Groen van Prinsterer voor hem het "uitgangspunt" geweest was tot zijn "begrip van de Vlaamse beweging" en dit sedert 1909. Hij beweerde dat een "Nederlands Vlaanderen" binnen een "gefederaliseerd" België een betere oplossing was dan een Groot-Nederlandse staat. ${ }^{172}$ Gerretson bedoelde dat hij opteerde voor een verbrokkeld België waarover Nederland, geruggensteund door Duitsland, gedeeltelijk de voogdij mocht uitoefenen. Eerder wezen we op de völkische verwantschap tussen het Nederlandse en het Duitse nationalisme. In de eerste helft van de negentiende eeuw werd door het nationalisme een semantische begripsbreuk veroorzaakt, waarbij onder meer de vrijheid van het individu verschoof naar de onaantastbare soevereiniteit van volksgemeenschappen. ${ }^{173}$ Tijdens die periode beoogde de antirevolutionaire politicus Guillaume Groen van Prinsterer, voorloper van Abraham Kuyper, een herstel van het ancien régime onder de vorm van een protestantse theocratie. ${ }^{174}$ In 1830 al sprak hij in rancuneuze bewoordingen over België en "het muitende [Belgische] gespuis". Dat heette beïnvloed te zijn door de verfoeilijke Franse en liberale ideeën, zoals de volkssoevereiniteit.

Zo'n België kon, net als na de Franse bezetting, de status van Frans wingewest toebedeeld krijgen en zo een bedreiging vormen voor Nederlands zelfbestaan. Indien men de breuk in het Verenigd Koninkrijk der Nederlanden had willen voorkomen, aldus Groen van Prinsterer, moest het protestantse Holland het zedelijk middelpunt zijn van de staat, als dam tegen het "onverdraagzame" katholicisme en de "Franse" nationaliteit. Kreeg die immers de overhand, dan werd België van Holland afgescheiden of werden de twee landsdelen Frans. Holland met héél België erbij was een staat. Maar slechts Holland met het noorden van België verenigd vormde volgens hem een (Nederlandse) natie. Er viel dus volgens de conservatief ook wel iets te zeggen voor een scheiding tussen Noord en Zuid, die hij geleidelijk aan ook positief begon op te waarderen. Zeker omdat België na 1815 binnen het Verenigd Koninkrijk zijn functie als anti-Frans bolwerk niet vervuld had, maar, zo betoogde hij, integendeel deels al verfranst was. Omdat België enkel nut had als barrière, zo luidde de redenering, moest men geen staatkundige eenheid maar net een zo wijd mogelijke kloof met dat land nastreven: "Nederland sluite zich aan bij het Germaanse Europa [...] de leus zij: 'beter dood te wezen, dan Frans.' In een in 1832 gepubliceerde artikelenreeks werkte hij zijn ideeën omtrent de kwestie verder uit. De politieke eenheid tussen beide landen had in het verleden, zo merkte Groen van Prinsterer op, niet zo lang geduurd. De gewesten waren voordien bijna zelfstandige staten onder 
dezelfde vorst. Zonder dat er gestreefd werd naar eenvormigheid werden de Nederlanden toch als één gebied onder dezelfde vorst overgeleverd. ${ }^{175}$ Groen van Prinsterer zocht zijn inspiratie in de Republiek der Zeven Provinciën (1588-1795), met de zeegewesten als kern. De functie van België, zo "begreep" men al in 1648, was slechts die van een tussenland. Volgende regel werd toen een leidraad voor de komende 150 jaar ${ }^{176}$ : "Houd Frankrijk, kan het wezen, te vriend; maar bovenal zorg dat hij uw nabuur niet zij." De auteur wees op de vereniging die er, volgens hem, ondanks de scheiding tussen Noord en Zuid aan het einde van de zeventiende eeuw bestond. Het was een "eenheid van werking en belang". Maar België was in de toenmalige Nederlandse republiek een "toevoegsel, een werktuig [...]; een bolwerk, in de eigenlijke materiële zin van het woord [...] dat zich niet zelf verdedigen kon, een lichaam, maar onbezield en dat van buiten kracht en leven ontving". Het systeem was "de grondslag voor het stelsel van [de] barrière [...], hetwelk, vooral ook in onze tijd, opmerking verdient".

België diende dus als vazalstaat van Nederland en als "voormuur tegen Frankrijk" te fungeren. Een vertrouwdheid met zo'n barrière dateerde in Nederland al van de vrede van Rijswijk in 1697. Die stipuleerde dat Nederland het recht had om garnizoenen in acht vestingen van de Spaans-Habsburgse Nederlanden te legeren. ${ }^{177}$ In 1713 werd deze barrière tegen Frankrijk uitgebreid met elf steden in de Oostenrijks-Habsburgse Nederlanden en het land van Kessel. In 1781 werd het barrièreverdrag door de Habsburgers opgeheven. ${ }^{178}$ Tussen 1795 en 1813 was Nederland een Franse satellietstaat. Nadien werd België binnen het Verenigd Koninkrijk der Nederlanden opnieuw een barrière. De Belgische revolutie had er echter voor gezorgd dat Nederland niet meer over een bufferzone tegenover Frankrijk kon beschikken.

Voor Groen van Prinsterer diende het barrière-systeem ook een Europees evenwicht te bevorderen. België moest daarom ad aeternitatem bij een mogendheid gevoegd worden die door ligging en kracht niet gevaarlijk voor Nederland kon zijn en tevens Frankrijk ontzag inboezemde. Het land diende herleid te worden tot "stof" waaruit voor Holland een bolwerk opgericht werd. Dat kon ook in 1815 gebeurd zijn. De Waalse gewesten hadden dan wel nood gehad aan een bijzondere behandeling, "maar in Vlaanderen, Antwerpen, Limburg, in een groot deel van Brabant, zag men overal het merk van de Nederlandse stam". België had zich toen opnieuw onder het Huis van Oostenrijk kunnen voegen. Parallel hiermee kon een anti-Frans Anglo-Pruisisch-Nederlands bondgenootschap ontwikkeld worden. In die constellatie bleef Noord-Nederland een soevereine staat en werd "de interne kracht van België gebroken" om er het "Nederlandse volkswezen" te versterken. Behalve 
tegen Frankrijk was het denken van Groen van Prinsterer op Pruisen gericht. Tijdens de naweeën van de Pruisisch-Oostenrijkse oorlog schreef hij in zijn brochure La Prusse et les Pays-Bas (1867) gunstig te staan tegenover een "nauwere aansluiting" bij Noord-Duitsland. "De Pruisen zijn, net als wij, van het Germaanse ras. Net als wij, is Pruisen vandaag nog in wezen een protestantste staat die zich verzet tegen het ultramontanisme. Nederland was steeds de Vormauer van Duitsland tegen Frankrijk." Niet lang na het uitbreken van de Frans-Pruisische oorlog verklaarde Groen van Prinsterer: "Mijn sympathieën voor Duitsland, ook voor Pruisen, heb ik evenmin in 1866 [tijdens de Pruisisch-Oostenrijkse oorlog, $B Y]$ verborgen, als ik ze thans verberg." Voor Nederland lag het echte gevaar niet in de oorlog, maar in de vredesonderhandelingen, waarbij het land geannexeerd kon worden. Maar dat was volgens Groen van Prinsterer zelfs niet de ergste ramp en kon de wedergeboorte van het Nederlandse volk inluiden.

Gerretson en de zijnen begonnen vanaf april 1915 voor De Vlaamsche Post in Gent artikels te schrijven. ${ }^{179}$ Daaruit blijkt dat hij inderdaad de geschiedopvatting bijtrad van Groen van Prinsterer, aan wie hij overigens een artikel wijdde. In een ander stuk beweerde Gerretson dat de Verenigde Nederlanden, zoals die ten tijde van Karel V bestonden, een ideaal en een voorwaarde voor een duurzame West-Europese vrede waren. Gedurende driehonderd jaar hadden alle grote staatslieden dat ingezien. Willem I begreep zogezegd "dat slechts verenigd en geruggensteund door het verwante Duitsland, Holland en Vlaanderen een waarborg zouden zijn voor de vrede van Europa". Voor wie het niet wou begrijpen, had een andere Groot-Nederlander nog diezelfde dag de volgende boodschap: "Holland [zal] verdwijnen, indien het zich van zijn algemeen-Nederlandse waarde niet bewust is, indien het niet op de versterking van de Nederlandse invloed is bedacht. [...] Stellen wij ons open voor Vlaanderen, dat is welbegrepen: voor onze eigen zaak." De Vlaamsche Post van 2 mei 1915 schreef dat Vlamingen en Nederlanders na eeuwenlange scheiding weliswaar neiging tot elkaar voelden, maar als volk elkaar niet helemaal begrepen. Zelfs was er een zeker conflict tussen het Hollands en het Vlaams karakter. De geleidelijkheid, die het samengroeien van beide delen van de stam kenmerkte, mocht dus niet miskend worden. Een ander stuk sprak over de bestaande kloof, die gedempt diende te worden. Daarvoor was het niet nodig in hetzelfde staatsverband te leven, maar wel om Vlaanderen te "zuiveren" van zijn verfranste burgerij. ${ }^{180}$ In De Vlaamsche Post van 22 juni 1915 bood Gerretson trouwens een voorsmaakje aan van de druk op de "antinationale" Belgische regering die hij later in Nederland met de Stem uit Amsterdam zou uitoefenen. ${ }^{181}$ Zeker na de oorlog, zo opperde 
hij, zou de belangrijkste tegenstelling in België, die tussen "flamingant" en "franskiljon", leiden tot hetzij een bevredigende oplossing of een breuk. Kwam de Belgische regering terug, dan zou ze de flaminganten ("de Germanen, de landverraders nietwaar?") proberen weg te vegen. Beschouwde die regering, net als de "franskiljons", de oorlog niet als een strijd van Latijnen tegen Germanen? "Wij vrezen zeer dat, indien onze waarschuwing in de wind wordt geslagen, de Belgische regering zich, op een ongelegen tijdstip, zal verrast zien door gebeurtenissen, waarvan zij de tragische ernst zal beseffen als het te laat is!" Deze praktische uitwerking van Gerretsons loyauteitstheorie liep vooruit op wat Deswarte in zijn drieluik over de verhouding van de Vlamingen tot de Belgische staat in De Vlaamsche Stem zou schrijven. Die Groot-Nederlandse ideologie beïnvloedde ook Vlaamse auteurs in $D e$ Vlaamsche Post, die nu gingen beweren dat Groot-Nederland meer zou hebben aan een sterk Nederlands Vlaanderen, dan aan een "verhollandst" (een geannexeerd) Vlaanderen. ${ }^{182}$

Zulke denkbeelden sloten aan bij wat Von Kühlmann voor ogen stond. In geval van een annexatie van België (zoals von Bissing die wenste), moest men volgens hem geen rekening houden met de Nederlandse toestand. Maar indien Duitsland zich terugtrok uit het hoofddeel van België, lagen de kaarten anders. Dan konden de Nederlanders als "nuttige werktuigen" in het Vlaamse vraagstuk aangewend worden om België "duurzaam te verzwakken", zoals hij dat op 23 augustus 1915 aan Berlijn meldde. De aanleiding voor die bedenking was een berichtje uit $D e$ Tijd van drie dagen eerder, waarin gemeld werd dat de Gentse universiteit in oktober zou heropend worden. Bij een onvoldoende aantal Belgische professoren zou, aldus het blad, het tekort door Duitsers aangevuld worden. Von Kühlmann schreef aan de rijkskanselier dat dit in haar bestaande en dus Franstalige vorm zou gebeuren (hoewel dat niet in De Tijd stond). Hij voegde eraan toe hoe dit artikel in Nederland onbehagen opgewekt had, omdat men daar hoopte dat in een Vlaamse universiteit ook Nederlandse professoren in overweging zouden genomen worden. ${ }^{183}$ Niets wijst er evenwel op dat het gouvernement-generaal die maatregel niet wou doorvoeren of zonder ingrijpen van Von Kühlmann niet geïmplementeerd had, al zou het zeker langer geduurd hebben. ${ }^{184}$ De beslissing was, zoals gezien, al in december 1914 genomen. En vanaf begin 1915 probeerde de Duitse bezetter met die belofte Vlaamsgezinden te lokken. ${ }^{185}$ $\mathrm{Al}$ in mei 1915 had Von der Lancken aan Berlijn gemeld dat er bijzondere rapporten over de vernederlandsing van de Gentse universiteit en de vereiste van een bestuurlijke scheiding voorbereid werden. ${ }^{186} \mathrm{Op} 1$ augustus rapporteerde Von der Lancken dat het probleem van de vernederlandsing van de 
universiteit van Gent de bijzondere aandacht van de Politische Abteilung opeiste. Er werd met name bestudeerd of de universiteit al niet vanaf de herfst heropend kon worden, zelfs indien dat voorlopig [het uiteindelijke doel bleef dus de vernederlandsing, $B Y]$ in de oude vorm moest verlopen. [Von Kühlmann wist dit, zoals aangegeven, ook. Toont dit niet aan dat hij in contact stond met het gouvernement-generaal?, $B Y]^{187}$ Blijkbaar stond gouverneur-generaal Von Bissing weigerachtig tegenover de inzet van Nederlanders. Hij meldde medio september aan Berlijn nog geen beslissing te hebben genomen over de heropening van de universiteit, maar verzweeg daarbij van plan te zijn de Franstalige universiteit op 1 oktober te willen heropenen. Pas onder druk van Den Haag en Berlijn, kwam hij op 29 september definitief op die beslissing terug. ${ }^{188} \mathrm{Zo}$ werd het pad geëffend naar de aankondiging van de vernederlandsing van de universiteit van Gent op 31 december 1915. Ondanks de invloed op die beslissing vanuit het Duitse gezantschap in Den Haag, was het verschil met wat het gouvernement-generaal voor ogen stond vooral tactisch.

Wat de Duits-Groot-Nederlandse beweging precies wenste, komen we te weten via een memorandum van 5 oktober 1915, getiteld Deutschland, Flandern, Holland. Dat verstuurde gezant Von Kühlmann twee dagen later naar Berlijn en was blijkbaar opgesteld door Gerretson, die de Duitser "onze Groot-Nederlandse vertrouwensman" noemde, in samenwerking met het onder "ons toezicht [dus van het Duits gezantschap, $B Y$ ] in het leven geroepen 'Vlaams comité' van Leiden". [B.Y.] Het bestond onder anderen uit de deserteur Cantillon, de activisten Remouchamps en Picard en diens vriend Derk Hoek. Het document bevatte een pleidooi voor een economisch, politiek en militair blok tussen Nederland, België en Duitsland. Dit zou ervoor zorgen dat België ná de oorlog geen Anglo-Frans bolwerk werd. Het obstakel voor Nederland was de Duitse bezetting van België. Die stond deze wenselijke "vrijwillige" belangengemeenschap in de weg. Maar Nederland, Duitsland en de Vlaamse beweging hadden ook een gemeenschappelijk belang: de indamming van de Franse invloed in België. Dat land heette vóór de oorlog al niet echt neutraal geweest te zijn en het conflict had de pro-Franse oriëntatie ervan zogezegd nog versterkt. Gerretson en de zijnen stelden als oplossing voor om België de rol van neutrale staat toe te bedelen. Een federalisering met zeer verregaande autonomie voor het Vlaamse landsgedeelte, zou dat statuut garanderen. Zo'n "federalisme" zou op zijn beurt de "Vlaams-Nederlandse" invloed in België doen toenemen, opdat het een dam zou opwerpen tegen het gevaar van een francofiele politiek. De auteurs gingen ervan uit dat de Belgische regering nooit zo'n programma zou aanvaarden. De "Vla- 
mingen" konden dan schermen met het concept "voorwaardelijke loyauteit" tegen de "deloyale" Belgische regering om hun samenwerking met Duitsland te rechtvaardigen.

Aangezien de oorlog waarschijnlijk op een vredesconferentie zou uitlopen, zou het bestaan van een Vlaams nationaal comité nuttig zijn om de eis tot federalisering van België af te dwingen. Zo'n comité moest al tijdens de oor$\log$ worden opgericht en geleidelijk uitgroeien tot een soort "hulpautoriteit voor gezamenlijk werk met de Duitse administratie". Naar buiten toe zou ze er onafhankelijk van optreden. Het comité kon dan bij een conferentie bij het Rijk "hulp zoeken". Het zo goed als "zelfstandige" Vlaanderen zou de "toenadering" tussen Duitsland en Nederland verzekeren. ${ }^{189}$ Von Kühlmann meldde zelf een aantal maanden later aan de kanselier dat "de mentale en economische assimilatie van Holland door Duitsland [zou plaatsvinden]. De innige doordringing en engere aansluiting (Angliederung) van de kleine Germaanse randstaten zal één van de belangrijkste taken van Duitsland zijn na de oor$\log { }^{19}{ }^{190}$ Op 23 oktober schreef hij aan Berlijn dat Kiewiet de Jonge, de secretaris van het Algemeen Nederlands Verbond, alsook de oud-ministers Colijn en Kuyper (beiden waren aangesloten bij de Anti-Revolutionaire Partij) akkoord waren met de inhoud van het memorandum van Gerretson cum suis; Von Kühlmann wees er ook op om de Vlaamse beweging niet te scheiden van de Groot-Nederlandse: er bestond een nauwe relatie tussen beide en het Duitse beleid in Nederland kreeg waardevolle steun van Nederlanders. ${ }^{191}$ De Duitse staatssecretaris van Buitenlandse Zaken, Von Jagow, stuurde op 30 oktober 1915 het document op naar Brussel. Hij merkte daarbij op het idee "daß die Flämische Frage ein Mittel bietet um eine Interessengemeinschaft zwischen Holland, Flandern und Deutschland herzustellen" genegen te zijn.

Von der Lancken had blijkbaar meer twijfels. Begin december wees hij in een schrijven naar het ministerie van Buitenlandse Zaken een onafhankelijk en neutraal hersteld België af. Een administratieve scheiding zou volgens hem onvoldoende zijn om na de oorlog de Duitse invloed in België te garanderen. Immers, een federale staat kende ook nog centrale instellingen en die zouden, zo beweerde hij, door de Franstalige Belgische elites gedomineerd worden. Daarom hadden de Vlamingen nood aan een Anlehnung bij Duitsland. ${ }^{192}$ Op 28 december 1915 onderstreepte de Duitse gezant in een schrijven naar Berlijn alweer hoe de Vlaamse beweging van het allergrootste belang was wanneer Duitsland België niet openlijk of bedekt zou annexeren. Net daarom moest het Duitse bestuur proberen om maatregelen te nemen die de Belgische staat niet meer uit de weg kon ruimen. In die optiek waren de anti-Belgische Jong-Vlamingen belangrijke bondgenoten. Von Kühlmann 
ging nu nog een stap verder dan te pleiten voor een bestuurlijke scheiding, zoals het memorandum van Gerretson cum suis dat deed. Hoewel het hoofddoel van een Vlaams-nationalistische beweging het nastreven van een gefederaliseerd België onder Duitse bezetting moest blijven, was dat een te zwak concept om de massa op te zwepen. Dan was volgens hem een "koninkrijk Vlaanderen" geschikter. ${ }^{193}$

Von Bissing ging begin januari 1916 nog op de rem staan. De kanselier had bij het hoofd van de Politische Abteilung in een brief van 1 januari 1916 achtereenvolgens de wenselijkheid van de vorming van een "Vlamingencomité" benadrukt en gesteld dat in de Duitse politiek tegenover België met alle mogelijkheden rekening gehouden moest worden. Dat impliceerde eveneens dat het mogelijk was dat het keizerrijk bij vredesonderhandelingen niet naar goeddunken over het lot van België kon beslissen. Dus zouden onderhandelingen gemakkelijker verlopen indien Duitsland internationaal kon wijzen op het bestaan van een Vlaams-nationale beweging. Von Bissing meende daarentegen in een schrijven van twee weken later dat de weg der geleidelijkheid bewandeld moest worden. ${ }^{194}$

In een rapport van 5 januari 1916 meldde Von Kühlmann aan Von Bethmann-Hollweg: "Durfte man die Angst vor Deutschland ganz allgemein als die eigentliche Ursache des Hasses der Holländer gegen unser Vaterland bezeichnen, so erhielt dieses allgemeine Gefühl ein besondere Motivierung durch die Möglichkeit der Einverleibung Belgiens durch das Reich." Maar de huidige situatie bood anderzijds ook mogelijkheden. De diplomaat schetste immers een scenario dat volgens hem in een kenterende Nederlandse publieke opinie leefde. Indien België niet of slechts deels (tot aan de Maas) door Duitsland geannexeerd werd, zou Nederland het Duitse gevaar als voorbij beschouwen. Maar voor de Nederlanders zou dan terstond het nog veel meer dreigende Frans-Engelse gevaar op de voorgrond treden. De reden hiervoor was dat dit "half-Franse" België, vervuld zou zijn van haat tegen Nederland. Ingeval de Entente zou zegevieren, zou die tot de annexatie van NederlandsLimburg en Zeeuws-Vlaanderen overgaan. Om van de voortdurende culturele bedreiging van Nederland vanuit het westen nog maar te zwijgen. Het enige hulpmiddel hiertegen was "ein vlämisches, d.h. holländisches Belgien". Op dat moment zou de "vervlaamsing" van België voor Nederland acuut en het "Vlaamse vraagstuk" een Nederlandse staatszaak worden. Zolang Nederland de annexatie vreesde, vond men daar de avances van Berlijn afschuwelijk. Maar in deze hypothese zou de Vlaamse beweging (lees: het activisme) niet meer vereenzelvigd worden met een verbrokkeld België dat aan het zegevierende Duitsland zou overgeleverd worden, maar wel met een Schutzwall 
tegen het Anglo-Franse gevaar. Hoe meer Nederland, aldus Von Kühlmann, overtuigd raakte van deze gedachte, des te voordeliger voor Duitsland. Het stond bijna vast dat Nederland niet gekant zou zijn tegen een annexatie van België tot aan de Maas. Bovendien zou de Vlamisierung van België op openlijke of bedekte steun in Nederland kunnen rekenen. Ook was het zo goed als zeker dat van nu af aan de defensieve houding van Nederland zich meer en meer tegen het Verenigd Koninkrijk, Frankrijk en het voormalige België [in plaats van tegen Duitsland dus, $B Y]$ keerde. Kwam het ertoe dat Nederland en Vlaanderen zich uit eigenbelang de rol van anti-Frans en anti-Brits bolwerk aanmaten, dan was dit de eerste stap naar de finalisering van de Duitse annexatiedoeleinden. ${ }^{195}$

Wat Von Kühlmann hier schreef, sloot aan bij het besproken rapport van Wichert. Die meldde dat de gevoerde propaganda van De Vlaamsche Stem, het Nederlandse publiek kon doen wennen aan het idee van een verdeling van Belgie in een of andere vorm. De verontwaardiging over een Vlaanderen, verdrukt door België, kon een alternatief worden voor de verontwaardiging over het "arme België", dat door Duitsland werd onderdrukt. Via De Vlaamsche Stem kon men "op onverdachte wijze het Germaanse stambewustzijn opwekken" en de nationale trots van de Nederlanders stimuleren. Daarom moest volgend principe doorlopend beklemtoond worden: "Wie Vlaanderen onderdrukt, is de vijand van Nederland; wie Vlaanderen wederom herstelt, is Holland's vriend." ${ }^{196}$ [B.Y.] De Vlaamsche Stem zou dus, anders gezegd, de Duitse belangen bevorderen door in te spelen op Groot-Nederlandse gevoelens.

Dat Nederland in de Duitse invloedssfeer gedreven moest worden, stond al in augustus 1914 vast. De plannen van de "Groot-Nederlandse beweging" die door Duitsland in het leven werd geroepen, gaven een concrete invulling aan dit idee. Het memorandum van oktober 1915 was ook een actualisering van de negentiende-eeuwse "christelijk-historische" denkbeelden. Daarbij werd gesteund op de hertekening van de Europese landkaart die Groen van Prinsterer beoogde. Daarin kon "een Hollandse overheersing over België zoals ten tijde van de Barrière [...] door het hegemoniale Duitsland verzekerd worden" ${ }^{197}$ Er bestond met andere woorden een ideologische verwantschap tussen die negentiende-eeuwse "christelijk-historische" ideeën en wat Gerretson onder auspiciën van Von Kühlmann verkondigde. Een vernietigd (of permanent verzwakt) België - waarvan de "interne kracht gebroken" was, zoals Groen van Prinsterer dat verdedigde - werd de anti-Franse barrière voor Nederland. En daar zou dan het "Nederlandse volkswezen" versterkt worden door een voogdij van Nederland. Maar het Anglo-Pruisisch-Nederlands 
bondgenootschap dat Groen van Prinsterer voor ogen stond werd nu vervangen door een bondgenootschap tussen Nederland en de Centrale machten ter voorbereiding van een assimilatie. ${ }^{198} \mathrm{Het}$ lag dus voor de hand dat het niet zou gaan om een unie van of een pacificatie tussen gelijkberechtigde staten.

Interessant is in dat verband de vergelijking met hoe Von Kühlmann dacht over de onderhandelingen aangaande het verdrag van Brest-Litovsk (3 maart 1918). Dat werd gesloten tussen de Centrale Machten en SovjetRusland op een moment dat hij staatssecretaris voor Buitenlandse Zaken was. Luidens het verdrag werden staten als Finland, Estland, Polen en Oekraïne ook "onafhankelijk" verklaard. Later zou Von Kühlmann bekennen dat hij bij die vredesonderhandelingen slechts gebruikmaakte van het recht op nationale zelfbeschikking in een "zuiver academische discussie", waarbij het echte doel was "door het nationale zelfbeschikkingsrecht eender welke territoriale concessie die we absoluut nodig hadden voor onszelf te verkrijgen". ${ }^{199}$ [B.Y.] Het idee van een "zelfstandig" Vlaanderen bij een Duitse overwinning in het westen, vervulde natuurlijk geen andere functie.

\section{Besluit}

De Duitse diensten intensiveerden tijdens het jaar 1915 op aanzienlijke wijze hun propaganda. In het kielzog van La Vérité verschenen twee andere pamfletten die we hiermee in samenhang moeten lezen: La Politique Belge en het Appel aux Wallons. De eerste twee vlugschriften putten uit verschillende bronnen die elkaar overlapten. De laatste twee hadden gemeenschappelijk dat ze zich deels door geschriften van Du Bois lieten inspireren. Bovendien was er voor alle vlugschriften ook een thematische vervlechting, want elk pamflet deed zich voor als uitgaande van Franstaligen en was provocerend voor Vlaamsgezinden. De twee laatste vlugschriften stelden zich bovendien als gallofiel voor. In La Vérité liep de laatste zin al op dit thema vooruit: "vive la Belgique unie et indivisible" (wellicht een allusie op "la France une et indivisible"). De inhoud van thema's die Vlaamsgezinden bekend in de oren klonken uit vooroorlogse wallingantische propaganda, werd op bijna groteske wijze uitgekristalliseerd: het flamingantische Antwerpen moest vernietigd worden, het Nederlands en de Vlaamse beweging uitgeroeid en België moest willens nillens geheel of gedeeltelijk bij Frankrijk worden aangesloten.

Er verscheen nog een vlugschrift toen Borms in Antwerpen Boven het pamflet La Vérité sur la Capitulation d'Anvers wederom onder de aandacht gebracht had: een tweede Lettre Ouverte au peuple belge. Daarin ging Arthur 
Limet door op het eerder ingeslagen pad. Hij publiceerde uittreksels uit de brochure van Girard en beweerde dat de vrede een bedreiging was voor het voortbestaan van België dat geannexeerd kon worden. Staatsmannen, militairen en journalisten hadden het publiek voorgelogen. België diende een eigen neutraliteitspolitiek te ontwikkelen, los van elk verdrag. In juni 1915 volgde een derde brochure van de "filantroop" met als ondertitel: Appel à la Paix. In dit geschrift beweerde Limet dat de Duitse overwinning vaststond. De slachting van de soldaten moest stoppen en met Duitsland diende een vrede afgesloten worden. Een snelle wapenstilstand, gevolgd door een vredesconferentie waaraan alle grootmachten deelnamen, was daarom aan de orde. De Germaanse en Latijnse cultuur moesten zich verenigen tegen het slavisme. Indien de Belgische koning en zijn regering de gevechten toch wilden doorzetten, voorzag hij, eens te meer, het einde van de staat. ${ }^{200}$

Overloopt men de chronologie, dan valt het op hoe de eerste brief van de "filantroop" bijna simultaan met La Vérité gepubliceerd werd. Vervolgens verscheen zijn tweede brief (april 1915), daarna La Politique belge après la Crise en het Appel aux Wallons (mei 1915) en, ten slotte, de derde brief (juni 1915). De vlugschriften van de filantroop die mooi aansloten bij de door ons bestudeerde pamfletten, kaderden in een bredere poging van de Duitse bezetter om defaitisme ingang te doen vinden, wantrouwen in het Belgische politieke bestel te verspreiden en proberen te bewijzen dat België niet neutraal was en de regerende klasse het land in een oorlog meegesleurd had. ${ }^{201}$

Op het moment dat de propaganda rond Buisset en de vlugschriften verspreid werden, kampte Duitsland met een ander vraagstuk: de opheffing van de tegenstelling tussen hoe Nederland te overtuigen dat het Rijk geen annexionistische bedoelingen had én het kleine buurland voor te bereiden op een Angliederung in het Rijk. Dat werd opgelost door de Flamenpolitik voor te stellen als middel om een zogezegd pro-Nederlandse barrière te scheppen om te verdonkeremanen dat ze een anti-Nederlands omsingelingsmanoeuvre was. Een Duits Vlaanderen zou Nederland inderdaad in een Germaans Mitteleuropa drijven. Dat werd dan voor Nederlands gebruik als volgt ingekleed. Een verminkt België, inzonderheid Vlaanderen, moest onder de voogdij van Nederland komen. Dat land zou, om Von Kühlmann te citeren, "als Lehrer und Freund mit diesen selbständig eingerichten flämischen Landesteilen ein besonderes enges Verhältnis unterhalten”. Deze gedachte was ook gebaseerd op "christelijk-historische" Nederlandse denkbeelden. ${ }^{202}$ Maar tegelijk stemde dit alles overeen met wat het Alldeutscher Verband vóór 1914 voor ogen stond en waarmee Berlijn ook vertrouwd was. Daarbij werd de Groot-Nederlandse beweging ten dienste van de Duitse belangen gescha- 
pen om de anti-Belgische en anti-Entente ressentimenten in Nederland te stimuleren. Anderzijds zou diezelfde beweging tegenover de Vlaamse beweging de Flamenpolitik met een Nederlandse pil moeten vergulden en salonfähig maken. Niet de Duitsers zeiden het, wél de "vrienden uit Nederland". De Nederlandse historiografie heeft het trouwens nog steeds moeilijk met de rol van Groot-Nederlanders in Duitse dienst. ${ }^{203}$

Via Groot-Nederlanders werden ook activisten beïnvloed door de barrière-ideologie. Zo beweerde de Jong-Vlaming Leo Picard medio juni 1915 dat de Hollanders België instinctmatig nog steeds beschouwden als een barrière die hen beschermen zou. Hij gaf hen daarin vanuit Hollands standpunt ook gelijk en beweerde dat de vooruitgang van de Vlaamse beweging de Nederlandse cultuur versterkte. Werden echter de Vlamingen aan "de werkingssfeer van de Nederlandse beschaving" onttrokken, dan betekende dit voor Nederland een beduidende verzwakking. ${ }^{204}$ Belangrijk is ook om erop te wijzen dat de "theoretische bombast" van de voorwaardelijke loyauteit, om Gerretson te citeren, op zich onvoldoende was om het activisme bij de flaminganten in Nederland uit te lokken. Er was ook een praktische onderbouw nodig. De besproken pamfletten leverden in dat opzicht het "bewijs" (of voorwendsel) dat een loyauteit aan België enkel voorwaardelijk kon zijn. De vlugschriften vertoonden dus ook een eenheid op het vlak van de finaliteit. De stemmingmakerij errond hielp om de sfeer te scheppen waarin medio 1915 het activisme in Nederland kon ontstaan.

Daarvoor bleek De Vlaamsche Stem, eens ze in Duitse handen was, een geschikt instrument. Op 19 juni 1915, enkele dagen na de publicatie van $L a$ Politique Belge in Antwerpen Boven, publiceerde Deswarte in De Vlaamsche Stem het artikel Naamlooze Misdadigers. Hij beweerde daarin dat La Vérité en La Politique Belge weleens de vrucht konden zijn van een ellendige en naamloze Duitse veldtocht maar besloot dat ze toch het werk geweest waren van annexionistische Fransgezinde "monomanen", die in de geest schreven van wat Maeterlinck, De Marès en Harry verkondigden. Op 28 en op 29 juni gingen ook Het Vlaamsche Nieuws en de Gazet van Brussel plots aandacht aan de drie vlugschriften besteden. Het Vlaamsche Nieuws hernam partieel het artikel van Deswarte die een "broederorgaan" heette te leiden. Een redelijk mens die dat stuk gelezen had, zo schreef de Gazet van Brussel op 28 juni 1915 over het Appel aux Wallons, moest zich de vraag stellen of het niet apocrief was.

Zulk een veronderstelling zouden wij zelfs terstond laten gelden, ware het niet dat de gedachten die in het opstel uitgedrukt zijn zo wonder- 
wel overeenkomen met de uitingen in het buitenland van mannen als Destrée, De Marès, Harry, Maeterlinck, enz. [...].

De argumentatie uit Naamlooze Misdadigers van Deswarte werd op 28 juni 1915 door de Gazet van Brussel hernomen. Het dagblad meldde dat ook De Vlaamsche Stem schreef dat zij "geenszins twijfel[de] aan de echtheid van de oproep". En als het blad uit Amsterdam het schreef, moest het wel waar zijn, daar men dat orgaan toch moeilijk kon "verdenken van vijandschap jegens de wallonisanten, wanneer men weet dat het verschillende keren gedrukt heeft Vive la France!". Het artikel van Deswarte werd de dag nadien, van gunstige commentaar voorzien, in Het Vlaamsche Nieuws hernomen. Anders gezegd, toen Deswarte met Spreken is Plicht (28 juni 1915) het eerste van de drie artikels publiceerde waarmee hij de Godsvrede verbrak, begon de activistische pers in België aandacht te besteden aan drie stukken die "de bijzondere aandacht der Vlamingen genieten", zoals de Gazet van Brussel dat verwoordde. ${ }^{205}$ Dat wijst op een coördinatie tussen het gouvernement-generaal en de Duitse ambassade in Den Haag.

De verspreiding van de vlugschriften diende uiteraard ook om de binnenlandse collaboratie te stimuleren. Want zoals vermeld, hadden de Duitse diensten op 18 juni 1915 in de hoofdstad de collaborerende vereniging gesticht die zich Vrienden van de Vlaamsche Zaak zou gaan noemen. Op dat moment waren de vlugschriften La Politique Belge en het Appel aux Wallons bekend. Op 8 juli had Jacob Lambrichts, de spilfiguur van die groep, een toespraak gehouden voor de Katholieke Vlaamse Bond. Hij klaagde er de (drie) "franskiljonse" en "anti-Vlaamse" vlugschriften aan die sedert maanden in het geheim de ronde heetten te doen. De werking noemde hij systematisch en als bewijs daarvoor stelde Lambrichts "het feit dat ze in alle hoeken van het land, op hetzelfde ogenblik verspreid waren". Die toespraak dateerde van ongeveer een week na de publicatie van de pamfletten in de Gazet van Brussel. Omdat Lambrichts toen al collaboreerde, is het naïef te denken dat die spreekbeurt doorging zonder medeweten van de Politische Abteilung. Bovendien kreeg wat hij zei nog eens ingang in Nederland, omdat De Vlaamsche Stem, die inmiddels in Duitse handen was, er medio juli voorpaginanieuws van maakte. ${ }^{206}$ In de vlugschriften, de propaganda rond Buisset en het uit de context gerukte citaat van Colleye ging naast een offensieve reflex, ook een defensieve beweging schuil. Immers, parallel met de activistische groepsvorming medio 1915, kwam er ook een Vlaamsgezind verzet op gang. Getuige daarvan het protest van Franck tegen de voorkeursbehandeling van Vlaamse gevangenen, het manifest-Van Cauwelaert en het gelijkaardig Brussels mani- 
fest. Dat flamingantische verzet beoogde ook de eenheid in de eigen rangen te herstellen. Want er waren Vlaamsgezinden die de Duitse propaganda geloofden of wilden geloven. Bij Henderickx is het bijvoorbeeld heel duidelijk hoe hij zich door al die propaganda liet meeslepen. In februari 1915 vond hij nog, net als Ryckmans, dat La Vérité het werk van grappenmakers was. ${ }^{207}$ Maar in maart hield hij een redevoering voor het Davidsfonds, waarin hij beweerde dat het "naamloze schotschrift" een onderdeel was van een listige veldtocht vanwege kortzichtige landgenoten tegen de Antwerpenaars in het algemeen en tegen Franck en Ryckmans in het bijzonder. ${ }^{208}$ De katholiek begon naar het activisme over te hellen toen Borms hem op 12 juni 1915 een artikel uit de Düsseldorfer Lokal-Anzeiger toonde. Dat blad behandelde het Appel aux Wallons en Un Parti National. Die dag noteerde hij verbitterd in zijn dagboek: "onze franskiljonse vrienden ontwapenen niet. Dat heet men Godsvrede [...]."209

Toch was niet elke Vlaamsgezinde onder de indruk van die Duitse pamfletten. Julius Hoste schreef over La Vérité in het Journal des Débats: "c'est le ton des polémistes allemands." Volksvertegenwoordiger Van de Perre meldde in november 1915 op grond van persoonlijke inlichtingen: "Alles toonde aan, dat [La Vérité $]$ uitging van Duitse regeringsagenten, die daardoor de Vlamingen trachtten op te hitsen om tweedracht te stichten." ${ }^{210}$ Henderickx zal er toen wel het zijne van gedacht hebben. Op 4 oktober 1915 immers schreef L'Indépendance Belge dat er in De Vlaamsche Post een brief van hem verschenen was met daarin drie klachten. Allereerst dat het Frans sedert het begin van de bezetting nog steeds de voorrang hield op het Vlaams, als toepassing van het zogezegde grondwettelijke beginsel dat het Frans de officiële taal van België was (cf. de brief van Buisset aan Von Bissing). Ten tweede, dat de Walen ongelijk hadden de Vlamingen te verwijten vijandig te staan tegen de verspreiding van het Frans in de Vlaamse massa. Daar was geen enkele noodzaak toe en het lokmiddel van administratieve carrières kon niet als voldoende reden ingeroepen worden (cf. La Politique Belge). Ten derde dat de Vlamingen wel te goeder trouw het Frans probeerden te leren. Maar hun kinderen moesten al het meer verwante en gemakkelijkere Engels en Duits leren. Dit gegeven deed hen twijfelen alvorens de extra belasting van een andere taal op te leggen. Die laatste passage berustte op de brief aan Het Vlaamsche Nieuws (30 augustus 1915) van Buisset. Hij beweerde daarin dat de Vlamingen het de Walen niet kwalijk mochten nemen indien ze weerbarstig stonden tegenover de studie van het Nederlands "à laquelle ne les contraint aucune nécessité impérieuse". ${ }^{211}$ Henderickx nam pas op 28 oktober 1915 kennis van het bestaan van deze "brief". Zowel De Vlaamsche Post als Henderickx zelf 
hebben L'Indépendance Belge gelaakt voor deze bewering. ${ }^{212}$ Er waren hem woorden in de mond gelegd die een flamingantische versie waren van teksten van Buisset en pamfletten van de bezetter. Le Vingtième Siècle en L'Indépendance Belge trapten in de val. "Cela ne nous étonne pas de la part du député d'Anvers, dont nous avons eu à déplorer plus d'une fois depuis le début de la guerre, les incartades germanophiles", zo meldde het eerste blad dat voortbouwde op zijn vete met Henderickx. Het gevolg liet zich raden: Henderickx, die al overprikkeld was, brak met de Belgischgezinde Vlaamsgezinden en geloofde nu rotsvast in een anti-Vlaams complot. ${ }^{213}$ De Nederlandse intriges zorgden er ook voor dat het activisme zijn eerste martelaren kreeg, wat natuurlijk nuttig is voor propagandadoeleinden. Uiteindelijk betaalden De Clercq en Jacob immers de prijs voor hun collaboratie. Ze werden in oktober respectievelijk als leraar en als kandidaat-leraar door de regering geschrapt. ${ }^{214}$ In dat kader brengen we de brief van Meert uit juli 1915 tegen het manifestVan Cauwelaert in herinnering. Daarin had hij onder meer de vermeende anti-Vlaamse campagne van de "franskiljons" gegispt. Medio november zou de activistische pers via de Nederlandse Nieuwe Courant zijn stuk instemmend overnemen. ${ }^{215}$

Het stuk werd deels hernomen in een uitgebreid voorpagina-artikel van August Borms: Van Cauwelaert, wat hebt ge met uwe broeders gedaan?. Daarin bestempelde Borms de katholieke voorman, die zweeg tegenover de "franskiljonse" aanvallen, als een gewezen leider van de Vlaamse beweging (het activisme viel voor de collaborateurs blijkbaar samen met dé Vlaamse beweging). Meert daarentegen had "zwijgen" in zijn brief een "lafheid" genoemd. "En omdat nu De Clercq en Jacob die lafheid [van het zwijgen] niet willen begaan", aldus Borms, "heeft Van Cauwelaert zich van hen losgescheurd en is hij zijn eigen broeders beginnen bekampen". ${ }^{216}$ Meert zal met de zaak wel verveeld gezeten hebben, want hij stuurde prompt een rechtzetting op. ${ }^{217}$ Helaas voor hem had die slechts een averechts effect. In de activistische pers werd ook dat schrijven voor propagandadoeleinden gebruikt. ${ }^{218} \mathrm{De}$ journalist Monet die de brief "een merkwaardig staaltje van de begripsverwarring, die de alles-ontbindende Duitse atmosfeer zelfs bij de bestmenende en eerlijkste flaminganten in België [i.c. Meert] gesticht heeft" noemde, zat er met zijn analyse niet ver naast. ${ }^{219}$ Als Meert, die door Van Cauwelaert na diens bezoek aan hem omschreven werd als iemand die "beter dan wie ook op de hoogte [was] van wat er in de Vlaamse wereld [...] omgaat", zich al liet vangen door de Duitse propaganda, laat het zich raden hoe andere Vlaamsgezinden konden reageren. ${ }^{220}$ Van Cauwelaert raadde Meert aan om zich kalm te houden. Tevergeefs. Hij meende overal "franskiljonse" complotten 
te ontwaren. Fredericq noteerde in zijn dagboek dat Meert zich "stapelgek" gedroeg en kind aan huis was bij de Kommandantur: "Zijn betrekkingen met de Duitse overheid zullen hem wellicht later duur te staan komen." ${ }^{221}$ Dat klopte. Meert werd later nog lid van de Raad van Vlaanderen, kreeg na de oorlog een gevangenisstraf van twintig jaar opgelegd en zou de rest van zijn dagen in ballingschap slijten. ${ }^{222}$ 


\section{HOOFDSTUK 7 RADICALISERING}

De Duitse propaganda-inspanning was tot medio 1915 maar ook nadien gebaseerd op de stelling dat de Walen en "franskiljons" van de oorlog gebruikmaakten om een campagne te voeren tegen de Vlaamse beweging en de Nederlandse taal. Anonieme drukschiften, (vermeende) uitspraken van een aantal Franstaligen, de berichtgeving in de Duitse en de door Berlijn gesubsidieerde "Belgische" pers moesten dat allemaal bewijzen. Anderzijds nam de bezetter maatregelen ten voordele van het Nederlands. Het lukte hem om zo gaandeweg een klein aantal activistische kernen te stichten. Pas door de doorbraak in Nederland was er echt sprake van een activistische beweging. Toch moet de omvang daarvan ook weer niet overschat worden. Zo had de Jong-Vlaamse vleugel van het activisme na één jaar werking slechts 68 leden. En dat ondanks alle inspanning die door Duitsland ondernomen werd en financiële mogelijkheden waarop ze kon bogen. ${ }^{1}$

Parallel ontstond er vanaf 1915 achter het front deining omtrent de taaltoestanden. Daaruit groeide een georganiseerde "frontbeweging" die politieke eisen stelde. Toen die doorbrak en de Flamenpolitik een deel van de flaminganten voor zich had gewonnen, ontstond het verhaal als zouden Vlaamse soldaten de dood ingejaagd worden omdat ze Franstalige bevelen van hun (Nederlandsonkundige) officieren niet begrepen. Dit is een legende, waarvan de oorsprong tot op heden een raadsel is. Ze vormt de fysieke pendant van de fabel over de uitroeiing van het Nederlands tijdens of na de oorlog door de Franstaligen en ligt in het verlengde van de dreiging die we in de eerdere Duitse propaganda terugvinden en waarbij aangekondigd werd hoe de bevrijding Antwerpen, ja zelfs grote delen van Vlaanderen kon ver- 
woesten. Van Everbroeck stelde in 1995 dat we niet precies weten wanneer de legende over de frontsoldaten ontstond. Volgens haar was de oorsprong niet te vinden in getuigenissen uit die tijd, noch in soldatenbrieven die het Groot-Nederlandse blad De Toorts afdrukte. Ze stond ook niet in dagboeken noch in open brieven die de frontbeweging afdrukte. Pas in Aan den Vlaamsche IJzer (1924) trof ze een verhaal ("enig in zijn soort") aan over de dood van een Vlaamse soldaat doordat een Franstalig officier zijn bevel niet correct kon vertalen. ${ }^{2}$ De Schaepdrijver poneerde in 1997 de hypothese, dat de legende niet aan het front, maar wel in de activistische propaganda ontstond. ${ }^{3}$ Müller wijst erop dat een frequent verwijt luidde dat de Franse bevelstaal het leven van Vlaamse soldaten in gevaar bracht. Hoe gegrond, aldus de auteur, die dramatische aanklacht was, is moeilijk te zeggen. ${ }^{4}$ Alle auteurs zijn het eens over het grote belang ervan. Voor Bruno De Wever kadert het verhaal in de mythe over de frontbeweging, die meteen ook een "funderingsmythe" voor het Vlaams-nationalisme is. Ze moet "het ontstaan en de ontwikkeling van het Vlaams-nationalisme verklaren". "Wils wijst op het flamingantisch geschiedverhaal, waarin de taalverdrukking culmineerde in de IJzertragedie. ${ }^{6}$

\section{Demoralisatie en frontbeweging ${ }^{7}$}

In de Duitse propaganda werd het lot van de Belgische en Vlaamse soldaten druk besproken, vóór er nog maar sprake was van een frontbeweging. Vanaf december 1914 drukte de Gazet van Brussel demoraliserende "Belgische (soldaten)brieven" af. Vanaf januari 1915 verschenen ze ook in andere bladen: Het Vlaamsche Nieuws en later in Antwerpen Boven en in De Toorts. ${ }^{8}$ Wat stond er zoal in en hoe werden ze becommentarieerd?

Arme jongens, die ginder, ver van huis, moeten vechten voor een land dat het hunne niet is, midden in de grootste ontberingen... Hebben de Belgen dan $[\ldots]$ niets te verwachten van hun machtige bondgenoten $[$ sic $][\ldots]$ Wat bittere ontgoocheling voor zo'n Vlaamse student, die als vrijwilliger voor vaderland en vorst ten strijde trekt tegen broeders van hetzelfde ras...

zo meldde de Gazet van Brussel op 11 december 1914. ${ }^{9}$ Contrasterend met dit soort "brieven" werden Duitse zegebulletins gepubliceerd. ${ }^{10}$ Ook vonden "Belgische (soldaten)brieven" hun weg naar de Duitse pers. Zo publiceerde het Berliner Tageblatt in november 1914 een "brief" waaruit moest 
blijken dat de Vlamingen erkenden dat de Entente verantwoordelijk was voor de vernietiging van België. ${ }^{11}$ Hetzelfde blad meldde een maand later hoe een luitenant de Vlaamse bevolking omschreef als Duitsers die de haat tegenover het Verenigd Koninkrijk deelden. ${ }^{12}$ Voorts drukte de Gazet van Brussel op 21 januari 1915 een Duitse "soldatenbrief" af waarin stond hoe kooplust de schrijver ervan en zijn vrienden duur te staan was gekomen. Ze hadden zoveel rolmops, chocolade, sardines, tabak en worsten verorberd dat ze er meermaals een indigestie aan overhielden. Daarnaast publiceerde het blad een "brief" van een Belgische soldaat die zich met het oog van een verminkte vriend op zijn netvliezen gebrand, beklaagde over het weinige eten dat voorhanden was: rauwe groenten en rapen. ${ }^{13}$ Deze techniek van "contrasterende stukken" vindt men overigens ook terug in de Gazette des Ardennes. Zo publiceerde dat blad op 15 november 1914 een brief waarin 63 Duitse soldaten een uitgebreid woord van dank richtten aan het hoofd van het militair hospitaal in Karlsruhe. Daaronder stond dan het artikel Les camps de concentration anglais, zogezegd geschreven door een Duitser die zich in zo'n kamp op het Britse vasteland bevond. Zeventien Duitse burgers waren er, zo heette het, op een week omgekomen als gevolg van Britse mishandeling. ${ }^{14}$ Nog in november 1914 publiceerde het blad de volgende "getuigenis" van een Nederlandse dame die met Belgische krijgsgevangenen gesproken had:

Les pauvres Belges ont devant eux l'ennemi et derrière eux les Anglais. Si les Belges veulent reculer parce qu'ils ne peuvent plus avancer, ils sont simplement massacrés par les Anglais. On les pousse en masse contre les fossés des Allemands où on les reçoit à la baïonnette. Ils sont obligés de faire l'assaut, qu'ils le veuillent ou non. Dans quinze jours, disait un jeune homme, il n'existera plus de soldats belges. Nous obtenons un pain entre plusieurs, alors que les Anglais se régalent de leurs provisions en chocolat, cakes, conserves, etc. ${ }^{15}$

Deze propaganda spoort met de gekende anti-Britse motieven en met het vernoemde fantasieverhaal uit de Gazet van Brussel. Uit een andere "brief" die een Belgische soldaat zogezegd zelf naar dat laatste blad stuurde, kon de lezer vernemen hoe obussen in de loopgraven "letterlijk stukken van mensen" in de lucht deden vliegen en tien soldaten levend begroeven. Daaronder stond een suggestieve Duitse "soldatenbrief" over het begraven van een gesneuvelde Fransman. In diens zak werd een brief aangetroffen, met de dameshand geschreven: "Mijn enige troost is, dat ons leger steeds zegeviert en dat ge de Duitsers telkens overwint..." ${ }^{16}$ Op 27 januari 1915 bespeelde 
het persorgaan het gemoed door een "briefschrijver" aan het woord te laten, waarnaast een arme weduwe met vijf kinderen woonde. Haar zoon meldde zijn beminde moeder dat hij in Calais lag met articulaire reuma en een zware bronchitis, opgelopen in de loopgraven. "...en ik lig hier in een varkenskot. De Fransmannen verstaan me niet en ze hebben geen hart." "Is dat nu niet om te schreien," zo vertrouwde de arme "moeder" de "lezer" toe. "Ik heb al zoveel hartzeer dat mijn jongen leeft als dat hij dood ware..." "Arm, arm Vlaams volk..." ${ }^{17}$ In een andere "brief" werd verhaald hoe een Vlaamse jongen van amper zeventien in hospitalen werkte, tussen lijken en te midden "van gekwetsten en tyfuslijders".

Het Vlaamsche Nieuws meldde het bezoek aan een "wegkwijnend jongmens" die "een kogel in de ruggengraat kreeg en hierdoor al zijn ruggenmerg" verloor. Zo ook aan een "man, die totaal verblind werd door het ontploffen van een shrapnell”. Net náást deze demoraliserende propaganda drukte het blad Vlamingen waakt! van August Borms af. ${ }^{18}$ In de Süddeutsche Monatshefte van april 1915 stonden tot een verhaal bewerkte uittreksels uit het "dagboek" van een Belgische soldaat van oktober tot november 1914. ${ }^{19} \mathrm{Het}$ personage kreeg de naam "Rolandke" mee, naar het blad beweerde, omdat hij zichzelf voortdurend zo noemde in de brieven naar zijn geliefde. Het verhaal begon bij de val van Antwerpen en volgde het hoofdpersonage in zijn terugtocht naar de kust, een overeenkomst met wat Harry in La Grande Revue van mei 1915 publiceerde. Meerdere passages bewijzen dat het om een apocrief document gaat, zo bijvoorbeeld die van 10 oktober: "Sie [de Belgische soldaten, $B Y]$ erhalten den strikten Befehl, ihre Eigene Verwundeten zu töten, damit Sie nicht lebend in die Hand der grausamen Feinde fallen." Toen het laatste deel van het regiment gevangen genomen werd, schreef het hoofdpersonage hoe vele officieren de dood verkozen boven een Duitse gevangenschap omdat de Belgische pers die zo vreselijk afgeschilderd had. Maar niets was minder waar. Belgische dagbladen hadden de Belgen voortdurend voorgelogen over de Duitse barbarij. Het eten in het kamp was uitstekend, zelfs in Antwerpen kon men nergens beter dineren. Eerder, op 26 december 1914, had de Gazette des Ardennes een variatie op dit thema gepubliceerd. Het blad beweerde dat een medewerker een uittreksel uit het dagboek van een soldaat had overhandigd op vraag van de betrokkene zelf. Daarin leest men hoe een Franse soldaat, eveneens in lijn met het verslag dat Harry gepubliceerd had, doodsangsten uitstond toen de laatste Franse soldaten voor de Duitsers op de vlucht sloegen. Daarna volgde een lofzang op de Duitsers en hun behandeling. En in lijn met het dagboek van "Rolandke", klonk het: "Comme nourriture, nous avons le café le matin, le bouillon à une heure et le 
café le soir. Le pain n'était pas mauvais. Ces Allemands, que l'on nous dépeignait comme des brutes et des bêtes féroces, nous donnent l'exemple du plus sublime dévouement." ${ }^{20}$ Er werden dus nogal wat dwaze leugens verspreid. Veel aanhang leverde dat allemaal niet op. Maar later bleef het wel herhaald worden en na de oorlog klopten de nationalisten aspecten eruit zelfs nog op. Ze konden daarbij ook deels op de realiteit voortbouwen. Want er bestonden in het Belgisch leger tijdens de Eerste Wereldoorlog onwettelijke taaltoestanden die naarmate het conflict aansleepte, steeds meer wrevel opwekten. De taalwet van 1913 voorzag in een tweetalige opleiding, maar werd niet toegepast. Bevelen werden louter in het Frans gegeven. In de lente van 1915 kwamen er voor het eerst klachten uit het leger over die gang van zaken.

Uit die tijd dateert een uitdrukking die men in nationalistische kringen voor waar aannam en soms nog aanneemt, namelijk dat de Vlaamse soldaten van hun officieren te horen kregen: "et pour les Flamands, la même chose." Een aanwijzing over de oorsprong daarvan vindt men in het artikel De Vlaming aan het Front uit De Vlaamsche Stem van 23 juni 1915. Daarin richtte een soldaat die na acht maanden strijd van het front teruggekeerd was zich tot de uitgever van het blad. Hij klaagde de taaltoestanden in het Belgisch leger aan. Tot zijn grieven behoorde het gegeven dat van (onder)officieren de kennis van het Nederlands niet gevergd werd. Ontwikkelde Vlamingen konden geen korporaal worden indien ze Fransonkundig waren; de theorie werd enkel in het Frans gegeven enzovoort.

De rekruten worden uitsluitelijk in 't Frans verwelkomd. De orders uitsluitend in 't Frans opgesteld. De Vlamingen weten zo goed dat alles in 't Frans gebeurt, dat de volgende zin spreekwoordelijk is geworden na iedere mededeling: 'Hetzelfde voor de Vlamingen.'21

Kortom, de uitdrukking "et pour les Flamands, la même chose" vindt niet zijn oorsprong bij Belgische officieren die weigerden in een vertaling van hun bevelen te voorzien en er dit spottende zinnetje aan toevoegden. In werkelijkheid betrof het een vertaalde uitdrukking van sommige Nederlandstalige soldaten die zich ergerden aan het eentalig Franse karakter van het Belgisch leger.

Sommige soldaten radicaliseerden vanaf de zomer, wat tot een (niet-fysieke) repressie van hogerhand leidde. Anderzijds werden er maatregelen genomen om de gelijkheid tussen beide landstalen te bevorderen. Maar het flamingantisme was natuurlijk verdacht gemaakt door de activistische collaboratie in bezet België. Pas medio januari 1916 werd een omzendbrief rondgestuurd waarin men van hogerhand de officieren "aanspoorde" om 
Nederlands te leren. Aan en achter het front ontwikkelden zich inmiddels katholieke Vlaamse studiekringen. Zij zouden overstappen van het formuleren van taalkundig-culturele naar politieke eisen. De eerste radicalisering van de "fronters" greep plaats na de vernederlandsing van de universiteit van Gent. De Belgische regering-in-ballingschap veroordeelde de heropening van de universiteit in oktober 1916, maar weigerde om een Vlaamse universiteit na de oorlog te beloven. Het gevolg van dit scharnierpunt in de Flamenpolitik was erg belangrijk: de relatief kleine groep Vlaamsgezinden die meewerkte aan de vernederlandsing van de universiteit door de bezetter trad buiten de Belgische wettelijkheid. Er ontstond ook een wijdere kloof binnen de Vlaamse beweging, waarvan het overgrote deel geen Nederlandstalige universiteit uit Duitse handen wou ontvangen. Anderzijds kon de bezetter, zo redeneerden sommigen ook achter het front, met een pennentrek verwezenlijken wat het vaderland 85 jaar had nagelaten. De Flamenpolitik had een groot aandeel in het scheppen van de frontbeweging. Die zocht toenadering tot de activisten, die ze geleidelijk aan ging vergoelijken of soms zelfs idealiseren. Anderzijds radicaliseerden tijdens de oorlog ook de Belgische-loyale Vlaamsgezinden. Onder leiding van Frans Van Cauwelaert pleitten die voor de eentaligheid van Vlaanderen, met een Gentse universiteit die na de oorlog vernederlandst moest worden en eentalige regimenten in het leger. Deze loyalisten oefenden druk uit op de regering om in oorlogstijd de taalwetten in het leger te laten toepassen.

\section{De propaganda intensiveert}

In Jong-Vlaamse kringen en meer bepaald bij de filoloog en apothekerszoon Edgar Rietjens vinden we een volgende belangrijke schakel in de genese van het verhaal over de frontsoldaten die sneuvelden wegens de bevelstaal der officieren. Na het uitbreken van de oorlog was Rietjens uitgeweken naar Nederland, waar hij in pro-Duitse en Groot-Nederlandse kringen vertoefde. Op 29 april 1915 woonde hij voor het eerst een vergadering van Jong-Vlaanderen bij. ${ }^{22}$ In mei liet Rietjens in De Vlaamsche Post zijn licht schijnen op het lot van de Belgische soldaten. Na een aanklacht tegen de vernederingen die de Vlamingen sedert 1830 moesten ondergaan, heette het dat zij hun plicht vervuld hadden op het slagveld: "Zij hebben niet geklaagd wanneer zij ter dood werden geleid door officieren die hen niet verstonden en de orders ontvingen!"23 In het 11 juli-nummer van De Vlaamsche Stem kaartte Frans Van Cauwelaert hetzelfde thema aan. Hij had het over de verwaarlozing van de Vlamingen 
door hun politici, over hun vernederingen en over "het bloedige, neen, het hemeltergende onrecht dat onze Vlaamse jongens wordt aangedaan, wanneer zij in de dood worden gevoerd door officieren welke hun taal niet verstaan". Dit artikel werd onmiddellijk gunstig onthaald in de activistische pers. ${ }^{24}$

Van Cauwelaert kon in Nederland ook De Vlaamsche Post lezen en de passus was blijkbaar bedoeld als een antwoord op Rietjens' uithaal. De twee waren overigens geen onbekenden. Enkele maanden eerder waren ze al te Utrecht met elkaar in debat gegaan. ${ }^{25}$ Vermoedelijk sprak de katholieke voorman zo'n harde taal om zich niet volledig te desolidariseren van een zich radicaliserende vleugel binnen de Vlaamse beweging. Zowel Rietjens als Van Cauwelaert protesteerden alleszins tegen het feit dat de Vlamingen gecommandeerd werden in het Frans. Geen van beiden had evenwel een causaal verband gelegd tussen het sterven van soldaten enerzijds en onverstaanbare bevelen van Nederlands-onkundige officieren anderzijds. Anders gezegd, ze hadden niet gesteld dat er Nederlandstalige doden vielen omdat de officieren Frans spraken. De stelling dat de activisten en zelfs de Vlamingen niet alleen met broodroof, maar ook met de dood bedreigd werden, dook ondertussen wel regelmatig op in de activistische propaganda, niet het minst in De Vlaamsche Post. De "vunzige bladen te Havre, Londen en in Holland" werden daarvan beschuldigd. Maar uiteraard werd ook de Belgische regering aangevallen, daar ze, zo beweerden de activisten, Vlaanderen geestelijk of zelfs fysiek wilde vermoorden. Kwam de Belgische regering terug, zo heette het, zou ze slechts een marionet zijn van Frankrijk. "Zij [zal] met geweld ons ras uitroeien.", zo meldde De Vlaamsche Post begin oktober 1915. Dat werd dan gekaderd binnen een continuiteit waarbinnen in 1830 Europa "het Belgische juk op de schouders van Vlaanderen” gelegd had. In dat land had het parlementarisme tot gevolg dat "Vlaanderen zijn slavernij aanvaardde in de illusie vrij te zijn”. Die afwijzing van België ging hand in hand met een verwerping van de democratie: "ons [...] van 't opslorpend Frans gevaar [...] zo weinig vermoedende volk, verre van zichzelf te redden, zullen we wellicht moeten redden tegen zijn wil en dank." Het doel van de "Belgische volksuitmoorders" heette in het blad de Vlaamse "gewettigde rassenhaat" tegenover Frankrijk af te wenden te zijn en een haat tegenover Duitsland op te wekken "teneinde de kunstmatige versmelting te bevorderen van de twee rassen in een Belgische ziel, die vervolgens in een Franse ziel zou opgaan". ${ }^{26}$ Wederom werden Vlaamsgezinde, anti-Franse gevoelens bespeeld.

Ook Rietjens liet zich niet onbetuigd in de anti-Belgische propaganda-inspanning. In een voorpagina-artikel van de Gazet van Brussel (20 juli 1916), getiteld De Haversche Politiek, werden zijn "verpletterende onthullin- 
gen" gepubliceerd. ${ }^{27}$ Naar het blad verhaalde, was hij de week tevoren vanuit Nederland naar België gekomen. In het Vlaams Huis te Brussel besprak hij aangelegenheden die, volgens hem, niet of nauwelijks bekend waren maar wel een vérstrekkende invloed zouden uitoefenen op de Vlaamse beweging. Die was er, zo vertelde hij, in Nederland de laatste maanden enorm op vooruitgegaan. Over de kentering van de Nederlandse stemming in pro-activistische zin was het Duitse gezantschap alleszins opgetogen. Eind 1915 had Von Kühlmann vanuit Nederland al voorzichtig aan Berlijn gemeld dat een toename van de Nederlandse sympathie voor Duitsland en een afname van die voor het Verenigd Koninkrijk niet te miskennen was. Amper een half jaar later rapporteerde zijn medewerker Wichert dat het bijna volledig op zijn conto geschreven kon worden dat men tegenwoordig in Nederland nog weinig over het ongeluk van België hoorde, maar wél over Vlaanderens nood. ${ }^{28}$ De Duitse overname van De Vlaamsche Stem en de investering van die zijde in nieuwe en Groot-Nederlandse propagandaorganen zoals De Toorts, Dietsche Stemmen en De Toekomst speelden daar ongetwijfeld een rol in.

Rietjens sprak in Brussel over de uiterst "verbitterde" stemming onder de Vlaamse soldaten. Als "bewijs" daarvan verwees hij naar de talrijke brieven van Vlaamsgezinden en van jongens die volgens hem nooit eerder van de Vlaamse beweging gehoord hadden. Officier August van Cauwelaert had zogezegd een brief naar zijn broer Frans gestuurd "over de wraakroepende manier waarop men [in het Belgisch leger, $B Y$ ] het beste van ons bloed verspilt". In dat schrijven zou staan dat er in het regiment van August, net als in het hele Belgisch leger, 80 procent Vlamingen waren. Op 100 doden, vermisten en gekwetsten bedroeg in zijn regiment het aantal Vlamingen 90. Ondertussen zaten de meeste Walen achter bureaus of in diensten achter het front, omdat daar de kennis van het Frans geëist werd. Dit schrijven was een propagandistisch verzinsel. ${ }^{29}$ De toehoorders konden dat ook wel weten omdat er onder andere in de Gazet van Brussel niets anders dan Duitse propaganda geschreven werd, waaronder die gefingeerde soldatenbrieven. Maar sommigen geloofden het misschien toch. Daarna volgden er nog wat spectaculaire "onthullingen" uit andere soldatenbrieven. Die werden op hun beurt in extenso in De Toorts afgedrukt en in Vlaanderen verspreid. ${ }^{30}$ Verteld werd, dat de Vlamingen tegen hun eigen volk streden of dat indien men binnen de acht dagen geen Frans leerde de degradatie een feit was. Als klap op de vuurpijl troffen Vlaamse soldaten die van de loopgraven terugkwamen met krijt op een muur het opschrift "tous les Flamins sont des boches!" aan, een lieflijkheid zogezegd afkomstig van een sergeant. De flamingantische soldaten werden zelfs stelselmatig uitgeroeid. Om het met Rietjens te zeggen: 
"Zodra men een flamingant onder de soldaten ontdekt, neemt men geen rust alvorens hij naar een plaats wordt verzet waar hij veel kans loopt er niet meer levend terug van te komen."

Blijkbaar werden, aldus Rietjens, de Vlamingen geregeerd door twee "dictators": eerste minister De Broqueville (in Le Havre) en ambassadeur Hymans (te Londen), met hun "lakeien": de katholiek Carton de Wiart, de socialist Vandervelde en de liberaal Goblet d'Alviella. Het is geen toeval dat uitgerekend die namen over de tong rolden. Begin 1916 was het voordien homogeen-katholieke kabinet namelijk uitgebreid met liberalen en socialisten, die de Vlaamse beweging minder genegen waren. En ook de katholiek Carton de Wiart stond niet als een Vlaamsgezinde bekend. ${ }^{31}$ Voorts knoopte de spreker aan met een thema dat vaak terugkeerde in de activistische propaganda, namelijk dat de "Haverse regering" aan de Entente overgeleverd was. Ze stond of viel met dit bondgenootschap $(s i c)$. Als de regering dus terugkwam, moesten de Vlamingen zich geen illusies maken. De politieke vrijheden zouden afgeschaft worden en eventueel zou België door Frankrijk of het Verenigd Koninkrijk bestuurd worden. Deze feiten moesten de ogen der Vlamingen openen. "Vlaanderen eist zelfregering [...] de Vlaamse beweging is een internationaal vraagstuk geworden waaraan het einde van de oorlog een oplossing [...] moet en zal brengen.” Begin augustus 1916 werd een ingekorte versie van dit stuk in de Duitsgezinde Limburger Koerier (Nederland) overgenomen. Van Cauwelaert vernam de gefingeerde brief van zijn broer uit dat blad. ${ }^{32}$ Wat we voordien in De Vlaamsche Post en zeer duidelijk in de redevoering van Rietjens vernemen, toont een belangrijke verschuiving in de Duits-activistische propaganda aan. Het ging niet alleen meer om de uitroeiing van de Vlaamse beweging of van het Nederlands. De Vlaamse soldaten, zo heette het nu, werden met een doelbewuste moord bedreigd door de Belgische staat. Het is in die context dat de bewering dat Vlaamse soldaten stierven omdat ze de bevelen van hun Franstalige oversten niet begrepen, later aannemelijk kon worden.

Gedurende de loop van 1917 radicaliseerde de frontbeweging verder. Niet alleen de oorlogsmoeheid, de taaltoestanden in het leger en de onwil van de regering van nationale eenheid om daar iets aan te verhelpen, speelden daar een rol in. Van belang was ook de groei van een door sommige flaminganten als anti-Vlaams gepercipieerd Belgisch nationalisme, waarbij sommigen om territoriale uitbreidingen van België vroegen en de angst dat België zijn neutraliteit zou verloochenen om een bondgenootschap met Frankrijk aan te gaan. ${ }^{33}$ Uiteraard speelde de Flamenpolitik hierop in. Ze vergrootte ook de breuk tussen "België" en "Vlaanderen" nog méér door een eerste 
ingreep in de bestuurlijke organisatie van België: de splitsing van het ministerie van Kunsten en Wetenschappen (november 1916). Op 21 maart 1917 kondigde gouverneur-generaal Von Bissing de "bestuurlijke scheiding" af. België werd zo administratief in een Vlaams en een Waals deel opgesplitst. Om het Vlaamse deel te besturen, werd door de bezetter een onverkozen parlement opgericht: de Raad van Vlaanderen. Die zou zogezegd "namens het Vlaamse volk" spreken. Duitsland wou zo België verder ontwrichten en tegelijk inspelen op het nieuwe principe van de geallieerden, het "zelfbeschikkingsrecht der volkeren”. De radicalisering waarvan sprake intensiveerde ook onder invloed van buitenlandse gebeurtenissen. Tijdens de lente van dat jaar waren Franse soldaten massaal aan het muiten geslagen en in Rusland had een eerste revolutie de kroon van de Romanov-dynastie door de straten doen rollen en een tweede revolutie zelfs een communistisch regime aan de macht gebracht.

Op 11 juli 1917, nog geen vier maand na de maatregel van Von Bissing, publiceerde de frontbeweging een Open Brief aan den Koning der Belgen, Albert I. De vorst heette de enige te zijn in wie ze nog vertrouwen had. De brief was een langgerekte aanklacht tegen de regering en de officieren die de taalgrieven niet tegemoetkwamen en flaminganten zouden minachten. De daden van de activisten, inzonderheid het aanvaarden van de vernederlandsing van de universiteit van Gent uit Duitse handen, werden goedgekeurd. Men was nog bereid bloed te vergieten, maar wilde de uitdrukkelijke belofte op papier dat na de oorlog "volle gelijkheid, volle recht" gegeven werd. Koning Albert I stelde echter een kabinet samen, met een nieuwe minister van Oorlog, Armand De Ceuninck, waarop er een grootschalige (maar wederom niet-fysieke) repressie tegen de Vlaamse beweging volgde.

De Ceuninck gaf op 22 augustus 1917 in een omzendbrief over het gebruik der talen te kennen dat eenieder de wens van de soldaat om door zijn meerderen in zijn moedertaal te worden toegesproken, als natuurlijk en rechtvaardig diende te beschouwen. Dit gold in het bijzonder in oorlogstijd, waarin een verkeerd begrijpen van bevelen ernstige gevolgen kon hebben. ${ }^{34}$ Zo gaf hij, onbedoeld natuurlijk, een voorzet om het verhaal dat Vlamingen door Franstalige bevelen stierven, of toch dat lot riskeerden, geloofwaardig te maken. De activistische en de Groot-Nederlandse pers greep deze omzendbrief aan in haar propaganda. Volgens het Duits-activistische Voor Vlaanderen waren de gevolgen van het taalprobleem in het leger foute diagnoses die Nederlandsonkundigen stelden "met betreurenswaardige gevolgen voor de patiënt”. Het blad had het voorts over de verwaarlozing, misprijzing en verongelijking van de Vlaamse soldaat die al begon in het instructiekamp 
en doorging tot in de gevangenis. En dat in een leger dat, zo beweerde Voor Vlaanderen, voor 80 procent procent uit Vlamingen bestond. ${ }^{35}$

Een andere toegeving gebeurde via een ministeriële dagorder van 28 augustus 1917. Die herinnerde de officieren aan de aansporing uit januari 1916 om Nederlands te leren. Om bevordering te halen in lagere graden zou "rekening gehouden" worden met die kennis. Dat alles stond natuurlijk mijlenver af van wat de frontbeweging, maar ook Van Cauwelaert cum suis wensten. Verdere tegemoetkomingen van regeringszijde volgden in september. In de praktijk was er een zekere verbetering in de taaltoestanden, ook onder invloed van de inspanningen van Van Cauwelaert. Die evolutie volstond nochtans niet meer voor de frontleiding die nu naast federalisme voor het naoorlogse België, ook geen bestraffing voor de activisten eiste. Ondertussen ontstond er omtrent die Franstalige bevelen geregeld deining in de activistische pers. Soms werden daarvoor berichten uit Vrij België overgenomen of vervalst. ${ }^{36}$ Ook werd in activistische bladen gemeld dat zelfs in Duitse krijgsgevangenenkampen de "marteling" van de Vlamingen doorging, niet door de Duitsers, maar wel door hun Franstalige oversten. Want ook daar werden alle bevelen in het Frans gegeven en "wie maar om een greintje eerbied dorst vragen voor het Vlaams kreeg niets dan hoon en spot, bedreiging of straf voor antwoord!" ${ }^{37}$ De activistische pers berichtte tevens over Vlaamse soldaten die gestraft werden omdat ze Franse bevelen niet begrepen en slecht uitvoerden. ${ }^{38}$ Vlaamse soldaten begonnen het te "verdommen" zich te laten beledigen en bevelen door Franstalige "goudvinken" die "te dom zijn om een woord Vlaams te leren". ${ }^{39}$ En in Het Vlaamsche Nieuws van 24 augustus 1918 vertelde de deserteur De Schaepdrijver dat tijdens de gevechten, als de stikgasdampen kwamen aangedreven en het leven van de jongens afhing van een goed gegeven bevel, de bevelen uitsluitend Frans waren. Het Vlaams was verboden..$^{40}$ Tot nu toe hadden we dus, chronologisch, de demoraliserende "Belgische soldatenbrieven" uit Duitse bron vanaf de herfst van 1914 waarbij de vreselijke toestand waarin (de Vlamingen in) het Belgisch leger zogezegd verkeerde(n) beklemtoond werd en de uitspraken van Rietjens en Van Cauwelaert over Vlaamse soldaten die stierven onder bevelen van officieren die hun taal niet verstonden (mei en juli 1915). Daarbij kwamen nog, vooral vanaf 1916, de "soldatenbrieven" over de schrijnende toestanden aan het front waar Vlamingen miskend en flaminganten bewust uitgeroeid werden. Dat laatste werd in augustus 1917 kracht bijgezet door de uitspraak van generaal De Ceuninck over het gevaar van fout begrepen bevelen. Maar nog steeds werd nergens een rechtstreekse en causale band gelegd tussen bevelen enerzijds en sneuvelen anderzijds. 


\section{Een verslag van het Vlaams-Belgisch Verbond}

Die causale band werd pas gelegd door het Vlaams-Belgisch Verbond. Deze flamingantische en Belgisch-loyale organisatie werd onder leiding van Van Cauwelaert in april 1917 te Den Haag opgericht. Ook de socialistische voorman Camille Huysmans sloot zich erbij aan..$^{41}$ Dit Vlaams-Belgisch Verbond schreef een ophefmakend verslag. Het klaagde onder meer in zeer strenge bewoordingen de taaltoestanden in het leger aan en eiste eentalige Vlaamse en Waalse regimenten. Het werd op 1 december 1917 gefinaliseerd en op 12 december aan de minister van Oorlog bezorgd. In januari 1918 verscheen het als drukwerk in Nederland onder de titel De Indeeling van de Belgische Weermacht. Verslag uitgebracht door de Legerkommissie van het Vlaamsch-Belgisch Verbond. ${ }^{42}$

De toon was snoeihard. "De nationale geest der Vlamingen wordt in het Belgisch leger ondermijnd. Ontelbaar zijn de Vlamingen die met vurige vaderlandse ijver in dienst traden om de krijgsdienst [...] als onverschillige vaderlandslozen te verlaten." Het heette dat het taalgemengd stelsel in het leger, waar de Vlaming naast het Frans ook vertaald "neger-Vlaams" te horen kreeg, berustte "op een grove miskenning van het vrije levensrecht der Vlamingen", zelfs een "een bloedige krenking van de [...] Vlaams-nationale gevoelens" was. In het leger werden de Vlamingen "zowat als een overheerst ras [...] behandeld". Men wou van de Vlamingen een soort "namaak-Walen" maken. "Een Vlaamse Vlaming past er niet!" De lijdensweg der Vlamingen begon vanaf het moment ze in dienst traden, leidde naar het oefenkamp en liep verder langs het front, tot in de gevangenis of tot het graf: "overal verwaarlozing, misprijzing, vernedering en verongelijking! En dat in een leger, waar zowat vier vijfden ( 80 pct.) der manschappen uit Vlaams-België afkomstig waren en het vaderland, voor zijn behoud zelf de Vlamingen zo nodig had als brood!" (de intertekstualiteit met wat het activistische Voor Vlaanderen schreef, is duidelijk). In het Belgisch leger, zo luidde de striemende anklacht, was alles erop ingericht om de Vlaamse nationaliteit en het "rasbewustzijn" eruit te commanderen. "De Vlaams-nationale geest, natuurlijke grondslag van zijn Belgische vaderlandsliefde wordt in de Vlaming zoveel mogelijk gesmoord." Het moest, volgens het drukwerk, voor eens en voor altijd uit zijn met een systeem dat de Vlamingen met geweld de weg der "verbastering" opdrong en de Vlaamse landstreek als een soort van WaalsFrans wingewest had ingericht. Die vaststelling gold ook voor het bestuur, gerecht en onderwijs. De staatsinstellingen moesten taalkundig volledig aan de "tweeledigheid" van België aangepast worden. 
Dat is in werkelijkheid geen scheiding, maar een aanpassing aan de werkelijkheid: bestuurlijke en culturele aanpassing... ${ }^{43}$ Vlamingen en Walen blijven [...] liefst wat zij zijn, waarom ze dan met alle geweld tot één Belgisch type willen samensmelten? Welke belangen worden daardoor toch gediend? In ieder geval de Vlaamse niet! En wat de Belgische belangen betreft, deze kunnen alleen maar gediend worden door een aanpassing aan de werkelijkheid [dus onder meer door eentalige regimenten, $B Y$ ].

Het rapport beklemtoonde dat de meeste gesneuvelden in het Belgisch leger Vlamingen waren. "In de eerste plaats kwam bij het offer van het bloed scherper dan in vredestijd de bevoorrechte positie der Walen op de voorgrond." In dit deel van het geschrift staat een passage die onze bijzondere belangstelling wekt:

Hoevele Vlamingen zijn er niet gevallen als slachtoffers van onbegrepen of verkeerd begrepen Franse bevelen en mededelingen? Hoevelen hebben niet met hun leven het misverstand van een Waalse meerdere bekocht?

Deze formulering had haar wortels in het antwoord van Van Cauwelaert op Rietjens in 1915. Maar er was een markant verschil. Immers, de soldaten heetten nu niet meer te sterven onder Franstalige bevelen van hun "Waalse meerdere". Neen, het was omdat ze Franstalige bevelen te horen kregen, die ze niet of verkeerd verstonden, dat ze het leven lieten. Met die "Waalse meerderen" werden in de brochure overigens niet alleen de Walen angeduid, maar ook de "verfranste Vlamingen", die zelfs "nog meer een steen des aanstoots" heetten te zijn dan "rasechte Walen". ${ }^{44}$ Maar die bedenking stond in een voetnoot, waardoor in de tekst zelf de dualiteit tussen Vlamingen en Walen gehandhaafd bleef. Het was krasse taal van Van Cauwelaert cum suis, die bewees in welke mate ook zij door de oorlog geradicaliseerd waren. $\mathrm{Na}$ de oorlog beweerde de historicus Armand Wullus dat Van Cauwelaert de brochure in het hele leger verspreid had. ${ }^{45}$ Dat valt te betwijfelen. Hoe kon de militaire censuur zoiets immers tolereren? Wel konden via het neutrale Nederland zulke brochures op ruimere schaal weerklank vinden. Op 4 januari 1918 verscheen in Vrij België van Hoste en Van Cauwelaert een gloeiend artikel. Dat stuk hekelde een serie "wraakroepende" voorvallen, waarbij zogezegd Vlamingen aan het front gestraft werden omdat ze Vlamingen waren. Aan het front, zo verhaalde het blad, was een algehele vervolging gaande, gericht tegen alle "stambewuste" Vlamingen. Ze werden door hun "franskiljonse" oversten bespioneerd, geprovoceerd, verdacht gemaakt en vernederd. Vrij Belgie had in hetzelfde nummer een volledige aanpassing van de Belgi- 
sche instellingen aan de "tweeledigheid" van België geëist. Die moest er dan komen door het invoeren van het Nederlands in de Vlaamse administraties en het Frans in de Waalse. Het dagblad schreef dat de "kunstmatige" eenheid van België voor de Vlamingen feitelijk niets anders betekende dan achterstelling op alle gebied. Ze moest plaatsmaken voor

...eendrachtige tweeheid, voor de Belgische tweeledige werkelijkheid van gelijkberechtigde volkeren. Vlamingen en Walen zullen mekaar beter kunnen verstaan en eendrachtiger samenwerken, als zij niet meer zullen gescheiden zijn door een stelsel van onrecht, gegrondvest op vooroordelen en onevenwichtige, valse eenheidsbegrippen.

De Vlamingen moesten zich niet aanpassen aan een verfranst staatswezen, want dat vermeende cement van de nationale eenheid heette een noodlottige splijtzwam te zijn. Integendeel moest de staatsstructuur aangepast worden aan "de Vlaamse en Waalse wezenlijkheid van België". Of nog: "Er kan geen tegenstrijdigheid bestaan tussen culturele autonomie en het Belgische staatsbelang." Delen van dit artikel waren ontleend aan het Verslag van het Vlaams-Belgisch Verbond. Hoewel de eisen van die organisatie zich op de eentaligheid van Vlaanderen toespitsten, was het duidelijk welke munt de activisten hieruit konden slaan. De woordkeuze toonde al een opvallende gelijkenis met de besproken analyse van Deswarte eind juni 1915. Hij had het over een "dubbel zelfbestuur" in het kader van het "volkdualisme" die naar hij beweerde de eenheid van België ten goede zou komen. ${ }^{46}$ Maar de inhoud was natuurlijk merkelijk anders: het was Van Cauwelaert en de zijnen te doen om de eentaligheid van Vlaanderen, niet om een bestuurlijke scheiding, waar ze tegen ageerden. ${ }^{47}$ Begin maart 1918 kondigde Vrij België de besluiten aan van de Landdag van de organisatie. De voornaamste daarvan waren de eentaligheid van het onderwijs in Vlaanderen (met inbegrip van de vernederlandsing van de Gentse universiteit), eentalige legereenheden en de vervlaamsing van openbare besturen en het gerecht. Tegelijk verwierp het Verbond met klem alle "kunstmatige hervormingen" die alleen aan de Duitse macht hun ontstaan ontleenden (zoals de "bestuurlijke scheiding")..$^{48}$ De liberaal Auguste Monet waarschuwde daarop in Verkapt Activisme, een artikel dat verscheen in de Nederlandse pro-geallieerde Telegraaf, dat de eisen van Van Cauwelaert en de zijnen door de activisten met hun praktijken vereenzelvigd zouden worden. ${ }^{49}$ Dat klopte, want volgens sommige activistische geschriften was er slechts een vormverschil tussen wat zij "eisten" en "verkregen" en wat Van Cauwelaert wilde. Het Vlaamsche Nieuws uit Antwerpen had het over de "prachtige redevoering" van Van 
Cauwelaert op de Landdag van het Vlaams-Belgisch Verbond: "indien gij dit geen activisme heet, dan hebt ge alle zin voor werkelijkheid en de ware betekenis der woorden verloren. De spreker zelf weert nog het woord, maar stapt in de zaak zelve met zijn beide voeten." ${ }^{\text {0 }}$ En op dat zogenaamd "activisme" kwam, weinig verwonderlijk, ook kritiek vanwege L'Echo Belge:

Il [Van Cauwelaert] se défend d'être activiste, mais quand on considère en quoi il differe des activistes on trouve seulement cette différence - importante, hâtons-nous de le dire - que c'est en dehors du pouvoir occupant, sans le secours de l'Allemagne qu'il prétend chambarder nos institutions. ${ }^{51}$

Het woordgebruik dat het Franstalige blad hanteerde, was geen toeval. Op 22 december 1917 immers, had de Raad van Vlaanderen, op aansturen van het Duitse gouvernement-generaal, de "onafhankelijkheid" van Vlaanderen uitgeroepen. De stap droeg de goedkeuring weg van de Duitse vloot- en legerkringen, kortom van iedereen die de oorlog tot het bittere einde wou doorzetten. De Duitse regering rekende op een vrede door onderhandelingen. In dat geval was het onmogelijk om naar buiten toe België te vernietigen. De onafhankelijkheid van België was immers de reden waarvoor het Verenigd Koninkrijk de oorlog verklaard had aan Duitsland. De tactisch meer gematigde Duitse kanselier verbood daarom onmiddellijk de maatregel. "Onafhankelijkheid" werd afgezwakt tot "politieke zelfstandigheid” en de Raad moest zich aan verkiezingen onderwerpen om aan de buitenwereld te bewijzen dat ze gesteund werd door de Vlamingen. Op 20 januari 1918 werd die "zelfstandigheid" openbaar gemaakt. Daarop werden "volksraadplegingen” georganiseerd om de vooraf aangeduide kandidaten van de Raad te "verkiezen". De ontnuchtering bij de activisten was groot. Want in elke stad liepen deze "verkiezingen" op een sisser uit. Zij die gingen stemmen, werden op massale tegenbetogingen onthaald. Uiteindelijk waren er maximaal 15.000 "ja”-stemmers op een bevolking van miljoenen. Al op 24 februari 1918 zette de Duitse bezetter zijn "verkiezingen" zelf stop. De nieuwe "verkozen" Raad van Vlaanderen stond volledig onder invloed van de meest radicale kringen in het Duitse keizerrijk. De leden ervan beseften zeer goed dat ze in geval van een Duitse nederlaag niet alleen hun broodwinning, maar ook - wegens hoogverraad - hun leven riskeerden. En dus werd hun hele denken gedreven door een haat tegen België. Pas toen in de zomer van 1918 de Duitsers in het westen in het defensief gedwongen werden, sprak de bezetter zich met het oog op onderhandelingen uit voor het voorwaardelijk herstel van de Belgische staat. De Raad van Vlaanderen bleef sluimerend bestaan onder de naam "Commissie van Zaakgelastigden".52 


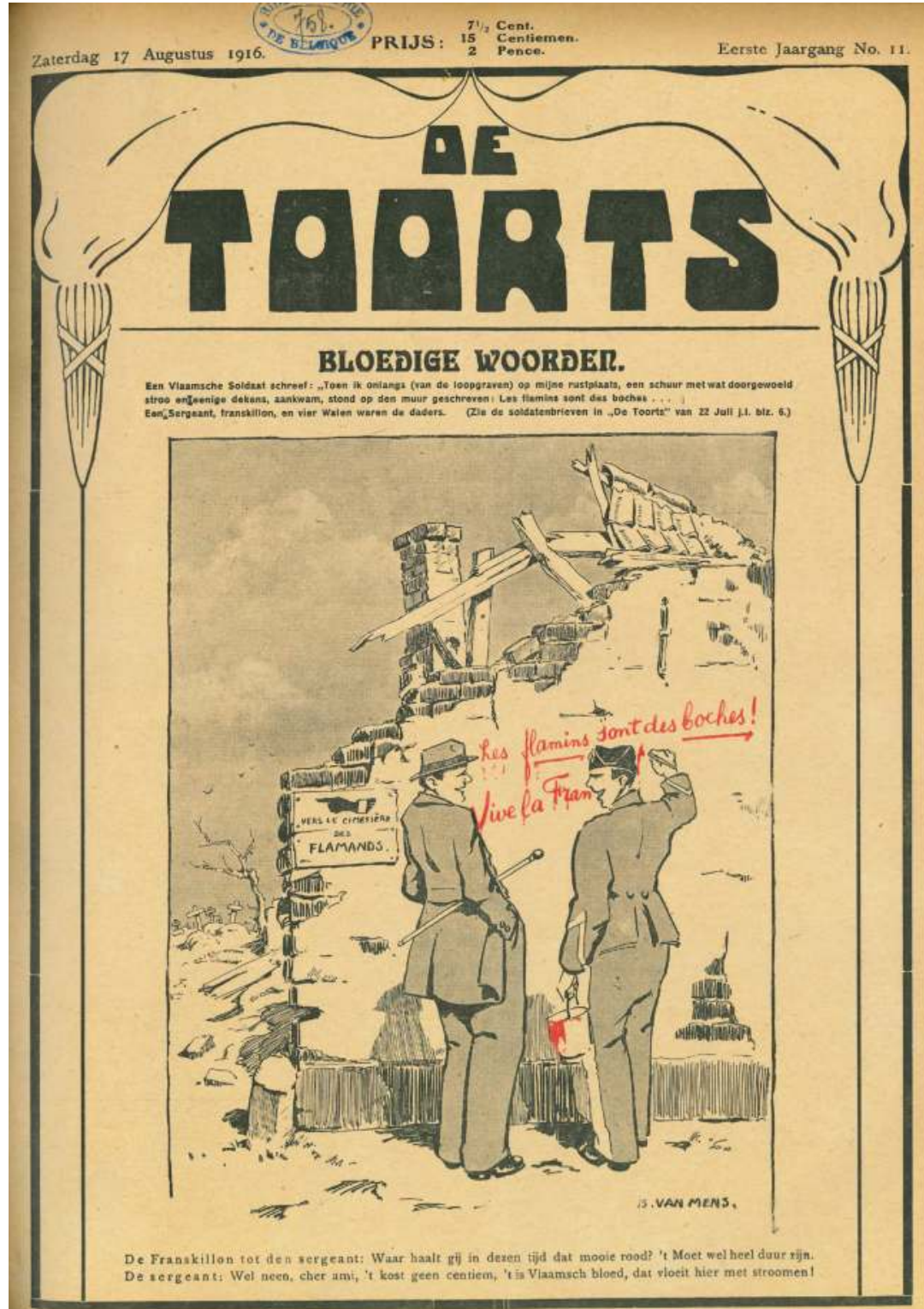

Afb. 20. Naarmate de oorlog vorderde, ging de Duitse bezetter beweren dat het Belgisch leger moedwillig Vlamingen uitmoordde.

De Toorts, 17 augustus 1916; KBR BE-KBRO0-Vi 7613 B 


\section{De "sublieme deserteurs"53}

Dat de regering elke fundamentele hervorming weigerde, deed ondertussen het ongenoegen bij de frontbeweging toenemen. Wel werd op de Kroonraad van 20 maart 1918 beslist de repressie tegen de Vlaamsgezinden te temperen. Maar voorts kwam men niet verder dan halve maatregelen. Zelfs de Vlaamse school voor onderofficieren, die bij wet van 1913 gedecreteerd was, was vijf jaar later nog geen feit. Ondertussen zocht de frontbeweging contact met de activisten. Dat gebeurde door zeven gedeserteerde flamingantische frontsoldaten, onder wie De Schaepdrijver en Charpentier, de zogenaamde "sublieme deserteurs". Zij kwamen in de Duitse propagandamolen terecht. Zo kwam het dat De Schaepdrijver in de activistische pers de "tirannie" van het Belgische militarisme en Vlaamse jongens die in Franse gevangenissen "gemarteld" werden, kapittelde. De officieren, zo vertelde hij, woonden ondertussen in prachtige villa's en de Walen verdwenen een voor een uit de vuurlijn. "In grote, vlammende letters laait het boven het IJzerfront: 'hier wordt een volk vermoord.' Het Vlaams bloed vloeit bij stromen. [...] Vlaams bloed is goedkoop!" ${ }^{44}$ Deze retoriek was overgenomen uit Vlaanderens Weezang aan den IJzer (juli 1918), een brochure van hemzelf en Charpentier. In die door de bezetter georganiseerde propaganda beschuldigden ze met name het Belgische officierenkorps ervan een geplande genocide op de Vlamingen in het algemeen en de flaminganten in het bijzonder uit te voeren:

Vlaanderen wordt vermoord. Het Vlaamse ras, eerst in zijn ziel en gave werkkracht aangerand, moet ook stelselmatig uitgeroeid: 'Il faut que l'offensive belge ait comme but principal de faire massacrer le plus de Flamands possible. Il importe de rétablir l'équilibre quantitatif entre les deux races et ensuite d'éliminer tous ces éléments de perturbation après la guerre.'

Deze apocriefe bewering werd toegeschreven aan Fernand Neuray, de hoofdredacteur van Le Vingtième Siècle. ${ }^{55}$ De inhoud van die stelling was des te dwazer omdat er, wegens de taalgemengde eenheden, helemaal geen Vlaamse regimenten waren die men de "dood kon injagen". ${ }^{56}$ Bovendien was van alle strijdende legers het Belgische het enige dat niet had deelgenomen aan de zelfmoordoffensieven van de Grote Oorlog. In de nasleep van de publicatie van Vlaanderens Weezang verschenen er becommentariërende 
artikels in de activistische pers. ${ }^{57}$ Zo beweerde Raf Verhulst in Het Vlaamsche Nieuws:

Wat is er goeds te verwachten van een België, dat nu, op het ogenblik dat de Vlaamse jongens [...] hun bloed vergieten, die Vlaamse soldaten [...] vervolgt, negeert, judast, in de gevangenis werpt of op laffe en verraderlijke wijze van kant brengt, alleen omdat zij taalrecht eisen? ${ }^{58}$

De martelaarscultus, begonnen bij het incident De Clercq-Jacob, bereikte een culminatiepunt. In die context was België geen vaderland, maar een staat die moedwillig het bloed der Vlamingen vergoot en derhalve moest verdwijnen. Dat was natuurlijk dwaze propagandistische praat. Maar de fronters en de activisten beweerden toch dat Vlamingen bewust vermoord werden om de belangen van Frankrijk en het Verenigd Koninkrijk te dienen. Ze waren eenvoudigweg slachtoffers van "Vlaamshaterij" in een leger dat de belangen van Frankrijk en Groot-Brittannië diende..$^{59}$ Zo was de cirkel rond, want al vanaf 1914 verkondigde de bezetter dat Vlaams bloed nutteloos vergoten werd voor de belangen van de Entente.

\section{De propaganda van de Raad van Vlaanderen}

In de ontwikkeling van het activisme speelde de Raad van Vlaanderen een niet te veronachtzamen rol. Hij ontpopte zich vanaf zijn ontstaan in de lente van 1917 tot een propagandamegafoon die de Duits-activistische voorstelling van zaken door de uitgave van brochures, pamfletten, boeken en het houden van lezingen een enorme weerklank gaf. Zo zorgde hij mee voor de nog grotere verspreiding van eerdere fabels - zoals die over de anti-Vlaamse campagne - maar zette hij er ook nieuwe in de verf. Voor wat de frontbeweging betreft werden de meest markante passages uit het Verslag van het Vlaams-Belgisch Verbond door de Jong-Vlaming George Roose, een lid van de Raad van Vlaanderen, in juli 1918 van commentaar voorzien en gebundeld in een brochure. ${ }^{60}$ Die droeg als titel: Wat Dr. Frans Van Cauwelaert zegt over de wantoestanden in het Belgisch leger aan den IJzer. De Vlaamsche Plicht. ${ }^{61}$ Zonder twijfel heeft de passus over de bevelen van Nederlands-onkundige officieren zo een nog grotere ingang gevonden dan ze al had. ${ }^{62}$

Wanneer men de brochure van Roose leest, wordt duidelijk dat Monet eerder dat jaar geen ongelijk had met zijn waarschuwing aan het adres van Van Cauwelaert. Het Verslag dat hij niet zelf geschreven had, maar zeker wel goed- 
gekeurde, werd hier immers volledig voor de Jong-Vlaamse en dus de Duitse zaak gerecupereerd. Roose juichte de indeling van het Belgisch leger in taalregimenten, die het rapport verdedigde, toe. Schaamteloze Belgische perslakeien waren er natuurlijk tegen, zo schreef hij, omdat dit zogezegd de vijand zou dienen. Vlaanderen moest die lieden echter uitspuwen. Het waren zij die bij het begin van deze Vlaming-dodende oorlog in Antwerpen en Brussel té vroeg gejuicht hadden om de dood van Vlaanderen. Die zin doet denken aan de propaganda uit de Gazet van Brussel van januari 1915 over het onheil dat Vlaanderen te wachten stond. De lezer mocht, aldus de auteur, niet vergeten dat uit dit Verslag niet de taal sprak van een activist, van een "verrader", van een "verkochte tegen vijf mark per dag!" [hij kende blijkbaar de stemming onder de Belgische bevolking, $B Y]$. "Neen, dikbuikige, best-Belgische-braveburgerman, dat is de taal van mannen die zelf tot het Belgisch leger behoren..." Het Verslag werd door Roose afgeschilderd als een enorme aanklacht tegen de Belgische regering. Het legde bovendien de vinger op de "verrotting" die Vlaanderens dood betekende: het verfransende en vijandige België.

Het eigen, Vlaamse ras werd er immers door uitgemoord: "België, de verdrukker en uitmoorder van de Vlamingen!" België had volgens Rietjens overigens reeds vóór de oorlog partij gekozen voor de Entente (de gekende Duitse propagandaleugen). Van Cauwelaert kon geen twee meesters dienen "die tot nog toe als onverzoenbare vijanden tegenover elkander staan, Vlaanderen en België”. Na de oorlog zou Gerard Walschap trouwens precies dezelfde woorden gebruiken, toen hij stelde dat het activisme "koos tussen Vlaanderen en België, twee vaderlanden voor ons tot dan toe identiek, en die plots tot onze verstomming onverzoenlijke vijanden waren". ${ }^{63}$ L'Echo Belge vroeg eind juni 1915 al duidelijkheid hieromtrent aan Vlaamsgezinden die het van collaboratie verdacht: "...pourquoi, s'ils continuent de croire dans les destinées de la Belgique, mettre en opposition la Belgique et la Flandre?". ${ }^{4}$ En in 1918 getuigde Cyriel Rousseeu over "een ogenblik van geweldige innerlijke strijd tussen het gevoel 'België' en het gevoel 'Vlaanderen'” die drie jaar eerder plaatsgevonden zou hebben bij een Vlaamsgezinde die hij ontmoette, alvorens die voor het activisme koos. ${ }^{65}$ Het propageren van deze stelling - dat Vlaanderen en België tegengestelden waren - was uiteraard een doel van de Flamenpolitik. Die zeer duurzame gedachte, die tot op vandaag de basis is van een zeker Vlaams-nationalistisch credo, wist de bezetter succesvol op een deel van de Vlaamse beweging te enten.

Volgens Roose wist Van Cauwelaert dat de vijand België was, maar durfde hij dat niet te zeggen. Herinnerde zijn brochure trouwens niet aan alles wat in de activistische pers stond? Wat hij op 4 januari 1918 in Vrij België schreef, 
zegden de Jong-Vlamingen al jaren vóór hem, zo beweerde Roose. De Vlamingen mochten, aldus de activist, nooit de term "bestuurlijke scheiding" gebruiken, "met zijn activistische geur". Maar het Verbond stal wél "heel de inhoud van het begrip en bijna heel het programma der Jong-Vlamingen, natuurlijk zonder ze te noemen". Anders gezegd, net als L'Echo Belge, beweerde ook Roose dat het Vlaams-Belgisch Verbond uit versluierde activisten bestond. In augustus 1918 vindt men in de activistische propaganda terug dat het minimumprogramma van de frontpartij de oorzaak geweest was dat op de Landdag van het Vlaams-Belgisch Verbond enkele "zogezegd" radicale eisen gesteld werden. ${ }^{66}$ Nochtans had Van Cauwelaert tijdens de lente van 1918 in privégesprekken met voormannen uit de frontbeweging geweigerd zich achter hun eisen te scharen. ${ }^{67}$ Anderzijds was hij natuurlijk ook geradicaliseerd door de oorlog. Wat Roose aan Van Cauwelaert verweet was dat hij niet als Vlaming sprak doorheen de brochure, maar wel als Belgisch volksvertegenwoordiger. Het Vlaams-Belgisch Verbond wendde zich immers volgens de auteur tot de regering. De christendemocratische leider, aldus Roose, vreesde dat het uitblijven van rechtvaardige hervormingen tot een "nationale ramp" zou leiden en wou die vermijden. Maar die "ramp" betekende wel de vrijmaking van Vlaanderen. De actie van Frans van Cauwelaert kwam er dus volgens Rietjens omdat aan het IJzerfront een oproer dreigde die België vernietigen zou. Dat scenario was de Jong-Vlaming natuurlijk niet ongenegen.

De fameuze passage in het verslag die ging over Vlaamse soldaten die stierven ten gevolge van niet begrepen bevelen van Nederlandsonkundige officieren werd in grote drukletters gepubliceerd en als volgt becommentarieerd:

...de Belgische meesters [...] onvermurwbaar neerblikkend op de dode Vlamingen... Vlaamse vaders, wroeters, tweederangsburgers in België, uw bloed! Vlaamse moeders [...] uw geweldige trots! [...] vermoord door het misverstand van Waalse meerderen! Vermoord! Hebt gij meer nodig om tot opstand te komen? Om de verrotting weg te snijden? Om Vlaanderen te redden nu er nog tijd is, van de dood door de enige weg die Vlaanderen redden kan, de weg leidend [...] naar Vlaanderens soevereine zelfstandigheid?

En waar Van Cauwelaert cum suis zich kantten tegen de taalgemengdheid in het leger, was dit in deze activistische propaganda maar een halfslachtige maatregel. Immers, de kanker was in die voorstelling van zaken België zelf. 


\section{Besluit}

Al begin 1915 werd er door de bezetter verkondigd dat Walen en "franskiljons" in den vreemde het Vlaams wilden uitroeien, ja er zich op verheugden het Vlaamsgezinde Antwerpen tot een puinhoop te herleiden. Tegelijk gebruikte hij vervalste en demoraliserende soldatenbrieven die dan in zogenaamd "Vlaamse" dagbladen verschenen. Nadat de Jong-Vlaming Rietjens op 5 mei 1915 verkondigd had dat Vlamingen stierven onder oversten die hun taal niet verstonden, nam Van Cauwelaert die bewering letterlijk over in het 11 juli-nummer van De Vlaamsche Stem. Naarmate de oorlog vorderde, beweerde de Duits-activistische propaganda in toenemende mate dat een Vlaams leven aan het front niets waard was en dat Vlamingen moedwillig uitgemoord werden. $\mathrm{Na}$ de oorlog meende Frans Van Cauwelaert dat "de ophitsende berichten die geleidelijk in het bezette gebied doordrongen omtrent de onwaardige taaltoestanden die in het Belgisch leger tot op het einde van de oorlog werden onderhouden" het activisme zichtbaar bevorderd hadden. ${ }^{68}$ Zeker nadat de leiders van de frontbeweging in de Duitse propagandamolen terechtkwamen, werden verzinsels over frontsoldaten die ook tot "in het bezette gebied doordrongen" nog opgeklopt. In dat klimaat ontstond het verhaal over de Franstalige bevelen als doodsoorzaak van Vlaamse soldaten. Ten laatste vanaf de zomer van 1918 was de legende van de Vlaamse soldaten die stierven doordat ze hun eigen Nederlandsonkundige officieren niet begrepen, een feit. De oorsprong ervan moeten we niet alleen zoeken bij de activistische propaganda, maar ook in een brochure van het Vlaams-Belgisch Verbond. Zoals gezien, werden beweringen uit die brochure dan overgenomen en becommentarieerd in een drukwerk dat een lid van de Raad van Vlaanderen in juli 1918 schreef. Het lijkt duidelijk in wat voor ongemakkelijke positie Van Cauwelaert en de zijnen zaten. Ze moesten radicaal genoeg zijn om niet alle voeling met de activisten te verliezen en te verijdelen dat de Vlaamse beweging blijvend verdeeld raakte. Toch bleven ze in de ogen van diezelfde activisten vooral slappe Vlamingen die in het beste geval de activistische theses schoorvoetend bijtraden. Natuurlijk beweerden die dat ook om de loyalistische Vlaamsgezinden te compromitteren. En niet zonder succes. Want het was net die schijn van activisme die hen verdacht makkte in de Franstalige vluchtelingenpers, maar ook bij andere Belgischloyale flaminganten, zoals Du Catillon. En daar moesten ze zich ook tegen verzetten. Sommige Franstalige dagbladen hadden hun posities tijdens de oorlog verstrakt: elke uiting van Vlaamsgezindheid heette nu de bezetter in de kaart te spelen. Wellicht was het onmogelijk om in oorlogstijd de kerk 
in het midden te houden. De scheuring in de Vlaamse beweging werd veroorzaakt omdat Duitsland zijn Flamenpolitik voerde en in de hand gewerkt door de Belgische regeringspolitiek die geen krachtig antwoord op het activisme en de frontbeweging formuleerde. Maar ook omdat de activisten, op de radicalen van Jong-Vlaanderen na, door een zeer groot deel van de loyale Belgischgezinde Vlaamsgezinden niet als verraders gebrandmerkt werden. Bovendien ontstond er tijdens de oorlog een frontpartij. $\mathrm{Na}$ de oorlog kon die haar propaganda, waaronder de onwaarheid over de Vlaamse soldaten die door Franstalige bevelen sneuvelden, verder verspreiden. $\mathrm{Zij}$ had zich immers niet gecompromitteerd door de collaboratie maar werd wél door het anti-Belgische gedachtegoed van de gevluchte activisten geïnfecteerd. Na de oorlog bleven de nationalisten de propaganda over het lot van de Vlaamse soldaten nog verder overdrijven. En waarom zou de propaganda trouwens niet doorsijpelen naar de hele Vlaamse beweging wanneer we ze lezen in een brochure die door Frans Van Cauwelaert, dus door de meest prominente figuur van de Belgisch-loyale vleugel, geprefaceerd en gesanctioneerd werd? Het verhaal over de IJzertragiek sluit aan bij de Duits-activistische visie over de geestelijke uitroeiing van Vlaanderen én het Vlaams-nationalistische geschiedverhaal. Dat begon bij de "anti-Vlaamse" omwenteling van 1830 die het zogezegd gezegende Verenigd Koninkrijk der Nederlanden vernietigd had en de Nederlandse volkstaal zou verdrongen hebben. Daarna volgde dan de zogeheten Waalse onderdrukking van Vlaanderen gedurende de negentiende eeuw, de taalverdrukking, de anti-Vlaamse "hetze" van de Eerste Wereldoorlog, de IJzertragedie en de Vlaamse "idealisten" tijdens en de anti-Vlaamse repressie "zonder maat of einde" na beide wereldoorlogen, waarbij de Vlamingen steeds als het morele of fysieke slachtoffer afgeschilderd werden. ${ }^{69}$ 


\section{SLOTBESCHOUWINGEN}

De imperiaal-nationalistische spanningen waaraan Europa in de twee decennia vóór de Eerste Wereldoorlog onderhevig was, straalden af op de Vlaamse en de Waalse beweging die beide een völkisch sentiment in hun schoot droegen. De eerste stroming werd daardoor tot Duitsland, de tweede tot Frankrijk aangetrokken. Zo werd de binnenlandse communautaire tegenstelling door krachtige buitenlandse vectoren aangezwengeld. De groei van het Germaanse völkische denken werd door bijdragen van ingeweken Nederlanders en Duitsers in België, in de periode vóór en tijdens de oorlog gestimuleerd. Buitenlanders die de pro-Franse kaart trokken, zoals de Brit Gérard Harry, stimuleerden de gallofilie. Over het pan-Latinisme in de Waalse beweging is in de historiografie trouwens zeer licht heengestapt. De stroming verdient een gedetailleerd onderzoek. Ze droeg ertoe bij dat Antwerpen en zijn fortengordel, symbool van de Belgische onafhankelijkheid, in het communautaire antagonisme een mikpunt werden. Weinig verwonderlijk prikkelde het beeld van een "verduitste" Scheldestad als epicentrum van de Vlaamse beweging de wallinganten. Dat een groep Vlaamsgezinden niet onwelgevallig stond tegenover het Alldeutscher Verband, gevoegd bij het feit dat deze pressiegroep tot de eeuwwisseling een Antwerpse afdeling had en later nog in Brussel een tijdschrift uitgaf, werkte het wantrouwen nog meer in de hand. Anderzijds gingen sommige Vlaamsgezinden op hun beurt die wallinganten ervan verdenken samen met Frankrijk een anti-Vlaams complot te smeden. Bij dit alles voegde zich een zekere aversie bij de militairen en in bepaalde segmenten van de Belgische bevolking tegenover Antwerpen. In legerkringen draaide die om het vermeende antimilitaristische karakter van de metropool, 
bij de burgers om de "hoogmoed" van de onneembaar gewaande vesting. Beelden uit dit narratief werden overgenomen in de literatuur. Deze binnenlandse polarisering hypothekeerde een toekomstige Godsvrede.

Werd de interne Belgische cohesie tot op zekere hoogte verzwakt, dan gold het omgekeerde voor het Duitse nationalisme. Over het algemeen worden Alduitse tendensen in de vooroorlogse politiek van het keizerrijk in de historiografie onderschat. Omdat de Duitse regering vóór de oorlog niet tussenkwam in de Belgische binnenlandse politiek, wordt betoogd dat de Flamenpolitik een totale breuk met de rijkspolitiek inhield, alsof die niet voordien al beïnvloed werd door Alduitse ideeën en er geen vooroorlogse samenwerking bestond tussen het keizerlijke staatsapparaat en imperialistische pressiegroepen. Historici verwarren het vooroorlogse non-interventionisme van Duitsland in de Vlaamse beweging en België met een desinteresse ervoor. ${ }^{1}$ Nochtans toonden de verslagen van de Duitse ambassade in Brussel aan dat Berlijn welwillend stond tegenover die beweging. Ambassadeurs meenden in elke vooruitgang van het Vlaamse element in België een terugdringen van de Franse invloed te zien. Uit hun rapporten sprak bovendien een völkisch verwantschapsgevoel. Ook bleek dat de katholieke regering als beste garant der Duitse belangen beschouwd werd. ${ }^{2}$ De schok van de oorlog, waarbij Berlijn overigens geen beroep meer kon doen op die regering, zorgde ervoor dat de Duitse elites de vertrouwde völkische denkbeelden in hun beleidskeuzes integreerden, met de Flamenpolitik tot gevolg. Dolderer, die een continuïteit tussen de vooroorlogse Duitse (geo)politiek en de Flamenpolitik verwerpt, betoogt dat de Duitse oorlogsdoeleinden geheel en al op de leest geschoeid waren van het vooroorlogse Alduitse programma. ${ }^{3} \mathrm{We}$ zien niet in hoe dit geen gevolg was van het feit dat er een doordeseming van de Duitse elites met het Alduitse gedachtegoed bestond. De radicalisering van 1914 in de Duitse samenleving, zoals hij dat doet, louter "een gevolg van de oorlog zelf" noemen, is te limitatief. De historicus beweert dat pas tijdens de Eerste Wereldoorlog voor het eerst in de Duitse maatschappij een rechtsradicalisme op massale schaal ontstond. Ter illustratie daarvan neemt hij de stichting van de Deutsche Vaterlandspartei in september 1917, die met 1,25 miljoen leden spoedig uitgroeide tot "een voorafschaduwing van een fascistische massabeweging". Welnu, het door de overheid gestichte en eveneens radicaalnationalistische Flottenverein had in 1899 al 130.000 leden. In 1906 bedroeg dat aantal net geen een miljoen. ${ }^{4}$ Inzake het georganiseerde nationalisme en de opkomst van grootschalige pressie-bewegingen van dien aard vormden de jaren 1890 enigszins een cesuur in de geschiedenis van het Duitse Rijk. ${ }^{5}$ Dat de Duitse regering geen Flamenpolitik voorbereid had, is 
overigens geen argument om uit te gaan van een geïmproviseerd karakter van dit beleid. In Duitsland was de regering immers maar zeer gedeeltelijk afhankelijk van het parlement. Daardoor konden die machtige radicaalnationalistische organisaties aan kracht winnen. In dat opzicht moet men het verleden analyseren in termen van relaties en betekenisgeving binnen netwerken. "'Dé" staat heeft immers nooit bestaan"; zo'n begrip wordt telkens opnieuw vormgegeven door "coalities en netwerken van belanghebbenden". 6

Dat de Flamenpolitik een improvisatie heette te zijn, bleek vooral een nuttig element in de activistische zelfverdediging. Die vaststelling geldt nog veel meer voor de vermeende anti-Vlaamse campagne. Sommige auteurs beschouwden of beschouwen die als de aanleiding tot het activisme. Die fictie berust op de overname van Duits-activistische en apologetische propaganda die bewust of onbewust niet kritisch geanalyseerd werd. Zo meldde Elias in 1969 dat het geen twijfel leed dat de teksten uit de vermeende antiVlaamse hetze voor vele Vlamingen de aanleiding waren om tijdens de oor$\log$ niet inactief te blijven "en zich voor te bereiden om een toekomst af te wenden die [...] door al wat macht had in de staat, noodlottig scheen te zullen worden voor de Vlaamse zaak"? In wezen vertolkte hij hier niets anders dan het betoog uit een in 1927 uitgegeven nationalistische brochure, getiteld Vlaanderens nood aan zelfstandigheid. Daarin lezen we dat in 1914 "onder Belgische uitgewekenen [...] duidelijk gebleken was dat al wie over maatschappelijke en financiële invloed beschikte nu maar voorgoed met de Vlaamse beweging wilde gedaan maken". En dit gegeven werd daarin ook als een aanleiding tot het activisme aanzien. Kortom, de bewijsvoering van de historicus beriep zich op partijdige bronnen.

Het bestaan van zo'n campagne bleef decennialang onaangevochten. Tot op zekere hoogte nog steeds, ook omdat na de studie van Wils uit 1974 die zogenaamde campagne niet meer onderzocht werd. Bovendien werden sommige teksten, niet het minst de pamfletten die we uitgebreid bestudeerden, nooit diepgaand geanalyseerd, waardoor het gemakkelijk was om ze als "franskiljonse" artefacten in plaats van als Duitse propaganda te beschouwen. Een effect van het geloof dat men hecht(te) aan die antiVlaamse campagne, was een onderschatting van de impact van de Duitse propaganda-inspanning. In realiteit werd die zo grootschalig en behendig uitgevoerd dat ze tot op heden historici ervan weet te overtuigen dat "de Vlamingen" het initiatief namen. Ook het tijdstip waarop de Flamenpolitik of het activisme begon moet dat mee helpen bewijzen. Over wanneer de Flamenpolitik begon, lopen de voorstellingen inderdaad uiteen. Elias en Vanacker hebben benadrukt dat dit pas in december 1914 het geval was, 
ondanks de gekende instructies van Von Bethmann-Hollweg aan het gouvernement-generaal over de ondersteuning van het Nederlands van begin september $1914 .{ }^{9}$ Wende meende dan weer dat men het juiste tijdstip voor het begin van de Flamenpolitik niet kon beantwoorden. Die stelling onderbouwde hij door te poneren dat het "van beslissend belang" was "dat bij het uitbreken van de oorlog daarvoor [voor een Flamenpolitik, BY] nog geen enkel concept bestond, zodat de Duitse inval in België nog niet van een 'flamenpolitisch' programma vergezeld ging”. Maar zo'n concept bestond wél bij de Alduitsers met wier denkbeelden de Duitse elites vertrouwd waren. Naar de Duitse historicus aangaf, waren Flamenpolitik en activisme "twee parallel verlopende, maar eerst van elkaar onafhankelijke processen". De polarisering binnen de Vlaamse beweging begon volgens hem vóór het schrijven van de kanselier op 16 december 1914, "vooral ten gevolge van de aanvallen vanwege de vluchtelingenpers" (sic).$^{10}$ Volgens Müller viel het begin van de Flamenpolitik samen met de opvolging van Von der Goltz door Von Bissing (dus eind november 1914). ${ }^{11}$ Dolderer en Müller betoogden dat de "operatieve fase" van de Flamenpolitik pas op 11 januari 1915, met de oprichting van de Dienst voor Vlaamse Aangelegenheden, van start ging. ${ }^{12}$ In werkelijkheid kon de Flamenpolitik veel sneller van start gaan. Nadat België in augustus 1914 achtereenvolgens het Duitse ultimatum afwees en een aanbod tot wapenstilstand weigerde, besliste Berlijn het land politiek te ontwrichten. Die gang van zaken was niet onvermijdelijk, zeker niet indien België gehandeld had zoals het sedert 1867 eveneens neutrale Groothertogdom Luxemburg. De katholieke Luxemburgse eerste minister, Paul Eyschen, was er sedert 1887 onafgebroken aan de macht. Slechts drie jaar minder lang dus dan de voor Duitsland betrouwbare Belgische katholieke regeringen. Het groothertogdom werd op 2 augustus 1914 bezet, maar bood geen weerstand. De volgende dag gaf Eyschen toelichting in de Luxemburgse Kamer. Hij wees er op het "bijzondere karakter" van de situatie en beweerde dat Duitsland het groothertogdom niet als een bezet land zou beschouwen. ${ }^{13}$ Dat gebeurde natuurlijk wel, maar Luxemburg behield gedurende de hele oorlog zijn regering en dynastie. Beslechtte Duitsland het pleit in zijn voordeel, dan zou het als bondsstaat in het federale Rijk ingelijfd zijn. Dat was initieel ook het aan België toebedeelde lot.

Maar nog in augustus 1914 begon in België de völkische Flamenpolitik, waarvoor de Vlaamse beweging tot op zekere hoogte ontvankelijk was. $\mathrm{Na}$ de val van Antwerpen op 9 oktober 1914, schreef de semi-officiële Kölnische Zeitung dat de staatsidee België "in rook was opgegaan". [B.Y.] ${ }^{14}$ Daarmee werd openlijk uiting gegeven aan de Duits-völkische gevoelens tegenover het 
kleine buurland. De val van de vesting had een enorm demoraliserend effect op de Belgen. In een klimaat waarin door sommigen onder hen naar verantwoordelijken gezocht werd, vond de Duitse propaganda die allereerst bij de "onbetrouwbare" Britten en later bij het Antwerpse gemeentebestuur. Dat laatste had te maken met de nasleep van de val van Antwerpen, die polemieken in de Belgische vluchtelingenpers uitlokte. Tussen 21 oktober en medio november 1914 bereikten die twisten een hoogtepunt. In de hysterische overprikkeling over de dramatische gebeurtenissen werden er in sommige Franstalige dagbladen die in het buitenland verschenen een aantal loze beweringen geuit. Zo bijvoorbeeld dat er te Antwerpen pan-Germanisten met de Duitsers collaboreerden; dat de de facto burgemeester Louis Franck daartoe behoorde; dat die laatste dan ook nog eens tegen de wil van de militairen de vesting (te vroeg) had overgegeven; dat er na de oorlog een militair tribunaal de schuldigen daaraan moest straffen; dat sommige flaminganten pan-Germanistische collaborateurs waren; dat de toestand te Antwerpen aantoonde dat de Belgen eertijds naïef waren met hun lakse nationaliteitswetgeving en de stad door Duitsers hadden laten overnemen enzovoort. Deze dagbladen lieten zich duidelijk opjutten door de herinnering aan vooroorlogse denkbeelden over een door Vlaamsgezinden gedoogde pan-Germanistische infiltratie van Antwerpen.

Vanaf begin november 1914 besefte het gouvernement-generaal dat deze heisa een perfect aanknopingspunt was voor het voeren van zijn völkische propaganda. Daarbij kwam het concept Godsvrede centraal te staan. Met zijn beleid bespeelde de bezetter de zwaktes daarin die de twisten rond de val van Antwerpen blootgelegd hadden. Voor Vlaams gebruik heette het dat de Vlamingen de Godsvrede onderhielden, maar hun ("franskiljonse") tegenstrevers niét. Zij voerden een hatelijke "anti-Vlaamse campagne". Het blijft opmerkelijk dat Vlaamsgezinden, die in de jaren vóór de oorlog zoveel aanvallen van sommige Franstalige dagbladen gewend waren, uitgerekend op een moment dat de Vlaamse beweging amper werd aangevallen plots een anti-Vlaamse samenzwering ontwaarden. Dat bewijst hun overprikkeling: ze percipieerden elke "verdachte" uitlating als een aanval op de Vlaamse beweging, ja op heel Vlaanderen. En dat in een oorlog waarin sommigen vreesden dat een toekomstig bondgenootschap met Frankrijk en het Verenigd Koninkrijk de Belgische politiek in een anti-Vlaamsgezinde richting zou stuwen. Zelfs een ogenschijnlijk detail, zoals de Franstalige weergave van Nederlandstalige plaatsnamen, kon in die context al tot enorme wrevel leiden. De Duitse propaganda zou die gevoeligheden bespelen en werd vanaf de herfst van 1914 door Nederlands- én Franstalige bladen in heel België verspreid. 
Zonder twijfel was de Gazet van Brussel, waarvan de uitgave nog onder Von der Goltz werd voorbereid, vanaf eind november 1914 een zeer belangrijk instrument hiertoe. De rol van Franstalige bladen die onder Duitse auspiciën stonden, verdient daarbij, net als het Oostenrijkse aandeel in de verspreiding van propagandaleugens, een grotere aandacht dan ze tot nog toe in de historiografie kreeg. Er ontstond inderdaad een "polarisering in de Vlaamse beweging”. Maar die was geen gevolg van aanvallen uit de Franstalige vluchtelingenpers, zoals Wende dat meende, maar wel van de Flamenpolitik zelf. ${ }^{15}$ Later beweerden activisten dat La Vérité sur la Capitulation d'Anvers van "vlak na" de val van de vesting dateerde. Misschien herinnerden ze zich daarbij de Duitse geruchten, die de basis van het vlugschrift vormden en inderdaad vroeger werden rondgestrooid. Vanaf medio november 1914 begonnen immers zowel de Duitse als de Oostenrijks-Hongaarse diensten met de constructie van het verhaal dat uiteindelijk tot het pamflet zou leiden. In Oostenrijk werd op 21 november 1914 de kat de bel aangebonden wanneer de correspondent van de Neue Freie Presse in Boedapest meldde hoe toen de Britten Antwerpen in de steek gelaten hadden, de Belgische regering “...der Stadt geradezu herausgefordert habe, um die deutschfreundliche Gesinnung der Bewohnerschaft zu dämpfen und zu vergiften". ${ }^{16}$ Dat narratief werd dan vanaf 26 november 1914 aangepast, aangedikt en aangevuld met de leugen over Franck, Ryckmans en De Vos die in Den Haag gesommeerd waren door twee Belgische ministers van Staat om zich te verantwoorden voor de overgave van de vesting. In de constructie van die propaganda werd gesteund op correspondenten van Duitse dagbladen, verbonden met het gouvernementgeneraal, die gefingeerde berichten naar hun dagbladen doorstuurden. Hun berichten in Duitse dagbladen werden dan als nieuws uit België in collaboratiedagbladen in het bezette land hernomen. De Duitse propaganda-inspanning vond weerklank in bezet België en in Nederland en zo in het Verenigd Koninkrijk en Frankrijk. De vertekende beelden werden tot in den treure toe herhaald, waardoor ze aan geloofwaardigheid wonnen. Eind januari $1915 \mathrm{zag}$ het vlugschrift La Vérité het daglicht. Het putte uit zeer diverse bronnen: de perspolemieken waarvan sprake; de Duitse propaganda die deze polemieken recupereerde; motieven uit de wallingantische propaganda; Bijbelse eschatologie en de Belgische literatuur. Die literaire belangstelling ging gepaard met een gerichte Duitse cultuurpolitiek. Met name de banden tussen Insel Verlag, die de Flamenpolitik een culturele dimensie gaf, het gouvernement-generaal en de firma Krupp springen daarbij in het oog. Belangrijk in de constructie van (en de perspropaganda voorafgaand aan) het pamflet waren ook figuren die al vóór de oorlog in de Belgische pers betrokken waren. 
De Duitse diensten toonden daarbij ook een meer dan gewone belangstelling voor de wallingantische propaganda in het algemeen en voor het tijdschrift La Jeune Wallonie in het bijzonder. Door op de vertrouwdheid van de Vlaamsgezinden hiermee in te spelen, probeerde de bezetter de indruk te wekken dat die wallinganten inderdaad niet alleen nooit rustten, maar integendeel hun activiteit zelfs opdreven in oorlogstijd. Ze wilden zogezegd de Vlaamse beweging afschaffen, België geheel of gedeeltelijk bij Frankrijk aanhechten en het Nederlands kortwieken.

Aanvankelijk had het maandenlange Duitse aandringen op personen binnen de Vlaamse beweging bitter weinig effect. Gerstenhauer beweerde in 1916 terecht: "Eine monatelange Aufklärungstätigkeit, eine Fülle von mühevoller vorbereitender Kleinarbeit ist nötig gewesen, um erst einmal eine Grundlage für das deutsche politische Vorgehen zu schaffen." ${ }^{17}$ Zelfs een aantal flaminganten die zich in het activisme begaven, verklaarden dat het begin van de oorlog de Vlaamse beweging had stilgelegd. Zoveel leiden we tenminste af uit getuigenissen van Karel Angermille, Cyriel Rousseeu en Edgar Rietjens. ${ }^{18}$ Toen Von Bissing in België zijn ambt opnam, stelde hij vast dat er gewoonweg geen Vlaamse beweging meer bestond. ${ }^{19}$ Von der Lancken kwam tot een gelijkaardig oordeel. Onze studie van de Flamenpolitik brengt bewijsmateriaal aan dat de eerdere these van Wils kracht bijzet. Het initiatief voor de Flamenpolitik ging inderdaad overal uit van de bezetter. Slechts onder invloed van zijn maatregelen en daar behoorde massale propaganda toe, ontstonden er activistische kernen. In Gent nam de Duitse militaire overheid het initiatief en ging ze aan de slag met een anti-Belgisch groepje. De Brusselse activistische kern zag pas in juni 1915 schuchter het daglicht. In Antwerpen kende het activisme nog minder succes. Pas in november 1915 was er in de Scheldestad een duidelijke lijn te trekken tussen activisten en loyalisten. ${ }^{20}$ Het lijkt op het eerste gezicht vreemd dat het activisme in Antwerpen niet op grotere schaal doorbrak, want die stad stond toch al erg vroeg in het brandpunt van de perspolemieken van 1914. Zonder twijfel speelde de invloed van de figuur van Louis Franck hier een rol. Samen met zijn Intercommunale Commissie kon hij blijkbaar lange tijd een tegenwicht bieden aan de Duitse Flamenpolitik, ook omdat hij een prominente rol bekleedde in het patriottische Comité National de Secours.

Tijdens de lente van 1915 schakelde de Flamenpolitik een versnelling hoger. In juni van dat jaar beweerde de Gazet van Brussel dat ze de inhoud van La Vérité enkele maanden tevoren niet hoefde te publiceren omdat er geen café in de hoofdstad was waar kelners of meiden geen exemplaren op zak hadden. ${ }^{21}$ Laat dat nog propaganda geweest zijn, het vlugschrift werd net als 
La Politique Belge en het Appel aux Wallons wel degelijk massaal verspreid. En bovenop die pamfletten voegden zich andere vertelsels, zoals het verhaal over de volksvertegenwoordiger Buisset die zogezegd bij het begin van de bezetting aan gouverneur-generaal Von der Goltz was gaan vragen om het Nederlands af te schaffen. We zien drie dwingende redenen waarom die leugen pas vanaf juli 1915 in de verf gezet werd. Ten eerste om het anti-activistisch verzet, dat zich in Nederland en België begon te organiseren, in de kiem te smoren. Voorts, uiteraard, om de Brusselse en andere Vlaamsgezinden in het bezette land tot collaboratie te overhalen. Maar vooral omdat deze onwaarheid de Duitse propagandadoorbraak in Nederland moest bespoedigen. De verspreiding ervan en van het drieluik pamfletten vormden immers een opstap naar een nieuwe doorbraak van de Flamenpolitik via Nederland. De Flamenpolitik was toen al bijna een jaar aan de gang. Het patriottisch enthousiasme van augustus 1914 was bekoeld en had plaatsgemaakt voor de grauwe oorlogsrealiteit. In die context kon de bezetter met meer succes inspelen op de ressentimenten van de Vlaamse beweging en stilaan een klein deel ervan van het Belgische nationale idee losweken. Ondertussen was in mei 1915 ook Italië toegetreden tot de Entente waardoor die voor sommige Vlaamsgezinden allicht een Latijnser karakter verkreeg. Bovendien deed de Belgische regering geen enkele belofte over de positie van het Nederlands na de oorlog. Sommigen redeneerden in die context: de bezetter doet dat wél en op een korte termijn. In Die Importierte Nation beklemtoont Müller terecht het belang van de impuls vanuit het keizerlijk gezantschap in Den Haag voor de Flamenpolitik. Ook beweert de historicus dat nog eind 1915 de Flamenpolitik niet in nauwe coördinatie tussen het gouvernement-generaal in Brussel en het Duits gezantschap in Den Haag gevoerd werd. Soms ageerden ze zelfs tegen elkaar. Zelfs was volgens hem het Duitse bestuur in Brussel begin augustus 1915 niet op de hoogte van het feit dat onder leiding van Von Kühlmann De Vlaamsche Stem door het Duitse gezantschap in Den Haag overgenomen was. ${ }^{22}$ Op grond van ons onderzoek betwijfelen we dit. Naast evidente discussies in oorlogstijd over de te volgen tactiek was er wel degelijk harmonie.

Van kapitaal belang in de ontwikkeling van het activisme, was de Duitse schepping van de Groot-Nederlandse beweging in 1915. In de historiografie is erop gewezen dat de belangrijkste figuur van die Groot-Nederlanders in dit manoeuvre, de Duitse "vertrouwensman" Gerretson zich beriep op de "loyauteitstheorie" uit het ancien régime om de Vlaamsgezinden te overhalen tot collaboratie. Maar de theorie van voorwaardelijke loyauteit vertoonde ook een verwantschap met de door vele Vlaamsgezinden gekoesterde hoop dat de oorlog hun volledig taalrecht zou schenken. Zo schreef zelfs het 
patriottische sluikblad De Vlaamsche Leeuw in 1915 ervan overtuigd te zijn dat op de dag wanneer de eindoverwinning behaald is, "we ook in dezelfde rechten zullen delen". ${ }^{23}$ De Duits-Groot-Nederlandse visie verdraaide dus het gegeven dat Vlaamsgezinden verwachtten dat na het conflict aan hun verzuchtingen op taalgebied gevolg gegeven werd. Dat werd dan: loyauteit aan België hangt af van "eisen" die al tijdens de oorlog door de Belgische overheid moeten ingewilligd worden.

Naarmate de frontbeweging tot bloei kwam, bleek dat ook de taaltoestanden in het leger voor de Duits-activistische propaganda een schier bodemloos vat waren waaruit geput werd om de flamingantische haat tegenover de Belgische staat aan te wakkeren. Met succes, want de Vlaamsgezinde gelederen radicaliseerden over de grenzen van het activisme heen. De fabel dat Vlaamse soldaten sneuvelden omdat ze de bevelen van Nederlandsonkundige Franstalige officieren niet begrepen kwam uit de rangen van de loyale Belgischgezinden voort en werd pas daarna door de Raad van Vlaanderen verspreid. Dat de Vlamingen in het algemeen en de Vlaamse beweging in het bijzonder door de Belgische staat niet alleen cultureel, maar zelfs materieel en fysiek, door de verwoesting van Antwerpen en delen van Vlaanderen bij de bevrijding en het zogenaamd moedwillige doden van Vlaamse soldaten, bedreigd werden, waren twee mythen die elkaar evident versterkten. Ook mag niet uit het oog verloren worden dat de activisten zulke mythen op termijn gingen (of wilden) geloven. Zij die zo verontwaardigd gereageerd hadden op de aanval op Franck, Ryckmans en De Vos, liepen nochtans in realiteit niet hoog op met het drietal. Nadat de drie begin 1916 schriftelijk protest aangetekend hadden tegen de vervlaamsing van de Gentse universiteit, schilderde het activistische blad Ons Land Franck af als een pseudo-flamingant, die thuis Frans sprak. (Borms beweerde trouwens dat hij al in 1915 met de "franskiljons" heulde.) De Vos heette dan destijds de "leider der franskiljons in de gemeenteraad" te zijn en Ryckmans likte slechts "om het sneer de Vlaamse kandeleer". ${ }^{24}$ Maar de activistische of Vlaams-nationalistische aversie tegenover de "franskiljons" was zeer groot. Bovendien was het overleven van de activisten finaal verbonden met de Duitse zege. De drang tot zelfrechtvaardiging wordt dan onweerstaanbaar. Die aandrang zou natuurlijk niet afnemen na de oorlog, toen sommige ter dood veroordeelde activisten om zichzelf te verschonen de "anti-Vlaamse campagne" als "zelfverdediging" voor hun optreden zouden aangrijpen en tegelijk de Duitse inbreng daarin minimaliseerden. Ze bouwden in hun apologie voort op de stelling dat Duitsland gewoon inspeelde op hun vragen, of eenvoudigweg de vooroorlogse wetgeving deed respecteren. Antoon Jacob schreef in De Vlaamsche Stem (8 september 1915) dat niet het 
optreden van de activisten ten voordele van Vlaamse zelfstandigheid maar wel het "onverantwoordelijk zwijgen" van de Belgische regering hierover in lijn met de Duitse belangen lag. Hij beweerde dat dit zelfstandige Vlaanderen een "levenskrachtig België" zou waarborgen. ${ }^{25}$ Zelfs beweerde Borms op zijn proces, in lijn met Jacob, dat de activisten "onrechtstreeks voor België [...] werkten". ${ }^{26}$ Het valt inderdaad op dat het activisme door protagonisten ervan afgeschilderd werd als een actie die zich inschreef in de vooroorlogse vaderlandslievende Vlaamse beweging. Laat dat dan nog allemaal deels zelfverdediging geweest zijn, toch blijft het opmerkelijk dat zelfs radicale activisten hun toevlucht zochten in een niet anti-Belgisch discours. ${ }^{27}$ Er was dus zeker nog een Belgisch bewustzijn aanwezig bij hen. ${ }^{28}$ Wils schrijft dat het feit dat een groot aantal flaminganten (zoals Faingnaert) geloof hechtten aan verhalen over "Waalse aanvallen" - dus over de vermeende anti-Vlaamse campagne - wijst op een zwakte van hun Belgisch natiegevoel. Dat klopt. Maar dat ze hun optreden op die manier ook jaren na de oorlog nog wilden legitimeren, ja hun onschuld wilden uitschreeuwen wijst er toch ook op hoe sterk dat natiegevoel nog was.

De Duitse bezetter probeerde in zijn voorstelling overigens de visie dat Duitse en Vlaamse belangen "gewoon" parallel liepen met mekaar te beklemtonen. Zo meldde Von Falkenhausen, de derde gouverneur-generaal van België, nog in juni 1918 aan de Commissie van Gevolmachtigden, de uitvoerende tak van de Raad van Vlaanderen, "daß in Flandern die Uberzeugung von der weitgehenden Ubereinstimmung der flämischen und der deutschen Interessen sich immer klarer und fester gestaltet". ${ }^{29}$ Amper twee maanden na de wapenstilstand lezen we in een anonieme activistische apologie een nagalm van die stelling: "dat [het] Duits belang met het Vlaams belang parallel liep, was nu wel niet onze schuld!” De schrijver liet daarbij anderzijds niet na te vermelden dat uit de houding van Duitsland "het activisme geboren" werd. ${ }^{30}$ Reeds tijdens de oorlog had Borms dit in een redevoering voor de Raad van Vlaanderen nog krasser verwoord: "zonder Duitsland, bestaat het activisme niet!"31 Zonder twijfel beseften sommige activisten wie de échte stichters waren van hun stroming, net zoals ze wisten dat Franck niet met de "franskiljons" heulde. Hun eigen "verdedigingsnarratief" tegen de "franskiljons" zal aanvankelijk maar deels geloofd zijn. Slechts na verloop van tijd raakten ze ervan overtuigd dat het de enige verklaring was voor hun optreden tijdens de oorlog. Dit narratief sijpelde door naar de historiografie die aanknoopte bij de activistische propaganda.

Hoewel er intussen méér dan honderd jaar verstreken zijn sedert de gebeurtenissen die we hier beschreven hebben, betreft het geen afgehandeld 
dossier. De reden is de enorme politieke impact van de Eerste Wereldoorlog op de Belgische staat. De historicus en politicus Bart De Wever beweerde in 2017 dat er met het activisme "binnen de Vlaamse beweging een nationalistische vleugel [ontstond] die voor het eerst staatkundige eisen formuleerde". 32 Die eisen waren tijdens de oorlog niet van een andere aard, noch op een andere manier verkregen als de "verzoeken" uit Tsjecho-Slowakije aan de Sovjet-Unie in 1968 om het land te komen "redden", zoals Lode Wils opmerkte. ${ }^{33}$ Maar dat neemt niet weg dat er met het activisme inderdaad een anti-Belgisch nationalisme in de schoot van de Vlaamse beweging ontstaan was. Het was dit nationalisme waarop Wichert doelde, toen hij het had over de voor de Vlaamse beweging volledig "nieuwe principes" die Deswarte eind juni 1915 begon te verdedigen. De verregaande impact van de Flamenpolitik ontging tijdgenoten niet. Zo schreef Whitlock in 1919 hoe de Duitsers lang vóór hun aankomst op de hoogte waren van alle politieke en sociale stromingen in België. Volgens hem bestudeerde de Politische Abteilung die vraagstukken met "een minutieuze zorg en een machiavellistische schranderheid". De bedoeling was duidelijk: "de [...] wig [drijven] die, naar zij hoopten, de Belgische bevolking zou verdelen en hen in staat moest stellen de ziel zelf van de [Belgische] natie [...] te doden..." ${ }^{34}$ [B.Y.]

Net in het drijven van een wig in België kan de rol van propaganda nauwelijks overschat worden. In Aan het Vlaamsche volk! (1917), het drukwerk waarmee de Raad van Vlaanderen zich voorstelde aan de bevolking, leest men al op de eerste bladzijde over de "onrustbarende geruchten" die niet lang na het uitbreken van de oorlog opgingen betreffende de toekomst van het Vlaamse volk en die inzonderheid tegen Antwerpen en het stadsbestuur geuit werden. ${ }^{35}$ Op 11 juli van datzelfde jaar stond in de Open Brief van de frontbeweging hoe men "vlakaf [...] stukken [durft te] verspreiden waar Antwerpen beschuldigd wordt van verraad en de Vlaamsgezinden de schuld van alles dragen". ${ }^{36}$ Nog een halve eeuw na het conflict verklaarde Picard: "het leek of Antwerpen door de flaminganten aan de Duitsers overgeleverd was. ${ }^{37}$ Die uitspraak deed hij omdat hij geloofde, of wilde geloven, dat de "franskiljons" vanaf oktober 1914 een campagne voerden tegen Antwerpen. De oorlogspropaganda was blijkbaar onderdeel van het nationalistische collectieve geheugen geworden.

In de geschiedschrijving die zich aan deze voorstelling laafde en ze legitimeerde, speelde de besproken brochure Aan het Vlaamsche Volk van H.D Mommaerts (niet te verwarren met de gelijknamige brochure van de Raad van Vlaanderen uit de voorgaande paragraaf) een zeer belangrijke rol. ${ }^{38} \mathrm{De}$ beweringen erin geven echter een volledig vertekend beeld van de situatie. 
Ze werden niettemin overgenomen in de historiografie en sommige ervan worden tot op heden herhaald. Propagandistische voorstellingen hebben de kwalijke gewoonte om niet te verzwakken, maar net versterkt te worden doorheen de jaren. Misschien ligt net daarin hun grootste kracht. Ze worden aangedikt, "gecorrigeerd" met andere onwaarheden en de oorspronkelijke bronnen worden niet meer geraadpleegd. Ook vandaag vindt men in wetenschappelijke werken voorstellingen terug die op propagandistische leest geschoeid zijn. Zo beweert Koen Hulpiau in de Nieuwe Encyclopedie van de Vlaamse Beweging (NEVB) onder het lemma Gazet van Brussel het volgende:

Vanaf zijn verschijnen [...] nam het blad een gematigd politiek standpunt in: 'Vlaamse Belgen willen wij zijn en blijven.' Over het oorlogsgebeuren wilde het onpartijdig informeren. Dat geschiedde soms kritisch voor de geallieerden en mild voor Duitsland. Duitsgezind toonde de krant zich aanvankelijk niet, maar financieel door de bezetter gesteund, publiceerde zij ook geen onwelgevallige bijdragen. ${ }^{39}$

Wetende dat dit Duitse blad het belangrijkste hoofdstedelijke propagandaorgaan van de Flamenpolitik was, dat vanaf zijn eerste editie uitsluitend de geallieerden aanviel, is deze voorstelling van zaken onthutsend. Vrints en Seberechts schrijven dan weer dat de bezetter de Vlaamsgezinde eis om de universiteit van Gent te vernederlandsen inwilligde. ${ }^{40}$ Nochtans werd die beslissing tot vernederlandsing door de bezetter eind 1914 buiten elk flamingantisch ingrijpen om genomen. De Politische Abteilung heeft dit gegeven zelfs niet verhuld. ${ }^{41}$ Vanacker beweert dat de activisten een "fraai palmares" konden voorleggen, met onder meer een volledig vernederlandste universiteit van Gent en een "federalistische staatshervorming". ${ }^{22}$ Maar dat "palmares" was op het conto van de bezetter te schrijven. De reden van de sterke doorwerking van allerlei mythen is dat tot de jaren 1960 Vlaams-nationalisten zowat het monopolie op de geschiedschrijving van de Vlaamse beweging bezaten.

Nog tot dat nationalistisch geschiedverhaal behoort de "schepping" van België door de grootmachten in 1830, als eentalige staat, die het Nederlands wou "uitroeien". Els Witte schrijft in de Nieuwe Geschiedenis van België over het "ontstaan" van België in 1830. ${ }^{43}$ Akkoord, wanneer men aanvaardt dat Frankrijk in 1958 of Duitsland in 1990 "ontstond". Dat zijn immers de data van hun twee meest recente staatsvormen. ${ }^{44}$ Verderop beweert dezelfde auteur dat de "stichters" (sic) van België geen meertalig land wensten. Gubin en Nandrin benadrukken in hetzelfde werk "het axioma van de taaleenheid 
als cement van de natie". ${ }^{45}$ Een enigszins vertekend beeld, want België was tijdens de negentiende eeuw geen Franstalige staat. De Grondwet bepaalde (en bepaalt) dat het gebruik der in België gesproken talen vrij was en enkel maar door de wet geregeld kon worden voor bestuurs- en gerechtszaken. Indien de elite 's lands eenheid wou cementeren middels het gebruik van het Frans, dan kon ze de streektalen efficiënt gefnuikt hebben. Maar zelfs een maatregel invoeren als de leerplicht om zo de Franse taal te verspreiden, zat er niet in. Die werd pas 84 jaar ná de Belgische onafhankelijkheid geïmplementeerd, toen de wettelijke vernederlandsing van het onderwijs zich al grondig doorgezet had. De visie over de Franstalige, Vlaamsonvriendelijke staat werd al in de laatste decennia van de negentiende eeuw door (sommige) Vlaamsgezinden beleden en gevoegd bij een eenzijdige ophemeling van het Verenigd Koninkrijk der Nederlanden waar de volkstaal dan wel zou gefloreerd hebben. De Duits-activistische propaganda versterkte het beeld van dat "Franstalige" en "anti-Vlaamse" België enerzijds en die Dietse sentimenten anderzijds.

De anti-Belgische Duitse Flamenpolitik verscherpte het Germaans-völkische bewustzijn bij een segment van de Vlaamse beweging. Zo ontstond er, zeer geleidelijk, onder Duitse invloed een Vlaams-nationalistische stroming met een anti-Belgische inhoud. In een conflict waarin overal nationalismen naar ongeziene hoogten gestuwd werden, kwamen de begrippen Vlaanderen en België zo, bij een deel Vlaamsgezinden, frontaal met elkaar in botsing. Er ontstond ook na de oorlog een "separatistische Vlamenpartei", dat het "Vlaams comité van Leiden" al in oktober 1915 als oplossing naar voren schoof in geval van een Duitse nederlaag. ${ }^{46}$

De Amerikaanse diplomaat G.F. Kennan, die jaren in de Sovjet-Unie en in nazi-Duitsland verbleef, beschreef later de Eerste Wereldoorlog als "de grote oercatastrofe van de twintigste eeuw", met het nationaal-socialisme en het Russische communisme die "in overweldigende mate de producten waren van die eerste grote holocaust van 1914-18". ${ }^{47}$ [B.Y.] Zonder de Eerste Wereldoorlog is het moeilijk om zich voor te stellen hoe die totalitaire regimes zich zouden vestigen om vervolgens tientallen miljoenen doden in de rest van de twintigste eeuw te maken. Neem de Eerste Wereldoorlog weg en er zou ook nooit een onstabiel Midden-Oosten ontstaan zijn zoals we dat vandaag kennen. Nooit zou ook het verval in macht van de Europese grootmachten die in 1914 samen een reusachtig gedeelte van het aardoppervlak beheersten zo abrupt en dramatisch geweest zijn. Maar hoe men de gevolgen van de Eerste Wereldoorlog beoordeelt, is toch ook weer subjectief. Zo is het bijvoorbeeld moeilijk om zich in te beelden dat de meeste Polen de Eerste 
Wereldoorlog betreuren. Zonder dat conflict was het bijna ondenkbaar dat dit land na meer dan een eeuw verdeeld te zijn opnieuw op de landkaarten zou verschijnen.

Het oordeel over Flamenpolitik en activisme wordt dus ook bepaald door hoe men tegenover de toekomst van België aankijkt. Voorstanders van een splitsing van België kunnen beide vanwege de stimulans die ze gaven aan een anti-Belgisch nationalisme eigenlijk geen "oercatastrofe" vinden. ${ }^{48}$ De breuk in de Belgische geschiedenis die in de zomer van 1914 begon, is vandaag het voorwerp van historisch onderzoek. De gevolgen behoren tot het onderwerp van een politieke discussie. De echte uitkomst van de Flamenpolitik is nog steeds onbekend. 


\section{NOTEN}

Sommige dagbladen, tijdschriften, bronnen of werken staan in de bibliografie als volgt aangeduid: Naam Bron [= NB]. In de eindnoten werd dan NB weerhouden.

\section{Algemene inleiding}

1 In de lopende tekst van het boek zelf hebben we een vertaald citaat steeds aangegeven met onze initialen: [B.Y.]. Wanneer er $B Y$ staat, betekent het dat het om onze commentaar gaat.

2 WILS, 2014, 164.

3 Voor wat volgt, zie, behoudens tegenstrijdige verwijzing, YAMMINE, 2011, 11-32, 315-342; WILS, 1992, 65-82.

$4 \quad$ HVN, 8 augustus 1918, 1-2.

5 Al die stellingen, ook dat de Vlaamsgezinden vóór 1914 niet de indruk hadden dat "de Duitsers" hen steunden, vindt men tot op heden in wetenschappelijke werken terug, zie bv. VANACKER, 36.

6 Gerechtigkeit, I, januari 1919, 629; FAINGNAERT, 316, 764; VON DER LANCKEN, 212.

$7 \quad$ NEVB, 126.

8 Activisten, 42-43.

9 HEYSE, 74.

10 PIRENNE, 207-221.

11 BASSE, 165, $47(2)$.

12 FAINGNAERT, 73-74.

13 WILLEMSEN, 1958, 3; WILLEMSEN, 1969, 29-30.

14 WILLEMSEN, 1958, 14, 3; WILLEMSEN, 1969, 40, 30. Volgens de auteur maakte de oorlog wel radicaal een einde aan die "vage germanofilie", WILLEMSEN, 1958, 15; WILLEMSEN, 1969, 41-42. 
WILLEMSEN, 1958, 14-15. In WILLEMSEN, 1969, 40 werd toegevoegd dat het Alldeutscher Verband zich tijdens de oorlog niet onbetuigd liet.

WILLEMSEN, 1958, 14-15; WILLEMSEN, 1969, 41.

ELIAS, 30. Voor de inspiratie van de auteur zie de gelijkaardige beweringen in PETRI, 1966, 528, vgl. het zeer apologetische PETRI, 1968, 325-328.

ELIAS, 97.

ELIAS, 101.

WENDE, 1969, 75 .

Gedenkschriften, 265.

WILS, 1974, 259, 328.

WILS, 1974, 29.

WILS, 1974, 259, 328, 255, 322.

ELIAS, 23.

VRINTS, 2002, 369.

YAMMINE, 2011; YAMMINE, 2013, 12-45.

WILS, 2015, 18-19.

WILS, 2014, 41-51, 153; WILS, 2015, passim.

DOLDERER, 2014, 289, 291, 294-298.

MÜLLER, 2020, 16-18, 36-39, 57, 314-316, vgl. WILS, 2014, 131-162.

[MOMMAERTS], 1, 3-14, vgl. [DE CONINCK], 33-45

De "Proclamatie van de Vlaamse volksraad" (hoofdstuk 2, par. 1) was het enige wat FAINGNAERT, 19, toevoegde an [MOMMAERTS].

Werden overgenomen: het citaat "après la guerre..."; La Vérité; de bewering dat het Journal des Réfugiés (een blad uit de vluchtelingenpers) vanaf 20 oktober 1914 aanvallen tegen Franck als Vlaamsgezinde lanceerde; de redevoering van Maeterlinck en de de artikels van Colleye en Harry, Activisten, 1919, 1-2, 85 (1), (2), 117-119.

BASSE, 165-166, had het over La Vérité, de redevoering van Maeterlinck en de artikels van Harry en Colleye.

FAINGNAERT, 14-19, 33-35, 56-57, 63-65, 130.

Gedenkschriften, 265.

PIRENNE, 214.

WILLEMSEN, 1958, 1-3; WILLEMSEN, 1969, 28-30; ELIAS, 16-17.

WILLEMSEN, 1958, 3 (1), vermeldde het "après la guerre..." in de lopende tekst, vgl. WILLEMSEN, 1969, 29 (3); ELIAS, 16 (1).

WILS, 1974, 19-26, 40-51; WILS, 2014, 30-39, 59-72.

WILLEMSEN, 1975, 22-26.

BUNING, 1979, 97 (vgl. FAINGNAERT, 27-28); VAN HAEGENDOREN, 269.

VANACKER, 2006, 19-20, 42.

VAN VELTHOVEN, 91-95.

SEBERECHTS, 71.

VANACKER, 2006, 18.

GVB, 28 juni 1915, 1.

Vgl. de vraagstelling in WILS, 1974, 19. 
50 Wel onderzocht SCHEPENS, 1983, 48-49 de eerste oorlogsmaanden van Le Vingtième Siècle.

51 AMARA, ROLAND, 63-64.

52 WILS, 2014, 72 (28).

$53 \mathrm{AB}$, april $1915,1$.

54 Voor wat de drie pamfletten betreft, hebben we een facsimile afbeelding opgenomen, zie afbeeldingen 12, 16 en 17.

\section{Hoofdstuk 1: Het vooroorlogse spanningsveld}

1 Voor wat volgt, zie, behoudens tegenstrijdige verwijzing, YAMMINE, 2011, passim; YAMMINE, 2013, 12-45; WILS, 2015, 216-237.

2 Toen Von der Goltz in 1916 stierf, volgde Von Bissing hem op als voorzitter van de Jungdeutschlandbund, VON DER GOLTZ, 335 (2).

3 Bayreuther Blätter, jg. 17, 1894, 350.

$4 \quad$ Allgemeine Zeitung, 23 mei 1898, 9.

5 Dietsche Warande en Belfort, 1900, 93, 196, 287-288, 300-301, 400, 405, 508-509, 518-519, 744-745; 1901, 98, 102, 208-209, 247, 313, 410-11, 420, 517, 543, 664; 1902, 88, 130-131, 184-185, 243, 294, 357-358, 412, 474-475, 525, 593-594; $1903,96-97,105,210,243,317,328-329,442-443,544,569-570,686 ; 1904,87$, 93, 196, 205-206, 290-291, 397-398, 420-421, 505, 615; 1905, 80-81, 281-282, 393, 396-397, 488, 491, 589-590.

6 Courrier de L'Escaut, 30 mei 1906, 2.

7 NEVB, 2521.

8 WILS, 1994, 262.

$9 \quad$ WILS, 2014, 160.

$10 \quad$ WILS, 2004, 135-136.

11 WILS, 2009, 28.

12 FREDERICQ, 1906, 8-9.

13 WILS, 2009, 171-172.

14 Neerlandia, augustus 1896, 3-4; februari 1897, 7-8; oktober 1896, 1-2; januari 1897, 6; september 1897, 13; april 1898, 1-3; mei 1898, 4; juni 1899, 3; september 1899, 1-2; november 1898, 6; 1901, 26-27; 1904, 20, 122; 1907, 4 .

$15 \quad$ Neerlandia, 1908, 241-242.

16 WILS, 2005, 187.

17 BALTHAZAR, VAN CAMPENHOUT, 247-248.

18 DELFORGE, 15-36; WILS, 2005, 185-195.

19 Het Handelsblad, 12 maart 1910, 1; Le Patriote, 12 maart 1910, 1-2; Journal de Bruxelles, 12 maart 1910, 1; Journal de Bruxelles, 13 maart 1910, 2; LPB, 13 maart 1910, 1-2; HLN, 13 maart 1910, 3.

20 DESTREE, 21-23.

21 THOOFT, passim; LOYEN, passim.

22 CAESTECKER, 323-349.

23 DE CORTE, 193, 234-235, 244-245, 248. 
Le Bien Public, 19 februari 1886, 2; LVS, 29 augustus 1904, 1; LM, 2 maart 1917, 3; Belgisch Dagblad, 12 februari 1918, 1.

LVS, 3 september 1904, 1.

DE BACKER, VAN CAMP, 39-40; DEGLAS, 23-24; Le Peuple, 8 september 1889, 1-2; Courrier de L'Escaut, 8, 10 september 1889, 1-2; Le Peuple, 22 november 1889, 1-2; Le Peuple, 24 november 1889, 2; Courrier de L'Escaut, 24 november 1889, 2; LIB, 28 november 1889, 3; HLN, 7 februari 1894, 4; LIB, 18 februari 1890, 2; Journal de Bruxelles, 7 maart 1901, 1; Journal de Bruxelles, 7 maart 1901, 1. NOWELL, 59-61; L'Echo des Mines, 1907, 568.

Neptune, 21 maart 1914, 5.

WHITLOCK, II, 212; Journal d'Anvers, 16 januari 1914, 5; La Semaine, 20 januari 1914, 4; La Semaine, 17 februari 1914, 5; La Semaine, 10 maart 1914, 4; Le Soir, 10 maart 1914, 4; Le Mercure Anvers-Bruxelles, 12 maart 1914, 4; Journal d'Anvers, 24 april 1914, 3; Journal d'Anvers, 17 juli 1914, 3; LIB, 15 juli 1916, 3; Les Nouvelles, 17 februari 1918, 2; De Telegraaf, Ochtendblad, III, 16 januari 1936, 5.

Het Handelsblad, 13 januari 1910, 2.

DE BACKER, VAN CAMP, 39-40.

DE CORTE, 193, 234-235, 244-245, 248; LEYSEN, BOEHME, 19-20.

LIB, 24 december 1907, 2; Le Matin, 19 januari 1914, 2.

Deutsche Wochenzeitung, 17 april 1914, 13-14; LM, 28 april 1914, 4.

VAN UFFELEN, 218; VRINTS, 2002, 57; Het Handelsblad, 1 december 1913, 5. BITSCH, 398-400.

WILS, 1963, passim; DE SMAELE, passim; DE MUELENAERE, 120-123; DE MAEYER, 386-396.

BITSCH, 398-400.

LUCIEN, 71-72.

CHAVASSE, 97-100; EEKHOUD, 1893, 170-171.

Globus, 1895, 237-241; 1899, 217-222; 1899, 21-24, 43-45.

ROLAND, 1996, 193-194; HAMMERN, 67-82, 75 (1); DE CORTE, 257 (3).

FRECH, 178-180; Frankfurter Zeitgemässe Broschüren, 1902/03, 141-176; KELLEN, KRUPP, 1904; EPKENHANS, STREMMEL, 17.

HAMMERN, 67-82.

LJW, februari 1911, 38 .

LJW, maart 1911, 1-5; april 1911, 14.

LJW, mei 1911, 41.

LJW, juni 1911, 34.

LJW, juli 1911, 41.

De Tiendaagse veldtocht (1831) waarbij Nederland probeerde België te heroveren, liep faliekant af. Wel behielden de Nederlanders voorlopig Antwerpen. Frankrijk snelde eind 1832 te hulp, ROVERS, 51-69; LJW, november (?) 1912, 28.

51 LPB, 6 maart 1912, 2. Het betrof een dispuut tussen de Liberale Volksbond, de Ligue Libérale en L'Association Libérale voornamelijk over de aanduiding van kandidaten die voorstander van de vernederlandsing van de Gentse universiteit waren, HLN, 5 maart 1912, 1.

$52 \quad$ LJW, april 1912, 1-3. 


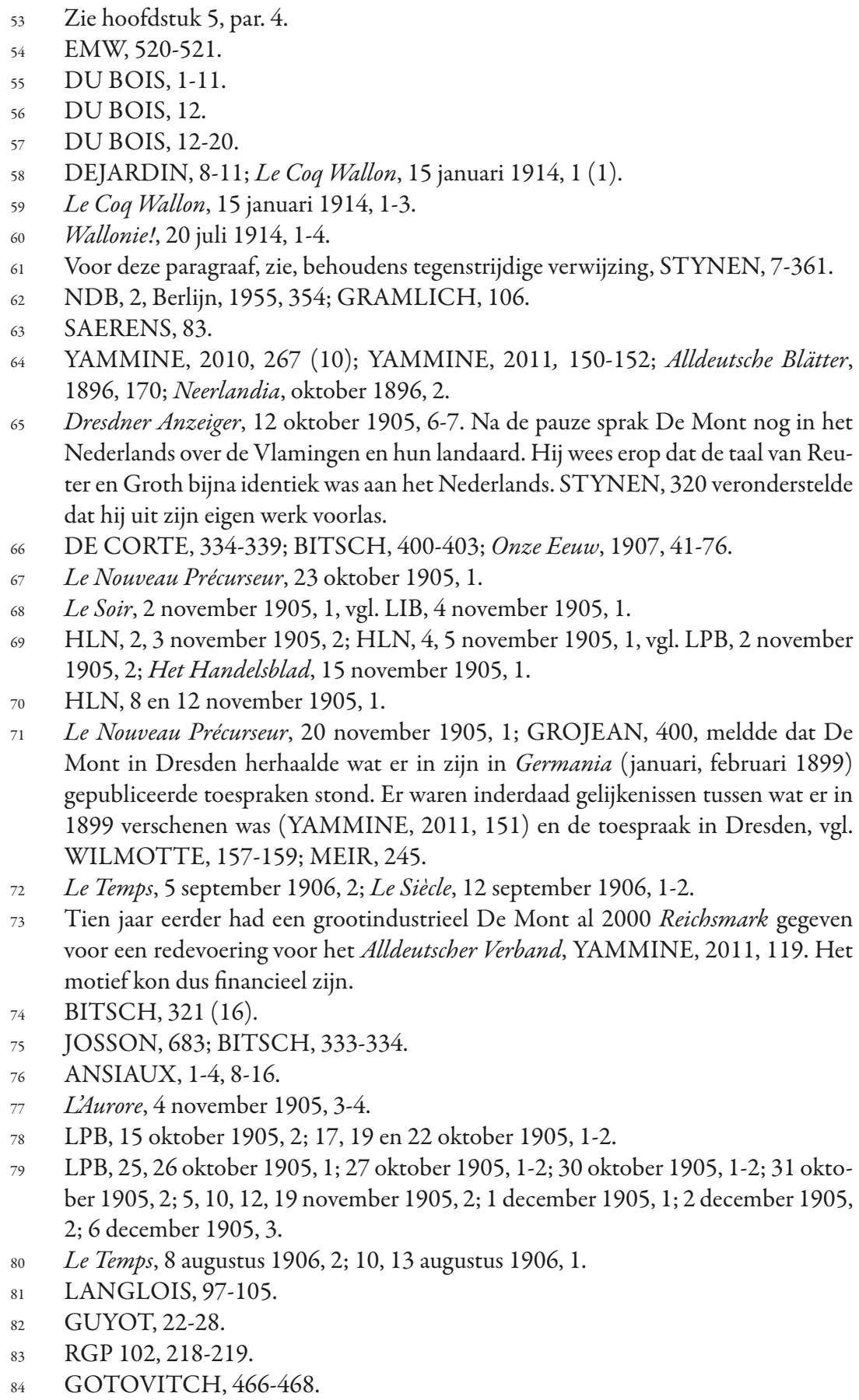




\section{Hoofdstuk 2: De Godsvrede tot de val van Antwerpen}

EGELHAUF, 37-38.

2 HV, 5 augustus 1914, 1.

3 DE SCHAEPDRIJVER, 72-73, 320-321; CLARK, 635.

4 KRETHLOW, 424, 442.

5 DEVLEESHOUWER, 287. Het parket onderzocht de zaak, maar wegens het uitbreken van de oorlog bleef dat zonder gevolg, LEB, 6 oktober 1915, 1.

6 LPB, 2 augustus 1914, 1.

7 LIB, 7 augustus 1914, 1.

8 GVB, 21 januari 1915, 1.

, DELFORGE, 132 (34).

10 De activistische vertaling van "orgueil" was "hoogmoed". Het betekent hier evenwel "trots".

11 CROMBOIS; La Chronique, 8 augustus 1914, 1.

12 [MOMMAERTS], 4-5; Le Soir, 9 augustus 1914, 2 en 13 augustus 1914, 1.

13 WILS, 2014, 181-182.

14 GVB, 17-18 januari 1915, 1, vgl. 6 februari 1915, 3; [DE CONINCK], 34-35.

15 BITSCH, 274-283; WILLEQUET, 390-395, 402, 418-421, 423-427.

16 FAINGNAERT, 19; ELIAS, 16; BUNING, "De vooravond en het begin", 1973, 197; YAMMINE, 2013, 41; Le Soir, 20 augustus 1914, 1.

17 Daudet verkocht er 12.000 exemplaren van vóór de oorlog en alleen al in het tweede deel van 191440.000 (LE NAOUR). DAUDET, VIII-IX.

18 LM, 19 t.e.m. 21 augustus $1914,1$.

19 LM, 22 augustus 1914, 1.

20 De Broederhand verscheen in 1845 en 1846, YAMMINE, 44-50.

21 Hieruit blijkt dat het artikel niet de Vlaamse beweging veroordeelde, (WILS, 2014, 61).

STREUVELS, 143-144. Tijdens de oorlog schreef Streuvels de kroniek In Oorlogstijd. Stukken ervan verschenen in de activistische pers. Dat vormde stof tot polemiek, WILS, 2014, 26-30.

23 SCHEPENS, 1985, 52; LM, 23 t.e.m. 27 augustus 1914, 1 en LM, 30 augustus 1914, 1; 5, 9, 11, 12, 14, 22, 26 t.e.m. 28 september 1914, 1.

24 VRINTS, 2005, 47-63.

25 HLN, 26 augustus 1914, 1. 
26 [MOMMAERTS], 6-7; FAINGNAERT, 19.

27 HLN, 21 augustus 1914, 1; VANACKER, 1985, 3.

28 HLN, 22 augustus 1914, 1-3; HLN, 23 augustus 1914, 1; Vooruit, 22 augustus 1914, 2. Het blad meldde dat de gevluchte censuur op 19 augustus 1914 verboden had dit af te drukken. Door te suggereren dat er Franse troepen waren te Luik, wilde Duitsland de indruk wekken dat het een preventieve aanval uitvoerde. WILS, 1974, 40-41 over het verbod om de val mede te delen. Pas later gaf Het Volk toe dat Luik gevallen was, HV, 31 augustus 1914, 3.

29 HLN, 22 augustus 1914, 1; HV, 23 augustus 1914, 1.

30 HV, 24 augustus 1914, 3; De Gentenaar-De Landwacht, 25 augustus 1914, 1. VANACKER, 1985, 5-8; HLN, 25 augustus 1914, 1. De Gentse hoogleraar Paul Fredericq meende terecht dat de uitval van een Vlaamsgezinde die zich afvroeg of België niet beter de zijde van Duitsland gekozen had, het gevolg was van het "onhandig" artikel uit Het Laatste Nieuws d.d. 22 augustus 1914, DPF, 38, 163164. Het anti-Franse sentiment bij de flaminganten was zeker niet algemeen, Het Nieuws van den Dag, 24 augustus 1914, 1-2.

31 Vooruit, 25 augustus 1914, 1; Vooruit, 26 augustus 1914, 3.

32 HLN, 22 augustus 1914, 1; LFL, 24 augustus 1914, 1.

33 LFL, 2 september 1914, 1; HLN, 3 september 1914, 3.

34 VANACKER, 1985, 6-7; HLN, 26 augustus 1914, 1. G.D. Minnaert, voorzitter van het Willemsfonds, hekelde in Het Volksbelang (29 augustus 1914, 1) de querulanten en riep op om de Godsvrede na te leven.

35 VANACKER, 1985, 6-7.

36 In Vooruit, 14 augustus 1914, 2 werd nog getwist over een artikel in het katholieke Fondsenblad van 28 juli. Het blad gispte onder meer dat de flaminganten eentalig Nederlandse straatnamen eisten. In Vooruit, 13 oktober 1914, 3 (op 9 oktober door de Belgische censuur geschrapt) had Camille Huysmans zich in een resem klachten terloops laten ontvallen dat er voor de arme Vlaming vóór de oorlog geen taalgelijkheid was. HLN, 3 september 1914, 3 had medegedeeld, dat de plakbrieven voor vluchtelingen "in het Vlaamse Knokke" uitsluitend in het Frans opgesteld waren, HLN, 3 september 1914, 3.

37 De verbinding tussen "Vlaams" en "Belgisch" kwam veelvuldig terug, HLN, 6 augustus 1914, 1; HLN, 14 augustus 1914, 3; HLN, 15 augustus 1914, 2; HLN, 19 augustus 1914, 4; HLN, 22 augustus 1914, 2-3; HLN, 10 september 1914, 1; Le Bien Public, 2 september 1914, 2; Het Volksbelang, 15 augustus 1914, 2.

38 Dus geen 80 procent dus zoals de latere flamingantische propaganda zou beweren. HLN, 13 augustus 1914, 3, overname uit Excelsior, 6 augustus 1914, 2.

\section{Hoofdstuk 3: Perspolemieken in de nasleep van de val van een "onneembare" vestiging}

1 MAES, passim; MULS, passim; MERTENS, 1977, 335-336; MERTENS, 1978, 399-418. 
Le Matin, 16 augustus 1914, 1; LPB, 17 augustus 1914, 1; LFL, 18 augustus 1914, 3; LIB, 18 augustus 1914, 3; Het Nieuws van den Dag, 18 augustus 1914, 3; HV, 19 augustus 1914, 2; Fondsenblad, 18 augustus 1914, 1; Vlaamsche Gazet, 18 augustus 1914,1 . Le Peuple, 11 augustus 1914, 3; Gazet van Antwerpen, 12 augustus 1914, 1; LVS, 12 augustus 1914, 2; Vooruit, 12 augustus 1914, 2.

LM, 7 oktober 1914, 1; Vooruit, 8 oktober 1914, 1; Journal de Gand, 8 oktober 1914, 1; Fondsenblad, 8 oktober 1914, 1; De Nieuwe Gazet, 9 oktober 1914, 1-2; HV, 9 oktober 1914, 2 en 11, 12 oktober 1914, 1; LFL, 9 oktober 1914, 3; Journal de Gand, 10 oktober 1914, 1; LFL, 7, 10, 12 oktober 1914, 1 en 11 oktober 1914, 2; Gazette van Gent, 9, 11, 12 oktober 1914, 1; De Gentenaar, 12 oktober 1914, 2; Vooruit, 12 oktober 1914, 1; De Nieuwe Gazet, 12 oktober 1914, 1; Gazette de Gand, 12 oktober 1914, 1.

7 Een Intercommunale Commissie was het niet. Ze bestond bijna uitsluitend uit Antwerpse politici, bankdirecteurs, zakenlieden en zelfs een geestelijke, MERTENS, 1977, 332-334. ring. Dat de Commissie met de goedkeuring van de regering ageerde of grootmoedige capitulatievoorwaarden bedongen had, noemde hij een verzinsel. 1914, 1; LM, 3, 12, 13, 20, 21 november 1914, 1; LM, 29 december 1914, 1; LEB, 23 oktober 1914, 1; LEB, 5, 12 november 1914, 1; LIB, 26 oktober 1914, 1; LIB, 28 oktober 1914, 2-3; LIB, 2 november 1914, 4; LIB, 9 november 1914, 2; LIB, 14 december 1914, 2.

22 AT, 29 oktober 1914, 1.

23 WILS, 2014, 67; LM, 14 november 1914, 1; LVS, 20 november 1914, 1.

$24 \quad$ JDR, 17 oktober 1914, 1, 2; MERTENS, 1977, 337.

25 JDR, 17 oktober 1914, 1, 2.

26 PENNELL, 110-113.

27 The Daily Mail, 17, 19 en 22 oktober 1914, 3; The Daily Mail, 23 oktober 1914, 4. 
De "sic" was een toevoeging van de auteur of van het dagblad. JDR, 18 oktober (b) 1914, 1, 2. Van het JDR, 18 oktober 1914 waren er twee edities, hier (a) en (b) genoemd: (a) had als hoofdartikel Le Vertu du nationalisme; (b) had als hoofdartikel "Remember Antwerp!".

JDR, 22 oktober 1914, 2.

Rotterdamsch Nieuwsblad, V, 26 oktober 1914, 2. B.J. Gerretson was de vader van de Groot-Nederlander en latere Duitse vertrouwensman F.C. Gerretson, BWN, III, Den Haag, 1989, 193.

JDR, 21 oktober 1914, 1, vgl. LEB, 13 december 1914, 1.

JDR, 21 oktober 1914, 2.

JDR, 21, 22 oktober 1914, 1.

De Grondwet, II, 24 oktober 1914, 3; Algemeen Handelsblad, 26 oktober 1914, 1.

Provinciale Noordbrabantsche en 's Hertogenbossche Courant, 17 oktober 1914, 2; WILS, 2014, 71.

AT, 27 oktober 1914, 1; JDR, 27 oktober 1914, 1.

Neues Wiener Journal, 28 oktober 1914, 7; JDR, 18 oktober (b) 1914, 2.

Het Journal had geërgerd gemeld hoe enkel te Antwerpen dagbladen opnieuw verschenen (quod non), JDR 18 oktober (b) 1914, 2.

AT, 21 oktober t.e.m. 24-25 oktober 1914, 1; 27 oktober t.e.m. 29 oktober 1914, 1; 31 oktober-1 november 1914, 1; 2 november 1914, 1; 6 t.e.m. 9 november 1914, 1; 14-15, 17, 19, 30 november 1914, 1; 5-6, 7, 9, 10, 11, 19-20, 28 december 1914, 1; 12, 19 januari 1915, 1; Positieve artikels (over Belgische dignitarissen) stonden in AT, 15, 18 december 1914, 1. Sporadische neutrale berichtgeving over de vluchtelingen vindt men in AT, 7 en 14 januari 1915, 1.

AT, 26 oktober 1914, 1.

AT, 3 december 1914, 1, vgl. AT, 4 januari 1915, 1.

AT, 18 november 1914, 1; AT, 7 januari 1915, 1.

Voor gelijkaardige stukken, cf. Vooruit, 15, 16 september 1914, 2. Die werden echter vóór de val van Antwerpen gepubliceerd en leidden mede daarom niet tot een polemiek. Er was bovendien op dat moment geen vluchtelingenpers.

JDR, 23 oktober 1914, 2.

JDR, 24 oktober 1914, 1.

WILS, 2014, 68; De Vlaamsgezindheid van Franck en Van Cauwelaert werd vóór de oorlog door Le Matin al gegispt. Wel had Franck applaus gekregen voor zijn verdediging van het liberale programma tegen het ontwerp van de katholieke schoolwet, Le Matin, 14 februari 1914, 2; Le Matin, 28 april 1914, 3.

Gedenkschriften, 256; WILS, 2014, 68.

De Stem uit Belgie, 30 oktober 1914, 3.

JDR, 24 oktober 1914, 1.

Dit klopte, zie La Prise d'Anvers, 1915, 3.

De Nieuwe Rotterdamsche Courant schreef twee artikels in deze lijn, NRC, Avondblad B, 21 oktober 1914, 1 en Ochtendblad A, 22 oktober 1914, 1.

JDR, 25 oktober 1914, 1, 2.

AT, 26, 31 oktober 1914, 1 .

AT, 26, 29 oktober 1914, 1. 
JDR, 29-30 oktober 1914, 1.

DE LOOZE, 199-297.

JDR, 31 oktober 1914, 2.

JDR, 31 oktober 1914, 1.

LEB, 7 november 1914, 1.

JDR, 7 november 1914, 1 .

JDR, 29-30 oktober 1914, 2.

LM, 1 november 1914, 1; De Tijd, 28 oktober 1914, 3; WILS, 2014, 71.

WILS, 2014, 71.

LIB, 22 oktober 1914, 2; LIB, 28 oktober 1914, 1; LIB, 31 oktober 1914, 1-2.

LIB, 26 oktober 1914, 1; LIB, 9 november 1914, 2.

LM, 23, 24 oktober 1914, 1.

LM, 30 oktober 1914, 1. In LM, 24 november 1914, 1, werden Nederlanders verdacht gemaakt voor hun vermeend aandeel in de terugkeer van de vluchtelingen. In LM, 18 augustus 1915, 1 verdedigde het blad zijn standpunt over het verzet tegen de terugkeer van de vluchtelingen, hoewel het de protesten toen al maandenlang gestaakt had.

LM, 7 november 1914, 1 .

LIB, 24 november 1914, 2.

$\mathrm{Na}$ de oorlog bleef Strauss beweren dat indien er op 9 oktober 1914 niet onderhandeld was, de stad pas 24 uur later had moeten capituleren, hetgeen de aftocht van het Belgisch leger ten goede zou zijn gekomen, De Telegraaf, Avondblad, I, 9 januari 1919, 2.

LM, 5 november 1914,1 .

LM, 8,10 november 1914,1 .

LEB, 3 november 1914, 1 .

LEB, 24 oktober 1914, 1 meldde reeds dat de vrienden van Franck betreurden dat hij en niet De Vos de echte burgemeester was. Voor neutrale artikels over Franck, zie LEB, 22 november 1914, 1; LEB, 8, 30 december 1914, 1.

LEB, 4 november 1914, 1.

De onderhandelaars ontmoetten inderdaad Von Beseler op het Duitse hoofdkwartier te Tildonk, NRC, Ochtendblad B, 31 januari 1915, 1-2; LEB, 24, 27 november $1914,1$.

8 LEB, 5 november 1914, 1, vgl. LEB, 21 november 1914, 1. MERTENS, 1977, 340 schreef enkel over twee artikels uit het Journal (6, 9 november 1914) die Strauss loofden. Maar die verschenen pas nà de berichtgeving in L'Echo Belge.

9 Vóór de oorlog bestond er geen rivaliteit tussen Le Matin, waar Strauss redacteur was en Franck, MERTENS, 1977, 332, 344. Begin 1916 betichtte Franck Strauss ervan een aandeel te hebben gehad in La Vérité, DPF, 71, 150-151.

MERTENS, 1977, 332-335, 338-339, 341-345.

Vgl. WILS, 2014, 71.

LIB, 26 november 1914, 2.

"En haut lieu" was onder politici een geijkte uitdrukking om de koning aan te duiden, WILS, 2014, 255.

LVS, 24 november $1914,1$. 
LM, 14, 26 november 1914, 1; LM, 22 december 1914, 1. Wel werden de polemieken over de perscollaboratie niet gestaakt. In LM, 17 februari 1915, 1 werd, afgaande op L'Echo Belge, toch weer beweerd dat de overgave van Antwerpen strijdig was met het belang van het Belgisch leger en het landsbelang.

\section{LM, 6 december 1914, 1.}

LM, 12 december 1914, 1.

LEB, 24 november 1914, 1; LEB, 9 december 1914, 1.

LEB, 24, 27 november 1914, 1; LEB, 8 december 1914, 1; De anval in LEB, 26 november 1914, 1 werd in LVS, 5 december 1914, 2 overgenomen.

MIKABERIDZE, passim.

LEB, 25 november 1914, 1; LEB, 8 december 1914, 1.

WILS, 2014, 137.

LEB, 22 januari 1915, 1; LEB, 10, 12, 22 februari 1915, 1; LEB, 2 maart 1915, 1.

LM, 28 oktober 1914, 1.

Zie voor een overname van die reden [MOMMAERTS], 11-12 en FAINGNAERT, 57.

AT, 5 november $1914,1$.

LM, 8 november 1914, 1 .

LM, 10 november 1914, 1. Voor wat volgt, zie LM, 13 november 1914, 1 dat steunde op het Journal van 6 november en La Belgique - Journal des Réfugiés van 10 en 11 november 1914.

HVN, 14 mei 1915, 1.

LM, 20 november 1914, 1.

LB, 6 november 1914, 2.

Kölnische Zeitung, 13 november 1914, 1.

BITSCH, 280.

LVS, 24 november $1914,1$.

Toen waren uittreksels uit het artikel uit de Kölnische Zeitung trouwens al verspreid in de Belgische pers, bv. in De Nieuwe Gazet, 21 november 1914, 1; 17 december $1914,1$.

LEB, 1 december 1914, 1.

AT, 28 november 1914, 1; LM, 5 november 1914, 1.

LVS, 11 december 1914, 1; LEB, 15 december 1914, 1, vgl. LIB, 31 december 1914, 4. Een andere uitval volgde in LEB, 16 december 1914, 1.

VANLANDSCHOOT, 1974, 160.

LM, 7 november 1914, 1 .

LEB, 18 november $1914,1$.

LIB, 25 november 1914, 2.

LEB, 17, 18 november 1914, 1.

LM, 25-26 oktober 1914, 1 .

Het Centrum, II, 28 oktober 1914, 2.

LEB, 23, 25 oktober 1914, 1; LEB, 24 oktober 1914, 2; LEB, 7, 16, 24, 29 november 1914, 1; LEB, 9, 16 december 1914, 1.

Sporadische kritiek op Antwerpsche Tijdingen kwam er vooral door becommentarieerde overnames uit andere dagbladen, zie bv. LIB, 31 december 1914, 4. 
De Stem uit België, 30 oktober 1914, 7 en Supplement, 27 november 1914, 1.

LEB, 9 december 1914, 1.

Voor wat volgt, zie LM, 13 november 1914, 1; La Presse, 7 november 1914, 1. La Presse schreef de Belgische regering volgende woorden toe: "voor de rijksambtenaren, behoudens magistraten, professoren en leraars die hun functie binnen de versterkte vesting Antwerpen uitoefenden, raden we voorlopig aan hun ambt niet te hernemen." [B.Y.] La Métropole haalde er de verdraaiingen uit. De regering had bv. niet gesproken over een vesting maar wel over een stelling; niet over professoren maar over bedienaren van erediensten enzovoort.

Vgl. LEB, 18 november 1914, 1.

LEB, 11 november 1914, 1. Voor La Belgique, zie LM, 13 november 1914, 1.

LEB, 13 en 15 november 1914, 1.

De Nieuwe Gazet, 10, 11 december 1914, 1; LEB, 15 december 1914, 1.

LM, 12 december 1914, 1.

LEB, 11 december 1914, 1 .

LEB, 24, 27 oktober 1914, 1; LEB, 13, 15, 18, 23 november 1914, 1; LM, 12 november 1914, 1; LM, 24 december 1914, 1; LVS, 12, 17 november 1914, 2; LVS, 29 november 1914, 1; LVS, 2 december 1914, 2; LIB, 13, 26 november 1914, 1; LIB, 24 november 1914, 2; LIB, 1 december 1914, 1-2; LIB, 21, 22 december 1914, 3; LIB, 28 december 1914, 2.

LEB, 7, 11, 15, 19, 20, 23 november 1914, 1; LIB, 13 november 1914, 1; LIB, 17 november 1914, 3; LIB, 26 november 1914, 2; LIB, 5 december 1914, 3; LM, 12, 20 november 1914, 1; LM, 24 december 1914, 1; LVS, 17 december 1914, 2.

L'Ami de L'Ordre, 29 november 1914, 1; L'Ami de L'Ordre, 7 december 1914, 1; LIB, 9, 15 december 1914, 2; LEB, 6, 9 december 1914, 1; LVS, 12 december 1914, 2; LVS, 20 december 1914, 1.

LEB, 18 november 1914,1 .

Souvenir de la Guerre, passim.

HVN, 23 januari 1915, 1; GVB, 31 januari-1 februari 1915, 1; GVB, 2, 3, 4 en 5 februari $1915,1$.

HV, 4 februari 1915, 1.

GVB, 5 februari 1915, 1.

Le Temps, 13 januari 1915, 6; LVS, 14 februari 1915, 2.

GVB, 28 februari-1 maart 1915, 3; DVP, 12 maart 1915, 1.

YAMMINE, 2011, 284-287.

LVS, 15-16 augustus 1915, 1.

WILS, 2014, 31.

WILLEMSEN, 1969, 29; DE SCHAEPDRIJVER, 152; WILS, 1994, 264.

Neerlandia, 1915, 41.

Limburg's Belang, 5 september 1914, 1.

De Standaard, Eerste Blad, 5 september 1914, 1; YAMMINE, 2011, 264-270.

Limburger Koerier, Eerste Blad, 15 september 1914, 2.

Nieuwe Courant, Ochtendblad, 3 januari 1915, 3. 
GVB, 10 december 1914, 2. In mei 1915 berichtte de Politische Abteilung dat de Limburger Koerier voldoende Duitsgezind was en in heel Limburg door hem verspreid werd, AMARA, ROLAND, 88, 92.

Limburger Koerier, Tweede Blad, 6 januari 1915, 1.

BALTHAZAR, VAN CAMPENHOUT, 261. Lamprecht getuigde inderdaad dat hij brieven kreeg “van Vlaamse studenten”, DVS, 10 juni 1915, 1.

GVB, 10-11 januari 1915, 1, vgl. HVN, 27 januari 1915, 1; HVN, 24 januari 1915, 1; GVB, 29 januari 1915, 4.

Het Centrum, Tweede Blad, 6 februari 1915, 1.

HLN, 17 juni 1907, 1.

VANACKER, 2006, 18 meende dat "de francofonen" ervan uit gingen dat de flaminganten hun ongelijk zouden inzien en dat België resoluut het Franse kamp zou kiezen. Dit is evident onjuist en ontleend aan de Duits-activistische propaganda.

Naast de in de lopende tekst besproken berichten schreef LM, 23 december 1914, 1 over een Duits dagblad, uitgegeven te Antwerpen "sous la direction, paraît-il d'un ancient agent de change en déconfiture et connu pour son flamingantisme rabique" (i.e. L'Avenir, hoofdstuk 4, par. 4).

In een eerste brief heette het dat er in Antwerpen "enkele pan-Germanisten" waren, LIB, 19 november 1914, 2. In een tweede had hij het over "ces pangermanistes qui ont besoin maintenant de faire leur mea culpa”, LIB, 24 november 1914, 2. Voor zijn derde brief van 22 december 1914, zie LIB, 5 januari 1915, 2. De vierde brief (11 januari 1915) hierover verscheen in LIB, 21 januari 1915, 2.

LEB, 28 januari 1915, 1.

BASSE, 47-48. Zie, voor het antwoord van Terwagne en het wederwoord van Wildiers, LEB, 4, 10 februari 1915, 1.

Zelfs de redactie van Antwerpsche Tijdingen, die het toch zwaar te verduren kreeg, heeft nooit gewag gemaakt van een "franskiljons" offensief in de vluchtelingenpers. Toen het blad bv. een catalogus opmaakte van alle roddelpraatjes en leugens die de ronde deden, schreef het niets over de agitatie van "franskiljons", AT, 18 november $1914,1$.

De Stem uit België, 8 januari 1915, 1.

LEB, 1 december 1914, 1 loofde bv. de Vlaamsgezinde publicist Cyriel Buysse. Als verzet tegen de germanofilie in Neerlandia had die immers zijn abonnement op dat blad opgezegd (Neerlandia, 1914, 199, 225-227; De Telegraaf, Avondblad, III, 27 november 1914, 1).

Het Centrum, 28 oktober 1914, II, 2.

WILS, 1974, 54 (30); NEVB, 2840-2841; WILS, 2000, 108, 190.

DVS, 4 februari 1915, 4.

Dietsche Stemmen, 1916, 440-451.

JDR, 18 oktober (a) 1914, 2; JDR, 7 november 1914, 1; LEB, 15 december 1914, 1. Voor november 1914 ging het om: La Métropole van 12 november met als "goede" steden: Brussel, Luik, Aarlen, Bergen en Verviers; L'Echo Belge van 15 november met Brussel tegenover Antwerpen vgl. met JDR, 31 oktober 1914, 2 en JDR, 25 oktober 1914, 2. Afgaande op wat Terwagne in L'Indépendance Belge van 
24 november 1914 schreef betrof het Luik en Brussel tegenover de "slechte voorbeelden" van Antwerpen, Brugge en Namen.

\section{Hoofdstuk 4: De Duitse diensten treden in actie}

FAINGNAERT, 209.

Minister van Staat Woeste werd daaromtrent op 7 en 8 september 1914 door Duitsers benaderd. De regering wees dit aanbod af, WOESTE, III, 9-11; Le Temps, 12 september 1914, 2; Le Petit Parisien, 25 december 1914, 1-2; OTTE, 487; DE SCHAEPDRIJVER, 94.

5 RIEZLER, ERDMANN, 216. Het citaat uit de lopende tekst is afkomstig uit het dagboek van Riezler. Wellicht weerspiegelt het de mening van de kanselier. RIEZLER, ERDMANN, 216 (1), 58-59.

7 Zie, behoudens tegenstrijdige verwijzing, YAMMINE, 2013, 33-39; WILS, 2014, 44-51.

8 LADEMACHER, 391, 401, vgl. WILS, 2015, 217 (1).

$9 \quad$ RGP 128, 7-14.

10 Die pogingen stopten pas toen met de geboorte van prinses Juliana in april 1909 koningin Wilhelmina een wettelijke troonopvolger kreeg, YAMMINE, 2011, 217.

11 De Tijd, 25 augustus 1914, 2.

12 TAMES, 68-69.

13 YAMMINE, 2011, 270-282.

14 YAMMINE, 2011, 295.

15 NRC, Avondblad A, 24 augustus 1914, 1.

16 BERKELAAR, DORSMAN, VAN HEES, 97.

17 PIRENNE, 211.

18 GILLE e.a., I, 27, gesignaleerd in WILS, 2014, 47 (16).

19 Gesetz- und Verordnungsblatt, Brussel, 5 september 1914, 1. WILS, 2014, 56 schrijft dat dit pas op 6 oktober 1914 gebeurde in het Staatsblad. Dat werd echter enkel door de Belgische overheid uitgegeven, niet door de Duitse bezetter.

$20 \quad$ NRC, Ochtendblad A, 15 september 1914, 1.

21 Reichspost, 21 september 1914,2; German posters, 20.

22 PIRENNE, 211; WENDE, 78.

23 Nieuwe Courant, 2 november 1914, 1.

24 Aldus een officiële mededeling van het Wolff-bureau, DVS, 4 februari 1915, 3.

25 GVB, 7 december 1914, 2.

26 Annales Parlementaires, 1920, 660.

27 MASSART, 284.

28 WHITLOCK, I, 248-249; Afgaande op een bericht van het Große Hauptquartier d.d. 3 september 1914, kopte de Vossische Zeitung (Morgen-Ausgabe, 4 september 1914, 1): Deutsche Reiterei vor Paris.

29 GILLE e.a., I, 27; II, 112. WILS, 2014, 47 (16).

30 German posters, 16, 20, 60, 64, 66, 68, 72, 78, 88, 90, 91, 94, 96; DAVIGNON, 90. 
German posters, 62; De aankondiging uit Deinze stond in contrast met de proclamatie waarvan De Tijd, 31 augustus 1914, 1 gewag maakte. Die meldde dat in bezet België een proclamatie verspreid werd in het Frans, Nederlands en Duits waarin onder meer gedreigd werd met doodstraffen tegen burgers die zich vijandig tegenover het Duitse leger opstelden.

GVB, 28 augustus 1915, 1.

DVS, 27 augustus 1915, 1; NRC, Avondblad B, 27 augustus 1915, 2.

NRC, Avondblad B, 28 augustus 1915, 1; DVS, 31 augustus 1915, 2.

NRC, Avondblad C, 3 september 1915, 2; DVS, 5 september 1915, 1.

GVB, 4 september 1915, 1; DVS, 8 september 1915, 1; Souvenir catalogue, 3; Vooruit, 23 augustus 1914,6 .

MÜLLER, 2020, 46 (22).

OSZWALD, 1928, 245, vgl. FAINGNAERT, 546.

YAMMINE, 2011, 295.

MÜLLER, 2020, 45 (18).

LVS, 28 december 1914, 1; YAMMINE, 2011, 296-297.

YAMMINE, 2011, 92-96, 291-293.

FISCHER, 1960, 92.

OSZWALD, 1927, 523.

DOLDERER, MÜLLER, 2015, 103-111.

DOLDERER, MÜLLER, 2015, 108, 110.

WILS, 2014, 49.

GDA, 1 november 1914, 4 .

LB, 15 oktober 1914, 1-2; Norddeutsche Allgemeine Zeitung, 16 oktober 1914, 1-2; Norddeutsche Allgemeine Zeitung, 25 november 1914, Sonderbeilage; FAINGNAERT, 76-95.

Les Conventions Anglo-Belges, 7; BRUNET, passim; LM, 2 april 1915, 1.

GVB, 7 december 1914, 1-2; GVB, 8 t.e.m. 10 december 1914, 2.

Het Centrum, 12 oktober 1914, 1; Rotterdamsch Nieuwsblad, V, 14 oktober 1914, 2.

Vossische Zeitung, Morgen-Ausgabe, 10 oktober 1914, 1; NRC, Avondblad, 11 oktober 1914, 1.

NIPPERDEY, 803.

Rotterdamsch Nieuwsblad, V, 14 oktober 1914, 2.

NRC, Avondblad, 11 oktober 1914, 1.

De Maasbode, 11 oktober 1914, 1.

LB, 14 oktober 1914, 1 .

Neue Freie Presse, Abendausgabe, 14 oktober 1914, 2; Norddeutsche Allgemeine Zeitung, 15 oktober $1914,1$.

BOWERSOX, 110-115; MÜLLER-MEININGEN, 105 (1).

Neue Freie Presse, 18 oktober 1914, 3-5.

De Tijd, 21 oktober 1914, 1.

Pester Lloyd, 21 november 1914, 1-2.

SZATMARI, 144.

GVB, 11 december 1914, 2. 
SCHWOB, III, 30 had geschreven hoe Herostratos in de nacht van 21 juli - de Belgische Nationale Feestdag - tot zijn daad was overgegaan, een detail dat de Oostenrijker misschien niet ontgaan was.

Pester Lloyd, 21 november 1914, 1-2.

Vossische Zeitung, Morgen-Ausgabe, 26 november 1914, 4.

De liberale Antwerpse politicus Cupérus meldde dat niemand eraan gedacht had om op 9 oktober 1914 de witte vlag op de toren te hijsen, De Nieuwe Gazet, 13 december 1914, 2.

Haagsche Courant, II, 3 november 1914, 1; NRC, Avondblad A, 8 december 1914, 1; Gedenkschriften, 256.

GVB, 29 november 1914, 1. Koning Albert wilde inderdaad te Antwerpen de strijd staken, maar gaf niet toe aan de Britten, wel aan kabinetschef en minister van Oor$\log$ De Broqueville, WILS, 1985, 21.

La Libre Belgique, 8, maart 1915, 4, vgl. LIB, 15 maart 1915, 3. De ontkennende repliek in Le Bruxellois, 26 maart 1915, 1.

LB, 26 november 1914, 4, vgl. LB, 21 december 1914, 1.

LB, 1 december 1914, 1.

Vgl. LB, 8 april 1915, 1 (deels overgenomen in de GVB, 12 april 1915, 4) met LB, 26 november 1914, 4 en LB, 1 december 1914, 1; JDR, 27 oktober 1914, 1.

LB, 1 december 1914, 1.

JDR, 7 november 1914, 1, vgl. LIB, 5 december 1914, 3.

GVB, 3 december 1914, 1.

Algemeen Handelsblad, 3 november 1914, 1.

Nieuwe Courant, Ochtendblad, 2 november 1914, 2.

WILS, 2014, 101.

AT, 21 oktober 1914, 1.

AMARA, ROLAND, 83-84.

AMARA, ROLAND, 75, 119.

Le Bien Public, 3 december 1914, 1.

Vooruit, 6 december 1914, 2; L'Echo de la Presse, 7 december 1914, 2; AMARA, ROLAND, 78.

LEB, 30 november 1914, 1.

Düsseldorfer General-Anzeiger, 9 december 1914, 2.

Rotterdamsch Nieuwsblad, III, 14 december 1914, 2. Wohlmann (of Vollmann?) was in de jaren 1880 attaché bij Le Temps. In 1889 werd hij de Brusselse correspondent van de Neue Preussische Kreuzzeitung, WILLEQUET, 415; AMARA, ROLAND, 75.

Neue Freie Presse, 10 december 1914, 3.

AT, 18 december 1914, 1; LM, 23 december 1914, 1; WILS, 2014, 70-71 betwijfelt de versie van La Métropole; De Tijd, 24 december 1914, 1; LVS, 30 maart 1915, 3 , vgl. LM, 16 februari 1915, 1.

LVS, 31 december 1914, 1.

De Nieuwe Gazet, 13 december 1914, 1.

LAvenir, 16 december 1914, 1.

GVB, 18 t.e.m. 25 december 1914, 1. 
DVP, 21 februari 1915, 1.

L'Avenir, 16 december 1914, 2.

GVB, 24 december 1914, 1.

Voor de besproken algemene thema's in L'Avenir, zie L'Avenir, 21, 24, 28, 31 december 1914, 1; LAvenir, 4, 7, 12, 14, 18, 20, 21, 23, 27, 28, 29 januari 1915, 1; L'Avenir, 3, 5, 12, 13, 17, 14, 24, 26, februari 1915, 1; L'Avenir, 14 februari 1915, 2; LAvenir, 25 februari 1915, 2; LAvenir, 5, 7 maart 1915, 1.

LEB, 2 januari 1915, 1; LEB, 16 januari 1915, 1 klaagde nog steeds geen antwoord ontvangen te hebben. De Vos-Van Kleef hield het er uiteindelijk op dat de redactie uit goede patriotten bestond, LEB, 12 maart 1915, 1.

Bv. in het rapport van Von der Lancken (14 mei 1915): “...de ondermijningswerken van de Frans-Belgische propaganda” [B.Y.], AMARA, ROLAND, 66, vgl. de berichtgeving over de "Franse terrreur" in België in de Münchener Neueste Nachrichten, n.a.v. het bijwonen van de Franstalige ULB-professor Dwelshauvers van een concert van een Keuls orkest in Brussel. Dwelshauvers werd ervoor door zijn collega's uitgesloten, LM, 8 mei 1915, 1.

Voor wat volgt, L'Avenir, 16 december 1914, 2; AT, 18 december 1914, 1; LAvenir, 18, 19 december 1914, 1.

Düsseldorfer General-Anzeiger, 9 december 1914, 2.

Rotterdamsch Nieuwsblad, 14 december 1914, 2; NRC, Avondblad A, 24 december 1914, 1; De Tijd, 24 december 1914, 1.

Het Vlaamsch Heelal, 19 december 1914, 1 (katholiek) meende dat men de daders bij sommige "moedige" vluchtelingen moest gaan zoeken.

LVS, 31 december 1914, 1.

WILS, 1974, 52-53.

LVS, 24 november $1914,1$.

LVS, 28 december 1914, 1.

GVB, 5 december 1914, 1; 2, 7 en 9 december 1914, 2.

GVB, 12 december 1914, 1.

GVB, 19 december 1914, 2.

The Daily News schreef op die manier, BRAYBON, 84 .

NRC, Avondblad B, 15 augustus 1914, 2.

GVB, 14 december 1914, 1.

GDA, 1 februari $1915,1$.

NDB, 19, Berlijn, 1999, 624-625; Vlaamsche Gazet, 22 december 1914, 1; AMARA, ROLAND, 74-75; hoofdstuk 4, par. 7; Frankfurter Zeitung und Handelsblatt, Erstes Morgenblatt, 12 december 1914, 1; Neue Freie Presse, 23 december 1914,6 .

GDA, 20 december 1914, 6 .

Vlaamsche Gazet, 30 december 1914, 1.

GVB, 31 december 1914, 1-2.

GVB, 5 januari 1915, 1.

GVB, 21 januari 1915, 1.

JDR, 1-2 november 1914, 1. Calza Bedolo schreef dit op 25 oktober. Het Journal publiceerde niet zijn aantijgingen over de "vreugde" van de Nederlanders, zie daar- 
voor Delftsche Courant, 6 november 1914, 2. De Italiaan was aanwezig tijdens de belegering van Antwerpen, KELLY, 49-50.

124 GVB, 13 januari 1915, 1.

125 LM, 21 januari 1915, 1; La Belgique, 15 januari 1915, 2, vgl. LB, 15 januari 1915, 1.

126 La Belgique, 16 januari 1915, 2. Zie hoofdstuk 5, par. 1.

127 GVB, 21 januari 1915, 1.

128 GVB, 29 november 1914, 1.

129 GVB, 21 januari 1915, 3; MERTENS, 1978, 404 beweerde dat het Nederlandse blad De Tijd op 4 februari 1915 als eerste over La Vérité had gesproken. Toen was volgens hem immers een brief verschenen met daarin een rechtzetting vanwege de hoofdredacteur van De Tijd over de verschijning van La Vérité. De Tijd heeft op die datum niet zo'n brief afgedrukt. Bovendien dateerden de eerste berichten uit $L a$ Belgique van 16 januari 1915 en de Gazet van 21 januari 1915. L'Avenir, 3 maart 1915, 2; MERTENS, 1978, 404 (72). GVB, 21 januari 1915, 1 (Hoofdstuk 5, par. 1).

GVB, 28 januari 1915, 4.

LB, 15 januari 1915,1 .

La Belgique, 27 januari 1915, 1.

L'Avenir, 30 januari 1915, 1.

DPF, 44, 101.

NRC, Avondblad B, 2 februari 1915, 1.

De Telegraaf, Avondblad 1, 6 februari 1915, 2.

MERTENS, 1978, 402.

139 In het officiële drukschrift van de gemeenteraad stond onder andere een logenstraffing van de inhoud van het pamflet, waarbij deels de inhoud van de brief van De Vos van 11 januari 1915 hernomen werd. Daarna volgde de melding van de klacht die neergelegd was tegen de "ellendige schrijuers" ervan, AT, 19 februari 1915, 1; La Prise d'Anvers, passim.

140 Zowel in de brief van 11 januari 1915 van De Vos als in La Prise d'Anvers stond dat de regering de daden van het gemeentebestuur niet aangeklaagd had noch daarover een onderzoek instelde en twee ministers van Staat naar Nederland gestuurd had. Maar pas in het tweede stuk stond daarbij: "quant au gouvernement, nous avons l'assurance que les actes de l'autorité communale ont été entièrement approuvés par lui", La Belgique, 15 januari 1915, 2; La Belgique, 22 februari 1915, 2 met daarin La Prise d'Anvers. MERTENS, 1978, 406 schreef afgaande op WILS, 1974, 54 (34) dat Poullet pas duidelijk de houding van Franck op 22 februari en op 14 maart 1915 goedkeurde. Deze visie kunnen we niet bijtreden: 1) op 22 februari publiceerde La Belgique een deel uit La Prise d'Anvers, waarin niets stond over Poullet; 2) op 14 maart verscheen er in hetzelfde blad een artikel over wat Poullet tegen een kunstenaar zou gezegd hebben. Ervan uitgaand dat die informatie klopt, zou Poullet die uitspraken ten laatste op 13 maart 1915 gedaan hebben.

$141 \quad$ La Belgique, 14 maart 1915, 2.

142 Soms gebeurden dergelijke aanvallen op grond van overnames uit de vluchtelingenpers, LVS, 24 februari 1915, 2; LVS, 27 maart 1915, 2, overname uit LM, 24 maart 1915, 1; LVS, 1 mei 1915, 2 en 2-3 mei 1915, 2; LVS, 20 mei 1915, 3. 
MERTENS, 1978, 405. De klacht werd medio januari neergelegd, La Belgique, 16 januari 1915, 2.

L'Avenir, 29 januari 1915, 1.

Voor wat volgt, zie L'Avenir, 18 februari 1915, 1.

Vgl. L'Avenir, 24 januari 1915, 1; GVB, 18 januari 1915, 1.

L'Avenir, 18 februari 1915, 1.

HVN, 13 maart 1915, 1.

GVB, 4 maart 1915, 1.

L'Avenir 28 februari 1915, 1 vgl. L'Avenir, 3 maart 1915, 1; L'Avenir, 4 maart 1915, 1.

L'Avenir 28 februari 1915, 1, vgl. L'Avenir, 3 maart 1915, 1 en GVB, 29 november $1914,1$.

L'Avenir, 4 maart 1915, 1.

GVB, 19 februari 1915, 1; HVN, 20 februari 1915, 3; DVP, B, 21 februari 1915, 3, vgl. DVS, 25 januari 1915, 3; AT, 24 februari 1915, 1.

LEB, 26 februari 1915, 1.

LM, 3 maart 1915, 1.

WILS, 2014, 101-104.

GVB, 13 december 1914, 1 (1).

GVB, 10 februari t.e.m. 13 maart 1915, 4; 14-15 maart 1915, 6; 20, 21, 29 maart 1915, 1; 2, 3, 6 april 1915, 4; 8 t.e.m. 10 april 1915, 4 .

LB, 18, 20 september 1914, 1.

LB, 26 september 1914, 2; LB, 7 oktober 1914, 2.

LB, 4, 17 november 1914, 1; LB, 23, 24 december 1914, 1.

LB, 1 maart 1915, 2.

LB, 20 juni 1915, 1.

Overdruk in LEB, 15 juni 1915, 1.

DVS, 1 maart 1915, 1; LVS, 11 maart 1915, 1.

FAINGNAERT, 170-172; DVP, 9 april 1915, 3.

WILS, 2014, 102-103.

[A. LIMET], passim. Uittreksels in L'Echo Belge, 12 juli 1915, 1; DELFORGE, 277-278.

AMARA, ROLAND, 83, 83-84 (49).

L'Echo Belge, 12 juli 1915, 1.

La Libre Belgique, 39, augustus 1915, 3.

DELFORGE, 277 (410), 280; LEB, 3 oktober 1915, 1.

LVS, 30 september 1915, 1; PASSELECQ, 41; GVB, 6 januari 1915 t.e.m. 13 maart 1915, 4; 14 maart 1915, 6; 11 maart t.e.m. 31 augustus 1918, 1; LB, 31 januari-1 februari t.e.m. 14 november 1917, 2 en LB, 15 november 1917 t.e.m. 3 maart 1918, 2, vgl. Le Soir, 18 augustus 1919, 1; FAINGNAERT, 59 (1). Pas in de GVB, 2 september 1918, werd gewag gemaakt van het feit dat een andere drukkerij klaargemaakt werd omdat het beheer en de redactie van het dagblad met ingang van 1 september 1918 "in andere handen" overgegaan waren. Inderdaad gaf pas toen de Politische Abteilung het dagblad aan de activisten, WILS, 2014, 99. Aldus WILS, 2014, 93. 
Voor wat volgt over Gent, zie, behoudens tegenstrijdige verwijzing, YAMMINE, 2011, 237-247, 302-310; YAMMINE, 2013, 38, 43; VANACKER, 2006, 22-23. Hammer, [maart] 1915, 131-132, vgl. het signalement in S.H.E. DOMELA NIEUWENHUIS, 26-27; Stemmen voor Waarheid en Vrede, 1915, 698-699. VAN DE VELDE, 15-24.

Vlaamsche Gazet, 8 december 1914, 1. Wel had de NRC, Ochtendblad A, 5 december 1914, 1, met minder details hierover al bericht.

Overdruk van het pamflet in De Belgische Standaard, 30 november 1915, 2, vgl. Belgisch Dagblad, 17 december 1915, 2. In VANACKER, 44 vindt men de vermelding van Domela's weinig succesvolle tocht naar Nederland. Cf. het tweede en onafhankelijk opgesteld verslag dat het pamflet bevestigt in het Belgisch Dagblad, 14 januari 1916, 1-2. Zie VAN DE VELDE, 64 over hoe Wirth zich als Groot-Nederlander aan de groep voorstelde. In het vlugschrift vindt men ook details over de aanhoudingen - in het bijzijn van Wirth - van de flaminganten Maes en Sevens (vgl. VANACKER, 48-49).

VRINTS, 2002, 44, vgl. AMARA, ROLAND, 66.

WILS, 2014, 83-90; VAN DE VELDE, 28, 30-35.

VAN DE VELDE, 36.

BORMS, 95.

WENDE, 84.

FAINGNAERT, 382-383; De Telegraaf, Avondblad, 28 januari 1916, 2.

VRINTS, 2002, 40, 43-44, 86.

AMARA, ROLAND, 66.

Zelfs FAINGNAERT, 173 liet zich ontvallen dat de Brusselse flaminganten zes maanden de Godsvrede naleefden.

De tot nu toe zeer summiere kennis over Rieth en de Flamenpolitik is te vinden in BUNING, 1974, 236-237; VANACKER, 1986, 2-3; FAINGNAERT, 210; AMARA, ROLAND, 377-378; VANACKER, 2006, 38; WILS, 2014, 99, (11).

DE BACKER, VAN CAMP, 41; SCHMOOK, 1976, 119.

Anvers-Bourse, 7 augustus 1914, 1; Le Matin, 9 augustus 1914, 3-4; Deutsches Volksblatt, 6 oktober 1914, 1; LM, 3 november 1914, 1; Belgisch Dagblad, 13 oktober 1916, 2; LVS, 26 oktober 1916, 1; LEB, 10 februari 1918, 1; Belgisch Dagblad, 12 februari 1918, 1; Belgischer Kurier, 16 februari 1918, 4.

LM, 3 november 1914, 1; LM, 1 december 1914, 1; LEB, 11 december 1914, 1; Le Petit Parisien, 18 januari 1915, 1-2; Les Nouvelles, 17 februari 1918, 2.

Belgisch Dagblad, 12 februari 1918, 1. Het Belgisch Dagblad dat in 1915 opgericht werd, was aanvankelijk Vlaamsgezind, maar verliet die positie. WILS, 2014, 147, 185 (74), 252 (82).

4 LVS, 2 februari 1915, 1, vgl. De Legerbode, 4 februari 1915, 3 en LEB, 7 februari 1915, 1. Andere bladen duidden Wertheimer zelfs aan als het hoofd van de Duitse censuurdienst, De Vrije Stem, 8, 1915, 3; LEB, 10 januari 1915, 1; Belgisch Dagblad, 24 maart 1916, 1; De Legerbode, 16 mei 1916, 2; LVS, 2 augustus 1916, 1; Belgisch Dagblad, 13 oktober 1916, 2; Informations Belges, 12 oktober 1917, 2; Het Vaderland, 16 oktober 1917,1 .

LIB, 28 november 1914, 6 . 
JÄGER, LANGEWIESCHE et. al., 373.

De Legerbode, 4 februari 1915, 3; Belgisch Dagblad, 7 december 1915, 2; Belgisch Dagblad, 13 oktober 1916, 2; Belgisch Dagblad, 17 juli 1917, 1; Belgisch Dagblad, 12 februari 1918, 1.

AMARA, ROLAND, 177 (30).

WHITLOCK, I, 656-659; WHITLOCK, II, 253-254, 356, 439-442, 700-701, $717,730,791,803$.

LVS, 26 oktober 1916, 1; Belgisch Dagblad, 13 oktober 1916, 2.

DE BACKER, VAN CAMP, 40.

BROUCEK, 125 (4).

De Indische Courant, III, 3 december 1941, 3.

Leidsch Dagblad, 30 mei 1941, 2; Het Volk, 31 mei 1941, 12.

De Indische Courant, III, 3 december 1941, 3.

PIETRI, 145.

MOTADEL, 375 (63), (64).

BRINGMANN, 312.

http://www.bundesarchiv.de

YAMMINE, 2012, 242-243 (32).

DOLDERER, 1989, 45-46; NEVB, 516-517.

In 2014 relativeerde Wils de rol van Haller die nochtans in al zijn andere werken een vooraanstaande rol toebedeeld kreeg, WILS, 2014, 106-108; WILS, 1974, 75 , 81-83; WILS, 1985, 25-26; WILS, 2005, 197.

MÜLLER, 2020, 45 (18).

BUNING, "Meer licht op de von Ziegesars", 1973, 317.

YAMMINE, 2011, 318.

BUNING, "Reismann-Grone", 1975, 252-253; DOLDERER, MÜLLER, 2015, 208-209.

BALTHAZAR, VAN CAMPENHOUT, 262.

WILS, 2014, 94 (3) betoogde dat Faingnaert stelde hoe "Haller pas contacten had [met het gouvernement-generaal] na de komst van Von Bissing". Maar in FAINGNAERT, 72-73 vernemen we dat Haller "reeds voeling heeft met de Politische Abteilung en [...] af en toe bij de gouverneur-generaal [Von Bissing] uitgenodigd wordt om verdere inlichtingen nopens de Vlaamse beweging te verstrekken". FAINGNAERT beweerde op 36, 209 en 346-347 dat er reeds contacten waren tussen Haller en Von der Goltz. Dit hoeft niet in tegenspraak te zijn met 178. Daar stond dat Dirr op een avond kwam aanbellen bij Haller. Was dat niet omdat Haller toen al verbonden was met de Politische Abteilung?.

BUNING, "Reismann-Grone", 1975, 253-254.

Voor wat volgt, zie De Tijd, 8 mei 1916, 2; NRC, Ochtendblad B, 13 mei 1916, 1; Le Temps, 21 mei 1916, 2.

De Toekomst, 1915, 496-498

LEB, 11 september 1915, 1

HVN, 1 januari 1916, 1. 
HVN, 7 januari 1916, 3. Omtrent hetzelfde tijdstip werd de naam van Haller door de Düsseldorfer General-Anzeiger met de Gazet van Brussel in verband gebracht. Hij liet dit rechtzetten in de GVB, 7 januari 1916, 3.

Archives, 362, 421; MÜLLER, 2020, 53.

WILS, 2014, 106-107 (22).

Belgisch Dagblad, 26 oktober 1915, 3.

FAINGNAERT, 178; DOLDERER, 2014, 289-291.

Vgl. ELIAS, 20-21.

WEHLBERG, 100-104.

DOLDERER, 1989, 43; VON DER LANCKEN, 214-216.

GVB, 22 juli 1915, 1, vgl. GVB, 28 juli 1915, 1.

HVN, 3 oktober 1915, 1 .

Het Duitse aandringen kan al vanaf de zomer van 1914 gebeurd zijn. In DVS, 15 maart 1915, 1 getuigde Du Catillon dat hij vóór hij uit Brussel naar Nederland vertrok met een flamingantische vriend sprak over de "nieuwe Duitse politiek van pootjes geven om de goede Vlamingen [...] tot vrienden te maken". Zijn vriend vertelde hem over hoe een hoge ambtenaar van de Zivilververwaltung zich plots zeer vriendelijk tegenover hem gedroeg. En later zou een ambtenaar van de Kommandantur die vriend bezocht hebben. De Duitser had de taalgrieven die de Vlamingen zouden hebben op papier gezet, met de (vergeefse) vraag die te onderzoeken en er zijn mening over te geven. Wegens de Duitse inval kon Du Catillon zijn functie van leraar Nederlands aan de Koninklijke Militaire School, waar hij in juli 1914 benoemd was, niet opnemen. Hij week daarop - dus nog tijdens de zomer - uit naar Nederland, waar hij in dienst van de Belgische regering werkte. In januari 1915 stelde hij zich in Le Havre ter beschikking van de regering om daarna wederom naar Nederland te gaan, NBW, X, Brussel, 1983, 92.

FAINGNAERT, 26-28.

Hoofdstuk 6, par. 4.

"Men kon al dadelijk merken dat er twee meningen tot uiting kwamen in het blad [De Vlaamsche Stem]..., FAINGNAERT, 130. De Vlaamsche Stem werd op 1 februari 1915 gesticht. Pas maanden later ontstonden er twee richtingen.

[DE CONINCK], 50.

YAMMINE, 2012, 233-256; FAINGNAERT, 23, 36, 40-41, 72-73, 178, 193194, 346-347. Al in DVP, 17 mei 1915, 1, stond hoe een afvaardiging van Waalse handelaars te Brussel met Von Bissing was gaan spreken "om hem het streven der Walen uiteen te zetten, en zijn sympathie te winnen”. Dat werd verbatim hernomen in Activisten, 133. In Activisten, 208, heette het dat er "oorlogswoekeraars" waren bij Walen en Vlamingen. In FAINGNAERT, 23, 40-41 werden dat dan enkel “Waalse oorlogswoekeraars" die met de vijand "onbeschaand handel" dreven.

FAINGNAERT, 36.

HVN, 13 oktober 1918, 1.

Vgl. WILS, 1974, 74 .

Deze bewering dook in juli 1915 in de Duits-activistische pers op (Zie hoofdstuk 6, par. 6). Het boek van Blunck uit 1915 werd toen vernoemd. Het verscheen dus tussen januari en juli 1915. In een rapport van Von der Lancken uit mei 1915 lezen we 
overigens al dat "de Walen" in het binnen- en buitenland een erg behendige politiek zouden nastreven om van de situatie gebruik te maken om hun oude "overheersing” te herstellen (AMARA, ROLAND, 84). Zie ook de boekbespreking in GVB, 17 juli 1915, 2 en DVP, 28 juli 1915, 2.

BLUNCK, 20.

FAINGNAERT, 36, 346-347; LVS, 21 september 1916, 1; De Vlaamsche Hoogeschool, 1 mei 1914, 1; LVS, 29 september 1915, 1. WILS, 1985, 27 (19). De Gentse perscensor Wirth had een Nederlandse moeder en een Duitse vader, YAMMINE, 2013, 38; YAMMINE, 2012, 242; WILS, 2014, 94.

Courrier de l'Escaut, 30 mei 1906, 2.

FAINGNAERT, 36-45.

Algemeen Handelsblad, Avondblad, II, 10 juni 1920, 2, vgl. FAINGNAERT, 43. FAINGNAERT, 44.

De Nederlander, 28 december 1914, 1 voor het verslag van 7 december; De Nederlander, 29 december 1914, 1 en 5 januari 1915, 1 voor het verslag van 12 december 1914, vgl. GERICKE, 321-323.

BALTHAZAR, Van CAMPENHOUT, 258-259; NEVB, 518. Picard was hem in Antwerpen gaan bezoeken, VANACKER, 68 .

GVB, 13 augustus 1915, 1, vgl. GVB, 20 juli 1915, 1.

WILS, 2014, 95.

Geciteerd in WILS, 2014, 97.

Zie het hoofdartikel onder de schuilnaam "Scheldeman" (Constant de Sadeleer) in GVB, 7 januari 1915, 1.

GVB, 2 februari 1915, 1.

WILS, 2014, 98; YAMMINE, 2013, 41.

WILS, 2014, 109.

Vgl. WILS, 2014, 323.

DVP, 6 maart 1915, 2.

Algemeen Handelsblad, 17 maart 1915, 1-2.

DVS, 20 maart 1915, 4.

FAINGNAERT, 43 vermeldde dat na de breuk tussen de Vlaamsgezinden " de belgicisten" Vermeylen, Hegenscheidt, De Veen en Mennes vergaderden om de Flamenpolitik en het activisme te bestrijden.

HVN, 14 mei 1915, 1.

LVS, 6 juni 1915, 1.

HVN, 6 juni 1915, 1.

DVP, 26 juni 1915, 3.

DVP, 28 juni 1915, 3.

DVP, 1 juli 1915, 3.

DVP, 7 juli 1915, 3.

Archives, XVIII; 421-423.

FAINGNAERT, 212.

VAN DE VELDE, 58; Hinderdael werd begin juli 1915 verantwoordelijke voor de censuur voor Jong-Vlaanderen, VAN DE VELDE, 63-64; BUNING, "Meer licht op de von Ziegesars", 1973, 326. 
LEB, 15 juni 1915, 1.

De Brusselse correspondentie van 25 juni 1915 werd in DVP, 8 juli 1915, 3 gepubliceerd. Over de klacht werd ook gewag gemaakt in HVN, 24 juni 1915, 1. WILS, 2014, 111. YAMMINE, 2011, 306-307; VRINTS, 51. VRINTS, 2002, 47-50. Begin maart 1915 gaf Schowalter in Antwerpen lessen Nederlands aan Duitse officieren, HVN, 9 april 1915, 1; LVS, 20 april 1915, 1; LEB, 27 april 1915, 1. WILS, 2014, 118. BORMS, 95; WILS, 2014, 119. HVN, 17 februari 1915, 1; GVB, 21-22 februari 1915, 4, vgl. DVS, 18, 21 februari 1915, 1; HVN, 31 januari 1915, 1.

LVS, 21 februari 1915, 2, overname in LM, 25 februari 1915, 1.

GVB, 13, 28 januari en 2 februari 1915, 1; L'Avenir, 18 februari 1915, 1; HVN, 17, 18 februari 1915, 1.

HVN, 18 februari 1915, 1; GVB, 21-22 februari 1915, 4.

GVB, 24 februari 1915, 3, vgl. voor een bevestiging De Telegraaf, Avondblad 1, 24 februari $1915,1$.

MASSART, 284 merkte op dat tijdens de eerste weken van de bezetting de correspondentie slechts in het Frans en in het Duits toegestaan was.

MÜLLER, 2020, 51.

GVB, 24 februari 1915, 4.

HVN, 4 maart 1915, 1.

DVS, 21 maart 1915, 2.

Volgens AMARA, ROLAND, 77 (32) werd Le Bruxellois gesticht door H.H. Rosenbaum, een Duitser die reeds lang te Brussel verbleef. La Libre Belgique (114, 1 maart 1917, 3) duidde hem aan als eigenaar van het blad en François Belvaux (pseud. "Marc de Salm") als hoofdredacteur. Het sluikblad schreef een artikel uit LB, 20 januari 1917, 2, waarin vermeld werd dat hoofdredacteur "Marc de Salm" zijn functie stopzette, aan Rosenbaum toe.

293 AMARA, ROLAND, 78-79; LB, 11 augustus 1915, 1 meldde dat er een nieuwe drukpers in gebruik genomen was. Le Bruxellois en de Gazet van Brussel gebruikten inderdaad vanaf die dag hetzelfde lettertype.

WILS, 1974, 66; VAN DE VELDE, 43.

AMARA, ROLAND, 77 (33); De Telegraaf, Avondblad, Tweede Blad, 24 juli 1915, 8. Volgens het Belgisch Dagblad (28 december 1915, 1) behoorden ook de als "halve Duitsers" omschreven broers Moressée en Kay Nyst (of Ray-Nijst, volgens L'Echo Belge, 11 december 1915, 1) tot de redactie.

VRINTS, 2002, 43-44.

AMARA, ROLAND, 78 (39).

WILS, 1974, 93.

HVN, 4 november 1915, 1. Men kon zich met name via Robert Van Genechten "die zich met de administratie voor Antwerpen gelast heeft", op het tijdschrift inschrijven. Daarbij werden dan twee adressen, waaronder de Rodestraat 44, opgegeven. Vlaamsche Gazet, 20 november 1914, 1 
LB, 1 december 1914, 1

Vlaamsche Gazet, 23 november 1914, 1.

L'Avenir, 18 februari 1915, 1.

Vlaamsche Gazet, 3, 8 december 1914, 1; WILS, 1974, 88-93.

Vlaamsche Gazet, 7 januari 1915, 1.

HVN, 14 januari 1915, 1. In HVN, 27 juni 1915, 1 werd een nieuw programma gepubliceerd, waarin de "strikte onpartijdigheid" uitgeroepen werd.

WILS, 2014, 114 (1).

HVN, 14 januari t.e.m. 26 april 1915, 1.

WILS, 1974, 93.

LM, 12 december 1914, 1.

LM, 6 januari 1915, 1; LM, 7 juli 1915, 1.

Le Temps, 14 januari 1915, 3; Le Temps, 31 januari 1915, 2; DVS, 1 februari 1915, 1; WILS, 2014, 114.

De Gazet van Brussel verhoogde het aantal pagina's van 2 naar 4 in zijn $31^{\text {ste }}$ editie, hoewel het dagblad al vanaf de eerste editie in Duitse handen was. Bij Le Bruxellois vond een vergroting van het formaat plaats in de $40^{\text {ste }}$ editie en werd het aantal bladzijden van 2 naar 4 verhoogd in het $53^{\text {ste }}$ nummer, op 17 november 1914. Bij de Vlaamsche Gazet vond de verhoging plaats in de $41^{\text {ste }}$ editie sedert het herverschijnen van het dagblad. De Duitse bezetter zal misschien afgewacht hebben of de door hem gestichte (of opgekochte) dagbladen een succes waren, alvorens het aantal bladzijden te verhogen.

WILS, 2014, 128.

Voor wat volgt over het optreden van Wirth: VANACKER, 1986, 1-15; LFL, 7, 12, 14 en 15 maart 1921, 1; BUNING, 1974, 233-264; WILS, 2014, 77-92.

VAN DE VELDE, 49-50.

HVN, 19 juli $1915,1$.

VRINTS, 2002, 79.

WILS, 2014, 90.

VAN DE VELDE, 88.

WILS, 2014, 90.

De Nederlander, 5 januari 1915, 1, vgl. GERICKE, 323-325.

AMARA, ROLAND, 78, (39).

GOTOVITCH, 474 (5).

RGP 137, 203.

LIB, 19 november 1914, 2.

ANGERMILLE, 22-23.

GVB, 5 januari 1915, 1.

GVB, 13 januari $1915,1$.

GVB, 28 januari 1915, 1.

HVN, 6 juni 1915, 1.

GVB, 4 maart 1915, 1.

LVS, 15 februari 1915, 2; LVS, 12, 14, 17 maart 1915, 1; LVS, 8 april 1915, 1; LVS, 20 april 1915, 3; LVS, 23, 27, 30 april 1915, 2; LVS, 2, 15 mei 1915, 3; LVS, 16 juni 1915, 2; LVS, 18, 24, 27 juni 1915, 1. 
Zo in LVS, 6 juni 1915, 1 en LVS, 16 juni 1915, 1.

LVS, 11 maart 1915, 1.

VAN DE WOESTIJNE, 267.

De Stem uit België, 8 januari 1915, 2.

De Beweging, Deel 1, 1915, 131.

NRC, Avondblad B, 2 februari 1915, 1.

De Telegraaf, Avondblad 1, 6 februari 1915, 2. De belofte van twee vernederlandste universiteiten (Gent en Leuven) was ontleend aan de suggestie van Graevell aan Von der Goltz, LVS, 28 december 1914, 1.

DVS, 16 februari 1915, 1.

WILS, 1974, 52-53, vgl. MERTENS, 1978, 405.

\section{Hoofdstuk 5: De waarheid over La Vérité}

[DE CONINCK], 35-36; FAINGNAERT, 33-35; Activisten, 3; BASSE, 165-166; Tegengestelde Vlaamsgezinde geluiden kwamen niet in de historiografie terecht, zie J. Hoste in Le Journal des Débats, 16 april 1915, 1; A. Vandeperre in De Belgische Standaard, 22 oktober 1915, 1 en Vrij België, 12 november 1915, 4; WILS, 1974, 78, 255; MERTENS, 402-403, 405; DE SCHAEPDRIJVER, 153; SAERENS, 91; VRINTS, 2002, 62-63; VANACKER, 1984, 144, (7); Volgens VANACKER, 1985, 2 (4) was La Vérité misschien een "commerciële kwakkel"; VANACKER, 2006, 42, 92; MOLENAAR, 516 (21); YAMMINE, 2011, 286-289; WILS, 2014, 74, 100-101; MÜLLER, 2020, 54-55.

2 (1) Voor de eerste versie (Den Haag), YAMMINE, 2011, 287-290; (2) De tweede versie (Den Haag) luidt "LA VERITE SUR LA CAPITULATION...”; (3) De versie uit Gent draagt als titel "Du TEMPS du 28 décembre 1914..."; (4) In het dagboek van Fredericq is een vlugschrift opgenomen, getiteld "DOOR HET FRANSKILJONISME WORDT TE GENT...." Fredericq schreef erbij: "Du Tijd" en "Du Temps du 28 décembre 1914". Dit was blijkbaar overgetypt van de originele exemplaren, getuige het aantal keren dat men "sic" erin aantreft. De inhoud ervan stemde grotendeels met (3) overeen. Nog in zijn dagboek werd de inhoud van het pamflet in een andere, getypte brief overgenomen, maar nu als onderdeel van een patriottisch protestschrift tegen La Vérité, DPF, 44, 103, 114-116.

3 Zo luidde de eerste zin: "Le 5 octobre les troupes allemandes forcerent [sic, forcèrent] la Nèthe." In de Nederlandse versies was dat: "forcèrent le passage de la Nèthe". "pour aller en Flandre" (Nederlandse versies) werd "Pour se replier sur la Flandre Orientale" (Gentse versie). Het getal 16.000 soldaten bedroeg in de Gentse versie 16.700. Het aantal troepen dat de grens overgetrokken was, bedroeg in het Gentse pamflet geen 20.720 (Nederlandse versies) maar 20.790. I.p.v. met 35 uur vertraagd te zijn (Nederlandse versies) heette de capitulatie in het Gentse stuk met 36 uur vertraagd te zijn. Soms werden andere woorden gebruikt (“compagnons" was in de Gentse versie "comparses"). In de Gentse versie waren de namen van de personen correct gespeld, op die van Ryckmans na ("Hyckmans").

4 DVS, 14 februari 1915, 2.

$5 \quad$ Nieuwe Courant, Tweede Avondblad, 12 april 1915, 1. 
6 JDR, 27 oktober 1914, 1; Le Bruxellois, 6 november 1914, 2.

7 GVB, 5 januari $1915,1$.

8 JDR, 27 oktober 1914, 1; Le Bruxellois, 6 november 1914, 2.

9 Dietsche Stemmen, 1916, 446 (1).

10 In het pamflet stond: "...faire argent de tout". Dit soort taalfouten is ook indicatief voor het apocriefe karakter ervan.

11 JDR, 22 oktober 1914, 2.

12 LIB, 28 oktober 1914, 2.

13 Hoofdstuk 3, par. 3.

14 LB, 1 december 1914, 1; LB, 15 januari 1915, 1; LB, 18, 20 april 1915, 1; LB, 5 mei 1915,1 .

15 LEB, 18 maart 1915, 1 schreef hoe het herstel van de Antwerpse forten, die tegen de geallieerden moesten gebruikt worden, door toedoen van het Antwerps gemeentebestuur betaald was. Dit soort berichten gaf La Vérité als "franskiljons" artefact misschien meer geloofwaardigheid bij Vlaamsgezinden.

16 Cf. "marchands" wat kan verwijzen naar het Bijbelse "marchands du temple", waardoor de verbinding met de joden duidelijker wordt. In Marc. 10, 15-17 wordt beschreven hoe Jezus de tempel reinigt van handelaars.

17 Matt. 23, 1-39.

18 Marc. 13, 1-2; Luc. 21, 6; Matt. 23, 1-2.

19 Apocalyps, 21,1-2.

20 Jes. 22, 1-3.

21 Jes. 11, 8.

22 HVN, 1 oktober 1917, 1.

23 HVN, 14 december $1917,1$.

24 STREUVELS, 246-247.

25 LEB, 29 oktober 1914, 1; DVS, 13 februari 1915, 1; WILS, 2014, 27-30.

26 Door Vlaanderen Heen, 1917, z.p.

27 Rome en Carthago vochten drie oorlogen uit tussen 264 en 146 v.C. Die mondden uit in de vernietiging van Carthago. De Romeinse staatsman Cato de Oudere beëindigde elke toespraak met "ceterum censeo Carthaginem delendam esse"; LEJEUNE, 9.

28 Voor het antisemitisme in La Nouvelle Carthage, CHAVASSE, 97-112.

29 CHAVASSE, 99, 109, (9).

30 Dagon was een der voornaamste goden van de Filistijnen. Samson verwoestte de tempel waar zij aan hem offers brachten en doodde duizend Filistijnen (Rechters, $16,30)$.

31 EEKHOUD, 1893, 144-156.

32 In zijn visioen ging het, aldus Eekhoud, om een explosie of een schipbreuk.

33 EEKHOUD, 1893, 210-212, 248-262.

34 EEKHOUD, 1893, 111.

35 LUCIEN, 215.

36 MAETERLINCK, 1901, 275-276.

37 VOM BRUCH e.a., 84 . 
KELLEN, 1915/6, 144-156. Kellen was al vóór de oorlog een kenner van de Europese en mondiale pers, zie KELLEN, 1908, passim.

KELLEN, 1915.

Gleanings in Bee Culture, vol. 22, nr. 3, 1 februari 1894, 1.

Süddeutsche Monatshefte, jg. 12, Heft 7, 1 april 1915, 19-30.

CHAVASSE, 98; In mindere mate vindt men dit antisemitisme ook in DE COSTER, 85-86. In de inleiding van Belgien sonst und Jetzt vinden we trouwens ongeveer dezelfde namen (De Coster, Lemonnier, Eekhoud en Maeterlinck) terug, KELLEN, 1915, 16; Süddeutsche Monatshefte, jg. 12, Heft 7, april 1915, 27-30.

$\mathrm{Zie}$, voor wat volgt, behoudens tegenstrijdige verwijzing, ROLAND, 1996, 194201; LUCIEN, 288; GOVAERTS, 738-761; VAN UFFELEN, 238-245; VAN DEN BERG, 217-242.

YAMMINE, 2011, 259-260.

FISCHER, 1967, 169-170.

Zie de rapporten van Von der Lancken van 8 februari 1916 en 31 juli 1917 over de samenwerking tussen de Politische Abteilung en Insel Verlag, AMARA, ROLAND, $176,289$.

ROLAND, 2009, 62-67, 73.

Eekhoud liep noch in 1903, noch in 1915 hoog op met de vertaling van Kellen. Naar aanleiding van het aprilnummer van de Süddeutsche Monatshefte schreef hij: “...wat me wat ontstemt is dat mr. Tony Kellen zonder twijfel denkt aan mijn Nouvelle Carthage dat door hem verhaspeld werd [om tegemoet te komen aan] de noden van een publiek van moffen." [B.Y.], EEKHOUD, 1915, 47.

ELIAS, 100. Privé meldde Eekhoud dat hij niets van de politieke strekking van dit blad afwist, GONNE, 32-33.

Mercure de France, 1 juni 1914, z.p.

LJW, 25 januari 1911, 1-3.

Dit was een verwijzing naar de woorden van Napoleon, ROSE, 321.

LJW, 25 januari 1911, 1-3.

DIRR, 213-224, 261-263, 270.

KRETHLOW, 429.

VON DER LANCKEN, 131 e.v.; De commandanten die op verzoek van de burgerlijke overheid gecapituleerd hadden, moesten na de oorlog voor de krijgsraad verschijnen, maar werden vrijgesproken, WILS, 2014, 65.

AMARA, ROLAND, 74-75.

AMARA, ROLAND, 75 (26). De Zentrum-politicus Bachem was dus ook hoofdredacteur van de Kölnische Volkszeitung. Geen wonder dat Rieth bij hem werd aangeraden voor de demarche betreffende het herderlijk schrijven van Mercier. Hij kende de Brusselse correspondent van het blad immers via het gouvernement-generaal (vgl. hoofdstuk 4, par. 7).

59 AMARA, ROLAND, 74-75; NEURAY, II, 328-335; LEB, 10 november 1915, 1; WILLEQUET, 415-416; GILLE e.a. I, 36-37. Wertheimer vervalste ook stukken uit het oorlogsdagboek van Streuvels voor Duitse propagandadoeleinden, LEB, 2 mei 1915, 1-2; DVS, 7 mei 1915, 1; De Stem uit België, 14 januari 1916, 9. HAGELWEIDE, 26. 


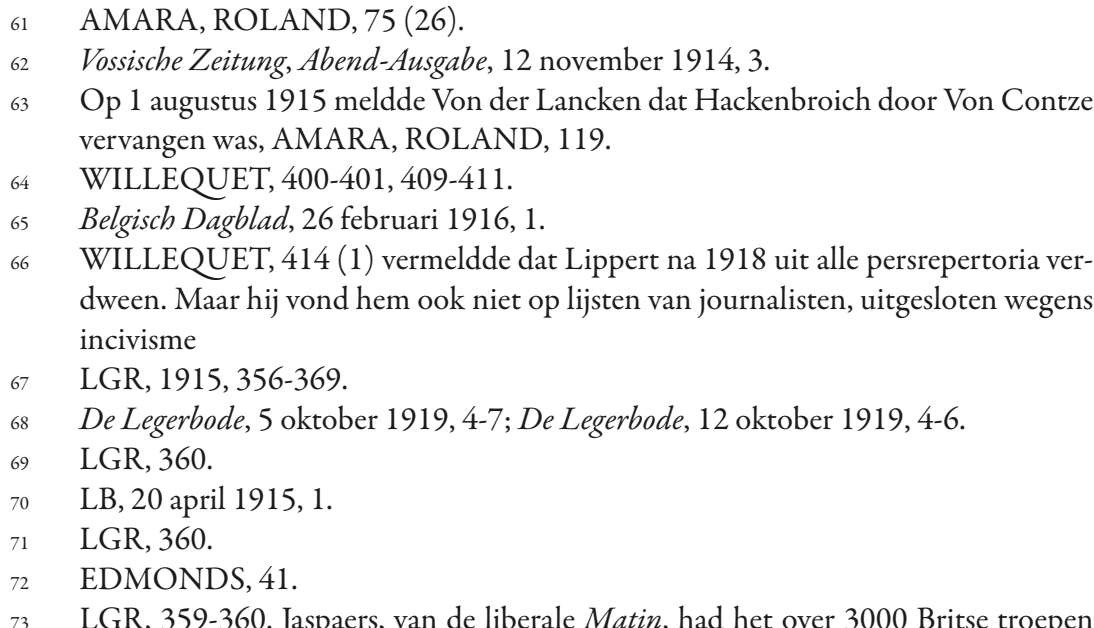

73 LGR, 359-360. Jaspaers, van de liberale Matin, had het over 3000 Britse troepen bewapend "met prachtige mitrailleuses", De Tijd, 15 oktober 1914, 2. Maar die voerde propaganda en moest dus optimistisch blijven.

74 De Legerbode, 12 oktober 1919, 4.

75 BUCHAN, 186, vgl. CRAPET, 1922, 58-59.

76 EDMONDS, 41 (2).

77 BUCHAN, 186.

78 Volgens de Duitse Illustrierte Geschichte des Weltkrieges (1914, 410-411) overschatten de Antwerpenaren het aantal Britse troepen met minstens dertig- tot veertigduizend. De Britten zouden immers altijd in cirkels gemarcheerd hebben, zodat de indruk gewekt werd dat ze een haast eindeloze rij vormden. Zo'n overdreven cijfer, dat we ook in La Grande Revue aantroffen, leert misschien meer over de Duitse oorsprong van het stuk.

79 EDMONDS, 44-45, vgl. DONNELL, 187-188.

80 LGR, 360; EDMONDS, 47; In De Legerbode, 12 oktober 1919, 4, wordt gewag gemaakt van drie Britse marinedivisies (in totaal 10.000 man) waarvan er twee op 5 oktober te Antwerpen aangekomen waren, vgl. Revue du Nord, 1922, 58.

81 LGR, 360.

82 De Nieuwe Gazet, 3 oktober 1914, 1; Le Matin, 3 oktober 1914, 1.

83 Le Matin, 7 oktober 1914, 1; LM, 7 oktober 1914, 1.

84 LGR, 361.

85 EDMONDS, 55-57; BUCHAN, 194.

86 LGR, 362-363.

87 De Legerbode, 12 oktober 1919, 5. Uit de notities van 6 oktober blijkt dat de commandant toen al wist dat de Belgische generale staf een spoedige terugtocht voorbereidde, LGR, 359.

88 LGR, 360-361.

89 LGR, 361. 


\section{Hoofdstuk 6: De top van de ijsberg}

1 La Libre Belgique, 38, augustus 1915, 2; De Telegraaf, Avondblad, I, 11 oktober 1915, 2. Vgl. ook PASSELECQ, 123. omdat men een telefooninstallatie probeerde neer te zetten in het fort van Lierse, BUJAC, 10.

EDMONDS, 32, (1).

LGR, 356.

Zie hoofdstuk 7, par. 1.

DVP, 14 mei 1915, 1.

LB, 11 december 1915, 1 .

LM, 2 juli 1915, 1; LEB, 6 juli 1915, 1.

LEB, 25 augustus 1915, 1.

LAvenir, 16 december 1914, 2.

AT, 25 januari 1915, 1; Vgl. de notities van drie Brusselse journalisten (6 februari 1918) over Antwerpenaars die door nogal wat mensen als min of meer germanofiel afgeschilderd werden omdat de havenstad vóór de oorlog vooral een Duits cliënteel heette te hebben, GILLE e.a., IV, 53.

GVB, 31 januari-1 februari 1915, 2-3.

HVN, 10 april $1915,1$.

YAMMINE, 2011, 289-290.

AMARA, ROLAND, 60-61.

Frankfurter Zeitung und Handelsblatt, Erstes Morgenblatt, 20 april 1915, 1; 24 april $1915,1-2$.

WILS, 1974, 78.

DVP, 18 maart 1915, 2.

$\mathrm{AB}$, april 1915, 1.

WILS, 2014, 122.

Le Progrès Libéral, 1 april 1915, 1-2. In HVN, 10 april 1915, 2 en DVP, 17 april 1915, 3 werd op het artikel uit het Brussels blad gewezen.

$A B$, juni (B) 1915, 1-2.

$\mathrm{AB}$, juli (A) 1915, 1-2.

Een overname van de inhoud van beide pamfletten vindt men in [MOMMAERTS], 15-17.

HVN, 24 mei 1915, 1; DVP, 28 mei 1915, 1.

AT, 4 juni 1915, 1.

De Nieuwe Gazet, 12 juni 1915, 1.

De leerplicht waarvan sprake in het pamflet, werd in mei 1914 ingevoerd,

Op 30 september 1914 vielen er, volgend op het Duitse bombardement, doden DUMOULIN, DUJARDIN, I, 573. Voor de tweetalige tekst van La Politique Belge après la Crise, zie AB, juni (B) 1915, 2.

WILS, 2014, 122. 
AB, juni (B) 1915, 2-3; Het Handelsblad, 29 januari 1914, 1; Gedenkschriften, 174; WILS, 2009, 140; Annales Parlementaires, 1913-1914, 1049-1078.

LVS, 24 augustus 1915, 1.

Raad van Vlaanderen, Verklaring aan het Vlaamsche Volk, 3.

DELMELLE, 36; Activisten, 36-37.

DU BOIS, 2.

LJW, 25 april 1911, 42-44, vgl. Le Soir, 2 april 1911, 2.

LJW, 25 april 1911, 42-44.

De vertalingen van het pamflet in de activistische propaganda zijn op elkaar afgestemd. Zo schreef Antwerpen Boven (juni (B) 1915, 2) dat het ging om "vertegenwoordigers van [...] de rijke financiers" en had de Gazet $(29$ juni 1915, 1) het over "vertegenwoordigers van [...] de rijke geldheren". Nochtans luidde de oorspronkelijke tekst: "représentants [...] de la haute finance" [het grootkapitaal].

GVB, 18-25 december 1914, 1, vgl. GVB, 15 mei 1915, 1 waarin gesteld werd dat het maar eens uit moest zijn met de vooroorlogse dorpspolitiek en de propaganda van Le Bruxellois (26 november 1914, 4 en 21 december 1914, 1).

GOTOVITCH, 473.

DESTREE, 16.

VAN GINDERACHTER, 2005, 43-44.

LB, 1 december 1914, 1 .

LB 29 maart 1915, 1.

Hoofdstuk 4, par. 4.

GVB, 2 april 1915, 3.

LB, 8, 20 april 1915, 1 .

Vgl. LB, 5 mei 1915, 1.

Op 24 mei 1915 maakte Het Vlaamsche Nieuws er voor het eerst gewag van. In YAMMINE, 2017, 246-252 bewezen we dat het pamflet van Duitse oorsprong was, maar duidden we nog niet de bronnen aan waaruit de propaganda van de bezetter putte.

GDA, 1 februari 1915, 1.

GDA, 8 november 1914,4 .

GDA, 6 december 1914, 4; GVB, 7 december 1914, 2.

Daaraan werd dan de volgende anekdote toegevoegd: “Toen de correspondent de koning verzocht de slag zelf te mogen zien, waarschuwde de vorst hem dat mevrouw Asquith [de echtgenote van de Britse eerste minister, $B Y$ ] die enkele dagen geleden haar nieuwsgierigheid wou bevredigen (!) een enorme angst beleefde en door granaten in levensgevaar kwam." [B.Y.] Het bericht was afkomstig uit de Berlijnse Nationalzeitung, cf. Pester Lloyd, 28 januari 1915, 7; Innsbrucker Nachrichten, 29 januari 1915, 4; HVN, 5 februari 1915, 1; L'Information, 7 februari 1915, 1. Margot Asquith bezocht inderdaad tussen 10 en 14 december 1914 koning Albert. Een Belgische officier en enkele andere soldaten vroegen haar of ze het Duitse geschut vanop de hoge terp wou zien. Ze deed dat, maar er kwamen géén granaten hun kant op, ASQUITH, II, 157-164. Er zat dus een kern van waarheid in het bericht dat aan Associated Press toegeschreven werd. Maar in tegenstelling tot wat in het "persbericht" stond, had de vrouw van de Britse eerste minister het front 
niet "enkele dagen geleden" bezocht, maar wel bijna twee maanden eerder, vgl. ASQUITH, BROCK, 54-60.

38 YAMMINE, 2017, 244-245.

39 Gazet van Brussel, 22 januari 1918, 1; YAMMINE, 2017, 259 (112); FAINGNAERT, 147. In de Süddeutsche Monatshefte, jg. 12, Heft 7, 1 april 1915, 24 had Kellen het stuk, toegeschreven aan de Associated Press, overigens deels hernomen. Was hij bij de constructie van La Politique Belge betrokken?

$40 \quad$ AB, juli (A) 1915, 2; DVP, 22 mei 1915, 3; HVN, 1 juni 1915, 1.

$41 \mathrm{AB}$, juli (A) 1915, 1-2. Voor de tekst waarop de inhoudsanalyse gebaseerd is, FAINGNAERT, 300-303 en GVB, 28 juni 1915, 1. Antwerpen Boven had de tekst maar partieel weergegeven.

42 De in deze paragraaf besproken artikels zijn La Neurasthénie Wallonne - Le Remède, Wallonie!, 20 juli 1914, 1-2; Le Devoir Wallon \& la France, ibidem, 2-3; Le Vrai Patriotisme Wallon, ibidem, 3; Le Monument Belge, ibidem, 3-4 en Figures françaises de Wallonie, ibidem, 4 (de literaire kroniek van Wallonie!).

43 DU BOIS, 7-8.

44 VERBRUGGEN, 232-233.

45 DIRR, 103-105.

46 Zie, voor dit pamflet, FAINGNAERT, 303-315; separatim in De Walen en de Statenbond; BASSE, 180; NEVB, 3414.

47 DIRR, 52, 95, 97-98, 110, 219, 229, 231, 249-250, 256-257, 260, 281, 306, 314, 345, 386, 430-432; Activisten, 96.

48 Vossische Zeitung, Abend-Ausgabe, 26 juni 1915, 1.

49 LVS, 8 juli 1915, 1; LM, 11 juli 1915, 1.

50 GVB, 28 juni 1915, 1.

51 GVB, 5 januari 1915, 1.

52 DVS, 3 april 1915, 1.

53 GVB, 13 april 1915, 1.

54 YAMMINE, 2017, 252-255.

55 DVS, 1 februari 1915, 1.

56 DVS, 9 mei 1915, 1.

57 DVS, 10 februari $1915,1$.

58 DVS, 16, 17 februari 1915, 1.

59 DVS, 15, 18, 20 en 27 april 1915, 1, vgl. DVS, 22 april 1915, 1.

60 DVS, 15 maart 1915, 1; DVS, 4 april 1915, 1.

61 DVS, 4 februari 1915, 4; DVS, 1 maart 1915, 1; DVS, 15 maart 1915, 1; DVS, 20 maart 1915, 4; DVS, 26 maart 1915, 2; DVS, 17 april 1915, 1; DVS, 10 mei 1915,1 . N.a.v. een artikel van oud-Germania medewerker Karl Lamprecht in een Duits tijdschrift, schreef De Vlaamsche Stem dat er blijkbaar in de Vlaamse beweging een buitengewoon kleine minderheid was die toenadering tot Duitsland zocht, DVS, 28 maart 1915, 1.

62 DVS, 14 februari 1915, 1; DVS, 22 februari 1915, 3; DVS, 25 februari 1915, 3; DVS, 1 maart 1915, 1; DVS, 17 maart 1915, 1; DVS, 20 maart 1915, 1; DVS, 26 maart 1915, 1; DVS, 19 juni 1915, 1. Het manifest van Reinhard en Josson werd 
wel gepubliceerd, met enkele dagen later de bedenking van Du Catillon dat beiden in feite voor de koning van Pruisen gewerkt hadden.

63 DVS, 20 maart 1915, 1.

64 DVS, 14 februari 1915, 2; DVS, 18, 21 februari 1915, 1; DVS, 22 februari 1915, 3; DVS, 7, 17, 20 maart 1915, 1; DVS, 20 maart 1915, 4; DVS, 21, 26 maart 1915, 2; DVS, 18 april 1915, 1; DVS, 6 mei 1915, 2; DVS, 19 mei 1915, 4; DVS, 13, 14 juni 1915, 1. Als reactie op de berichtgeving uit De Vlaamsche Stem waarvan sprake in de lopende tekst beweerde DVP, 8 mei 1915, 1, dat de Gazet van Brussel een "katholieke en liberale nitgever" had. De GVB, 15 mei 1915, 1 spuide nog wat meer mist door te beweren dat ze geen oorlogsblad was, omdat vóór de oorlog al tot haar oprichting besloten was en het eerste nummer normaal in september 1914 moest verschijnen, zij het dan onder een andere naam (een duidelijke allusie op De Standaard, zie hoofdstuk 3, par. 8). In DVP, 18 mei 1915, 1 heette het dat er liberalen en katholieken in de redactie van het hoofdstedelijke orgaan zetelden. LEB, 9 mei 1915, 1. DVS, 14 februari 1915, 2; DVS, 15 maart 1915, 1; DVS, 6 april 1915, 2. DVS, 4, 31 maart 1915, 1; DVS, 4 april 1915, 1; DVS, 12 mei 1915, 1; DVS, 24 juni $1915,1$.

68 DVS, 4 mei 1915, 1.

69 DVS, 1 maart 1915, 1, vgl. DVS, 15 maart 1915, 1 en DVS, 14 april 1915, 1.

70 DVS, 3 februari 1915, 1; DVP, 4 maart 1915, 7.

71 DVS, 2 maart 1915, 2; DVS, 8 maart 1915, 1, vgl. DVS, 18 april 1915, 2. LEB, 19 maart 1915, 1; DVS, 20 maart 1915, 1; DVS, 1 april 1915, 1; DVP, 22 april 1915, 2; DVS, 26 april 1915, 4; DVS, 30 mei 1915, 1.

DVS, 9, 13 maart 1915, 3.

DVS, 17 maart 1915, 4.

BUNING, 1974, 243.

DVP, 12 maart 1915, 1; DVS, 26 maart 1915, 1; DVP, 31 maart 1915, 4-5; DVS, 1, 7 april 1915, 1; DVP, 30 mei 1915, 4, vgl. DVP, 11 april 1915, 1; DVS, 30 mei 1915, 1; DVS, 3 juni 1915, 4.

76 LM, 31 maart 1915, 1; LM, 6 juni 1915, 1 loofde het blad aanvankelijk.

77 LEB, 19 maart 1915, 1.

78 DVS, 13 april 1915, 3; LEB, 14 april 1915, 1.

79 DVS, 3 april 1915, 1.

80 DVS, 9 mei 1915, 1.

81 DVS, 26 juni 1915, 1.

82 De Amsterdammer, nr. 1965, 1915, 3-4; DVS, 24 februari 1915, 1; De Amsterdammer, nr. 1969, 1915, 11; DVS, 22 maart 1915, 1.

83 DVS, 28 maart 1915, 1.

84 LEB, 30 maart 1915, 1.

85 DVS, 6 april $1915,1$.

86 LEB, 9 mei 1915, 1; DVS, 25 mei 1915, 4.

87 LEB, 30 mei 1915, 2.

88 DVS, 3 juni 1915, 3; DVS, 10 juni 1915, 1.

89 LEB, 4 juni 1915, 2. 
DVS, 5 juni 1915, 3; LEB, 6 juni 1915, 3; DVS, 7 juni 1915, 1.

WILS, 1994, 266; RIEZLER, ERDMANN, 346 (3).

RIEZLER, ERDMANN, 279 (7).

RGP 137, 192.

RGP 137, 444.

RGP 137, 61, 68; KRAAIJESTEIN, SCHULTEN, 217, 220; BUNING, “'De Vlaamsche Stem' en 'De Vlaamsche Post'”, 1975, 71; WILS, 1994, 266.

MÜLLER, 2020, 59.

Zie, voor deze paragraaf, behoudens tegenstrijdige verwijzing, [WICHERT].

YAMMINE, 2017, 252-253; Die problemen werden in DVP, 30 mei 1915, 4 bekend gemaakt, vgl. DVP, 7 april 1915, 2.

WILS, 1974, 116, 119.

VAN HEES, 36-43, 75-88; BWN, III, Den Haag, 1989, 193-196.

WILS, 2014, 140.

FAINGNAERT, 130; ELIAS, 41 en, tot op zekere hoogte zelfs VANACKER, 2006, 59 .

WILS, 2014, 140.

De Telegraaf, 22 augustus 1915, 2.

YAMMINE, 2017, 252-253.

De Telegraaf, 22 augustus 1915, 2; WILS, 2014, 139-145.

Het is dus niet zo dat de Duitse legatie niet begreep dat precies de anti-Duitse houding van De Vlaamsche Stem haar Vlaamse standpunten minder verdacht maakte (VANACKER, 2006, 59).

WILS, 2014, 141.

WILS, 2005, 196.

Voor wat volgt, DVP, 11, 14, 15 mei 1915, 1.

De aanleiding voor Deswarte om in DVS, 23 mei 1915, 1 te spreken ten voordele van het federalisme was een brochure van Derk Hoek, getiteld Vlaanderen en de Belgische kwestie. Deswarte viel die brochure al aan in DVS, 27 april 1915, 1. Dat deed ook de Nederlandse en anti-activistische staatsraad Struycken (DVS, 16 mei 1915, 4). In DVS, 31 mei 1915, 1 onderschreef Deswarte de kritiek van Struycken op Hoek. Die had de mogelijkheid tot annexatie van Vlaanderen door Duitsland opengelaten. Maar hij gaf Hoek gelijk wat het federalistische element in zijn brochure betrof. Hoek repliceerde in DVS, 31 mei 1915, 1; LVS, 18 juni 1915, 1; DVS, 28 juni $1915,1$.

DVS, 29 juni 1915, 1.

VRINTS, 2002, 29.

DVS, 30 juni $1915,1$.

Zie bv. Activisten, 11-35.

Hooger Leven, 31 januari 1914, 1; DVS, 1 juli 1915, 1.

ELIAS, 97.

HVN, 8 september $1915,1$.

LEB, 26 juni 1915, 1.

DVS, 29 juni $1915,1$.

DVP, 25 juni 1915, 1; LEB, 29 juni 1915, 1; DVS, 2 juli 1915, 1. 
WILS, 2014, 142.

LEB, 1 juli $1915,1$.

DVS, 2 , 3 juli $1915,1$.

LEB, 1 juli 1915, 1.

LEB, 5 juli 1915, 1.

GVB, 1, 2, 5 juli 1915, 2; HVN, 7 juli 1915, 1; DVP, 12 juli 1915, 1.

DVP, 11 juli 1915, 1; GVB, 22 juli 1915, 1; DVP, 19 juli 1915, 3.

Het betrof dus de positie die Picard eerder tegen Deswarte verdedigd had, cf. de vorige paragraaf.

De opstand in de Nederlanden; de Franse revolutie; de Belgische revolutie.

WILS, 2014, 142.

De Vlaamsche Stem had in een aankondiging Vlamingen en Nederlanders opgedragen de Guldensporenslag te komen herdenken. De Vlaamsche Post (11 juli 1915, 3) nam dit bericht met instemming over.

DVS, 13 juli 1915, 3; DVP, 15 juli 1915, 2; NEVB, 742-744.

JACOB, 8-10; DVS, 17 juli 1915, 1.

ELIAS, 35-36, vgl. FAINGNAERT, 133.

DVS, 28 juni 1915, 1.

[WICHERT].

LVS, 17 juli 1915, 1.

AMARA, ROLAND, 105.

NRC, Avondblad A, 13 juli 1915, 1.

DVP, 20 juli 1915, 3.

Getypte brief van Meert.

VANACKER, 2006, 93-94, 118.

MÜLLER, 2020, 61-62.

NRC, Ochtendblad A, 21 juli 1915, 5; De Belgische Standaard, 29 juli 1915, 1.

[WICHERT].

De Telegraaf, 22 augustus 1915, 2; [WICHERT].

YAMMINE, 2012, 247; De Telegraaf, 22 augustus 1915, 2.

VANACKER, 2006, 59.

Het "Bussumer-telegram" bevatte wel de vraag naar een "bevrijdend woord", maar op dat moment stond het dagblad al onder Duitse controle.

[WICHERT].

Archives, 395.

Nieuwe Courant, Avondblad, 23 maart 1915, 1; AMARA, ROLAND, 92.

DVP, 8 april 1915, 1.

NRC, Avondblad, A, 13 juli 1915, 1.

Annales Parlementaires, 1920, 660.

Behoudens tegenstrijdige verwijzing verwijzen we voor de "zaak-Buisset" naar YAMMINE, 2012, 233-256.

GVB, 17 juli 1915, 3.

GVB, 23 juli 1915, 2.

NRC, Ochtendblad A, 20 juli 1915, 2; GVB, 21 juli 1915, 1. Dezelfde verdraaiingen vindt men in het becommentariërende artikel in de GVB, 28 augustus 1915, 1. 
HVN, 25 juli 1915, 1.

HVN, 30 augustus 1915, 1, vgl. HVN, 25 juli 1915, 1.

GVB, 10 januari 1915, 1. In de GVB, 3 februari 1915 schreef De Sadeleer wel dat de beschuldigingen die "Franselaars" tegen Vlamingen de wereld inzonden elke grond misten. Dat bleek uit de handelswijze van de Duitse overheid. Op de nieuwe bankbiljetten bekleedde het Nederlands een nog mindere plaats dan op dat van de Nationale Bank van België. Er werden dus bewust tegenstrijdige signalen gelanceerd.

HVN, 18, 22, 25 juli 1915, 1; GVB, 21 juli 1915, 1. In de GVB, 23 juli 1915, 2 werd de naam van Buisset voor het eerst onthuld. Het was dus niet in augustus 1915 dat de Duitse diensten wisten welke munt ze uit de brief konden slaan, zoals beweerd in WILS, 2014, 94; GVB, 23, 24 juli 1915, 2; 27 juli 1915, 1; 29, 30 juli 1915, 2; 1 t.e.m. 4 augustus 1915, 2; 5 augustus 1915, 3; 10, 12, 13 augustus 1915, 1; 15 augustus 1915, 2; 19 augustus 1915, 3; 27, 28 augustus 1915, 1. Vgl. HVN, 6,10 augustus 1915,1 .

DVP, 6 augustus 1915, 1; HVN, 8 augustus 1915, 1.

HVN, 30 augustus 1915, 3. Het commentaarstuk op de brieven verscheen al in HVN, 20 augustus 1915, 1.

HVN, 20 augustus 1915, 1.

GVB, 27, 28 augustus 1915, 1.

GVB, 28 augustus 1915, 1; HLN, 15 april 1910, 2; HLN, 22 februari 1913, 2.

Het commentaarstuk van Borms in HVN, 30 augustus 1915, 1 stemde soms letterlijk overeen met wat de GVB, 28 augustus 1915, 1 schreef.

WILS, 2014, 150.

VAN HEES, PUCHINGER, I, 20, 22, (1). In 1930 gaf Gerretson "het gehele inzicht" van Groen van Prinsterer als volgt weer: "Scheiding nu om hereniging later mogelijk te maken: scheiding nu om in België door de ontwikkeling van het Ned[erlandse] element te scheppen van een hereniging, van een Ned[erland] dat weer 'bolwerk' tegen Frankrijk zal kunnen zijn", VAN HEES, PUCHINGER, II, 47-48.

LEERSSEN, 60-64; WILS, 2004, 135-136.

Voor wat hierna volgt, zie, behoudens tegenstrijdige verwijzing, GROEN VAN PRINSTERER, 1831, 37-68 en 145-148; GROEN VAN PRINSTERER, 1930, 116-121; GROEN VAN PRINSTERER, 1847, 397-429; GROEN VAN PRINSTERER, 1870, 310-324.

GROEN VAN PRINSTERER, 1930, 116-121.

Inderdaad bijna van 1648 tot 1798.

FREY, FREY, 1995, 389-390; WILS, 2005, 89.

ONNEKINK, BRUIN, 2013, passim.

Voor wat volgt, zie DVP, 26 april 1915; 2 mei 1915, 2; 11, 14 en 15 mei 1915, 1.

DVP, 2 mei 1915, 2-4.

DVP, 22 juni 1915, 1.

DVP, 2 mei 1915, 1-2.

MÜLLER, 2020, 62-63. Op 26 augustus liet de Kölnische Zeitung vanuit Brussel weten dat men van bevoegde zijde van zo'n besluit geen kennis had en dat van een beroep op Duitse professoren nooit sprake was, De Tijd, 20 augustus 1915, 3; 27 augustus 1915, 1; LEB, 21 augustus 1915, 1; LVS, 2 september 1915, 2. In LEB, 
15 september 1915, 1 werd gewag gemaakt van de heropening van de universiteit in oktober 1915 op grond van een bericht in een Nederlands blad. L'Echo sprak dit echter tegen op grond van wat een Brusselse correspondent op het ministerie van Wetenschappen en Schone Kunsten vernomen had; LM, 19 september 1915, 1. MÜLLER, 2020, 64 beweert daarentegen dat Von Kühlmann een beslissende rol speelde in de vernederlandsing van de Gentse universiteit door de bezetter.

Op 16 januari 1915 vertelde men op de Kommandantur aan advocaat Van de Putte uit Elsene dat de Gentse universiteit vernederlandst ging worden, WILS, 2014, 56-57; Zie ook hoofdstuk 4, par. 8 en p. 253 van dit werk. In Le Temps, 27 juni 1915, 2 stond dat Von Bissing aan een groep flaminganten formeel de vervlaamsing van de universiteit van Gent zou hebben beloofd en dat hij dat hoopte te doen vóór het einde van het jaar. Toch zou het bijzonder moeilijk zijn om geschikt onderwijzend personeel voor alle vakken te vinden. "On se contenterait donc au début de flamandiser les cours spéciaux." AMARA, ROLAND, 66.

AMARA, ROLAND, 113.

MÜLLER, 2020, 63-64.

VANACKER, 2006, 71-73; WILS, 2014, 150-152; MÜLLER, 2020, 69-71.

WILS, 2014, 153.

WILS, 1994, 267; MÜLLER, 2020, 72.

WENDE, 1969, 80; MÜLLER, 2020, 72-73.

MÜLLER, 2020, 73-74.

VRINTS, 2002, 44.

RGP 137, 45-47.

[WICHERT].

WILS, 2014, 154-155.

Uit De Beweging, 1915, Deel 2, 37 (1), 25-27, blijkt dat Gerretson tijdens een voordracht op 8 januari 1915 in Leiden gegeven, citeerde uit Nederlandsche Gedachten in het algemeen en uit 1832 in het bijzonder.

FISCHER, 1967, 479.

DELFORGE, 278-279.

Bij die propaganda sloot NORDEN, 1915 aan. La Libre Belgique (49, oktober 1915, 3-4) meldde dat deze brochure door de Kommandantur overal prominent uitgestald was. Op 1 november 1915 schreef Von der Lancken dat ze ondanks een zeer agressieve toon een grote afzet gekend had, AMARA, ROLAND, 156. WILS, 1994, 267.

DVP, 15 juni 1915, 1.

YAMMINE, 2017, 252-253, 255-256; GVB, 28, 29 juni 1915, 1; HVN, 29 juni $1915,1$.

YAMMINE, 2017, 256-257.

LUYCKX, 1996, 100. Volgens Ryckmans kon het ook gaan om het werk van kwaadwilligen die Antwerpen in een pro-Duits daglicht wilden plaatsen.

HVN, 5 maart 1915, 1.

LUYCKX, 1996, 101. 
Journal des Débats, 16 april 1915, 1; Vrij België, 12 november 1915, 4.

HVN, 30 augustus 1915, 4.

DVP, 10 oktober 1915, 1; DVS, 14 november 1915, 1.

LIB, 4 oktober 1915, 1; LIB, 24 november 1915, 3.

YAMMINE, 2012, 245-247.

GVB, 11 november 1915, 1.

HVN, 12, 20 november 1915, 1; DVP, 16 november 1915, 1.

Op 8 november 1915 publiceerde de Nieuwe Courant (Ochtendblad, 2) deels het schrijven. Meert schreef de redactie van dat blad daarop (Nieuwe Courant, Avondblad, 16 november 1915, 1) dat hij er niet op gerekend had dat zijn schrijven van juli nog in november gepubliceerd zou worden. Hij merkte op dat de brief niet gericht was tegen het manifest-Van Cauwelaert, maar tegen de aankondiging ervan. De volledige brief van Meert vindt men in de GVB, 11 november 1915, 1.

Zo bijvoorbeeld DVP, 23 november 1915, 1.

De Telegraaf, 12 november 1915, 2.

Gedenkschriften, 219.

DPF, 70, 293-294.

DE BRUYNE, 56-70.

\section{Hoofdstuk 7: Radicalisering}

VANACKER, 2006, 79.

VAN EVERBROECK, 221-222.

3 DE SCHAEPDRIJVER, 189-190, 329. Later poneerde ze dat het een "externe mythe" en een "ideologische constructie" betrof die een vrucht was van "de inspanningen van de frontbeweging, die na de oorlog geleidelijk wordt ingepalmd door Vlaamse collaborateurs", De Morgen, 11 juli 2008.

4 MÜLLER, 2020, 156.

5 DE WEVER, 27.

$6 \quad$ WILS, 2009, 34, vgl. MÜLLER, 2020, 318.

7 Over de frontbeweging, zie WILS, 2014, 170-176, 203-225, 247-266, 277-297 en VANACKER, 2000,passim.

8 Staaltjes hiervan vindt men in AB, 8 augustus 1915, 2-3.

9 GVB, 11 december 1914, 1.

10 GVB, 13 december 1914, 2; GVB, 31 januari-1 februari 1915, 3, vgl. GVB, 19 februari 1915, 4; HVN, 24 februari 1915, 1.

11 Pester Lloyd, 25 november 1914, 4.

12 Reichspost, 27 december 1914, 6.

13 GVB, 21 januari 1915, 1, gesignaleerd in WILS, 1974, 76.

14 GDA, 15 november 1914, 4, vgl. GDA, 1 november 1914, 2; GDA, 22 november 1914, 3; GDA, 29 november 1914, 3-4.

15 GDA, 8 november 1914, 3.

16 GVB, 3 januari $1915,4$.

17 GVB, 27 januari 1915, 4.

18 HVN, 30 januari en 17 februari 1915, 1. 
19 Süddeutsche Monatshefte, jg. 12, Heft 7, 1 april 1915, 39-49.

20 GDA, 20 december 1914, 4-5.

$21 \quad$ DVS, 23 juni $1915,1$.

$22 \quad$ NEVB, 2612-2613.

23 DVP, 5 mei 1915, 1.

24 DVS, 11 juli 1915, 1; DVP, 16 juli 1915, 1-2; GVB, 22 juli 1915, 1; HVN, 25 oktober 1915, 3; Vlaamsch Leven, 1916, 476; JACOB, 20.

25 DVS, 19 maart 1915, 4.

26 DVP, 3 t.e.m. 6 en 9 oktober 1915, 1.

27 Voor wat volgt, zie, behoudens tegenstrijdige verwijzing, GVB, 20 juli 1916, 1.

RGP, 137, 34, 67-68. Rietjens was lid van het "Vlaams comité" van Leiden, WILS, $2014,150$.

WILS, 2014, 217.

Voor staaltjes van dit proza, zie De Toorts, jg. 1 (1916) nr. 4, 7-8; nr. 7, 6-7; nr. 10, 4-5; nr. 13, 6-7; nr. 19, 8; nr. 25, 6; nr. 29, 6; nr. 30, 6-7.

32 Limburger Koerier, 28 juli 1916, 1. Naar WILS, 2014, 217 aangeeft, had Rietjens in de Limburger Koerier het propaganda-verhaal over August Van Cauwelaert geschreven. Afgaande op Vrij België, 4 augustus 1916, 5 (overname in Limburger Koerier, 12 augustus 1916, 1) blijkt dat Van Cauwelaert de toespraak van Rietjens uit de Limburger Koerier vernomen had. Rietjens en Van Cauwelaert schreven overigens elk nog twee brieven naar het Nederlandse dagblad om over de kwestie te redetwisten (Limburger Koerier, 14 augustus 1916, 2; 24 augustus 1916, 1; 28 augustus 1916,2$)$.

33 WILS, 2014, 179-180.

34 NRC, Ochtendblad B, 15 september 1917, 2.

35 Voor Vlaanderen, december 1917, 3-4.

36 GVB, 31 januari 1918, 2. Dit bericht lijkt ons een vervalsing, gebaseerd op Vrij Belgie, 30 november 1917, 6 .

37 GVB, 1 oktober 1918, 1.

38 Uilenspiegel van Leuven, 19 mei 1918, 5; De Eendracht, 29 juni 1918, 1-2; HVN, 22 juni 1918, 1 .

De Nieuwe Tijd, 24 augustus 1918, 1.

HVN, 24 augustus 1918, 1.

AMARA, ROLAND, 281 (1).

De Indeeling, eerste bladzijde (niet genummerd) (1), 60, 67, vgl. RUDIGER, 218228.

Citaten in De Indeeling, 14, 6-7, 11-12, 26, 15, 41-42.

De Indeeling, 9, 17, 22, 23, 10 (1).

RUDIGER, 222-223.

Vrij België, 4 januari 1918, 3; DVS, 28 t.e.m. 30 juni 1915, 1. Zie hoofdstuk 6, par. 4.

$47 \mathrm{Al}$ in Vrij België, 26 november 1915, 2 werd door Van Cauwelaert het onderscheid gemaakt tussen "bestuurlijke scheiding" en "bestuurlijke aanpassing" (de eentaligheid van Vlaanderen). 


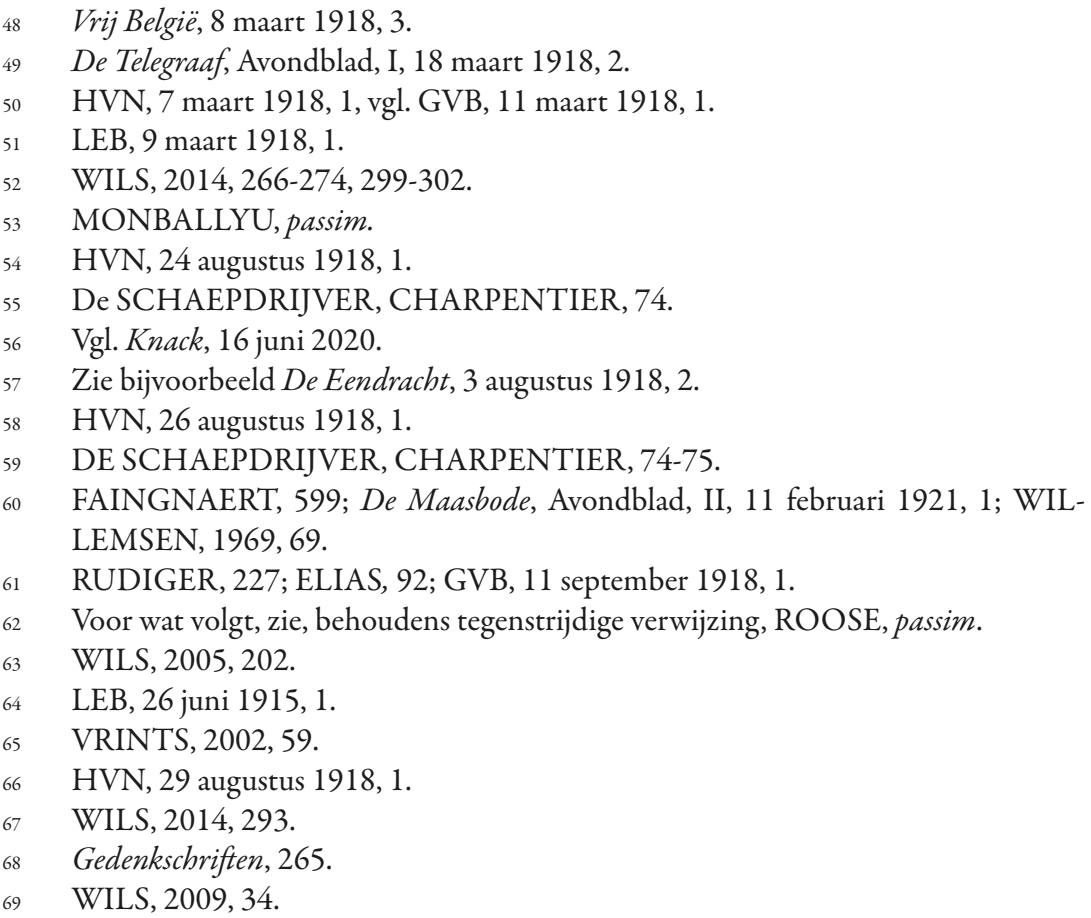

\section{Slotbeschouwingen}

1 Tot op zekere hoogte werd en wordt de geschiedschrijving hier beïnvloed door de flamingantische voorstelling waaruit moest blijken dat er vóór 1914 geen germanofilie in de Vlaamse beweging schuilging. 
17 Akademische Turnzeitung, 1916, 105.

18 ANGERMILLE, 10; Dietsche Stemmen, 1916, 282.

19 VRINTS, 2002, 44.

20 VRINTS, 2002, 44, 84-86.

21 GVB, 28 juni $1915,1$.

22 MÜLLER, 2020, 61, 66-67, 74-75.

23 Gec. in WHITLOCK, I, 645.

24 FAINGNAERT, 383-384; WILS, 1974, 101.

25 DVS, 8 september 1915, 1.

26 YAMMINE, 2011,331.

27 In DVS, 17 oktober 1915, 1 schreef Jacob wel: "of een Vlaams Vlaanderen ook een Duits belang is, kan ons onverschillig laten."

28 WILS, 2020, 386 (16), vgl. 148.

29 Raad van Vlaanderen, het activisme, 35-36, vgl. Geschiedkundig overzicht, 104-105.

30 Van flamingant tot "landverrader", 3, 29.

31 Geschiedkundig overzicht, 119-120.

32 SEBERECHTS, 212.

33 WILS, 1974, 31.

$34 \quad$ WHITLOCK, II, 249. "Les Allemands exploitèrent la question [flamande] pour ébranler les fondements même de l'Etat belge." schreef Leo Van der Essen een jaar later in The Times, numéro spécial, 323.

35 Aan het Vlaamsche volk!, 3.

36 Open Brief, 6.

37 YAMMINE, 2011, 284.

38 Cf. het belang ervan als bewijsmateriaal voor het gegeven dat de activisten niet als eersten de Godsvrede schonden in DOSFEL, 14 (1).

39 NEVB, 1235.

40 VRINTS, 2002, 87; SEBERECHTS, 75.

${ }_{41}$ Zie hoofdstuk 4, par. 6.

42 VANACKER, 2006, V.

43 DUMOULIN, DUJARDIN, I, 29.

44 Correct is: "de Belgische onafhankelijkheid" of "het ontstaan van het Koninkrijk België".

45 DUMOULIN, DUJARDIN, I, 195-197, 402-403.

46 MÜLLER, 2020, 71.

47 KENNAN, 3.

48 Vgl. WILS, 2015, 237. 



\section{BIBLIOGRAFIE}

\section{Dagbladen}

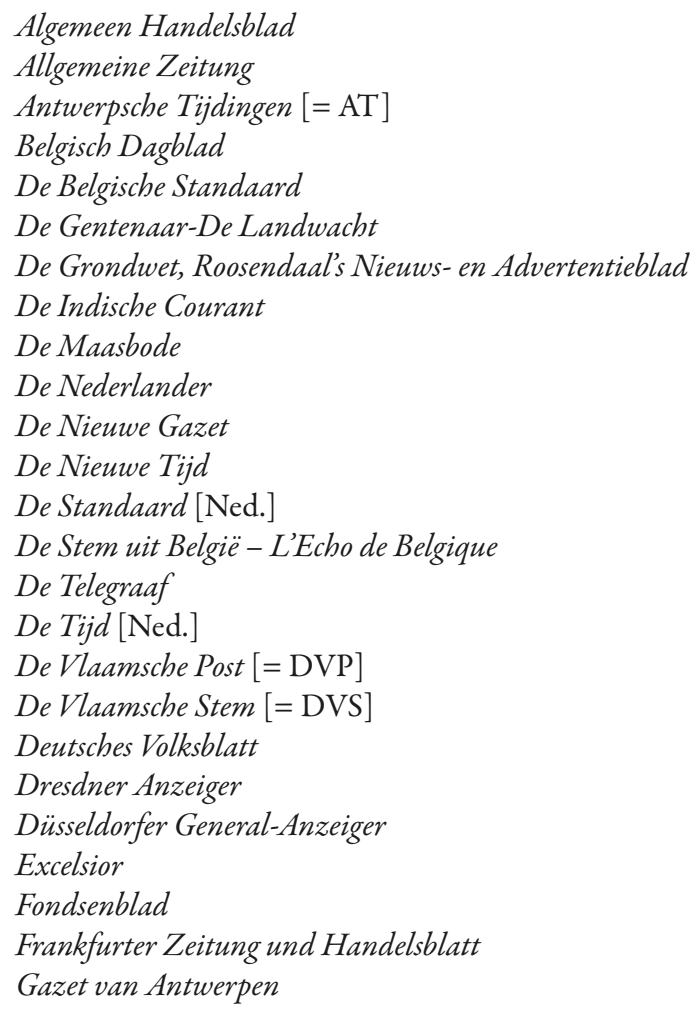


Gazet van Brussel [= GVB]

Gazette des Ardennes [= GDA]

Gazette van Gent

Haagsche Courant

Het Centrum

Het Handelsblad van Antwerpen

Het Laatste Nieuws [= HLN]

Het Nieuws van den Dag

Het Vaderland

Het Vlaamsche Nieuws [= HVN]

Het Volk [= HV]

Het Volk [Ned.]

Het Volksbelang

Informations Belges

Innsbrucker Nachrichten

Journal d'Anvers

Journal de Bruxelles

Journal de Gand

Journal des Réfugiés [= JDR]

Kölnische Zeitung

L'Ami de L'Ordre

L'Aurore

L'Avenir

L'Echo Belge [= LEB]

L'Echo d'Anvers

L'Echo de Bruxelles

L'Echo de la Presse

L'Indépendance Belge [= LIB]

L'Information

La Belgique

La Belgique (Journal des Réfugiés)

La Chronique

La Flandre Libérale [= LFL]

La Métropole [= LM]

La Meuse

La Presse

Le Bien Public

Le Bruxellois [= LB]

Le Courrier d'Anvers

Le Journal de Gand

Le Matin

Le Nouveau Précurseur

Le Patriote

Le Petit Bleu du matin [= LPB]

Le Petit Journal 
Le Petit Parisien

Le Peuple

Le Progrès Libéral

Le Siècle

Le Soir

Le Temps

Le Vingtieme Siècle [= LVS]

Leidsch Dagblad

Neptune

Neue Freie Presse

Nieuwe Courant

Nieuwe Rotterdamsche Courant [= NRC]

Norddeutsche Allgemeine Zeitung

Pester Lloyd

Provinciale Noordbrabantsche en 's Hertogenbossche Courant

Reichspost

Rotterdamsch Nieuwsblad

The Daily Mail

Vlaamsche Gazet - Het Laatste Nieuws

Vooruit

Voralberger Volksfreund

Vossische Zeitung

\section{Opiniërende tijdschriften}

Akademische Turnzeitung

Antwerpen Boven [= AB]

Courrier de l'Escaut

De Amsterdammer

De Beweging

De Eendracht

De Gids

De Hollandsche Lelie

De Legerbode - Le Courrier de L'Armée

De Toekomst

De Toorts

Deutsche Wochenzeitung für die Niederlande und Belgien

Dietsche Stemmen

Dietsche Warande en Belfort

Door Vlaanderen Heen

Frankfürter zeitgemässe Broschuren

Gerechtigkeit, Monatshefte für auswärtige Politik 


\section{Germania}

Gleanings in Bee Culture

Globus

Hammer

Het Vlaamsch Heelal

Hooger Leven

L'Echo des Mines et de la Métallurgie

La Grande Revue [= LGR]

La Jeune Wallonie [= LJW]

La Libre Belgique

La Revue Bleue

La Semaine

Le Coq Wallon

Le Mercure Anvers-Bruxelles

Le Messager de Bruxelles

Le Petit Belge

Les Nouvelles

Mercure de France

Neerlandia

Ons Land

Onze Eeuw

Revue du Nord

Stemmen voor Waarheid en Vrede

Süddeutsche Monatshefte

Uilenspiegel van Leuven

Vlaamsch Leven

Voor Vlaanderen

Vrij België

Wallonie!

Zeitschrift für Bücherfreunde

\section{Aangehaalde bronnen en werken}

"DOOR HET FRANKILJONISME [sic] WORDT TE GENT IN HANDSCHRIFT VAN HAND TOT HAND OVERGELEVERD. La Vérité sur la capitulation d'Anvers", in Dagboek Paul Fredericq [= DPF], 44 (16 januari 1915 - 14 februari 1915), [Gent], [1915]

"Historicus Lode Wils: 'Ik hoop dat Bart De Wever niet de Boris Jeltsin van Vlaanderen wordt"', Knack, 16 juni 2020

"Vijf Vlaamse mythen in hun blootje", De Morgen, 11 juli 2008

[A. DE CONINCK], De Waarheid over het Vlaamsche volk, 's Gravenhage, 1917

[A. LIMET], Lettre ouverte au peuple belge par un philanthrope, [Brussel], [1915] 
[F. WICHERT], “Die Zeitung 'De Vlaamsche Stem' als politisches Werkzeug. Vorläufiger Bericht von dr. Wichert, Leiter der Hilfsstelle. Geheim!', [Den Haag], [1915]

[H.D. MOMMAERTS], Aan het Vlaamsche Volk, s.l., [1917]

[Memorandum uitgegeven door het Katholiek Vlaamsch Hoogstudentenverbond, Leuven en de Kathol. Vl. Oud-Hoogstudentenbonden], Vlaanderens nood aan zelfstandigheid, s.l., 1927

[Nationale Bond voor Belgische Eenheid], Geschiedkundig overzicht van het aktivisme, Brussel, 1929

Activisten, Gent, 1919

AMARA, M. en ROLAND, H., Gouverner en Belgique occupée, Oscar Von der Lancken-Wakenitz, Rapports d'activité (1915-1918), Brussel, 2004

ANGERMILLE, K., De lotgevallen van een activist - van Antwerpen naar Antwerpen! (1914-1929), Borgerhout, 1931

Annales Parlementaires (1913-1914); (1919-1920)

ANSIAUX, M., "La pénétration allemande en Belgique", Congrès international pour l'extension de la culture et de la langue française, première session, Liège, 10-14 september 1905, Parijs, 1906, pp. 1-16

ASQUITH, M. en BROCK, E., Margot Asquith's Great War diary (1914-1916): the view from Downing Street, Oxford, 2014

ASQUITH, M., The autobiography of Margoth Asquith, II, Londen, 1936

BALTHAZAR, H. en VAN CAMPENHOUT, N., Twee Jonge Vlamingen in de Groote Oorlog, Oorlogsdagboeken en levensverhaal van de flaminganten August Balthazar en Leo Picard, Tielt, 2014

BASSE, M., De Vlaamsche Beweging van 1905 tot 1930, Eerste Deel, Gent, 1930

BERKELAAR, W., DORSMAN, L., VAN HEES, P., Pieter Geyl. Ik die zo weinig in mijn verleden leef. Autobiografie (1887-1940), Amsterdam, 2009

BITSCH, M.-T., La Belgique entre la France et l'Allemagne (1905-1914), Parijs, 1994

BLUNCK, H.F., Belgien und die niederdeutsche Frage, Jena, 1915

BOIS, A., DU, Le Catéchisme du Wallon, Bergen, 1902 [= DU BOIS]

BOIS, A., DU, Waterloo (Belges ou Français?), Roman, Parijs, 1902

BORMS, A., "Bijdrage tot de geschiedenis van het Antwerpsch aktivisme”, Vóór - 1830 - Na. Een bundel opstellen en gedichten. In opdracht van den 'Dietschen Bond', Santpoort, 1930, pp. 95-100

BOWERSOX, J., Raising Germans in the age of empire: Youth and colonial culture (18711914), Oxford, 2013

BRAYBON, G. (red.), Evidence, history and the Great war: Historians and the impact of 1914-1918, New-York, Oxford, 2005

BRINGMANN, T.C., Handbuch der Diplomatie, 1815-1963, Auswärtige Missionschefs in Deutschland, München, 2001

BROUCEK, P., Ein General im Zwielicht, die Erinnerungen Edmund Glaises von Horstenau, III, Wenen, 1988

BRUNET, E., Calomnies Allemandes. "Les Conventions Anglo-Belges", Parijs, s.d.

BUCHAN, J., Nelson's history of the war, vol. III, The Battle of the Aisne and the events down to the fall of Antwerp, Londen, 1919

BUJAC, E., Anvers (1914), Le Stucage, l'Effort, l'Agonie, Brussel-Parijs, 1919 
BUNING, L., “'De Vlaamsche Stem' en 'De Vlaamsche Post': hoe stonden ze ten opzichte van elkaar?”, Wetenschappelijke Tijdingen, jg. 34, nr. 1-2, 1975, kol. 29-38 en kol. 63-92

BUNING, L., "De vooravond en het begin van het radicale activisme te Gent", Wetenschappelijke Tijdingen, jg. 32, nr. 4-5, 1973, kol. 193-216

BUNING, L., "Het persfenomeen 'De Vlaamsche Post', Wetenschappelijke Tijdingen, jg. 33, nr. 4-5, 1974, kol. 233-264

BUNING, L., "Meer licht op de von Ziegesars", Wetenschappelijke Tijdingen, jg. 32, nr. 6, 1973, kol. 310-317

BUNING, L., "Nieuw licht op het Brusselse activisme", Wetenschappelijke Tijdingen, jg. 38 , nr. 2, 1979, kol. 193-228

BUNING, L., "Reismann-Grone, het Alldeutscher Verband en de Vlamingen”, Wetenschappelijke Tijdingen, jg. 34, nr. 4-5, 1975, kol. 223-262

CAESTECKER, F., "In het kielzog van de Natie-Staat, de Politiek van nationaliteitsverwerving, -toekenning en -verlies in België (1830-1909)", Belgisch Tijdschrift voor Nieuwste Geschiedenis, jg. 27, nr. 3-4, 1997, pp. 323-349

CHAVASSE, P., "Le Cosmopolitisme antisémite de Georges Eekhoud dans La Nouvelle Carthage", Ninenteenth-Century French Studies, vol. 38, 2009-2010, pp. 97-112

CLARK, C., Slaapwandelaars: hoe Europa in 1914 ten oorlog trok, Amsterdam-Antwerpen, 2015

COLLEYE, R., BOUE DE VILLIERS, M., Une nuit florentine, drame en cinq actes en prose, Brussel, 1914

CRAPET, A., "Le général Deguise et la défense d'Anvers en 1914", Revue du Nord, vol. 8, nr. 28, 1922, pp. 54-63

CROMBOIS, J.F., Camille Gutt and postwar international finance, New York, 2011

Dagboek Paul Fredericq [= DPF], 38 (9 augustus 1914 - 29 augustus 1914), [Gent], [1914]

Dagboek Paul Fredericq [= DPF], 44 (16 januari 1915 - 14 februari 1915), [Gent], [1915]

Dagboek Paul Fredericq [= DPF], 70 (17 november 1915 - 3 december 1915), [Gent], [1915]

Dagboek Paul Fredericq [= DPF], 71 (22 januari 1916 - 27 januari 1916), [Gent], [1916]

DAUDET, L., L'Avant-guerre, études et documents sur l'espionnage juif-allemand en France depuis l'affaire Dreyfus, Parijs, 1913

DAVIGNON, H., Belgium and Germany, Parijs, 1915

DE BACKER, M. en VAN CAMP, L., "Het hof van Rieth van vroeger tot nu", Jaarboek Mortselse Heemkundige Kring, 1986, pp. 35-50

DE BRUYNE, A., "Hippoliet Meert (1865-1924), Vader van het Algemeen Nederlands Verbond”, Neerlandia, jg. 76, 1972, pp. 56-70

DE CORTE, B., Het tijdschrift Germania in het kader van de Vlaams-Duitse betrekkingen, Onuitgegeven Licentiaatsverhandeling, Leuven, 1982

DE COSTER, C., La légende et les avontures hérö̈ques, joyeuses et glorieuses d'Ulenspiegel et de Lamme Goedzak au pays de Flandres et ailleurs, Brussel, 1966

De Indeeling van de Belgische Weermacht, Verslag uitgebracht door de legerkommissie van het Vlaamsch-Belgisch Verbond, s.l., 1918 
DE LOOZE, H., Toen den Duitsch kwam: het Waasland tot de Duitse bezetting (augustus-oktober 1914), Sint-Niklaas, 2014

DE MAEYER, J., De rode baron, Arthur Verhaegen (1847-1917), Leuven, 1994

DE MUELENAERE, N., Belgen zijt gij ten strijde gereed?, Leuven, 2019

De Raad van Vlaanderen. Aan het Vlaamsche Volk!, s.l., [1917]

DE SCHAEPDRIJVER, K., CHARPENTIER, J., Vlaanderens weezang aan den IJzer, Kortrijk, 1918

DE SCHAEPDRIJVER, S., De Groote Oorlog: het Koninkrijk België in de Eerste Wereldoorlog, Amsterdam, 2008

DE SCHRYVER, R. (red.), VAN CAUWELAERT, F., Gedenkschriften over Vlaamse Beweging en Belgische politiek. Uit het archief van Frans van Cauwelaert 1, Antwerpen, 1971 [= Gedenkschriften]

DE SMAELE, H., Rechts Vlaanderen: religie en stemgedrag in negentiende-eeuws België, Leuven, 2009

De Walen en de Statenbond van Vlaanderen en Wallonië, [Brussel], [1916]

DE WEVER, B., Greep naar de macht, Vlaams-nationalisme en Nieuwe Orde. Het VNV (1933-1945), Tielt, 1994

DEDEURWAERDER, J., Professor Speleers: een biografie, Antwerpen, 2002

DEGLAS, C., Rampen in Belgie, Tielt, 2005

DEJARDIN, P., Raymond Colleye et le mouvement wallon pendant la guerre au front et à l'extérieur, Brussel, 1924

DELFORGE, P., La Wallonie et la première guerre mondiale, pour une histoire de la séparation administrative, Namen, 2008

DELMELLE, J., Albert du Bois: activiste, doctrinaire et prophète, Namen, 1969

DESTREE, J., Lettre au Roi sur la séparation de la Wallonie et de la Flandre, Brussel, 1912

DEVLEESHOUWER, R., Les Belges et le danger de guerre (1910-1914), Leuven, 1958

DIJK, M., Frederic Carel Gerretson (1884-1958): tussen vrijheid en gezag, een studie naar de maatschappijkritiek van prof. dr. F.C. Gerretson, Utrecht, 1999

DIRR, P., Belgien als französische Ostmark, zur Vorgeschichte des Krieges, Berlijn, 1917

DOLDERER, W. en MÜLLER, J., "België vernietigen. Het kronkelpad van een citaat", Wetenschappelijke Tijdingen, jg. 75, nr. 2, 2015, pp. 103-111

DOLDERER, W., "Een beleid uit één stuk? Continuïteit en discontinuïteit in de Duitse Flamenpolitik”, Wetenschappelijke Tijdingen, jg. 72, nr. 4, 2014, pp. 289-317

DOLDERER, W., Deutscher Imperialismus und belgischer Nationalitätenkonflikt, Die Rezeption der Flamenfrage in der deutschen Öffentlichkeit und deutsch-flämische Kontakte (1890-1920), Melsungen, 1989

DOMELA NIEUWENHUIS, S.H.E., De crisis in Vlaanderen en de Vlaamsche Beweging in verband met Groot-Nederland, s.l., 1915

DONNELL, C., Breaking the fortress line, 1914, Londen, 2013

DOSFEL, L., Katholiek aktivistisch verweerschrift, Gent, 1918

Du TEMPS du 28 décembre 1914. La Vérité sur la capitulation d'ANVERS, [Brussel], [1915]

DUMOULIN, M. en DUJARDIN, V. (red.), et. al., Nieuwe Geschiedenis van België, I, Tielt, 2005 
EDMONDS, J. E., History of the Great War, based on official documents by direction of the historical section of the Committee of Imperial Defense, Military Operations, France and Belgium, 1914, II, Londen, 1925

EEKHOUD, G., Journal Inédit: du 18 avril au 15 août 1915, [Brussel], [1915]

EEKHOUD, G., La Nouvelle Carthage, Brussel, 1893

EGELHAAF, G., Theobald von Bethmann-Hollweg, Biographie, Hamburg, 2013

ELEY, G., "Reshaping the right: radical nationalism and the German Navy League (18981908)", The Historical Journal, vol. 21, nr. 2, 1978, pp. 327-354

ELIAS, H.J., Vijfentwintig Jaar Vlaamse Beweging, I, Antwerpen, 1969

EPKENHANS, M. en STREMMEL, R. (red.), Friedrich Alfred Krupp, Ein Unternehmer im Kaiserreich, Essen, 2010

FAINGNAERT, A.L., Verraad of Zelfverdediging? Bijdragen tot de geschiedenis van den strijd voor de zelfstandigheid van Vlaanderen tijdens den oorlog van 1914-18, Kapellen, 1933

FISCHER, F., “Kontinuität des Irrtums: Zum Problem der deutschen Kriegszielpolitik im ersten Weltkrieg”, Historische Zeitschrift, Bd. 191, aug. 1960, pp. 83-100

FISCHER, F., Germany's aims in the First World War, New York, 1967

FRECH, S., Wegbereiter Hitlers? Theodor Reismann-Grone. Biographie eines völkischen Nationalisten (1863-1949), Paderborn, 2009

FREDERICQ, P., Schets eener geschiedenis der Vlaamsche beweging, I, Gent, 1906

FREDERICQ, P., Schets eener Geschiedenis der Vlaamsche beweging, III, Gent, 1908

FREY, L. en FREY, M., The Treaties of the War of the Spanish Succession: an historical and critical dictionary, Westport, 1995

GERICKE [= D. HOEK], F., Van het Slagveld der Natiën, Een Boek over België in dezen Tijd, behelzende tal van persoonlijke herinneringen, reisbeschrijvingen, stemmingsbeelden, indrukken, opmerkingen, beschouwingen, anecdoten en verhalen over het land België, zijne bevolking en hare levenswijs tijdens den nog woedenden oorlog, Den Haag, 1915

German posters in Belgium Their Value as Evidence New Texts and Documents with a Foreword to the Reader by Henri Davignon, Londen, 1918

Gesetz-und Verordnungsblatt für die Okkupierten Gebiete Belgiens, [Brussel], [1914]

Getypte brief van Hyppoliet Meert op 2 blzn. d.d. 17 juli 1915; "Reactie gericht aan de redactie van De Witte Kaproen over hun oproep tegen de Vlaamsche Post"

GILLE, L., OOMS, A., DELANDSHEERE, P., Cinquante mois d'occupation allemande, I, (1914-1915), Brussel, 1919

GILLE, L., OOMS, A., DELANDSHEERE, P, Cinquante mois d'occupation allemande, II, (1916), Brussel, 1919

GILLE, L., OOMS, A., DELANDSHEERE, P., Cinquante mois d'occupation allemande, III, (1917), Brussel, 1919

GILLE, L., OOMS, A., DELANDSHEERE, P., Cinquante mois d'occupation allemande, IV, (1918), Brussel, 1919

GONNE, M. (red.), Contrebande littéraire et culturelle à la Belle Epoque, Leuven, 2018

GOTOVITCH, J., "La légation d'Allemagne et le mouvement flamand entre 1867 et 1914", Belgisch Tijdschrift voor Filologie en Geschiedenis, jg. 45, nr. 2, 1967, pp. 438478 
GOVAERTS, B., "Essay. De Kleine Oorlog van Anton Kippenberg", Dietsche Warande en Belfort, jg. 135, 1990, pp. 738-761

GRAMLICH, J., Die Thyssens als Kunstsammler, Investition und symbolisches Kapital (1900-1970), Paderborn, 2015

GROEN VAN PRINSTERER, G., Antirevolutionaire Staatkunde, IV, 1930

GROEN VAN PRINSTERER, G., Nederlandsche Gedachten, I-L, Amsterdam, 1870

GROEN VAN PRINSTERER, G., Nederlandsche Gedachten, Tweede Deel, 's Gravenhage, 1831

GROEN VAN PRINSTERER, G., Ongeloof en revolutie. Eene reeks van historische voorlezingen, Leiden, 1847

GROJEAN, O., La Belgique et le Pangermanisme, Brussel, 1906

GUYOT, Y., "German designs on Holland and Belgium", North American Review, vol. 184, nr. 606, 1907, pp. 22-28

HAGELWEIDE, G., Literatur zur deutschsprachigen Presse, eine Bibliografie: Von den Anfängen bis 1970, IX, München, 1998

HAMMERN, U. [= T. KELLEN], “Georges Eekhoud”, Germania, 1903, pp. 67-82

HEYSE, T., Index documentaire. Tome I. L'Université flamande, Gent, 1919

http://www.bundesarchiv.de

Illustrierte Geschichte des Weltkrieges 1914, s.l., s.d.

JACOB, A., De Vlaamsche Stem, Amsterdam, 1920

JÄGER, G., LANGEWIESE, D., et. al., Geschichte des deutschen Buchhandels im 19. und 20. Jahrhundert, Band I, Das Kaiserreich (1871-1918), Teil 3, Frankfurt am Main, 2001

JOSSON, M., Frankrijk, de eeuwenoude vijand van Vlaanderen en Wallonië, Breda, 1913

KELLEN, T., "Die Firma Krupp und ibre soziale Tätigkeit", Frankfurter zeitgemässe Broschüren, Bd. 22, H. 5 (1902/03), pp. 141-176

KELLEN, T. en KRUPP, F., Friedrich Alfred Krupp und sein Werk, Braunschweig, 1904

KELLEN, T., Belgien sonst und jetzt; über 200 Bilder aus dem Lande zwischen Maas und Schelde, Berlijn, 1915

KELLEN, T., Das Zeitungswesen, Kempfen-München, 1908

KELLEN, T. en KRUPP, F., Krupp-Bibliographie, Leipzig, 1903

KELLY, C.B., Best little stories from World War I: Nearly 100 true stories, Naperville, 2014

KELLY, P.J., Tirpitz and the imperial German Navy, Bloomington, 2011

KENNAN, G.F., The decline of Bismarck's European Order: Franco-Russian relations (1875-1890), Princeton, 1980

KOCH, C., Giftpfeile über der Front: Flugschriftpropaganda in und nach dem Ersten Weltkrieg, Essen, 2015

KRAAIJESTEIN, M., SCHULTEN, P., Wankel evenwicht. Neutraal Nederland en de Eerste Wereldoorlog, Soesterberg, 2007

KRETHLOW, C.A., Generalfeldmarschall Colmar Freiherr von der Goltz Pascha, Eine Biographie, Paderborn, 2012

LA VERITE SUR LA CAPITULATION D'ANVERS, ANVERS, VILLE INFAME, VILLE DES JUIFS, DISCOURS prononcé par M. Hymans à la Haye, [Brussel], [1915]

La Vérité sur la prise d'Anvers, Antwerpen, 1915 
LADEMACHER, H., Die belgische Neutralität als Problem der europäischen Politik 1830-1914, Bonn, 1971

LANGLOIS, H., La Belgique et la Hollande devant le pangermanisme, Parijs-Nancy, 1906

LE NAOUR, J-Y., 1914: La grande illusion, Parijs, 2012

LEEMANS, G., PRAET, R., VANDEWEYER, L., "Alleen in u - O Koning - geloven wij nog": open brieven van de Vlaamse frontbeweging tijdens de Eerste Wereldoorlog, Antwerpen, 2017

LEERSSEN, J., Nationaal denken in Europa: een cultuurhistorische schets, Amsterdam, 2006

LEJEUNE, A., The concise dictionary of Foreign Quotations, Londen, 1998

Les archives du Conseil de Flandre (Raad van Vlaanderen), publiées par la Ligue nationale pour l'unité belge, Brussel, 1928

Les Conventions Anglo-Belges, s.l., s.d. [1915?]

LEYSEN, C. en BOEHME, O., 100 Jaar Ahlers in Antwerpen. Een familiebedrijf in een wereldhaven, Antwerpen, 2009

LOYEN, R., Haven in de branding, Leuven, 2008

LUCIEN, M., Eekhoud le rauque, Lille, 1999

LUYCKX, D., "Adelfons Henderickx en het activisme in Antwerpen tijdens de Eerste Wereldoorlog. Eerste Deel: in 1914”, Wetenschappelijke Tijdingen, jg. 53, nr. 1, 1994, pp. 21-33

LUYCKX, D., "Adelfons Henderickx en het activisme tijdens de Eerste Wereldoorlog, (Tweede Deel: in 1915)”, Wetenschappelijke Tijdingen, jg. 55, nr. 2, 1996, pp. 91-110

MAES, T.G., MULS, J., Antwerpen, 1914: bolwerk van België tijdens de Eerste Wereldoorlog, Antwerpen, 2013

MAETERLINCK, M., La Vie des Abeilles, Parijs, 1901

MASSART, J., Belgians under the German eagle, Londen, 1916

MEIR, G., Pol de Mont. Een studie over zijn leven en werk, Antwerpen-Amsterdam, 1932

MERTENS, J., "Louis Franck in het verzet tijdens de Eerste Wereldoorlog”, Belgisch Tijdschrift voor militaire geschiedenis, jg. 23, nr. 4, 1977, pp. 331-346 en nr. 5, 1978, pp. 399-418

MIKABERIDZE, A., The burning of Moscow: Napoleon's Trial by fire 1812, Barnsley, 2014

MOLENAAR, L., De rok van het universum, Marcel Minnaert, astrofysicus (1893-1970), Amsterdam, 2003

MONBALlYU, J., Deserteurs voor de Vlaamse Zaak. Over de Vlaamsgezinde militairen die naar de vijand overliepen, Brugge, 2012

MOTADEL, D., Islam and nazi Germany's War, Londen, 2014

MÜLLER-MEININGEN, E., Der Weltkrieg 1914-1915 und der "Zusammenbruch des Völkerrechts". Eine Abwehr- und Anklageschrift gegen die Kriegführung des Dreiverbandes, Berlijn, 1915

MÜLLER, J., "Nation-building avant la lettre? Deutsche Flamen- und Besatzungspolitik ab 1914", BISCHOFF, S., JAHR, C., MROWKA, T., THIEL, J. (red.), Belgica Terra Incognita? Resultate und Perspektiven der Historischen Belgienforschung, Münster, 2016, pp. 146-154 
MÜLLER, J., Die importierte Nation, Deutschland und die Entstehung des flämischen Nationalismus (1914-1945), Göttingen, 2020

NEURAY, F., La Belgique Nouvelle, à travers quatre ans de guerre, II, Brussel-Parijs, 1918

NIPPERDEY, T., Deutsche Geschichte (1866-1918), Band I, Arbeitswelt und Bürgergeist, München, 1994

NORDEN, F., La Belgique neutre et l'Allemagne, d'après les hommes d'Etat et les juristes belges, Brussel, 1915

NOWELL, G.P., Mercantile States and the World Oil Cartel (1900-1939), New York, 1994

OLDENBURG, J., Der deutschen Ostmarkenverein (1894-1934), Berlijn, 2002

ONNEKINK, D., BRUIN, R.E., De vrede van Utrecht, Hilversum, 2013

Open Brief aan den Koning der Belgen Albert I door de Frontsoldaten, s.l., 1917

OSZWALD, R.P., "Die deutsche Flamenpolitik und das Gutachten von Prof. Bredt vom parlementarischen Untersuchungsausschuss", Historische Zeitschrift, dl. 136, 1927, pp. 518-525

OSZWALD, R.P., "Die Errichtung des deutschen General-Gouvernements Belgien 1914”, DOREN, A., KIRN, P., KÜHN J. et. al., Staat und Persönlichkeit, Erich Brandenburg zum 60. Geburtstag, Leipzig, 1928, pp. 234-269

OTTE, T.G., July Crisis: the world's descent into war, Summer 1914, Cambridge, 2014

PASSELECQ, F., La Question flamande et l'Allemagne, Parijs-Nancy, 1917

PENNELL, C., A Kingdom United, Popular responses to the outbreak of the First World War in Britain and Ireland, New York, 2012

PETRI, F., “Nog eens de Flamenpolitik”, Wetenschappelijke Tijdingen, jg. 27, nr. 5, 1968, kol. 325-328

PETRI, F., “Zur Flamenpolitik des I. Weltkrieges. Ungelöste Fragen und Aufgaben”, Dauer und Wandel der Geschichte. Festschrift Kurt von Räumer, Münster, 1966, pp. 513-536

PIETRI, F., Mes années en Espagne, (1940-1948), Parijs, 1954

PIRENNE, H., La Belgique et la guerre mondiale, Parijs, 1929

Raad van Vlaanderen, het activisme tijdens en na den oorlog, Antwerpen, s.l., s.d.

Raad van Vlaanderen, Verklaring aan het Vlaamsche Volk, s.l., s.d.

RIEZLER, K., ERDMANN, K.D. (red.), Tagebücher, Aufsätze, Dokumente, Göttingen, 2008

ROLAND, H., "La diffusion de l'oeuvre de Georges Eekhoud en Allemagne", Textyles, Revue des lettres belges de langue française, nr. 13, 1996, pp. 193-203

ROLAND, H., Leben und Werk von Friedrich Markus Huebner (1886-1964), vom Expressionismus zum Gleichschaltung, Bonn, 2009

ROOSE, G.P.M., Wat Dr. Frans Van Cauwelaert zegt over de wantoestanden in het Belgisch leger aan den IJzer. De Vlaamsche Plicht, Leuven, 1918

ROSE, J.H., The life of Napoleon, Vol. 1, Frankfurt am Main, 2018

ROVERS, F., "Dan liever de lucht in!": Jan Van Speijk en de Belgische Opstand, Hilversum, 2000

RUDIGER, Flamenpolitik. Suprême espoir Allemand de domination en Belgique. D’Après des documents de la "Section Politique" du Gouvernement Général du Grand Quartier Général Allemand et de la IVe. Armée Allemande, Brussel, 1921 
SAERENS, L., Vreemdelingen in een wereldstad: een geschiedenis van Antwerpen en zijn joodse bevolking, Tielt, 2000

SANDERS, R., Aan den Vlaamschen IJzer, Antwerpen, 1924

SCHEPENS, L., Brugge Bezet, 1914-1918, 1940-1945: het leven in een stad tijdens twee wereldoorlogen, Tielt, 1985

SCHEPENS, L., Koning Albert, Charles de Broqueville en de Vlaamse beweging tijdens de Eerste Wereldoorlog, Tielt-Bussum, 1983

SCHMOOK, G., Stap voor stap langs kronkelwegen: Gedenkschriften, Antwerpen, 1976

SCHWOB, M., Les Oeuvres complètes de Marcel Schwob, Vies Imaginaires (1867-1905), III, Parijs, 1927

SEBERECHTS, F., Onvoltooid Vlaanderen, van taalstrijd tot natievorming, Antwerpen, 2017

SMIT, C., Bescheiden betreffende de Buitenlandse Politiek van Nederland, 1848-1919, Derde Periode (1899-1919), Tweede Deel (1903-1907), RGP 102, Den Haag, 1958 [= RGP 102]

SMIT, C., Bescheiden betreffende de Buitenlandse Politiek van Nederland (1848-1919), Derde Periode, Zevende Deel, Buitenlandse bronnen (1914-1917), RGP 137, ’s Gravenhage, 1971 [= RGP 137]

SMIT, C., Bescheiden betreffende de Buitenlandse Politiek van Nederland (1848-1919), Derde Periode (1899-1917), Vierde Deel (1914-1917), RGP 109, 's Gravenhage, 1962 [= RGP 109]

SMIT, C., Bescheiden betreffende de Buitenlandse Politiek van Nederland VI, Buitenlandse bronnen (1899-1914), RGP 128, Den Haag, 1968 [= RGP 128]

SOEN, V., Vredehandel: adellijke en Habsburgse verzoeningspogingen tijdens de Nederlandse Opstand (1564-1581), Amsterdam, 2012

Souvenir catalogue What German invasion means; an exhibition of photographs, proclamations, relics \& c. at the City art gallery, Leeds, Dec. 21, 1914 to Jan. 16, 1915, Leeds, 1914

Souvenir de la Guerre, Maurice Maeterlinck, à la scala de Milan, s.l., s.d.

STREUBEL, C., Radikale nationalistinnen: Agitation und Programmatik rechter Frauen in der Weimarer Republik, Frankfurt-New York, 2006

STREUVELS, S., In Oorlogstijd, Brugge-Nijmegen, 1979

STYNEN, L., Pol de Mont, een tragisch schrijversleven, Kalmthout, 2017

SZATMARI, E., Das rote Ungarn: der Bolschewismus in Budapest, Leipzig, 1920

The Times, numéro spécial consacré à la Belgique, Brussel, 1920

THOOFT, G., Berlijn-Antwerpen, Economische en politieke aspiraties in Duitsland met betrekking tot de haven van Antwerpen, Onuitgegeven Licentiaatsverhandeling, Gent, 2001

TIEDAU, U., "De Duitse cultuurpolitiek in België tijdens de Eerste Wereldoorlog”, Bijdragen tot de Eigentijdse Geschiedenis, nr. 11, 2003, pp. 21-45

VAN DE VELDE, M., Geschiedenis der Jong Vlaamsche beweging (1914-1918), 's Gravenhage, 1941

VAN DE WOESTIJNE, K., Verzameld Werk, VIII, Bussum, 1950

VAN DEN BERG, H.F., "Nederlandse letterkunde als Belgische literatuur. Over de weg van de Duitse uitgever Anton Kippenberg naar Vlaanderen in de Grote Oorlog en 
de weg van de Nederlandstalige Vlaamse letteren naar Centraal-Europa in de vroege twintigste eeuw", Neerlandica Wratislaviensia, nr. 25, 2016, pp. 217-242

VAN DER ESSEN, L., L'Invasion en Belgique, de Liège à l'Yser, Parijs, 1917

VAN EVERBROECK, C., "'Een bewustzijn geboren uit het vuur.' Vlaamse slachtoffers van de Eerste Wereldoorlog", MORELLI, A. (red.), De grote mythen uit de geschiedenis van België, Vlaanderen en Wallonië, Berchem, 1999, pp. 215-222

Van flamingant tot "landverrader", Een bladzijde over de wording en de ontwikkelingsdrang van het activisme, Den Haag, 1919

VAN GINDERACHTER, M., Het Rode Vaderland, de vergeten geschiedenis van de communautaire spanningen in het Belgische socialisme voor WO I, Tielt, 2005

VAN HAEGENDOREN, M., Geel en Zwart van de driekleur van oude en andere Belgen tot 1980, Leuven, 1980

VAN HEES, P., "Frederik Carel Gerretson als Groot-Nederlander", Wetenschappelijke Tijdingen, jg. 43, nr. 1, 1984, pp. 36-43 en nr. 2, pp. 75-88

VAN HEES, P., PUCHINGER, G., Briefwisseling Gerretson-Geyl, Deel I, 1911-1928, Baarn, 1979

VAN HEES, P., PUCHINGER, G., Briefwisseling Gerretson-Geyl, Deel II, 1929-1934, Baarn, 1980

VAN HERREWEGHEN, A., “De Gazet van Brussel (1914-1918)”, De Vlaamse Beweging tijdens de Eerste Wereldoorlog, Mededelingen van het Colloquium ingericht te Leuven op 15 en 16 november 1974 door de Afdeling Geschiedenis van de $19^{\text {de en }} 20^{\text {ste }}$ eeuw, Leuven, 1974, pp. 144-153

VAN UFFELEN, H., Moderne niederländische Literatur in deutschen Sprachraum (1830-1990), Münster, 1993

VAN VELTHOVEN, P., Franstaligen tegen Vlamingen, Hoe België als natie mislukte, Soesterberg, 2012

VANACKER, D., "De Vlaamsche Post”, Wetenschappelijke Tijdingen, jg. 45, nr. 1, 1986, pp. $1-15$

VANACKER, D., De frontbeweging: de Vlaamse strijd aan de IJzer, Koksijde, 2000

VANACKER, D., Het activistisch avontuur, Gent, 2006

VANACKER, D., "De onmogelijke Godsvrede”, Wetenschappelijke Tijdingen, jg. 44, 1985, nr. 1, pp. 3-8

VANACKER, D., "Vlaams verzet tegen De Vlaamsche Post", Wetenschappelijke Tijdingen, jg. 43, nr. 3, 1984, pp. 142-166

VANLANDSCHOOT, R., "Dagboekaantekening van Cyriel Verschaeve op 8 december 1914 als prefiguratie van de eisen van de frontbeweging (1917-1918)", De Vlaamse Beweging tijdens de Eerste Wereldoorlog, Mededelingen van het Colloquium ingericht te Leuven op 15 en 16 november 1974 door de Afdeling Geschiedenis van de $19^{\text {de }}$ en $20^{\text {st }}$ eeuw, Leuven, 1974, pp. 154-161

VERBRUGGEN, C., Schrijverschap in de Belgische Belle Epoque, Een sociaal-culturele geschiedenis, Nijmegen, 2009

VOM BRUCH, R., SCHALENBERG, M., WALTHER, P.T. (red.), “...Immer in Forschen bleiben”: Rüdiger Vom Bruch zum 60. Geburtstag, Stuttgart, 2004

VON DER GOLTZ, C., Denkwürdigkeiten, Berlijn, 1932 
VON DER LANCKEN-WAKENITZ, O., Meine dreissig Dienstjahre (1888-1918), Potsdam-Paris-Brüssel, Berlijn, 1931

VRINTS, A., “Moffen buiten!', de anti-Duitse rellen in augustus 1914 te Antwerpen”, JAUMAIN, S., AMARA, M. et. al. (red.), Une guerre totale? La Belgique dans la Première Guerre Mondiale, Brussel, 2005, pp. 47-63

VRINTS, A., Bezette Stad, Vlaams-nationalistische collaboratie in Antwerpen tijdens de Eerste Wereldoorlog, Brussel, 2002

WEHLBERG, H., Die internationale beschränkung der Rüstungen, Stuttgart, 1919

WENDE, F., "Enkele opmerkingen over het karakter van de Duitse Flamenpolitik 19141918 en over Lode Wils' boek 'Flamenpolitik en aktivisme”, Wetenschappelijke Tijdingen, jg. 34, nr. 4-5, 1975, kol. 213-224

WENDE, F., Die belgische Frage in der deutschen Politik des Ersten Weltkrieges, Hamburg, 1969

WHITLOCK, B., Belgium, a personal narrative, I en II, New York, 1919

WILLEMSEN, A.W., Het Vlaams-nationalisme (1914-1940), Groningen, 1958

WILLEMSEN, A.W., Het Vlaams-nationalisme 1914-1940, Utrecht, 1969

WILLEMSEN, A.W., Twintigeeuwen Vlaanderen: De Vlaamse beweging 2: van 1914 tot 1945, Deel 5, Hasselt, 1975

WILLEQUET, J., "La légation d'Allemagne, la presse et milieux de presse bruxellois entre 1887 et 1914", Revue Belge de Philologie et d'Histoire - Belgisch Tijdschrift voor Filologie en Geschiedenis, vol. 36, nr. 2, 1958, pp. 388-435

WILMOTTE, M., La culture française en Belgique, Parijs 1912

WILS, L., "De geschiedenis van Holland en de verschillen tussen de Nederlandse en de Belgische identiteit", Ons Erfdeel, jg. 47, 2004, pp. 133-137

WILS, L., "Elias of het gevecht met de geschiedenis", Wetenschappelijke tijdingen, jg. 51, nr. 4, 1992, pp. 193-209

WILS, L., "Het aandeel van de Flamenpolitik in de Vlaamse natievorming", Belgisch Tijdschrift voor Nieuwste Geschiedenis, jg. 45, nr. 2-3, 2015, pp. 216-237.

WILS, L., Flamenpolitik en aktivisme, Leuven, 1974

WILS, L., Frans Van Cauwelaert en de barst in België (1910-1919), Antwerpen, 2000

WILS, L., Het ontstaan van de Meetingpartij en haar invloed op de Belgische politiek, Antwerpen, 1963

WILS, L., Honderd Jaar Vlaamse Beweging, Geschiedenis van het Davidsfonds II, Leuven, 1985

WILS, L., Onverfranst, Onverduitst? Flamenpolitik, activisme, frontbeweging, Tielt, 2014

WILS, L., Op zoek naar een Natie. Het ontstaan van Vlaanderen binnen België, Kalmthout, 2020

WILS, L., Van Clovis tot Di Rupo, de lange weg van de naties in de Lage Landen, Antwerpen, 2005

WILS, L., Van de Belgische naar de Vlaamse natie, een geschiedenis van de Vlaamse beweging, Leuven-Den Haag, 2009

WILS, L., Vlaanderen, Belgie,, Groot-Nederland: mythe en geschiedenis, Historische Opstellen, gebundeld en aangeboden bij het bereiken van zijn emeritaat als hoogleraar aan de K.U. Leuven, Leuven, 1994 
WOESTE, C., Mémoires pour servir à l'histoire contemporaine de la Belgique, III, Brussel, 1937

YAMMINE, B., Drang nach Westen, de fundamenten van de Duitse Flamenpolitik (18701914), Leuven, 2011

YAMMINE, B., Drang nach Westen, de ideologische basis van de Flamenpolitik (18701914), Proefschrift, Leuven, 2010

YAMMINE, B., “De 'Flamenpolitik' als continuïteit van de Duitse geopolitiek”, Belgisch Tijdschrift voor Nieuwste Geschiedenis, jg. 43, nr. 2-3, 2013, pp. 12-45

YAMMINE, B., "Honderden keren probeerden de Walen ons ervan te overtuigen dat er geen Vlamingen meer waren”, Wetenschappelijke Tijdingen, jg. 71, nr. 3, 2012, pp. 233-256

YAMMINE, B., "Nieuw licht op de Duitse propaganda tijdens de Eerste Wereldoorlog, De genese van het controversiële pamflet La Politique Belge après la Crise", Wetenschappelijke Tijdingen, jg. 76, nr. 2, 2017, pp. 224-262

\section{Naslagwerken}

Neue Deutsche Biographie, herausgegeben von der Historischen Kommission bei der Bayerischen Akademie der Wissenschaften [=NDB]

Biografisch Woordenboek van Nederland [= BWN]

Nationaal Biografisch Woordenboek [= NBW]

Nieuwe Encyclopedie van de Vlaamse Beweging, Tielt, 1998 [=NEVB]

Biografie Nationale du Pays de Luxembourg depuis ses origines à nos jours [=BNPL]

Encyclopédie du Mouvement wallon, Charleroi, 2000 [= EMW]

\section{Repertoria voor verder archiefonderzoek}

VANDEWEYER, L., Archief van de Dienst van het Sekwester van de Administratie der Domeinen (1919-1996), [Algemeen Rijksarchief, BE-A0510/I 484], Brussel, s.d.

VANDEWEYER, L., Het conglomeraatsarchief van de Raad van Vlaanderen, het Propagandabureau, Nationaal Verweer, de Nationalen Bond voor de Belgische Eenheid, Jacques Pirenne en Henri Pirenne (1908-1939), [Rijksarchief Brussel, BE-A0510/I 530], Brussel, 2012 



\section{PERSONENREGISTER}

Albert I, Koning der Belgen 54, 65, 117 , $118,122,126,154,190,234,237$. 266, 302

Allenby, Edmund 203

Álvarez de Toledo y Pimentel, Fernando (de hertog van Alva) 73

Andree, Richard 40

Angermille, Karel 187, 321

Ansiaux, Maurice 47, 48

Bachem, Julius 163

Baie, Eugène 48, 49

Barker, Ellis 49

Bary, Heinrich, von 38

Basse, Maurits 14, 19, 20

Below, Fritz, von 68

Belvaux, François 236

Berchtold, Leopold 184

Bergen, Emiel, van 165, 167, 172, 173

Berger, Maurice 55, 56, 62

Bernard, Charles 81, 250-252, 263

Berryer, Paul 66

Beseler, Hans, von 65, 66, 75, 80, 124, 127

Bethmann-Hollweg, Theobald, von 17, $27,32,106,107,109,114,116,117$, 164, 284, 318

Bismarck, Otto, von 26, 37
Bissing, Moritz, von 27, 54, 116, 155 , $161,162,164,166,177,189,232$, 273-276, 281, 282, 284, 290, 302, 318,321

Bley, Fritz 115

Blunck, Hans-Friedrich 164, 169, 173, 274, 277

Bodenhausen, Eberhard, von 44, 210, 255

Bodenhausen, [?], von 129

Bogaerts, Frans 164, 172

Bois, Albert, du 42-44, 232, 233, 240245

Bongard, Oscar 120, 121

Borchling, Conrad 115

Borms, August 22, 97, 161, 165, 172$177,183,188,198,228,238,248$, 268, 275, 286, 290, 291, 296, 323, 324

Boué de Villiers, Maurice 241

Breydel, Jan 130

Broqueville, Charles, de 39, 66, 88, 124, 237, 301

Brulez, Lucien 269

Buchan, John 219

Buisset, Emile 111, 169, 229, 272-277, 287, 289-291, 322

Bujac, Emile 220 
Bülow, Bernhard, von 217

Buning, Lammert 20

Buysse, Arthur 261

Calza Bedolo, Gino 144, 185

Cantillon, Eugène 282

Carton de Wiart, Henri 69, 301

Catillon, Léonce, du 157, 179, 249, 313

Cauwelaert, August, Van 300

Cauwelaert, Frans, Van 16, 19, 35, 75, 79, 102, 186, 212, 213, 231, 264, 268-270, 272, 274, 276, 289, 291, 298-301, 303-307, 310-314

Ceuninck, Albert, de 302, 303

Charpentier, Jules 309

Churchill, Winston 65, 121, 122, 124, 127,202

Claß, Heinrich 27, 31, 32, 114, 210

Clercq, René, de 252, 254, 262, 264 , 266-270, 272, 291, 310

Colijn, Hendrik 283

Colleye, Raymond 19, 42-44, 94, 95, 239-245, 268, 289

Coninck, Pieter, de 130

Cooreman, Paul Emile 124, 126, 128, $133,138,139$

Coremans, Edward 33-34, 39, 124

Corvillain, Joseph 37, 208

Coster, Charles, de 209

Daudet, Léon 58

Deguise, Victor 65, 66, 73, 75, 79, 120, $186,197,219,220$

Delaitte, Julien 41

Delecourt, Victor 58

Delvaux, Frédéric 45, 46, 80

Demaegt, Johan 249, 261

Destrée, Jules 35, 160, 224, 233-236, 268, 289

Deswarte, Albéric 68, 247, 248, 250, 252, 257-264, 266, 267, 269, 272, $281,288,289,306,325$

Devreux, Emile 273-275

Dirr, Pius 165, 166, 213, 214, 224, 244, 245
Dix, Arthur 31

Dolderer, Winfried 17, 18, 116,316, 318

Dolfuss, Engelbert 164

Domela Nieuwenhuis, Edzard 250

Domela Nieuwenhuis, Jacob 249

Domela Nieuwenhuis, Jan Derk 159$161,165,184,249,250$

Dossin, Emile, de 219

Drumont, Edouard 205

Dupont, Emile 35

Ebstein, Otto 13

Eekhoud, Georges 39, 40, 65, 205-209, $211,213,214,218,224$

Eggen, Johan 269

Elias, Hendrik 15-17, 19, 20, 266, 317

Eyschen, Paul 318

Faingnaert, Arthur 14, 19, 20, 105, 162, 167-171, 238

Falkenhausen, Ludwig, von 324

Fallon, Albéric 255

Fischer, Fritz 15

Franck, Louis 35, 65-67, 69, 70, 72, 73, 75-82, 84, 85, 89, 99, 101, 102, 124, 126-128, 133, 134, 136-139, 143, 148-151, 185, 186, 190, 197, 198, 212-214, 221, 222, 247, 273, 274, $276,289,290,319-321,323,324$

Francqui, Emile 163

Fredericq, Paul 32, 149, 170, 292

French, John 202

Fromme, Franz 115

Gaedertz, Karl Theodor 31

Gendebien, Alexandre 242, 243

Gerretson, B.J. 72

Gerretson, Frederic Carel 168, 221, 257 260, 263, 269, 270, 272, 277, 278, 280, 282-285, 288, 322

Gerstenhauer, Max Robert 114, 164, $165,174-177,183,321$

Geyl, Pieter 13, 14, 110, 278

Girard, René 158, 287 
Gobineau, Arthur, de 45

Goblet d'Alviella, Eugène 301

Goffinet, Constant 127

Goltz, Colmar, von der 27, 54, 110, 114, 115, 139, 162, 166, 169, 187, 214, 273-275, 277, 318, 320, 322

Gotovitch, José 15

Graevell, Harald 28, 31, 115, 139, 155

Greindl, Jules 117

Grey, Edward 119

Groen van Prinsterer, Guillaume 278280, 285, 286

Grosemans, Hendrik 170

Groth, Klaus 31, 44

Gubin, Eliane 326

Gutt, Camille 55

Guyot, Yves 49

Hackenbroich, Louis 163, 215, 216, 246

Haig, Douglas 202

Harry, Gérard 19, 56, 92, 93, 102, 151, $157,190,217-221,248-250,268$, $288,289,296,315$

Hartmann, Felix, von 163

Hasse, Ernst 28-30, 108

Hecke, Gustaaf, van 60

Hegenscheidt, Alfred 276

Henderickx, Adelfons 82-88, 99-101, $117,131,132,147,155,175,176$, $188,216,230,290,291$

Hennebicq, Léon 50

Herostratos 124

Herremans, Jef 167

Hertling, Georg, von 166

Heyse, Théodore 13

Hindenburg, Paul, von 116

Hinderdael, Jef 174

Hirschberg, Anton, von 91

Hoek, Derk 170, 171, 184, 257, 282

Hoste, Julius, jr. 181, 249, 264, 268-270, 290, 305

Hoste, Julius, sr. 35, 60, 181

Huebner, Friedrich-Marcus 211

Hulpiau, Koen 326

Hürter, Ludwig 38, 175
Huysmans, Camille 35, 212, 213, 253 , 304

Hymans, Paul 124, 126, 128, 133, 138, $139,196,198,301$

Impe, Paul 87, 96

Jacob, Antoon 189, 252-254, 258, 264, $268,270,272,289,291,310,323$, 324

Jacobs, Henri 101, 102

Jaensch, Carl Theodor 29

Jagow, Gottlieb, von 106, 210, 283

Joffre, Joseph 202

Josson, Maurits 29, 30, 131, 154-157, 170, 172-174, 176, 177, 254

Jottrand, Lucien 58, 83

Keim, August 27, 97, 166

Kellen, Tony 40, 208-211, 224

Kennan, George Frost 327

Kiewiet de Jonge, Jan Hendrik 96, 283

Kimpe, Reimond 161

Kippenberg, Anton 210, 211, 224

Kolping, Adolf 38

Kropp, Paul 159, 178

Krüger, Paul 174

Krupp, Alfred 40

Krupp, Friedrich Alfred 40

Krupp, Gustav 210, 224

Kühlmann, Richard, von 255, 281-287, 300, 322

Kuyper, Abraham 96, 278, 283

Lademacher, Horst 16

Lambrichts, Jacob 172, 176, 289

Lamprecht, Karl 31, 97

Lancken-Wakenitz, Oskar, von der 13, $17,66,116,158,162,163,166,174$, $178,210,214,215,224,228,267$. $281,283,321$

Langlois, Hyppolite 49

Lemonnier, Camille 40, 209

Liliencron, Detlev, von 165

Limet, Arthur 159, 287 
Lippert, J.P. 217

Lloyd George, David 202

Ludendorff, Erich, von 109

Lüttwitz, Walther, von 110

Maeterlinck, Maurice 19, 40, 92-94, $147,157,208,209,224,233,248$ $250,268,288,289$

Marès, Roland, de 55, 77, 93, 250

Massart, Jean 111

Mattheüs, evangelist 201

Mauw, Louis 75, 82

Max, Adolphe 72, 73, 85

Meert, Hippoliet 114, 149, 268, 291, 292

Mercier, Désiré 163, 248

Mertens, Jozef 65, 193

Meseberg-Haubold, Ilse 17

Minnaert, Marcel 249, 250, 254

Molenaar, Leo 193

Molen, Jan, van der 72

Mommaerts, Hendrik David 18-20, 82, 161,325

Monet, Auguste 149, 150, 190, 291, 306,310

Mont, Pol, de 44-48, 59, 62, 76, 80, 84, 95, 114, 186, 212

Müller, Jakob 18, 116, 193, 211, 294, 318,322

Muls, Jozef 56

Nandrin, Jean-Pierre 326

Napoleon, Frans keizer 42

Neuray, Fernand 86, 87, 309

Norden, Friedrich 31, 164, 172

Oever, Karel, van den 88, 89, 101

Opstraet, Antoon, van 181

Ostaijen, Paul, van 180

Osthaus, Karl Ernst 142

Oszwald, Robert-Paul 114, 115, 183

Palmerston, Henri John Temple 242

Passelecq, Fernand 227-229

Perre, Alfons, Van de 102, 290
Petri, Franz 114

Pfister, Hermann, von 28, 31, 115

Picard, Edmond 205, 243

Picard, Leo 34, 97, 164, 170, 183, 249 , $250,254,263,282,288,325$

Piérard, Louis 252, 253

Pirenne, Henri 13, 14, 19

Poullet, Prosper 150, 262

Prayon-Van Zuylen, Alfons 28, 29

Prims, Floris 67, 101, 189

Raemaekers, Louis 272

Raet, Lodewijk, de 170, 171

Reinhard, Frans 29, 154-157, 173, 174, $176,177,184,254$

Reismann-Grone, Theodor 28-30, 40, 108, 116, 164, 165, 208, 209

Remouchamps, August 282

Reuter, Fritz 31

Reventlow, Ernst, zu 118

Ridder, André, de 258, 269, 270

Rieth, Heinrich Peter 37, 38, 162, 163 , 208

Rieth, Henri 38, 162-165, 172, 173 , $178,182,208,216$

Rietjens, Edgar 298-301, 303, 305, 311 313,321

Riezler, Kurt 106, 107

Rodenbach, Albrecht 40, 59, 83

Rogier, Charles 46, 242, 243

Roose, George 310-312

Rousseeu, Cyriel 311, 321

Rudelsheim, Marten 52

Ryckmans, Alphonse 37, 65, 66, 77, 79, 124, 126-128, 133, 134, 136-139, $143,148,149,151,185,186,190$, 197, 198, 208, 221, 222, 229, 247 . $290,320,323$

Sabbe, Julius 46

Sadeleer, Constant, de 171, 172

Saerens, Lieven 193

Samassa, Paul 31

Sandt, Maximilian, von 114, 160, 162, $164,179,214,273$ 
Savornin Lohman, Anna, de 69

Schachs, [?] 163

Schaepdrijver, Karel, de 303, 309

Schaepdrijver, Sophie, de 193, 294

Scherl, Erwin 121, 122, 124

Schlieffen, Alfred, von 53

Schotthöfer, Fritz 142

Schowalter, August 174, 175

Schwob, Maurice 48, 49

Seberechts, Frank 20, 326

Shaw, Bernard 140

Simons, Leo 96

Simons, Paul 173

Sint-Aldegonde, Marnix, van 73

Sixt von Arnim, Friedrich 112

Sleeswijk, Jan Gerard 165

Sonnenschein, Carl 38

Steinmetz, Sebald Rudolf 31

Strauss, Louis 65, 80, 81

Streuvels, Stijn 59, 64, 203

Surlet de Chokier, Erasme Louis 242, 243

Te Lintum, Cris 96

Terwagne, Modeste 79, 100, 186, 189, 200

Thelen, Willem 169, 170, 172

Tirpitz, Alfred, von 106

Titus, Romeins keizer 202, 203

Trimborn, Karl 163, 164, 176

Valckenier Kips, Jan Hendrik 31, 257

Vanacker, Daniël 17, 20, 60, 159, 193, 270, 271, 317, 326

Vandervelde, Emile 301

Velde, Henry, Van de 142

Velde, Maurice, van de 184

Velthoven, Paul, van 20

Vercruysse, Edgar 84

Verhulst, Raf 75, 82, 90, 183, 202, 203, 205, 310

Vermeylen, August 170-172, 276

Vessem, Antoon Johan, van 269

Voltaire 76
Vos, Jan, de 65, 66, 72-74, 77, 79, 81, 84, $124,127,135,146,148-151,185$,

186, 197, 198, 200, 222, 247, 320, 323

Vos-Van Kleef, Désiré, de 135

Vriendt, Juliaan, De 34

Vrints, Antoon 17, 159, 183, 193, 326

Walschap, Gerard 311

Wandeleire, H., de 112

Wappers, Jacques 70-72, 76-78, 144

Wattez, Omer 35

Wende, Frank 16-18, 318, 320

Werder, Hans, von 159

Wertheimer, Julius 163, 165, 214-216, 224, 246

Wever, Bart, De 325

Wever, Bruno, De 294

Weyler, Karel 82

Whitlock, Brand 111, 163, 325

Wichert, Friedrich 255-258, 260, 263, $264,267,269,272,285,300,325$

Wien, [?] 133, 216

Wilhelm II, Duits keizer 26, 39, 108, 161

Willemsen, Arie Wolter 14, 15, 19, 20

Willems, Jan Frans 58, 83

Willem van Oranje 73

Wilmotte, Maurice 41

Wilser, Ludwig 29

Wils, Lode 16-18, 20, 78, 82, 155, 157, 171, 174, 193, 228, 294, 317, 321, 325

Wirth, Hermann Felix 160-162, 182, 249

Witte, Els 326

Woeste, Charles 39, 129

Woestijne, Karel, van de 170, 172, 189

Wohlmann, [?] 134, 216

Wolf, Julius 31

Wullus, Armand 305

Ziegesar, Adolf Johann Albert, von 29, 179

Ziegesar, Joseph Haller, von 29, 114 , $164,165,169,172,183$ 
